


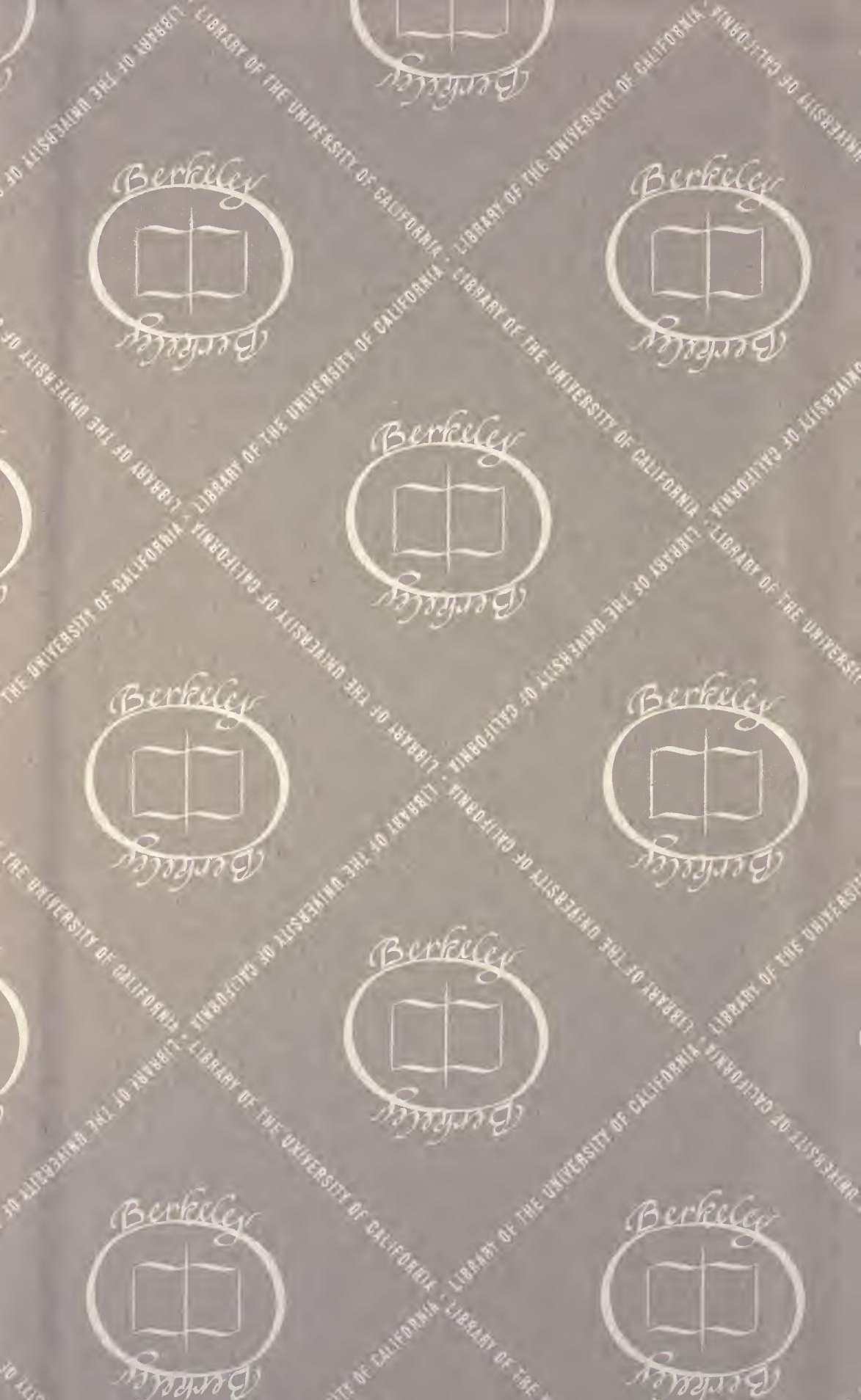





SKRIFTER UTGIVNA AF

\section{SVENSKA LITTERATURSÄLLSKAPET I FINLAND}

XCIII.

\section{PEHR KALMS}

ESA TILL NORRA AMERIKA

^ NYO UTGIFVEN

AF

FREDR. ELFVING OCH GEORG SCHAUMAN.

ANDRA DELEN.

HELSINGFORS 1910. 


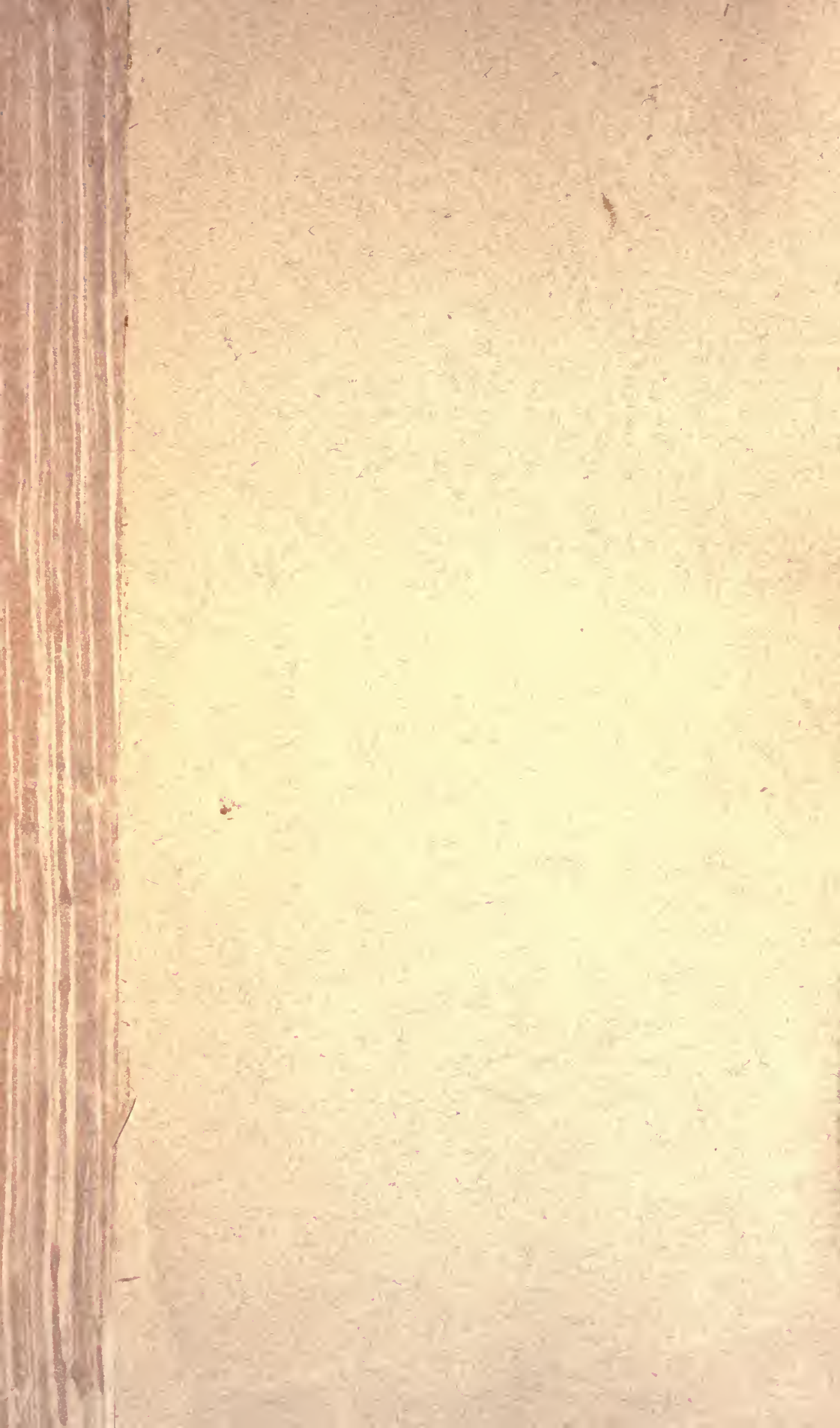




\section{SKRIFTER}

UTGIVNA AV

\section{SVENSKA LIPTERATURSÄLISKAPPT}

\section{FIN L AND}

XCIII

-19.2010 



\section{PEHR KALMS}

RESA TILL NORRA AMERIKA

A NYO UTGIFVEN

$A F$

FREDR. ELFVING OCH GEORG SCHAUMAN.

\section{ANDRA DELEN.}

MED ETT FÖROR D

$\Lambda F$

GEORG SCHATMAN.

HELSINGFORS

TIDNINGS- \& TRYCKERI-AKTIEBOLAGETS TRYCKERI 1910. 

FÖRORD.

K ALM dröjer ännu i denna del af sin Resa till Norra I Amerika till en början vid England. Han fortfar att med samma omständlighet som i första delen beskrifva hufvudsakligen naturförhållandena och landthushållningen, men äfven annat som det synes honom nyttigt för läsaren att känna. Efter en sju månaders vistelse $\mathrm{i}$ England stiger han ändtligen i Gravesend den 5 augusti I748 ombord på skeppet Mary Gally, destineradt till Philadelphia.

Om förberedelserna till resan meddelar KALM nästan intet. Vi få icke veta huru han utrustade sig för sin forskningsfärd, och detta hade dock åtminstone för eftervärlden varit af ett visst intresse. Vår vetgirighet tillfredsställes emellertid fullständigt genom en anteckning af KALM, som bevarats löst instucken i hans dagböcker.

KALM uppräknar först de klädesplagg han medtagit. Blott för kuriositetens skull återgifves hans anteckning härom: "Hatt. En gammal d:o. 2 röda nattmyssor. I hvit dito. En skinn-myssa. 8 halsdukar. 4 nattkappor. 6 par halfärmar. - manchette-skiortor. - gröfre skiortor. En gră kappråck. En brunaktig råck. En blågrå dito. En svart schaggväst. En röd Regarns tröja. En dito utan ärmar. Et par 
svarta schagg-byxor. Et par svarta skinnbyxor. Et par guhla skinnbyxor. 4 par grå Regarnsstrumpor. 3 par hvita ullstrumpor. - par grå dito. 2 par trådstrumpor. Et par stöflar. 2 par skor. En gul och röd Silckesnäsduk. En dito. En blå Bomulsnäsduk. En blărandig Lärftsnäsduk. En svart skinnråck. Et par gula handskar. Et par bruna dito. Et par blå fingervantar. Et par hvita ullvantar.» Den öfriga utrustningen bestod af: «Gehäng Härsvängare [= Hirschfänger]. Käpp, med alnmått. Käppen med yxa på. Et par Puffertar. Klädesborste. Par skoborstar. Et par metalls skospännen. Et par silfverspän. Rakknifvar med deras tilbehör. Puderask och Puderborste. Rijt-lådan, penslar, Tusk. Ritningar. Silcke, rödt, grönt, guhlt, blått, svart. Tråd, röd, grön, gul, blå, svart. Söm- och Synålar. Knappnålar, alla slagen. Rijtpapper. Postpapper. Skrifpapper, 2 slag. Tryckpapper. Brunt Papper. Böckerna at lägga örter uti. Svafvel. Eldståhl. Bläckglas. Bläck-pulver med des strutar. Bläckhorn, det hopkramade. Nafvare. Linealer. Bokhållare. Fijn Kamb. Kamb. Blyarspennor. Skrifpennor. Tälgknif med gaffeln. Fällknif med gaffel etc. Noch en utan gaffel. Sax och Knipor. Microscope. Oblater at försegla bref med. Lack och Petser. Rhabarb. och andra medic.» I en särskild kolumn uppräknas följande instrumenter: "Astrolabium med des foder. Compassen med Taskan. 3:ne Thermometrar. Perspective. Uhr. 2:ne ögonglas. Svenska foten.» Den medtagna litteraturen utgjordes af: "N. T. G. $[=$ Novum Testamentum Græce]. M. P. [= Meum Psalterium ?], LinNæI Genera Plantarum, Species Plantarum, Flora Suecica, Fauna Suecica, Systema Naturæ. RaII Synopsis Stirp. Britann. Wolfens Anfangs Grunden 'T. III. WALleril Mineralogie. BäUnlers Mitleid. Artz. Millers Gardeners Dictionary Vol. III. Dictionarium Anglico-Latinum. Dictionarium Gallico-Anglicum. Fransk Grammatica. Engelsk Grammatica. Gronovir Flora Virginica. Euclides af KeIl. Plinir Historia Naturalis, 3 Tomer. GERARDI Meditationer. Almanachor. it $[\mathrm{em}]$ Engelska dito skrifna uhr SerenII Diction. Exempl. af Linnæi Faun. Suec., af Flora Zeylon. Charta öfver Norra America. D:o öfver Europa.» KaLıl hade dessutom enligt sina anteckningar att medtaga: "Passen med deras Foder. Mr. Collinsons Paquetter till Logan och Franklin, it. 4 bref. Mr. Warners anhörigas bref. Dr. Mitchells bref.»

Öfverfärden till Amerika gynnades af god vind och vackert väder; "näppeligen lärer någon haft en nöjsammare resa öfver detta stora världenes haf än vi denna 
gången", säger KaLm. Den I5 september förankrade Mary Gally vid Philadelphia. Under resan hade KaLm varit flitigt sysselsatt med naturvetenskapliga iakttagelser, för hvilka han redogör vid sidan af sin beskrifning af själfva färden öfver Atlanten.

Med Kalms ankomst till Amerika ökas läsarens intresse för reseskildringen. I form af dagboksanteckningar intill slutet af året $\mathrm{I} 748$ meddelar KALM sina intryck och iakttagelser från Pennsylvanien - särskildt den del däraf som tidigare tillhört Sverige (Nya Sverige) -, från New Jersey och New York. Har reseskildringen, så vidt den rör England, ett öfvervägande naturhistoriskt och agrikultur-ekonomiskt innehåll, så erbjuder den amerikanska delen ett jämförelsevis större intresse för kulturhistorikern och etnografen. KaLM ger fullt med notiser om seder och bruk, om landets kolonisation, om koloniernas förhållande till England, om deras ekonomiska, sociala och politiska tillstånd, om undervisningsväsendet, om de religiösa förhållandena och särskildt om kväkarne och judarne, om svenskarne i Pennsylvanien, om indianerna - hvilka han dock skall behandla närmare i en följande del af resebeskrifningen -, om negrerna, m. m. Af personhistoriskt intresse är att läsa om KaLms förhållande till Benj. Franklin, "den Pennsylvanien har att tacka för så mycket godt - - och den lärda världen för de många nya decouverter vid electriciteten", och till Joнs BARTRAM, en annan utmärkt medborgare i Pennsylvanien, som i likhet med FrankLin stod KaLm till tjänst med råd och dåd ${ }^{1}$ ). Med dessa notiser omväxla naturligtvis de

1) I sin öfver hufvud sympatiska karaktäristik af denne intressante, self-made man (s. 168 i denna upplaga) förebrår KALM honom att ha varit «en trög och senfärdig skrifvare, som ej vårdat sig att till pappers föra sina många vackra observationer», och omnämner såsom mindre lyckad en kort 
naturvetenskapliga och praktiska, omfattande äfven sådana saker som medel mot sjukdomar och ohyra - betecknande är att KALm slutar denna del med angifvandet af botemedel mot tandvärk.

Stötestenen i Kalms Resa är stilen. Men äfven den synes mig i skildringen af Amerika få lif, ja, någon gång t. o. m. behag. Naturbeskrifningarna äro stundom vackra i sin enkelhet och omedelbarhet, såsom t. ex. denna: "Vi kunde ännu ej märka det ringaste tecken till höst, mer än det, att åtskilliga frukter voro mogna; ty i öfrigt stodo alla trän så gröna, och marken var så full med allehanda blomster, som här i Sverige vid midsommartiden. I kärr och bäckar skällde grodorna hela natten

reseskildring, som BARTRAMS vänner $\mathrm{i}$ London förmått honom att $\mathrm{i}$ tryck utgifva: «den som af den vill döma om mannens skickelighet bedrager sig gräseligen».

Med denna reseskildring åsyftas uppenbarligen skriften Observations on the Inhabitants, Climate, Soil, Rivers, Productions, Animals, and other matters worthy of Notice. Made By Mr JOHN BARTRAM In his Travels from Pensilvania to Onondago, Oswego and the Lake Ontario In Canada, VIII + 94 pg., London I75I. Till BARTRAMS skrift var fogad, såsom äfven på titelbladet angifves, en beskrifning af Niagara vattenfall, som $K_{A L M}$, «A Swedish Gentleman», meddelat en sin vän i Philadelphia i ett bref från Albany, dat. 2 sept. 1750. Af den statliga Calendar of the Papers of BENJAMIN FRANKLIN in the Library of the American Philosophical Society, som i fem band utkom i Philadelphia 1908, framgår att vännen var FRANKLIN och att KALM bedt honom förbättra engelskan, ifall han ärnade publicera brefvet (I, 5). KaLMs bref hade redan tidigare (i januari I75I) blifvit tryckt $\mathrm{i}$ den engelska tidskriften The Gentleman's Magazine, sanuolikt på FrankuINs föranstaltande. Där ingår äfven samma bild af Niagara som i BARTRAMS skrift, enkom tecknad till KALMs text, måhända efter hans anvisningar.

BARTRAMS Observations med Kalms beskrifning öfver Niagara omtrycktes 1895 i Rochester, N. Y. Af detta i 300 numrerade exemplar utgångna omtryck har Helsingfors Universitetsbibliotek lyckats anskaffa ett exemplar. I förordet till boken fälles följande smickrande omdöme om $\mathrm{K}_{A L M}$ : "This gentleman is well known to be a man of worth and great skill in natural history, and his little piece, besides the candour and veracity of the writer, derives a great value from its being the only account in our language of this stupendous object». 
igenom tusentals, och i gräset höllo syrsor och gräshoppor sådant ljud, att den ena svårligen kunde höra hvad den andra talte. Träna voro ock fulla med fågelsvärmar, de där prålade med margfalliga sköna färgor, och deras lekande tunga samt gälla ljud uppväckte luften från alla sidor att härma deras läte.” Icke utan rörelse läser man skildringen af KALMS första intryck från Nya världen. "Jag fann det jag nu var kommen i en annan värld; ty hvart jag på marken kastade ögonen, mötte mig mest öfverallt sådana växter, dem jag ej kände och hvilka arter jag aldrig sett förut. Blef jag varse något trä, så måste jag stanna och fråga mina följeslagare, hvad det kallades. Den första ört, som likasom bad mig vara välkommen, eller den ögonen först föllo på, var en Andropagon, eller af grässläktet, den delen nämligen af örtekunskapen, som jag haft mitt största nöje med." Den äkta forskarentusiasmen lyser fram ur sådana rader. - Hvad KALm fullständigt saknar är esprit d'arrangement och litterär smak. Och sedan ännu en sak: sinne för humor. Han tager allt så fruktansvärdt allvarligt, för att icke säga ledsamt, och om till äfventyrs skildringen någonstädes tager en humoristisk vändning (såsom t. ex. i berättelsen om indianernas kunskap i Gamla Testamentet, s. 234), så beror detta egentligen icke på honom själf. Jo, en gång kan man tala om ett afsiktligt skämt från KALms sida - det är då han säger att kakerlackorna "hafva trott att de icke böra mer än vägglössen vara från den nya världen uteslutna". Men om skämtet är synnerligen lyckadt lämnar jag därhän. 
Första delen af denna nya upplaga af Kalus Resa till Norra Amerika utkom redan 1904. I slutet af inledningen till densamma utlofvades de återstående delarna till de närmast följande åren, om blott Svenska Litteratursällskapets medel tilläte förverkligandet af detta beslut.

Sällskapets bestyrelse har emellertid icke ansett sig kunna förr än i 1909 års budget upptaga ett anslag för tryckningen af andra delen af KaLms Resa. Häraf det långa och beklagliga uppskofvet med offentliggörandet af fortsättningen.

Vid utgifvandet af föreliggande del ha följts de principer som angifvits i inledningen till första delen (s. XLVII-XLVIII). Utg. hade hoppats kunna bifoga texten en reproduktion af den karta af Lewis Evans som KaLu omnämner i ett bref till Wargentin (se inledningen till del I, s. XXXI) och som bör finnas i Kungl. Vetenskapsakademiens bibliotek i Stockholm. Enligt bref från nämnda biblioteks föreståndare har kartan emellertid icke kunnat påträffas där. Måhända skola förnyade efterforskningar leda till positivt resultat före utgifvandet af tredje delen. I hvarje fall skall till den bifogas någon samtida karta öfver de trakter KaLu berest.

Helsingfors, i maj ıوı.

GEORG SCHAUMAN. 


\section{Rättelser,}

gjorda i denna upplaga af

\section{Kalms Resa till Norra Amerika,}

Tom. II.

(Hänvisningarna gälla texten i den gamla upplagan.)

Pag. 2 rad. 5 nfr.: «Kitan» till «Kritan».

$$
\begin{aligned}
& 3 \text { » 2-3 ufr.: «korsverke» till «Korssverke». } \\
& 15 \text { ufr.: «knnde» till «kunde». } \\
& 11 \text { nfr.: «Lja» till «Lia». } \\
& 7 \text { » } 10 \text { " "Woordford» till «Woodford". } \\
& 8 \text { » } 5 \text { ufr.: "slagtad» till "slaktad». } \\
& 10 \text { " } 8 \text { » «deremellan» till «der emellan». } \\
& 16 \text { " } 11 \text { nfr.: «dessar» till «dessa». } \\
& 28 \text { 》 } 10 \text { » "Äfvenbök» till «Afvenbök». } \\
& 32 \text { » } 15 \text { ufr.: «fanns» till «famns». } \\
& 54 \text { » } 3 \text { » «hvillket» till «hvilket». } \\
& 55 \text { » } 5 \text { nfr.: «kann» till «kan». } \\
& 57 \text { » } 6 \text { » «somrar» till «sommar». } \\
& 62 \text { " } 8 \text { ufr.: «kria» till «krita». } \\
& 9 \text { » «kritades och» till «kritades». } \\
& 70 \text { » } 15 \text { nfr.: «mathematisk» till "mathematiske». } \\
& 72 \text { » } S \text { ufr.: «förosakadt» till «förorsakadt». } \\
& 77 \text { » } 12 \text { nfr.: «aftnorna» till «aftnarna». } \\
& 83 \text { » 17-18 ufr.: «Rjsknippor» till «Risknippor». } \\
& 88 \text { » } 11 \text { ufr.: «är» till «än». } \\
& 91 \text { » } 3 \text { » "Cinquefvil» till «Cinquefoil». } \\
& 92 \text { » } 3 \text { » "lema» till «lemna». } \\
& 94 \text { » } 11 \text { » «i floden Thames, floden Midway, som var» till } \\
& \text { «var i floden Thames, floden Midway, som». } \\
& \text { » } 99 \text { » } 4 \text { » "Ingefara till "Ingefära». } \\
& \text { " } 102 \text { " } 5 \text { » «Gravesand "till «Gravesend". } \\
& \text { » } 104 \text { » } 3 \text { nfr.: «hafsstränden» till «hafsstranden». } \\
& \text { » } 111 \text { " 10-11 nfr.: «ögnasigtet» till «ögnasigte». }
\end{aligned}
$$


Pag. 116 rad. 3 o. 8. nfr.: "Bay af Biscay» till «Bay of Biscay».

» 137 » 10 nfr.: «toppsegell» till «toppsegel».

» 140 » 8 » «jötärnarna» till «Sjötärnorna».

» 141 » 4 ufr.: «Hanvar» till «Han var».

》 " 9 » «mln» till «min».

» \ 2 nfr.: «flsk» till «fisk».

» 147 » 8 ufr.: «Hafs-Tärran» till «Hafs-Tärnan».

» 148 » 3 nfr.: «Latituden» till «Longituden».

- 153 » 8 " «sina» till «fina».

» 171 » 12 ufr.: «öfväxt» till «öfverväxt».

» 172 » 11 nfr.: «Dellavare» till «Dellaware».

" 173 » 16 » «häster» till «hästar».

» 176 » 5 ufr.: «Germantowe» till «Germantown».

» 177 » 15 » "Nevlights» till "Newlights».

" 178 " 1 " "Newligths» till «Newlights».

" 180 » $T$ " «Mectings » till "Meetings»

» 181 » 7 nfr.: «uprrättadt» till «uprättadt».

\195 》

6 ufr.: «täflat» till «täflar».

7 » «folkskarar» till «folkskaror».

8 » «långländta» till «lågländta».

202 » 4 » «varieterer till «varieteter».

209 » 10 nfr.: «henna» till «denna».

210 " 10 " "ploger» till "plogen».

224 » 15-14 nfr.: «Det trän, som Castanieträ, brukades hälst til stängsel» till «Det trä, som brukades hälst til stängsel, var Castanie-trä».

2 ufr.: «rutar» till «rutnar».

264 » 3 ufr.: «Herras» till «Herrars».

271 » 2 » «stamrroten» till «stamroten».

275 » 2 nfr.: «Linnei» till "Linnæi».

291 " 10 " «Toumef» till «Tournef».

300 » 12 « «194» till «154».

319 » 8 ufr.: «hästerne» till "hästarne».

320 » 5 nfr.: «Hiracium» till «Hieracium».

》 4 » "Achilleg.» till «Achillea».

324 " 10 " "Withe» till «White».

349 " 3 » «midagen» till "middagen».

362 » 15 》 «inkomna» till «inkomma».

369 » 14 » «et» till «en».

376 » 17 ufr.: «afmålande» till «afmålade».

378 》 12 "Béte puant» till «Bête puante».

385 » 5 nfr.: «fordrat» till «fodrar».

393 » 7-8 ufr.: «fogeles» till "fogelens».

418 » 2 ufr.: «varetet» till «varietet».

421 » 5 » «Hyckery» till «Hickery». 
Pag. $434 \mathrm{rad} .5$ ufr.: «redii» till «radii».
» 438 » 3 nfr.: «styckan» till «stycken».
» 442 » 12 » «Podes» till «Pedes».
»444 " 4-5 nfr.: «gifve» till «gifva».
» 452 " 11 ufr.: «rrodde» till «trodde».
" 454 » 6 nfr.: "plägas» till «plågas».
» 455 " 13 ufr.: «mannnaminne» till «mannaminne».
» 457 » 3 " «höglåndtare» till «högländtare».
» 458 » 5 nfr.: «berärtelse» till «berättelse».
" 465 " 13 " "fingo" till "fingo de".
» 477 » 6 ufr.: «Isländare» till «Irländare».
" 488 " 11 » «sådan» till «sådant».
" 490 " 1 " "gräshopparna" till "gräshopporna».
» 492 " 17-16 nfr. «Europerne» till «Europeerne».
» 499 » 6 nfr.: «låmna» till «lämna».
» 509 " 14 " «berättelsert» till «berättelser».
» 513 » 1 ufr.: «och» till «oss».
" 526 andra kolumnrubriken: "Englisk Manufactum» till "English Manufacture.

Dessutom har någon gång interpunktionen ändrats. 



\section{En}

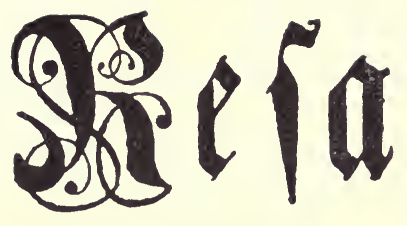

Til

Serotta AMERICA, $\mathfrak{P a ̀}$

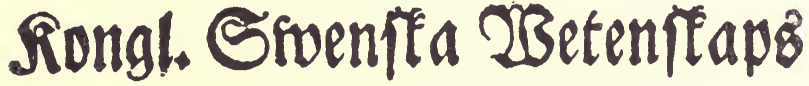
Academiens befallning,

Dd)

Publici foftnad,

goórtáttad

श्रा

PEHR KALM,

Oeconomix Profeffor $i$ Åbo, famt Lebamot af Sinngl. Sronfe 23 BtenffapbrAcademien.

\section{Tom. II.}

Hzed Rongl. Mlaj:ts Zuletnabigfte Privilegio.

$$
\text { STOCKHOLM, }
$$

₹rgat på LARS SALVII Eoftnad, 1756. 



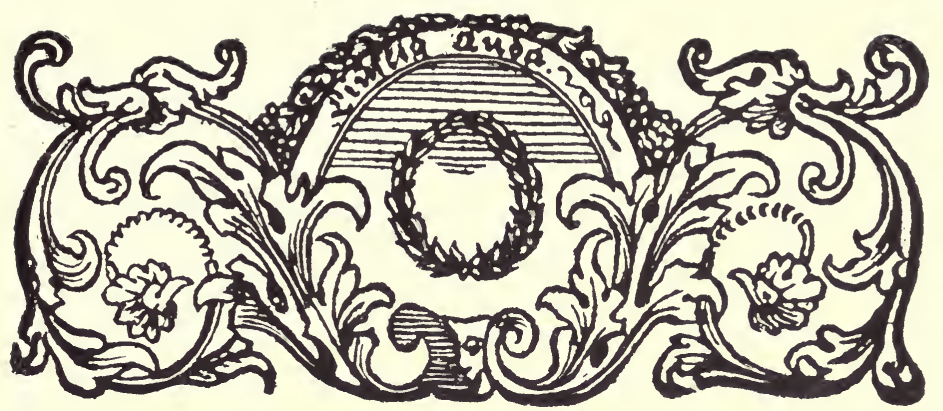

Å r 1748 .

Den 6 Julii.

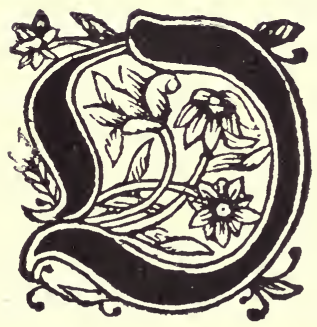

.m morgonen reste jag tillika med då varande Kyrkoherden vid Svenska Församlingen i London, Mag. Toвıas Bıовск, och en Ängelsk Gentleman, öfver floden Thames til Essex, at der bese landet. Så snart vi kommo öfver floden, var landet ungefär til en Ängelsk mil helt lảgländt, at vandra öfver, innan vi kommo upp der det började blifva backot. Detta lågländta landet har i forna tider varit en del af Floden 'Thames; men är nu genom de mullvallar, och bankar, som äro upkastade vid bräddarna af floden, skildt ifrån densamma, och gjordt til nytta, samt indeldt til åkrar, ängar och beteshagar. När det är högt vatten i Floden, som sker 2 gånger om dygnet, står superficies af vatnet gemenligen mycket högre, än desse lågländta fält, så at om de förenämde mullvallar ej vore, skulle vatnet då flöda öfver alt, och göra, at desse stora fält skulle se ut, som en stor sjö. Hela detta lågländta landet var | sönderskurit p. 2 $\mathrm{i}$ åtskilliga delar, genom djupa och en famns breda diken, 
hvilket skett, at derigenom afleda vatnet och uptorrka landet. Desse diken gjorde dessutom här samma tjenst, som häckar eller gärdesgårdar, at hindra boskapen, at komma från betesmarkarna in på åkrar och ängar. På de fläste ställen voro desse diken fullväxte af Arundo vulgaris palustris C. B. den boskapen afbitit så långt de kunnat komma åt. Korn var nu egenteligen sått på dessa lågländta åkrar, hvilket nu stod mycket härligt. Jordmon var lera. En del af dessa ăkrar låg i träde. Nu höllo de som bäst på, at slå hö, på de ställen, som voro lämnade til ängar.

Gödning. Vi funno här i Essex, så väl som alt omkring Gravesend i Kent, at boskaps dyngan var utförd och lagd antingen vid någon åker eller vid nâgon äng, hvarest den var hopkastad i stora fyrkantiga högar, dock ej allena för sig, utan hopblandad hvarftals med torf, at så ligga och brinna tilhopa, innan den kom at brukas på åker, äng, eller i trägård. Hemma vid gårdarna sågo vi gödningen både i Essex och Kent samlad och handterad, på samma sätt, som förr är beskrifvit vid Little Gaddesden 1. Del. p. 251. och följande.

Krita. Här och där på denna sidan i Essex äro äfven kritbärg af samma art och beskaffenhet, som i Kent. Vi sågo på et och annat ställe, at Kritan var utförd på åkern, der den låg dels lasstals, dels utbredd, öfver åkerstyckena, at göda dem med.

Hus. Böndernas hus här i Essex voro dels murade

p. 3 af bara tegel, dels med korss/verke och tegel deremellan, dels voro de af korssverke och bräder spikade derpå, dels af korssverke med spjälar på, hvilka voro öfverklistrade och smetade med ler och kalk. Desse sista voro endast de, som beboddes af torpare och annat fattigt arbetsfolck. Sjelfva Farmernas eller Böndernas gårdar voro så väl bygde, at de väl kunnat tagas för vackra Herregårdar. Taken voro dels täckte med taktegel, dels med halm. Uthusen, såsom lada, loga, m. m. jemte det fattiga folkets stugor, voro gemenligen täckte med halm, på sätt, som vid Little Gaddesden är beskrifvit förut 1. Del. p. 202. 
Desse halm-tak gjordes här mycket höga, samt ganska branta, så at rägn och väta ej kunde stanna derpå, utan rann hastigt af, hvaraf taket kom at mindre rötas, och följakteligen kunde det stå långt flera år, än et flatare tak. De gjordes ock nog tjocka, nämligen ibland til 2 och ibland til 3 qvarters tjocklek. Väggarna på en del af ladorna voro äfven af Flintsten. På somliga ställen höllo de nu som bäst på, at göra halm-tak.

Råg var i Kent nog sällsynt, så at der voro få ställen, hvarest syntes något stycke land besådt dermed; men i Essex åt denna kanten voro nästan sả många Råg- som Hveteåkrar. Den var nu mäst fullmogen, och halmen började blifva nog blek, då deremot Hvetet, som växte bredevid honom, nu först begynte at matas eller sätta kärna til korn, och var hel grönt.

Kyrkan, som låg i Essex på en hög backe midt emot Gravesend, syntes mycket gammal och var mäst hel och hållen bygd af Portlands sten om hvilken är förut talt i 1. Del. p. 371.

St. Foin. På högderna lågo åtskilliga ängar, hvilka p. 4 voro beväxte endast med St. Foin, som nu var afslagit och lagt i stora vålmar.

Höstackar. Höet vid gårdarna var äfven här satt i sådana stackar, som äro beskrefne vid Little Gaddesden förut 1 Del. p. 211, och voro til skapnaden lika lador eller hus. På samma sätt skäres äfven höet derifrån med en särdeles dertil gjord knif.

Vattu-hoar. Mäst vid alla gårdar, så här i Essex, som i Kent, hade de vatu-hoar, antingen at gifva hästar vatten utur, eller ock, at hafva det vatten uti, som de ville bruka til kokning; hvilka hoar voro gjorde dels af Portlands-sten, dels ock af Bly. Vatnet hölt sig mycket svalt deruti. De af Bly, voro gemenligen fordrade utanpå med bräder, emedan det mjuka Blyet annars vek sig ut eller in, om någon kom att stöta derpå.

Handskära. At skära Råg och Hvete, bruka de på denna trackten i Essex icke Lia, som i Sverige på de flästa ställen, utan små handskäror; men til korns och 
hafras upskärande brukades Lia. Järnet på hand-skärorna, som de hade, voro krökt som på våra; men nästan halfparten smalare, at det så mycket lättare måtte kunna stickas in emellan säden. På undra sidan voro de icke slipade jämna $\mathrm{i}$ ägget, utan de hade med en fin fil filat små reflor helt tätt utmed hvarandra, snedt tvärtöfver skäran i ägget; tvifvelsutan, at halmen så mycket fortare måtte gå af, samt desutom ligga stadigt då de ville skära af den. På öfra sidan var den $\mathrm{j}$ ägget slipad hel jämn.

p. 5 Lia. Den Lia de här betjente sig af, at slå gräs med, var til järnet mycket stor och bred; emedan han annars ej så lätt skulle kunna stå emot den tjocka gräsväxten, som är på en stor del af Ängelske ängarna. Vi mätte en Lia, hvars järn var 7 qvarter och 2 tum långt, samt 2 och en half tum bredt.

Om aftonen reste vi tilbaka til Gravesend.

Mjölkens Ansning. \&c. Här i Kent bruka Farmerne eller landtmännerne endast några få kor, så at de icke få mera mjölk, än de sielfve behöfva til sitt egit hushåld. När mjölken är nyss mjölkad, sila de den samma i fyrkantiga lådor af Bly. Längden af en sådan mjölk-låda är ungefär 4 a 5 qvarter: bredden 3 a 4 qvarter. Ibland äro de af lika längd och bredd: djupleken en tvärhand. När denna lådan silas om morgonen inemot full af mjölk, lämnas den, at så stå i 24 timar, eller til nästa morgon, då grädden skumas af; men den qvarlämnade sura mjölken brukas antingen för folket, eller som mäst sker, at gifvas àt svinen. På samma sätt, den mjölk, som silas den ena aftonen, blir afskumad den nästföljande, så at de om sommaren aldrig lämna henne, at längre stå $\mathrm{i}$ bunken, än et dygn eller 24 timar; men om vintren får den stå halftannat dygn eller 36 timar; så at af den mjölk, som är silad om morgonen, blir gräddan icke aftagen förr än nästa dag om aftonen. Af denna grädda kärnas sedan Smör. Jag berättade för de Ängelska qvinfolken, huru länge vi i Sverige låta mjölken stå, innan vi taga filet af henne, då de svarade, at vi på det sättet intet kunna få p. 6 så | godt smör, som de; ty de sade sig hafva försökt, at 
då en kärnar smör af en sådan grädda, som är tagen af en så sur mjölk, har det smöret icke halfparten af den angenäma och behageliga smaken, som det Ängelska i gemen hafver. Et sådant smör, kärnadt af en så mycken löpen mjölk, kalla de här girughets Smör. De trodde jämväl, at så mycket smör kan fås af söt grädda, som af sur. De läto mjölken här i Ängeland aldrig stå så länge, til dess den blef, som våra filbunkar, med så tjock grädda och mjölk; ty de veta här ej hvad filbunka är. De sade sig därföre bruka Blykäril, at sila mjölken uti; emedan den om sommaren håller sig svalare deri. Jag frågade: om de icke brukade träkäril, at sila mjölk uti? de svarade: nej; emedan en syra sätter sig fast $i$ trädet, som skämmer mjölken, hvilken syra de ej så lätt kunna tvätta bårt. Blykärilen tvättas väl, emellan hvar gång de brukas, med varmt vatten, at ej den minsta mjölk, eller syra deraf får lämnas qvar i dem; emedan den skulle skämma gräddan, och följakteligen smöret. Ingen eller ganska litet ost göres på denna orten i Kent. I Essex hafva de en myckenhet kor och boskap. Kärnan som de bruka, är en horizontelt på en ställning liggande tunna, större eller mindre, alt som de hafva myckenhet af mjölk til och har smala bräder, satta inuti långs efter, fulla med hål, at mera arbeta gräddan. Denna tunna vrides omkring med en vef.

\section{Den 7 Julii.}

Gäss. Mig berättades i dag af dem, som sade sig sjelfve hafva sett det, at i Lincolnshire | och andra orter p. 7 i Ängeland, plåckas en gång om året, nämligen om sommartiden mäst alla fjädrar och dun af lefvande gäss, hvilka, då de varit någon tid, åter få nya dun och fjädrar i det stället, fast de skola se nog förstälda ut i början, när de äro nyss plåckade. De, som hafva denna plägseden, med sina gäss, föregifva, at de dun och fjädrar, som plåckas af gåsen medan hon är lefvande, skola hafva den egenskapen, at då de läggas i bolster, och någon ligger uppå et sådant, at de blifva tilhopa kramade, skola de strax, 
så snart en går utur sängen, pösa up igen och utvidga sig til samma högd som förr, så at det föga skal kunna synas om någon legat i sängen. Sådan elasticitet skola desse dun hafva. Åtminstone skal det vara en ganska stor skilnad derutinnan imellan dem, som äro plåckade af en gås, medan hon ännu lefver, än när hon är död. Eljest brukades så här i Kent, som i Essex nog gäss af Landtmännerna; likaledes nog Anckor.

At få kalf-kött hvitt. Provincen Essex här i Ängeland är i synnerhet fram för andra berömd för sina kalfvar, som hafva et skönt, fett, mycket mört och ganska hvitt kött. Och at det må blifva så mycket hvitare, såg jag, under mitt vistande i Woodford, at Farmerne eller Landtmännerne brukade lägga et stort stycke krita i en ho, der de hade sina gödkalfvar, at låta kalfven slicka deraf, hvilket efter deras mening skulle göra så mycket, at köttet blir hvitare; men utom detta sättet blef mig i dag berättadt et annat grepp, nämligen: om de slagta, til exempel, vid klockan 6 efter middagen, en kalf på vanligt sätt, då de sticka honom i halsen, och låta blodet p. 8 rinna så när af honom, at han är | mäst död. Då de se, at intet stort blod är mera qvar, stämma de blodet, at det ej mera får rinna, och at kalfven kommer sig någorlunda före: låta honom så lefva til följande dagen om morgonen, då de aldeles slakta honom. En kalf slaktad på detta sätt, sades hafva långt hvitare kött, än om de hade slaktat honom på vanligt sätt och dödat honom på en gång. Den vittre Doctor Lister talar äfven härom sålunda i sin Journey to Paris p. m. 157. „Hvad Får och „Oxkött i Frankriket angår, så gifver det icke vårt An"gelska efter; dock kan jag ej säga, at det öfverträffar „det; men deras kalfkött är ej at likna med vårt Ängelska, „emedan det är rödt och groft. Jag tror intet folk i „Europa förstår så väl at handtera denna slags mat, som „de Ängelske. Detta var en tid enskylt för Essex; men „nu är det nogsamt bekant, at ingen ting bidrager mera „til hvitheten och mörheten af kalfkött, än at ofta tappa „blodet af dem, och at gifva dem mycken föda af mjölk 
„och mjöl: utom det, at de få di sina egna mödrar. Ge„nom blodens mykna aftappning uttömas de röda kulor „af blodet, och alt blir til et hvitt Serum eller Chylus.

Smör. Uti Canterbury i Kent skal Smöret ej säljas pund-tals eller med vigt, som eljest öfver alt i Ängland brukas, utan det är gjordt fyrkantigt och jämt som et bräde, och säljes efter alntal. Smöret i Essex sades vara en god del bättre och välsmakeligare, än det, som göres i Kent, åtminstone bättre än det, som finnes omkring Gravesend.

Krita til husväggar. Vid en by som låg ej långt från en af kritgroparna, sågo vi et uthus, hvars väggar voro hel och håll|na upmurade af krita, den de skurit i fyrkantiga stycken. Det var endast i hörnen af huset, samt vid dör och fönstergluggar, som de murat med Tegel. En och annan af dessa kritstenar, om jag får så kalla dem, var til en del af luften skämd, och börjat falla sönder; men de fläste voro släta och oskadde. Huset syntes hafva stått i 8 à 12 år.

Hedera. Vid åtskilliga gårdar växte Hedera arborea C. B. tätt vid väggarna, hvarest den klängde sig up, och öfvertäkte ofta hela långa väggen, som såg häraf mycket väl ut. På lika sätt öfverklädde den mångenstäds murar omkring kyrckor, gårdar och trä-gårdar. Murarna af det förr omtalta gamla Clostret voro till en stor del öfverdragne härmed.

Vinranckor. Vid ganska många gårdar i Gravesend, samt vid en stor del af Farmernas eller Landtmännernas och andra så rikas som fattigas gårdar rundt omkring på landet, hade de planterade Vinrankor på de sidor om husen och stugorna, som vette mot Solen, hvilkas väggar denna tiden om året mäst voro öfverklädde dermed.

Kersbärsträn. Kent är den ort, som har namn deraf, at deri växa ej allenast de bästa och välsmakeligaste Kersbär i Angland, utan ock, om någon vil sätta tro til deras berättelse, uti hela verlden. Hvart ut en vil gå, utan för Gravesend, så väl som längre ut på landet, får en mäst allestädes vid gårdarna se stora fält och parcker 
planterade endast med Kersbärsträn. Annorstädes finnas p. 10 stora trägårdar af Äp|len och Päron, antingen planterade särskildt för sig sjelfva, eller ock utblandade med Kersbärsträn. Kersbärsträden äro planterade ordine quincunciali. Marcken under dem ligger på somliga ställen aldeles i linda, och brukas antingen til äng eller betesmarck. På södra sidan om Northfleet kyrka var en stor trägård af Kersbärsträn. Jorden var der emellan Kersbärsträn upplögd, fin gjord och med hvete besådd, hvilket nu stod der så skönt och härligt, som på något ställe, jag sett åt denna kanten. Af jordens bruk och beredning syntes, som hade de länge betjent sig af detta landet til åker. Åtskilliga Äpel-trän voro äfven här planterade. Kersbärsträden voro nu fulla med bär. Jorden lärer varit väl ansadd; emedan det ej kunde märckas, at träden giordt hvetet magrare näst under dem. Vid det jag var öfver i den delen af Essex, som ligger midt emot Gravesend, märkte jag, at mäst allestäds, hvart jag vandrade omkring, fick jag nästan aldrig se något Kersbärs-trä, mindre någon hel trägård deraf, och aldraminst så mycket, som omkring Gravesend i Kent. Detta gaf mig anledning, at fråga folket i orten om orsaken, hvarföre de icke vinlägga sig, at plantera här så mycket Kersbärs-trän, som i Kent, hvilket ligger strax bredevid dem, endast at Floden Thames skiljer dem åt? de lämnade mig til svars: at det ej väl låter göra sig; emedan kersbären i Essex aldrig kunna få den behageliga smak, som i Kent. Andre sade, at emedan jordmonen i Essex är grus (Gravel); så ville ej Kersbärsträden der fort: tvärt emot trifvas Päron-trän der väl. p. 11 Emellan Gravesend och Rochester blef jag ock varse / en ganska stor myckenhet af Kersbärs-trägårdar på ömse sidor om vägen, i synnerhet mot Gravesends sidan. Kersbärs träden voro här planterade icke ordine quincunciali, utan alt i fyrkant. Vidden emellan hvart trä var 8 alnar. Marcken emellan och under träden var öfver alt upbrukad til åker, eller ock besådd med Saint Foin, Clover, eller Vicia vulgaris sativa J. B. At bruka dessa trä-gårdar tillika til åker, tyktes dock hafva någon olägenhet med 
sig; ty emedan bären mognade några veckor för hvetet; så nödgades de, der de ville hafva nytta af bären, på många ställen både rundt omkring och under träden samt emellan dem, trampa ned hvetet, och den sådda säden, hvilket vi sågo vara skedt öfver alt, så med Hvete, som med Korn och Hafra; men der Trägårdarne voro besådde med Clover, St. Foin och Vicia, var ej den olägenhet; emedan desse höslag gemenligen voro afslagne och bärgade, innan bären blefvo fullmogne. Ängelske Trägårdsmästare påstodo, at fruktträden då trifvas bäst, och bära den ymnigaste och mäst välsmakeliga frukt när jorden under och emellan träden hålles brukad och lös, som en upkörd åker, utan at sädesarter, grässlag eller ogräs tilllåtes at växa derpå. De hade skutit och hängt fullt med döda Kajor, Råkor, Kråkor, Skator \&c. up i trädens qvistar, at afskräcka deras Cammerater, at komma dit, antingen at skada träden eller säden. Af dessa uphängde halfrutnade och stinkande foglar, var ej svårt, at på långt håll känna, när någon Kersbärs-trägård var i nägden. Hela denna tiden fördes dageligen hela Båtlaster från Gravesend til London, med Kersbär af flera slag.

\section{Den 8 Julii.}

Åkrar. Många af de åkrar, som lågo i träde, voro så. fulla af qvickrot (Fl. Svec. 105) at det var ynckan värdt. Jag blef aldrig varse något dike på alla de åkrar, som voro i nägden omkring Gravesend, ej eller deromkring: inga vattufåror inga åker-renar. De lägsta ställen voro besådde med Gumrik, som gemenligen hade 12 à 13 korn i hvardera raden. Färgen af jorden och emellan på åkren, var en kött-färg: mullen ganska lös med nog små runda släta flintstenar och kritbitar deribland. På somliga ställen kunde tydeligen ses, at diken behöfts; emedan vatnet der stannat och syrts, så at hvetet stod ganska tunt. Mångenstäds voro trädesåkrarne ej ännu upkörde, sedan säden skars af dem förledit år; utan de lågo aldeles öfverväxte med ogräs. 
Wau. (Linn. Flor. Svec. 439.) som brukas til gul färg, var på åtskilliga ställen updragen med rot och alt, bunden i små kärfvar, och satte mot hvarandra på åkern at torrkas, på samma sätt, som vi göre med hampa och lin. Dess frön voro ännu ej stort mer, än halfmogne. Den växte här dels i myckenhet vildt, dels planterades den med flit.

\section{Den 9 Julii.}

Ängar. De låga ställen i Kent vid Themse strömmen, voro indelte $\mathrm{i}$ ängar och beteshagar. Desse lågo så lågt, at då det var högt vatten $\mathrm{i}$ Floden Thames, var vattubrynet mycket högre än desse ängar och beteshagar; p. 13 men mullbanckarna vid sidan af Floden hindrade vat|net, at öfversvämma dessa låga fält, hvarom förut är talt. Inga trän växa på dessa lågländta ängar, utan i stället för häck eller annan gärdesgård omkring dem, hafva de gräfvit djupa, och ungefär en famns breda diken, hvilka nu stodo mäst fulla af vatten, och gjorde här samma tjenst som annan hägnad, at hindra boskapen at gå deröfver från den ena beteshagen eller ängen til den andra. Arundo (99) vulgaris palustris J. B. och Scirpus (Linn. Flor. Svec. 39.) eller hafssäf växte i största myckenhet i dessa diken, och voro konas bästa föda. De gräsarter, hvaraf växten på dessa ängar förnämligast bestod, voro Alopecurus culmo erecto, (52.) Gramen secalinum pratense elatius, Moris. samt Aira (67.) eller Gramen lanatum Dalech. Desse gjorde här den finaste, tätaste och frodigaste gräsväxt, som någon på sin äng kunde sig önska. Nu slogs här som bäst. Beteshagarna voro indelte i flere afdelningar, så at då boskapen gick den ena veckan på den ena beteshagen, fick gräset växa i 2 eller 3 andra, der boskapen gått förut; och när boskapen varit här en vecka, flyttades han sedan i den beteshagan, som först af alla dessa vid sista omhvarfvet blifvit från deras bete befriad. Härigenom skedde til en del, at gräset gick boskapen midt på benet. I hvar beteshaga var gemenligen en liten damm med slutta sidor eller bräddar åt någondera kanten, 
at boskapen måtte få där vatten; emedan diksbräddarna med flit voro gjorda så branta, at de ej kunde komma åt at dricka dervid. På ängarna fanns ej det minsta tecken til måssa; emedan det täta och frodiga gräset förhindrat så|dant. På de flästa ställen voro ängarna jämna och p. 14 släta, utan någon tufva, men på somliga enkannerligen längre upp mot åkrarna, voro nog tufvor, fast små. Uti en och hvar af dem, som vi gräfde sönder, fans en myckenhet små gula myror. På åtskilliga ställen, der de nyss och i dag slagit hö, funno vi lös mull i små högar nyligen och tör hända i denna vecka til en del hopdragne, och liknade en mullvadshög; men då denna mull utkastades fans den full af förenämde myror. Således äro de uphof til dessa tufvor. Men vi fingo ock tilfälle, at uptäcka en annan orsak til dem här på orten, som var Juncus Acutus panicula Sparsa. C. B. Denna växte på många ställen i ganska stor myckenhet: hade den egenskap, at altid växa i tufvor: rördes ej af något Creatur för des hårdhet och sträfhet skull; fäster i sig damb, strå, och annat, som drifves af vädret. Så snart denna kommer at växa på den jämnaste marck, gör den samma, inom få år, henne full med tufvor.

Gödslens förmerande. Mullen, som upgräfves, vid det förenämde diken göras, fördes efter någon tid af TTarmerne eller bönderne hem, hvarest den lades i fä-gården hvarftals med gödslen, efter boskapen i högar, at ligga der och brinna tilhopa med den samma, som sålunda gjorde en utvald gödsel.

\section{Den $\frac{9}{20}$ Julii.}

Gärdesgårdar. Pá något enda ställe sågo vi gärdesgårdar, som voro gjorde mäst af språtar, hvilka gärdes gårdar skola på somliga ställen här i landet vara nog brukelige. De gö|ras på det sätt, at i stället vi hos oss sätta tvänne stafrar i bredd, sättes där endast en enda, hvilken merendels ej är längre, än högden af gärdesgården. Emellan hvar stör är vid pass en aln. I stället för 
gärdsel brukas smala språtar, eller qvistar af trän, som vridas skiftevis i bugter om stafrarna, på det sätt, at då den ena stafvern blifvit lämnad på vänstra sidan om den horizontelt lagda språten, kommer den nästföljande, at blifva på högra sidan om den samma; och så vidare.

Serratula. Foliis dentatis spinosis. Linn. Flor. Svec. 662 , eller Åkertisteln växte mångenstäds til största myckenhet i den lösa mullen, på vallar. På somliga ställen var han afslagen, at han icke måtte få tilfälle, at mogna och fröas, samt få skäma bårt de åkrar och kryddgårdar, som voro deromkring. Annorstädes hade de den i Sverge brukeliga elacka plägseden, at de lämnade Tisteln orörd, hvarigenom han så mycket bättre fick frihet at utsprida sig alt omkring, och blifva skadelig för den sådda säden och andra Kryddgårds växter.

Vägar. Mäst allestäds på ömse sidor om landsvägar voro Hagtorns häckar, planterade, at en gick eller reste här, som i en Allée eller i en trä-gård. Desse landsvägar hade ej den beskaffenhet, som hos oss i Sverige, nämligen, at vägen låg högre, än landet deromkring, utan är här aldeles tvärt emot, nämligen så, at vägen merendels går djupt ned i jorden til 12 a 3 alnars djup, så at mången skulle tro, det vägen vore endast någon uttorrkad bäck. Gemenligen är på endera sidan om vägen, (om p. 16 icke på bägge) på vallarna eller de höga sidor en gångväg, hvaruppå de, som vandra til fots, gå, så at de icke äro i fara för dem, som köra eller rida. At vägarna äro så djupa, tyckes komma deraf, at här i landet brukas ganska stora vagnar med flera hästar före, på hvilka lägges en ganska stor tyngd. Genom många års körning, synes desse vagnar så hafva ätit sig ned i marcken, och gjort vägen så djup; deremot hafva häckarna, som äro planterade på ömse sidor om vägen; ökat mullen, dels af dam, som fastnadt dervid, dels af de löf, som de årligen fälla, dels af den jord, som liksom en liten vall skåtas upp mot rötterna, då häcken göres, eller omlägges. Men förnämsta orsaken tyckes dock komma af vagnarna; emedan åkrar, ängar, och betesmarker på sidorna äfvenledes 
merendels ligga högre, än vägen. Jordmon, som här består af sandgrus och klapper, och som strax drager vatnet i sig, gör, at desse vägar, ej hafva mycken olägenhet af rägn. Vid mycken nederbörd rinner väl något vatten in på dessa vägar; men det varar ej länge, och är dessutom rinnande vatten utom Floden Thames, här ganska sällsynt.

\section{Den $\frac{1}{2}{ }_{1}^{0}$ Julii.}

Bönor. På hvilkendera sidan jag kom ut omkring Gravesend i Kent, fick jag altid, vid hvar Farmers gård, se något stort Bönland. På somliga ställen voro helt stora åkrar och fält endast besådde därmed. Det var gemenligen det slaget, som har små och smala skidor. På alla ställen jag såg dem, voro de sådde i rader. Distancen| eller vidden emellan hvar rad var oviss; ibland var den til 5 goda quarter; ibland mindre, ända til endast et quarter, som dock syntes för tätt. Det var ej för mycket, då bara 2 quarters vidd var lämnad emellan raderna. Vidden emellan hvart Bön-stånd i raden, var ock ej likadan, utan sådan, som de sådt dem, då de skyndat sig dermed. Jag såg dem stå en half aln från hvarandra. Ibland hade de ock näppeligen mer, än en tums vidd emellan sig. Gemenligen stodo de et quarter från hvarandra, hvilken rymd de säkert behöfde, om ej litet mera. Orsaken hvarföre Bönorne såddes i rader, var dels, at de så mycket beqvämligare måtte komma åt dem, at med en hacka ränsa bårt ogräset emellan dem, samt sedan bättre kunna afplảcka deras gröna skidor, dem de sända til London, at säljas; dels, at de, genom mullens upkastning til stjelken, befordrade Bönornas växt. Sedan stjelken någorlunda hunnit til des längd, afhöggs tåppen, at den ej mera måtte skjuta i längd, utan använda all kraft på Bönornas mognad. De voro sådda på särskildt tid. Hvaraf skedde, at då somlige stycken framviste mogna Bönor, begynte stjelkarna på andra ställen just at slå ut i blommor. Den förnämsta orsaken, hvarföre här sås så mycket Bönor, är, at de dermed föda hästar och svin om vinteren. 


\section{Den $\frac{11}{2}$ Julii.}

Svartmyllans tjocklek. Vid en af Krit-groparna var p. 18 en trägård, som bestod dels af | Kirssbärs- och dels af Valnötte-trän. Här hade de på en sida mot Krit-gropen tagit bârt all svartmyllan eller matjorden, som lảg ofvanpá Kritan, hvilken matjord ej var svart, utan fast mer af en Köttfärg. Tjockleken af svartmyllan eller matjorden var hăr merendels $3^{1 / 2}$ quarter: på somliga ställen $4^{1} / 2$ quarter: annorstäds 3 qv. och dervid. Öfversta superficies af Kritan var ock icke horizontelt, utan gick mera likasom i vågor.

At göra Vin af Russin. Min värdinna, der jag: hade mit quarter här i Gravesend, hade vin, som hon sjelf gjordt af Russin, hvilket var så skönt, at de, som ville anses at vara Kännare af viner, hade svårt före, at skilja det från Madera vin. Mig lämnades Receptet huru det gjordes, som var sådant: Til hundrade skålpund Smirna Russin lägges 45 à 50 Kannor vatten, hvilket sedan röres om 2 gånger hvar dag i 14 eller 16 dagars tid. Russinen kramades derpå väl, och vinet (eller den utkramade saften af Russinen) gjutes i et ankare, som innehåller vid pass 30 Kannor. Sedan tages et stycke brunt papper, som stickes fullt med hål, och lägges öfver sprund-hålet. Något af vinet, eller den utkramade saften, måste förvaras uti et käril, til at fylla upp ankaret, alt efter som det arbetar sig ut, eller jäser öfver. Det måste så stå til dess det aldeles vändt igen at jäsa. Deruppå tages 3 quarter väl distilleradt Bränvin, et skålpund af det bästa Såcker, p. 19 hvitan | af 16 ägg, et unce alun, som är kokadt i et quarter vatten. Alt detta blandas väl tilsammans, och lägges i ankaret, som skakas väl om, sprundas, och lämnas så at stå $i$ et år, innan det tappes af. Vid föregående märckes, 1:mo at när en i början blandar Rusinen och vatnet tilhopa, slås vatnet $i$ et kar eller vatten-så, som bör vara ganska ren. Emellan det de bägge omröras i samma käril, öfvertäckes kärilet med något kläde, at dam och dylikt ej må komma deruti. 2:do Hvispas Sockret och ägghvita, innan alun lägges deri; ty om du skulle 
lägga alun deri tillika, skulle det göra, at äggen ystades. Vatnet, deri alun är kokadt, bör ock stå til dess det blifvit svalt, innan det slås til Sockret och äggen.

At göra et svagare vin. Sedan du på förenämde sätt gjort et starkt vin, slår du å nyo 20 Kannor vatten på de utkrystade Russinen, och låter det stå en vecka, hvarefter det kramas från Russinen, gjutes i et 15 Kanneankare; och när det ej mera jäser, lägges deruti halfparten så mycket af Spiritus vini, Socker, ägghvita och alun, som i det förra. Efter 3 veckors tid kan det vara färdigt, at kunna aftappas. Detta svaga vinet kan ej hålla sig länge, utan sedan det blifvit tappadt i Bouteiller, måste det snart blifva updruckit. Men det starckare blifver dess bättre och behageligare, ju längre det sedan får stå orördt, och det i flera år.

Anm. Vin sålunda gjordt af röda Smyrna-Russin p. 20 blifver sött; men af svarta Smyrna-Russin blifver det liksom Madera-vin.

Strata terræ. Straxt W. om Nordfleet, som ligger ungefär par Ängelska mil W. om Gravesend, var vid landsvägen en stor grop, derutur de tagit dels Pebblestone, at lägga på vägen, dels sand til åtskilligt behof. Här hade vi et ganska godt tilfälle, at på dess branta väggar eller sidor se huru strata lågo, som voro i denna ordning. 1) Öfverst Pebblestone, större och mindre, utblandad med en någorlunda fin tegelfärgad sand, dock at Pebblestone, gjorde det mästa, 5 quarter tjockt. 2) En tegelfärgad något fin sand $1 / 2$ aln. Den var här tjockast, men smalare åt bägge sidor, til dess det aldeles förlorades uti Pebblestone. 3) Pebblestone utblandad med en någorlunda fin tegelfärgad sand, som n. 1. en aln; dock var tjockleken af detta stratum ej allestäds likadan; ty här midtpå var det smalast, men emot bägge sidorna blef det tjockare. 4) Samma sand, som n. 2. et quarter, förlorade sig likaleds i Pebblestone. Eljes voro altid strata af denna sand hel rena och fria från Pebblestone. 5) Pebblestone utblandad med nog mycket af den tegelfärgade sanden, sex quarter. 6) Samma sand som n. 2. en aln; men vi kunde klarligen 
se, at denne ej kommit hit på en gång, utan småningom; ty den var delt i helt små strata. 7) En mörck tegelfärgad p. 21 eller brunaktig lera 4 tum. Denna låg på somliga ställen näst ofvanpå Kritan: på andra ställen låg sanden n. 6. näst ofvanpå kritan. 8) Krita $2^{1} / 2$ quarter. Detta var et det raraste vi ännu sedt i någon sandgrop. Det var mäst krita; men ock nog utblandad med små Pebblestones. Åtskilliga stycken af kritan voro utanpå hel släta, til skapnaden ovala eller runda, och hade samma figur, som Pebblestones; men då de slogos sönder, bestodo de af bara krita. Detta hvarfvet var ej lika tjockt öfver alt; utan smalnade af, emot bägge sidor, til dess det aldeles förlorades. 9) En tegelfärgad gröfre sand, mycket utblandad med Pebblestones, 3 alnar. 10) Krita utblandad med fin ljus sand, små Pebblestones, samt en myckenhet af söndermalna mussel- och Snäcke-skal, 3 quarter tjockt; men det var mångenstäds smalare, ända til et quarter. 11) En hel fin ljus på gult stötande sand, fri från alla heterogeneis, 2 alnar tjockt; och ho vet, huru långt ned? emedan det nedrasade gruset, sanden etc. hindrade oss, at se längre ned. Obs. at tjockleken af et och hvart af desse hvarfven ej var likadan, utan ibland tjock, ibland smal, ibland aldeles försvann, likasom hade någon med en skåttkärra i forna tider stjelpt af desse strata hit: hvilket alt kan tilskrifvas vågens olika sqvalpning, stormar, med mera. Från denna backen kan vara et eller halfannat musquet-skått til nästa kritgrop, hvars sidor bestå af bara krita, och är 12 och flere famnar djup; så at en således kan vara säker, p. 22 at hela denna nyssbe/skrefna backe med sina många strata, hvilken ligger högre, än superficies af backarna vid kritgropen, för visso står på krita. Alla strandbackarna vid Thames $1 \frac{1}{2}$ musquet-skått nedanför denna backe, bestå af bara krita, antingen ren, eller utblandad med Flintsten och små Pebblestones.

Svin. At hindra, det ej desse kreatur hvarken måtte böka upp jorden, eller tränga sig in i åkrar, genom häckarna, voro de uti Kent och Essex både ringade i trynet, 
samt buro på halsen deras triangel-formiga trä-ok, aldeles på samma sätt, som det sker hos oss här i Sverige.

Alm. När vi i dag spatserade ned vid stranden af elfven nedan för Nordfleet, hvarest mäst hela elfsbackarne bestå af krita, med isprängde Flintstenar här och där, samt svartmylla, fast af en tegelfärg der ofvanpå; så märckte vi, huru de stora Almar, som växte i häckarna på elfsbacken, hade gått med sina rötter genom svartmyllan, som här var en aln tjock, eller mera, ända ned til kritan; men så snart de råkat den, så fants ganska sällan, at de trängt sig ned i den samma, utan började då löpa horizontaliter ned i svart- eller den tegelfärgade myllan, ofvanpå kritan. Vi märkte detta på mer än många Almar. Kritan lärer vara för hård för deras rötter. Det var endast på et enda ställe, som jag kunde se, at et par Alm-rötter trängt sig ned $\mathrm{i}$ en springa $\mathrm{i}$ kritan til 2 à 3 quarters perpendiculairt djup. Bac|ken hade rasat ned, eller blifvit underäten af vatnet $i$ floden; så at jag helt tydeligen på ganska många trän kunde se detta.

\section{Den $\frac{12}{23}$ Julii.}

Om morgonen reste vi öfver floden til Essex, at se huru der såg ut.

Åkrar. På de lågländta ställen vid floden Thames, som voro bakom mullvallarna (se T. I. p. 476), var landet med diken genomskurit, och indelt i åkrar, ängar och beteshagar. En del af åkrarna lågo nu i träde; voro lagde hel flata; men fulla med vattfårar, längs efter, ungefär 5 alnar emellan hvardera fåren, jordmon var en grå lera. Några små Pebblestones syntes här och där. På somliga ställen voro stora stycken besådde med Bönor, hvilka tycktes trifvas här bättre, än på något ställe jag i Ängland sett. De voro sådde med öppen hand, och ej i rader. På åtskilliga ställen var sått Hvete, hvilket stod härligt. Åkern var der lagd i små ryggar eller uphögningar, af par alnars bredd hvardera: ryggarna nog låga: inga renar utpå åkerstyckena. Men af alla sädesarter var 
gumrik här det mästa, som nu stod skönt och härligt; stjelkens längd 5 à 6 quarter, 2 och flera stånd af en rot: uti de fläste ax 27 strida korn: åkern lagd i Broad-land, ungefär 10 alnar emellan vattufårorna. Alla desse åkrar, ängar och beteshagar voro med diken afskilde från hvarandra; så at hvar Farmer hade sin egendom, äfven här,

p. 24 skild från grannar|nas, at han fick ansa och vårda den, som han bäst ville och gitte.

Hafre. Vi sågo på åtskilliga ställen i Essex stora åkrar, hvilka hel och hållne voro besådde med hvit hafre. Af annan slags hafre funno vi icke. Åkrarna àt denna kanten voro mera af svartmylla, än omkring Gravesend uti Kent: jordmon var tegelfärgad. Ganska mycket små Pebblestones, samt andre små flintbitar lågo på en stor del af åkrarne i Essex. På somlige åter var mycket litet deraf. Förnämsta afsigten, hvarföre de så i Essex, som i Kent, så en myckenhet af Hafre, är, at de fordra hästar dermed.

Gårdar: Hus. Vi fingo, under det vi i dag spatserade omkring uti Essex, se en stor hop af Farmers gårdar, hvilka här hade samma utseende, som på de öfriga ställen i Ängland, der vi varit, nämligen, at de liknade Herregårdar mera, än bondgårdar. Husen, som Farmerne sjelfva bodde uti, voro merendels af tegel, gemenligen par råningar höga, täckte mäst med taktegel; dock voro ock en stor del, som fingo låta sig nöja med halmtak, hvilka här gjordes brante och tjocke. Dagsverks-karlar, hvilka mäst äro det samma, som hos oss i Sverige Torpare, hade somligstäds hus, hvars väggar bestodo af Korssverke med Ekbräder slagne utanpå. Stenhusen voro utanpå kalkslagne och hvita. Strax vid gården var altid Logen och Ladan, hvilken gemenligen var på lika sätt gjord, som i p. 25 Upland uti Sverige, | nämligen alla under et tak, Logen midt uti och Lador på ömse sidor, utan någon vägg eller skildnad deremellan. Bägge Ladorne voro utan golf; men Logen hade golf af bräder, at tröska på, hvilket golf var merendels lagdt på bara marken. Logen hade stora dörar på ömse sidor, at de kunde på ena sidan köra in med 
hela sädes lasset och lassa af uti Logen, och sedan köra ut på den andra sidan. Hela huset, både logen och ladorne hade väggar af korssverke med ekbräder slagne horizontaliter utanpå, samt et högt och brant tak, täckt med 2 à 3 quarters tjock halm. Bredevid Logen, eller ock ibland för sig sielf, hade de et litet skjul, som stod på stolpar, med halmtak på, stundom väggar dertil af ihopvridna språtar, uti hvilket skjul de hade sina plogar och andra åker-redskap; gemenligen hade de ock sådana skjul för deras vagnar och åk-don. Emot och upför stugu-väggarne voro ofta planterade Vinrankor, hvilka öfvertäckte hela väggen. Inga hölador brukades hvarken vid gården, eller ut på ängarna, utan höet sattes alt i stack.

Krita. De som här bodde, berättade, at här och där vid stranden af Thames uti Essex äro kritbrott, der de taga krita; men at samma krita icke är så god, som den, som gräfves i Kent. Vi sågo, at de på några ställen fört krita ut på trädes åkrarna, hvilka mäst här lågo på högden, och at de lagt kritan der lasstals, hvarest hon ännu var antingen outbredd, eller ock redan utspridd, och dels äfven nedkörd. Jag / frågade, om de mycket brukade här göda åkern dermed, och hvad nytta den gör? Mig svarades, at de nog bruka den til gödning på åkern: at den i synnerhet är god på kall grund: at då de gödt åkern härmed en gång, kunna 7 och flere år gå förbi, innan de göda å nyo: at de funnit mångfalt bättre, at bränna kritan först til kalk och så föra samma kalk ut på åkern; men at det samma äfven är långt kostsammare. Vi sågo här och där på de åkrar, som lågo på de lågländta fält vid Thames, at de varit gödda med krita.

Råg. Vi blefvo i dag varse åtskilliga stora Råg-åkrar uti Essex, hvilka stodo nu ganska vackre. Jag frågade folket, om de bruka baka bröd af denna säd, eller hvarföre de så den? de svarade, at inga andra, utom fattigt folk, bruka den til bröd; men förnämsta orsaken, hvarföre de så den, är, at de föra den til London, der de sälja den åt handlande, som deraf utskeppa stora quantiteter utomlands, at der försäljas. Jordmon här i Essex, 
som på denna kanten är mycket torr, nog sandig och full med Pebblestone, synes nästan vara mera tjenlig för Råg, än för Hvete. På sandåkrarna voro Rågstånden 2 alnar långa; de fläste axens längd 4 à 5 tum; Rågen skön och härlig var alt sådd i 10 alnar breda Broad-land.

Trappor, dem vi betjente oss af, at stiga uppå hästar, och hvilka tilförene T. I. p. 297 äro beskrefne, voro här p. 27 mäst vid alla går/dar. På lika sätt hade de sådana uti Kent mäst allestäds. Qvinfolken hade härigenom ganska beqvämt, at komma på hästen.

Gödsel-stackar. På samma sätt som förut T. I. p. 251. 252. är nämnt om gödsel, at den lägges $i$ högar at rutna, sågo vi äfven i dag, så vid hvar Farmers gård, som ofta ute vid åkrarna. Gödselen, som blifvit samlad i fägården, var tilhopa kastad i stora fyrkantiga högar, at brinna eller rutna tilsamman. Gemenligen och merendels var den lagdt hvarftals af boskaps dynga och torf eller mull, så at, då de lagt et hvarf af torf eller mull nedast, lades derpå et hvarf af obrunnen boskaps dynga, som til största delen var bara halmbyssie, och så skiftevis torf och dynga. Ganska ofta voro desse gödsel-stackar lagde ute bredevid någon åker, at vara så mycket närmare til hands sedan; men den var ganska sällan lagd på sjelfva åkern, utan mäst strax bredevid, der det dock tyckes varit nyttigare, at lägga den på et stycke af trädesåkern, efter den ändteligen skulle föras ut under öppen himmel; emedan det ställe, som gödselen legat på, kunnat blifva gödt endast af den saft, som runnit ned deraf. Vi mätte en sådan gödsel hög, lagd bredevid en åker, och befunno den vara 51 alnar lâng, 3 alnar bred, och endast $1 \frac{1}{2}$ aln hög, lagd hvarftals af torf och dynga.

Genista spinosa Raj. syn. 475. Växte här på sandp. 28 hedar i grufvelig myckenhet; så at den | öfvertäckte mäst hela sandheden. De högsta stånd voro par alnar. Den låg här på många ställen afhuggen, och i stora högar. Mäst vid hvar gård, i synnerhet hos de fattigare, voro stora högar deraf, hvilken de brukade i stället för annan ved til bränsle. 
Hägnad om åkrar. Hela Landet åt denna sidan var på sätt som i de öfriga delar, der jag vistats af Ängland, indelt i åkrar, ängar; betshagar, utmarker etc. som mäst hvardera var omstängd med en häck af hagtorn, deri sedan åtskilliga andra löfträn äfven tagit sitt hemvist, som Alm, Ek, Ask, Slån, Biörn-bärs buskar, Ligustrum, med flere; dock hade Almen på alla orter i Ängland företrädet fram för andra trän, undantagande Hagtorn, hvaraf häckarna voro. Vi sågo här på et och annat ställe häckar omkring någon sida af åkrar, som bestodo af bara Alm. Vi blefvo här och där äfven varse någon Ek, som i Kent omkring Gravesend är rar at få se. Bok och Afvenbök (Carpinus) syntes hvarken här, eller har jag sedt nảgon deraf i hela Kent, som bägge dock växte i myckenhet i Hertfordshire. På något enda ställe hade de någon gerdesgård af språtar ihopvriden, sådan som är beskrifven pag. 14 . Eljest voro häckarna här mångenstäds nog usle, så at de ej kunna stå emot sådana bångstyriga kreatur vi hafve i Sverige; men på de ställen, der häckarna voro i sit rätta stånd, kunde de altid hindra den ostyriga|ste oxe eller häst, at komma in $\mathrm{i}$ åkern. De kunde väl på många ställen hafva så svaga häckar, emedan där på betesmarkerne gifves en sådan ymnighet merendels af godt och skönt bete, at kreaturen behöfva ej gå, at söka bättre. Dessutom födes Svinen merendels hemma vid gården, och gå sällan långt från den samma. Häraf sker, at mångenstäds vid häckarna står gräset $i$ största frodighet, och ej afbites af något kreatur, samt örterna ut med vägen aldeles orörde.

St. Foin. Vi sågo en och annan täppa på högderna, som var besådd med bara Saint Foin, hvilken dock nu var afslagen och hemförd. De, som bodde här på orten, berättade, at de på långt när icke sår så mycket Saint Foin i Essex, som i Kent; emedan den där ej vil trifvas så väl, som i sidstnämde ort. Mon derföre, at i Kent äro mera kritbärg och kritbotten, än i Essex? Utom denna blefvo vi här och där varse täppor af bara Clover, som 
äfven nu var slagen och bårtförd. Fåren voro ock redan släpte dit at beta på stubben.

Bohvete. Här och där syntes stora åkrar, hvilka voro besådde med bara Bohvete. Jag vet mig aldrig sedt det härligare, än här. Det stod nu som bäst i blomma; men hade ej ännu satt frö. Jordmon var en torr sandmylla, full med smả Pebblestones.

p. 30 Åkrar. På alla åkrar, som lågo här på högderna, var ej något dike; ej eller någon åker-ren, utan endast vid sidorna af häckarna; men den samma så smal, at ingen kunde slippa der fram, utan måste då nödvändigt gå på åkerstycket. Hvar Farmer hade sina åkrar, ängar och beteshagar afskilda för sig, utan at hafva at göra med andra. Somliga täppor voro här besådde med Hvete, andre med Råg, andre med gumrik, andre med Hvithafre, andre med ärter, andre lågo i träde. Jag blef här på högderna ingenstäds varse, at Bönor voro sådda annorstäds, än vid gårdarna: Trädesåkrarna voro mycket väl ansade, och mullen på dem helt fin. På somliga låg krita utförd; annorstädes var gödsel utförd, och lagd lasstals, ännu outbredd. På slutten af en backe voro trädesåkrarna lagde i alns breda och half alns höga ryggar (stitches), at genom körning så mycket bättre utrota ogräset.

Ormbunkar (Pteris Linn. Flor. Suec. 843) hade här samma oart, som i Sverige, at då de en gång begynt växa på en åker, äro de sedan svåra at utrota. Jag såg i dag på flera ställen, at den växte så väl ut på trädesåkrarna, som bland rågen, frodigt och i stor myckenhet.

Ärter. Vi sågo på åtskillige ställen stora ärt-åkrar. Ärterna syntes stå härlige. De voro ej sådde i drill eller p. 31 rader, utan med full $\mid$ hand, såsom hos oss vanligt är; inga ruskor eller qvistar och sådant fants under dem, utan de lågo på bara marken; skidorna voro redan tämmeligen matade. Jag öpnade några, men fann i hvardera en grufvelig myckenhet små maskar, och, som tycktes, ej alla of et slag. Jag räknade öfver 170 maskar i en enda skida. I de mäst matade skidor fans de mästa maskar; men i dem, som voro litet matade, syntes få, och merendels 
inga, somliga af de fullmogna skidor voro dock äfven fria för maskar. På en annan ärtåker, der ärterna ännu voro mycket litet matade, kunde vi ej finna någon mask $\mathrm{i}$ skidorna. Tör hända, at de insecter, som varit orsaken til de många nyss omtalte maskar, redan slutit sin kårta lefnadstid och dödt bårt, när desse senare ärter började blomma, och de sålunda sluppo denna ohyran. Lycklig den, som så kan så sin säd etc. at de Insecter, som pläga på åkern och landet tilfoga denna skada, komma antingen för bittida eller försent.

Om afton foro vi tilbaka hem til Gravesend.

\section{Den $\frac{1}{2} 3$ Julii.}

Et sätt at rida. I Ängeland bruka de mycket ett sätt at rida, som är mäst ovant och obrukeligt hos oss $\mathrm{i}$ Sverige. Det är, at två personer, den ena en mansperson, den andra et qvinkön sitta bägge på en och samma häst. Karlen sitter frammanföre, styr och regerar hästen på vanligt sätt; men Fruentimret | eller qvinsperson sitter bakom honom på samma sätt, som qvinfolck bruka sitta til häst, nämligen tvärts öfver. Det är här ej sällsynt, at se dem så komma ridande, ej allenast i små städer och ute på landet, utan äfven midt i London; men i synnerhet då de om sommartiden rida ut om staden, at förlusta sig.

\section{Den $\frac{14}{2}$ Julii.}

Hö-bärgningen, Höstackar. - Ängarna voro nu til mästa delen slagne; på några ställen höllo de dock än på at slå: På ängen handterades höet på samma sätt, som förut är nämnt i denna Resebeskrifning T. I. pag. 438. När det var väl torrt, sattes det i famns höga, och, ned vid marcken, famns breda vålmar, hvadan det sedan förcles til det rum der stacken skulle göras. Om ängarna lågo nära til gården, fördes höet hem, och sattes der i stack; men lågo de något godt stycke frạnn gården, sattes stacken på ängen. På högländta ställen bestod höet mäst af St. 
Foin; men på lågländta af gräsarter. Höet kördes til stacken med vagnar: men der ängarna voro släta, betjente de sig af et behändigt sätt, som bestod deri, at de hade et rep, som var fäst i järnstaklarna eller järnkedjan, dermed hästen drog. Detta rep sattes rundt omkring vålmen, och sågades likasom in bakpå vid nedra delen deraf, sedan fästes repet med en krok i kedjan, då hästen släpade hela vålmen til stacken, som då gjordes på ängen. Der

p. 33 syntes litet eller intet hö, som lämnades efter | vålmen pả ängen, utan vålmen kom mäst hel och hållen til staden. I stället för bro fyllde de diken med hö, deröfver de körde. Höstackarna gjordes antingen runda, som Fig. 1 eller aflånga och i skapnad af et hus, som Fig. 2. Alt

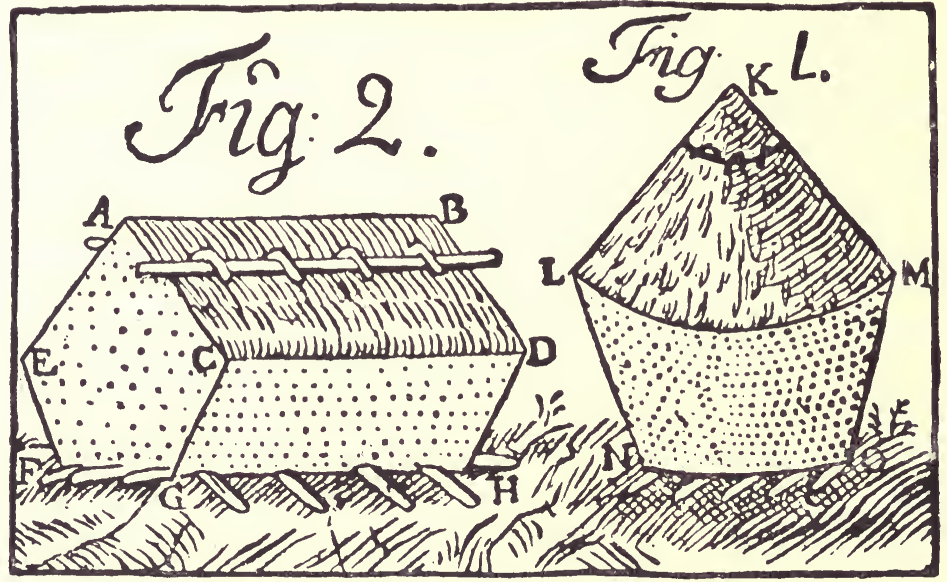

som stacken gjordes, så trampades höet starkt, at det måtte ligga stadigt. I början, och då stacken än är låg, hafva de hästar på den samma, at trampa den; sedan högre upp förrättas trampningen af flera Karlar. När de fått stacken färdig i endera af förenämde figurer, skäres sidorna LN och MO uti fig. 1. och EF och CDGH uti fig. 2. med en särdeles dertil gjord knif, släta eller jämna, dels at boskapen ej må så lätt kunna rifva af honom, dels at rägn och väta ej må fastna derpå, dels at den måtte 
se så mycket bättre ut. Jag vil för tydelighet kalla de öfre och sluttande sidor $\mathrm{AE}$ och $\mathrm{ABCD}$ Fig. 2. och KL, KM Fig. 1. tak, och de nedre och tväre LN, MO,| Fig. 1. p. 34 och EF, CD GH sidor eller väggar; stackarna göras altid så, at de äro bredast vid takbandet, och smalna sedan med deras sidor mer och mer af, ända til botten. Detta alt sker, at rägn och väta, som kommer drypandes från deras tak, ej må röta väggarna eller sidorna. Nu följer, huru taket på dem göres. De täckas gemenligen med halm, sum här tages af Hvete; emedan de räkna det bäst. Någon gång täckas de med hö, men ej så ofta. Då resa de en stege emot höstacken, at den kommer at ligga långs efter taket; sedan taga de en smal halmkärfva, som är med halm ombunden vid hvardera ändan. Denna lägges nederst vid takbandet LM, CD, på det sätt, at den kommer at ligga horizontelt. Sedan sticka de en smal käpp genom hvardera ändan midt igenom denna halmkärfva in i stacken, at kärfvan må ligga stadigt. På denna kärfva lägges sedan lös halm til en tvärhands tjocklek, eller et quarter, eller ock litet mera, sålunda, at smala ändan af halmen vändes uppåt mot toppen af stacken, och den tjocka lägges tvärt öfver ofvannämde kärfva; dock så, at ändarna gå litet utanför de nedre sidorna af stacken, at hindra, det vatnet, som vid våt väderlek rinner ned, ej må hälla på samma sidor. Sedan de lagt halmen sålunda, hafva de til hands långa smala språtar, som äro hvässte i ena ändan. Af dem tages en, som stickes med den hvassa ändan ned i stacken på ena sidan af den pålagde halmen; dock mot öfra delen af den samma; språten vikes så| tvärts öfver halmen; men at få honom at ligga qvar, och p. 35 tillika fästa halmen, hafva de en annan språta af 4 à 5 quarters längd, hvilken är hväst på bägge ändar, och midt på litet utskuren på en sida, at den kan vikas tilhopa, som hosstående Figur, utan

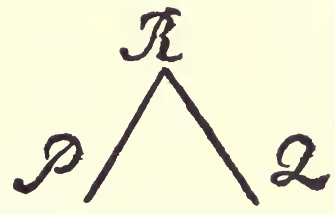
at gå af. Denna språta $\mathrm{PQR}$, sålunda viken, sättes på det sätt ned i stacken, at ena ändan $\mathrm{P}$ går på ena sidan, och 
den andre $Q$ på andre sidan om den långa tvärt öfver halmen lagde språten, krystes eller slås så ned den vikta språten $\mathrm{PQR}$, då den fäster den långa språtens ända och tillika trycker ned halmen, samt håller den fast. Sedan tages ny halm, och lägges ofvan för denna på föreskrefna sätt fästa, på det sätt, at storändarna af den nya halmen komma at ligga öfver och täcka lilländarna af den nedanföre förr lagda halmen, tillika med språten, som var satt tvärtöfver den. På denna nya halm sättes ingen språte, utan man tager ännu annan halm, och sätter där litet ofvanföre, och då först fästes den samma med en lång språte tvärt öfver, på sätt, som ofvanföre är beskrifvit. Härmed fortfares upföre, til dess en kommer til toppen, och äfven där fäst halmen. Sedan flyttes stegen litet mera på sidan, och börjas åter ned vid takbandet, at täcka på föreskrefne sätt, tätt in til det, som redan är täckt, och fortfares så upp àt. Den raden, som täckes hvar p. 36 gång, från | takfoten upp til toppen, innan stegen ömsas, är så bred, som karlen kan nåka til at lägga, då han står på stegen. En eller par karlar äro nedanföre, som tilreda halmen, och gifva den upp åt den, som täcker, hvilken lägger denna halm bredevid sig, til des han behöfver honom. At han må hafva halmen desto bättre til hands, har han 2:ne stycken käppar af 5 à 6 quarters längd, dem han sticker ned i stacken, i bredd uti en horizontel linea,

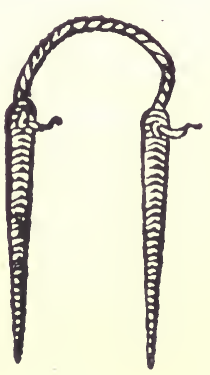

vid pass en aln från hvarandra. Ofvanföre och mot desse lägges halmen; men om det blåser hårdt, har han ännu dessutom 2:ne andra käppar, hvardera af en alns längd, hvasse i ena ändan, och tilhopa fästa med et band i den andra, af hosstående Figur. Han sticker dessa käppar ned i stacken, den ena på nedra sidan om halmen, och den andra på öfra sidan, då bandet, som är emellan dem, kommer at ligga tvärt öfver halmen, och håller honom fast, at han ej kan blåsa bårt. Så snart karlen lagt 2 rader af halm, eller ömsat stegen 2 gångor, har han en någorlunda tjock käpp eller 
kafle af par alnars längd, dermed han bultar ned halmen, at ligga jämn, samt sedan stryker långs ned efter halmen med den samma, begynnandes öfverst vid toppen af stacken, och så nedåt, då han ock sopar bårt all den lösa halmen, som sitter på stacken, och gör halmtaket på den hel slätt. Derefter fortfor han at / täcka den öfriga delen p. 37 af taket på stacken på föreskrefne sätt. Nedre sidorna (BD och CE) stå aldrig perpendiculert, utan äro altid gjorde så, at ju mera uppåt, ju mera luta de utåt, så at den är smalast ned vid jorden, och bredast upp vid takbandet. Både de trinda och fyrkantiga hafva denna egenskapen, hvilket förekommer, at ej vatten, som dryper ned från takfoten, kan falla på de nedra sidor och röta dem. Ingen stång sättes midt uti en stack, som hos oss. På somliga ställen göra de mycket stora och höga stackar. När då stacken blir så hög, at de ej mera kunna hinna kasta höet nedifrån up til karlen på stacken, göres på endera sidan af den samma en bro af bräder, eller en dörr, som ligger på 2:ne stänger, hvarpå en karl ställer sig, til hvilken höet först kastas, som sedan vidare befordrar det up på stacken. När stackarna täckas med bara hö, ibland ock när de täckas med halm, göras de ofta släta utanpå med bara en räfsa, så at de dermed likasom kamba nedefter stacken utanpå. Skapnaden på höstackarna, och sättet at göra dem, var allestäds här på orten samma, som nu beskrifvit är. De mästa höstackar voro här täckte med halm. Up vid röstet af höstacken ligga altid språtarna bara och otäckte, och komma sålunda där at synas. Stackarna voro altid så lagade, at taket blef mycket brant, på det rägn och vatten så mycket snarare måtte rinna af.

Järngafflarna, som de betjente sig af, voro af àtskillig storlek och längd. På dem, hvar|med de kastade upp höet på stacken, var sjelfva järngaffeln 2 quarter lång, samt et quarter emellan grenarna, fäst vid skaftet med en järnring, som på en ispik: skaftet 2 famnar långt; dock alt som en ville. De små gafflar, at kasta ut höet på ängen med, voro af 1 quarter och 1 tums längd, samt 
4 tum emellan gafflarna; skaftet efter behag. Grenarna på alla desse gafflar voro ej rake, utan litet krokuta. Figur på en sådan hö-gaffel kan ses uti Herr Archiaterns och Riddarens Linnær Skånska Resa p. 303. fig. B.

När de gjorde här en höstack, stod gemenligen en karl, och med en af förenämde järntjufvor kastade upp höet. En eller par karlar togo mot det och bredde det jämt ut på stacken, som de funno bäst. Sedan voro ofta 4 stycken, hvilka ej annat gjorde, än beständigt trampade det. Med en räfsa gjordes de nedunder eller vid de nedra sidor släta, och äfven räfsades bårt höet, at stacken nederst måtte vara så mycket smalare, och vidare uppåt.

\section{Den $\frac{1}{2} \frac{5}{6}$ Julii.}

Om morgonen spatserade vi från Gravesend til Rochester, hvilket är belägit 7 Ängelska mil från den förstnämda orten.

Utsigten af Landet. Vi hade hela denna vägen en omväxling af åkrar, ängar och Trägårdar, alla omplanterade med Hagtorns häckar, däri stodo allehanda slags p. 39 löfträn, som Alm, Fläder, Björnbärsbuskar, Ask, Ek,| Benved (Cornus), Asp, Hedera arborea C. B. Slån, Liguster, Alster (Euonymus), Acer campestre \& minus C. B. låto sig infinna. Här och där låg någon vacker gård. Landet var här, som på de mästa orter, där vi varit uti Ängland, icke jämnt och slätt, utan en beständig kedja och omväxling af något höga och lång slutande backar, samt dälder där emellan. Desse högder hade allehanda slags figurer, ibland runda som Limpor, ibland aflånga, ibland annorledes. Inclosurerne eller åker och ängs täpporne lågo så väl midt ofvanpả och på sidorna af backarna, som ända ned til och uti dälderna. På somliga ställen voro desse backar nog stupande. De bestodo alla af bara krita, hvilken endast hade ofvanpå sig en matjords skårpa til $1 \frac{1}{2}, 2,21 / 2$ ja 3 quarters tjocklek, dock merendels ej mera, än mot 2 quarter tjock, hvilket vi tydeligen kunde se hela resan, hvaräst Landsvägen lopp öfver desse backar, 
och de kommit at gräfva på sidorna om vägen. Til förtigande, at det samma viste sig i alla kritgropar, som här och där voro upkastade. På hela denna resan kunde vi ej se det ringaste tecken til någon flytande och rinnande bäck eller å, undantagandes floden Midway, som stryker förbi Rochester. Sådane rinnande vatten lära ock på kritbärgen och i nägden af dem vara nog sällsynte. Mästa delen af de inclosurer, eller med häckar omplanterade täppor, som vi i dag sågo, voro åkrar, besådde dels med Hvete (Triticum hybernum aristis carens C. B.), Gumrik, Hvit-Hafre, | Bönor eller Ärter. Jag vet ej af hvilketdera slaget det var mer, antingen af Hvete eller Korn. Det syntes, som det var mera Korn åt Gravesends sidan, och at Hvetet hade öfverhand omkring Rochester. Af Hafre var minst. Stora Hummel-gårdar blefvo vi ock varse på somliga ställen. Åt Gravesends sidan voro vidlöftiga inclosurer eller täppor planterade med Kersbärsträn; men mot och vid Rochester var ej så mycket däraf. När vi kommit en mil från Gravesend, tog en liten skog emot, hvilken bestod af allehanda ofvannämde löfträn, hvartil vi fingo lägga som en stor raritet 2:ne trän, dem vi ej förut haft den fägnad at få se vildt växande i Ängland, nämligen vår Björk, som stod uti et litet kärr, samt Enbuskar, af hvilka sista vi sågo åtskilliga på en kritbacka, där de växte på skarpa kritan, och hade näppeligen et halft quarters svartmylla ofvanpå kritan; men syntes dock stå tämeligen frodigt.

\section{Trägårdar af Kersbärs- Äpple- Päron- och Valnöt-} trän. Jag nämde nyss förut, at vi sågo här en stor myckenhet Trägårdar, planterade med Kersbärsträn, och andra fruktträn. De anmärkningar jag gjordt vid Kersbärsträn här på orten, äro förut anförde vid den 7 Julii. Hvad de andra frukt-trän angår, så blefvo vi likaledes varse en myckenhet Äppel- och Päronträn, planterade antingen i samma trägård med Kersbärsträden om hvarandra, eller ock för sig sjelfva allena. Jorden under och emellan dem var | på samma sätt, som något förut eller vid den 7 p. 41 Julii är nämnt om Kersbärsträden, upplögd, och brukad 
til åker eller äng, så at desse fruktträn stodo midt iblancl säden eller gräset. De voro ock mycket skickeligare än Kersbärsträn, at säd såddes under och emellan dem; emedan säden merendels blef så snart, om ej förr, mogen, som deras frukt, och således afskars, då de ej behöfde trampa ned säden vid fruktens hämtande. Vid sidorna af desse trägårdar, samt ofta vid sidorna af åkrar, och hemma vid gårdarna, stod nog af stora Valnọtt-trän, dit planterade, och nu fulla med frukt.

Strata terræ. Det sades litet förut, at mäst alla backar emellan Gravesend och Rochester bestodo af bara krita, endast at öfverst låg et tunt stratum af svartmylla; dock blefvo vi på 2 à 3 ställen varse, at somlige af dessa kritbärg hade öfverst på sig, ej krita, utan en backa af sand, stundom utblandad med små Pebblestones, hvilken sandbacke låg ofvanpå kritbärget, som var där under; och var märkvärdigt, at de kritbärg, som hade en sådan sandbacke eller samling af sand på sig, voro gemenligen de högsta backar af alla vi sågo denna vägen; men huru denna sand i forna tider kommit hit, antingen genom nảgon flod, eller på hvad sätt, kan jag ej säga. Vi funno ock, at sanden $i$ en sådan backa, ofvanpå kritan, ej var af enahanda slag, utan bestod af flere arter, som lågo hvarftals på hvarandra. Jag vil anföra deras läge i en

p. 42 af desse backar, där landsvägen | gick midt igenom. 1) Öfverst svartmylla af $1 \frac{1 / 2}{2}$ à 2 quarters tjocklek, men nog utblandad med sand. 2) En gul, hårdt i klimpar hopsittande fin sand, $5 \frac{1}{2}$ quarter. 3) En ljusgul hel fin lösare sand, 6 quarter. 4) En ganska fin grå sand, 6 quarter, och ho vet huru långt, emedan botten af gropen hindrade oss at komma längre ned? men at den icke måtte gå för mycket djupt, kunde slutas däraf, at backarna på ömse sidor nedanföre bestodo af bara krita, som vi sågo på ömse sidor af landsvägen, hvilken var ingrafven i dem. Här och där, i hvardera af ofvanupräknade sand-strata, satt någon liten bit, jag vet ej hvad jag skal kalla det, som såg ut likasom det varit en bårtrostad spik. 
Hägnad om åkrar, ängar \&c. Omkring mäst alla inclosurer, som åkrar, ängstäppor, trägårdar, m. m. voro planterade häckar af Hagtorn; men de voro på somliga ställen nog släta. På något enda ställe var någon Risgärdesgård: stundom, fast sällan, fick en ock se någon sådan språtgärdesgård, som är beskrefven förut pag. 14 .

Åkrarne, vi denna dag sågo, lågo både öfverst på högderna, och på deras sidor. Jag nämnde nyss förut pag. 39. hvad sädesarter voro sådde på dem. Aldrig syntes på och vid dem något dike, inga vattufåror, hvilka bägge ock kunde vara här mindre nödige; emedan kritjorden lärer draga alt vatnet ned i sig, i | anseende hvartil, vi ock icke blefvo varse det ringaste flytande vatten på hela denna vägen. Jag såg ock inga diken vid landsvägen, til tecken, at vatnet lärer icke länge kunna hålla sig där qvar. Om vid någon enda häck ibland fants något dike, syntes det endast vara gjordt, at få mull därutur, til at göra en bank, hvaruppå häcken blifvit planterad, samt at få mull, at kasta på rötterna af Hagtornen, som blifvit satt $\mathrm{i}$ häcken. Inga åkerrenar ut på åkern, utan endast hel smala vid sidorna af den samma ut vid häckarna; men så smala, at en svårligen kunde komma där fram, mindre slå där något hö. På mästa delen af desse åkrar låg fullt med små Pebblestones. Landet låg hel jämnt och slätt, så väl det som var besådt med hvete, som det med andre sädesslag, utan några ryggar eller uphögningar. Ganska mycket ogräs var på en stor del af deras trädes åkrar: somlige voro så fulla af Qvickrot, som hade den varit dit sådd: andre fulla med vill Vallmoge, åtskillige slags tistlar, samt andra ogräs. Men det var icke at undra öfver; emedan åkern på sådana ställen ända til denna tid på året blifvit lämnad okörd. Af et sådant åkerbruk är ej svårt at begripa, hvi deras Hvete- KornHafre- Ärt- och Böne-åkrar stå så fulla med vill vallmoge och andre ogräs, nämligen til en del däraf, at de så illa handtera trädesåkrarna, och lämna ogräset all frihet at få fröa och så sig. Jag märkte, at de brukade mycket, at släppa hästar, får och kor at beta på de samma; men | 
p. 44 med det de mente sig hafva en nytta, gjorde de sig dubbel skada; ty ehuru de väl gemenligen åto upp den villa vallmogen; så lämnades dock åtskillige af de andra argaste ogräs, som tistlar \&c. merendels at stå orörde af kreaturen. Ofta lämnades en sådan trädesåker, at ligga 2 à 3 år obrukad och som en beteshage. Då skedde väl, at när jorden fick likasom en skårpa af gräsvall öfver sig, antalet af tistel och andra ogräs minskades; men så snart en sådan betesmark åter plögdes upp, jorden blef lös, och gjord til åker, samt besådd med säd, fingo de mångfalliga i jorden liggande ogräsfrön likasom nytt lif, kommo upp i dagen, grodde, och qväfde mångenstäds bårt säden; ty deras frö hafva den egenskapen, at om jorden är hård, och för dem obeqväm at komma upp, kunna de ligga många år ned i jorden, utan at gro eller taga skada; men qvickna så snart jorden röres och omvändes. Häraf se vi huru plöjande flera resor om sommaren, uti en med ogräs bekajad åker, är mycket nödigt. Ärterna här på åkrarna voro dels sådde i rader, och jorden emellan uprörd, ogräsen utrotade, samt mullen makad til roten och stjelken i en hög; men så sågo vi ock ärtland sådda på samma sätt i rader, men aldrig ränsadt eller jorden uprörd emellan, utan ogräsen höllo på, at aldeles förqväfja och taga lifvet af ärterna. Mångenstäds voro ärterna sådde $\mathrm{i}$ broad cast som hos oss, och där fingo ogräsen och ärterna kämpa med hvarandra, som de bäst orkade p. 45 och gitte. Ingenstäds voro är/terna risade. Vid den här brukeliga Harfven och Välten är intet synnerligt at påminna; de äro mäst lika våra. Plogen i Kent har däruti förmon, at vändbrädet kan lätteligen flyttas på hvilkendera sidan om Plogen en vil. Men i öfrigt förtjenar den ingen ting mindre än befordran; emedan den är ganska tung och obäklig. Jorden på alla dessa åkrar var af naturen så lös, at de kunde $\mathrm{i}$ den starkaste torka köra den upp när de ville. De satte $i$ en sådan lös jord mäst altid 3 par hästar, stora, som största Dragon-hästar, för denna Plogen, då en fullvuxen Person fordrades at hålla Plogen, samt en gåsse, at drifva på hästarna; ja ibland sågo 
vi, at ända til 5 à 6 par sådana stora hästar voro satte för en plog. En sådan jord, til hvilkens upplöjande de här körde med 3 par hästar, kunne vi altid i Sverige med Wessmanlands Plogen, men i synnerhet med Herr Baron Brauners, lika väl och fint helt vist upplöja med et par hästar, om ej med en enda. Kentiska Plogen har den egenskap, at han plöjer djupare, än mäst andra plogar. Vi sågo dock pả somliga ställen i dag trädesåkrar, hvilka lågo ganska väl ansade och upplögde, så at jorden var mör och fin, som den bästa nyssfullbordade trägårds säng. Bönor voro mäst sådde i rader, och handterade på sätt, som tilförene pag. 16. är omtalt; dock voro de äfven på et och annat ställe sådde, som hos oss, eller uti broad cast.

Vägarna voro här nog goda. Fast grunden var af p. 46 krita, och således stadig; så låto de dock ej nöja sig dermed, utan grof sand och små Pebblestones voro öfveralt förde därpå, hälst som krita $\mathrm{j}$ våt väderlek är nog sliprig. På ömse sidor om vägen voro merendels häckar, och gick vägen, i synnerhet i backar, djupt ned i marken, ända til 4 à 5 alnar. Inga diken voro vid vägen.

Väderqvarn. Här och där syntes på högderna någon väderqvarn, bygd på vanligt sätt. Vid Rochester var en väderqvarn, som pumpade upp vatten til Stadsens behof.

Västanvind mycket i Ängland. At Västanvädret på denna orten i Ängland måste vara et bland de långvarigaste och strängaste väder, syntes klarligen däraf, at i trägårdar, som dock lågo hel jämna, och ej så särdeles mot detta väder, lutade träden undan från Västan med öfra delen ansenligen mot Östra sidan, hvilken sneda och lutande växt tvifvelsutan förenämnde Västanväder förorsakat.

Kyrkor, de gamle mäst af Flintsten \&c. Jag har nämt förut T. I. p. 479. 480. at mäst alla gamla Kyrkor här på orten voro bygde af Flintsten, så Chadwell i Essex, som Northfleet W. om Gravesend, och åtskillige andre i Kent. I dag blefvo vi äfven varse, at många Kyrkor i Rochester voro til största delen up $\mid$ murade af bara Flinta, 
endast at de brukat något Portlands sten deribland. Vi gingo sedan ifrån landsvägen upp til en by, där vi sågo en gammal Kyrka, hvilken de nu höllo på at göra til et mälthus. Denne var likaledes mäst hel och hållen upmurad af Flintsten, endast at fönsterkarmar och ramar, samt dörträn voro af Portlands sten. Fönsterna voro hel små. Det syntes väl på et och annat ställe tegelstenar $i$ muren; men det kunde tillika nog tydeligen ses, at muren där varit sönder, och at samme tegelsten var et af senare tiders verk. Vi besågo sedan en annan Kyrka, som likaledes til största delen var upmurad af flintor; dock at Portlands sten var här och där inblandad i muren. Fönsterkarmar och ramar, samt dörrträn voro altid i alla sådana gamla Kyrkor af Portlands sten. Äfven ofta hörnen på Kyrkoväggarna och tornen. Fönsterna voro mäst nog små. Hvaraf kan vara anledning at sluta: 1) at Tegelbränneri i forna tider lärer på dessa orter varit mindre bekant, åtminstone ej särdeles i bruk. 2) At Glasbruken ej eller lärer de tider varit för månge. På Södra sidan af en annan Kyrka har fordom varit 3 stora dörar i bredd; men blifvit sedan med flinta igenmurade, och gjorde endast til små fönster. En del af dessa gamla Kyrkor stodo nu til et tecken af deras ålder djupt ned i jorden, så at deras golf var långt djupare ned, än yttra superficies af Kyrkogården. Således har antingen Kyrkan sunkit, eller p. 48 mullen på Kyrkogården blifvit ökad, genom de där | begrafnas stoft och kistor, med mera, som dit blifvit fördt, eller ock, måtte alla desse orsaker sammanstöta. Eljest märkte jag, at de, på de flästa ställen här på orten, och äfven i Essex, brukade Kyrkogårdarna, hvarest de begrafvit sina döda, til beteshagar för hästar, åsnor eller Svin; men i synnerhet för de förstnämde. På somliga ställen nyttjades jämväl Kyrkogården til äng, så at de afslogo gräset, innan kreaturen släptes dit in.

Rochester är en vacker och tämelig stor samt mycket gammal Stad, belägen på ömse sidor om floden Medway, ungefär 27 Ängelska mil från London. Här omkring äro åtskilliga högder, och ligger en del af Staden jämväl 
därpå; men det mästa är dock ned i dälderna mot Elfssidan. Husen äro mäst af sten, en del rätt vackra. Åtskilliga Kyrkor äro här, somlige af gammalmodig byggnad. Öfver floden Medway går en stor stenbro, som räknas för en af de förnämsta i Ängland. I Staden är en Domkyrka och Biskops-säte. Et stycke nedan för staden ligger det bekanta Chatham, där Ängelska Örlogsskeppen til en del byggas, omlagas och förvaras.

Om aftonen kommo vi tilbaka til Gravesend.

Den $\frac{1}{2} \frac{6}{7}$ Julii.

Brunn i fasta kritbärget. Emellan 2:ne af kritgroparna vid Northfleet gick en udd ut af | bara krita, som p. 49 de lämnat orörd, af 8 à 9 famnars bredd. På ömse sidor om denna udd voro stora kritgropar af 6 à 7 famnars djup. Sidorna däraf voro perpendiculaira. Vid en sida af denna udd hade de grafvit en brunn ned i täta och fasta kritbärget. Denna brunn var rund, af 7 quarters diameter, och omkring murad med tegelsten. Jag mätte hans djup, och fann, at den från öfversta jordbrynet ned til öfversta superficies af vatnet däruti, var $281 / 2$ aln djup. Vatnet, som här togs, var mycket klart och välsmakeligt, som det bästa källvatten, samt mycket lättdruckit. De, som bo här omkring taga härifrån alt det vatten de behöfva til kokning, matlagning, bryggd, bränning, klädes tvätt, til Punch, Thée \&c. Dessutom vatnas dageligen 8 hästar och 4 kor med samma brunsvatten; ty oansedt Floden Thames är här strax bredevid, så gifva de dock hästarna och boskapen ej af des vatten, emedan det är mycket salt, ty Floden (refluxus maris) förer upp salt vatten från hafvet, hvaraf hästar och boskap sades fara illa, om de skulle dricka däraf. Ehuru torr sommar det är, skal dock aldrig märkas, at vattnet minskas i denna Brunn. Jag frågade, om folket, som drucko däraf, befunno sig väl därefter? de svarade, at bättre vatten icke kan gifvas, än detta, samt at de aldrig må illa däraf, eller äro fram för andra underkastade några vissa sjukdomar. 
Jag drack nu rätt nog däraf, utan at märka därefter den p. 50 ringaste olägenhet. Jag har ock vid hela mit vi|stande så i Gravesend, som annorstäds i Ängland, icke kändt det minsta af en dylik effect, som någre tilskrifva kritvatnet, nämligen, at en ovan därvid skal i början hafva diarrhée; innan han blir van därvid. De mästa och tör hända alla Brunnar i Gravesend, äro gräfne i bara hårda kritbärget, så at det vatten jag vid måltider och då jag varit törstig, hela tiden druckit, ej varit annat, än det, som silat sig genom kritan; men jag har ej märkt den ringaste ändring i kroppen däraf.

\section{Den $\frac{1}{2} \frac{7}{8}$ Julii.}

Strata terræ. På Södra sidan om väderqvarns backen, som låg vid Gravesend, var en stor grop, där de tagit sand. Här fingo vi se hvaraf backen på den sidan bestod, samt räkna strata i den samma, hvilka voro följande: 1) Öfverst Svartmylla $1 / 2$ aln. 2) Svartmylla och en fin sand blandade tilhopa, $1 / 2$ aln. Desse tilsamman gjorde en gul färg. 3) En ljusgrå fin sand 3 qv. uti den samma voro här och där som Ochra- eller rostfläckar. 4) Ljus ocherfärgad sand, som gick $i$ vågor, $1 / 2$ tum. 5) Den förut n. 3. nämnde ljusgrå sand 3 qv. 6) En rost- eller mörk ocherfärgad sand en tum. 7) En fin mycket ljus sand 5 qv. 8) En ocherfärgad fin sand $1 / 2$ tum. 9) Den vid n. 7. nämnda fina mycket ljusa sanden, som gick ända til botten på gropen, och ho vet huru långt ned?

Längre upp på backen var en annan sandgrop, som p. 51 med sin basis var högre, än kullen | af den föregående. Där voro hvarfven i denna ordning: 1) öfverst svartmylla ungefär $1 / 2$ aln, fast nog utblandad med en fin tegelfärgad sand och små Pebblestones. 2) Pebblestones 4 à 5 quarter. Desse Pebblestones voro af knäckars storlek merendels, kålsvarta, rundaktige eller ovala, hel glatta utanpå, likasom de varit slipade eller slätade. När en sådan slogs sönder, så befans, at den var af bara flinta. Aldrig syntes några kantiga. 
3) En ocherfärgad fin sand, 5 quarter.

4) En fin hvit sand, $1 / 2 q v$.

5) En ocherfärgad sand, en tum.

6) En fin hvit sand, 2 tum.

7) Den ocherfärgade sanden, 2 tum.

8) Den fina hvita sanden, 2 tum.

9) En grå i tärningar fallande lera, $1 / 2$ tum.

10) Den fina hvita sanden, 2 tum.

11) Den grå leran $1 / 2$ tum.

12) Den ocherfärgade sanden, 2 tum.

13) Den fina hvita sanden, en tum.

14) Den grå leran, en tum.

15) Den fina hvita sanden, $1 / 2$ tum.

16) Den grå leran, en tum.

17) Den fina hvita sanden, 3 tum.

18) Den ocherfärgade sanden, en tum.

19) Den fina hvita sanden, 2 tum

20) Den grå leran, en tum.

21) Den fina hvita sanden, 3 tum.

22) Den grå leran, $1 / 3$ tum.

23) Den fina hvita sanden full med rostfläckar, $2 q v$.

24) En ljusgrả sand, en tum.

25) Den fina hvita sanden, $1^{1} / 2 q v$.

26) Den ocherfärgade sanden, en tum.

27) Den fina hvita sanden, 1 qv.

28) Den ocherfärgade sanden, en tum.

29) Den fina hvita sanden, 1 qv.

30) Den ljusgrå sanden, full med rostfläckar, en aln.

31) Den ocherfärgade sanden, $6 q v$.

32) Pebblestones, utblandade med en ljusgul sand, 3 qv.

33) Den fina hvita sanden, 2 alnar, kunde sedan för djupet i gropen ej mera ses. Om alla desse strata tilkommit vid skapelsen, syndafloden eller något annat tilfälle, lämnas til andra, at gissa om. Hela denna höga sandbacken lärer förmodeligen stå på fasta kritbärget; emedan alla fält häromkring bestå af bara krita med en tunn jordskårpa där ofvanpå. 
Måssa. På de hårdaste kritbackar syntes väl ibland någon fin Hypnum; men så märktes dock, at denna orten omkring Gravesend, ej var särdeles benägen för måssa. Det syntes ej tecken därtil, ehuru noga jag såg därefter, hvarken på åkrar, eller inclosurer och täppor, de där voro sådde med Clover, Saint Foin \&c. ja icke en gång på renarna vid häckarna.

Oniscus cauda obtusa integerrima. Linn. faun. Suec. 1256. fans i myckenhet allestäds på kritbärgen, at den p. 53 på dessa orten likasom tagit / sit hemvist. När någon kom vid honom, drog han sig ihop, at den låg hel rundaktig, och såg ut som et helt litet svart gläntsande ägg. Denne är större, än våra ordinaire gråsuggor.

\section{Den $\frac{1}{2} \frac{8}{9}$ Julii.}

Phalcena subulicornis spirilinguis; alis superioribus subcæruleis, punctis sex rubris; inferioribus omnino rubris. Linn. faun. Suec. 814. Denna vackra Fiäril, som prålade med dess sköna röda färg, hade i synnerhet tagit sit hemvist i gamla med små buskar öfverväxta kritgropar, där den flög i myckenhet; men utom dem var han sällsynt. Han flög mycket långsamt och ej så snällt, som de andre Fiärilar; satt ganska mycket på blomman af Scabiosa prat. hirs. C. B.

Aranea abdomine fusco ovato, linea exalbida pinnata, cauda bifurca. Linn. faun. Suec. 1223. fans här i myckenhet så på kritbackar, som på andra ställen. Jag såg honom ock uti Essex. Den accurata Beskrifning, som Herr Archiatern och Riddaren Linsæus gjordt uti sin Fauna Suecica på anförda ställe, om sättet huru denne gör sit bo, befriar mig, at utföra det samma, emedan denne Spinneln gjorde det här i Ängland mäst på samma sätt. Skillnaden är endast den, at vi funno sådana hans konstiga bo och giller ej allenast utsatte öfver gräset, utan ock i sidan af sluttande backar, där jorden rasat ned, hvarest han gemenligen utvaldt sitt bo, där någon liten grop af p. 54 en näfves / vidd och djup gick in i backen. Där gjorde 
han sit cylindriska bo ned i förenämde hål, ofvanför hvilket han utspridt sit nät på alla sidor, at det liknade en stor tratt, i synnerhet om några små buskar voro i negden, på hvilka han fick fästa somliga ändar af sina nät, då en fiskare, som sätter ut Ryssior, icke kan behändigare ställa dem. Ofta hade han gjort sit bo upp i buskarna, då ifrån hans cylindriska hål armar af hans nät gingo ut til par alnar på hvar sida, at intet insect fick komma vid buskan, innan det var insnärdt i nätet. Han sielf satt altid antingen i botten, eller öpningen af sit cylindriska och en öppen pung lika hål, färdig at springa til vägs så snart något rof var at vinna. När något insect fastnat, sprang han straxt dit, och bet det några gångor i hufvudet, bar det sedan in til början af sit näste, hvarest han åt det upp. Det var et nöje at se hvad arbete han hade med Curculionerne; ty som desse äro öfvertäckte med et hårdt skal, så kunde han nästan aldrig taga redo på dem. Så snart de kommo på hans nät, angrep han dem; men de voro så kloke, at de drogo in fötterna och hufvudet. Då han väl bet dem i skalet, men utan verkan; ty så snart han lämnade dem, började de åter kräka, då han å nyo sprang upp, och bet dem; men lika fåfängt, så at han omsider blef trött, lopp in i sit bo, och lät dem vandra sin väg. Han hade altid ned i botten af sit bo et hål, hvarigenom han, då nöden trängde, kunde hafva sin undanflykt, och ej blifva instängd, dả han altid sökte | sin p. 55 säkerhet bak om någon qvist eller ned i jorden, när någon kasade efter honom; men så snart en åter blef tyst, kröp han genom hålet in i sit bo, kom fram i öpningen af det samma, at se efter om någon fara vidare var på färde, eller om alt var fredligt. Jag ref ibland sönder deras boet, då de gemenligen efter en eller par dagar hade det färdigt igen.

Svin. Uti Kent hafva Farmerne gemenligen ej flera Svin, än de behöfva til deras egen nödtorft, så at de sällan komma at sälja något däraf; men uti och nära omkring London hålla Bränvinsbrännare en stor myckenhet, ofta från 200 til 600 stycken, dem de föda med drank 
och annat, som blir öfver vid bränningen; och sedan desse kreatur blifvit nog feta, säljas de til Slaktare med stor fördel. På lika sätt och til samma ändamål hålles vid stärckelse-bruken et stort antal af Svin, hvilka födas och gödas med det, som blifver afskrädt af hvete, då Stärkelse tilverkas. Huset, hvaruti Svinen hållas, blifver ränsadt och tvättadt hvar dag.

Åkrar, Hvete, Korn \&c. Åtskilliga gamla och käcka Farmer här på orten berättade, at när åkern är väl omlagad, kan man efter Hvete få 20:de kornet, ibland ock litet mera; men åkern måste då vara väl ansad. Sammaledes kunna de få 20:de kornet af korn på en väl skött

p. 56 åker. Sädesslagen ömsas årligen, | nämligen när åkern legat en sommar i träde, besås den antingen med Hvete eller Rofvor, därefter med Bönor, så med Korn eller Hafre. Trädesåkern köres om sommaren gemenligen 3 gångor; om de så hinna, köres den 4 gångor, samt harfvas och vältas emellan hvar gång. Krita brukas ock här til gödsel på åkern, och då han en gång blifvit gödd dermed, behöfva de ej göda honom på 10, 14 eller flere år. På styf lergrund sades kritan vara skön. Bland andra sätt, at göda åkern, räknas et såsom det bästa, at fålla fåren om sommaren på den samma om nätterna uti en liten trång fålla, at de stå hel tätt tilhopa. En och annan käck Farmer sade sig sjelf försökt, at så Hvete i rader, och plöja upp jorden med horsebreak (en liten nätt plog, som drages af en enda häst) emellan raderna; men det har ej velat lyckas för dem. Dock trodde de, at det kunde gå an. Eljest brukas horsebreak här mycket, at plöja och ränsa bårt ogräsen emellan de sådda rader med Bönor och Ärter, aldenstund det lisar mycket arbete. Rofvor sås äfven här i Kent mycket, för Får, Svin och Oxar, at föda och göda dem med. Bästa tiden at här så Hvetet, sade Farmerne sig funnit vara ungefär en Månad för Michaëls-mässo (efter gamla stylen); många så det ibland en Månad efter, men det sättet hålles ej för så godt.

Ängsskötsel, St. Foin, Clover \&c. Deras mästa ängar p. 57 här på orten besås med nå|gra vissa höslag, som St. Foin, 
Clover, Vicia, Lucerne \&c. St. Foin sades trifvas ganska väl på Kritbackar, det ock vi öfver alt klarligen funno. För 30 år tilbaka visste de här ej så mycket af des bruk, som nu, hvilket de lärt från Frankrike. St. Foin är en ståtelig föda för hästar; men för Kor är den torkad ej så god, som godt hö; emedan de ej mjölka så mycket efter den, som efter hö. När den en gång blifvit sådd, kan den ibland stå 16 och flere år, innan den behöfver sås om. Den gifves åt hästar, antingen hel, som den är, eller skäres den i en hackelse-kista sönder med stjelk och alt helt små, blandas så ut med hafra, agnar, Bönor eller ärter, och gifves sedan åt hästar, som må ganska väl derefter. De få ej här slå St. Foin mer, än en gång, om sommaren. Clover brukas ock mycket nu at sås här; men den står ej så länge, som St. Foin, innan den måste sås med Hvete eller annat, och et stycke land besås om. De bärga nästan aldrig mer än 2 slåttar däraf, innan den sås om, ej eller lönar det mödan at låta den stå längre; ty när en slagit den 2 år eller 2 somrar, tyner den därefter så mycket af, at de näppel. kunna gå med lian därpå, därföre när de 2 somrar, och ganska ofta endast en sommar, afslagit den samma, plöjes åkern å nyo upp, besås med Clover; men ehuru den ej kan stå länge, innan den skal sås om, så lönar den dock ganska mycket omaket, hälst här på orten, där på Kritbärgen inga ordinaira grässlag vella fort; emedan denne Clover första sommaren, då den slås, gifver en så ganska stor ymnoghet af et mägtigt och godt hö. Til föda för hästar är den förträffelig, men ej så för Kor; emedan de väl mjölka mycket däraf, men mjölken får någon särdeles smak därefter, och är på långt när ej så behagelig, som när Kona födas med godt gräs; i synnerhet kan en ganska väl känna denna Clover-smaken i mjölken, om Kona få gå ute om sommarerı och äta den gröna Clovern; men då måste en taga vara därpå, at de ej må få äta efter behag däraf; ty Clovern smakar dem så väl, at de ej kunna hafva återhåld, utan ibland äta de den så begärigt, at de svälla up och dö. Clovern har ock däruti företräde fram för andra höslag, at den gemen- 
ligen kan slås 2 gångor om sommaren. Somlige hafva ock nu börjat at så Lucerne, men ovisst ännu, huru det vil lyckas. Tares (Vicia vulg. sat. Park.) sås här ock af en del til foder, och visste Farmerne näppel. något höslag, hvarefter Korna gifva så mycket mjölk, som då de äta af, hälst om den är grön, hvilken mjölk tillika smakar väl; dock är det befunnit, at Kor gifva den behageligaste mjölk, då de äta godt gräs. På ganska många ställen här i Ängland slå de sina ängar 2 gångor om sommaren, ibland ock 3 gångor; men då släppa de sällan Creaturen at beta derpå, hvarken om Vår eller Höst. Dock berättade Farmerne, at höet af den senare slåttern ej är så godt och kraftigt, som af den förra.

p. อ̇9 Bönor, sås här mycket, och brukas til föda för hästar och svin. Likaledes gifva de àt hästar och svin ärter til mat.

Krita. Det är ej bekant, at Krita brukas til någon ting i trägårdar; men i hummelgårdar brukas den af somliga som en gödsel, då den förut utblandas med annan gödsel.

Ost, Smör \&c. Mäst hvar Province i Ängland har något särdeles, som den frambringar mer och bättre, än en annan. Således meddelar gemenligen Kent bättre Humla och Kärsbär än andre Provincier: Hertfordshire bättre Hvetmjöl: Cheshire och Glochester-shire bättre Ost, Suffolk bättre smör, o. s. v. Härvid är märkvärdigt, at den Province, som gifver det bästa smör, kan ej meddela så skön Ost, och tvärt om. Orsaken sades vara, at til hvardera så smör, som ost, fordras den bästa och fetaste mjölk. Där de göra smör, göra de äfven ost; men de bruka först at kärna smör af mjölken, och sedan göra de ost af den samma, hvilken ej kan bli god; emedan den mästa kraften af mjölken är redan bårttagen.

Råg, sås äfven här i Kent af en del, som dels försälja den, dels bruka utblanda den med hvete, mala och göra bröd däraf. Halmen säljes til Watermen eller Roddare och de som gå med båtar och Jaktar fram och tilp. 60 baka til och från London, hvilka bruka lägga / halmen 
på botten af båten, och på sätet, at de resande må sitta så mycket bättre, och ej sudda eller orena sina Kläder.

\section{Den $\frac{1}{3} \frac{9}{8}$ Julii.}

I dag reste jag med Till-båten til London, at höra, om ej Capitain och det skepp, jag skụlle gå öfver med til America en gång måtte blifva resfärdigt, samt fölgde efter middagen en af Till-båtarne ned til Gravesend tilbaka.

Kritans nytta. På de åkrar, som ligga i negden omkring Gravesend, bruka de ganska sällan, eller nästan aldrig at göda sina åkrar med krita; emedan jorden, som där är mäst en mylla, är förut så lös och torr, at den behöfver ej blifva lösare; men längre därifrån, där de hafva våta, lågländta och af lera bestående åkrar, göda de dem då och då med krita. Alla åkermän och Farmers härstädes komma därutinnan enhälligt öfverens, at den förnämsta nyttan, kritan gör såsom gödsel på en åker, är pả et sådant land, som består af en styf lera och kall jordmon; ty hon löser up samma lera, gör den beqväm at frambringa säd til myckenhet. Det är ock därföre, som Farmerne i Essex, hvarest ingen krita är til finnandes, äfven de, som bo långt bårt, komma hit ned til stranden af Thames, där kritbärg äro, köpa här många lass krita, och föra dem lång väg öfver land, | at därmed göda p. 61 sina åkrar, som bestå af en styf lera. De, som bo längre in i Kent, och hafva dylik lerjord, förbättra den på samma sätt med krita. I sandig jord sades kritan icke göra någon nytta.

De både nära och längre härifrån boende betjena sig således af denna til gödsel på deras åkrar och ängar. Från Essex, Midlesex, Surry, och ganska många andra orter af de Ängelska Provincier, som antingen ligga nära Thames, eller eljest vid sjökanten, föres med små Fartyg allehanda matvaror til London, som hvete, korn, hafre, smör, ost \&c. När samma små Fartyg skola gå hem från London, vela de icke gå toma tilbaka; därföre komma de 
til någon af dessa kritgropar, lasta sina Fartyg med krita, som de här kunna hafva för et ringa pris, och föra den hem, hvarest de antingen bränna henne först til kalk, innan de lägga henne på åkern, eller ock lägga henne på åkern, som de få henne.

Utländska skepp taga ock ofta vid Hemresan härifrån en stor myckenhet krita med sig.

Grunden af vallarna och Bankarna på ömse sidor om Thamsen äro gjorde af denna krita, dels emedan den binder väl, dels emedan de icke hafva något annat stenslag. Den är lagd där både i större och smärre stycken.

Uthusen voro på åtskilliga ställen upmurade af bara krita.

Det förnämsta, hvartil kritan här brukas, är, at de på åtskilliga ställen bränna kalk däraf, hvarom litet nedanföre mera.

I Comedie-husen i London brukade Lindansare, och de som gingo på rep och linor, at gnida deras skor starkt under med krita, på det de ej måtte halka; äfven kritades repet då något.

\section{Den $\frac{2}{3} \frac{1}{1}$ Julii.}

Anmärkningar vid krita och Kritbärgen vid Northfleet och annorstädes i Kent. Northfleet är en by, som ligger en liten Ängelsk mil W. om Gravesend på samma sida om Elfven. Här, och så ända til Gravesend bestå alla Elfsbackarna vid Thames, och landet däromkring af bara krita, endast at en tunn mylla eller matjord ligger öfverst. Här finnes vid Thames stränder den ena stora kritgropen ofter den andra både af ansenlig vidd och stor djuplek. Desse kritgropar äro merendels fyrkantige. Deras sidor perpendiculaira. Djupleken på desse gropar från öfversta superficies ned til botten 8, 12, 15. och flere famnar. De höra ej til en och samma person, utan äro åtskillige, som hafva del deri, hvilka äro Gentlemen, som vistas i Lon-

p. 63 don; men hafva dock här folk, som bo vid krit/groparna, at se efter, det med arbetet må gå väl och rätt til. At 
kritan här blifvit tagen för många hundrade år tilbaka, kan slutas, utom hvad en har af gamla Häfdateknare, äfven dels af groparnas myckenhet och ganska stora vidd och djuplek, dels af det ansenliga antal af gamla gropar, som nu til en stor del äro med grus igenkastade, och med hvarjehanda slags trän och örter öfverväxte.

En del Kritgropar, hvarest de nu bröto och brände kritan, voro när til Elfven; andre åter några musquetskått därifrån; ty de hade bårttagit alt det dugeligare närmare Elfven, så at där ej annat var lämnat, än höga backar fulla med den mull de afrislat, då de tagit kritan, jämte den mull, som legat öfverst, tillika med stycken af flinta, krita, tegelstenar och annat skräp.

Uti dessa kritgropar hade vi ganska godt tilfälle at se, dels huru tjock matjorden och mullen är, som ligger ofvanpå kritan, dels hvarjehanda hvarf och strata af krita, samt hvad i den finnes med mera.

Öfverst och ofvanpå kritan låg matjorden eller svartmyllan, gemenligen til $2^{1 /} / 2$ quarters djup, utblandad med små flintbitar, hvilka sảgo ut lika med dem, som ligga på öpna fältet, dem Solen blekt och gjordt hvita. Färgen af denna matjord var brun. Dock var Svartmyllan ej allestäds öfverst lika tjock; ty | rätt som den var $2^{1 /} / 2$ quarter tjock, så gick den som en boge eller vigg ned, til 2 alnars perpendiculairt djup. Bredden af en sådan vigg var icke eller allestäds likadan; ty ibland var öfre delen til 5 à 6 alnars vidd, ibland näppel. til en aln, o. s. v. Djupleken af sådana viggar var ock olika, nu mer, nu mindre; dock var gemenl. matjorden utom och ofvanför desse viggar $2^{1} / 2$ quarter.

Därefter tog kritan mot; men var öfverst ej aldeles ren, utan utblandad något litet med den bruna jorden, til 6 quarters tjocklek. Denna utblandade kritan såg sålunda smutsig ut. Uti den samma suto nog flintstycken, äfven fullt med små Pebblestones; hvilka bägge, så flintstenar, som Pebblestones aldeles liknade dem, som ligga upp i dagen, och blifvit blekte af Solen; hvilket tyckes vela säja, at desse ställen af krita, som nu äro 2 alnar 
perpendiculairt under öfversta superficies af jordskårpen. fordom legat upp $i$ dagen och Solen. $V i$ gräfde in $i$ backen och befunno allestäds sådana blekta flintstycken och Pebblestones. När desse blekte flintstycken, som lågo in i backen, slogos sönder, sågo de ofta inuti ut, likasom flinta, då hon varit uti elden, men dock ej blifvit så hårdt bränd, at hon gått til glas.

Stundom fans til 4 alnars perpendiculairt djup i

p. 65 sjelfva kritan stora fläckar af en | half à 1 alns diameter, hvilka bestodo af bara sådan brun mylla, som ligger öfverst, och är den samma, som vi kalle Svartmylla. Så uti desse fläckar, som i kritan rundt omkring dem, voro fullt af smả Pebblestones. Vi funno sådana fläckar vid många kritgropar.

På somliga ställen nödgades de bårtkasta matjorden, flintstenar, Pebblestones och annan utblandad mylla, ända til 3 alnars perpendiculairt djup, innan de kunde få ren krita, at nyttja til kalkbränning.

At jag nu måtte se, huru hvarfven voro i desse kritgropar, samt hvaraf väggarna i dem bestodo, vil jag anföra de anmärkningar, jag vid en och annan af dem gjorde:

Uti en af desse kritgropar närmast til Gravesends sidan, voro strata i denna ordning:

1) Öfverst och ofvanpå kritan var Svartmylla eller matjord, hvilken här til färgen var merendels brun, ungefär af $1 / 2$ alns tjocklek, mer eller mindre; ty den var ej öfveralt af samma tjocklek, utan gick ibland som viggar eller kilar ned i kritan, på 4, 6 à 8 quarters djup, samt olika bredd.

2) Dernäst en krita utblandad med Pebblestones och något af förerämde Svartmylla, at hon ej var helt ren, til $1 / 2$ alns tjocklek, mer eller mindre. Denne krita var p. 66 nå|got lös, och ej så hård, som de perpendiculaira väggar i kritgroparna.

3) Sedan kom et mäst horizontailt löpande stratum af bara rötter, ungefär af $1 / 8$ à $1 / 4$ tums tjocklek. Det bestod ej af annat, än bara små rötter, af hvilka de största voro af en gåspennas tjocklek; men man kunde ej taga 
reda på hvad för slags rötter desse varit. De voro ej särdeles rutnade, jag inbillar mig, at de voro fina rötter af Hagtorn, hvilka lupit ned så långt, och då de funnit under detta stratum en hårdare krita, ej kunnat gå längre ned i jorden, utan sedan lupit horizontaliter uppå det samma, och således tid efter annan formerat detta. Hvad som gaf mig anledning til denna tanka, var 1) at kritan, som ligger näst under, är ganska hård. 2) At jag fann friska och växande Hagtorns rötter, af samma tjocklek, som nyss nämdes, hvilka lupo just horizontaliter bland de audra rötterna i detta stratum.

4) Hårda Kritbärget 3 famnar. Huru det blef längre ned, kan jag ej säja; emedan det nedrasade gruset och mullen hindrade, at mera kunna se därefter.

I en af de kritgropar, som voro närmast til Northfleets Kyrka, voro strata af kritan i denna ordning:

1) Jordskårpan och matjorden, ungefär $1 / 2$ aln.

2) Hårda kritbärget 29 à 30 alnar ungefär. Flint- p. 67 stycken voro här och där utblandade däri.

3) Et stratum af bara flinta, lagd helt tätt vid hvarannan, af $1 / 2$ à 1 quarters tjocklek.

4) Hårda kritbärget, $4^{1} / 2$ aln.

5) Et stratum flinta, af 1 à $1 \frac{1}{2}$ tums tjocklek. Flintan låg äfven här hel tätt vid hvarannan; men flintstyckerna voro helt tunna, lika som små tunna brädbitar; ofta lågo par stycken sådana tunna bitar på hvarandra.

6) Hårda kritbärget, 9 alnar.

7) Et stratum flinta, aldeles likadant med N. 3.

8) Hårda kritbärget par alnar; och ho vet huru långt ned; emedan botten af gropen hindrade mig, at se djupare?

Anmärkn. Uti krithvarfven nedan för N. 3. syntes någon enda flintsten här och där.

Uti en annan af desse stora kritgropar närmare mot Gravesend, voro strata sålunda:

1) Öfverst svartmylla, ungefär af en alns tjocklek; men utblandad med krita, at färgen af denna jorden var mäst lik tegel. 
2) Krita, 2 famnar.

3) Et stratum af flinta, helt horizontelt, som hade det varit lagdt med flit efter vattupass, af $1 / 2$ à 1 quarters tjocklek.

4) Krita, 5 famnar ungefär.

p. 68

5) Et stratum af flinta, lagdt på samma sätt, som N. 3. horizontelt och efter vattupass af $1 / 2$ à 1 quarters tjocklek.

6) Krita, netto 6 quarter.

7) Et hvarf flintsten, likadant med de föregående, $1 / 2$ à 1 quarter.

8) Krita en famn, och tör hända mycket djupare; emedan den nedrasade mullen hindrade mig at se det mera.

Obs. 1. At desse strata af flinta bestodo endast af en enda flintstens högd, och ej af flere staplade på hvarandra; det såg så ut, som om någon hade et flackt, jämnt och slätt fält af bara krita, hvaröfver breddes et stratum af enkel flintsten, så tätt, at den ena rörde vid den andra, och lade så krita därpả.

Obs. 2. Flintsten, som låg i desse hvarf, var somligstäds tjockare, inemot et quarters tjocklek: annorstäds tunnare, ända til en tunn skålla af en fjerndels tums tjocklek. Emellan desse strata af flinta, syntes uti sjelfva kritan sällan någon flintsten; endast någon enda här och där. I kritan var, fast ganska sällan, någon liten ibland oval, ibland klotrund Pebblestone.

Uti förenämde stratis af flinta, omgifves flintan med krita helt tätt, likasom kritan varit blöt, dả flintan kommit dit, at hon sunkit ned i kritan, och at sedan en annan blöt krita kommit at ligga därpå.

p. 69 Desse strata eller hvarf af flinta emellan kritan äro synnerlige. Flintsten ligger här så horizontelt och så tätt til hvarannan, som hade den med flit af människo-händer blifvit ditlagd. Huru har den väl i en sådan ordning först kommit dit?

Hela backen vid Themse-strömmen W. om Gravesend, bestod af bara krita; men vid des basis jämt vid vattu- 
brynet, då floden (refluxus maris) är högst, var et sådant stratum af flintsten, som nyss omtaltes, hvilket låg på samma sätt helt horizontelt, som hade det varit lagdt efter vattupass. Flintstyckena lågo här aldeles jämnt intil hvarandra. Detta flint-stratum kunde ses vid lågt vatten, nästan en half Ängelsk mil långs efter Elfstranden.

Färgen på dessa perpendiculaira väggar i kritgroparna är merendels snöhvit. Annorstäds hade den fått en gulaktig färg, nämligen där, hvarest ofvanföre var svartmylla och trän, hvarifrån ibland någon vätska silade sig ned, och rann öfver sidorna. Pả de ställen, där många kalk-ugnar finnas, äro de perpendiculaira väggar af den myckna stenkåls röken mäst svarta.

Pả somliga ställen, där kritan nyligen fallit ned, var fullt med svarta prickar deruti, då den slogs sönder, af små knappnåls knappars storlek, just likasom en Lichen bör|jat där växa. I et och annat stycke satt stora rost- p. 70 fläckar, hvilka somligstäds förtärt nảgot.

I de perpendiculaire sidor eller väggar af kritgroparna äro gemenligen fullt med springor, hvilka gå dels perpendiculariter, dels horizontaliter, och skära af hvarandra ungefär ad angulos rectos. Bredden på en sådan springa är ej lika, ibland sả liten, at man näppeligen kan sätta en knifsudd däruti, ibland åter äro de bredare, at en väl kan få in et finger. Jag kan just ej säja af hvilketdera slaget, antingen perpend. eller horizont., det finnes mera, dock tyckes de horizontela göra största antalet. När jag kallar springorna perpendiculaira, är det ej sả at förstå, at de voro så efter mathematiske reglor, utan de stodo ibland just perpend. ibland nära därintil. Det samma är at märka vid ordet horizontelt.

I de gamla kritgroparna hade de somligstäds gräfvit stora hål in som hvalf. De som bodde där när intil, sade, at de mente dem i forna dagar varit brukade til källare. Hvalfven däruti hade icke tagit någon särdeles skada of tiden, ej eller väggarna; dock syntes, at kritstycken då och då fallit ned från hvalfvet. Kritan i desse gamle källarväggar, som voro perpendiculaira, var full med 
springor, som gingo både perpendiculariter, horizontaliter, p. 71 och äfven oblique eller snedt före. Jag för|står med oblique eller snedt, det som är som et medium emellan perpend. och horizont. eller tämeligen nära därtil. Desse sneda springor voro allestäds rätt få, och på långt när ej så många, som de andre.

Vidden emellan de horizontela springor var ingen ting mindre än likadan; ty då det ena stratum (om jag så må kalla det) var tjockt, var ofta det andra helt smalt. I de gamla källare var vidden emellan hvarfven merendels et quarter, dock ibland mera, ofta en tum, ja ibland endast en half tum, eller en smal rimsa. Spingorna voro gemenligen sådana, at man näppeligen kunnat få en knifsudd i dem; i andra kunde hela knifsbladet lätteligen stickas in. Ej eller var altid et och samma stratum af lika vidd emellan springorna; ty oansedt det gemenligen ville hålla sig vid en och samma vidd, skedde dock ibland, at när det en stund varit af en och samma vidd, det då småningom blef smalare, och omsider ändades i en angulum acutissimum. Springorne förhöllo sig ej eller lika; ty nu kunde en springa gå helt noga horizontelt, så långt som väggen var i en kritgrop; nu rätt, som hon gått litet horizontelt, stannade hon tvärt af, och en annan horizontel springa började där, 1, 2, 3 eller flera tum, antingen ofvanföre eller under, och så vidare. När en tog löst et kritstycke, som satt emellan 2:ne horizontela p. 72 springor, var | både undra och öfra sidan däraf, et planum eller slätt, utan uphögning, samt gemenligen af litet mörkare färg, än kritan däruti, til et tecken, at luft och vatten kommit däremellan. Stenkålsröken, hvilken kommer från kalkugnarna, som finnes mäst i alla desse gropar, kan ock hafva förorsakadt samma mörka färg. Understundom rätt som en linea lopp horizontaliter, vek hon af och lopp helt snedt.

Af de horizontela rämnor voro gemenligen några hufvudrämnor, som merendels fölgde hela väggen utåt, och voro större, än de andre. Vidden emellan hvardera af dem var åtskillig, $1,1 \frac{1}{2}$ à 2 alnar, sällan under 3 
quarter; men rummen däremellan voro ofta sönderdelte med små horizontela rämnor.

De perpendiculaira springor äro ej eller af samma beskaffenhet; ty ibland gå de uti en rätt linea ända upp före hela väggen. Ibland, dả de gått et stycke, stana de tvärt af, och då börjar en annan litet på endera sidan at gå upp i lin. recta; vidden på en sådan springa förhåller sig på samma sätt, som är sagt om de horizontelt gående. Distancen emellan de perpendiculaire har sig äfven pả samma sätt som i de horizontala, nämligen ej lika, utan ibland vid, ibland smal, ofta til endast en tums bredd, och väl mindre; men ibland til 1, 2, 3, 4 och 5 quarters bredd.

Gemenligen höllo desse perpendiculaira rämnor vissa väderstreck; ty merendels gingo de från $\mathrm{O}$. til $\mathrm{W}$. och från N. til S, eller om det skulle vara en liten afvikning, från W. til N. och $\mathrm{O}$. til S. samt från $\mathrm{S}$. til $\mathrm{W}$, och från N. til $O$. Men detta var så litet, at det föga kunde märkas. Dock syntes stundom någon, som gick från denna regel, och lopp, til exempel, från $\mathrm{SO}$. til $\mathrm{NW}$. från NO. til SW. o. s. v. Likväl skedde denna afvikelse nog sällan. Gemenl. lảgo de, som först blef anmärkt, och det $\mathrm{i}$ kritgropar, som voro hela Ängelska milen från hvarandra.

När kritstyckena togos utur bärget, så voro gemenl. deras sidor, som setat mot den perpendiculaira rämnan, hel plana, och så släta som de varit skurna jämna med en knif efter en lineal.

De kritväggar, som varit längre i dagen, och på hvilka både Sol, luft och rägn längre fått verka, äro långt mera fulla både med perpendiculaira, horizontela och obliqua eller sneda springor, än den, som nyss upbrytes. Åtminstone kunna de förra mycket tydeligare märkas; ty en gammal krita, som länge varit i dagen, är mäst hel söndersprucken, då uti en nyssbruten man svårligen, utom de stora horizontela och perpendiculaira springor, kan blifva varse någon rämna.

Ibland ses i de större rämnor, at tunna och flata flintbitar, som tunna skifverstyc/ken, fyllt up rämnan. p. 74 Mon den generats dit, sedan kritan rämnat så sönder? 
Således ses, at kritbärgen hafva sin art at rämna sönder, äfven som gråbärgen hos oss.

När krita legat sin tid i öpna luften under sol och rägn, blifva ofta helt små hål på den sidan däraf, som vetter upát, at den varder som pipog. Hålens djuplek är dock sällan öfver 1 à 2 Geom. lin.

Flintan, som fans i kritbärgen, hade icke någon viss skapnad, utan var mäst alt i oformliga stycken, just som då en smälter metall eller någon malm, och låter den rinna på marken uti hvad form en behagar.

De största Flintstycken äro af en alns längd; fast man får sällan se något så stort. De flästa $1 \frac{1}{2}$ quarter à $1 / 2$ aln.

Mäst all flinta är här svart; dock finnes här och där något ljusaktigt stycke.

På stranden vid Elfven Themse, ligger somligstäds fullt med flinta; men oansedt stranden i 6 timar står under vatten, och i de andra 6 i öpna luften, har den dock ej tagit annan förändring däraf, än at en del är utanpå af en hvit färg, eller ock ibland stötande litet på blått. sảdan, som flinta plär vara, dà den ligger pả backar i fria luften, och Solen får skina der pá, och bleka den. Eljest voro mästa delen af flintstyckena här sâ rena och svarta, då de slogos sönder, som de, hvilka nyligen togos utur kritbärget.

p. To Flintan hade ibland utanpa sig likasom en rost-äten eller ocherfärgad skárpa. Ofta fans ock uti sådana rostätna ställen. Figuren var, såsom förut nämndes, som malm, smält och runnen på jorden huru den sielf velat. Gemenligen voro styckena aflånga, samt fulla med knylor och ojämnheter utanpå. De liknade ock ofta finger, fötter, tappar, bållar, en del af en hand, gethorn, små kalfhorn, \&c. Inuti var den gemenligen svart; men ock ofta full med ljusare fläckar, mer eller mindre.

De Heterogenea och främmande eller mindre allmänna ting, som funnos i desse kritgropar antingen i kritan eller flintan, äro i synnerhet desse:

1) Strålflinta, sâ får jag kalla en art af sten, hvilken 
sätter sig som en svamp ofvanpå flintan, är bred och flat, består af parallela trådar hårdt sammansatte, hvilke gå perpendiculairt, mot sin flata sida, liknar alldeles amiantlikt Strålgips uti Prof. W AllenI Mineralogie p. 55 endast, at detta är något tätare. Til färgen är det hvitt eller ljusgrått. Den är dock en art af flinta; emedan den mot eldstảl tager eld. Den sätter sig ej allenast på flinta, utan ock ibland på krita.

2) Musselskal finnes såväl i kritan, som fastvuxna uti hålen på flintan.

3) Crystaller. Ofta när man bryter eller slår sönder et flintstycke, finnes däri små bärg|crystaller helt tätt. p. 76 Gemenligen är vid dem något tomt rum lämnadt.

4) Klotrunda flintbitar eller af Ängelsmännerna så kallade Chalk-egg. Desse finnas esomoftast fastgrodde vid flintan. Utanpå är et sådant krit- eller rättare flint-ägg öfverdragit med en hvit kritskårpa af en half lin. tjocklek; men dả den slås sönder, fảr en se, at den består merendels af bara flinta. De äro gemenligen klotrunda, stundom ock litet aflånga; ibland äro de helt solida och bara flinta; men ibland iholige midt uti, då in centro ligger nảgot litet krita, antingen at den sitter fast vid flintan, eller ock är lös, så at, då hon skakas, höres huru kritan stöter emot sidorna däruti. Från en sådan iholighet, är icke något hål eller gång til yttra peripherien eller yttra kanten, utan flintan är solid rundt omkring hålet. Desse äro små som Svale-ägg eller Byss-kulor, och äfven stora som Styckekulor.

Uti somlige Kritgropar suto Karlar och slogo i små bitar sönder de där samlade flintstycken, at sälja åt resande och andra, at slå eld med.

Vid Kritgroparna och ofta annorstäds voro murarna på husen och omkring gården bygde endast af flinta, i det de slagit i tu de stora flintstyckena, och så vändt den svarta flata sidan utåt; men den gamla rundaktiga ytan inåt.

Åtskilliga Kyrkor finnas på denna orten, upmurade nästan endast af flinta och kalk, | hvilka bägge, så flintan, p. 77 
som kalken, äro tagne ur dessa kritgropar. Således hafva desse kritgropar varit i stånd at framgifva mäst alt, hvad som behöfs til en hel Kyrkas upsättning.

En och annan Kritgrop, där de i forna tider tagit krita, är nu lämnad öde, och står fullväxt med allehanda trän och örter. Bland träna äro i synnerhet Liguster, Viburnum, Törnbuskar, Cornus fiem. i ganska stor myckenhet.

Här och där är i kritgroparne qvarlemnad midt uti någon vägg eller sida, hvilken ser ut antingen som en hög gammal mur eller pelare.

När Solen skiner vid det en vistas uti en kritgrop, kostar det ganska mycket pa ögonen, at se på den hvita kritan.

Caniner hade på ảtskilliga ställen sina hål och bon i den lösa nedrasade mullen och kritan, där de om aftnarna syntes i stor myckenhet.

Tättingar hade deras nästen i de urgrafne hvalfven.

Uti en af kritgroparna var anlagd en vacker Trägåıd, full med åtskilliga fruktträn samt hvarjehanda KöksKryddgårds-växter.

I Kritgrufvorna vid Rochester, hvilka lågo halfannan Svensk mil ungefär från de nu beskrifna vid Northfleet, hade Kritväggarna aldeles samma beskaffenhet, som de p. 78 förut omtalte, nämligen, at de gingo i lika ho|rizontela och perpendiculaira sprickor: ägde samma heterogenea: hade likaledes sådana strata af flinta, lagde tätt vid hvarannan, samt en, 2, 3 à flere famnar af krita emellan hvart sådant stratum. I kritan emellan dessa strata satt äfven här och där något flintstycke.

Beskrifning huru de bränna Kalk, af krita vid Northfleet, och annorstäds i Kent. Jag har nämnt förut, at alt Landet omkring Northfleet bestâr af bara krita, hvaruti de gräfvit djupa grufvor, och därutur tagit både krita och flinta, dels at säljas utomlands, dels at af kritan bränna kalk. Sättet huru kalkbränningen här förrättas, är följande, som jag vil berätta $i$ den ordning, som det sker: De bryta med en järnstör stora stycken lösa från 
sidorna på kritgroparna, och låta dem ramla ned til botten på grufvan. De begynna denna brytning öfverst mot dagen, sedan de förut bårttagit myllan och jorden, som ligger ofvanpå kritan, och fortfara så ned åt ända til botten; men ej mera på en gång, än det kan räcka til bränning uti en eller par veckor. Alla de andra väggar på kritgrufvorna, som de lämnat at bryta, äro mäst perpendiculaira; men den väggen, där de bryta, är nog sluttande så at de kunna gå up och utför den samma merendels.

De stycken, som nedfallit, och ännu äro mycket stora, huggas sönder i smärre stycken med en järnhacka.

Därefter hafva de gjordt sig likasom en stubbe eller huggstock af krita, hvarpå lägges den i någorlunda smärre bitar på förenämde sätt slagne kritan, och med en hacka, som liknar en sådan, som vi pläge hacka qvarnstenar med, endast at ägget af hackan ej går parallelt med skaftet, utan ad angulum rectum, eller tvärtföre mot skaftet, som på en skarf-yxa, hacka ännu kritan uti smärre bitar, så at dé största kritbitarne sällan blifva större, än en knytnäfve. Denne hackan är uti ägget ungefär par tum bred.

De Flintstenar, som finnas bland kritan, samlas och lägges i en hög, at förvaras, och sedan säljas de bårt.

De hafva sedan et Rissel af 5 quarters Diameter ungefär, hvars botten är gjordt af smala järntenar omhvefvade med ståltrå. Desse järntenar äro satta, som vanligt är i såll, at de göra fult med fyrkantiga hål eller quadrater. Hvardera latus af en sådan quadrat eller fyrkantigt hål är $1^{1} / 2$ à $1^{3 / 4}$ à 2 tum. Detta Rissel hölts af en person, under det den andre med en skåfvel kastade den sönderhugna kritan däri, då altid de stycken, som voro mindre än hảlen i botten på risslet, gingo igenom och föllo ut, tillika med den krita, som vid hackningen smålats sönder til mjöl. De kritstycken, som blefvo qvar i Risslet kastades därutur i korgar, hvilka blefvo burne til kalkugnar, at brännas til kalk; men de smärre styckena, som föllo ut genom hålen af Risslet, | tillika med det fina mjölet, lämnades at ligga qvar på backen, och fördes ej til kalk- 
ugnen. Orsaken, hvi de ej ville bruka det, sades, at det släcker ut elden i kalkugnen, emedan det är så fint.

Skåfveln, som de öste kritbitarne med, var litet uthålkad, aldeles lik sådana skåflar, som brukas i Spanmålseller Salt-bodar, endast at den var något bredare. Bredden eller lat. tranvers. af skåfvelbladet var 3 qv. 4 tum; latit. perpendicularis 1 quarter, 4 à 5 tum: nederst och rundt omkring var den skodd med järn.

Korgarna, som de små kritstyckena östes uti, och uti hvilka de buru kritan til kalkugnen, voro gjorde af Videspråtar eller telningar, til skapnad som en Pocal eller Bägare; högden af dem 2 qv. 1 tum; diametern vid Basis något mera än 1 qv. diametern ofvantil $2^{1} / 2$ qv. à 2 quarter, 4 tum.

Sedan de öst korgarna fulla, af hvilka här var en stor myckenhet, buros de af Qvinfolk til kalkugnen, hvarest en Karl var, som tog emot korgen, kastade eller stjälpte kritbitarne därutur öfver eller på kalkugnen, dock på sådant sätt, at han slängde dem til vägs, så at de ej kommo at ligga på hvarandra, utan spriddes jämt omkring bredevid hvarandra.

Kalkugnen var bygd af Tegel. När han var tom, och en ofvanifrån såg nid $\mathrm{i}$ honom, var han til skapnad p. 81 likasom en bä|gare eller Pocal, rund såsom han varit dragen med en Cirkel; men smal nederst, och vidgade sig från alla sidor mer och mer ut, ju högre han blef. Diametern vid Basis eller botten af ugnen innantil var 11 quarter à 3 alnar; men ofvantil vid öfversta superficies var diametern $6 \frac{1}{2}$ aln, somliga litet mera. Perpendiculaira högden inuti från botten til öfversta kanten 11 alnar 1 quarter. Nedantil vid botten var ugnen utanpå bygd perpendiculair til 3 à $3^{1} / 2$ alns högd, hvarifrån han sedan som en parasoll vidgade sig ut på alla sidor. De hade där lagt på den perpend. muren öfverst bjälkar horizontaliter, på hvilka de satt andra smalare bjälkar, hvilka alla lutade utåt, som en parasoll. Näst innan för samma bjälkar voro lagda stora Kritstycken, och straxt innom dem, tegelmuren af kalkugnen, som stödde sig och up- 
bars, vid det den mer och mer utvidgade sig, af dessa tätt vid hvarandra upstälta och en parasoll formerande bjälkar; ty om ej desse varit, hade öfra delen af ugnen ej kunnat stå. Med öfra ändan voro desse uprätte bjälkar fästade vid andra horizontelt lagda bjälkar, som voro inhugne $i$ en enkom därtil gjord ställning, hvarpå var gjordt som en botten, därpå de kunde gå och spatsera omkring ugnen, samt bära krita, stenkål, och annat, som behöfdes, til den samma. Ned vid botnen hade kalkugnen 4 stycken öpningar eller ugns-munnar, därigenom den fullbrända kritan kunde uttagas, och hvar|igenom vädret fick altid spela in, och elda up kålen i ugnen, at det var altid et starkt drag. Hvardera ugnsmun, som var fyrkantig, hölt 5 quarter i bredd, och en aln i högden. Den perpendiculaira delen af ugnen, eller den nedra var utanpå en octangel eller ått-kant, på det sättet, at då en af latera stod perpendiculair, var ungsmun $i$ den nästa, då öfre delen af latus stod lika långt ut, som den perpendiculaira, men gick sedan mer och mer inåt, ju längre ned det kom, da nederst var ungsmunnen. De hade merendels bygt et plank omkring ugnen af bräder, med 2 ingångar på, en på hvar sida, at hindra vädrets altför mykna blåsning. Detta brädplank var på yttra sidan af ugnen; ty på den andra sidan gjorde backen med dess perpendiculaira sidor, tätt vid hvilken kalkugnen var bygd, samma tjenst. Botten af backen, hvarest de nu togo kritan, var horizontel med öfra brynet eller bräddarna på ugnen.

När de bränna kritan til kalk i denna ugn, lägges nederst tårt ris eller qvistar, at tända up elden med: så stenkål et tunt stratum: så et stratum af de sönderslagna kritbitarna: åter et tunnt stratum af stenkål: och så alternatim S.S.S. ända til des den Pocal- eller Bägar-formiga ugnen är full. Elden tändes på nedantil, och breder sig så mer och mer upåt, alt efter som de nedanföre varande stenkålen blifvit upbrände: är ock kritan ge|menligen bränd til kalk, fast den ännu sitter tilhopa i samma bitar som den var, då den lades in.

Alt som kritan blir fullbränd, tages styckerna ut 
nedanföre vid botten af ugnen, genom de ofvanbeskrefna ugns-munnar. Då den kritan, som är ofvanföre, alt mer och mer sjunker ned i des ställe. Och at ännu mera befrämja detta, hafva de en lång antingen enkel, eller tveklufven eldgaffel, som de ränna här och där ned i ugnen ofvan ifrån, och röra omkring, då kritbitarna desto snarare falla ned. Kritbitarna karades ur ugnen med ofvanbeskrefna breda skåfvel.

Det bränsle de härtil bruka är endast och allenast stenkål, undantagandes, at då de först tända på en ugn, hafva de nederst Risknippor, at tända pả med; emedan stenkålen ej annors sả lätteligen vela fatta eld. Litet från ugnen ligga stora högar af stenkål; men innan de brukas, slås de med en järnhammare sönder i helt små bitar, föga större, än en lillfinger-ända. En stor del är så små som damm. Karlarne föregofvo, at de således bränna bättre och jämnare, och fả ej vara tjockare; emedan et tunnt hvarf af sådant, är nog tilräckeligt, at upheta och bränna det stratum af kritbitar, som ligger ofvanpå, eller under det samma. Så snart Karlen slagit sönder i helt små bitar så mycket stenkål, som han tycker vara tilräckeligt til några korgar, tager han vatten $i$ et p. 84 ämbar, och slảr det / tunnt öfver samma sönderkrossade stenkảl, dels at dermed hindra, at de ej må af vädret blåsas bårt, sedan de nu til en del äro som mull, dels ock, emedan de skola hetta starkare, då de sålunda komma i ugnen. Kảlen läras, sả tillagade, af qvinfolk $\mathrm{i}$ ofvanbeskrefna korgar och sättas rundt omkring ugns-kanten, hvadan Karlen tager dem, och slår dem i ugnen, alt som han finner nödigt.

Ingen må tänka, at hvarfven eller strata af dessa stenkâl i kalkugnen äro så tjocka, at då de lagt et sådant hvarf ofvanpả den hvita kritan, skal ej kritan mera synas, utan bara svarta stenkålen, ingalunda: desse stenkåls hvarf äro både tunna och ganska glesa: 2 eller 3 à 4 sådane korgar, som förut vid kritan är beskrefne, göra tilfyllest til et stratum up vid öfversta kanten på ugnen, där den dock är vidast. 
På samma sätt förhåller det sig med strata af kritan, at kritbitarne ej ligga så tätt, at en ju mäst öfveralt kan se Stenkåls-bitarna emellan dem.

Någon torde tänka, at Kalken, som brännes af denna krita, måste förlora mycket af sin hvita färg, medelst det, at de svarta stenkålen blandas skiftevis om den samma: eller ock fråga, om stenkålen sedan skiljes från kritbitarna? Svar: stenkålen skiljas ej från kritbitarna sedan kritan är bränd, ej eller skulle det låta göra sig, emedan, som förr är sagt, stenkålsbitarna äro helt små, och en stor del | af dem som bara stoft; utan de blifva qvare, och p. $8 \tilde{5}$ blandas tilhopa med kritan; men det bör märkas, at då stenkålen blifvit brände, hafva de förlorat all sin svarta färg, och fått en ljus, så at kritan til sin hvithet tager ganska ringa skada däraf. Dessutom föregifva de, at en kalk bränd af krita, som är utblandad med söndermårad stenkåls aska, skal vara långt mera bindande i murar, än all annan kalk, hvilket de tilskrifva stenkåls askan.

Vid hvar ugn äro 6 personer, 3 män och 3 qvinnor. 2:ne af Karlarna hafva den syslan, at bryta kritan lös, och hugga den sönder i små stycken, samt lyfta korgarna på qvinfolkens axlar; men så sker dock ofta, at qvinfolken äfven få hjelpa til at hacka sönder kritan i små stycken. Bägge Karlarne och alla 3 qvinfolken hjelpas åt, at fylla korgarna med kritbitar, då gemenligen Karlarne ösa kritbitarna i Rislet, och qvinfolken slå dem i korgarna. Qvinfolken måste mäst allena bära korgarna på hufvud och axlar från stället, där kritan tages til Kalkugnen. Likaledes måste de bära stenkåls Korgarna från stället, in til Kalkugnen. Den 3:die af Karlarna är beständigt vid Kalkugnen, hvarest han tager Kritkorgarna af Qvinfolkens hufvud och axlar, och slår Kritan i ugnen. Likaledes slår han stenkålen $i$ deras hvarf uti ugnen. Kårteligen han förrättar alla de syslor, som fordras vid sjelfva ugnen, dessutom hjelper han | til, då han har tid, p. 86 at boka sönder stenkålen $\mathrm{i}$ små bitar.

Hvart Qvinfolk bär altid 3 Korgar hvar gång, nämligen, hon har en brädbit af par tvärfingers bredd, samt 
ungefär $1 / 2$ alns längd, uti hvilket är et rep eller band, som'med ena ändan är fäst $i$ en ända af träbiten, och med den andra $i$ den andra. Detta band lägges med lyckan öfver den öfra delen på hufvudet, så at brädbiten kommer at stå tvärt öfver axeln, då en korg sättes at stödja sig på brädbiten, och de andra 2 i bredd på hufvudet, under det, at Qvinnan lutar hufvudet litet vid det hon går. Pả hufvudet hafva de en gammal manfollzs hatt, och under trädbiten och bandet et valmarsstycke, at trädbiten och bandet ej må göra ondt pả ryggen.

När desse Kalkugnar blifvit en gång uptände, sades de brinna hela àret natt och dag, endast at de under Jultiden vid de förnämsta högtids dagarna lemnas at slåckna ut; men sả suart de äro förbi, uptändas de ả nyo, och. fortfares därmed natt och dag ända til nästa Jul.

Den Krita, som lägges om morgonen i ugnen at brännas, blir däruti, ibland 2, ibland 3 dagar, innan den hinner igenom den samma och blifver fullbränd. Merendels räckna de 2 dagar til dess bränning. Under det hon således kommer at gå igenom ugnen, befordras hennes bränning, ej allenast af de stenkals hvarf, som ligga henne

p. 87 närmast, utan | äfven, därjämte af teglet i ugnen, som är mycket varmt af den långvariga bränningen. Hettan i ugnen är så stark, at flintbitar som kommit at följa mecl Kritstyckena i ugnen, förvandlas til et hvitt glas.

Så snart den i ugnen lagde kritan är fullbränd, och har gått igenom hela ugnen, at den nu är mot botten, tages den ur ugnen med den ofvanföre beskrefna skåfvelen. Botten utanföre rundt omkring ugnen vid ugns-munnarna är af breda fyrkantiga släta tegelstenar. De brända Kritbitar läggas i stora högar pả sådana ställen, som äro i skjulet, hvilket är rundt omkring ugnen, och när de fått alla vrår så fulla, at ej mer kan där rymas, föres den därifrån med stora kärror ned til stranden af Thames, som löper straxt där bredevid, hvarest den lägges osläckt i fartyg, och föres up til London at försäljas. Eljest när de taga stycken af denne brända krita, och slå litet vatten därpå, börja de småningom röka, och blifva så heta, at 
en ej kan hålla handen därvid. Omsider falla de sönder til et fint mjöl, aldeles på samma sätt, som det sker med annan osläckt Kalk af Kalksten.

När Kritan är fullbränd, är hon ansenligen lättare, än hon var förut, samt full med små sprickor, likasom då en lagt spiklera i elden. Färgen utanpå är gråacktig, som tvifvelsutan kommer af stenkålen och röken. Brytes et sådant stycke sönder; så är det ej|så hvitt inuti, som p. 88 det var medan det ännu var obrändt.

Flintstycken af 5 tums längd och 1 tums diam. som kommit at kastas med Kritan i ugnen, äro genombrände, och snöhvita alt igenom, at de se ut som Holländska hvita Krus.

De brända Kritstyckena äro så sönderspruckne och fulle med springor, at de falla i små bitar, dả en tager i dem. Den delen af dessa stycken, som varit mot sprickorna, är ock mörkare til färgen, än den, som varit inidt emellan samma springor; emedan nảgot stenkåls rök tvifvels utan trängt sig in i sprickorna.

At ej denna släckta Kalken mảtte spillas bårt, då den slogs i skeppet, hade de en ränna hopslagen af bräder, af 8 à 10 quarters bredd, samt ungefär 4 alnars längd, den de satte stupande vid sidan af Fartyget, hällde så ur Kärran Kritbitarna i denne rännan, då den rasade ned i Fartyget. En sådan ränna brukas ock altid vid skeppen, när obränd krita föres uti dem.

Jag har nämnt förut, at omkring alla dessa ugnar nedantil är bygdt et skrank af bräder, dels at hindra, det ej vädret måtte ligga för starkt på ugnen, dels och förnämligast, at de därinnanföre måtte kunna hafva de brända Kritbitar, som de taga ur ugnen, innan de köras ned til Fartyget eller Jackten, som förer dem til London. Detta skrank är väl af bräder, men dess fot är somligstädes til 6 quarters högd, af bara tegel. Til tak öfver | detta skjul, p. 89 är den altan, at jag så må kalla det, som går rundt omkring öfversta brädden af ugnen. Emellan ugnsmuren nedantil och detta skrank eller plank äro gemenligen 10 qv. à 3 alnar. Skranket har 2 öpningar, en på 
hvar sida af ugnen, där de lasta de brända Kritbitar på kärran.

Kalkugnen är altid bygd helt när intil det stället, där de bryta kritan, at de ej måtte hafva för lång väg, at bära Korgarna och Kritan; därföre ses ock här och där stå gamla obrukbara ugnar, som de lämnat, sedan de brutit bårt all Kritan när vid dem, och det börjat blifva för långt at bära Kritkorgarna.

Qvinfolken få hvardera ungefär 8 pence om dagen, hvarföre de göra ganska väl rätt; ty de arbeta merendels som slafvar. De sade sig blifva lönte på det sätt, at en Qvinsperson får 1 pence, när hon burit 16 Korgar med Krita til Kritugnen, hvarföre de ock hade ganska brott om. Den som hade upsigt öfver dem, stadfästade hvad Qvinfolken sagt, at de få 1 p. för 16 Korgar de burit, då de kunna förtjena 12 , 15 à 18 p. om dagen, alt som de äro flitige. Karlarne få hvardera 9 à 10 Skillingar om veckan. Mat och alt måste de hålla sig sjelfva.

Litet från Rochester mot Gravesends sidan voro åtskillige Kritgropar, dem de togo krita utur, hvilken stöttes lös med järnstörar: hackades än vidare sönder med järnhackor: bultades sönder omsider til små klimpar och p. 90 bi|tar med järnknöster, som sedan fördes til ugnen, där de brändes til Kalk. Sedan de bultadt sönder en hop Kritstycken til mindre bitar, fördes ej alt det sönderbultade til Kalkugnen, utan de lade det först $\mathrm{i}$ et groft Rissel, och risslade bårt hvad som gâtt sönder til mull, hvilket de ej togo. De Flintstenar, som funnos i Kritan, skildes därifrản, och kastades tilhopa i en hög, samt försåldes til den, som behöfde dem. Kalkugnarne voro här bygde helt och hållna ned i jorden, så at öfversta Kanten af Kalkugnen var horizontel med markens superficies. Ugnarne voro ock här $1 / 3$ del mindre än de, som äro vid Northfleet, ja in mot dubbelt mindre; men eljest mäst af samma form, undantagandes, at nederst är endast et draghål, i stället at i dem vid Northfleet äro flere. De gingo ock här genom en gång ned til samma drag-hål, som på en tjäru-mila hos oss i Österbotten. Eljest äro väggarne 
alt murade af tegel. Karlen sade, at den Krita, som han den ena morgonen lägger in, kan vara färdig bränd, at uttagas den följande morgonen. Den Kalk de här bränna föres ej til London, utan upbrukas alt vid Rochester och där i nägden.

Kritan brändes i öfrigt här aldeles på samma sätt, som vid Northfleet, nämligen skiftevis af sönderstötta stenkål och Kritbitar, m. m.

\section{Den 1 Augusti.}

St. Foin brukas mycket här i Kent. De fläste kalla det här Cinquefoil, som de brutit från St. Foin. När det en gång blifvit sådt, kan det stå 10 à 12 år, utan at behöfva sås om, på hvilken tid de kunna slå det hvart år. Efter den tiden, sedan det börjar blifva något tunnt, at det ej synes löna mödan at slå; plöja de icke ännu upp den grund det växt på, utan låta det stå qvar 23 à 4 år, under hvilken tid de lämna Kreaturen, dock i synnerhet får, frihet at gå därpå i bet, hvarigenom Landet tilllika blifver gödt. De nödgas sålunda förfara härmed; emedan här i Kent är mycket liten Ängsmark och bete för får. När de då plöja upp et sådant Land, besås det gemenligen första Året med ärter; dock stundom med annat, alt som det finnes nödigt. För hästar är St. Foin en skön föda, både om sommar och vinter; men om det gifves, sedan det blifvit tort, åt Kor, äta de icke mera däraf, än endast öfversta blommknoppen, mäst alt det andra skräda de bårt, och trampa under fötterna. Det är försökt, at så det på somliga ställen i Essex utaf de frön, som de tagit härifrån Kent; men det har nästan på intet sätt velat fort, utan stått så usell, at det ej lönt mödan, at vidare så det. Jordmon är där sand och Gravel.

Clover. Här på orten sås ock mycket Clover. Våren är gemenligen den tid, då det sås; men de få ej slå det för än om nästa | sommar därefter. Det sås nästan aldrig p. 92 mer, än 2 somırar å rad, och ganska ofta ej mer än en enda sommar, hvarefter de gemenligen lemna det om nästa som- 
mar, sedan det. blifvit slagit, för fåren at beta på; emedan, som ofvanföre är sagt, man nödgas göra så, efter här är mycket trångt om bete, och de då tillika hafva den förmon, at åkern gödes vid det fåren gå i bete därpå. Korna äta Clovern begärigt både färsk och torr med stjelk och alt.

Vicia sat. Likaledes sår man mångenstäds här Tares eller Vicia sat. til foder för Kreaturen. Det förnämsta, hvartil den brukas, är, at de skära up henne grön på denna tid om året, och ger henne åt hästar hemma, som äta henne ganska begärigt. Mera lämnes ej at stå qvar på Landet däraf, än som det pröfvas nödigt til dessa fröns samling för nästa år; ty denne är en planta annua, som mảste sås hvart År, och det om Våren bittida, då den vid denna tiden kan tagas upp til foder åt Kreaturen. Det är vid samma tid, som de här hålla sina hästar hemma vid husen, af orsak, at de ute $\mathrm{i}$ inclosurerne blifva så mycket oroade af flugor och andra insecter.

Rofvor. De bruka både här, och på andra ställen i Ängland, at jämväl sả rofvor. Tiden, då de gemenligen så dem, är vid pass i dessa dagar. Jag var i dag på en stor inclosure efter middagen, som för middagen blifvit besådd med rof-frö. Hela inclosuren blef lagd til rofland. Landet ligger hela sommaren förut i träde. Vid början p. 93 af Julii föra | de gödseln ut på detta Landet, se förut T. I. p. 483. hvilken gödsel är merendels halmbyssie, sådant som samlas i fägården, och där legat under boskapen, samt blifvit utblandadt med deras dynga. Sedan detta blifvit utfördt på åkern och lagt där lasstals, bredes det ut så snart som en hinner, samt plöjes ned; därefter harfvas åkern, och vältas, at den blifver väl fin. Förnämsta orsaken, hvarföre de här så en sådan myckenhet af Rofvor, är, at de med dem föda och göda både får och oxar om vinteren.

Åkerbruket. De ställen, som en i höst tänker beså med hvete, äro sådane, som antingen nu ligga i träde, eller ock, där bönor nu växa, hvilka de i höst plöja upp, och beså med hvete. 


\section{Den 2 Augusti.}

Källor mycket rara här på orten. Jag har ofta förut gjordt den anmärkning, at springkällor med springåder och flytande bäck från dem, sådane som i ymnoghet gifves i Sverige, äro ibland sällsynte pả de orter jag förut varit i Ängland. Det samma har jag ock märkt här i Kent, och äfven $\mathrm{i}$ den delen af Essex, som ligger midt emot Gravesend; Landet består pá bägge ställen af höga backar och högder, med djupa dalar emellan, och somligstäds, enkannerligen på ömse sidor om floden Thames, stora lågländta fält, så at mången af alt detta kunde sluta, at i dälderna emellan backarna, samt på de låga fälten strax nedanför högderna, skulle finnas en myc/kenhet af rinnande bäckar, samt stort förråd af Springkällor här och där; men ingen ting är mera sällsynt. Vid mit vistande i Gravesend, vandrade jag tämmeligen omkring på alla sidor, var äfven par gångor öfver til Essex och där spatserade flitigt omkring; men hade ändock ej den förmon, at fă se en enda Källa, med rinnande vatten, ej eller en enda rinnande bäck, mer än strax W. om Northfleet. Alt det rinnande vatnet jag här såg, var i floden Thames, floden Midway, som passerar förbi Rochester, samt den lilla bäcken W. om Northfleet. Frågas en Ängelsman, om här finnes några Källor, så svarar han strax ja, och de som därhos äro sköna; men då han skal visa ut dem, är det ej annat, än en djup brunn ned i Kritbärget, den han säger hafva en springåder; emedan vatnet däri ej kan tömas ut, då den dock ligger några famnar djupt ned. Det är visst at Landet är här ganska vackert, i så måtto, at det genom häckarnas plantering omkring alla inclosurer öfveralt liknar en Trägård, jämte det, at den continuerliga omväxlingen af höga Kullar och djupa dälder, utan at se någon större sten, än en Gåsse kan häfva, ökar storligen des behagelighet; men så saknas dock här den täcka utsigt af Cristal klara rinnande bäckar och deras susande i de gröna dälder; et sådant nöje vet ingen här af. Jag talar här om de ställen jag varit på; ty på ảtskilliga andra 
p. 95 orter i Ängland finnas en myckenhet af sköna $\mid$ springkällor. Alt vatten som invånarne behöfva, så för sig sjelfva, som för sina Kreatur, skal samlas antingen uti djupa brunnar i Kritbärgen, eller i stora gropar och dammar i inclosurerne, därest rägnvatnet stannar och tjenar åt Kreaturen, som där beta, til drick; hvarföre ock sådane gropar altid äro vid sidorna helt lång sluttande, at boskapen må kunna gå dit ned och dricka. Men någon torde fråga om orsaken, hvarföre här finnas så ganska få, eller snart sagt inga källor och bäckar, där dock Landet består af backar och högder, samt djupa dälder: det ock här rägnar ibland ansenligen? Så svarar jag, at jag ej kan just veta det, men följande observationer har jag gjordt: 1) öfveralt hafva de här djupa brunnar ned i Kritbärgen, så närmare Thames, som längre därifrån, hvaruti är en ymnighet af vatten, som aldrig tryter. 2) Öfversta superficies af jorden består af en lös mylla, därpå en nästan aldrig ser stanna något vatten, ehuru det rägnar, utan det sjunker strax in, och öfra superficies är snart tort, åtminstone ofvanpå. 3) Där de gräfvit groparna så djupa, at de äro något ned i Kritan, stannar vatnet däri, och står i flere dagar, innan Solen hinner torka upp det. 4) När en gräfver aldrig så litet in i Kritan, där den sitter i backen, är den helt fucktig och däfvig inuti, och ju djupare en gräfver, ju fucktigare och våtare är hon. 5) Uti Kritgrafvarne finnes Kritan ej ligga p. 96 helt tätt och / solid, utan är full både med horizontela och perpendiculaira springor. 6) Går en bittida om morgonen i en Kritgrop, innan Solen hunnit torka up daggen, eller ock på et fält, där Kritstycken ligga, skal en finna, at Kritan är sliprig, och nästan mera våt, än annan jordart. Af alla dessa rön tyckes följa, at rägnet och snön, som faller, ej kan stanna i den öfversta mullen; emedan hon är för lös: at den går ned til Kritan: at Kritan hafver en egenskap, at draga fuktigheten til sig: at vatnet silar sig djupare ned genom de många perpendiculaira och horizontela springorna i Kritan: at ej många bäckar därföre kunna finnas på Kritbärgen; emedan de likasom slucka alt vatnet i sig, innan det hinner samlas til at göra 
en bäck: at säd och ärter, som växa på Kritbärgen därföre ej behöfva torkas bårt; emedan Kritan, som ligger därunder, drager tör hända om natten daggen ned til sig, och om dagen dunstas upp af det vatten som ligger ned i springorna. Af denna brist på Källor och flytande vatten sker, at boskapen undertiden om sommaren, då det är lång och stark torka, komma at lida mycket. De måste då ofta drifvas några Ängelska mil, innan de kunna vatnas. Det berättades, at de på somliga ställen ej hade annat vatten at betjena sig af til matlagning, än endast sådant, som samlas i Kritgroparna, hvilket är hvitt och tjockt, och ofta så fullt med små insecter, at de måste både sila och | koka det förut, innan de drista sig at p. 97 bruka det.

St. Foin. Jag har nämnt förut, at de mästa inclosuren, som här i Kent brukas til ängsmark, voro besådde härıned. Jag såg i dag ställen, där St. Foin i år blifvit slagen, bärgad och hemförd; men hade redan, emedan inga Kreatur blifvit släpte därpả i bet, så tiltagit i växt, sedan den tiden, at den nu var af $11 / 2$ quarters högd, med en ymnighet af lena och mjuka blan utslående från roten och stjelken, som stod dessutom mycket tät; så at jag tror, det de än en gång i denna sommar kunna få slå den.

\section{Den 3 Augusti.}

Salicornia, dess nytta. Salicornia herbacea Linn. Flor. Suec. 1. Rai. syn. 136. växte på de lågländta stränder af Thames, som vid hvar flod (refluxus maris) öfversvämmades af Thamsens salta vatten; ty en bör veta, at vatnet i hela den delen af Thames, som är vid och nedanför Gravesend, är mycket salt; emedan floden, som sker 2. gångor om dygnet, drifver det salta vatnet upp från hafvet. Denna örten låto Angelska Fruntimren plåcka vid denna tiden, och insylta, som skedde på följande sätt: örten togs, där hon växer, hel och hållen, afbröts vid roten. Således samlades däraf så mycket som behöfdes: hon tvättades väl i kall vinätticka, den ena stjelken och örten däraf 
efter den andra, at alt damm och orenlighet, som fastnat vid henne måtte sköljas bårt. De få ej tvätta henne i p. 98 vatten; | emedan om hon sedan lägges i vinätticka, (som bör ske); så skämmer vatnet, som sitter fast vid örten, bårt vinättickan, at hon blir svagare, hvarigenom hon blir oklar och full med mögel, och sålunda blir altsammans bårtskämt. Sedan de således tvättadt stjelkarna, eller örten ren i vinätticka, och lagdt dem på et bord, at vinättickan får litet rinna af; taga de en stenburk af den storlek, som de hafva Salicornia til, lägga örten däri til dess hon blir full, slå så god och hel ren vinätticka därpå, så mycket, at det står aldeles öfver örten i burken. Derpå taga de senap, mal den sönder helt torr; emedan den har ingen kraft, eller åtminstone ej är så stark, om den är omalen och hel: skär så en ren linnklut af den trindhet och vidd, som burken är inuti, och så än en annan linnklut af samma vidd: sömmar dem vid kanterna til en rund påse: fyller den med den malna torra senapen, at den är af et knifsblads tjocklek allenast: sömmar ej allenast igen hålet, som senapen lades in igenom, utan gör äfven en myckenhet tvärstyng midt öfver i korssvis, just som då en stoppar et täcke eller lifsstycke med blår eller bomull, at den må ligga jämt. Denne så fyllda påsen lägges ofvanpå Salicornia, som ej allenast trycker den ned, at alt står under ättickan, och intet ofvanföre, utan ock gör, at det ej kan sätta sig något mögel där ofvanpå. Sedan hafva de en stor sämsk-lapp, som räcker väl öfver burken. Denne lägges öfver burken, uch bindes väl til, p. 99 at kraften af vinättickan ej måtte förloras. De låta / det så stå i 14 dagar, eller en månad, och se så til, om Salicornia ännu behåller sin gröna färg, hvilket om hon gör, så taga de näglikor, Ingefära, Peppar, muskotblomma af hvardera $1 / 2$ unce och $1 / 2$ unce Jamaisk Peppar, (all spices) koka dem tillhopa, låta dem kallna, och så lägga dem $\mathrm{i}$ burken til Salicornia, binda å nyo om, sedan de lagt senaps posen på, som förr sades, och lämna det så at stå til dess de behöfva det; men om de skulle se, som gemenligen händer, at Salicornia ej behållit sin gröna färg, utan för- 
vandlat sig i en gul färg, taga de den samma tillika med vinättickan, den ligger uti, lägga det med förenämde Specerier i en malmgryta, koka alt så länge, til dess Salicornia, som hade en gul färg, då den lades däri, får en vacker grön färg, hvarvid märkes, at det röres då och då, medan det kokar. Så snart den då fått sin förra gröna färg, som sker gemenligen innom en half timas tid, fast ibland mer eller mindre, taga de den af elclen, slå altsammans i burken, lägga senaps påsen på, binda sämsk-lappen öfver, och förvara det til dess det behöfves. Ofta göra de ock så, at sedan de ränsat dem i vinätticka, dả de nyss äro plåckade, slå de ren vinätticka på dem, och med föresagde specerier strax koka dem, hvarvid märkes, at fast de äro gröna, då de läggas i malmgrytan, blifva de dock helt gula, så snart de blifva varma; men det måste fortfaras med kokningen, til dess de få igen sin förra | gröna färg, och därefter förfares med dem, p. 100 som förut är lärdt. De fara aldrabäst, om de förvaras $i$ en burk, uti et någorlunda varmt rum. De brukas om hösten och vintertiden vid stek och annan mat, på samma sätt, som insyltade valnötter eller gurkor, utan at något lägges vidare til dem. Obs. Vinättickan, som de tvättas och sköljes uti, slås bårt, sedan de blifvit rengjorde.

At insylta Champignioner. Fruntimret insyltade dem så: de plåckade dem medan de ännu voro helt små, då de bäst sig hålla, koka dem i mycket salt vatten ungefär 10 minuter, taga dem ut, lägga dem $i$ et Linnkläde at torka. Sedan taga de Vinätticka, hel-Peppar, och muskotblomma, koka det tilsammans, och slå äfven litet hvitt vin däruti. När det kokat litet, taga de det af, låta det kallna, lägga Champignionerne, sedan de blifvit torra, uti en glasburk, slå vinättickan och de andra specerierne därpå, at det täcker öfver dem, har så en sämsklapp, som de binda öfver glaset, at det är väl täpt: bruka så däraf när det behöfves. De stora Champignioner insyltas ej, utan stufvas färska. De små, som voro insyltade, voro af den storlek som finger-ändar, och bestodo 
af hela pileus och pedunculus med lameller och alt, intet bårttagit: de tvättas $e j$, innan de läggas $i$ saltlakan at kokas.

Vid Middagstiden kom Capitain Lawson från London ned til Gravesend, hvart skeppet redan gått förut den $\frac{20}{31}$ Julii.

Gravesend är en liten fläck, som ligger på et behageligt ställe i Kent, tätt vid floden Thames, ungefär 22 Ängelska mil från London. Husen äro til en stor del af sten, fast somlige gamle och ej så präktigt bygde. Gatorne ojämna, irregulaire, och belagde med flinta. I Staden är en vacker Ängelsk Kyrka, och et Presbyteriskt Bönehus. Utanpå Ängelska Kyrkan läses desse ord: Hanc ædem incendio lugubri deletam Georgius II. Rex Munificentissimus, Senatus Consilio, instaurandam decrevit; hvilket tillika pekar på den brand, som denna lilla stad för några år tilbaka undergick, då en stor del däraf lades i aska. I och omkring staden äro åtskilliga Kryddgårdar, hvadan en myckenhet Köks-Kryddgårds frukter nästan dageligen föras upp til London, utom hvad til sjöfarande föryttras; och är i synnerhet Gravesends Sparis berömd, hvilken räknas för den bästa i hela Ängland. Inbyggarenas förnämsta näring består här $\mathrm{i}$ allehanda slags matvarors och liqueurers försäljande til sjöfolk och resande. Alla skepp, som komma utifrån til Lıondon, få här Tullbetjenter om bord. Här förse sig ock mäst alla skepp från London med färska matvaror, innan de begifva sig til sjöss. Skeppen gå gemenligen några dagar förut

p. 102 från London hit ned, dels | at förskaffa sig färskt, dels at liksom undergå af Tullbetjenter en ny clarering, innan de gå til sjöss, då Capitainerne och Passagerarne gemenligen komma 4 à 5 dagar efter skeppet hit ned. Midt emot Gravesend på andra sidan om Elfven Thames i Essex, ligger Fästningen Tilburgfort kallad, som commenderar inloppet til London. Emellan Gravesend och 
London gå dageligen åtskilliga små jagter eller båtar, de där föra Passagerare och andra resande fram och tilbaka.

\section{Den 5 Augusti.}

Resan. Efter middagen Kl. 6. stego vi om bord på skeppet Mary Gally, som fördes af Capitain Lawson, och ärnade sig til Philadelphia i Norra America. Vi seglade då i HERrans Namn från Gravesend, och foro et godt stycke ut för floden Thames, innan vi kastade ankar, hvarest vi lågo til följande morgon $\mathrm{Kl}$. ungefär 3, då resan vidare fortsattes.

\section{Den 6 Augusti.}

Vi fortsatte om morgonen vår resa ned efter Elfven Thames, och så ut i Canalen, hvarest vi sedan gingo nedan för Kusterna af Ängland. Vi kunde ständigt se stränderna af Ängland, och voro stundom vid loverandet när in til dem. De bestå alla af Kritbärg, som äro höga, stå branta och inemot perpendiculaira. Efter ögonmåttet tyckes högden af dessa branta kritstränder, från vatnet upp til gräsvallen, vara 3 à 4 famnar, somligstäds | mer, p. 103 annorstäds mindre. Vi kunde ögonskenligen se, at i desse voro äfven sådana förr omnämde strata af bara flinta, hvaraf et var just midt emellan vattubrynet och öfversta skårpan, gick helt horizontelt, som hade det varit lagt efter vattupass, och syntes mäst hela stranden utåt. Längre ned, litet från vattubrynet, syntes et annat, men det var afbrutit och otydeligt. Ofvanpå dessa Kritbackar lågo härliga åkrar, på hvilka säden, som mäst var bara hvete, börjat blekna och blifva färdig til skörd. Vi kunde dock ej se några skylar eller skuren säd; men redan i början af förra veckan sågo vi Rågskylar från Gravesend i Essex.

Om aftonen Kl. 6. vid pass, ankommo vi til Deal, utan för hvilken vi kastade ankar.

Deal är en liten fläck eller stad, belägen på stranden uti ingången af en vik, som hafvet här gör. Husen äro 
mäst alla bygda af tegel, samt täckte dels med concavt, men mäst med slätt (plana) taktegel. En enda Kyrka är i staden, ej stor, mäst utan torn, endast en liten Kur i dess ställe. Kyrko-gården tämmeligen stor, och har rundt omkring sig en allée planterad af Alm, i hvilken en kan gå och spatsera. Invånarena må tämmeligen väl, och nära sig förnämligast med handel; ty som mäst alla skepp, som komma från London, och ärna sig genom Canalen, eller ock tvärtom, pläga ligga här en dag eller mera; så p. 104 förse de sig gemenligen här med allehanda / slags friska matvaror, utom bränvin och annat, fast de ock fả betala det rätt drygt, emedan folket vet, at taga väl skäl därföre. En stor del få ock sin föda grenom roende, i det de föra de resande från skeppen til landet, samt därifrån tilbaka, för hvilket alt de låta dyrt betala sig. Med fiskande förtjena de ock vackert, sälja den färska fisken åt sjö-folket, som komma här at ligga. I sista Kriget idkade de flästa Kaperi, och därigenom lade tilhopa stora summor. Hamnen är ej särdeles god; ty den är öppen för $\mathrm{S}$. och $\mathrm{O}$. som har frihet, at från hafvet storma härpå; men så vil det dock ej göra til saken; emedan det är merendels $\mathrm{i}$ brist af samma väder, som skepp lägga sig hit på redden. Här lämna skeppen lotsen, som de haft från London eller Gravesend. När O. och S. storma starkt, känna de det i Deal, emedan det ligger öppet för desse väder. Här taga ock de skeppen lots, som ärna sig til London.

\section{Den 7 Augusti.}

Om morgonen for jag i land til Deal, där jag var tils mot aftonen.

Lumbricus marinus. När hafsvatnet vid ebb föll ut vid Deal, gingo fiskarena ned på de lägsta ställen, som hafvet nu lämnat, hvilka voro öfvertäckte med en fin sand, hvarest de grofvo up de hafsmaskar, som hafva sit tilhåll under sanden vid hafsstranden, och äro beskrefne af Herr Archiatern och Riddaren Lisneus uti dess Västp. 105 götha resa pag. 189. | samt äfven nämde i dess Fauna 
Suec. §. 1270. De grofvo up dessa kräk, som äro en art af metmaskar, på det sätt, at de hade en liten grep af järn med 3 grenar eller tinnar, med hvilken de grofvo upp den lösa sanden, där desse maskar hade sitt tilhåll, då de gemenligen under 3 quarters djup ned i sanden fingo dem igen. Det tecken, som de hade, at kunna veta, hvar desse maskar höllo til, är, at de vid högt vatten krypa up ur sanden, och ligga ofvanpå honom; men så snart det blir ebb och vatnet faller ut, krypa de ned under sanden; imedlertid så länge de varit ofvanpả sanden, lämna de sin träck efter sig, som är bara fin sand, och ser ut, som små maskar lågo i ring, eller ock kringellika former på den andra sanden. Desse uphögde sandringar gifva fiskarena vid handen stället, där maskarna uppehảlla sig, och dymedelst förråder dem. De maskar de få, samlas i Käril, och brukas til agn pả krokar efter hvitling och koljor (Cods). De kalla dem Logvorms.

Machine at vinda up båtar. Vid Deal är ebb och flod, då vatnet i 6 timar stiger högt up och i 6 timar faller ganska mycket ut; därföre, at få upp båtarna, at de må stå säkre, och ej slås sönder af vågen, då det börjar blifva högt vatten, hafva de på stranden, ofvanföre där båtarne stå, perpendiculairt stående vindståckar, med hvilka de genom et rep, som är fästadt ned i båten, vinda up den samma, så högt de vela på stranden.

\section{Den 8 Augusti.}

Om morgonen Kl. 3 förr middagen lämnade vi Deal, och fölgde strömmen därifrån ut efter Canalen, fast ej fortare än strömmen dref. Vi hade på högra handen litet från oss Ängelska vallen, som bestod af bara krita, var tämmeligen hög, och stod merendels perpendiculair. Vid Kl. 10. förr middagen passerade vi Dover, som är en liten fläck, med et Castell ofvanföre på en högd. Landet var här efter Kusten somligstäds helt brant, annorstäds långt sluttande, til en half Ängelsk mil ungefär, då höga Kritbackar där ofvanföre togo emot, som ej voro perpendiculaira, utan mera sneda, samt nu öfverväxte med gräs. 
När Landet gått så långsluttande et stycke, blef det åter brant och perpend. at bara hvita kritan syntes. Efter middagen blåste en liten kul, då vi loverade af och til emellan Ängelska och Franska vallen. Vi voro ibland ej långt från den Franska, så at vi tydeligen, i synnerhet med Perspectiv, kunde se både hus, åkrar \&c. Här påminner jag mig hvad jag läst i Cambdens Britannia, nämligen, at han säger, det han snart var af den mening, at Angland i forna tider, setat ihop med Frankrike eller Flandern, där nu Dovern och Calais ligga, genom någon smal arm, och at hafvet sedan skölgt bårt den samma, eller någon annan händelse, oss nu obekant, kommit at rifva bårt p. 107 samma arm eller näs. Jag för min del är ganska benä|gen at tro det samma, när jag besinnar följande: nämligen, at Ängland gör midt emot Calais emellan Deal och Dover en udd ut, samt at Flandern vid Calais gör en udd ut mot Ängland: at bägge uddar bestå af samma jordart, nämligen af höga perpendiculairt stående Kritvallar: at landet på bägge sidor här, nämligen så i Ängland, som Flandern, har samma facies och utseende: består af en samling af kullriga och långsluttande högder af Krita: så at om en, som sedt Kusterna af Ängland, finge här se Kusterna af Frankrike, och ej visste, at det vore det samma, skulle säkert tro, at det vore Ängelska vallen och dess högder. På Ängelska vallen sågo vi här och där någon vacker Kyrka, liten by \&c. Åkrarne lågo på högder, men trän voro här rara, och deras indelning $\mathrm{i}$ inclosurer genom häckar blefvo vi ej varse. En myckenhet af Marsvin eller Isor tumlade om aftonen utan för vårt skepp allestäds i hafvet. Om aftonen begrofs på vanligt sjösätt en hustru af de för Religion flycktande från Pfaltz i Tyskland, som til 60 stycken af män, qvinnor och barn nu reste med oss öfver til de Ängelska Colonier i America, at där sätta sig ned. Begrafningen skedde på det sätt, at sedan de bundit henne i segelduk, fästes en hop med stenkål i en gammal påse vid fötterna, dả hon lades på et bräde, och släptes så från brädet i sjön, sönk strax ned til botten. Några Psalmer söngos förut. 


\section{Den 9 Augusti.}

Resan. I dagningen lämnades skeppet at drifva vidare med strömmen så länge den räkte; men förut, så länge strömmen var emot oss, hade vi kastat ankare. Vi gingo i dagningen förbi en af Änglands uddar, som kallades Dunguness. Kl. 9. blef strömmen mot oss, då vi kastade ankare, nästan midt mot Fair leight. På hafvet var nu så lungt, at vatnet näppeligen rördes, utom det at strömmen dref dẹt. Vi kunde helt tydeligen se härifrån Ängelska vallen, som somligstäds var hög, brant och stupande, nästan mäst perpendiculair, annorstäds lảng sluttande. De perpendiculaira jordvallar vid hafvet bestodo här ej af Krita, utan af en ljusgrả jord. Vi kunde ingenstäds se tecken til Krita i dem. Franska vallen låg. så långt från oss, at vi näppeligen kunde se den. Kl. 12 förr middagen begynte det năgot blåsa, då vi lyfte ankare, hissade segel, och med lovering drogo oss fram. Vi voro ibland aldeles under Ängelands vall vid Fair leight, hvilken vall här ej bestod af Krita, utan af en grå fin sand, så mycket vi med perspective och blotta ögonen kunde finna, utom det, at Capitain Lawson bekräftade det samma. Denne vallen var ock nog brant, at ingen kunde klifva up på den, utan stega eller annat verktyg; men somligstäds var den långsluttig. Landet här ofvanföre var, som det öfriga Ängland vi sett, en samling af högder | bredevid hvarandra med dälder emellan; dock voro högderna här mera långsluttige. På dem lågo åkrar, ängar och beteshagar, som alla voro ornstängde med gröna häckar och löfträn. Här och där syntes någon Kyrka på högderna, med hel litet stackigt och spitsigt, fast tjokt torn, hvilka blifvit så bygde, at vädret, som här har stort fält at samla sina krafter på, ej måtte blåsa dem omkull. Kritstränder eller bärg kunde vi här ej blifva varse. Mot aftonen kastade vi ankare en liten stund; men som det började blåsa sakta östanväder vid Kl. 9, lyftes åter ankaret, och resan fortsattes hela följande natten. 
Hafsdjur. Eljest sågo vi et slags hafsdjur flyta på vattnet, ungefär af hos stående figur. Färgen var mäst violett, det var rundt, och öpnade sig up nästan som en pung, då man såg midt uti det som 4 hvita ringar. Det måste vara någon art af meduser. Jag kunde ej fåł tilfälle at fånga någon. Storleken var åtskillig, somlige hel små, af en tums diameter, andre och de störste mot et quarter midt öfver.

\section{Den 10 Augusti:}

Resan fortsattes vidare hela denna dagen med en önskelig och behagelig vind, som dref skeppet fort, utan at några vågor gingo på sjön. Om morgonen $\mathrm{Kl}$. 7. fingo p. 110 vi Ön Wight i ögnasigte, som ligger utanför Porth $\mid$ mouth och hörer til Ängland. Så väl hon, som landet däromkring syntes bestå af Krita; emedan vallarna voro snöhvita. Hon är ock nog högländig.

Färilar. Under det vi seglade här ute på hafvet, så at vi endast kunde se långt från oss litet af Angelska Vallen, men ej nảgot annat land, kommo hvita Färilar flygande öfver sjön, samt fölgde ibland skeppet et stycke. Ibland flögo de ock skeppet förbi. Jag kunde ej få fast på någon, at få se hvad species det var; men de liknade aldeles de snöhvita Kål-Färilar, både til skapnad och storlek. Jag såg dem ej sätta sig någorstäds på skeppet. Vi sågo dem äfven i går. Alle undrade huru desse kräken dristade sig så långt ifrản stranden.

Vid middagstiden gingo vi Ön Wight förbi, som var et mycket högt land; men dock vid stränderna merendels långsluttande. Jordmon var där af Krita, men denna Krita sades ej vara så god, som den vid Gravesend, utan mera hård. På ömse sidor om On Wight syntes höga branta stränder af bara Krita. Landet ofvanpå denna Ö syntes sönderdelt med häckar. Kl. 5 efter middagen började vi se Ön Porthland snedt fram för oss på långt håll. Eljest sågo vi allestäds midt för oss Ängelska vallen, fast p. 111 mycket långt ifrån. Den | var mäst nog brant, och syntes 
helt hvit; men om det var af Krita, någon hvit stenart, eller annat, kunde jag för den långa distancen ej urskilja.

\section{Den 11 Augusti.}

Resan. Vi seglade fort hela föregående natten, och jämväl denna dagen. Kl. 6. om morgonen sågo vi Bolthead, en udd af Angland, innan för hvilken Pleymouth ligger. Marsvin tumlade då och då $i$ vatnet. Vid Middagstiden stillades vädret merendels af, så at skeppet ej kunde komma särdeles fort. Eljest var vårt skepp en ganska stark seglare, så at få skepp kunde spisa däremot. När börden var någorlunda god, och vi om aftonen i skymningen eller något förut vid ljusan dag sågo endast öfversta masten af något skepp för oss, hade vi följande dagen om morgonen $\mathrm{Kl}$. 7 à 8 gemenligen lämnat det samma efter oss. Skepp, som hissade segel tillika med oss, blefvo så efter, at om seglen hissades om morgonen, voro de om aftonen utur vårt ögnasigte. Capitainerne, som voro om bord, tilstodo, at de näppeligen sett något skepp, som seglat så starkt. De uträknade det så, at då andra skepp uti en tima seglade 3 mil, seglade vårt på samma tid 5 mil. Vi lämnade vid Middagstid Ängelska vallen, och sågo den ej mera; emedan vinden dref oss närmare intil Franska sidan, hvilket land vi dock icke sảgo; emedan det var så ganska långt från oss. Vi fingo efter middagen ej se någon sjöfogel.

\section{Den 12 Augusti.}

Resan. Vi fullfölgde vår resa, fast vädret var nog emot oss; men Kl. 11. begynte det blifva mäst lungt, så at det gick nog sackta för oss. Vi sågo nu ej något land, utan vatten och himmel. Åtskilliga skepp blefvo vi dock varse rundt omkring oss. Inga Sjö-foglar syntes i sjön, ej eller något sjö-gräs. Et slags fisk, som Angelsmännerne kallade Bottle-nose, och är en art af Delphinus; viste sig ibland $\mathrm{i}$ vattubrynet. Kl. 3. efter middagen 
kommo stora svärmar af dessa Bottle-noses, som summo bredevid skeppet, och hoppade ibland högt upp i vädret ofvanpå vatnet. De fölgdes åt i stora hopar. Desse hafva et hufvud nästan som en Bouteille, hvadan de ock fådt sitt namn på Ängelska. Sjömän hugga dem ibland med harpon och äta dem. Capitain Lawson berättade, at här i begynnelsen eller ingången af Canalen är gemenligen antingen storm, eller mulit, rägnigt och töknigt väder. Kl. 4. efter middagen sågo vi en Fiskmåse flyga öfver hafvet där vi seglade. Sjö-folket sade, at vi nu i dag vid middagstid voro ungefär midt emot The Lands end, eller yttersta udden af Ängland àt denna Kanten.

Hafvets lysande. Om aftonen sent sågo vi, huru här och där flöt på hafvet som eldgnistror, i synnerhet där vatnet kom at skakas: en ting, som är allmän på p. 113 dessa orter, | och af oss förr upteknad i Norrige, Tom. I. p. 102. Vi kunde ibland se en sådan gnista liksom flyta på vatnet en hel minut innan den slocknade; men gemenligen räckte deras sken sällan öfver en half minut. Sjöfolket berättade, at ingen ting är vanligare, än at se dessa ljus: at de betyda ingen ting: at de i synnerhet visa sig ganska mycket vid och straxt efter Nordan storm: at de ibland synas, som hela hafvet vore fullt med eld: at ock detta sken ibland sätter sig på master, segel \&c.

\section{Den 13 Augusti.}

Resan. Börden var både största delen af natten, såsom ock denna dagen tvärt emot oss, så at vi endast med loverande måste hjelpa oss fram. Kl. 6. om morgonen mötte vi et Franskt skepp, som först hissade sin flagg, då de pả vårt skepp äfven hissade deras flagg, hvarefter hvardera for sin väg; men då vi loverade, kommo vi at taga samma kosa som det, då vi efter $1 / 4$ tima hunno upp det, och förnummo, at det kom från Havre de Grace och ärnade sig til St. Martinica. Vi seglade Kl. 7 bredevid hvarandra, och $\mathrm{Kl} .11^{1 / 2}$ för middagen hade vi lämnat det så långt efter oss, at vi näppeligen 
kunde se det, fast det brukade et segel mera än vi. Vid middagstid sågo vi en sjö-fogel af fiskmås-slägtet flyga förbi, den de kallade Shair-water. Vinden saktade sig mer och mer, samt var WSW. Medusce flöto ibland på vatnet, sådana, som förr äro omtalte.

Procellaria. Kl. $13 / 4$. efter middagen sågo vi den p. 114 fogeln, som af Herr Archiat. Linnжus uti des Faun. Suec. 249. kallas Procellaria, och i Ängelska Böcker Petrell, flyga, som en Svala, et stycke bakom skeppet, och satte sig då och då på vatnet, på hvilket han ibland stod eller gick et litet stycke, och àter flög upp. Sjö-folket sade, at han gemenligen synes emot elackt väder; men påstodo tillika, at de ibland sett honom i vackert väder, och utan at storm fölgt därpå. Han flög så långt bakefter skeppet, at en näpppeligen varit $i$ stånd, at kasta med en sten til honom. Capitain Geeverson trodde, at han därföre synes mycket i elackt väder; emedan han för blåsten och vågornas kastande ej kan sitta på vatnet. Vi sågo den sedan flera gångor flyga öfver vatnet, och sätta sig ned ibland på det samma. Han hölt mäst til på sådana ställen $i$ hafvet, där vårt skepp nyss förut gått fram, så at vatnet ännu var stilla och jämnt. Vi kunde ej annat se, än at han ibland for under vatnet på $1 / 2$ tima och mera, det ock sjöfolket påstodo vara sant. Det syntes ibland, som tog han någon mat $\mathrm{i}$ vatnet.

Dufvors nytta. Så väl alla 3 Capitainerne, som 2:ne Fruentimmer, hvilka voro på skeppet, berättade, at Dufvor brukas stundom i London, til at föra fram bref, hvilka bindas fast vid dem. Dufvan tages från den plats en vil skrifva brefvet til, och | föres til London. Då brefvet är färdigt, bindes det fast vid dufvan, som strax släppes, då hon oförtöfvadt flyger til sit förra hemvist, och när hon kommer dit, flyger hon in i dufhuset, hvarest brefvet tages af henne. At sådant brukas på många ställen i verlden, är bekant.

Tecken til väderlek. En af Capitainerne sade, at när det blåst litet, och det sedan lugnar af, och hafsvågen går från något väderstreck; så sker gemenligen, at vinden 
sedan kommer från det väderstreck, som är tvärt emot det vågorna komma från. Träffar ofta in.

At hafva välsmakeligt vatten på skepp. Det vatten, som brukades til Thée, kokning, dricka \&c. var tagit uti London i floden Thames, och förvaradt i stora oxhufvuden och tunnor af Ek, samt igensprundade at gömas tils dess det behöfdes. När detta vatnet tages först, är det tjockt och grumligt, som alt vatten $\mathrm{i}$ Thames; men då det får stå någon tid, sätter det tjocka sig ned på botten, så at det rena och klara vatnet stảr ofvanpå. Deraf at det står täpt och igenlyckt i tunnor, och luften ej får spela därpå, begynner det at luckta nog illa, så at det ej vore behageligt at dricka det straxt; men at förekomma detta, hafva de gemenligen bak på skeppsdecket stående par ganska stora stenkrukor, hvardera snart af en Svensk Tunnas innehåll. Vatnet, som är i Oxhufvuden, tappas p. 116 ur dem i äm|bare, och så slås det i dessa stora krukor, til dess de blifva fulla, đå de lämna locket på krukorna at stå antingen til en del, eller ock helt och hållet öppit en god stund, at Juften må hafva fri tilgång til vatnet, hvarigenom det mister all den elaka lukt det hade förut, och blir helt rent och välsmakeligt. När de tömt ur dessa krukor, tappa de utur tunnorna nytt vatten, gjuta det i stället, och låta det stả i par timar eller mera, dả den elaka lukten gått bårt. Tages vatten, som luktar illa däraf, at det stảtt $\mathrm{i}$ et täpt Käril, och sättes at stâ på et bord eller ute under öpen himmel i en skål, mister det på en liten stund sin vedervärdiga lukt. När vatnet, som tages i Thames, kommer at stå länge täpt och igensprundadt i Tunnor, och en sedan vid öpningen sätter et ljus til vatnet, skal det taga eld, som alla Capitainerne och Fruentimmren berättade, hvilka mente, at alt vatten, som länge stått täpt och igensprundadt skal hafva samma egenskap.

Mot aftonen komma vi utur Canalen och i Bay of Biscay. 


\section{Den 14 Augusti.}

Resan. Vi fortsatte vår resa, fast vinden var nog emot oss, och dessutom merendels lungt. Orten där vi nu seglade, var The Bay of Biscay, som är en vik hvilken hafvet gör emellan Frankrike och Spanien. Capitainerne sade, at det allmänt hålles före, at i den/na vik, och straxt där utanföre, skola gå de längsta och bredaste vågor af alla, som ej äro så kårta och afbrutna, som $i$ Norr- och Öster-sjön, fast de vågor, som gå på stora hafvet emellan Europa och America näppeligen skola gifva dessa Biskayska efter. Det skal ej här vara ovanligt, at få se en våg, som är en half Ängelsk mil bred eller tvärt öfver, samt högden proportionerad därefter. Nu var det mäst lungt, så at det blåste ingen ting; men svallvågorna gingo grufveligen långa, at skeppet vickade ganska mycket. Vi sågo hela denna dagen endast et skepp långt ifrån oss. Hela efter middagen lågo vi mäst stilla på et och samma ställe. Denna och några af de föregående dagar, blefvo vi inga Sjögräs pả vatnet varse.

Medusa. Vi sågo hela denna dagen en art af medusis, flyta på vatnet, hvars beskrifning skal gifvas i et annat verk. Vi sågo jämväl på åtskilliga stycken, som flöto i hafvet, at en stor myckenhet af små fiskar af 3 à 4 tums längd hade skåckat sig ornkring dem, och plåckade altför et af dem. Desse, som så blefvo af sådana små fiskar sönderslitne, voro til färgen mycket röda, lika som de hade blödt däraf; men ingen blod kunde märkas i dem vi togo up. De hade ej den egenskap, som manietterna i Norrige, nämligen, at förorsaka stor sveda åt den, som tvättar sig därmed, eller stryker något däraf på kroppen: ty | vi inbillade en ung dräng, som fölgde med oss, at p. 118 den, som tvättade sig dermed, får oförlikneliga hvita händer, hvaraf han öfvertalt tvättade helt noga bägge händerna både utanpå och innantil, til det han gnuggat dessa meduser aldeles sönder, lät det ock torka in af sig sjelft, utan at känna den ringaste sveda eller olägenhet däraf, tvärt emot alles vår förmodan. Mannen var mycket en- 
faldig, så at han ej haft det förstånd, at dölja sig, om det börjat förorsaka någon smärta på hans händer. Ängelsmännerne kallade dem Blobbers.

Färsk Kötts förvarande. När sjöfolket slagta något af de Kreatur, de hafva med sig om bord til förfriskning, sänka de stycken af Köttet, som nyss blifvit slagtat, utom bord i salta hafsvatnet en liten stund, då det sedan skal hålla sig bättre i några dagar, än om de lämnat det ligga färskt. Annat salts påströende brukades icke.

Procel/aria. Efter middagen sågo vi àtskilliga gångor Stormväders fogeln flyga öfver vatnet, och följa tätt vid vattubrynet. Skapnaden af clen på lảngt håll, samt sättet at flyga, liknade så aldeles en Svala, at en, som ej kändt honom, hade svårligen kunnat tro det vara annat, än en Svala. Han flög omkring på alla sidor om skeppet, både när och långt ifrån; men syntes aldrig sätta sig på vatnet. Kl. 7. efter middagen sàgo vi på en gång 3 stycken af p. 119 dem flyga efter hvaran/dra. Detta var nu ganska långt ut på hafvet, och vida från något land. Hvar må de därföre taga sitt nattherbärge? hvar värpa de ägg och frambringa ungar? mon deras mat äro de små fiskar, som näst ofvanföre äro omtalte vid medusa? Utom dem sågo vi inga andra lefvande djur, än en Sheerwater, som kom och lade sig på vatnet, varandes af fiskmås-slägtet, samt vid middagstid en svärm af Isor, som passerade förbi oss. Desse gå mäst altid i hopar flere tilsammans. De hoppade ibland högt upp ur vatnet.

\section{Den 15 Augusti.}

Resan. Hela natten förut var aldeles lungt. Några låga svallvågor gingo väl ännu; men vatnet var ofvanpå aldeles slätt. Vi sågo här och där på vatnet flyta skumm och fradga, hvilket sjö-folket sade förorsakas af sig sjelft i stilla väder, och gemenligen beboda flera dagars lugn. Kl. 12. förr middagen begynte det blåsa litet NO. då vi finge i HErrans Namn vidare fortsätta vår resa.

Hafsvatten. När Linn-Kläderne för Passagerarna eller andra, som voro om bord, blefvo orene, brukade de, 
at tvätta dem rena med det salta hafsvatnet, som de togo utom bord; men desse Kläder hade den olägenhet med sig, at ehuru de torkades i Solen, och syntes vara så torra, som någonsin kan ges, började de dock at vätskas och blifva våta, | så snart som väderleken och luften blef fuktig och rägnaktig. Capitainerne berättade, at de haft Kläder, som hafsvatnet kommit at genomblöta, dem de sedan haft i Solen at torka til dess, de trodt dem ej kunna blifva torrare, hvarpå de nedlagt dem i Kistor bland andra Kläder; men då de efter en Månad tagit upp samma Kläder ur kistan, hafva de varit helt fucktige, samt möglige öfver alt; emedan Kläder blötte i salt vatten, hafva den natur, at de draga fuktighet ur luften til sig.

Efter middagen började NO. vinden blåsa något, så at vi med nöje fingo fortsätta resan. Vảgorna gingo ännu så små, at man med en liten båt kunnat segla bredevid oss utan fara, och de 3 föregående dagar var hafvet så lungt och slätt öfver alt, at en trygt med en julla kunnat ro därpå hvart en velat. Eljest gick hela denna dagen svallvågen från $\mathrm{NW}$. til $\mathrm{SO}$. och då efter middagen det började blåsa NO. var et nöje at se, huru på hafvet nu voro 2:ne slags vågor, nämligen svallvågor, de där gingo från $\mathrm{NW}$. til SO. och de vågor, som nu upväcktes af vädret kommo från $\mathrm{NO}$. til $\mathrm{SW}$. så at de gingo långs efter ryggen af de förra. Desse vädervågor voro ännu helt små; emedan de ej hunnit at bryta och tvinga de andra, at göra sig följe. Vi foro på et ställe öfver en ström, eller så kallad Current, som kunde skönjas däraf, at vatnet och vågorna där bullrade och slogo | inot hvarandra mera än på andra ställen; men Capitainerne kunde ej veta huru den gick. Kl. 2. efter middagen vandrade en svärm af Bottlenoses förbi skeppet, och gick emot vädret. Efter middagen dog åter en af det folket från Pfaltz, som ärnade sig öfver til America, at bo där, och blef om aftonen på vanligt sätt kastad utom bord i hafvet. 


\section{Den 16 Augusti.}

Resan. Vi fortsatte med en härlig vind vår resa. Vågorna gingo ännu helt låga, at en utan fara kunnat segla här på hafvet med en någorlunda stor båt. Skeppet strök nu tämmeligen fort, och befants med loggandet löpa 91/2 Engelsk mil i timan. Vi sågo då och då marsvin tumla bredevid oss $i$ hafvet. Et slags sjögräs sågo vi ofta i dag flyta i vatnet, som såg ut som en Kylsa af rödlökar tilhopa bundne. Denna Kylsan var ungefär af en Knytnäfvas storlek: til färgen blek. Det var ogörligt så för skeppets fart, som för det, at skeppet sköt dem med vatnet långt ifrån sig, at kunna få någon af dem. Luften var i dag mycket kulen, at vi väl behöfde handskar på händerna. Utom kölden, var ock luften tämmeligen däfvig, så at då någon stått en stund ute på däcket, blef han nästan som vảt om händerna. Stället där vi nu foro, fans vid middagstiden vara emellan 47. och 48. gr. latit. Mot aftonen kom en svärm med Marsvin simmande vid p. 122 skeppet. Det syntes, som | de hade et nöje däraf, at se på skeppet och dess seglande. Skeppet gick nu ganska fort; men desse voro ännu snällare; ty de summo förbi skeppet sin kos. Mot aftonen sågo vi på långt håll en Sjöfogel.

Ankor. $\mathrm{Vi}$ hade försedt oss med allehanda färska matvaror på sjön, som får, gäss, ankor, höns, svin, kål, gurkor, ärter, bönor \&c. Ankorna föddes med korn och friskt vatten. Det salta vatnet var ej tjenligt för dem. När de fingo sönderskurna Kålblan, åto de dem ganska gerna. Jag försökte på samma sätt at skära sönder skalen af färska Bönor och gifva dem; men de ville ej äta däraf, ehuru hungrige de ock voro. På samma sätt ratades bönskalen af får och gäss; men hönsen åto dem, sedan skalen blifvit sönderskurne i små bitar.

\section{Den 17 Augusti.}

Resan fortsattes med en önskelig vind. Kl. $7 \frac{1}{2}$ förr middagen kom en hel svärm af Purpoises löpande tätt 
bredevid skeppet; men hölt sig i synnerhet näst fram för stammen, väl $i$ en god tima. Det syntes, som de hade sin ro däraf, at de sågo och hörde vatnets brusande vid framstammen. Ibland då någon af dem kom at lämnas litet efter, hade han nog brått, at åter laga sig framför stammen igen. Desse fiskar gå altid i stora hopar. Kl. 10. förr middagen sågo vi en Landfogel; men af hvad slag, kunde vi ej veta. Vi gissade, at denna villat sig bårt, då den flu|git från Irland. Kl. 11. blefvo vi varse 6 p. 123

stycken sjöfoglar, som aldeles sågo ut som grå fiskmåsar, där de lågo på vatnet. Skeppet lopp ibland $7 \frac{1}{2}$, ibland 8 Ängelska mil i timan. $\mathrm{Vi}$ voro vid 47. gr. latit.

Tecken til tilkommande väderlek. Det hade nu pá 3:dje dygnet varit et och samma väder, som någorlunda blåst; men vågorna gingo ändock små, som sades vara mycket ovanligt på detta haf. Capitainerne mente, at detta gemenligen plär vara et tecken, at samma väder, som då blåser, skal påstå länge; däremot då vågorna första dagen det blåser börja resa sig högt, är det merendels et tecken, at den väderleken och börden ej blir långvarig.

De förr omtalte i Kylsor flytande och rödlök-lika sjögräs, syntes äfven $\mathrm{i}$ dag på vatnet. Om aftonen fingo vi se en myckenhet gnistor i hafvet, och skummet, som förorsakades af skeppets fart vid framstammen, samt ute på hafvet af vågornas brusande, var aldeles lysande; dock ej med sådant sken, som de förenämde gnistror, utan sådant, som rutit trä plägar visa i mörkret.

\section{Den 18 Augusti.}

Resan fortsattes med en härlig vind. Kl. 9. förr middagen kommo Purpoises til många hundrade; så at de viste sig både framföre, bakefter och på sidorna om skeppet, liksom fullt däraf. De fölgde med skeppet en god tima, och syntes förundra sig däråt. Längden | af desse var från 2 til 4 alnar, under buken hvita, rostrum liksom på en gås eller gåsnäbb. Det var et nöje at se, huru de ibland kastade sig upp i vädret och gjorde luftsprång 
ofta til par alnars högd, samt 2, 3 à 4 alnars längd. Ibland sprungo 2:ne tillika upp, och viste sig som 2:ne harar i bredd. Ibland då de hoppade upp, föllo de öfver ända, så at buken vändes up, och ryggen ned. Efter middagen kom en liten fogel, lik en Talg-oxe, och satte sig fram pả skeppet, men då folket ville taga honom fast, flög han bakom seglen, at de ej mer kunde få igen honom. Denne stackaren hade kommit vilse i sjön, och sökte nu här sin hvila. Mot aftonen sågo vi en sjöfogel, som sjöfolket kallade Shearvater. Han liknade nog en mörkgrå fiskmåse, samt flög ofvanpå vatnet, likasom han sökt efter fisk. Sjögräs, likt måsstappar, flöt här och där i sjön.

\section{Den 19 Augusti.}

Resan fortsattes med en önskelig vind. Skeppet lopp 8 Ängelska mil i timan. Ingen fogel viste sig: ej eller något Sjögräs. Kl. 4. efter middagen sågo vi några stora fiskar et stycke från skeppet hoppa högt upp i vädret. Somlige sade, at de voro Purpoises; andre kallade dem albicols, och sade, at de voro sköna til mat. Luften var eljest i dag nog sval, så at vi väl behöfde hanskar och

p. 125 goda kläder på kroppen. Om aftonen begrofs åter | på vanligt sätt en af Palatinska Qvinfolken, som i dag hade dödt. Mot aftonen sảgo vi en sjöfogel flyga öfver vatnet, som var nog lik en fiskmåse.

Stenkåls rökens verkning. Capitainerne beskylte Stenkåls röken i London för, vara ganska skadelig för deras takel och tog, i det han gör dem sköra och likasom röter dem. Men andre nekade, at rök af Stenkål hade sådan oart.

Madera-vin. Alla så Passagerarne, som Capitainerne berättade, at Madera-vin blir långt utvaldare, än förr, om det kommer at föras på sjön någon tid. Det är ock därföre, som Köpmän och andre Gentlemen i London sätta samma vin om bord på skepp, som gå öfver til America, låta föra det fram och tilbaka, och betala frackt därföre, då det efter et sådant förande blir ganska utvalt. Det 
sades ock hafva den synnerliga egenskap, at om det är surt, och det sättes så, at Solen får skina därpå, mister det all sin syrna, och blir skönt som det var förut.

\section{Den 20 Augusti.}

Resan fortsattes med god vind.

Purpoises. Kl. 4. efter middagen kom en stor myckenhet af Purpoises på alla sidor omkring skeppet; men de höllo sig mäst fram för stammen, lekte och hoppade högt $i$ vädret på sätt, som förr är omtalt. Ofta då de hoppade upp ur vattnet, pustade de til så hårdt med deras mun, likasom det kostat mycket på dem | at göra p. 126 sådana språng. De fölgde skeppet ungefär $3 / 4$ tima, innan de lemnade det.

Orten, där vi i dag seglade, räknades vara vid 44 . gr. 30. min. Latit. samt $27^{\circ}$. Longit. W. om London. Stormväders fogeln flög här och där öfver vatnet; men kom ej när til skeppet. I dag blefvo vi ej varse några sjögräs. Vi sågo här ej andra fiskar, än ofvannämde Purpoises, dem sjöfolket sökte at hugga med harponer, då de lupo fram för stammen; men det var ej görligt at råka dem, emedan de hinte ej måtta til, innan desse fiskar voro långa stycket bårt. Eljest var sjöfolkets enhälliga berättelse, at de emellan Europa och de Azoriska Öarna, dem de kallade de Västra Öarne, sällan eller aldrig fả se någon annan fisk, än nyssnämde Purpoises, och fiska fördenskul aldrig efter någon fisk; men så snart de hunnit förbi de Azoriska Öarna, få de på deras västra sida en ymnoghet fisk, och det af mångahanda slag. Likaledes, skal det vara på Södra sidan om samma Öar; men ej så på den Norra.

\section{Den 21 Augusti.}

Resan. Vi fingo ännu njuta vår härliga vind. Capitainerne och sjöfolket sade, at de aldrig sedt hafvet på alla dessa orter vi farit fram så stilla som nu, och än 
mindre hade de haft en så långvarig Östanvind; ty emellan

p. 127 Europa och de Azoriska Öarna skal | vara mycket rart, at se Östanväder öfver par dagar, utan det mästa vädret stryker där gemenligen från Väster; men så snart en kommer på Västra sidan om Azoriska Öarna, har man, hälst vid denna årstiden, et ombyte af väder, så at det Västra ej är där så långvarigt. Häraf sker, at ehuru någon i sjelfva verket ej gjordt mer, än en tredje del af resan, då en från Europa kommer midt emot eller förbi samma Azoriska Öar, räkna dock Sjöfolket, at de hunnit halfva vägen, dả de kommit dem förbi; emedan de därefter ej behöfva fruckta så mycket för motvind. Eljest sker sällan, at en får se desse Öar på resan til och från America, så framt ej storm eller någon annan händelse förorsakar det; emedan många fördolda klippor ligga utanföre dem i sjön, som de sjöfarande gerna söka undvika. Vid Middags-tid togo Capitainerne Solens högd, samt uträcknade däraf Latit. den de höllo vara 43 grad. 24 min.; Longit. så at vi nu skulle vara $30^{1} / 2$ gr. Väster om London. Ingen fogel, ingen fisk, intet Sjögräs viste sig denna dagen för våra ögon. Vatnet $i$ hafvet hade ej här någon annan färg, än vi sedt hela resan. Sjöfolket, som många gångor seglat från Ängland til Pensylvania, berättade, at vatnets färg på hafvet är allestäds en och den samma, undantagandes, då en kommer närmare til America, där det blir grundt, och sandbanckar äro under, hvarest färgen blir något ändrad. Skeppet lopp merendels 6 Ängelska mil i timan.

p. 128 Lycktorne, som de här betjente sig af, at bära ljus uti, voro ej gjorde af glas; emedan det snart kan stötas sönder; utan somlige af tunnt horn, som dock kunde taga skada, om elden kom för när til hornet; andre voro gjorde af Marienglas eller Vitrum Moscoviticum. Desse voro de bäste; ty dels voro de ganska klare, som det bästa glas, dels kunde de ej taga särdeles skada af eld, dels kunde de ej spricka så snart sönder. 


\section{Den 22 Augusti.}

Resan fullfölgdes med god vind.

Tecken til väderleken. Capitainerne försäkrade oss Kl. 12. förr middagen, at innom 24 timar skulle vi hafva SW. vind. Jag frågade orsaken därtil? de svarade: emedan molnen, som synas i SW. vända kanten eller hufvudet för sig mot NO. och tyckas börja stiga upp därifrån. Efter middagen sågo vi en Sjöfogel flyga långt ifrån, samt mot aftonen en annan Sjöfogel, hvilken liknade en Tärna, dock af mörkare färg. Han flög et stycke från skeppet; men ingen fisk, och intet Sjögräs blefvo vi varse. Det räknades nu, at vi voro halfvägs til Philadelphia.

\section{Den 23 Augusti.}

Resan fortsattes. När det var stjernklart, så voro nätterne ej så mörka, och i synnerhet gjorde Jupiter denna tiden mycken / tjenst för en halfmåne med det starka p. 129 sken som han gaf från sig, at nätterna ofta voro så ljusa, som då månan är i fylle midt på himmelen. Kl. 7. förr $\mathrm{m}$. vände vädret sig til $\mathrm{S}$. och började blåsa något mera, då vi seglade något fortare, så at skeppet Kl. 11. förr middagen lopp 8. Ängelska mil om timan. Kl. 12. togs Solens högd, då vi befunnos vara uti $42 \mathrm{grad}$. $53 \mathrm{~min}$. Latit. Om morgonen fick en och annan se någon flygande fisk, och Kl. $3^{1} / 2$ efter middagen fick ock jag första gången se dem, då 4 à 5 på en gång flugo upp ur hafvet fram för stammen, och sedan öfver vatnet ej långt från vattubrynet, til des de åter släpte sig ned i vatnet. Längden, som de således flögo, var ungefär så stor, som en kunnat kasta med en sten. Det gick ock nog fort för dem. Vi fingo då och då se någon Sjöfogel flyga långt bårt ifrån oss; men han var altid allena, så at vi ej blefvo varse flera foglar följas åt. De syntes vara en art af fiskmåsar med långa och smala vingar. Längre mot aftonen sågo vi 3 à 4 däraf flyga tilsammans. 


\section{Den 24 Augusti.}

Resan. Med et tämmeligen starkt SSW. väder fortsatte vi förleden natt vår resa; men sedan blef vinden knapp och mäst emot oss, så at vi näppeligen kommo ur fläcken. Nu började vi denna förr middagen se en myc-

p. 130 kenhet af Sjögräs flyta klastals på vatnet. Än/gelsmännerne kallade det Golf-Weed, och sade at det kommer från Spanska viken vid Florida. Af andra kallas det Sargazo. Vid Middagstiden befans af Solens högd Latit. här vara 42 gr. $27 \mathrm{~min}$. och hölts Longit. vara emellan 38. och 39. Väster om London. Kl. 6. efter middagen sågo vi et skepp långt fram för oss, komma emot oss; men då det blef oss varse, tog det en hel annan kosa, tvifvelsutan af frucktan, at vi vore kapare.

Tecken til väderleken. Blåst spåddes oss däraf, at den öfra skyn stod i strimmor, likasom utkammad ull eller Linblår, samt var gles; hvilket sades aldrig slå felt at beboda blåst. Desse strimmor gingo från NW. til SO. som vädret då blåste. Det hade blåst mäst hela dagen NW. men om aftonen stannade vädret tvärt af och blef lungt, som sjöfolket sade vara et tecken, at vinden följande dagen skulle blåsa från en annan kant; emedan lugn gerna gör ändring $\mathrm{i}$ vinden.

\section{Den 25 Augusti.}

Resan. Föregảende natt var det så lungt, at vi mäst lågo stilla. Kl. 4. förr middagen begynte det blåsa W. som tiltog mer och mer, så at vi nu nödgades taga en annan kosa, och låta skeppet gå til NW. Vinden öktes ännu starkare. Vågorna gingo ansenligen stora. Åtskillige af de från Pfaltz med oss öfvergående qvinfolk och barn

p. 131 hade vid | middagstiden lagt sig på däcket at sofva, då en våg kom och skölgde öfver hela däcket, så at hon kom in på den ena sidan och gick ut på den andra, hvaraf det blef et faseligt buller af qvinfolk och barn, som nu voro blefne så våta, som de varit dragne ur sjön. 
Toback. Ängelska Sjöfolket brukar på långt när ej så mycket Toback, som våre Svenske. Få af dem röka. Månge hafva nästan aldrig haft pipan i munnen. Åtskillige af Capitainerne, som hela sin tid vistats på sjön, brukade det aldrig. Om några af sjöfolket brukade det, så skedde det mäst at tugga det samma.

\section{Den 26 Augusti.}

Resan. Vinden var oss emot, så at vi endast med loverande måste hjelpa oss fram. Om morgonen sågo vi en stor Taskkräfta, til färgen röd, flyta på vatnet. Ingen fogel, ingen fisk, intet Sjögräs blefvo vi varse.

Skepps däckets tvättning. Både om mornarna bittida och aftnarna strax efter Solgången lät Capitainen bära upp flere ämbare med vatten af det, som pumpades upp ur skeppet, med hvilket han lät väl tvätta och skölja däcket. Orsaken, hvarföre detta skedde, var, dels at hålla däcket snygt och rent, dels at hålla bräderna fuktiga; ty Solens värma om dagarna gjorde däcket helt torrt, hvaraf bräderna torkat tilhopa och åstadkommit, at | däcket sedan börjat läka, om vi ej så alt för et hållit bräderna fuktiga. Dessutom som bräderna af en långsam torrka dragit sig tilhopa, och gjordt stora springor; så hade det skedt, at antingen rägn trängt sig ned igenom springorna, och vätt det som varit därunder; eller ock åstadkommit röta $\mathrm{i}$ springorna medelst det vatten och annat som fastnat qvar i dem; hvilket alt nu förekoms.

Blåcken på detta skepp voro gjorde af alm. Skifvan däri af Lignum vite, som sades komma från Ostindien, och är et ganska hårdt trä, hvilket af rägn och väta ej sväller, som är altför nödigt för skifvor: blåckaxeln, som går genom skifvan, var antingen af agrifolium, eller ock af Iron-Wood.

\section{Den 27 Augusti.}

Resan. Kl. 11. förr middagen fingo vi åter en härlig vind, så at resan nu begynte å nyo fortsättas med stor 
skyndsamhet. Om morgonen sågo vi en Sköldpadda, af en alns längd vid pass, den där simmade uppå vatnet et litet stycke från skeppet, utan at låta skeppet skrämma sig. Vi sågo då och då stycken af Sjö-gräs flyta på vatnet. Om morgonen gingo vågorna ganska små, så at en trygt med en julla kunnat ro på hafvet; men sedan SO. vinden begynte blåsa, började de växa i storlek mer och mer, och om aftonen vid Solens nedgång blef en p. 133 stark NO. / storm, som påstod ungefär til midnatten. Capitainerne berättade, at Västanvinden här på Oceanus Occident. i synnerhet härskar mäst; men af Östanvädret är ej en tredjedel så mycket, därföre går gemenligen resan från America til Europa långt fortare, än från Europa til America. Om vintern blåser det både starkare och längre, än om Sommaren, då ock vågorna gå mycket högre, än vid denna tiden. Om sommaren varar gemenligen et väder här ej länge, utan ömsar snart om. Stormen räcker ock om Sommaren ej länge, sällan öfver $1 / 2$ à 1 dag, och vågorna lägga sig snart därefter. Det sker ock merendels, at då om Sommaren är blảst och storm på et ställe, kan det vara mäst lungt några mil därifrản; men om vintern sträcker stormen sig merendels öfver hela Sjön.

\section{Den 28 Augusti.}

Resan. Med en tämmeligen god vind fortsatte vi vår resa. Vi sågo åtskilliga gångor flygande fiskar, som flögo upp utur vattnet straxt frammanför stammen af skeppet: foro så et litet stycke ofvanför vatnet, innan de kastade sig ned igen. Gemenligen flögo de emot vädret, då de kommo upp, samt merendels ej högre, än ungefär en aln ofvanför superficies af vatnet. De förr omtalte Tärnor med långa smala vingar syntes dă och då flyga ofvanpå vatnet. Sjö-gräs (Golf-weed) flöt här och där i vatnet.

p. 134 Orten, | där vi nu vistades, var vid $40 \mathrm{gr} .50 \mathrm{~m}$. Latit. samt $44^{\circ}$. Longit. W. om London. Vågorna blefvo efter middagen ganska små, så at en väl med en liten båt kunnat ro på hafvet. 
Dolphin. Om aftonen sent fingo vi första gången se den fisken, som Ängelsmännerne kalla Dolphin, och af Herr Artedius uti dess Gen. pisc. p. 15. Coryphrena cauda bifurca; samt af de andra Hist. nat. Hippurus. Af dessa Dolphins voro åtskillige, som viste sig så väl bakefter som fram för skeppet. De sågo makalöst täcka ut, då de vältrade sig i vattubrynet, prålade med en hög blå färg, som mäst försvann, då de kommo upp ur vatnet. Ibland hoppade de til en famns högd perpendiculariter upp i vädret från vatnet. Sjöfolket kastade ut en krok, därpå de satte litet af Höns tarmar, då de voro så lyckelige, at de fingo en af dessa Dolphins, hvaraf halfparten blef vår aftonmåltid. Han hade uti sig små fiskar, men de voro så illa medfarne, at vi ej kunde utröna til hvad slägte de hörde; emedan de hade mist det mästa af sin skapnad. Han måste blifvit huggen någon tid tillförene vid något annat skepp; ty han hade i ryggen en ganska stor skråma, som dock nu var tilhopa läkt.

\section{Den 29 Augusti.}

Resan. Vädret var nu mäst emot oss. Sjö-gräs syntes då och då. Den förr omtalte Tärnan viste sig hela dagen och flög öf|ver vatnet; men aldrig blefvo vi varse, at p. 13 s hon lade eller satt sig ned clärpå. Vi sågo många af detta slags Sjö-foglar. Hela denna dagen sågo vi en stor myckenhet af flygande Fisk, som ständigt flögo upp utur vatnet, höllo sig så et stycke i fria luften, innan de gofvo sig ned igen. Ofta flögo på en gång väl hundrade stycken bredevid hvar andra upp ur vattnet, då de ibland fölgde alla åt en kosa: ibland, dock sällan togo de särskildt väderstreck. Alle, dem jag härtils sett flyga upp, hade tagit sin kosa antingen rätt midt emot vädret, eller ock åtminstone snedt emot det samma. Jag har ingen blifvit varse, som flugit med vädret eller fölgt vinden åt. De flyga längre eller kårtare stycken i sänder. Det längsta jag sett dem på en gång flyga, kan vara et godt byssskott. De flyga ej högt, utan följa nog tätt superficies 
af vatnet. Sällan öfver en aln högre än vattubrynet. Häraf sker, at då de flyga, och möta någon våg, stöta de ofta däremot, och måste så fara ned i vatnet. Ibland då de flugit et stycke, och gifvit sig ned i vatnet, komma de $i$ ögnablecket upp igen och flyga åter et stycke. Sjö-folket sade alle, at Dolphinerne jaga efter dem, och drifva dem upp utur vatnet, samt at desse flygande fiskar äro deras förnämsta föda. Vi sågo ock ögonskenligen i dag, at Dolphinerne jagade efter dem, samt då desse fiskar flögo upp utur vatnet, kastade Dolphin sig högt upp i vädret

p. 136 efter dem; | men hade ej den lyckan at kunna följa dem efter, utan måste falla strax ned igen. Deras flygt liknar ganska mycket gröningars. Vi sågo nog af Tärnor i dag; men kunde aldrig skönja, om de jagade efter dessa flygande foglar, ehuru vi noga sökte at gifva akt därpå. Om aftonen syntes Stormväders fogeln, flyga här och där på vatnet, ofta flere tilhopa.

\section{Den 30 Augusti.}

Resan. Vädret var oss emot, så at vi endast med loverande måste hjelpa oss fram. En hel svärm med Stormväders foglar fölgde, förr middagen, et stycke bak efter skeppet, ungefär et byssskott från det samma, där de mäst flögo öfver vatnet, dock satte de sig ibland därpå. De synas mäst utvaldt, at så följa skeppen; emedan vatnet är mycket slätt, där skeppet gått fram; men på alla andra ställen är det mera ojämnt af vågens häfvande. Ibland flögo de näppeligen par famnar bak efter skeppet. Capitain Lawson sade, at de följa skeppet därföre, at de må plåcka upp och äta sådant som kastas utifrån skeppet. Vi häfde ut hö-smål, då de i myckenhet samlade sig, och satte sig där ofvanpå. De satte sig ibland på vatnet; men höllo ändock altid ut vingarna. Denna Svärmen, som ofta bestod af 30 à 40 fölgde oss hela dagen, ända långt in på natten. $\mathrm{Om}$ dagen hördes ej deras låt, men om natten skreko de ibland. De flögo mäst altid tätt p. 137 vid vattubrynet, sällan | högt upp. Vi sågo tydeligen at 
de plåckade upp sådant, som fallit från skeppet, i synnerhet af excrementis humanis; och när de fingo se något dylikt, samlade de sig där omkring i stor myckenhet. Vi märkte aldrig, at de lade sig ned pả vatnet at simma, utan stodo ibland därpå, men dock altid med utsträckta och fläcktande vingar.

Tecken til väderleken. I går om afton blixtade ibland ganska starkt i de tjocka molnen, som då gingo; dock hördes ej det ringaste tecken til dunder. Jag frảgade Capitainerne, hvad det skulle betyda? de svarade, at det vid denna Årstiden betyder ingen ting, utan är endast et tecken, at luften är mycket varm; men om vinteren, dả Sjöfolket ser, at det blixtar, få de ganska brott, at taga ned sina toppsegel; emedan då de äro säkre, at inom få timar därefter hafva en grufvelig häftig storm. Likaledes då de på dessa orter om vintertiden se en molnfläck komma upp från $\mathrm{NW}$. hasta de sig så fort de kunna, at taga ned alla sina toppsegel; emedan de litet därefter säkert få storm.

Vid Middagstid sågo vi et stycke trä flyta på vatnet, som var fullt med Lepas eller Bernicles på alla sidor. $\mathrm{Vi}$ foro ock då öfver en Currant på et ställe, som vi kunde höra och se af den särdeles susning och sqvalpning vågen gjorde. Inga Sjögräs, inga fiskar, utan endast par Tärnor viste sig i dag.

\section{Den 31 Augusti.}

Resan fortsattes, fastän mäst med lovering. Stormväders foglar kommo i myckenhet som mygg, och fölgde bakefter skeppet hela denna dagen på samma sätt, som de gjorde i gâr. Sjöfolket tyckte ej särdeles om dessa foglars sällskap, utan kallade dem Witches (Trollpackor).

Sjö-Tärnan, hvarom ofta förut är nämdt, syntes dã och då. Inga fiskar blefvo vi varse, ej eller nảgot Sjögräs. Det hölts före, at vi voro ungefär vid 41 gr. Latit. samt 47 gr. Longit. W. om London.

Svinens kringlöpande. I förrgår blef et af de Svin vi hade om bord yrt i hufvudet, jag vet ej af hvad orsak, 
så at det började alt för et löpa eller hvirfla sig omkring. När man böd til at hålla det stilla, arbetade det med all kraft emot, och ville vända sig omkring. Capitain lät skära af det et öra, samt svantsen, hvarefter det kom sig före och blef lika frisk, som förr.

Ost. I största delen af Ängelska ostar finnes et litet hål boradt, som dock är igenfyllt med ost. Desse hål båras upp med en särdeles nafvare, at se efter om osten är god inuti, då någon vil köpa honom, hvarefter ostbiten, som boras ut, pluggas in i hålet igen. En Fru, som fölgde med oss på skeppet, berättade, at från Normandie i Frankp. 139 rike föres öfver til Ängland en slags ost, som | då den nyss är gjord, lägges ned i hästclynga at ännu blifva bättre, hvaraf han utanpå skal få en ganska vedervärdig lukt, men dả han skäres upp, och yttersta skảrpan skalas af, är det en den bästa delice, som kan ges. Franske, som flyktat öfver til Ängland, hafva af Ängelsk mjölk gjordt lika sköna Ostar, som de Franska.

\section{Den 1 Septemb.}

Resan. Vinden var nu mäst emot oss. Stormväders foglarne fölgde äfven i lag efter skeppet $\mathrm{i}$ en stor myckenhet, flögo ock eljest allestäds omkring på sjön. Kl. 10. förr middagen sågo vi et stycke trä flyta på sjön, omkring hvilket sumo Dolphins hundrade tals i en hop. Sjöfolket sade, at Dolphins gemenligen samla sig hopetals omkring trästycken som flyta i sjön, och följa med dem, så at, då Sjöfolket få se något sådant trästycke, äro de gemenligen säkre, at få se en svärm Dolphins rundt omkring det samma. Sjö-gräs syntes dá och då flyta på vatnet, af det slaget, som Sjöfolket kallade Golf-weed, och berättades, at det kommer från hafsviken vid Florida. Strax efter middagen kommo några stycken Landfoglar, som liknade ganska mycket strandsvalor, hvilka flygo omkring skeppet, och satte sig ibland på sidan antingen af skeps-suden eller seglen. Deras flygt var just som Svalors, storleken lika. Ofvanpå gråbruna: under hvita: 
stjärten litet grenig. Et häftigt rägnskur dref dem sedan bårt ifrån oss: sả län|ge de fölgde oss, flögo de merendels p. 140 på den sidan om skeppet, som lugnet var.

\section{Den 2 September.}

Resan. Vinden var nu, GUdi låf! något bättre för oss; ty den begynte vid midnattstiden blåsa från N. och är här märkeligt, at gemenligen hela långa tiden, då vinden skulle ändras, skeddle det näst vid midnattstid. Vågorna gingo nu ej särdeles stora. Om morgonen bittida sågo vi inga Stormväders foglar bak efter skeppet; men Kl. 9. vid pass började redan några visa sig. Jag har ock tilförene nämt, at vi om morgonen bittida ej sett til dem, fast de sedan längre in pả dagen fölgdt skeppet hundrade tals. Det var i dag sällan mera, än par stycken af dem, som fölgde skeppet, och ofta sågo vi hela lảnga stunden ingen. En gåsse kom at fälla sin hatt utom bord, och dâ den kom litet frản skeppet, samlade dessa foglar sig i myckenhet, ransakande den noga, och ibland satte sig där på.

Sjö-Tärnorna, som vi nästan dageligen sett hela resan, syntes nu då och då; men Kl. 9. förr middagen kommo de flygande til många hundrade, och foro omkring allestäds på sjön. Vi sågo efter middagen äfven nog af dem, fast ej i den myckenhet, som förr middagen. Sjö-gräset syntes nog i dag flyta $i$ sjön. Vi bödo til at fả något däraf; | men förgäfves; emedan det flöt sả långt frản p. 141 skeppet. Efter middagen kom en Fiskmåse, helt särskild från Sjö-Tärnorna, och flög litet från skeppet. Han var litet större, än de. Sjöfolket slöto så af de foglar de sågo i går, som af denna, at vi måtte vara i nägden af Newfoundland. Vid middagstid togs af Solens högd Latitudo, som var 40 grad. 20. min. och Longit. hölts vara vid 49 . grad. W. om London.

Kl. 3. efter middagen kommo några stycken Dolphins och summo bak efter skeppet: gingo sedan frammanför det samma, då 2:ne stycken af dem blefvo af Sjöfolket 
huggne och fångade med harpon. Längden af hvardera af dem var 5 quarter. Latit. perpend. litet bak hufvudet, där den var bredast var netto et quarter Latit. transvers. ibid. $1 / 2$ quarter: färgen ofvanpå ryggen vid hufvudet en hög, skön, grön med Silfverbotten, inen bak mot stjärten en högblå färg: under magen hvit: hade ej 7, utan bara 6 pinnas, nämligen duæ pectorales, '2 ventrales; una caudæ, som räckte från anum ända in mot stjärten, och 1 dorsi, som räckte efter hela ryggen ända til stjärten. När dessa simmade bak efter skeppet, skedde det mycket långsamt, så at det var ej svårt at hugga dem. Då de blefvo upskurne fans i dem 5. handa slags djur, nämligen en ostracion, en liten fisk med blå ögon, som nyss blifvit p. 142 tagen och ännu lefde, af par tums / längd; en annan liten fisk; samt et ovanligt sjö-insect: it. en flygande fisk. Jag lade strax alla dessa $\mathrm{i}$ spiritu vini at förvaras; emedan ingendera af dem var ännu skadad. Denna smalnade af på alla sidor från hufvudet till stjärten, hvarest Latit. perpend. $1 \frac{1}{2}$ tum, och transv. $3 /{ }_{4}$ tum eller en liten tum. Bredden af stjärten bak til, från yttra sidan af ena grenen til den yttra af den andra 8 tum. Den flygande fisken hålls vara bästa agn åt honom, och dernäst bitar af des egit kött, eller inelfvor af en annan fångad Dolphin, som en gammal Sjöman sade. Köttet bereddes som annan fisk, antingen kokadt med smör på, eller skurit i skifvor och stekt $i$ en panna i smör: smakade nog skönt, fast litet torracktigt: var helt salt-löst, fast han lefde $\mathrm{i}$ det saltaste vatten.

En Sköldpadda lảg och sof på vatnet efter middagen. Storleken af den ungefär en aln. Mot aftonen tog Capitain Lawson ảt mig en stor knippa af Golf-weed, eller det Sjö-gräs, som vi sett alla dagar flyta i Sjön. Så snart jag fick upp det, var mit första göromål, at se efter, om inga insecter skulle finnas däri: då jag var så lycklig, och fann däri par rara insecter, som bägge voro af Cancer slägtet: det ena liknade Taskkräftor, den andra Räkor; men bägge ganska små; af Task-kräft slaget fick jag 3 . stycken, och af Räkslägtet 8 . stycken. Jag satt dem i 
början i et glas, då jag noga beskref dem. Uti glaset for den | lilla Taskkräftan upp och ned samt omkring på alla sidor, som en pil, alt som hon ville. Ibland for Hon mycket långsamt, ibland stod hon stilla vid någon sida $\mathrm{i}$ glaset, eller ock på botnen. När Hon fick fast någon af Räkslägtet, grep hon med sina framklor om den, och dödarle den utan barmhertighet, samt sög saften utur den. Det var ock därföre, som desse Räkor voro så rädde at komma när in til henne. Hela dess skapnad var aldeles som en Taskkräfta. När den samm, skedde det altid med ena sidan, eller ock med bakdelen förut. De simma nu meil ena sidan förut, nu med den andra. Hon kunde stoppa sina främre klor ända in i munnen på sig. Antennæ voro $\mathrm{i}$ en continuerlig rörelse. Jag lämnade dessa, at stå öfver natten uti et glas tillika med Räkorna, och då jag om morgonen återtog glaset, hade Taskkräftan dödat alla Räkor, och ätit ut inälfvorna af en stor hop. Taskkräftorna voro ännu helt qvicka. Då jag lade dem i spiritu vini, dödde de ej strax, utan summo par gångor omkring i flaskan, innan de satte lifvet til. Den lilla Räkan samm med en otrolig qvickhet och snålhet $i$ vatnet. Ibland då den stod ned i botnen i glaset, gjorde hon et hastigt språng, så at hon i ögnablecket var upp i vattubrynet, just som då en loppa hoppar, eller närmare, som en $P_{0}$ dura. När hon simmar, så rör hon alla fötterna oförlikneligen tätt: ibland simmar hon ordinairt som andre, med fötterna ned: ibland lig|ger hon ock aldeles på ryggen. Så snart som hon stannar at ej mera röra fötterna, sjunker hon ned til botten. Beskrifning på dessa Taskkräftor och Räkor skal gifvas i et annat verk.

Golf-weed. Detta hade vi nu sett flyta i sjön en lång tid, nu i mer, nu i mindre myckenhet. Det flyter i större eller mindre kylsor, hvar kylsa är merendels af en half alns längd och bredd, det är en art af Fucus, hvars caulis är, tenuissimus, rotundo-angulatus, til färgen ganska mörkgrön. Denne grenar sig ständigt och hvar gren skjuter ut en myckenhet af blan eller folia, linearia, 1 à $1 \frac{1}{2}$ linearum latitudine, ganska tunna, per margines crebris 
denticulis notata, så at desse blan likna ganska mycket folia af muscus Islandicus. Färgen är gröngul: Frukten liknar tämmeligen små omogna Enbär, helt runda, gröngula, utan på mäst släta, endast litet knagliga, undantagandes där någon Eschara kommit at fastna på dem. Desse små bär sitta ad alas foliorum på små kårta pediculi af 2 à 3 liniers längd: ibland och merendels sitter endast et bär vid hvar ala, ibland flere, ända til 3 stycken; men flera kunde jag ej blifva varse. Mästendels var bara et bär vid hvar ala; dock voro månge alæ där inga bär funnos. Somlige af bären voro helt små, til et tecken, at de ej voro ännu fullväxte. När et sådant bär skars sönder, fick man se, at det var inuti aldeles ihåligt och p. 145 tomt, och bestod endast af et tunt skal | eller skinn ytterst. Orsaken hvarföre detta var så ihåligt, måtte varit, at det skulle så mycket lättare kunna flyta uppå vatnet. Caulis lycktade eller ändade sig altid uti ofvanbeskrefna blan, och voro bladen alt smalare mot ändan. Pả undra sidan af bladen växte ut här och där som små helt smala rötter af 2,3 à 4 lin. längd; eljest är superficies af bladen helt slät, och på undra sidan synes nelvus longitudinalis folii, som är convex eller uphögd. Utom ofvanbeskrifna insecter, som uppehålla sig i den samma, sitter ock fullt af Eschara, samt Dentalium cornuforme s. spirale. Detta är den ört, som vi tilförene altid i denna Resebeskrifning kallat Sjögräs, sedan vi lämnade Europa, och hafve vi ej blifvit varse någon annan hafsört, än denna, på hela vår Resa. Styrmannen berättade, at de uti America taga detta Golf-Weed, torka och stöta det sönder til pulfver: ge däraf in àt qvinnor, som äro i barnsvånda, och skal det då vara et det bästa hjelpe-medel. Han sade ock, at de betjena sig af detta i febrar; men för hvad orsak och på hvad sätt, kunde han ej säga. Dessutom skal, så efter Styrmannens, som Capitainernes berättelse, då en seglar til Vestindien eller Södra America, hela Sjön eller hafvet på somliga ställen finnas öfvertäckt af denna växt til flera mils längd. Gemenligen tros, at desse Golf-Weeds komma 
från hafsviken vid Florida, och med Currants drifvas därifrån omkring $\mathrm{i}$ hela hafvet.

En Svala kom om aftonen sent flygande rundt omp. 146 kring skeppet, satte sig upp i masten, syntes vara nog trött, flög ibland hel när intil Cajut-fönstret, liksom hon ville bege sig ditin.

\section{Den 3 Septemb.}

Resan. Vi nödgades nu hjelpa oss med loverande mot vädret. Om morgonen blefvo vi varse en så kallad Tropicbird flyga et stycke från skeppet. Vi sågo denna dagen nog Golf-weed flyta i Sjön, och vi togo up åtskilliga kylsor däraf, dem vi ransakade noga; men fingo inga andra rariteter däri, än dem vi beskrefvo i går, nämligen en myckenhet af de små Krabb-taskor, samt Räkor, som då funnos däri, hvilka vi i dag noga undersölkte, och jämförde med de tilförene gifna beskrifningar. Vi sågo sedan sällan något af desse Golf-weeds, at ej någon liten eller större Krabb-taska låg däribland eller ofvanpå. Ibland fingo vi ock se någon Krabbtaska af en Knytnäfvas storlek simma upp i vattubrynet, som continuerligen rörde fötterna tätt; emedan hon strax sank ned så snart hon öfvergaf at sparka med fötterna. Inga foglar, blefvo vi i dag varse. Efter middagen sågo vi et slags Medusa, som Ängelsmännerna kalla the Spanish man of war, och andra the Portugis man of war, flyta på vatnet. Den liknar långt ifrån en stor blåsa af et quarters diameter, har en skön röd på violett stötande färg, och säges vara af alla me|dusis den mäst brännande, då något däraf kommer på bara kroppen; men vi kommo ej så när, at vi kunde få dem upp i skeppet, at nogare se dem. Mot aftonen sågo vi en och annan Stormväders fogel flyga omkring oss öfver vatnet, sällan bak efter skeppet, utan mäst på endera sidan, och långt därifrån. Hafs-Tärnan syntes då och då. Om aftonen i Solgången kom en Hai af ansenlig storlek simmande bak efter skeppet; men gick strax bårt igen. När sjöfolket få en sådan, äta de stjärten, som skal vara 
den bästa delen däraf; men det andra kasta de bårt eller gifva det åt Svinen. De beskylte Fransoserna därföre, at de skola äta honom hel och hållen. Litet för Solgången sågo vi åtskilliga gångor i $\mathrm{S}$. et godt stycke från oss vatten sprutas upp i myckenhet högt i vädret, hvaraf Sjöfolket slöto, at där måtte varit någon Hvalfisk.

\section{Den 4 Septemb.}

Resan. Om morgonen Kl. 4. hugnade HERren oss med en härlig vind, fast den blåste något sakta, med hvilken vi började igen fortsätta vår resa. Tropicbird syntes äfven denna morgon. Hafs-Tärnan syntes då och då. Mäst hela denna dagen sågo vi som oftast hela Svärmar til hundrade tals af flygande fiskar, komma upp utur vatnet, och flyga långa stycket, innan de gofvo sig ned igen. Det längsta de flögo, innan de foro ned, var et p. 148 godt musquett-skott, och längsta tiden / de voro upp utur vatnet var $1 / 4$ minut, eller tör hända in emot en half minut. Kosan, som de vid sitt flygande altid togo, var, som förr är anmärkt, mäst tvärt ernot vädret, eller ock ibland snedt mot det samma; men aldrig kunde jag få se, at de fölgde med vinden och undan vädret. Tör hända, at de ej då kunde flyga så väl, eller at vädret dref dem snarare at falla ned. Golf-weed syntes i dag flyta til större myckenhet $\mathrm{i}$ hafvet, än vi sett någon dag tilförene. Inga Stormväders foglar kunde vi i dag blifva varse. Orten där vi nu voro var vid 40. grad. 29. min. Latit. Bor. samt ungefär vid $49 \mathrm{gr}$. $30 \mathrm{~min}$. W. om London.

\section{Den 5 Septemb.}

Resan. Med den härliga vinden fortsattes vår resa, så at vi lupit sedan Kl. 12. i går middag til Kl. 12 i dag middagstid 182. Ängelska mil. Inga Stormväders Foglar blefvo vi denna dagen varse: men tämmeligen mycket Hafs-Tärnor, som Ängelsmännerne kallade Shearwater. Förr middagen sågo vi då och då hela svärmar af Fly- 
gande Fiskar komma up utur vatnet, och flyga på sätt som tilförene är beskrifvit. Golf-weed flöt nog på vatnet. Vid middagstid togs Solens högd och befants, at vi voro i $40 \mathrm{gr}$. $3 \mathrm{~min}$. men efter andra uti $39 \mathrm{gr}$. $53 \mathrm{~min}$. Longituden räknades nu emellan 53 och 54 gr. W. om London. När vågen gick hög, och brusade mycket, var dess öfversta kulle helt grön, som då en ser genom et grönt glas. Vi hade mäst hela denna dagen, utom de ordinaira vågor, som fölgde med vädret, et slags andra falska och ganska stora vågor, som kommo från $\mathrm{SW}$. hvaraf Capitainerne slöto, at på detta stället $\mathrm{i}$ hafvet varit par dagar förut en stark SW. storm. Desse falska vågor började visa sig redan i går efter middagen.

\section{Den 6 Septemb.}

Resan. Med önskelig vind fortsattes resan. Skeppet lopp merendels 8 Ängelska mil i timan. Om morgonen sågo vi en Tropicbird, som flög omkring skeppet. Den liknar nog en fiskınåse; men har 2. långa fjädrar i stjärten. Til färgen är han hvit. Vi sågo dessa foglar sedan flera gångor $i$ dag. Af Golf-weed syntes $i$ dag mera flyta $i$ Sjön, än någonsin tilförene, så at det tycktes, som det svårligen kunde tros, at all den stora myckenheten däraf, som vi sett hela resan flyta på vatnet, skulle endast komma från hafsviken vid Florida. Likaledes sågo vi i dag mera flygande Fiskar, än någonsin tilförene. Somlige af Sjöfolket säja, at då de komma upp ur vatnet, fölga de hvad kosa som hälst, så mot som med vädret; men jag fruktar, at de samme icke gifvit noga aktning på deras flykt. Alla dem jag til denna stund sett, hafva aldrig flugit med och undan vädret, utan antingen tvärt emot vädret, eller ock snedt för det samma; e. g. om vädret kommit från | SO. hafva de vid upflygandet, antingen tagit sin kosa til SO. eller ock snedt mot det samma, eller ock til NO. eller SW. samt de puncter emellan SO. och de nämde väderstreken; merendels fölgde de tätt utmed vatnet; men så såg jag likväl någon gång, at de 
flögo til en famns högd från vatnet; dock skedde sådant merendels, när de flögo upp från högsta toppen af en hög våg, och vågen strax föll ned. Alla af Sjöfolket sade, at de ibland flyga så, at de komma på däcket af skeppet. Vi sågo hela stora Svärmar ibland flyga upp tillika. Ingen Stormväders fogel viste sig i dag; Hafs-Tärnor syntes då och då. The Spanish man of war seglade då och då förbi oss på vatnet. Skeppet hade gått från i gâr middag til middagstiden i lag, 196 Ängelska mil.

\section{Den 7 Septemb.}

Resan fullfölgdes med härlig vind. Sjö-Tärnor syntes nog: Flygande Fiskar likaledes: Golf-weed mycket. Inga Stormväders Foglar eller andra Foglar fingo vi denna dagen se. Vi voro vid middagstid uti $38 \mathrm{gr} .54 \mathrm{~min}$. Latit. Bor. samt 62 grad W. om London. Fràn Kl. 12. i går til Kl. 12. i dag middagstid eller på 24 timar, hade skeppet lupit 186 Ängelska mil: The spanish man of war syntes ofta i dag simma eller flyta på vatnet.

Vid Solens nedergång blefvo vi varse et skepp långt p. 151 ifrån oss i S. som kom sedan när|mare til oss. Detta satte oss i någon fruktan; emedan vi mente, at det vore en Spansk Kapare, eller annan Sjöröfvare, som strax efter Krig pläga fara omkring och plundra skepp; men vår räddhoga försvann, när vi sågo, at det Kl. 10. efter middagen gick oss förbi litet framföre oss, och tog sin kosa mera til N. än vi.

Tecken til väderleken. Vi märkte altid på denna resan, at då himmelen eller molnen voro röda orn aftonen vid Solens nedergång, fölgde ofelbart andra dagen äärefter starkare väder och blåst, än vanligt var. Så var ock himmelen röd i går, samt et starkt väder i dag.

\section{Den 8 Septemb.}

Resan. Än fingo vi njuta vår härliga vind. Vid middagstid togs Solens högd, och befans, at vi voro vid 
38 gr. 24 min. Latit. Bor. samt ungefär vid $65 \mathrm{gr}$. W. om London. Sedan middagstiden i går hade skeppet lupit 184 Ängelska mil. Golf-weed syntes då och då. HafsTärnorna flögo uti Sjön på åtskilliga ställen. Om morgonen syntes Tropic-Fogeln par gångor. Han flyger långsamt, och högt upp i vädret, och tyckes, som han endast kom til skeppet, at se därpå, hvarefter han flög sin väg.

Observ. vid Hafs-vatnet. Vinden som nu blåste från $\mathrm{N}$. var tämmeligen kall, / och hade gjordt luften nog kulen. Vågorna gingo ganska stora: hvarvid vi märkte, at dả en stod vid sidan af skeppet mot vädret, och någon våg kom fräsandes starkt, gaf hon då tillika från sig en varm ånga, hvilken kom på den, som stod därvid; til et tecken, at hafsvatnet nu var varmare än luften.

Hvetemjölet, som vi hade om bord, hade nu af hetan tagit en syra til sig, så at hvad vi gjorde däraf, smakade surt. Capitainerne berättade, at de uti Västindien bruka at torka mjölet förut väl på en Badstugu-lafva eller Kölna, innan det packas in; då det gerna håller sig väl, och icke tager en sådan syra til sig.

Kl. 9. om aftonen kommo vi på et ställe i hafvet, där vågorna gingo grufveligen stora, och snart sagt de största vi sett hela denna resan, fast vädret var nog fogligt. Capitainerne dömde däraf at detta stället måste vara $\mathrm{i}$ skillnaden emellan yttra hafvet, och den inra delen af Americanska viken; ty $\mathrm{Kl}$. 12. därefter kommo vi til sådana ställen, där vågorna gingo helt små, fast vädret blåste lika starkt. Vi hade eljest under hela denna r'esan, ibland kommit på sådana ställen, där vågorna gått större, än på de andra, fast vinden varit alt likadan, dem Sjöfolket tilskrifvit en starkare storm på samma ställen en dag förut.

\section{Den 9 Septemb.}

Resan fortsattes med god vind. Hafs-Tärnorna syntes hela dagen. $\mathrm{Vi}$ sågo ock et annat slags foglar, som liknade i flygt och skapnad Änder. Golf-weed flöt allestäds i hafvet. Strax efter middagen sågo vi en stor myckenhet 
af nyss omtalte foglar, som sades likna änder. Styrmannen, som var hemma i Philadelphia, kallade dem Shearwaters. De måste vara en art af fiskmåsar, fast de flyga något fortare. $\mathrm{Vi}$ sågo ögonskenligen, at de togo upp fiskar utur hafvet och åto dem, desse voro ej hvita, utan bruna på ryggen, samt mäst af den storlek, som en fiskmåse. Kl. 4. efter middagen började vi få se fläckar i vatnet af en annan färg. Hafsvatnet hade gemenligen, hela sjön elller hafvet öfver, en mörkblå färg: men i dag började samma färg blifva något ljusare. Det besynnerligaste var, at vi ibland sågo helt långa, men nog smala fläckar, ungefär af 12 à 14 famnars bredd, hvarest vatnet hade en ljusgrön färg, aldeles skild ifrån det andra vatnet. En af Capitainerne sade, at det förorsakas af fina Sjögräs som flyta cläri. Andre mente, at någon bank gick därunder. Vi seglade öfver en, som lopp från NW. til SO. men vi ångrade mycket där, at vi glömde bårt taga up vatten af den $i$ et ämbare, och ransaka det, om däri skulle finnas någre heterogenea. Mot aftonen sågo vi en annan

p. 154 Sjö-fogel som | flög litet frản skeppet, den Ängelsmännerne kallade Sea-Hen. Stormväders foglarne, dem vi på några dagar ej sett til, började åter visa sig, och flögo dels omkring Sjön ut med vatnet, dels fölgde de til ansenligt antal et stycke bak efter skeppet, där det gått förut.

\section{Den 10 Septemb.}

Resan. Än var vinden tämmeligen god. I dagningen sågo båtsmännerne en stor fogel flyga omkring skeppet, och ibland sätta sig upp i masten, den de togo för en uggla. En liten Land-fogel kom förr middagen och satte sig på seglen: men vi sågo ej hvart den sedan tog vägen. Denne dag var rart nog at få se något Golf-weed flyta i hafvet, som Sjöfolket togo för et tecken, at vi ej måste vara långt från land; ty när en kommer så när landet, at det blir så grundt, at de börja loda, skal en ej mera se til något Golf-weed. Kl. 10. förr middagen kom en hel svärm Purpoises (Delphinus antiquorum), dem vi ej sett 
på en långan tid, nu til några och 30 stycken, som summo til skeppet, och fölgde det samma en fjärndels tima, på sätt, som ofvan beskrifvit är, nämligen hoppandes ibland upp i högden. Vi sågo ock tämmeligen mycket $\mathrm{i}$ dag af den Medusa, som Ängelsmännerne kalla The Spanish man of war, flyta i hafvet. Hans färg och skapnad var mäst som en lunga af et Kreatur, hopkramad på ömse sidor. Ibland när någon liten våg kom, stjälpte hon omkull dem, men de reste sig strax upp igen De vände gemen- p. 155 ligen den smala och vassa kanten upåt. Hafs-Tärnorna syntes då och då. Shearwater viste sig ock nảgon gång, ryggen brun, mäst med hvit ring om halsen. Han samm på vatnet: hade en särdeles och nog långsam flygt. Efter middagen kom en hel svärm af Purpoises på vanligt sätt simmande til skeppet, och fölgde det en liten stund. De kommo både från NW. och NO. farande. Vi sảgo eljest hela sjön rundt omkring full däraf. Hafsvatnet blef nu ljusare och ljusare. Vi sågo ock långt ifrån på et eller annat ställe fläckar af den ljusgröna färgen. Somliga Ängelsmän kallade Purpoises Sea-Hogs. Stormväders foglarne flögo omkring på sjön. Mot Solens nedergång kommo 2:ne Svalor, af samma slag, som tilförene, som flugo omkring skeppet, och sätte sig ibland på det samma, liksom de ville här taga nattherbärge. Vi fingo ändteligen en af dem fast, den vi satte i en lyckta öfver natten at hvila, och ärnade släppa henne nästa morgon.

\section{Den 11 Septemb.}

Resan. Vinden blef nu tämmeligen mot oss. Af Golf-weed sågo vi knapt 2 à 3 klasor eller stycken hela denna dagen. Stormväders fogeln flög här och där öfver vatnet. Et slags fisk, som Ängelsmännerne kallade Bonitos, kom om morgonen i myckenhet til skeppet, och fölgde oss sedan hela denna dagen, | nu på ena sidan om skeppet, p. 156 nu på den andra. Vi sågo helt små fiskar simma i hafvet, efter hvilka desse Bonitos jagade, och gjorde då i vatnet en sådan rörelse, som hade där varit en tämmeligen stark 
forss eller ström, hoppade ibland något up utur vatnet. Då de åstadkommo denna rörelsen, voro de mäst alle i en hop, fickte om hvarandra; men kommo dock aldrig så när skeppet, at någon kunde huggas med harpon.

At förvara Smör om Sommaren. Smöret, som vi hade ombord, smälte nu mäst upp af värman, och blef äfven litet härskt. Capitainerne, som ofta seglat til Vestindien, berättade, at de på samma resor brukat taga en stor tunna, fylla den med hafsvatten, sätta Smör-fjälingen däri, at hafsvatnet står högre på sidorna af fjärdingen, än smöret är i den samma: ömsa så dageligen hafsvatnet därpå, at altid friskt hafsvatten sattes i stället; därigenom skal smöret i desse varma Länder på skeppen hålla sig längre än eljest.

En hop med Purpoises hoppade til myckenhet långt ifrån oss i vatnet, och gingo frản $\mathrm{IV}$. til $\mathrm{O}$. men de kommo ej til skeppet. Då och dả fingo vi se någon Spanish man of war. Dessutom blefvo vi i dag äfven nog ofta varse en art af meduser, som Ängelsmännerne kallade Blubber, flyta p. $15 \pi$ på vatnet, gemenli|gen af en ordinair tentalriks storlek, brun midt uti, men bräddarna rundt omkring af en ljus färg, som städse voro i rörelse. Vid middagstid kommo 6. stycken Dolphins, som fölgde bak efter skeppet, af hvilka vi höggo med harpon en, den vi fingo. När han skar's upp, fans i dess maga en myckenhet med smả fisk, af fingers längd; men de voro redan sả bårtsmälte, at ingen kunde taga redo på dem. Dess färg är förut beskrifven; här vil jag lägga det til, at han under buken är väl hvit, men stötande likväl ganska mycket på gult, samt har här och där på sidorna om magen små trinda fläckar af en hög blå färg: pinna dorsalis är, då den nyss kommer utur vatnet, likaledes af en skön blå färg. Stormväders foglarne flögo om aftonen i ganska stor myckenhet allestäds omkring pâ sjön; men i synnerhet grufveligen mycket på de ställen, där vårt skepp skridit fram. Vi sågo ögonskenligen, at de plåckade något upp utur sjön, men hvad det var, kunde vi ej veta. Tör hända de små fiskar, som vi sett simma upp i vattubrynet. I dag fingo 
vi ock se åtskilliga ej tilförene af oss sedda Sjö-gräs, flyta i hafvet, et som kallades Roch-weed: et annat, som liknade et pärlband: et annat, som var hvitt $1 / 2$ alns långt, smalt, lika bredt öfver alt, och hel rakt.

\section{Den 12 September.}

Hela natten förut, och denna morgon var det helt lungt, sả at flaggan ej vändes af | nảgot väder. Et skepp, p. 158 som vi hela dagen i går såg lảngt framför oss, syntes i dagningen något bakefter vårt skepp, men tog likväl samma kosa, som vi. $\mathrm{Vi}$ fruktade alle, at det var en Spansk Kapare eller Sjöröfvare, och voro nu icke särdeles väl til mods, men sedan vädret börjat blảsa litet, och vi hissat segel, lämnade vi det snart, då vår fruktan mer och mer försvann. Par dagar efter vảr ankomst til Philadelphia, kom detta skepp efter, hvarpå var fullt med Tyskar, som foro öfver til America, at där sätta sig ned. De hade varit rätt så rädde för oss, som vi för dem och trodt, at denna dagen skulle blifva den sidsta.

Om morgonen kom en Hackspik, och satte sig på Taklen. Färgen på ryggen var grå spräcklig, den tycktes ganska trött, och lärer gömt sig på någon sida, emedan, dả Matroserne höllo på at sätta ut flera segel, kom han åter fram, flög rundt omkring skeppet, och lät höra sit läte, hvarefter vi ej sågo, hvart han tog vägen, utan han lärer hafva satt sig på yttra sidan om skeppet på något ställe. Äfven sågo vi en annan Landfogel af Sparfslägtet komma flygande til oss; men vi visste ej sedan, hvart han for. Kl. 11. förr middagen kom en hel svärm af Purpoises tumlande $\mathrm{i}$ vatnet. $\mathrm{Vi}$ sågo dem på långt håll komma från NW. ända til skeppet, och då de hunno fram, hade de ej lust at töf/va där, utan summo straxt förbi til SW. Skeppet gick nu ganska långsamt; hvaraf jag gissar orsaken, hvi de ej gåfvo sig tid at följa med skeppet, som de eljest plägade; ty de hade ej tảlamod, at fara så långsamt. Kl. 1. efter middagen kom en stor svärm af det fiskslag, som kallas Bottle-noses, tumlade i vatnet från $\mathrm{SW}$. 
til NO. de voro faseligen stora, väl af 6 alnars längd. Deras skapnad och gång är så lik Purpoises, at det är ingen tvifvel, det de ju bägge böra komma under et Genus. Deras noss eller gap liknade någorlunda en Bouteille, hvaraf de fått sit namn. De foro tätt förbi skeppet, utan at uppehålla sig därvid. Några Dolphins gingo vid middagstid bakefter skeppet; men lämnade det efter en liten stund. Stormväders fogeln flög allestäds omkring på vatnet, at söka sin föda. Vi sågo i dag inga Hafs-Tärnor. The spanish man of war seglade då och dả förbi oss, prálade med sin höga violette eller Purpurfärg.

\section{Den 13 September.}

Redan i går tyckte Capitain Lawson, som en stor del af resan för sjukdom måst merendels hålla sig vid sängen, at vi af alla tecken vore mycket nära til Americanska Landet; men som Styrman efter sin uträckning var af annan mening, och matroserne hvarken om aftonen från öfversta masten sågo något land, eller vid lodandet pả p. 160 flere famnar funno bot/ten, måste Capitain nästan taga sina ord tilbaka. Vi fullfölgde då om natten sakteligen vår resa med en maklig vind. Kl. mot 3. om morgonen befalte Capitain Lawson, at de för större säkerhet skul likväl ville kasta ut lodet. Det verkstältes, och vid första utkastningen ropade Matrosen: 10. famnar vatten, då blef et buller på skeppet. Understyrman sprang sjelf, at kasta ut lodet, och befann ibland 10. ibland 14. famnar; men huru noga han förrättade sin sysla, vet jag ej; ty en liten stund därefter ropade han 14. famnar, då skeppet gaf til en stöt mot sjöbotten, och så litet emellan, 4. andra hårda stötar. Det kan ej uttalas med hvad bestörtning och fruktan vi alle blefvo betagne, när vi sågo, at skeppet lupit på en sandrefvel. Detta skedde Kl. half 5. om morgonen, då det ännu var mörkt, fast månen sken nảgot. Vi visste $e j$ hvar vi voro, och fruktade, at vi lågo på landet. Vi voro 80. personer om bord, och på skeppet var endast en enda båt. Näppeligen hade någon af oss, 
så länge han lefvat, med en sådan hast och en dylik fruktan stigit upp af sin säng. En och hvar anförtrodde den gode Guden sin nöd. Hvad vi bönföllo om, blef hördt: skeppet kom strax löst från sandbanken. Vi togo kosan något tilbaka, och undsluppo så faran. När det dagades fingo vi se hela fasta landet af America, som mot hafssidan är lågt med hvita sandstränder, hvilka litet längre upp äro beväxte mäst med Tallskog. Vi | fingo då se, at stället, vi stötte på, låg utan för Maryland, vid 37 gr. 50 min. Lat. Bor. ungefär en liten Svensk mil från fasta landet, och midt emot den ort, som kallas Arcadia. Sedan det blef ljust, tog jag Bibeln at trösta mig med, och vid det jag öpnade den samma, var Psalm. 107: 23 och följ. det aldraförsta, som ögonen föllo på. Ord, hvilka passade sig så på vårt då varande tilstånd, likasom de med flit blifvit upsökte.

Vinden var hela denna dagen, GUDi låf! mycket blid och härlig: vågorna gingo så små, at man med en liten båt kunnat utan fara ro hvart man velat på hafvet. Vatnet vi sågo, hela denna dagen, hade en naturell sjögrön färg. Inga foglar blefvo vi varse; men en hoop Purpoises sågo vi hoppa $\mathrm{i}$ vatnet på långt håll. Et enda skepp viste sig, som mäst hade samma kosa, som vi. Vi fölgde nu Kusten af Maryland, och gingo ej längre därifrån, än at vi kunde hafva honom i ögnasigte. Någon Spanish man of war viste sig ibland; men inga Sjö-örter, och ingen medusa blef jag varse. Emedan vi om aftonen ej hunno fram til Cape Henlopen, där vi skulle taga Lots; så gingo vi följande natten af och til, utan för viken Dellaware.

Tecken til väderleken. Om aftonen var nog mulit, så at det syntes liknelse til rägn den följande natten; men efter Solens nedgång började en stark dagg at falla, så at |Kläderna blefvo hel däfviga utanpå, och af böcker, p. 162 som sjö-folket kommit at lämna öpna liggande på Kajutan, blefvo de bladen, som lågo öpna, helt våta, nästan, som om någon spilt vatten på dem, fast de lågo ej stort öfver en half tima efter Solens nedgång under öppen himmel. 
Ängelsmännerne sade, at när i Ängland faller stark dagg om aftonen, blir ofelbart om andra och nästföljande dagen en stark hetta. Capitainerne, som varit ofta i Vestindien, sade, at samma äfven händer där.

Fluga. Ordinaira flugor hade varit i Kajutan hela vägen; så at vi sålunda ej kunne visst sluta, om de samme äro indigenæ uti America, eller först förde dit från Europa.

\section{Den $1 \pm$ September.}

Resan. Om morgonen började vi åter fortsätta vår resa med en härlig vind. Vi hade nu på vänstra han- den, eller W. om oss, ständigt land, som låg lågt. Stränderna syntes snöhvita af den fina sanden de bestodo af, och litet ofvanför dem var marken öfvertäckt med tallskog. Kl. half 8. förr middagen fingo vi Lotsen om bord, som sjelfmant lrom ut til oss från Cape Henlopen, hvilket är en by, på en udd, som stranden på W. sidan om oss sköt ut i sjön. Hela landet på denna sidan sades höra til Pensylvania; men på östra sidan om Dellaware Bay til New Jersey. Af Lotsen fingo vi förnimma, at Capitaine p. 163 Mesnard, | med den vi först i Våras ärnade gå öfver til America, och som redan afseglat ifrån Ängland uti Maji, först för 18 dagar sedan ankommit hit: til America: haft en ganska lång passage, dels för lugn och stilla väder, dels för motvind skul. Från Cape Henlopen, där vi togo Lots til Philadelphia, räknas 150 Ängelska mil; men från elfsmynningen til Philadelphia ungefär 90 sådana mil. Vi fortsatte nu vår kosa långs efter Dellaware Bay, och hade från 4. til 10. à 11. famnars djup där vi seglade; men eljest ligga här och där sandreflar, på hvilka då och då skepp vid storm blifvit olyckelige. Inga sjö-gräs, inga medusce eller andra sådane hafs-djur viste sig nu mera för oss. Någon fisk syntes hoppa här och där utur vatnet, och sades denna viken vara mycket fiskrik. Som förut är omrördt, så syntes stränderna bestå af höga trän, och berättades så af Lotsen, som af Styrman, hvilken var född i Philadelphia, at landet alt omkring dess stränder är 
öfverväxt med den skönaste skog, tjenlig til skepps byggnad. Den hugges där ned, och föres verket härifrån i stora flottar til Philadelphia eller andra platser här på orten, där skeppshvarf finnas. En stor del af de skepp Ängelsmännerne, i synnerhet Köpmän, bruka, huggas och byggas i deras Colonier här i Norra America. Däraf sker, at Skepps Capitainer hvar höst gemenligen resa hit öfver från Ängland, och tilbringa vintern här med | skepps- p. 164 byggnad, så at de med första vår-dag äro färdige, at gå härifrån med sina nya skepp. Emedan de Ängelske i detta Kriget mist många skepp, som Franske och Spanske Capare bårttagit; så kommo nu i denna höst åtskillige Capitainer hit, at låta bygga nya $\mathrm{i}$ stället.

Längre in på dagen började vi se land på bägge sidor, alt af samma beskaffenhet och utseende, och blef viken nu smalare. Litet efter middagen kommo vi til början af Dellaware River eller Flod, som sedan löper upp til Philadelphia, och långt förbi den samma. Den var här i mynningen mot $1 / 2$ Svensk mil bred, men blef sedan alt smalare och smalare, och är vid Philadelphia ej fyllest en Ängelsk mil bred. Landet på ömse sidor är lågländt, öfverväxt ända til stranden med stor och tjock skog, af Ekar, Hickeries, samt andra trän. Vi sågo här och där vid dess stränder små släta fält, vid hvilka i lunder stod någon gård. Boskapshopar gingo $i$ bet här och där på stränderna. Somligstäds stodo löfträden af en rödbrun färg, sådan, som Rönnar hos oss sent om hösten. De som här bodde. berättade, at desse trän blifvit i Sommars skadde af åskan och ljungeld. Stora Störar viste sig ibland i floden, och hoppade upp ofvanpå vatnet. Fiskmảsar syntes ock då och då, som tycktes likna våra. Omkring gårdarna vid stranden sågo vi små åkrar och somligstäds täppor med ordinaira gärdesgårdar | omkring. Likaledes här och där hö-stackar. Från stranden kom med vädret blåsande en behagelig lukt ifrån de slagna ängar, och växterna på marken.

Vi fullfölgde sedan vår resa med en önskelig vind et godt stycke in på natten. Uti skymningen foro vi 
förbi New-Castle, en liten stad, belägen på västra sidan om Floden. Det var redan så mörkt, at vi kunde föga se något af staden, annat, än ljus brinna i fönsterna. Denna staden säges först blifvit anlagd af Holländare, och altså den äldsta stad i landet, äldre, än både Philadelphia, och andra städer här på orten; men uti handel är han dock ej at likna mot Philadelphia, fast han i åtskillige ting har större förmoner af naturen, än Philadelphia, som til äfventyrs, at det är mer än sällan, at floden om vinteren blir där så tilfrusen, at ju skepp kunna gå ut och in, då däremot elfven vid Philadelphia mäst hvar vinter blir tilfrusen, at seglation för några veckor måste stanna af; men som landet omkring Philadelphia, och än längre upp, är starkt bebodt, som alla föra sina varor til Philadelphia, och den en gång fått företrädet; så måste den andra staden altid stå efter. Jag sade, at Holländarne säges vara de förste, som anlagt denna stad.

Detta skedde den tic̉en, dả landet hörde Sverige til; men Holländarne trängde sig af hat här in, och ville p. 166 småningom och oförmärkt | utstänga de Svenska, såsom folk, hvilket hade gjort inbrott i deras land. Detta lyckades dem; ty då de Svenske ej längre kunde tola detta deras lands inkräcktande af främmande, brast det ut i et uppenbart Krig, då de Holländske, som mägtigare, gjorde sig mästare af landet; men deras glädje var tämmeligen stackot; ty få år därefter kommo de Ängelske, och togo landet ifrån dem. De hafva ock in til denna dag i frid besutit det samma. Längre in på natten kastades vårt ankare; emedan Lotsen ej dristade, at gå längre i mörkret, för sandbankar, hvilka lågo här och där i floden.

\section{Den 15 September.}

Resan. Uti dagningen lyftes vårt ankare och resan fortsattes upp åt floden. Mäst allestäds på ömse sidor om den samma, var landet bebodt, fast dock tämmeligen glest. Vid Kl. 8. förr middagen seglade vi förbi Chester, en liten stad på västra sidan om floden. Hela denna 
morgon viste Styrmannen, hvilken var född i Philadelphia, mig de ställen, hvarest Svenskar ännu bodde. Vi kommo ändteligen, Gudi låf! lyckeligen fram til Philadelphia Kl. 10. förr middagen, och hade således ej varit mera på vägen från Gravesend til denna stad, än in emot 6. veckor, eller nogare, ej fyllest 41 dag, då det äfven inberäknas, som vi lågo vid Deal, at förse oss med et och annat nödigt af färsk mat \&c. hvilket räknas bland en af de bästa passager eller öf/verfarter; då man däremot ofta om vinteren måste använda, 14, 15, 16, 17, 18, 19 och flere veckor från Gravesend til Philadelphia. Näppeligen lärer någon haft en nöjsammare resa öfver detta stora verldenes haf, än vi denna gången, hvilket ock Capitaine Lawson flere resor besannade, säjandes, at han aldrig sett så blid väderlek och fri från storm på detta hafvet, under alla de resor han förr farit däröfver. Mäst var vinden ej hårdare, än at en kunnat med en lagom stor båt segla utan fara bredevid skeppet, utan at behöfva frukta, det vågen skulle slå in. Ja, ofta hade man med en ökståck, eller julle kunnat utan rädsla segla jämte skeppet. Pả hela resan slog aldrig någon våg öfver Kajutan, ej eller slog någon våg öfver den öfra delen af skeppet mer, än en enda gång, hvilket var bara en svallvåg, och det uti vackert väder, då en stor hop med Tyskar lågo och solade sig på däcket. Våra Kajutfönster suto hela resan i sit ställe, utan några lukor eller annat därföre, hvaraf kan ses, huru fogeligt vädret var.

Det som ännu gjorde denna sjö-resan nöjsammare, var Capit. Lawson, hvilken på hela vägen viste mig den kärlek och ömhet, som hade jag varit en af hans närmaste anhörige.

Så snart vi anländt til staden, och kastat ankare, kommo en myckenhet af Stadsens inbyggare om bord, at höra efter bref. De / togo med sig bårt så många, som de kunde, antingen för sig eller sina vänner. De andre bref, som ej blefvo bårttagne, lät Capitaine föra til lands, och lämna in på et Coffé-hus, at hvar och en kunde där vidare höra efter dem, på det han ej skulle blifva besvärad 
därmed. Alla brefven gåfves bårt, utan at Capitaine tog det ringaste af någon därföre. Jag for sedan Kl. 12. tillika med Capitaine til lands, som tillika gaf sträng befallning til Under-Styrman, at ej lämna någon af de Tyska frihet at gå til lands, innan de betalt deras frakt, eller at någon annan lagt det ut för dem, eller köpt dem.

Recommendations-bref äro både nyttige och nödige för den, som reser til någon främmande ort. Han blifver därigenom snart både känd, älskad och trodd. Ho kan bygga något särdeles förtroende med den, som en förut hvarken sett eller hört af? Vid min afresa från London fick jag Recommendations-bref med mig från Herr Abr. Spalding, Mr. Peter Collinson, Dr. Mitchell och andra til deras bekanta här på orten. Jag hade därföre ej svårt at komma fort. Mr. Benj. Franklin, den Pensylvanien har at tacka för så mycket godt han bidragit til dess uphjelpande och välgång, och den lärda verlden för de många nya decouverter vid Electriciteten, var den förste, som gjorde mig bekant: gaf mig all nödig underrättelse, p. 169 och beviste mig margfallig ynnest. | I följe med Svenska Kyrko-Rådet Jacob Bengtson och Conterfejaren Herr Gust. Hesselius, Bror til Sal. Mag. Andreas och Samuel Hesselius, hvilka bägge varit Kyrkoherdar i Christina i Nya Sverige, och til Framledne Provincial-Nedicus uti Nerike och Wermland Doct.. Joh. Hesselius, spatserade jag i dag omkring i Staden, at bese den samma, samt på fälten strax där utanföre. Herr Gust. Hesselius hade fölgt hit til landet med sin Broder Mag. Andreas, redan år 1711. och alt sedan den tiden beständigt vistats här. Jag fann, det jag nu var kommen i en annan verld; ty hvart jag på marken kastade ögonen, mötte mig mäst öfveralt sådana växter, dem jag ej kände, och hvilka arter (species) jag aldrig sett förut. Blef jag varse något trä; så måste jag stanna, och fråga mina följeslagare, hvad det kallades. Den första ört, som likasom bad mig vara välkommen, eller den ögonen först föllo på, var en Andropagon, eller af Gräs-slägtet, den delen nämligen af örte-kunskapen, som jag haft mit största nöje med. Jag grufvade mig, 
huru jag skulle gå i land med, at taga reda på så mycket nytt och obekant. Tvenne de första dagar användes, at bara gå och gapa på växterna, utan at våga mig ihop med dem til någon närmare bekantskap.

Om aftonen fick jag mit herbärge hos en liten handlande af Qväkare, et mycket godt | och ärligt folk, som mästa delen af det slaget är, hos hvilken jag tillika med Jungström fingo Kammare, ljus, sängar och sängkläder, uppassning, samt 3. gångor spisa om dagen, där vi så behagade, för 20. Skillingar Pensylvanie-mynt (är emellan 4. och 5. Plåtar) om veckan; men ved, tvätt, och vin, i fall jag det äskade, borde särskilt betalas.

\section{Den 16 September.}

Innan jag går längre, vill jag lämna en liten beskrifning på staden Philadelphia; emedan jag framdeles ofta i min Resa kommer at nämna honom. Jag vil här införa et och annat, som jag satt mig til minnes om den saken, vid mit vistande på denna orten.

Philadelphia, Hufvud-Staden uti Pensylvanien, (som är en del af det fordom så kallade Nya Sverige) är en af de förnämsta, och näst Boston den störste af Städerna i Norra America, belägen likasom i medelpuncten af de Ängelska Colonier härstädes, vid 39 gr. och några och 50 min. Norr om Æquatorn, samt inemot 75 grader W. om Londons meridian.

År 1683. (eller som somliga vela, år 1682) blef den först anlagd af den bekanta Qväkaren William Penn, som fått hela detta landet til skänks af Konung CARL II. i Ängland, sedan Sverige lämnat alt åtal därpå. Staden skulle efter Penns utstakning komma at ligga | på et stycke land eller en del af en udd, som göres af bägge Flodarna Dellaware och Skullkil, och således blifva i fyrkant 2. Ängelska mil lång, samt en bred, då den ena eller östra ändan af Staden skulle ligga vid Floden Dellaware, och den andre eller Västra vid Skullkil, vid hvilka bägge Floder ock hus då bygdes. Det utstakades ock 
då 8. långgator, hvardera 2. Ängelska mil långa, samt 16 tvärgator, hvardera af en sådan mils längd, alle desse ansenligen breda och i linea recta. Platsen var den tiden mäst en ödemark, öfverväxt med stor skog, och hörde 3:ne Bröder til af de Svenska, vid namn Suenssöner, hvilka ock bodde därpå. För ortens fördelaktiga läge skull ville de svårligen gå på, at skilja sig härifrån; dock förmådde Penn dem ändteligen, at lämna sig denna platsen, mot det han gaf dem några få Ängelska mil därifrån dubbelt så mycket land igen; dock har sedermera dels han sjelf, dels hans arfvingar genom flera mätningar nog stympat från dem samma land, under föregifvande, at de tilvält sig mera, än dem tilkommit.

Sedermera som i hast et så stort antal inbyggare icke kunde fås, som fordrades til hela denna stora platsen, har man, tils vidare, lämnat floden Skullkil, och bygt Staden endast långs efter Dellaware, som nu stryker tätt förbi den samma på Östra sidan och ej litet befrämjar p. 172 dess handel, utom den vackra / utsigt staden därigenom äger. De hus, som i början upsattes vid Skullkil, blefvo äfven småningom flyttade därifrån hit.

Staden ligger altså på et behageligt ställe, sträcker sig långs efter floden mäst från Norr til Söder; är något mer än en Ängelsk mil lång, samt på somliga ställen en half mil bred, om ej mera. Grunden är jämn, utan nảgra särdeles högder, består af sand utblandad med litet lera. Förfarenheten har äfven vist, at denna orten är ganska hälsosam.

Gatorna äro regulaira, täcka och rymliga. De mästa äro 50. Ängelska fot breda, Archstreet 66. fot, och Marketstreet, eller den förnämsta, hvarpå marknader hålles, är ända til 100. Äng. fot bred. De gator, som löpa mäst från N. til S. eller efter Stadsens nu varande längd, äro 7. stycken, utom en liten ned vid Floden Söder om torget, som kallas Waterstreet. De nu varande tvärgator, eller de, som äro ärnade at löpa från Dellaware til Skullkil, äro 8 , och gả mäst från 0 . til W. Jag säger, at de gå mäst så; ty de afvika alla litet från dessa väderstrek. Alle 
desse gator, utom de bägge, som äro närmast til elfven, gå uti en rätt linea, och skära de förra af de senare vinkelrätt eller ad angulos rectos. Somlige af dem äro stenlagde, andre ej; emedan det för den sandblandade jordmonen skull, som snart super i sig vätskan, synes vara mindre nödigt. Men den goda inrättningen är, efter Ängelska sät|tet, vid de mästa af dem, at på hvardera p. 173 sidan närmast til husen är gatan til en famns bredd, och ibland mera, belagd med jämna, flata och släta stenar, samt stolpar af par alnars längd satte näst därutom til 3 à 4 famnar ifrân hvarandra. Nyttan och förmon häraf är, at på de å ömsa sidor om gatan närmast husen lagde flata stenar gå de, sorn vandra til fots; men de som rida, eller fara med vagnar, kärror eller andra åkdon, färdas endast midt på gatan. De ofvannämde stolpar hindra, at ingen med häst eller vagn kan skada dem, som gå vid sidorna inom samma stolpar, utan äro de där säkre både för vårdslösa Kuskar och åkare, samt för den orenlighet, som hästar, vagnar och kärror kunna stänka från sig. Rännor under taken, som väl afledas, göra ock vid rägnväder eller snöens smältning dem som gå därunder fria för olägenhet upifrån.

Husen äro täcka och sköna, ofta flera våningar höga: nästan alla bygde antingen af tegel eller gråsten. De fläste äro af tegel, som slås och brännes förträffeligt strax utan för Staden. Af gråsten äro ock åtskilliga upmurade. Denna gråsten består af en blandning af svart eller grå i vågor gående skimmer, utblandad här och där, samt mer eller mindre emellan flagorna med en grå lös ganska fingrynig Kalkstens art, samt då och då något ljust sandkorn; dock at skimmern är mäst $\mid$ rådande. Stundom var ock blanningen annorlunda, som längre fram under den 11 Oct. skal omröras. Den brytes i ymnoghet här i landet, låter lätt hugga sig, och har den förmon, at han icke fuktar sig vid våt väderlek. Utvald kalk til murning brännes ock här öfveralt. Husen äro täckte med spån af den, som de Svenske kalla Hvita Enen, och de Ängelske, Hvita Cedern (Cupressus thyoides Lins. Spec. 1003: 3) 
hvilken växer här i myckenhet i kärr och morass, fast han är nu redan tämmeligen uthuggen, och ännu är ej minsta anstalt gjord til dess fredande. Detta är et träslag, som är otroligt lätt; men tillika et af dem, som af dem här växa aldralängst står emot röta; är därföre förträffelig til tak, emedan de ej tynga på väggarna, och kunna vara hela mans-åldrar. Dock hafva åtskillige redan märkt, at desse tak af Hvita Enen eller Hvita Cedern torde framdeles blifva en skada för denna stad; ty $\mathrm{i}$ anledning däraf, at sådane tak äro ganska lätta, hafva de mäst vid alla stenhus byggnader, enkannerligen dem af tegel, gjordt här mycket tunna murar; men som detta träslag är nu snart utödt, och de framdeles i brist däraf måste-bruka tyngre tak, antingen af taktegel eller annat, så lära de få blifva omtänkte, när desse af Hvit Ceder blifva förskämde, och til förekommande, at ej murarna må tvingas ut, at antingen sätta stolpar under taket, eller

p. 17ă rifva ned murarna och göra nya, eller på annat sätt | göra dem fasta och stadiga. $\mathrm{Nu}$ desse sista åren har en och annan börjat nyttja taktegel.

Ibland de Publique hus märkes först Kyrkor, hvilka äro åtskillige; emedan GUD dyrkas här på mångfalt sätt.

1. Ängelska kyrkan, ligger i Norra delen af Staden litet från torget: är af alla den vackraste: försedd med et lågt, litet och osynligt torn, däri en liten Klåcka hänger, hvarmed ringes til Gudstjenst och för Lik. Äfven är här et urverk, eller timklåcka, som slår. Denna Kyrkan kallas Christi-Kyrka, och har blifvit anlagd vid sista slutet af näst föregående hundradetal; men förbättrad och mera prydd för några få år sedan. Här äro 2:ne Präster, som hafva sin mästa lön från Angland. Vid början af detta Seculo förestod Svenska Kyrkoherden Mag. Rudman, snart i 2. år, den här varande Ängelska Församlingen, under deras egen Prästs frånvaro.

2. Den Svenska, som eljest kallas Wicaco Kyrka, ligger vid Södra ändan af staden, och nästan utan för den samma, vid floden på det behagligaste ställe af alla 
Kyrkor härstädes. Om denna får jag framdeles mera orda, när jag kommer at handla i synnerhet om de Svenska här på orten.

3. Den Tyska Lutherska; ligger på NW. sidan af staden: hade vid min ankomst til America et litet torn; men som en oförståndig Byggmästare satt det dit, innan murarne blefvo väl torre, tvingade dess tyngd | murarna ut, at de omsider om hösten 1750, då de fingo hit et vackert orgeverk från. Tyskland, nödgades taga det ned. Här är endast en Präst, hvilken tillika betjenar de Tyska Lutherska i Germantown, predikar nu den ena söndagen här, den andra där. Den första Lutherska Präst vid denna Församling, var Mr. Mühlenberg, hvilken år 1743. lade Grundvalen til denna Kyrka: och sedan han kom at flytta til en annan Församling, har han haft til efterträdare Mr. Brunholtz, en Dansk från Schlessvig, hvilken ännu är qvar. Bägge hafva blifvit hitsände från Halle, och skaffat här, med sina synnerliga upbyggeliga gåfvor margfalt nytta. Näst förr än denna Kyrkan upbygdes, hade de Tyske härstädes ingen Präst, utan betjente sig då af den så allmänt älskade Svenska Kyrkoherden i Wicaco Herr Dylander, hvilken predikade i Svenska Kyrkan hvar Söndag först om morgonen bittida Tyska, sedan i ordinaira Högmässan Svenska, och efter middagen Ängelska, och däremellan reste han uti veckan omkring pã landet, och predikade för de omkringströdde Tyskar, så at han ofta innom en vecka hölt 16. predikningar. Det var ock först efter hans död, hvilken timade i Nov. år 1741., som de Tyske, hvilka här vistas, begärte Präster från Tyskland. Denna Tyska Lutherska Församlingen är nu mycket talrik, sả at i Kyrkan är nog trångt om Söndagarna. Uti Kyrkan äro läktare, men ingen / Sakerstia. De mässa ej, utan läsa alt upp för Altaret; men predikan sker från Predikstolen.

4. Den gamla Presbyterska, ligger litet från torget på S. sidan om Market street, är medelmåttig stor, upbygd år 1704, som årtalet på norra gafvelen utvisar. 
Yttra taket formerar mäst en half cirkel, eller något när en half hexagon. Den vänder sig i N. och S. och märkes, at Presbyterianerne äro ej så laggranne, at vid sina kyrkor $\mathrm{i}$ akt taga ständigt et visst väderstreck, som det sker $\mathrm{i}$ andra länder.

5. Den nya Presbyterska blef upbygd år 1750. uti NW. delen af staden, af de så kallade Newlights, med hvilket namn förstås de, som affallit från en eller annan Religion til den bekanta Whitefield, som år 1739 och 1740 , samt 1744. och 1745. vandrade mäst genom alla Ängelska Colonier i Norra America och predikade. Hans vältalighet, behageliga uttal, synnerliga ifver och stora gåfvor at predika, gjorde, at han ofta, i synnerhet de 2 första åren, i sina predikningar på fälten hade från $8,10,15$, til 20,000. åhörare. Hans afsikt med denna sin predikning var, at samla penningar til et barnhus, som var uprättadt i Georgien. Han fick här ibland uti en enda predikan til 70 Pund Sterling: ja, uti 2ne predikningar, som han hölt år 1740. på en och samma Söndag i Philadelphia, samlade p. 178 han 150 pund Sterling, eller ungefär | 300 Ducater. Ofvannämde Newlights äro denna tiden bara Schismatici från den Presbyterska kyrkan, och kalla sig sjelfva Presbyterianer; ty oansedt Whitefield var i början en Präst af Ängelska kyrkan; så föll han dock småningom derifrån, och då han kom 1744. til Boston i Nya Ängland, discurerade Presbyterianerne så länge der med honom, at han mäst $i$ alt antog deras satser; ty Whitefield var ingen stark Disputator, och kunde således af detta sluga folket snart ledas hvart de ville. Detta gjorde ock, at han vid sit senare vistande i Norra America ej hade aldeles det tillop af åhörare, som förra gången. Desse Newlights upbygde först åt sig år 1741 . et stort hus $\mathrm{i} W$. delen af denna staden til at förrätta sin Gudstjenst uti; men som de efter Whitefields bårtgång kommo at dela sig, såldes, utom andra orsaker, samma hus sedan ungefär vid början af år 1750. til Staden, at förvandlas til en Academie. Hvarefter de så kallade Newlights låto upsätta den här 
nämde kyrckan. På östra gafvelen står med förgyldta bokstäfver dessa ord:

\author{
Templum \\ Presbyterianum \\ Annuente Numine \\ Erectum Anno Dom. \\ MDCCI.
}

6. Den gamla Tyska Calvinska, är belägen i WNW. ändan af Staden, liknar til | skapnad någorlunda Ladu- p. 179 gårdslands kyrkan i Stockholm, är dock ej ännu aldeles färdig, fast de $\mathrm{i}$ flera år predikat deruti. Så länge den förr omtalte Svenska Kyrkoherden Dylander lefde, hade desse Tyskar ingen Präst, utan bevistade altid den af Dylander förrättade Tyska Gudstjensten i Wicaco kyrka; men när de Tyske Lutherske efter hans död begärte Präster från Halle, förskaffade desse sig äfven Präst från Dodrecht i Holland. Den första Präst som dả sändes hit, var Mr. Slaughter, hvilken ännu vid min ankomst til America var der qvar; men hade år 1750. den förtreten, at en annan Calvinisk Präst nyligen dit öfver kommen från Holland, genom list och baktal sả stälte sig in hos en del af hans åhörare, at mer än halfparten af dem föllo ifrån honom. Hvarpå, sedan bägge desse Präster stridt i kyrkan med hvarandra om predikstolen flere Söndagar ả rad, så at ock den nysskomne Prästen för samma orsak sades hafva gảtt Lögerdags afton förut upp i Predikstolen och settat der hela natten, at utestänga den andra, och bägge parternas åhörare haft der sammastädes, til allas åtlöje och tal, med hvarandra både slagsmål och hvarjehanda förargelser; så blef kyrkan efter ransakning af Magistraten tildömd Mr. Slaughter, såsom oskyldig.

7. Den nya Tyska Calvinska. Den nyss omtalte tilkomne Prästs anhang lät upbygga den samma litet från den förra, sedan de tap/pat saken. Dock som vid slutet p. 180 af år 1750. denna Präst så konstigt dref sit spel, at han omsider låckade mäst alla den andras åhörare på sin sida; 
så lärer förmodeligen denna nya bygda kyrkan blifvit mindre nödig.

8 och 9. Tvenne Quakarenas kyrkor eller så kallade Meetings, den ena vid torget, och den andra i Norra delen af staden. Uti dessa finnes, efter detta folkets sätt, hvarcken Altare, Predikstol, Mässhake, eller annan Kyrkoprydnad, utan bänkar och några ljusarmar. Här komma de tilhopa 3 gångor hvar Söndag, och dessutom vissa gånger i veckan eller månaden, hvarom mera längre fram.

10. Den Anabaptistiska, i Norra delen af Staden.

11. Den Påfviska i SW. delen af staden; är et någorlunda stort hus, vackert siradt inuti, och äfven med orgor försedt.

12. Den Mohraviska eller Zinzendorffiska, är et stort hus, som Herrenhuterne hyrt sig i Norra delen af Staden. De höllo här sin Gudstjenst både pá Tyska och Ängelska, icke allenast 2 à 3 gångor hvar Söndag, utan ock hvar Söknedag, om aftonen, sedan det blifvit mörckt; dock nödgades de om vintern 1750. uphöra med dessa nattsammankomster, sedan en och annan kitslig ungdom åstadkommit der åtskillig förargelse medelst en så kallad guckuh, eller liten pust gjord för barnlek (hvilken vid hopklämp. 181 mandet låter guckuh); med denna in|stämde de uti någon mörk vrå under sången, ej allenast vid slutet af hvar vers, utan ock mäst vid slutet af hvart rim i versen.

De af Ängelska Kyrkan, Newlights, Quakare och Tyska Calvinska, hafva nu deras begrafnings platser på någon sida utom Staden, och ej vid deras kyrkor (undantagande de Ängelske ibland). De andre begrafvo sina döda på kyrkogården. Nohraverne hvar de kunna få; Negrerne begrafvas på et visst ställe utan för Staden.

$\mathrm{Nu}$ vil jag nämna litet om de andra publique byggnader.

Stats-huset eller Assembly-huset ligger i W. ändan af Staden, är et stort vackert hus, hvilket gör mästa prydnaden i Staden, med torn midt på, och klåcka deruti. Här kommer Provinciens Deputerade tilhopa gemenligen hvart år uti October månad, eller ock oftare, der om- 
ständigheterne så fordra, at rådslå om landets bästa, samt hålla deras små Parlament eller Riksdagar. Här öfverses de gamla Lagar, och upsättas nya.

Uti en ända af detta hus är Bibliothequet, som blifvit uprättadt år 1742. då genom den vittre Mr. Benj. Franklins bedrifvande någre af de förmögnaste Stảndspersoner och andre sammansatt sig, at til en början sammanskjuta hvardera 40 skillingar, och sedan gifva hvar för sig ảrligen 10 skillingar, alt i Pensylvaniæ-mynt, til hvarjehanda nyt|tiga böckers upköpande. Desse, som så sammanskutit, få fritt låna de härigenom samlade böcker. Androm lämnas ock frihet, at mot pant låna böcker härifrån til en viss tid; men en sådan bör för hvar vecka betala något visst, nämligen 8 pence för en bok i Folio, 6 p. för en i Quarto, och 4 pence för de andra mindre. När tiden är ute, til hvilken en fảtt låna någon bok, bör hon återställas, annars får han böta. Alla dessa penningar användas sedan dels til Bibliothecariens lön, dels til flera böckers uphandling. Här var redan en vacker samling af utvalda och sköna böcker, mäst i Ängelska språket: en hop äfven på Latin och Fransöska; men ganska fả på nảgot annat språk. Directeurerne af detta Bibliotheque viste mig den ynnest, at de gofvo Bibliothecarien befallning til at lämna mig til låns under hela den tiden jag vistades här, hvad bok jag begärte, utan at jag skulle betala det ringaste för lånet. Bibliothequet öpnades hvar Lögerdag efter middagen från kl. 4. til 8. Utom böcker voro här äfven åtskilliga Mathematiska och Physiska Instrumenter, jämte stora samlingar af Naturalier. Et eller annat litet Bibliotheque, hopsamladt och inrättadt mäst på samma sätt som detta, finnes på andra ställen här i Staden.

Rådhuset (the Court-house) står midt på Marketstreet, straxt W. om torget, är et vackert hus med et litet torn på och klåcka deruti. | Under och rundt omkring p. 183 detta hus hålles enkannerligen vecko-marcknaderna.

Academien ligger i W. ändan af Staden: var förut, som förr är omtalt, en kyrka för Whitefields efterföljare; 
men köptes 1750. til Academie, eller rättare, Schola och Gymnasii hus, hvarefter det på åtskilligt sätt blef ändradt. Ungdomen undervises här uti sådana stycken, som hos oss plägar läras vid Trivial-Scholor och Gymnasier. Framdeles tänka de låta inrätta läsningarna här på samma sätt, som vid ordinaira Academier.

Vid slutet af sista kriget, som Ängland hade, blef här vid Södra sidan af Staden, tätt vid floden, en Skants anlagd, at hindra Franska och Spanska kapares upkomst til Staden. Innan detta verkstältes, var här en ganska stark tvist; emedan Quakerne förkastade alt försvarsverk, såsom stridande emot deras Religions puncter, hvilka ej tillåta en Christen at föra hvarken offensiva eller defensiva krig, utan tro vår HErre om godt. Flera skrifter växlades här den tiden bảde pro och contra. Dock sedan några fiendteliga kapare tagit bårt $i$ älfven somliga af Stadsens fartyg, funno ganska många, om ej alla af Quakarena, äfven för sin de] rådligt, at åtminstone med penningars försträckande underhjelpa Försvars-verkets hastiga i stånd sättande.

Bland de naturliga förmoner denna Stad äger, räknas med fog följande:

p. 184 Dess belägenhet uti et behagligt Climat, der vintrarne ej äro för stränga, utan nog kårta, och somrarne ej för brännande: der landet rundt omkring gifver i största ymnoghet de frukter, med hvilkas skötsel Landtmannen sysselsatt sina händer. Deras September och October likna början af vår nu varande Augustus; och ofta är begynnelsen af Februarius hos dem så behagelig, som slutet af vår April, eller början af vår Maij. Sjelfva deras kallaste vinterdagar synas somliga år icke vara annat, än som en tämmelig långt framskriden Vår i den medlersta delen af Sverige, och Södra af Finland.

En ymnoghet af godt och skönt vatten; ty ehuru här i staden icke gifves källor med flytande vatten, så finnas dock vatturika brunnar mäst vid hvar gård, som ock flerestäds ute på gatorna, hvilka gifva et utvaldt vatten både til matlagning, dricka, och at göra linkläder 
ganska hvita, samt til andra behof. Gemenligen måste en grafva 30 à 40 . fot, innan vatten möter. Det vatten, som finnes i floden Dellaware är ock ej at förkasta. Et fel som begås i architecturen, och gör, at dessa brunnars sköna vatten på somliga ställen i staden blifver nog skämdt, får jag framdeles nämna.

Floden Dellaware tjenar förträffeligen til handelens befrämjande. Den är en af de största floder. Ned vid des mynning är han | öfver en half Svensk mil bred, midt emot Staden Willmington 2 Ängelska, och här vid Philadelphia $3 / 4$ Äng. mil tvärt öfver. Philadelphia ligger väl vid pass 90 à 100 Ängelska mil upp i landet från hafvet, eller der Dellaware faller ut i hafsviken; dock är älfven hela denna vägen, der skeppen gå, näppeligen någorstäds under 5 à 6 . famnar djup, så at de största skepp kunna komma upp til Staden, och der lägga sig tätt vid bryggan, hvarest är 5 famnars djup, och god ankar-grund; Vatnet är här vid staden saltlöst, som gör, at skadeliga maskar, hvilka i hafvet satt sig vid skeppen, och bårat sig in i dem, dö bårt eller falla af, så snart fartyget legat liten tid här i floden.

En olägenhet har dock denna Staden til sin handel derutinnan, at älfven mäst hvar vinter til 1, 2, 3, och ibland, hela fulla 4. månader blifver belagd eller upfyld med is, då under den tiden all seglation hit och härifrån måste afstanna, hvilken svårighet Boston, Newyorck och andre närmare hafvet belägne Städer äro befriade före.

Vid Staden är Ebb och Flod, ja den går til 30 äng. mil ännu längre upp, nämligen til Trenton. Skilnaden vid Philadelphia emellan det högsta och minsta vatten vid ordinair Ebb och Flod, är 8 äng. fot.

Forssarne och fallen uti Dellaware vid Trenton, och uti Skullkil litet från Philadel|phia, hindra, at de längre upp i landet icke kunna nyttja dessa floder til sina varors upp och nedbringande, utan nödgas föra dem på kärror och vagnar til och från Philadelphia. Man har dock omtalt, at framdeles göra dessa floder navigable för stora båtar och mindre fartyg. 
Åtskillige skepp byggas här hvart ảr på de flera här uti och vid Staden varande skepshvarf; dock äro desse, bygde af Americansk ek, på långt när ej i varaktighet och godhet at jämnlikna med våra af Europæisk Ek.

Denna Staden drifver en stark handel så väl med inbyggarena i landet, som til andra orter; i synnerhet til Westindien (hvarmed i Norra America förstås Americanska öarna Jamaica, Barbados \&c.), Ängland, Irland, Portugal, samt til åtskilliga af Ängelska Colonierne på fasta landet i Norra America. Inge andre, än Ängelska Cronan tilhörige skepp, få komma hit at drifva handel. Den handel, som för denna Staden mäst räntar, är den Westindiske; ty dit försändes mäst dageligen en myckenhet af mjöl, smör, kött och andra matvaror, kimbar, bräder och annat träverke; hvaremot föres tilbaka derifrån antingen Såcker, Sirap, Rum, Indigo, Mohogony-trä \&c. eller ock redbara penningar. Det rätta Mohogony-trä, som kommer från Jamaica, är nu snart aldeles utödt. Til Ängland förskeppas dels sådant, som kommit från Westindien; dels p. 187 af landets egna Producter, som | träverke, svart Valnötträ, Ekplankor til skepp, skepp här bygda, järn, skinvaror, tjära (denna kiöpes från Nya Jersey, och äro tallskogarne derigenom snart utödde,) eller sändes ock til Ängland redbara penningar. Tilbaka derifrån tages allahanda i Ängland Fabricerade varor, som finare och gröfre kläden, lärfter, allehanda järn- och metall-arbeten, hvarjehanda Varor från Ostindien \&c. ty det är at märka, at mäst alt kläde och Manufactur-Varor, som förslites och brukas här i landet, kommer hvar bit från Ängland. Til Irland försändes en myckenhet Linfrö årligen, samt upbygde skepp: til Portugall en myckenhet Hvete och Spanmål, mjöl, omald Mays: til Spanien ibland Spanmål. Alla de penningar, som således i Irland, Portugal, Spanien, och annorstädes kunna hopskrapas, gå strax til Ängland, at betala de varor med, som tagas derifrån, och vil det ändock ej räcka til, at fylla de hål, som skulden förorsakat.

At så mycket klarare må skönjas, hvad denna Stad och Province i flera år genom sin handel tagit från Äng- 
land, vil jag här lämna et utdrag utur Ängelska Tullböckerna, som ger uplysning i den saken, hvilket jag fått af Ingenieuren Mr. Levis Evans i Philadelphia. Han anmodade en sin vän i London, at lämna honom et utdrag på huru mycket gods blifvit sändt från Angland til Pensylvanien i flera års tid, hvilket han ock erhölt. Sjelfva godset sättes här ej upp, utan ungefär | dess värde i penningar. Man har utdragit sådana Listor ur Tullböckerna, för alla Provincier i Norra America, til at därmed visa Parlamentet i Ängland, at desse Länder tagit mera af Änglands Varor, sedan de uprättat deras egna Pappers Penningar. Jag vil gifva samma utdrag vid slutet af denna Tom, som jag tagit det utur sjelfva Originalmanuscriptet.

Dervid märkes allenast, at berörde upsats börjas med Juletiden 1722. och slutes med samma tid 1747. I första columnen är upfördt värdet af främmande varor, som förut blifvit tullade i Ängland. I andra columnen, Änglands egna Fabricerade Varor, som til Pensylvanien blifvit utskeppade. I sista columnen står summan tilhopaslagen af bägge föregående. Ned under är tilhopa adderat hvar column för sig. Än märkes, at $i$ denna Tabellen är ej innebegripit det lärft, och åtskilligt annat, som årligen från Skotland och Irland gåt i myckenhet til Pensylvanien.

Än ytterligare kan en finna hurudan handelen är härstädes af antalet på de större och mindre Fartyg, som årligen pläga gå til och från denna stad. Jag vil endast anföra några få år af det jag utdragit utur Pensylvaniens Gazetter. Tiden är här från den 25 Martii ena året, til samma dag det nästföljande.

$\begin{array}{crrrrr}\text { Ăr } & 1735 . & \text { Inkomne } & 199 . & \text { Utgångne } & 212 . \\ \# 1740 . & \# & 307 . & \# & 208 . \\ \# 1741 . & \# & 292 . & \# & 309 . \\ \# 1744 . & \# & 229 . & \# & 271 . \\ \# 1745 . & \# & 280 . & " & 301 . \\ \# 1746 . & \# & 273 . & \# & 293 .\end{array}$


Men det är stor anledning at tro, at Philadelphia och de öfriga dessa Coloniers handel på andra orter skal i framtiden mera af- än tiltaga, derest ej andra författningar göras, hvilket frädeles skal bevisas.

Ifrån denna staden tager icke allenast största delen af inbyggarena i Pensylvaninen de köpmans- och Manufactur-varor, de behöfva, utan en ganska stor del af dem, som bo uti Nya Jersey drifver jämväl här dageligen en stark handel.

Almänna stora marknader hållas här 2 gånger om året, nämligen d. 16. Maij och d. 16 Nov. st. vet. men dessutom är här marcknad 2 gångor hvar vecka, nämligen hvarje Ons- och Lördag, då Landsfolket både från Pensylvanien och Nya Jersey föra in en myckenhet af allehanda slags matvaror och landets Producter, så at Staden härigenom har en ganska stor förmon, och vore til önskandes det samma fördelaktiga sed vore äfven brukelig i våra Svenska Städer. En är här säker at om marknads-dagarna fả hvad som af Landtmanna-varor behöfves; men det sökes ock förgäfves deremellan. Altså p. 190 behöfver en | ej i ovisshet löpa til torget eller passa upp vid tullarna, efter det som är af nöden. De kunna sålunda här altid hafva färsk mat. Mästa delen af folket här i staden hade derföre merendels ej mera mat uti sit hus, än som det kunde räcka til nästa marknads dag, dả de fingo åter alt nytt, friskt och färskt. Om sommaren hålles här mäst hvar dag en sådan marknad; emedan matvarorne för den starka hettan icke kunna hålla sig länge. Desse vecko-marknader hållas här på 2 ställen i Staden; dock är den vid Råuhuset den förnämste: den börjas kl. 4 eller 5 om morgonen, och slutes kl. 9. för middagen.

Omkring Staden är intet staquet: ej heller är här annan tull än stora sjötullen.

Gouverneuren öfver denna Province har sit säte här i staden. Han utnämnes väl af Penns arfvingar; men får ej tilträda syslan, innan han af Konungen i Ängland är confirmerad. 
Quakarene från mäst alla kanter i Norra America hålla här en gång om året deras stora allmänna möte.

En Vetenskaps Societet blef här år 1743. inrättad. Den skulle hafva at göra med allehanda märkvärdigheter i de 3 Natursens riken, samt i Mathematique, Mechanique, Physique, Chemie, Oeconomie, Manufacturer \&c. men det påkomne kriget gjorde alt til intet: sedan har den härtils ej å nyo blifvit uprättad.

Magnetens variation befans år 1750. d. 30. Octob. st. p. 191 vet. vara här 5 grad. $45 \mathrm{~min}$. W. hvilken variation togs efter den nya middags linien, som då om hösten drogs $\mathrm{i}$ Philadelphia, och var något öfver en Ängelsk mil lång. Af gjorda observationer har det funnits, at variation aftager här ungefär en grad på 18 à 20. år.

Skilnaden emellan Barometerns högsta och lägsta har blifvit funnen efter flera års observationer, gjorda af Mr. James Logan, vara 28,59 och 30,78 tum.

Trenne Boktryckare äro här; och komma en gång hvar vecka här ut 2:ne Ängelska avisor, och en Tysk.

År 1732. d. 5. Sept. st. vet. kändes en liten jordbäfning vid middagstiden här i Staden, och på samma tid i Boston i Nya Ängland och Nontreal i Canada: orter öfver 60. och flera Svenska mil ifrån hvar andra belägne.

1737. uti Novemb. kom den bekante så kallade Printsen af Libanon, Schich Sidi hit, hvilken det året reste igenom en stor del af Ängelska Colonierna i America.

Samma år d. 7. Decemb. st. vet. om aftonen kl. 11. kändes en tämmelig jordbäfning här i Staden, hvilken dock icke varade öfver en half minut. Han märktes på samma tid och stund i New Castle, New Gork, New London, Boston och på andra ställen i Nya | Ängland, som p. 192 Gazetterne intygade. Orter så vida skilde från hvarandra.

1741. in Decemb. kom Gref Zinzendorff hit och vistades här på orten tils mot nästföljande Vår. För sit ovanliga upförande härstädes voro många Ängelsmän, äfven af de förnämare, af den tanka, at han ej varit så aldeles riktig i hufvudet.

Hvad antalet på Stadsens inbyggare vidgår, så har 
jag ej kunnat få det visst. Redan 1746. räknades de vara öfver 10,000 . och sedan den tiden har staden otroligt tiltagit. Af dödslistorna kan ock ej något säkert slutas; emedan de vid alla kyrkor icke hålla så riktig räkning dermed. Af de antingen uti Gazetterne eller särskildt för sig utkomna dödslistor, vil jag endast anföra några.

År 1730. blifvit döde 227. Personer.

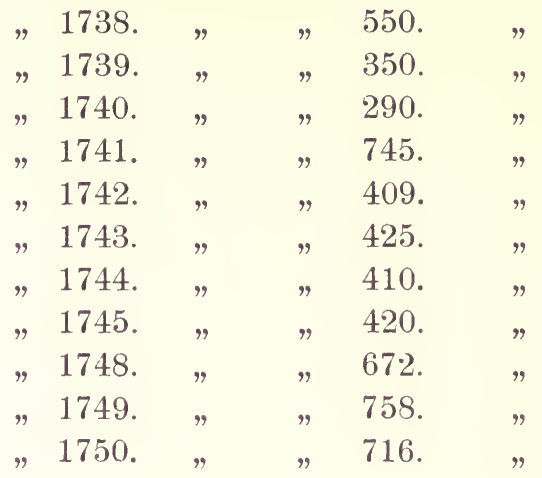

Af dödslistorna finnes, at de sjukdomar, hvaraf de mäst dö, äro Lungsot, febrar, Convulsioner, Pleuresie, blodstörtning, vattusot.

På de årligen födda har jag ej kunnat få någon visshet; emedan vid somliga Kyrckor hålles så godt som ingen ordning härmed. At förtiga, det Quakarene, som göra här nästan det mästa antalet, låta aldrig Christna eller döpa siná barn, ehuru de likväl pläga tämmeligen uptekna de födda.

At döma om årliga antalet af de döda til myckenheten af invånarena i denna Stad, tager här ej lag; emedan orten får hvart år så starck tilökning, från andra länder. Således ankommo år 1749 om sommaren hit från Europa mot 12,000 af Tyska nationen, hvaraf en ganska stor del blefvo qvar här i Staden. Samma år om våren räknades gårdarna i Philadelphia, sorn befunnos vara 2076.

Staden svärmar altså redan med inbyggare af mångahanda slags nationer, Gudsdyrckan, sysslor, slögder och ämbeten. Här finnas utvalda mästare mäst i alla handt- 
verk, och göres mycket nu så godt här, som i sielfva Ängland; dock äro här ej ännu några särdeles finare yllefabriquer; tör hända derföre, at de bekomma kläde så lätt från Ängland, och de hitförda Får tyckas småningom aftaga $i$ godhet.

På matvaror är här en Herrans välsignelse, och kunna de fås til nog billigt pris. Landet vet näppeligen, at gifva exempel på särdeles dyr tid.

En och hvar, som endast erkänner en Gud för all tings Skapare, Uppehållare och Rege|rare, samt icke lärer eller företager något mot Regeringen och den allmänna ron, har frihet at här bygga, bo och idka sit lofliga handtverck, han må i öfrigt hafva så tokot Religion han någonsin vil. Ingen blir för sin villfarande lära i andeliga saker oroad, när han ej stöter emot hvad nyss nämndt är. En och hvar är af Lagarna så beskyddad til sig sjelf och sin egendom, samt njuter här en sådan frihet, at det i visst afseende kan sägas, at en inbyggare här är som en Konung i sit hus; och at det vore svårt at finna om någon til sin frihet hvarcken kan önska eller ernå större förmoner.

När det noga öfverväges, hvad nu kårteligen sagt är; så lärer det lätteligen kunna begripas huru det varit möjeligt för denna Stad, at på så kårt tid upväxa från et intet til sådan storlek och välmåga, utan at någon mägtig Potentat här antingen med straffs påläggande för den treska, eller med stora penninge-summors tilskjutande hulpit det ringaste til at sätta honom i det stånd, han nu är, då den likväl redan i prydnad, goda ordningar, behageligt läge, naturliga förmoner, handel, rikedom och förmögenhet gifver få, äfven af de uråldriga städer i Europa efter. Det har ej varit nödigt at med tvång drifva folk at sätta sig här ned; utan tvärt om hafva folk af mångahanda tungomål lämnat fädernesland, hus och hem, anhöriga och annat, vågat sig på et | stormande haf och vidlöftig sjöresa, och likasom trängt sig hit. Andra länge bebodda länder stå toma och sucka efter folk, då deremot Pensylvanien, som vid år 1681 ej var annat, än en ödemark, och svårligen hade 1500 själar, nu i folkrik- 
het täflar med många Konungariken i Europa. Det har fått de folkskaror, som andre til sin oboteliga skada antingen försmått eller förskutit.

Som et vedermäle af denna platsens forna usla utseende och förakteliga tilstånd, står ännu litet norr om Wicaco Kyrka på elfsbacken qvar en gammal eländig träkoja, som hört til en af de Suenssöner, af hvilka grunden til Philadelphia köptes. Ehuru det var det ynkeligaste hus i hela Staden; sả kunde det dock berömma sig deraf, at när det stod i sin bästa välmagt, lågo alla de andra husen i Staden antingen ned i jordenes gömor, eller växte ännu deras ämne i skogen. Der rökte ur des korsten, när Hjortar, Miockar, Espanar och Bäfrar om ljusa dagen hade deras hviloställen på Philadelphiæ torg, gator, Kyrkogårdar och tomter: jag menar, på de ställen, der innom kảrt tid prägtiga byggningar skulle upstiga. Här hördes i denna koja slammer af spånråckar, när ännu inga konstiga Fabriquer här voro uprättade, och innan verlden ännu visste hvad et Philadelphia i America var. Men med alla dessa förträffligheter är dock detta huset nu på yttersta uphällningen, och lärer det efter några få | p. 196 år blifva så omöjeligt at finna det här, som det vid des början var svårt at tro, at det skulle hafva til efterträdare en den förnämsta Stad i America; men nu til annat.

Plägsed. Den plägsed var här i Philadelphia, at dả någon mötte qvinfolk på gatan, lämnades dem gärna den sidan, som är näst väggen på husen. Skedde det ej, så hölts han för obelefvad och plump. Jag har nämt förut, at gatorna här äro af den beskaffenhet, som i London, näml. at midt efter gatan köres med kärror; men på ömse sidor vid husen äro stenlagde ställen af en famns bredd ungefär, der de gå til fots. Där utanföre stå trä stolpar, at hindra det kuskar och åkare ej måga köra på folket. På samma sätt, om någon spatserar på gatan med et Fruntimmer, borde han altid lämna henne, at gå på den sidan, som är närmast vid husen. De taga detta noga i akt, ej allenast med Fruntimmer, utan ock ofta 
med manfolk, så at, om den jag gick med var förnämare än jag, lät jag honom altid gå på den sidan, som var närmast vid husen; så at den sidan vid gåendet på gatan, svarade emot högra sidan hos oss. Jag har sett de manfolk, som varit så fäfänga häruti, at om de velat bevisa den andra heder, hafva de nu gảtt på högra sidan om den andra, nu åter lupit på den vänstra, snart återigen til den högra, alt som de kommit at gå från den ena sidan på gatan til den andra. Denna sed lärer kommit | deraf, at den, som går närmast ut åt gatan, der de köra med hästar, kan ofta blifva öfverstänkt med orenlighet, och derföre hafva de ansett den sidan, som af mindre heder.

\section{Den 17 September.}

Foglars förkjusning af ormar. Handelsman Peter Kock berättade, at han med egna ögon förleden vecka sett, huru en fogel, som de här kalla Katt-fogel, emedan han låter som en katta, flugit af och til på qvistarna i et trä, och låtit mycket illa på sit vanliga sätt. Nedan för trädet, dock ej vid roten, utan en god famn derifrån, har legat en af de stora svarta ormarna, som hållit hufvudet up i vädret, och beständigt haft ögonen på fogeln, som flög i trädet. Fogeln har först flugit på de öfversta qvistarna, sedan begynte komma alt längre och längre ned, til des han ändtel. kommit ned på marken, då han hoppadt til det stället hvar ormen låg, som då gapade up, tog honom i munnen, och började svälja ned honom; hvarpå Handelsman Kock slog ormen ihjäl, då han nyss hunnit svälja ned fogeln. Jag hörde sedan åtskilliga påstå detsamma om denna orm. Om Skaller-ormen är det bekant. I dag spatserade jag utom Staden på fältet, at se hvilka örter der växte. Jag fann här en hop af Europæiska, och sådana, som äfven växa i Sverige, men så fann jag dock tillika et långt större antal af sådana, som endast äro Americanska.

Platanus. Vid stränderna af Dellaware-Elf växte p. 198 ymnogt Platanus foliis lobatis. Linn. H. Cl. 447. Gron. 
Flor. Virg. 119. eller Platanus occidentalis. Catesby Hist. Carol. Vol. 1. p. 56 t. 56. Af de härvarande Ängelska kallades den dels Button-wood, dels ock mäst Water-Beech, och af de Svenska Vattenbok eller ock Vasbok. Den växte ock eljest naturaliter på lågländta ställen; men så tycktes dock sidor, bräddar och stränder af Elfvar, åar och bäckar vara des egenteliga ställe och hemvist, eller solum natale \& locus naturalis. Den var ock ganska god och lätt at plantera på torrare ställen, der jorden fants någorlunda god. Som den har mycket stora löf, och dem i myckenhet, så brukades den nog här at planteras vid gårdar och hus, at med sina stora löf om sommaren gifva en härlig skugga mot den starka solhettan, om sommaren, då bänkar mångenstäds voro gjorde under den, på hvilka de kunde sitta i skuggan. En och annan af de Svenska hade större och smärre askar, skeppor och annat, som Villarne gjordt af detta trädets bark. De brukade fordom, då de bodde här, göra skeppor häraf at plåcka blåbär uti. Barken var in emot af en lin. Geom. tjocklek. Locus naturalis af detta trä var äfven uti kärr, och egenteligen i sänka ängar, där Ask och rödblommiga Lönnen växte. Det växte ofta til et ganska högt och tjockt träd, at näppeligen en Furu hos oss kan blifva tjockare. Frukten eller p. 199 des frö sitter qvar på trädet ända til vå|ren, då den först midt i April månad börjar öpnas, och frön falla bårt. Mon fröna förr ej äro mogna, och duga ej förr at sås? Det räknas för et trä, som växer fortast af alla trän. På de lågländta ängar emellan Philadelphia och Gloucesters färga hafva desse inrotat sig på ömse sidor om vägen på somliga ställen långs efter gärdesgårdarna, at man om sommartiden nästan reser här som genom en Allée. I den delen af Philadelphia, som ligger vid den Svenska Kyrkan, stå långs vid elfsstranden eller backen helt stora trän häraf. Jag såg at knopparna på dem suto qvar i ymnighet d. 4 Martii st. vet. 1750. Den började blomma här år 1749 d. 27 April st. vet. Vid Chelsea uti London i Ängland finnas åtskilliga af dessa trän planterade, som redan i högd täfla med de största Ekar. 
Mot Rödsot berömdes följande som oförlikneligt: Canel kokas i vatten: litet af samma vatten slås sedan i bränvin uti en skål: deröfver lägges par pipskaft tätt bredevid hvarandra, och en bit såcker derpå: tändes eld på bränvinet, som lämnas at brinna en stund, til dess Såckret blifvit något brändt. Af detta Såcker tager Patienten in, dricker ock något af bränvinet och Canelvattnet. Det sades, at mången, som endast tagit in detta en gång, har straxt blifvit botad. Följande utgafs ock för mycket godt: näml. stek et stycke af den röda Ängelska osten, och ät det på en smörgås.

\section{Den 18 September.}

Om morgonen gick jag med Svenska Målaren Herr Gust. Hesselius utom staden til Mr. Bartrams gård, som ligger 4 Ängelska mil från Philadelphia åt Söder och litet från den vägen, som går til Maryland, Virginien och Carolina. Jag började nu få tilfälle at se, huru landet här såg ut, som var flatt och jämt, öfverväxt med allehanda slags löfträn. Jordmon var sand, utblandad med lera, dock syntes sanden hafva öfverhanden. Här och der syntes de ställen, der skogen var bårthuggen, och landtmän bodde, som hade sina åkrar och plantationer rundt omkring sig. Vid hvar bondgård var en myckenhet af allehanda sköna fruktträn. Mulbärsträn, Valnötträn af flera slag, Castanieträn, Sassafras och andra växte fullt i skogarna. Villa Vinrankor af flera arter klängde sig ofta ända up til toppen på de högsta trän, och annorstädes öfverklädde de gärdesgårdarna, hvilka likasom dignade under deras tyngd. Persimon (Diospyros virginiana Linn. sp. 1057) växte här på de våta ängar och omkring vattengölar. Des små äplen eller frukt, som är nog skön, när den blifvit frostbiten, men duger ej förut at ätas, såg redan nog behagelig ut. Hesselius samlade några häraf, och bad min dräng smaka på landsens frukter. Han hant näppeligen bita 2 eller 3 gånger deri, innan han fick förfara, hvad egenskap den hade, då den ej hunnit blifva 
p. 201 mogen och af frosten tilredd. Munnen drogs så / ihop på honom, at han svårligen kunde tala, och en mycket vedervärdig smak upfylte den samma. Han fick häraf en sådan vämjelse til denna frukt, at ehuru angenäm den är vid sednaste hösten eller början af vintern; kunde han sedermera under hela vårt vistande i America näppeligen förmås at smaka den samma vid den tid på året, då den likvist var behagligast. Han tyckte, at om han smakade honom antingen bittida på året eller sent, så hade han mäst samma obehagliga smak, som han förnam vid sit första rön.

Trän hvaraf skogarna omkring Philadelphia nu bestå. Til nöje för dem, som hafva lust at veta, hvad slags skogar pá denna orten äro, och om de hafva samma slags trän, som våra, eller äro mycket skilda, vil jag här införa en liten Förtekning på de Trä-slag, som växa villa uti skogarna i negden omkring Philadelphia. Jag utesluter här sadana arter, som endast växa til hel små buskar, och aldrig större. Den ordning jag här vil följa, skal blifva efter myckenheten af hvart slag, sả at det trä, som finnes här i största myckenhet, skal få främsta rummet, och så följakteligen; och det, som är här mycket sällsynt, och hvaraf jag pả negden vid denna Staden endast funnit et eller annat stånd, skal blifva det sista, eller ibland dem.

Hvita Eken (Quercus alba. Linn. Sp. 996: 10.) i god jord.

Svart Ek. (Quercus rubra. Sp. 996: 9.)

p. 202 Spansk Ek. (variet. prioris).

Hickery, en art Valnöt. (Juglans alba. Sp. 997: 2.) Af denna finnes här 3 à 4 särskildta varieteter.

Rubus occidentalis. Linn. sp. 493 eller Amer. Björnbärsbuskar.

Lönn med röda blommor. (Acer rubrum. Linn. Sp. 1055) uti kärren.

Sumach (Rhus glabra. Sp. 265) i skogar och på högländta skogs-ängar, samt gamla åkrar.

Vinrankor af åtskilliga slag, som Vitis Linn. Spec. 203: 3, 4, samt flera. 
Americansk Fläder. (Sambucus Canadensis. Linn. Spec. 269). Vid gärdesgårdar och på skogsängar.

Kärr-Ek (Quercus Phellos. Sp. 994) uti kärren.

Maji-Blomsterbuskar (Azalea lutea. Sp. 150) i skogarna på torra ställen.

Tupp-spår-Hagtorn (Crategus crus galli. Sp. 476) i skogarna.

Landt-Blåbärsbuskar, en art Vaccinium.

Castanie-Ek (Quercus prinus. Sp. 995) i god jordmon. Hundträ (Cornus florida. Sp. 117) mäst i all slags jordmon.

Tulipan-trä (Liriodendron. Sp. 535) i hvarjehanda jordmon.

Vilska Kersbär (Prunus Virginiana. Sp. 473).

Kärr-Blåbärsbuskar, en art Vaccinium, i god jordmon.

Prinos verticillatus. Sp. 330. uti kärr.

Vattu-Bök. (Platanus occidentalis. Spec. 999).

Fiskareträ (Nyssa. Spec. 1058) på fält, backar.

Gyllenträ (Liquidambar styracifua. Spec. 999) vid vattugölar.

Ahl, en variation af vår Svenska, var bara en buske.

Castanie-trä (Fagus Castanea. Spec. 997) på åkrar, fält, skogsbackar.

Svart Valnöteträ (Juglans nigra. Sp. 997) på samma ställen, som nästföregående.

Rhus radicans. Spec. 266. klef up för trän.

Lönn med Asklöf (Acer negundo. Spec. 1056) i kärr och på våta ställen.

Villa Plommonträn. (Prunus domestica. Linn. Spec. 475).

Hvit Alm. (Ulmus Americana. Spec. 226).

Törnbuskar, på lågländta ställen.

Sassafras (Laurus Sassafias. Spec. 371) i lös god sandblandad jordmon.

Currants, en art af Mespilus, på lågländta ställen, i kärr.

Ask (Fraxinus excelsior Spec. 1057) på lågländta ställen. 
Smilax laurifolia. Spec. 1030, uti skogar, vid gärdesgårdar.

Skedträ (Kalmia latifolia. Linn. Spec. 391) vid norra sidan af backar.

Mulbärsträ (Morus rubra. Spec. 986) på fält, backar, vid gårdar.

Det förgiftiga trä (Rhus Vernix. Spec. 265) på våta ställen.

Röd Ek en synnerlig variation af Quercus rubra. Linn. Spec. 996.

Troll Hassel. (Hamamelis. Spec. 124).

Persimon. (Diospyros Virginiana. Spec. 1057).

Krabbträ. (Pyrus coronaria. Spec. 480).

Röd En (Juniperus Virginiana. Spec. 1039) på magra torra ställen. ställen.

Spicewood (Laurus restivalis. Spec. 370) på våta

Jernträ (Carpinus Ostrya. Spec. 998) i god jordmon.

Afvenbök (Carpinus betulus. Spec. 998) med nästföregående.

Bök (Fagus sylvatica. Spec. 998) i god jordmon.

Butter-nütts trä, en art Vallnötträ; på elfsbackar.

Pensylvanska Gran, på norra sidan af backar och ned i dälder.

Hummel-kopp-Björken (Betula lenta Spec. 983) vid sidor af floder.

Cephalantus occidentalis. Spec. 95, på våta ställen.

Jersey-Tall (Pinus Tada. Sp. 1000) på torra sandhedar.

Sallad-trä (Cersis Canadensis. Spec. 374) i god jord.

Locust-trä (Robinia Pseudo-Acacia. Spec. 722) vid åkrar.

Bäfverträd (Magnolia. Linn. Spec. 535 \&c.) uti kärr. p. 205 Lind (Tilia Americana. Spec. 514) i god jord.

Honey-Locust-trä (Gleditsia. Spec. 1056) i god jord. Nössle-trä (Celtis occidentalis. Spec. 1044) på fält.

Papaw-trä (Annona muricata. Spec. 536) i god jord. 
Vi besökte i dag åtskilliga af de Svenska, som här satt sig ned, hvilka mådde mycket väl. En af dem vid namn Anders Rambo, hade et vackert Stenhus 2 våningar högt, samt en stor trägård der bredevid. Vi blefvo allestäds mycket väl fägnade, och vistades öfver följande natten hos nyssnämde Rambo. Vi kunde ännu ej märka det ringaste tecken til höst, mer än det, at åtskilliga frukter voro mogne; ty i öfrigt stodo alla trän så gröna, och marken var så full med allehanda blomster, som här i Sverige vid Midsommars tiden. I kärr och bäckar skälde grodorne hela natten igenom tusendtals, och i gräset höllo Syrssor och Gräshoppor sådant ljud, at den ena svårligen kunde höra hvad den andra talte. Träna voro ock fulla med fogel-svärmar, de der prålade med margfalliga sköna färgor, och deras lekande tunga samt gälla ljud upväckte luften från alla sidor at härma deras läte. Trägårdarna, der vi i dag vandrat fram, hade ingen annan stängsel, än låga gärdesgårdar. De voro dock upfyllte med allehanda slags sköna frukter. Vi blefvo i | början halfhäpne, när vår vägvisare steg öfver hägnaden in $\mathrm{i}$ en af dessa trägårdar, och samlade åt oss åtskilliga behageliga frukter. Ännu mera öktes vår förundran, när vi blefvo varse, at ägarne ej en gång brydde sig om, at vända ögonen på oss. Vår följeslagare lämnade oss til svar, at de här ej äro så nogräknade om något litet frukt, som på många andra orter i verlden; emedan de hafva en så stor ymnoghet deraf. Vi märkte sedan mer än ofta, at de i Sverige och Finland äro mycket mera nogräknade om et par rofvor uti rof-landet, än de här om de välsmakeligaste frukter.

\section{Den 19 September.}

Dagg. Om natten förut hade det fallit ganska mycket dagg, som jag märkte om morgonen, när jag gick ut i gräset, hvilket var så vått, som hade det rägnat om natten. Bladen på örter och trä voro nu så våta, at dropparna ej mera kunde sitta på dem, utan måste för 
deras myckenhet rinna af. Besynnerligt härvid var, at daggen ej allenast satt på öfra sidan om bladen, utan ock i ymnighet på den undra. Jag ransakade med flit ganska många blan, så af trä som örter, så dem som voro högre från jorden som dem som voro närmare, och befann det alt lika, så at undra sidan hade ej stort mindre dagg på sig än den öfra. Bladen af Verbascum mas latif. lut. C. B. tager jag undan; ty daggen var tämmeligen på öfra sidan af dem, men föga på den undra.

Persiker, Äpplen \&c. Hvar Landtman eller den som bodde på landet, vare sig bonde eller hvad, hade gemenligen vid sit hus en större eller mindre trägård, deri gemenligen voro planterade en myckenhet af åtskilliga slags fruktträn, som Persike-trän, Äpple-, Kersbärs- och Päronsamt andra trän, och det af flera sorter. Vid denna tiden voro Persikerne mäst mogna. Uti Europa och i synnerhet i Sverige, är detta en mycket rar frukt, som hålles i stort värde, och ätes sällan af andra, än de Stora och förnäma; men här sågo vi hos hvar bonde hela trägårdar upfyllta med Persike-trän, hvilka nu voro sả fulla med Persiker, at marken ned under dem ofta låg så öfvertäckt deraf, at vi näppeligen funno et ledigt ställe, der vi kunde sätta foten. En stor del blefvo ock der qvar liggande; ty de orkade ej at förtära en sådan myckenhet. En del fördes til Staden och såldes: en del åts färsk, så af gårdsfolket, som af främmande. En och hvar som kom, hade frihet at gå in i trägården, och äta så mycket han ville. En myckenhet af dessa Persiker samlades och gåfves åt svinen til deras föda. Eljest brukade de ock at förvara dem til vintren, som skedde på det sätt: de klöfvo en Persika i 4 delar, kastade bảrt stenen, som var uti dem: trädde hvardera delen på en tråd: hängde dem ut på gården at torkas i öpna luften och solskenet, til des de voro fulltorra, då de togos in, och förvarades sedan i käril til vintern. Men som detta sätt at torka dem ej var så särp. 208 deles godt, | i anseende dertil, at rägn ibland vid denna tiden inföll, som skämde och rötte dem, då de hängde i fria luften; så brukade andra följande sätt at torka dem, 
som var långt bättre. De skuro på ofvannämde sätt sönder dem i 4 delar, trädde dem antingen på trå, eller lade dem ock på et bräde, som sattes ut i öpna luften då det var solsken. När de sålunda blifvit någorlunda torra, eller så, at en del af fuktigheten gått ifrån dem, sattes de uti en bakugn, sedan brödet blifvit nyss tagit derutur, der de stodo litet: togos så ut och sattes en stund ut $\mathrm{i}$ luften: åter sattes de in, och ömsades så några gånger, til des de blefvo så torra, som det behöfdes; ty at torka dem i ugnen alt på en gång, skulle göra dem för torra, och taga bårt en del af deras behaglighet. De lägga dem sedan i käril, at förvaras til vintern. De brukas i tortor eller Pastey, eller ock kokas och lagas de til, som vi i Sverige tilreda torkade äplen och päron til mat. En del här torka och förvara äplen på samma sätt. Persike-träden sades alla blifvit i början planterade hit af Europæer; men trifvas nu så väl, och behöfva ej mera ans, än Äppeloch Päron-trän hos oss i Sverige, och näppeligen det. I trägårdar voro sällan planterade andra trän, än Äppeloch Persike-trän. Här i landet voro få Päron-trän, och då någon hade dem, voro de äfven planterade i trägården. Kersbärs-träden voro ibland planterade i trägårdar, men gemenligen på ömse sidor om vägen til gårdar, | eller långs vid gärdesgårdar. Mulbärsträn stodo på backar vid gårdarna, och ibland in på gården. Svarta Valnötträn växte antingen på backar och fält närmast ut vid gården, eller långs efter gärdesgårdarna, eller ock mäst i skogen. De hade ock här ej andra trän af detta slaget, som de gjorde nytta af, än svarta Vallnötträn, Juglans nigra, Lin. spec. 997. Castanieträden voro lämnade ute på åkrarna, något hvar stående här och där, på torra betesmarker, eller i skogen och skogsbackar.

Okra var en växt, som växer vildt uti Westindien, (det är, på Americanska öarna), men planterades nu här i Kryddgårdar. Hos Miller uti des Gard. Diction. heter den: Ketmia indica, folio ficus, fructu pentagono recurvo esculento, graciliori \& longiori. ibid. sp. 18. Fröhuset, hvilket är en lång skida, skäres sönder medan det ännu 
är grönt, och kokas i soppor, då den gör soppan tjock som en tjock välling, hvilka slags soppor af somliga hålles för en delice. Negrerne älska denna ganska högt.

Capsicum annuum. Linn. hort. Cliff. 59. Kallades här Peppar. Den fortplantades likaledes i Kryddgårdar. Då frukten är mogen, är hon helt röd utanpå, och brukas til stek, eller kokadt Kött, i det de då strö deraf på Köttet, eller lägga litet i saucen, då det gör en ganska behagelig smak. Likaledes då gurkor insyltas blandas de deribland. När de äro små, stötas eller skäras de helt p. 210 smått sönder, | blandas med salt, förvaras i en flaska; och då en har stekt eller kokadt Kött, eller stekt fisk, strös deraf något derpå, dá det åstadkommer en härlig smak. Eljest smakar hon ampert, som peppar.

Rhus. Af den art af Trä, som Herr Archiater och Riddaren Linnæus kallar Rhus, funnos här i landet flere slag. Det här mäst gängse, och som här mäst öfver alt fans, var Rhus foliis pinnatis serratis lanceolatis utrinque nudis. Linn. Spec. T. I. p. 265. eller Rhus foliis pinnatis serratis. Gron. Flor. Virg. 148. De Ängelske kallade det Sumach. De Svenske hade intet särskildt namn derpå, utan kallade det som de Ängelske. Dess bär eller fruckt är röd, och sades brukas at färga med, då det skal gifva samma färg som bären. Detta trä får här räknas som et ogräs; ty dả någon åker lemnas at ligga i linda för få ảr til at hvila sig; så växer denne deruti ganska mycket; emedan foglarne föra bären omkring. Då samma jord sedan skal plöjas up igen, äro dess rötter et stort hinder för plogen. Des fruckt sitter qvar hela vintern; men hon fäller nog tidigt sina löf om hösten; dock ronna de förut på samma sätt som Rönnlöf hos oss i Sverige. Då topparna eller klasorna med bären kokas, skal deraf kunna göras et svart bleck. Bären ätas af gåssar, utan at det bekommer dem illa. De smaka mycket sura. När en skär af stammen, så finnes, at den är ej stort annat, än bara kärna. Af åtskilliga jag skurit, har jag funnit, at de med p. 211 de|ras ålder visst gå til 10 år, och mästa delen öfver et år. Vid deras afskärning utkommer en gul saft emellan 
barken och trädet. De blifva sällan högre än $3^{1 / 2}$ aln. En eller 2 af de yttersta safringar äro hvita, alla de andra innanföre af en gulgrön färg. Det är ej svårt at skilja safringarna från hvarandra. Kärnan är mycket stor, ofta til $1 / 2$ dig. Geom. diamet. och väl mera, brun, samt så lös, at den med en sticka kan påtas bårt, just som Fläder, Hallon och Björnbär i Sverige. Den växer fullt vid gärdesgårdar, omkring åkrar och på gamla i linda lagde åkrar. Syntes brinna bra, då det lades i elden, sprakade ock ej stort.

\section{Den 20 September.}

Om morgonen spatserade vi ut i fälten och skogarna utan för Staden, dels at samla frön, dels at inlägga örter. $\mathrm{Vi}$ voro egenteligen vid denna tiden sysselsatte med hvarjehanda nyttiga och rara fröns samling, torkning och inläggning, dem vi sedan ännu denna höst sände med fartygen genom Ängland hem til Sverige.

Poyson-tree, d. ä. det förgifftiga trä, kallades af Ängelsmän och Svänskar en art af Rhus, som växte uti kärr och morass nog allmänt här på orten. Somlige af de Ängelska kallade den Schwamp-Sumach. De Svenske brukade Ängelska namn; fast den ock fick heta af några Kärr-Saltenbrass. Af Örte-Scribenterne kallas den på Latin: Rhus foliis pin|natis integerrimis, petiolo integro. Linn. Spec. 265. eller kårtare: Rhus Vernix. När det skäres af, kommer en hvitgul saft ut emellan barken och trädet: sättes färska trädet, eller denna saften til näsan, lucktar det mycket vedervärdigt. Detta trä är just icke bekant för så särdeles många dygder; men väl för andra egenskaper som föga lända til des beröm; som til äfventyrs, at det på visst sätt är skadeligt för vissa människor, då andre deremot icke hafva den minsta olägenhet deraf. Sålunda kan den ena människan handtera det på alt sätt, skära af det, flå af barken, vrida det emellan händerna, lukta derpå, stryka saften på sig, m. m. och det utan all skada. Deremot, om åter en annan, antingen skär det af, eller gnuggar det, eller tager det bart i handen, eller 
luktar derpå, eller handterar det på något sätt, medan det är färskt, eller luktar på en annans hand, som handterat det, eller går i röken der detta brännes, få de strax en tilräckelig minnesbeta; ty ansigtet, händer, och ofta hela Kroppen sväller faseligen up med en olidelig värk och pina. Stundom slår det fullt med blảsor up i ansiktet, på händer eller ock andra delar af Kroppen, at en ser ut, som vore en full med skabb eller Spetelska. På somliga plägar efter năgra dagar den yttersta tunna huden låssna af, som då en brändt sig. Vissa personer tola sả litet detta trä, at om de endast komma när intil der det växer, och ångan deraf drifves med vädret på p. 213 dem; svälla de så upp, som nyss om/talt är. På några svullna ögonen så igen, at de icke kunna se på en eller par dagar, ja ibland mera. Jag känner flera familier, der den ena Brodern eller Systern kan skadelöst handtera detta trä huru den vil; men en annan af Syskonen får ej komma dit i negden, om han vil undfly at blifva bränd. Ofta vet en icke, at han handterat detta, eller varit det för när, innan ansigtet eller händerna börja med deras sveda och upsvällande gifva det tilkänna. Jag har sett gamla gubbar, som varit räddare för detta trä, än för en huggorm. Ja, jag vet den, som endast genom dess skadeliga ångor svullit til hela sin Kropp up, som en stock, at man måst med lakan vända honom. När jag om vintern 1750. berättade för Jungström, som fölgde med mig hela resan, hvad särdeles egenskaper detta trädet hade, log han deråt, och hölt alt sådant för en ogrundad dikt; hvartil han styrktes deraf, at han om hösten förut så många gångor handterat och afbrutit det samma, samt burit det $\mathrm{i}$ händerna, vid det han samlat frön deraf, ja, lagt många stånd deraf in i örte-böcker, utan at hafva märkt den minsta olägenhet derefter. Han ville, som en Philosoph på sit sätt icke antaga något för giltigt, hvartil han ej såg tilräckeliga skäl: han styrktes än mera deri, när han fann, at han hela förra sommaren 1749. mer än ofta skadelöst handterade detta trä. Men om sommaren år 1750. började hans philosophie at vackla; ty han fick 
upsvullna händer och | en stark sveda och kliande i ögonen, så ofta han det minsta rörde dervid. Ja, han hade ej allenast samma olägenhet af denna Rhus, utan ock af et annat species, som kallas Rhus radicans, se Linn. spec. 266. hvilken på långt när ej är så förgiftig som denna. Han blef så öfvertygad om dess skadeliga verkan, at jag på slutet hade svårt före, at förmå honom, at samla frön deraf åt mig. Hon skadade honom ej allenast om sommaren, och då han var svettig, utan äfven om vintern, när både han och trädet voro kalla. Häraf läre vi, at en, som i långan tid varit lik som skattfri för des förgift, kan med tiden finna sig likasom naken och blått för det samma, och förfara deraf samma olägenhet, som den svagaste. Hvad mig angår, så har jag gjort på mig allehanda försök dermed. Jag har handterat den på alt sätt, strukit på mig dess saft, tälgt och brutit af den, skafvit barken bårt, och gnidit den emellan händerna, luktat derpå, burit den länge i bara handen, och det alt mer än många gångor, utan någon den minsta skada. Men sả fick jag likväl en gång förfara, at den just icke var aldeles kraftlös på mig. Jag skar den af midt om en het sommardag, då jag var något svettig, och bar den mot en half tima i handen, luktade då och då derpå. Samma dag märkte jag väl intet något särdeles derefter, endast litet om aftonen; men nästa morgon vaknade jag af et starkt kliande på ögnelåcken och rundt omkring ögonen, som var sả starkt, at jag svårligen kunde hålla händerna derifrån. Jag slapp det, när jag en god stund badat ögonen i Is-kallt vatten; inen hela dagen voro ögonlåcken mycket styfva. Mot aftonen kändes åter kliandet litet, men följande morgonen fick jag vid upvaknandet min förra ögonklåda starkt igen, och blef den med samma bot som förr stillad. Detta varade hvar morgon mot en veckas tid, under det at ögonen voro mycket röda, och ögnelảcken stela, sedan försvann det. Samma gång strök jag en myckenhet af den saft, som flöt af trädet, på min hand, at det satt hel tjockt derpå. Efter 3. dagar upkommo der fullt med små blädror eller blåsor; men gingo snart bårt, utan särdeles 
skada. Mera har jag ej af denna örtens verkan förfarit, ej eller längtat derefter. Jag fann, at det kunde endast utöfva sit våld på mig, när jag var svettig. Jag har ej ännu hört exempel derpå, at någon dödt genom des verkan, utan svedan går gemenligen efter några dagar öfver. Villarne hafva fordom brukat, at göra sina rör eller pipor, hvarigenom de blåste, af detta trä; emedan det har stor kärna. Somlige berättade, at om någon får utslag af des förgiftiga ångor, och då tager trädet deraf, bränner det til Kål, blandar Kålen med ister, och stryker det på de upsvullna ställen, skal det strax blifva bättre. En och annan sade sig sjelfve hafva försökt detta. På somliga ställen utöda de det samma med flit, at det med sit förgift $e j$ mả skada arbets-folket.

p. 216 Bärg-arter. Jag fick i dag til skänks åtskilliga Bärgarter, samlade här i landet, bland hvilka i synnerhet märkas följande. Bärg-Crystall, hvit och ganska genomskinlig: är den, som Herr Prof. D. Wallerius uti des Miner p. 108. kallar Crystallus hexagona (pellucida) non colorata; denne fins mycket här i Pennsylvanien uti åtskilliga stenarter, enkannerligen i en ljusgrả Kalksten. De äro merendels långa och tjocka som et lillfinger, och ibland så genomskinliga, at högre ej kan gifvas. Jag har fätt dem här, som varit mot par qvarter långa, samt så tjocka, som en medelmâttig Karls ben; men desse hafva icke aldeles varit så genomskinliga, som de smärre. Pyrites Cubicus D. D. Browallii, eller Marchasitæ hexaëdricæ tessulares. Wall. Min. pag. 211. desse äro accurat af en cubisk figur, men af olika storlek: somliga ej större, än at hvar sida är endast af $1 / 4$ tums bredd: andre och de störste til 2. tums bredd på hvar sida. Somlige voro helt och hållit gläntsande på alla sidor, at man allestäds kunde se, det de bestodo af Svafvelkes. På andra var endast en eller par sidor af en gläntsande Svafvelkesfärg; men de andre åter mörkbruna. Största delen var på alla sidor så mörkbrunfärgade; men då de slogos sönder, syntes rena Svafvelkesen i dem. De finnas vid Staden Lancaster här i Provincen, der de ibland ligga ofvanpå jorden; men mer- 
endels fås de ned i jorden vid brunnars och andra gropars gräfning, ofta til 8. och flera fots djup un|der jorden. Herr Gust. Hesselius hade åtskilliga af denna stenarten, dem han sade at han först bränner, sedan stöter eller mal sönder til pulfver, och rifver dem så på vanligt sätt, som andra färgor, då han deraf får en skön rödbrun färg, hvilken han brukade til målning. Svarta Brynstenar finnas här i landet; men äro mycket rara. Marmor-arter af ảtskilliga slag gräfvas up i denna Provincen. Enkannerligen är et slag af hvit färg med ljusgrå på blått stötande fläckar, som tages några få Ångelska mil från staden: låter väl arbeta sig, fast den just ej är bland de finaste Marmor-arter. Häraf göres en myckenhet grafstenar, Spishällar, Kransar och Ramar omkring spisar och dörar, gålf näst fram för spisar, med åtskilligt annat; en stor hop graf-stenar och annat af denna sten uthuggit och arbetadt föres härifrån til åtskilliga orter i America. Marienglas fås här på många ställen, och somliga stycken tämmeligen stora, samt så sköna, som någonsin det Ryska. Jag har sett stycken af en half alns längd, och mera, och har jag $\mathrm{i}$ min samling af de Pensylvanska dem, som äro $1 \frac{1}{2}$ quarter långa, och mäst så breda. De Svenska hafva vid sin första hitkomst fordom brukat göra sig Fönster häraf. En ljusgrå fin och tät Kalksten finnes här på mer än många ställen i landet, hvaraf en skön Kalk brännes. Somliga af dessa äro så fulla med fina genomskinliga Bärg-Crystaller, at nästan halfva sten består deraf. Men dessutom brännes somligstäds ned emot| Hafssidan mycket Kalk af Ostronskal, hvilka de om vintern föra up från Hafvet i myckenhet. Denna af Ostronskal brända kalken sades ej vara så god til murning, som den af sten; men bättre än den til hvitlimning. Stenkål hafva de icke ännu funnit i Pennsylvanien; men längre up i landet, der Villarne bo, har man sett dem. Äfven finnas de i myckenhet längre emot Norr vid Cap Breton, som alla enhälligt berättade.

Vin af landets frukter. Åtskillige Fruentimmer härstädes tillagade vin af några sådana frukter, som finnas 
här i landet. De, sum i synnerhet brukades härtil, voro följande: Röda och hvita Vinbär, hvilka här planterades i trägårdar, och trefs mycket väl: en gammal Sjöman, som ofta varit i Newfoundland, berättade för mig, at Röda Vinbär skola der växa vildt i största myckenhet. Än göres här vin af Smultron, hvaraf finnes nog i skogarna; dock äro de ej så behagelige, som våra Svenska, utan mera syrlige. Likaledes tilredes här ock vin af de Americanska Biörnbär (Rubus Occidentalis Linn.) hvilka växa här öfveralt på åkrar, värre och argare nästan, än Törne och Tistel hos oss. Frukten är dock mycket skön. Uti Maryland prässas äfven vin af de villa vindrufvor, som växa der i skogarna. Af Hallon och Kersbär, som bägge här med flit planteras, tilredes ock af många skönt vin. p. 219 Sättet huru de här göra vin af röda Vinbär, be|höfver jag ej beskrifva; emedan vi här i Sverige kunna den saken långt bättre, än de i Norra America.

\section{Den 21 September.}

Ligustrum. Här och der i buskar och skogsbackar växte den vanliga Ligustrum Linn. Flor. Suec. 4. men om den hörer til de växter, som från urminnes tider vuxit i detta Land, eller om den först blifvit hitförả från Ängeland, och sedan bären deraf af foglar kringförde, kan jag ej säga. Här brukas mäst öfveralt hägnader och stängsel omkring åker och äng af trän, eller sönderklufna trådor; men så har dock en eller annan mera eftertänksam, som velat spara skogen för framtiden, redan börjat på somliga ställen anlägga häckar omkring sina ägor. Desse häckar äro gemenligen af förenämde Ligustrum, hvilken är planterad på en liten bank, som blifvit upkastat. Jordmon allestädes här omkring är en lera utblandad med sand, som gör, at den är nog lös. Häckarne af detta trä äro goda, der inga bångstyriga Kreatur finnas; ty Svinen hafva här allestäds deras trä-ok, som likna Trianglar, på halsen, och den andra boskapen var ej eller så oregerlig; men der Boskapen är van at bryta sig in i hägnader, 
kunna desse häckar svårligen hålla honom ute. Närmast til Philadelphia få inga Svin gå lösa, utan måste ständigt hållas inne.

Landets beskaffenhet. Efter middagen fölgde jag ut med Handelsmannen Petter Kock, | (född i Carlscrona i Sverige) til hans gård pả landet, som lảg ungefär 9 Ängelska mil frăn Staden åt $\mathrm{NW}$. kanten. Landet på ömse sidor om vägen var på de flästa ställen öfverväxt med hög skog, alt af bara löfträn. Jag kunde ej der se et enda barrträ. De fläste af löfträden voro Ekar af ảtskilliga slag, dock syntes ock deribland Castanie-trän, Valnöt-trän, Locust-tree, Äppleträn, Hickery, Björnbärsbuskar med flera. Landet var nu här mera ej jämnt, utan började likna någorlunda med Ängland, så at det gick i buckter upp och ned. Nu foro vi upföre en långsluttig backa: nu åter ned $\mathrm{i}$ en däld, och så ömsevis. Inga bärg eller stora stenar, utan skogen var nedantil gles och marken jämn, så at vi kunde se, på långt håll, emellan träden, och utan möda både spatsera och rida derunder; emedan inga buskar voro, som hindrade. Där de gräfvit up jorden, samt här och der på marken lågo små stenar af det skimmeraktiga stenslaget, som de bygga sina hus af, och skal framdeles nogare beskrifvas. När vi rest et litet stycke, fingo vi gemenligen se et litet öppet fält, der de bårthuggit skogen, och anlagt antingen en gård, betesmark eller något annat. Atskillige af Gentlemen hade här och der sina gårdar, som voro mycket vackre, ofta med alléer af planterade trän från landsvägen til gården. Husen voro här alla af sten, antingen af tegel, eller den skimmeraktiga stenen, som här öfveralt $\mathrm{i}$ landet finnes. Här|liga trägårdar af åtskilliga slags fruktträn, som Äplen, Persiker, Castanie-trän, Valnötträn, Kersbärsträn, Quittenträn, Vinrankor, med flera hade en och hvar, äfven Handtverkare, Bönder, och Torpare, anlagt omkring eller vid de ställen och gårdar der de bodde. Uti dälderna framtilrade somligstäds någon liten bäck med et klart Cristall vatten. Åkrarna på ömse sidor om vägen voro nu mäst bärgade. De sädesslag, som ännu stodo qvar, voro antin- 
gen Mays eller Bohvete. Det förra var planterat mäst vid hvar gård, til större eller mindre myckenhet, växte mycket frodigt och långt, til 3, 4 à 5 alnars högd, stjelken full med gröna blan. Det senare var ock sått mångenstäds, och hade de redan på et och annat ställe börjat taga up det. Nyttan med mera, af dessa sädesarter, skal framdeles utföras.

Sedan vi ridit 6 Ängelska mil, kommo vi til Germantown, en Stad eller By, som har endast en gata; men är mot par Ängelska mil lång. Denna Stad bebos til största delen af bara Tyskar, som tid efter annan kommit hit öfver från Tyskland, och satt sig här ned, efter de här njuta den frihet, som de näppeligen på någon annan ort i verlden kunde fã fägna sig af. De äro snart sagt allesamman handtverkare, den ena $\mathrm{i}$ det, den andra $\mathrm{i}$ et annat, som ock nu förfärdiga här allehanda slag i den ymnighet och fullkomlighet, at denna Provincen innan kårt lärer behöfva ganska litet från des moder gamla

p. 222 Ängland. | Husen i denna Staden voro mäst alla upmurade af den skimmeraktiga stenen, som öfveralt finnes här i landet åt Philadelphia sidan; ty annorstädes är han rarare. Somlige voro dock af tegel: mäst alla par våningar höga, somlige ock mera. Taken voro täckte med takspån af det träslag, som här i landet kallas white Ceder. Skapnaden på hus-taken var antingen som bondstugor i Sverige, at de gjorde en acut-rect- eller obtus angel, alt efter deras högd eller längd, eller endera af hosstående figurer,
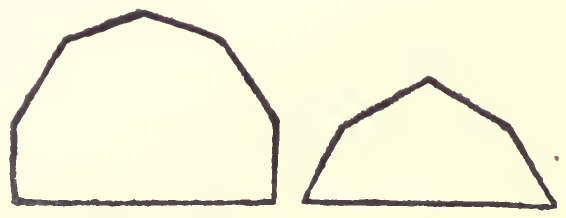

hvarest det ena har 4 sidor, det andra 6, så at latera af angeln kommo at brytas mer eller mindre. Många tak voro så gjorde, at de kunde spatsera derpå, varandes gallerverk rundt omkring. Mångenstäds voro altaner utan- 
för öfra våningen mot gatsidan, at stå på och se ut àt gatan. Utanför fönsterna, äfven af öfra våningen, fast den ock var 3 våningar hög, voro gemenligen luckor, at låta igen. En och hvar som här bodde hade sin vackra trägård vid sit hus. 2 à 3 vackra Kyrkor syntes här, den ena Luthersk, den andra Calvinisk, den tredje hörer til Quä|kare. Folket var så mycket, at det strömmade på gatan. Mennonnisterne hafva ock här en Meeting eller Kyrka.

\section{Den 22 September.}

Sedan jag varit uti Kyrkan, använde jag den öfriga delen af dagen, at tala med åtskilliga Gentlemen, som länge bodt här på orten, at göra mig liunnig om et och annat, som angick landets märkvärdigheter.

At hålla mjölk sval om Sommaren. Hr. Petter Kock hade strax vid sin gård en skön källa, som sprang up utur en sandbacka, och gaf den ymnighet af vatten, at en liten bäck deraf flöt beständigt frản källan. Öfver källan hade han bygt af skimmersten et hus, som brukades til visthus, och uti bäcken, som vid en sida af huset rann från källan, hade han satt fullt med krukor och stenfat fulla med mjölk, som uti detta kalla vatnet hölt sig mycket väl om sommaren, hvilken gemenligen i denna delen af verlden är ganska varm. Sådana hus bygde öfver källor och brukade til detta ändamål, fant jag sedan mångenstäds här i landet.

Gärdesgårdar. Til hägnad omkring åker, äng \&c. brukades öfveralt här på orten gärdesgårdar af trä. På något enda ställe fick jag se, at de börjat anlägga häckar, hvilka voro mäst af Ligustrum. Gärdesgårdarne voro ej här af den skapnad och structur, som / hos oss, utan de p. 224 hade tagit stolpar af 2 à 3 alnars högd, och i dem bårat 4 à 5 hål, vid pass en half aln emellan hvart hål, eller ock mera; en af dessa stolpar gjorde här samma gagn, som et par, eller ock tu par störar hos oss i Sverige. Desse stolpar sattes alla i rad, der de ville hafva gärdes- 
gården, ungefär 2 à 3 famnar emellan hvar stolpe. De hade sedan stuckit breda trodor af $1 \frac{1}{2}$ à 2 qvarters bredd i hålen på stolparna, så at en sådan gärdesgård på långt håll såg ut som Fållkedjor eller fä-fållor hos oss i Sverige. De voro ej eller tätare, än desamme: ty de voro endast gjorde, at utehålla den stora boskapen, som kor, hästar och får. Svin hållas här näst utanför Philadelphia mäst hemma vid gården, så at de aldrig fingo tilfälle, at gå in genom denna glesa stängselen. Det trä, som brukades hälst til stängsel, var Castanie-trä; emedan det står längst emot röta, och en sådan gärdesgård kan väl stå vid lag öfver 30 år; men der de ej hade tilgång dertil, betjente de sig af den hvita, eller ock af den svarta Eken. Röd Ceder är bäst af all slags trä, at stå emot röta; men den måste alt köpas här, och växer ej i negden af Philadelphia til den myckenhet, at den kan räcka til gärdesgårdar; dock äro ganska många af gärdesgărdarna omkring Philadelphia deraf.

Ved. Den bästa ved, som finnes här på orten, sades enhälligt vara den, som hugges af Hickery, hvilken gifver p. 225 en stark hetta, | men duger ej til gärdesgårdar, emedan han rutnar snart under öppen himmel. Dernäst är hvit Ek, också black oak, eller den svarta Eken, tjenlig til ved. Mången skulle tycka, at emedan Staden Philadelphia är omgifven med skog på alla sidor, veden ej skulle vara dyr; men sådant slår dock felt, hvilket härrörer deraf, at den stora och höga skogen, som står närmast in vid Staden, hörer vissa Gentlemen til, som äro rike och ej fråga efter penningar. Desse nännas ej en gång hugga af deras vidlöftiga skog så mycket de sjelfve tarfva til egit behof, mindre at sälja något deraf åt andra, utan låta den stå och växa til framtiden, då han kan bli mera dyr. Det enda de nu låta hugga deraf, är åt Snickare, Vagnmakare \&c. som kunna betala dem väl derföre. Det betaltes nu, denna tiden, för en uptrafning af Hickery-ved af 8 fots längd, 4 fots högd, och längden af veden deri 4 fot, 18 schillings i Pensylvaniæ-mynt; men om samma uptrafning var af Ek, kostade den 12 sådana schillingar. De som förde ved til Staden, voro bönder, som bodde 
långt derifrån. Det var nu här en allmän klagan, at ved vid denna tiden var mångfalt dyrare, än den varit i fordom dag; orsaken sades, dels at Staden på kårt tid så ansenligen tagit til, at den nu är 4 à 6 gånger större och folkrikare, än den varit i gamla folkets barndom: dels de många Tegelbruk, som här äro anlagde, och öda skogen: dels at landet är mera / upbrukadt och bebygdt, mera p. 226 skog för landets upodling bårthuggen, och mera gårdar på landet, som bränna skog: dels åtskilliga järnbruk, som nu äro uptagne och i gång. De spådde ock, at i framtiden torde denna staden blifva en dyr ort på ved.

Björnbärs-Vin, som är ganska skönt, gjordes här sålunda: bären tagas, saften prässas ut, och samlas i et Käril. Til en half gallon sảdan saft tages en half gallon vatten, som blandas tilhopa, dertil lägges 3 कु brunt Såcker: hvarefter det bör stå en tid, innan det brukas. Kersbärs-vin gjordes på samma sätt, endast at de vid prässningen sågo til, at stenarna eller kärnarna af Kersbären icke kommo at kramas sönder; ty då fảr vinet en osmak deraf.

Persiker. Af Persiker brännes bränvin sålunda: Persikerne skäras sönder i stycken: stenarna kastas bårt: de blöta stycken läggas tilhopa i et Käril, deri de stả ungefär 3. veckor, eller en månad, at de väl tagit sin röta, läggas så i en bränvins panna och brännas til bränvin, som sedan distilleras ännu en gång. Detta bränvin är väl ej så godt, at det kan brukas, som något utvaldt af de förnäma; men så är det godt nog, at gifva át arbets-folk.

Äplen. På samma sätt, som om Persiker nämnt är, distilleras äfven bränvin af äplen; men härtil tages i synnerhet de äp/len, som fallit af träden, innan de hunnit p. 227 blifva mogne.

Phytolacca foliis integerrimis. Linn. H. Cliff. 177. Gron. Flor. Virg. 161. växte i ganska stor myckenhet vid gårdar, vägar, i häckar, buskar, samt här och der på fälten. Resa hvart en ville här i landet, så viste sig på ofvannämde ställen en stor myckenhet häraf. Mästadelen hade redan mogna bär, som sutto klastals, och sågo ganska 
behageliga ut, fast de ej dugde at äta: en och annan blomstrade dock ännu. På somligá ställen, såsom i häckar och vid hus, växte den ofta til par famnars högd; men ut på fälten var hon altid kårt; dock kunde ingenstädes synas, at boskapen ätit den. En Tysk, som bodde här i landet, vid namn Sleidorn, en Såckerbagare, berättade, at Fürgarena samla des rötter, och bereda deraf en gul färg.

Ickornar. Af Ickornar finnas här flere slag; de små ground squirrels brukas mycket at hållas i bur; emedan de äro små, och förnämligast, emedan de se vackra ut, fast de ej gerna blifva sả aldeles tama. De större slagen göra ofta stor skada åt plantagierne, i synnerhet på Mays, i det de klifva up på Maysen, och skala sönder Kornen, äta up bara hjärtat eller den lösa och söta kärnan midt i Kornet. Ofta komma de til många hundrade på en gảng til Mays-landen, och kunna ibland på en natt nästan p. 228 aldeles ödelägga en bondes he/la årsväxt; derföre är i Maryland en och hvar landtman förbunden, at årligen upvisa 4. Ickornar, som han dödat, hvilkas hufvuden gifvas àt Öfveruppsyningsmannen, at intet underslef må ske dervid; och på andra ställen får den, som skjuter en Ickorn, 2. pence af den almänna Cassan för hvart hufvud han uppvisar. Köttet af dem ätes, och hålles för en delicatesse, skinnet säljes; dock värderas det ej mycket. Ickornar äro här skaller-ormars och andra ormars förnämsta föda. Det är ock här allas enhälliga tro och berättelse, at då skaller-ormen, som ligger ned på marken, fäster ögonen på en Ickorn, fast den ock sitter högst up i et trä, kan den så förkjusa honom, at han kommer dansande ned efter trädet, och kan ej stanna förr, innan den rändt eller sprungit midt $i$ gapet på ormen, som då först flera gångar slickar öfver honom, och gör honom våt med sin spott, at den må blifva hal, hvarefter han sväljer honom ned i sig så hel och hållen som han är. När Skaller-ormen på detta sätt gjordt et godt mål, lägger han sig at hvila, utan at bry sig om någon ting.

Raccoon. Raccoon kallas här det fyrfotade djur, som är beskrifvit af Herr Archiater och Ridd. Linneus uti 
Kongl. Svenska Vet. Acad. Handlingar för År 1747. p. 277. under namn af ursus cauda elongata. Denna finnes här på orten i stor myckenhet, och är en arg hönstjuf. Han efterjagas med hundar, | och då han klifver up i trä, p. 229 skakas han ned af någon, som klifver dit up efter honom, då hundarna sedan bita honom ihjäl. Köttet ätes som en skön mat. Os penis brukas, at påta och ränsa tobakspipor med. Skinnet säljes gemenligen til Hattmakare, som af håren förfärdiga Hattar, hvilka $\mathrm{i}$ godhet komma närmast til bäfverhattar: svantsen säljes, at bära omkring halsen. Ormar äta honom ofta.

Ostronskal. Åtskilliga af Ängelsmännerna berättade, at Ostronskal blifvit fundne i stor myckenhet vid Potomackfloden uti Virginien. De sade sig sett hela backar deraf. Stället skal ligga par Ängelska mil från hafvet. Ägaren til landet brukar at bränna kalk af dem. De finnas der til par famnars djup, och mera. Man har ock funnit dem på andra ställen, i synnerhet i New Yorck, vid gräfning, såsom ock en stor myckenhet af Ostron och andre skal, flera Ängelska mil från hafvet. Somlige mena, at Indianerne fordom bodt på sådana ställen, och då de ätit Ostrorna, lämnat skalen der efter sig $\mathrm{i}$ en hög. Andre kunna ej begripa, huru de just kunnat komma at kastas på et ställe $\mathrm{i}$ en sådan myckenhet.

Indianerne här i landet. Det berättades af alla om Indianerna, som bo här i landet, at de äro ganska godt folk, då en lefver $\mathrm{i}$ frid med dem. Ingen kan hålla tro och lofven högre, än de. När främmande af deras allie/rade p. 230 komma til dem, bevisa de dem mera godt och huldhet, än han af egna kunnat vänta. Herr Petter Kock lemnade mig följande Historia om deras upriktighet: det är näppeligen mer än 2. År, sedan en af Ängelsmännernas Köpmän, som reste omkring bland de Villa, at sälja och upköpa hvarjehanda, blef der hemligen ihjälslagen; utan at någon visste af hvem. Mot et år derefter fingo de Villa eller Indianerne spaning om, hvilken af deras egna gjordt denna slemma gerning. De bakbundo då strax den samma, sände honom ned hit til Philadelphia under vakt, lefve- 
rerade honom til Gouverneuren, och sade, at emedan han begått en sådan grufvelig ting på de Ängelska, hörde han mera ej til Indianerna, som ock ej ville mera hafva at beställa med honom, utan de öfverlemnade honom til Gouverneuren, at döma och handla med honom efter Ängelska Lagen, som hans brott förtjent. Missgerningsmannen blef därpå hängd härstädes. Pả deras skarpsinnighet har man (som mer än hundrade mig berättat) flere ganger haft det prof, at då de stundom komma ned til Europæiska Colonierne, at handla med Gouverneurerne därstädes om något angelägit, sätta de sig ned på gålfvet, så snart de komma in til Gouverneuren, och då han föreställer dem Propositioner, som ibland äro många til antalet, hvarpå han äskar deras svar, hafva de en sticka i handen, hvarpå de med en knif göra sina tecken, utan p. 231 vi|dare skrifning. Andra dagen derefter komma de up til Gouverneuren, och gifva honom svar på hela Hans proposition, lemna honom svar just i den ordning, som han förestält dem Propositionerne, utan at hoppa öfver någon Proposition, eller rubba ordningen af de samma, och det alt så accurat och punctuelt, som hade propositionerne blifvit skrifteligen til dem lemnade. En Historia roade mig mycket: Sleidorn berättade, at då han en gång varit uti New York, har uti hans logement bland andra Indianer varit en gammal gubbe. Denne, sedan han fått något $\mathrm{i}$ hufvudet, har han börjat tala med Sleidorn, sagt sig kunna läsa och skrifva Ängelska. Sleidorn har då begärt, at han måtte få föreställa honom frågor, hvartil Indian samtyckte: han frågade då, om Indian visste hrem som först lät omskära sig? Indian svarade: Fader Abraham. Derpå begärte Indian lof, at äfven få framställa en fråga, hvilket då det blef honom efterlåtit, frågade han: hvilken var den första Qväkare? Sleidorn svarade, at den och den hålles derföre; nej, sade Indian, Mardochai var den första Qväkare, ty han ville ej taga hatten af sig för Haman. Alla intygade, at ganska månge af desse villa hedningar hafva en mörk kunskap om syndafloden, dock ej alla, som jag sjelf af dem förstått. 
Jättar. Man ville aldeles försäkra, at Jättar bodt här i fordna tider. Det gafs en dubbel anledning at tro sådant: 1. emedan | någre, som för några år tilbaka kommit at gräfva på et ställe $\mathrm{i}$ jorden, råkat på en graf, deri de funnit människo-ben af en faselig längd; benpipan sades varit mot 14 fot lång: lårpipan af lika längd, och tänderna proportionerade derefter. Flera ben funnos icke der. De som förstått sig på anatomien och sedt dem, hafva aldeles intygat, at de varit människoben. En tand deraf blef öfversänd til en curieux Man i Hamburg. 2. Den Historia, som Indianerne, hvilka bo i nägden, der desse ben blefvo upgrafne, hafva, den de fått man efter man, eller at deras förfäder berättat för dem, hvad de hört af sina förfäder, näml. at der vid en flod bodt en ganska stor och lång man i forna tider, som brukat at bära Indianerna, som ville der fram, på sin rygg öfver floden, och således vadat igenom vatnet, som likväl varit mycket djupt: en och hvar, som for eller kom på detta sätt deröfver, betalte til honom något litet, til exempel, något af Indian Korn eller Mays, några skinvaror, kårteligen han hade sin föda endast derigenom, at han var som en Färjekarl för Indianerne, som ville öfver floden.

Åkrar. Jordmon härpå orten består til det mästa af sand, som dock är utblandad mer eller mindre med lera. Bägge äro gemenligen af en blek tegelfärg. Landet har det utseende, at det icke skal vara altför fett. Det samma bekräftades af dem, som bodde här. När en ảker blifvit sådd i 3 år å rad med några sä|desslag, vil han icke bära något af värde mera, om han ej varder väl gödd, eller ock lämnad, at för några år ligga $\mathrm{i}$ linda. De hafva här ej särdeles förråd på gödsel, derföre betjena de sig merendels af det senare, nämligen, at lemna åkern för några år obrukad, då den öfverväxes med allehanda slags örter och trän. Imedlertid tager Landtman up åker åt sig på et annat ställe af obrukad jord, som i början ger ymnig frukt. De kunna ännu här lätt bruka denna Methoden; ty jordmon är lös, at den lätt kan tagas up, och hvar jord-brukare har gemenligen et vidt utsträckt 
land, som hörer honom til. Landets sed at ej hålla boskapen inne om vintertiden, eller at icke hålla dem på åkern, hindrar dem, at få gödsel.

Boskap. All den boskap de här äga, är i början förd från Europa. Indianerne hafva förr Europeernas hitkomst ej haft några kreatur, äfven som de fläste af dem ännu ej bry sig dermed. När kreaturen, vare sig kor, oxar, hästar, får eller svin, först komma hit öfver från Ängland, äro de så store som der; men deras afföda blir något mindre, så at de uti tredje à fjerde generation äro af den storlek, som de här mäst vanliga kreatur äro. Climatet, jordmon och födan lära bidraga härtil.

Folket i landet. Märkvärdigt var äfven det, som enhälligt berättades om folket i landet, näml. at de gemenligen komma här förr til mogna år, och få här tidigare p. 234 förstånd, | än i Europa; men de blifva ock förr här gamle. Här är ej rart, at se små barn vara så qvicka och färdiga at gifva svar på frågor, at en kan högeligen undra derpå, likasom det voro gammalt folk; men så räcka de här ej gerna til den ålder, som i gamla verlden; at se en som är född här i landet, hinna til 80. à 90. år, är ganska sällsamt. Jag talar om dem, som i början kommit från Europa; ty Indianerne, eller de gamla invånare, hinna ofta til en hög ålder; dock blifva ej eller de så gamle nu, som i forna tider: orsaken är förnämligast deras myckna bränvins supning, som de fătt och lärt af Europeerne. De som äro födde i Europa, och komma hit at bo, blifva gemenl. här mycket äldre, än de, som af Europæiska Föräldrar äro födde här i landet. Uti det sista Kriget har man fått erfara det, at de af Europeer i Ameriea födde på långt när ej härda så ut i Krigsexpeditioner, belägringar och långa sjöresor, som de i Europa framalstrade, utan desse Americanske dö bårt nästan som flugor: de hafva otroligt svårt, at vänja sig vid främmande Climat. Qvinfolken sades ock förr här återvända at få Barn, än i Europa; efter 40. a 45 år är det rart, at se en hustru eller qvinna föda; ja, somlige stanna på 30: de talet. Jag frågade om orsaken til alt detta; men de 
kunde ej gifva mig något skäl dertil. Somlige skylte på öfverflödet, andre på den ostadiga och ganska föränderliga väderleken; ty de trod/de, at näppeligen någon ort kan finnas i verlden, der väderleken är så obeständig och så många ändringar på en dag underkastad, som här; så at, rätt som det är den starkaste värman, kan det innom få timar vara en stark köld, och så i annat, så at ibland på en dag kan vara 4,5 a 6 . särskildta förändringar i väderleken.

Träden i landet sades hafva samma beskaffenhet, som Folket. Skepp, som byggas af de här i landet växta trän, äro $j$ varaktighet icke at likna med dem, som byggas af de Europæiske träslagen, hvilket alla enhälligt intygade. När et sådant här bygt skepp varat 6,8 a 12 år, duger det föga mer. Hinner det öfver 12 år; så får det räknas för et under. Orsaken til alt detta är ej så lätt at finna igen. Somlige gofvo skulden på trädet, andre på sättet at bygga skepp, som här mäst sker af rådt timmer, då det ej får tid, at tilbörligen torkas förut. Jag tror, at bägge orsaker lärer sammanstöta. Jag såg här Ekstubbar, der trädet för 8 . a högst 12 . år tilbaka varit afhuggit, at de hade öfverst en hård skårpa; men bröts den sönder, fant jag trädet i stubben mäst bårtrutnadt och nästan lika som et mjöl, at jag kunde rifva honom sönder med händerna; der dock våra Ekstubbar i Europa kunna stå i långan tid, innan de taga en sådan förmultenhet.

Om aftonen reste vi tilbaka til Philadelphia.

Den 23 September.

Hare. Inga ordinaira Harar finnas här, utan endast en art, som är midt emellan Hare och Canin. Desse göra stor skada, då de komma in på Kål- och Rof-land.

Hvarföre en del af Norra Americas örter blomstra så sent, och sällan bära mogen frukt i Europa. Månge hafva undrat, huru det kommer til, at när Norra Americas växter blifva öfverförde och planterade i Europa, så blomstras största delen ganska sent, och deras frukt hinner 
sällan bli mogen, innan vintern kommer på; der det dock af Rese-beskrifningar är bekant, at kölden i Pensylvanien, och ännu mera i Nya York, Nya Ängland och Canada, är om vintrarna rätt så sträng, som i Sverige, och at vintrarne i Ängland uti Europa äro mycket mildare, än i Norra America. Vid min afresa til denna verldenes del, blef jag af åtskilliga vittra män anmodad, at söka få reda på denna saken. Jag vil derföre i stället för svar lemna här några anmärkningar jag gjordt om Norra Americas Climat och örter, och lemna den benägna Läsaren sjelf frihet, at göra slutsatser. 1) Det är sant, at vintrarna i Pensylvanien, och än mera i Nya York, Canada \&c.; äro ofta så stränga som i Sverige, och altså mycket kallare, än i Ängland, och de Södre länder i Europa; således fant jag, at uti Philadelphia, som dock är öfver 20. grader

p. 237 Söder om somliga delar af Stverige, föll Celsii 'Thermometer om vintern til 24. grader under 0 . eller frysnings puncten, och mig försäkrades dock, at de vintrar jag vistades der, voro ej ibland de strängare, utan af de vanliga, hvilket jag ock kan sluta deraf, at floden Dellaware ingendera af de vintrar jag var här, blef belagd med så stark is, at de vid Philadelphia kunde köra deröfver, hvilket dock ofta plägar ske. När en nu besinnar denna elfvens bredd, hvarom förut vid beskrifningen om Philadelphia är talt, samt at ordinaira skilnaden emellan Ebb och Flod äro här 8. Ängelska Fot; så lärer det utan svårighet finnas, at det skal vara en tämmelig Köld, som kan lägga en så tjock bro eller is öfver denna elf. 2) Men så är tillika sant, at om vintrarne ibland äro här hårda; så äro de derhos gemenligen ganska kårta. Det kan med fog sägas, at vintrarne uti Pensylvanien merendels icke äro öfver 2. månader långa, och ibland icke det. Imedlertid anses det som en ovanlig ting, när vintern varar här i 3. månader, eller litet deröfver. En händelse, som sedan får rum uti Almanachor och tideböcker, såsom mycket synnerlig. Bättre til Norr äro dock vintrarne något längre, och i Norra delen af Canada lära de täfla med vảra Svenska. De af mig dageligen under mit 
vistande i America gjorde Meteorologiska Observationer, som för hvar månad skola vid slutet af hvarje Tom införas, lära | kunna gifva ljus i denna saken. 3) Är hettan p. 238 här.om sommaren ganska stark, och varar mycket länge. Jag tilstår, at jag sett Thermometern i Åbo i Finland stiga om sommaren tämmeligen när til den högd, som i Pensylvanien; men så är dervid den skilnad, at då Celsii Thermometer i Åbo kan hinna en enda gång på 2. ellel 3. somrar til 30. gr. öfver frysnings puncten, går han ej allenast i Pensylvanien, utan ock i Nya York, Albany och en stor del af Canada mäst hvar dag i 3. månaders tid til samma 30. grad, ja ibland och ofta än högre. Uti Philadelphia har han 2. eller 3. gångor om de somrar jag varit i America, stigit ända til 36. grader öfver frysnings puncten. Man kan tämmeligen tryggt säja, at uti Pensylvanien är största delen af April, hela Maji, Junii, Julii, Augusti, September, och en god del af October, som vår Svenska Junius och Julius, alt gamla stylen ment. Man kan då se, hvad en så stark och långvarig värma kan uträtta. Här beropar jag mig åter på mina Meteorologiska observationer. Af denna starka och långvariga hettan härrörer, at Meloner, Vatten-meloner eller Arbuser, samt Pumpor af flera slag, sås här på öpna sängar och fält, utan några glas eller andra täckelser öfver dem, och de hinna dock blifva mogne uti Julii månad: at Kersbär börja blifva mogna i Philadelphia vid d. 12. Maji st. vet. och de börja ofta skära hvetet uti Pensylvanien i | början af Junii Månad st. vet. \&c. 4) Räknas i Pensylvanien hela September, samt halfva October, och ibland mera, nästan för den behageligaste tiden i hela året; ty de förra sommarmånader hafva varit för heta. Förenämnde tid kan uti värma svara ungefär emot vảr Julii månad med början af Augusti, efter gamla stylen. Uti September Månad stå altså nästan största delen af örterna här som bäst i blomma: ja, en stor del af växterna börja först långt in i September Månad slå ut sina blommor. Denna härliga och vakra årstiden, med klar himmel och varma solskens dagar, bidrager tvifvelsutan ej litet härtil. Ehuru 
således desse blomster mycket sent spricka ut, hinna de dock blifva mogne innan medlersta delen af October. Men hvarföre desse icke förr komma fram, utan så sent på hösten, kan jag icke gifva något svar på, utan jag frågar tilbaka: hvarföre här i Sverige Centaurea Linn. flor. Suec. 709. Jacea nigra prat. latif. C. B. och Gentiana Linn. flor. Suec. 203. Gentiana autumnalis ramosa C. B. och Solidago flor. Suec. 685. Virga aurea vulg. latif. C. B. komma fram först vid slutet af sommaren? och deremot hvi Hepatica Linn. flor. Suec. 445. och Viola flor. Suec. 716. Viola mart. inod. sylv. C. B. och Daphne flor. Suec. 311. med flere, blomstra så bittida om våren? det har să behagat alla tings Skapare förordna. Men hurudan väderleken är i Pensylvanien desse höstmånader, kunna mina p. 240 här gjorde Meteoro|logiske observationer utvisa. Jag vil här endast påminna, at jag vid dessa Meteorologiska observationers anställande, altid, så mycket görligt varit, sökt hafva Thermometern på sådana ställen, dit Solen ej kommit och der hon icke, genom det hon legat på väggen, näst förut, fått göra observation och Thermometerns visande falskt. Hurudan väderleken är hos oss i September och October, veta vi alle. 5) Ar märkvärdigt, at af de örter, som växa villa i Pensylvanien, äro någre, som äfven der ej hinna alla år få mogna frön, innan kölden kommer. Sådana äro vissa arter Gentiana, asteres, och andre; men så har Skaparens allvishet rättat här det ena efter det andra; ty nästan alla desse örter, som hafva denna egenskapen, at så sent komma fram med sina blomster, äro herbæ perennes, eller som kunna, i brist af frö, fortplanta sig genom nya telningars eller skåtts framskjutande nästa år från samma, eller från en ny rot. 6) Förr än Europeerne kommo hit, beboddes America af Indianer eller villa Americaner. Desse lefde så godt som af intet åkerbruk, eller ganska litet, utan födde sig förnämligast med jaga och fiska. Skogarna fingo således stå för dem i frid, om $e j$ ibland någon skogseld kunde ödelägga några stycken deraf. Historien intygar ock, at landet var vid Europeernas ankomst fullt med höga tjocka 
skogar. Således följer, at då de större trän, samt vatten och strand-örter undanta|gas, hafva mästa delen af de p. 241 andra Norra Americas växter, tör hända i några tusende år, fått lof at växa i skugga under och emellan trän, och kunna för den orsaken skull naturaliter anses som plantæ sylvestres \& in umbrosis nascentes; nu fälla träna om hösten här sina löf til sådan myckenhet, at de öfvertäcka marken under träna til en tvärhands tjocklek, och mera. Desse löf ligga qvar långt in pá följande sommaren, innan de rutna, och hindra således ganska mycket de örter som under dem växa, at komma fram, utom det at de tillika med träna beröfva örterna Solens strálar. Genom bägge föregående, nämligen tränas skugga, och löfvens påliggande, tvingas ju de på dessa ställen upkomne växter, at mycket senare hinna til blomma, än eljest. Må en då derföre skulle kunna säja, at desse örter härigenom på så många hundrade års förlopp vant sig, at komma mycket sent $\mathrm{i}$ blomma, och at det nu fordrar en lång tid, innan de kunna afkläda sig sin förra vana, och deremot vänja sig, at hasta något fortare?

\section{Den 24 September.}

Vi använde denna dagen, til största delen, at samla frön af allehanda slags örter, samt at inlägga de rarare.

\section{Den 25 September.}

Petrificeradt trä. Af Herr Hesselius fick jag til skänks et litet stycke petrificeradt trä, som blifvit funnit $\mathrm{i}$ jorden här i nya Sveri|ge. Det var 4 tum långt, 1. tum bredt, p. 242 $1 / 4$ tum tjockt, färgen var hvit, och kunde man helt tydeligen se, at det varit trä; ty der det var gjordt slätt, syntes alla ränder af fibræ longitudinales, och var svårt at skilja detta från et stycke ask, som varit tälgd slätt. Det var skurit af et större stycke löst. Man hölt det här för petrificeradt Hickery. Jag fick sedan af andra til skänks flera stycken häraf. Hr. Lewis Evans berättade 
för mig, at de funnit mot Virginiæ sidan uti jorden en helpetrificerad klabb af Hickery, hvarpå äfven barken sutit qvar, dock petrificerad.

Hr. Joh. Bartram var en Ängelsk Landtman, och bodde ungefär 4 Ängelska mil från Philadelphia, hvilken förvärfvat sig en ansenlig insigt i Natur-kunnogheten och Natural-Historien, hvartil han tycktes varit som född. Uti sin ungdom hade han ej haft tilfälle at gå i Schola, och lära nảgot; men genom egen flit och trägit arbete, utan andras undervisning, hade han gjordt sig så hemma i Latin, at han kunde läsa och förstå på det språket, hvad bok han ville, äfven dem, som voro fulla med Botaniska termer. Han har gjordt flera år i rad många resor til åtskilliga aflägsna ställen i Norra America, endast at upsöka och samla hvarjehanda slags mindre bekanta växter, af hvilka han sedan dels planterat en del uti sin lilla Botaniska örtegård, dels sändt antingen frön eller lefvande p. 243 rötter öfver til Ängland. | Man har at tacka honom för ganska många de raraste växter, dem han först uppfunnit, och hvilka tilförene aldrig varit bekanta. Han äger et skarpt förstånd, och har varit en ganska flitig Observator, som låtit ingen ting undfly sin upmärksamhet; men kan derhos icke undgå, at bära namn af en trög och senfärdig skrifvare, som ej vårdat sig, at til pappers föra sina många vackra observationer. Hans vänner i London nödgade honom, at lämna dem et utdrag af en sin resa, hvilken de sedan i god afsigt, men mindre försigtigt hastade sig at låta trycka; men de skadde honom mera derigenom; ty i anseende dertil, at Bartram icke var fallen, at upskrifva hvad han viste, blef denna lilla piecen nog mager på nya rön. Den som af den vil dömma om mannens skickelighet, bedrager sig gräseligen. Han har i den ej röjt en tusende del af den margfalliga. kunskap han sig förvärfvat i alla 3. Natursens riken, och uti Naturkunnogheten, enkannerligen hvad Norra America angår. Jag har ofta undrat huru han kunnat komma på alt det han har sig bekant, och har jag at tacka honom för ganska mycket; ty han hade den berömvärda egenskap, at aldrig dölja 
eller hålla hemligt och för sig allena det han visste, utan meddelte det gerna. Jag kommer framdeles här och der, at nämna denna mannen; ty jag skulle räkna mig til största nesa, om jag skulle förtiga en annars narnn, och tilägna mig, hvad jag endast inhämtat af honom.

Westindien kallades här på orten hela Södra America, p. 244 och de orter deraf, som ligga i Zona torrida, som i synnerhet Americanska Öjarna derstädes; sảledes, at segla til Westindien var här det samma, som segla til Jamaica, Barbadas, Bermudas, Cuba, Hispaniola, eller dylika ställen. På samma sätt förstode de ock i London ordet Westindien, nämligen om de Södra delar af America; men at segla från London til Pensylvanien, Virginien, Maryland, Carolina, New-Yorck, New-Ängland \&c. var ej at segla til Westindien, utan bara til Pensylvanien \&c. eller ock til Norra America.

Musslor. Uti de lergropar, som de gräfvit NW. om staden, då de slagit tegel, och hvilka nu voro fulla med vatten, som kunde komma dit af en liten rännel, hvilken flöt der bredevid, fans en myckenhet af Concha testa oblonga ovata longitudinaliter subrugosa, postice compresso-prominula. Linn. Faun. Suec. 1332. De lära först kommit hit från floden, då det varit högt vatten i bäcken; emedan desse lergropar ej äro gamle, utan i senare tider gräfde. Stadsgåssarna skola ibland vada ut i vattnet, och samla en myckenhet af dessa musslor, dem stadsfolket sedan köpa af gåssarna, koka och äta som en delice.

Crategus fol. lanceolato-ovatis serr. glabr. ramis spinosis Linn. Spec. 476. är et slags | hagtorn, hvilket de p. 245 planterat här på somliga ställen til häckar, $i$ brist af vår Europæiska hagtorn. Bären voro röda, af samma storlek, skapnad och smak, som den ordinaira Europæiska hagtorn. Den tyckes dock ej vara bland de bästa til häckar; ty löfven voro redan mäst affalna, der de dock på alla andra trän ännu suto qvar. I öfrigt hade det grufveligen långa och hvassa taggar, at försvara sig med. Desse taggar voro af 2 a 3 tums längd, sades brukas, eller kunna brukas i brist af annat af bönder och andra 1) i stället för Knapp- 
nålar, at sätta i skjortor, tröjor \&c. 2) Til Korfstickor. 3) Till Tobaksstickor, at sätta i Tobaksrullar. 4) At påta och ränsa Tobaks-pipor med. Uti bären voro 2. stenar.

Ek. Herr Bartram bekräftade äfven, at den Ek, som växer här i America, ej hade på långt när den egenskap, at kunna så länge stå emot röta, som den Europæiska. Vid en af Floderna här i landet, Hudsons river kallad, der de föra ned allehanda slags varor up från landet, äro deras lastbåtar bygde af 2:ne slags trän, nämligen den delen, som beständigt står ned i vatnet är bygd af den svarta Eken; men den öfre delen af lastbảts sidorna, som. ibland äro under vatnet, och ibland ofvanföre, och följakteligen mera benägne till röta, äro bygde af den så kallade röda Cedern (Juniperus virginiana Linn. spec. p. 246 1039.) här i | Landet, hvilken af trä är den, som här snart sagt längst stảr emot röta. Af den svarta Eken göra de derföre botten; efter som floden är mycket stenig, och båtarna ofta komma at stöta på; så, gör denna Eken, som är mjuk, det, at hon deraf ej spricker och klyfver sig, utan dess mjukhet vid stötningen mot stenen hindrar det samma; men förenämde Ceder skulle ej duga dertil, efter den är hård och skulle snart spricka eller spjelka $\mathrm{i}$ stycken. När Eken ock beständigt är under vatten tager hon ej så snart röta.

Päron-trä. Man fick köpa här om hösten goda Päron; men så sades här dock allmänt, at desse trän ej vexa särdeles fort här i landet.

Skaller-orm. Hvad jag under mit vistande i America anmärkt om Skaller-ormen, dess art och egenskaper, m. m. finnes infört uti Kongl. Svenska Vetenskaps Acad. Handl. för år 1752. p. 308 seqq. 1753. p. 52. seqq. hvarthän jag visar Läsaren.

Björnar finnas här upp i landet til en tämmelig stor myckenhet, och göra ofta skada. Hr. Bartram sade, at när han griper någon af boskapen, an, dödar han pả det sättet, at han biter et hål på skinnet af Kreaturet, blåser så uti det med hela sin kraft, hvarmed han fortfar til dess Kreaturet sväller grufveligen up, och dör; emedan vädret 
löper emellan köttet och yttra hinnorna. En gammal Svensk | Nils Gustafson, en man af 91 år, sade, at i hans barndom var här fullt af Björnar; dock gjorde de sällan skada på Kreaturen. När någon blef ihjälskuten, tillagades Köttet som Svin-Kött, och var det rätt godt. Än i dag vid Maurices River, när de få nảgon björn, tilreda de Köttet som andra skinkor. Nu finnes här på orten omkring Philadelphia och Nya Sverige ganska få, så at sällan synes någon; emedan de äro utödde. Uti Virginien dödas desse Björnar på åtskilligt sätt, och Köttet ätes der öfver alt, så af de förnämare och rikare, som af de fattiga, hvilka hålla detta Björn-kött för rätt så godt, som fläsk. På många ställen dersammastädes, der de för myckenheten af Björnar icke kunna hålla Svin, vinlägga de sig, at fånga eller döda dessa skadedjur, och bruka deras Kött i stället för Svinens. De Americanska Björnar sades dock ej vara sả grymme och farlige, som de Europæiske.

\section{Den 26 September.}

Grodblad [Plantago (Fl. Svec. 122.) latif. glabra. C. B.] växte vid vägar, på utmarker, i trägårdar, ängar \&c. til stor myckenhet. Hr. Bartram sade, at han funnit denna ört mångenstäds på sina resor; men visste ändock icke, om hon var naturell från America, eller först kommen från Europa. Hvad som gaf honom anledning til denna tanka, var, at de Indianer, som här bodde och hade ifrån urminnes tider haft stor kunskap om | allehanda slags örter, berättat, at denna ört ej växt här i landet för än Europæerne kommit hit. Det namn, som Indianerne gifva på Groblad, är, at de kalla den Ängländars fot, och säga, at hvar en Europæer går fram, växer denna efter i hans fotspår.

Svinmålla (Chenopodium fol. sinuato-cand. F.) växte tämmeligen $\mathrm{i}$ trägårdar; men var deremot nog sällsynt vid hus, gator, dyngstackar, åkrar. Detta tyckes intyga, at den ej eller i början varit här i America, utan lärer blifvit förd bland andra frön från Europa. Således sades äfven, 
at Renfana, som fants växa här och där vid häckar och vägar, samt hus, på samma sätt blifvit omkring spridd af Europæiska frön.

Verbena communis, flore cæruleo, C. B. vistes mig af Hr. Bartram växa litet från dess hus på en liten slätt vid Philadelphia. Detta var det enda ställe, som han sade sig funnit den, i hela America, och derföre lärer hon äfven kommit at spridas hit af frön, från Europa.

Strata terræ. Vid det Hr. Bartram nu hölt på at bygga sig et hus här i staden, hade han låtit gräfva djupt ned i jorden för en Källare, och kastadt up mullen, då här syntes följande strata:

1) Ofverst var en tunn svartmylla, som bestod af mörk tegelfärg til et qvarters tjocklek.

p. 249 2) En tegelfärgad lera utblandad med mycket sand, af lika färg, så at sanden snart sagt var mera än leran, til 4. alnars tjocklek.

3) Små Klappurstenar; af storlek som fingerändar, med grus deribland. Desse små Klappurstenar bestodo af en ljusare eller mörkare qvarts, hel släta utanpå och rundaktiga, til $1 / 2$ alns tjocklek.

4) Den N. 2. med sand utblandade tegelfärgade leran tog sedan mot, och var ovisst, huru djupt den gick. Mon floden i fordna tider stått här, och gjordt desse strata?

Ostronskal \&c. på höga orter. Hr. Bartram berättade, at han funnit ej allenast Ostronskal, utan ock skal af åtskilliga sådana snäckor och musslor, som hafva sit tilhåld i Hafvet, öfver hundrade Ängelska mil från Hafvet, och äfven på de höga bärgen, som skilja Ängelska Colonierna från Indianerna. Desse bärg, som kallas The blow mountains, äro ansenligen höga och gå uti en Continuerlig sträckning från N. til S. eller från Canada ända til Carolina, endast at der är på et eller annat ställe en öpning, likasom det ned flit vore gräfvit, hvarigenom de stora floder, som flyta hit ned, rinna från öfra delen af landet ofvanför bärgen. Hr. Bartram försäkrade, at luften på desse bärg 
är gemenligen kallare altid, än uti dälderna och landet der nedanföre.

Cassia Chamcecrista Linn. spec. 379. växte på skogsängar och äfven här och där på utmarkarna, hälst om de voro buskige. Dess blan likna ganska mycket mimosa, och hafva äfven den egenskap, at då en slår til dem, draga de sig tilhopa, lika som en planta sensitiva.

Kråka. Här finnes äfven kråkor, som äro mycket litet skilda från våra ordinaira i Sverige. De äro af samma storlek, som våra; men mäst kål-svarta. Deras läte eller ljud är dock ej så groft, utan mera gällande, och som et medium emellan Kråkor och Råkor. Jag såg dem i dag i tämmeliga stora hopar.

Jätt-grytor. Hr. Bartram berättade, at han på sina resor åt de Norra orterna af de Ängelska Colonier sett vid Floderna i bärgen hål, hvilka efter hans beskrifning voro aldeles sådana Jätt-grytor, som hos oss finnas i Sverige, och af mig äro beskrefne uti Kongl. Vetenskaps Academiens Handlingar. Han sade sig haft Bref-växling med Kongliga Vetenskaps Societeten i London derom; ty andre hafva gifvit dem den raison til dessa gropars första ursprung, at Indianerne utgräfvit dem, at i Krigstider gömma och förvara sin spanmål och andra sina angelägna ting deruti; men han nekade dertil, och föregaf, at då isen lägger sig om vinteren, fastnar en hop Klappursten vid den samma. När nu snön om Våren smälter, blir mycket vatten $\mathrm{i}$ floden, så at det går öfver sådana ställen, der desse Jätt-grytor eller bärgs-källor | äro. Isen kommer sålunda at flyta deröfver, då ofta sker, at en eller flere af de Klappurstenar, som frusit fast vid isen, då den lagt sig om hösten vid sidor och botten på floder, falla ifrån isen ofvanpå bärget, och föres så af vatnet til dess de fastna i någon ihålighet eller ojämnt ställe i bärget, der de börja vridas omkring då vatnet strömmar och stöter på dem, och nöta således ut hål i bärget: utom det, at vatnet med sit omhvirflande och löpande omkring stenen, äfven hjelper til, at bårtnöta och släta stenen eller bärget. Det är visst, at denna stenen, som råkat i 
sådana hål, omsider blir utnött, men så ersätter floden om våren gerna det samma, derigenom, at nya stenar ofta komma at falla deri. Det som sålunda nötes af bärget och af stenarna, blir som til en sand eller grus; men då vatnet om Våren, och eljest, då det är högt, kommer at rusa och hvirfla omkring uti dessa hål, sköljer det bårt all denna lösa sanden. Sådan var hans mening om Jättegrytors ursprung, hvilken han sade, at Kongl. Vetenskaps Societeten i Ängland tyckt mycket om och gillat. Mina observationer om Sommaren 1743, under mit vistande på Landsort, kunna utvisa, at detta har rum ibland, och at jag äfven då redan utfann just det samma; hvilket uti et Memorial til Kongl. Vetenskaps Acad. som förvaras bland dess otryckta handlingar, är än vidare utfördt. Men at alla Bärggrytor så först blifvit til, har man stor orsak at tvifla.

p. 252 Mulbärsträ \&c. Af detta trä finnes här flera arter, som växa vildt öfveralt, så i Södra som Norra America i skogarna. Den, som här mäst växer, är Morus rubra. Men sả bekräftade Hr. Bartram, at lıan äfven funnit det hvita mulbärsträdet här vildt, fast det är nog rart. Jag frảgade honom och andra, hvi de ej anlägga Silkes-manufacturier här; emedan de hafva sådan ymnighet af mulbärsträn, hälst, som samma trän vela här sả otroligt fort, (ty det är märkt, at om bären falla ned på jorden, der jorden är lös, sticker sig strax up en myckenhet af unga telningar)? mig svarades, at det ej lönar mödan här, at anlägga Silkes-manufacturer; emedan arbetsfolket är så dyrlegt; ty man måste gifva en Karl i dagspenning $21 / 2$ a 3. och äfven flera Ängelska Skillingar, och en qvinsperson proportionaliter derefter; utan de höllo före, at sädesarternas såning, jämte hampas, lins m. m. lönte här bättre omaket, och fordra ej så mycket kink, som Silkesmaskarnas ans. Enkannerligen hade säden i Angelska Colonierne i Södra America den bästa afgång. Men at Silkesmaskar väl kunna trifvas här, och må väl af dessa mulbärsträn, bevistes af en Gouverneur uti Connecticut i New-England, som haft sin gård ännu långt Norr om 
New-Yorck, hvilken haft Silkesmaskar på samma sin gård, som trifvits mycket väl, och spunnit åt honom så mycket Silke, som han behöft at kläda sig och hela sin familia med.

Vinrankor växa här i landet af åtskilliga slag villdt.

När en reser hit eller dit, får en på oändeligen många ställen se, huru Vinrankorna växa antingen vid trä- eller gärdes-gårdar. De klänga sig up på trän och gärdesgårdar, samt öfvertäcka dem ofta helt och hållit, hänga dessutom på sidorna ned. Det ser ut på långt håll likasom der humla kommit at klifva på något och öfvertäckt det. Jag frågade Hr. Bartram och andra, hvi de ej plantera vingårdar här, och prässa vin af dessa villa Vinrankors drufvor eller frukt? mig svarades, at det har härmed samma beskaffenhet, som med Silkes-fabriquerne, nämligen, folket är dyrlegt, och det lönar sig ej så väl som åkerbruket; men förnämsta orsaken är tvifvelsutan den, at vin prässadt af de flästa slag, som finnas i Norra America, är surt och slätt, och smakar ej på långt när så väl, som det af Europæiska drufvor.

Arum acaule, foliis hastato-cordatis acutis, angulis obtusis. Iinn. spec. 966. växte på våta ställen. Mr. Bartram berättade, at Indianerne koka blomstjelken (spadicem) med frön af den samma, och äta den som en delice; medan fröna än äro rå, kännas de helt ampra och bitande på tungan; men så snart de blifva kokta, mista de största delen af denna ampra egenskapen.

Sarothra Linn. Spec. T. I. p. 272. växte pả fälten och under buskar i torr sandmylla, | ymnigt utan för Philadelphia. Den liknade mycket blåbärsris hos oss i Sverige, när det börjar spricka ut, och bladtopparna ännu äro rödaktige. Hr. Bartram sade, at han sändt den til Dr. Dillenius, som ej vetat, hvad han skulle göra dermed, eller til hvad Class och Genus den skulle föras. Eljest skal den vara en skön sår-ört. Hr. Bartram sade sig en gång hafva fallit af en $\mathrm{yr}$ häst, som äfven då tillika slagit honom, så at bägge hans lår blefvo illa sårade. Han hade tagit denna, kokat och bundit den öfver låren, då svedan, 
som förut var ganska häftig, i hast försvunnit, och han på kårt tid kommit til sin förra hälsa.

Larix. Som jag läst uti Hr. Millers Dictionaire, at Hr. Peter Collinson haft uti sin trägård en sort utaf larix, den han fått från America; så frågade jag Hr. Bartram, om han visste något deraf? han svarade, at han sändt den samma til $\mathrm{Hr}$. Collinson, och at den växer vildt uti Östra Jersay; men på intet annat ställe hade han funnit den här i America. Den skiljes frân de andra sorter af Larix derigenom, at den har mycket smärre Conos, än de andre. Denna Larix fannt jag sedan växa i största ymnoghet i Canada.

Äppelträ trodde Hr. Bartram blifvit hitförde af Europærna, och ej varit här förr; men Persike-trä sade han varit här tilförene, och blifvit fundne öfver största delen

p. 255 af A/merica växa vildt. Andre, som jag här talade med, voro af den tankan, at Persike-trädet blifvit infördt och planteradt först af Europeerna och aldrig varit här förut: men Fransoserne uti Canada berättade sedan enhälligt för mig, at vid Micisippi, och åt den trakten finnas Persiketrän vildt växa i myckenhet.

\section{Den 27 September.}

Diospyros, virginiana Linn. spec. 1057. Kallades af Ängelsmännerne här på orten Pérsimon, och af de Svenska Mispel eller Mispelträ. Det växer hälst på våta ställen rundt omkring vattugölar. Jag har nämnt förut, at detta träds Frukt, innan den blir mogen, är ganska bitter och adstringerande, så at om man äter den samma då, drager det nästan munnen aldeles ihop, och har en mycket obehagelig smak; men sedan den blir mogen, som sker ej förr, än den blir frostbiten, är den en nog väl smakelig frukt, och mycket behagelig at äta. Här bruka de at äta den rả; men ej särdeles pả annat sätt. Uti en bok, som är en beskrifning öfver Virginien, vid ordet Persimon, ses, at de tilreda och äta den på flera sätt. Herr Bartram berättade för mig, at de äfven här bruka den til Confect 
eller Sweat meat, som de kalla; samt at någre dessutom göra vin af frukten, som skal vara et af de behageligaste. Hos H. Bartram hade någre af dessa Äplen fallit ned på marken, och voro sålunda mera eller mäst | fullmogne, derigenom at Solen skint på dem. Vi togo up några af dem, och åto deraf, då jag befann, at de hade mycket sannt, som säga, at dennas frukt är mycket angenäm; ty bland de frukter, här på orten finnas, som äro behagelige och välsmakande, får äfven denna räknas, då den af Kölden blifvit genombiten.

Verbascum foliis utrinque tomentosis decurrentibus Linn. Flor. Suec. 186. växte i ymnoghet och ganska stor myckenhet så vid vägar och gärdesgårdar, som på torra åkrar och högländta betesmarker af sandblandad jordmon. De Svenske kallade den öfveralt Vilsk Tobak; men sade derjämte, at de ej visste om Indianerne någonsin betjent sig af den samma til Tobak. Bladen brukades af de Svenska til linda om fötter och armar mot hettan i febrar; en del brukade bladen som Thée at dricka, då de hade löst lif. En Svensk berättade, at man plär taga roten, koka den i vatten, til decoct, som sprutas inuti Kreaturs sår, som äro fulla med maskar, då de alla skola dö och falla ut.

\section{Den 28 September.}

Ängarna, som lågo i skogslundar, och voro afslagne, voro här ganska gröna och vackra af det gröna gräset; men om de lågo på backar, eller betesmarker eller på de högre ställen, hälst emot Solen, hade gräset på dem mäst en brun och torr färg. Åtskillige, | som voro hemma p. 257 från Virginien, berättade mig, at för den starka hettan och torrkan skul äro betesmarkerne och ängarna der mäst altid af en brun och likasom bränd färg; så at de der icke hafva det nöjet och den behageliga utsigten af gröna ängar, som vi i Norra delen af Europa få fägna oss af.

Phytolacca växte i myckenhet ut på betesmarkerna och under trän på små backar. Dess svarta bär voro nu mogne. Vi sågo i dag, at små blåaktiga foglar, af storlek, 
som våra gröningar, kommo ned från träden, satte sig på buskarna af Phytolacca, och åto up dess blan.

Om aftonen spatserade jag ut til Herr Bartrams gård.

\section{Den 29 September.}

Gnaphalium latifolium americanum. C. B. (Gn. margaritaceum. Linn. spec. 850.) växte här i en grufvelig myckenhet på alla utmarker, skogsängar, backar, skogstäppor \&c. Den var til längden åtskillig, alt efter jordmon och stället den stod på. Ibland var han ganska grenig, ibland rätt litet. Han luktade nog starkt; men lukten var ljuflig. Ängelsmännerne här kallade den Life everlasting, det är, evinnerligt lif; emedan dess blommor, som bestodo til en stor del af torra gläntsande silfverlika blan (foliolis calycinis), förändrade sig icke, sedan den blef torr. Han blomstrade ännu, til en stor del, som bäst; men en

p. 258 del var ock redan utblomstrad, och började släp|pa bårt sina frön. Ängelska qvinfolken brukade gå ut, och samla denna i myckenhet, den de togo med stjelk och alt, satte den sedan med allehanda andra vackra blomster, som de samlade ut på marken, och äfven dem de fingo i trägården, uti Krukor, med eller utan vatten, ställte sedan Krukorna i spisen i rummen der de vistades, såsom en prydnad. Ängelska qvinfolken voro ganska mycket för den plägseden, at hela Sommaren hafva allehanda slags, både för ögon och näsa, vackra blomster i krukor och påttor, antingen uti eller uppå spisen, samt ibland på bordet eller i Fönstren. De ömsade gemenligen hvar Lögerdag, eller ock oftare, nya blomster i sina krukor; emedan de gamla börjat vistna, förfallna och förlora sin färg. Denna Life everlasting var en bland dem, som de hafva hela vintern igenom uti sina rum; emedan hans blommor sågo altid likadana ut. Herr Bartram berättade en annan nytta af denna, nämligen, at man tager blomstren och stjelken, kokar dem i vatten, och med vatnet, eller örten bunden i en påsa, bönar det ställe, som man har värk uti, eller är eljest stött. 
I stället för lin bruka en del här i landet en art af apocynum, kallad Apocynum cannabinum. Linn. spec. 213. hvilkens stjelk de bereda på samma sätt, som vi göra med lin och hampa. De spinna och väfva häraf åtskilligt gröfre tyg. Villarna gjorde i forna tider deraf pungar, fisknät och fisk-refvar \&c.

Vattnets aftagande eller tillandningar. Jag frågade p. 259 Herr Bartram, om han på sina resor märkt efter, om vatnet affallit, och at nu vore land, der fordom varit Sjö? Han svarade, at efter de observationer han gjordt, är han benägen, at döma, det största delen af detta landet $i$ forna tider aldeles stått under vatten, och det til många mil up i landet. De skäl, som gofvo honom anledning, til den tankan, voro följande: 1) Up vid The blew-mountains, eller blåa bärgen, som ligga öfver 300 Ängelska mil från Hafvet, finnes på de samma vid gräfningen här och der lösa Ostronskal, samt skal af andra musslor och snäckor. Desse fås ock der i jorden nedan för bärgen. 2) Finnes en grufvelig myckenhet af petrificerade musselskal i samma nyssnämde bärg, både i Kalk-, Flint- och Sand-sten. Han sade, at det var otroligt hvad myckenhet af petrificerade musselskal finnas $i$ den stenart, hvaraf bärgen der bestå. 3) Finnes på flera ställen, så i Virginien och Maryland, som här i landet, och i New-York, vid gräfning i jorden, en myckenhet af Ostron- SnäckeMussle och dylika skal, merendels ännu hela och oförrutnade. 4) Hafva de vid brunnars gräfning, så här i Philadelphia, som annorstädes, fått til 18. fots djup, stockar, trän och rötter ned i jorden, samt Eklöf ännu til en stor del oruttnade. 5) De fetaste marker här i landet och den bästa svarta jord ligga i dälder, hvilka däl|der gemenligen äro genomskurne af en elf eller bäck. Vid nedra och den lägre sidan af desse delar är merendels något bärg, som, der vatnet rinner fram, synes, som vore det genomgräfvit med flit. Herr Bartram inbillade sig, at desse dalar i forna tider varit Sjöar, at vatnet småningom nött bårt bärget och skurit sig ut, hvarigenom de blifvit torra, och den myckna slem och gyttja, som i forna tider 
fölgt ned med vattnet, och satt sig i botten på Sjön, eller nu varande dal, är det, som gjordt jorden der så fet. Sådana dalar, och utskärningar i bärgen, finnes mảngenstäds här i landet. En sådan är, som en flod gör här i Pensylvania emellan samma Province och New York, der vatnet löper midt emellan tu bärg, om hvilket de skämtvis säja, at hin håle gjordt det samma, då han gick derigenom härifrăn Pensylvania til New York. 6) Hela facies af The blew mountains skola tydeligen utvisa, at vatnet i forna tider stått öfver dem; ty de äro afbrutna pả särdeles sätt; men de högsta af dem jämna. 7) Då någon berättat för Indianerne, at musselskal funnits i samma höga bärg, samt at man tyckes hafva anledning deraf, at tro, det Hafvet i forna tider stått vid samma bärg, och äfven öfver dem; hafva de svarat, at de undra ingen ting derpå, emedan deras förfäder hafva berättat för dem, at vatten $\mathrm{i}$ forna tider stătt öfver dessa bärg. 8) Vatnet uti bäckar, strömar p. 261 och floder aftager äfven. I Qvarnar, som blifvit bygde för 60. år tilbaka vid bäckar, och då haft ymnigt vatten största delen af året, hafva nu så litet, at de näppeligen kunna gå oftare, än när det antingen rägnat starkt, eller när snön om våren smälter. At vatnet här förminskas, sker af landets upodling och skogens bårtrödning från det den varit i forna tider. 9) Landet flytter ock sig vid Hafsstränderna längre och längre ut, som sker deraf, at Hafvet continuerligen sköljer och kastar mera och mera sand up til stränderna från dess djup, och således gör en tilökning til landet. Vid alt detta trodde han en ting förtjena upmärksamhet, nämligen, at de musselskal, som finnas längre i Norr inväxte och petrificerade i bärgen, äro sådana, som denna tiden ej kunna finnas eller fås igen uti Hafvet, som ligger der nedanföre til samma latitude med orten, der desse petrificerade musselskal brytes: man kan ej få se några af samma slag lösa vid Hafsstranden, förr än en kommer ända til Carolina i Söder. Han gjorde häraf inkast, hvad en skal tänka om Burnets mening, at Solen gått annorlunda för syndafloden än nu: frågade ock, om ej de stora ben, som upgräfvas stundom i Siberien, 
och hållas för Elephantben, ej synas bevisa och intyga det samma, hälst som inga Elephanter denna tiden för den starka kölden i Siberien kunna trifvas der; men om Solen gått för syndafloden som Burnet skrifvit, så hade hon väl kunnat varit der. Men / alt detta nu anförda. tyckes äfven kunna härledas dels af den allmänna syndafloden, dels af tillandningar, dels af floders ömsning, eller at vid snö-smältning af stor vattuflod elfverna af någon händelse lämna sin förra gång, och göra sig utlopp på något annat ställe.

Jättgrytor. Litet från Herr Bartrams gård rann genom skogen en liten bäck. Pả et ställe, der han lopp öfver en häll, viste Herr Bartram mig åtskilliga smả, af oss så kallade, Jättgrytor eller Bärgsgrytor, der utholkade i bärget. Vi kunde här helt tydeligen se, at de hade samma origine, som förut p. 250. är omtalt, nämligen at någon Klappursten kommit at stanna uti någon utholkning eller grop i bärget, och der genom vatnets rinnande och strömmande derpå börjat rulla och vändas beständigt omkring, och sålunda utäta och svarfva härda bärget; ty när vi kände med handen ned i dem, voro de fulla med små klappurstenar, hvars yttra superficies var hel slät och rundaktig, och nästan som svarfvad. Uti en och hvar af dem voro sådana små Klappurstenar.

Herbce Europce Septentrionalis. Herr Bartram lät mig. se en hop inlagda örter, som han samlat på sina resor, bland hvilka följande voro de, som äfven växa i Norra delen af Europa.

Betula foliis acuminatis serratis. Linn. Flor. Suec. 776. C. B. den har han tagit på Cathill mountains.

Betula foliis orbiculatis crenatis. Linn. Flor. Suec. p. 263 777. på åtskilliga lågländta ställen up emot bärgen.

Comarum (422). Quinquefolium palustre rubrum C. B. på ängar i Östra Jersey emellan bärgen.

Gentiana (201) major lutea C. B., på fält up emot bärgen. Denne var ganska lik med vår; men der voro ej den myckenhet af blommor vid hvar ala, som i vår. 
Linncea (522). Campanula Serpyllifolia C. B. På bärgen i Canada, löpande efter jorden.

Myrica (817.) fol. lanceol. fructu sicco, vid floden Susquahanough i Norr på våta ställen.

Potentilla (416.) caule fructicoso. På morasig mark eller låga ställen emellan Dellaware och New York river. Trientalis (302.) På Catshill mountains.

Triglochin (299.) eapsulis sexlocularibus ovatis, vid salt-källorna när de fem Nationer.

Indianernas grafvar. Herr Bartram viste mig et bref från Östra Jersey, deri berättades, huru då man år 1744. uti April, hållit på at gräfva för en källare, hade de vid gräfningen råkat på en stor sten, som en grafsten, och då de med möda fått up den samma, hafva de ungefär 4 . fot under den samma funnit en hop med människoben, samt en hel kaka bröd, gjord af Mays, som ännu låg oskämd, p. 264 så at àtskillige Gentlemen för cu|rieusitet åto af samma bröd. De slöto häraf, at detta varit en af Indianernas förnämsta Herrars graf; ty deras sed är, at lägga mat och annat, hvad den döda haft kärt, emedan han lefde, med honom i grafven. Längden af denna sten var 8. fot: bredden, der den var bredast, var 4 . fot, $31 / 2$ tum; tjockleken på ena kanten 15. tum, och på den andra 12. tum. Stenen bestod af samma grofva bärgart, som finnes här på orten; men icke nàgra bokstäfver eller andra characterer på. Skapnaden 'af den var sådan, som hosstående, figur utvisar.

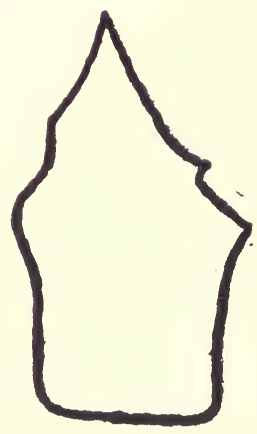


Indianernes sädes-slag \&c. Det sädesslag, som de i synnerhet plantera och cultivera, äro Mays, hvartil de hafva små åkrar: dessutom plantera de en stor myckenhet af Squashes, som äro en art af Pumpor eller meloner, hvilka de cultiverat från urminnes tider. Europæerne, som nu bo här i landet, | hafva förskaffat sig frön deraf från Indianerna eller Americanerna, och cultivera mycket i sina kryddgårdar. De äro en mycket skön mat, när de väl tilredas. De kokas gemenligen, och sedan stötas de sönder, som vi göra med rofvor, då vi vele laga rof-mos, strös så litet peppar eller andra krydder deri, då de äro färdige at ätas. Än så de åtskilliga slags Bönor, som de mäst förskaffat sig af Europæerne, likaledes hafva de åtskilliga slags ärter, dem de merendels haft från urminnes tider, och innan Europæerne kommo hit i landet. Förenämde Indianernes Squashes planteras nu tämeligen af Europæerne, och äro bland de aldraförst mogna Pumpor mycket sköna at äta, men duga ej at förvaras; emedan de icke hålla sig så väl. Dock har jag sett somliga förvara dem goda långt in på vintern.

\section{Den 30 September.}

Sånings tiden \&c. här. Hvete och Råg sås om hösten vid denna tiden, och skäres gemenligen midt uti eller vid slutet af Junii månad, st. vet. Ofta blifva de så tidigt mogna, at de kunna skäras i början af Junii månad, efter gamla stilen, ja, man har exempel, at man skurit dem i slutet af Maji. Korn och Hafra sås i April, och blifva mogna til skörd uti medio Julii gemenligen. Bohvete sås i begynnelsen, eller ock midt uti Julii månad: blifver sedan mogit och skäres up vid denna tiden, eller litet senare. Sås det förut, | som uti Maji eller Junii, gör det ej annat än blomstrar, och blifver litet eller alsintet korn deri. Här förstås alt den gamla stilen.

Kor. Hr. Bartram och åtskillige andre berättade, at största delen af de Kor, som Angelsmännerne hafva här i landet, äga sit ursprung af dem, som de köpt af de 
Svenska, då de blefvo ägare af detta landet, och at de sjelfve fört få hitöfver från Europa. De Svänske hade åter antingen Kor med sig från Sverige, eller köpte de dem af de Holländska, som bodde här.

Murgrön eller Hedera Linn. flor. Svec. 190. var på et ställe utan för Staden planterad emot väggen af et stenhus, som den på sitt vanliga sätt hel och hållen öfvertäckte med sina sköna gröna löf, at en icke kunde se til muren för den samma. Den lärer tvifvelsutan först blifvit hitförd från Europa; emedan jag ej blef henne varse på något annat ställe under mina resor i Norra America; men villa Vinrankor sảg jag på et och annat ställe med flit vara ledda up för väggarna på husen.

Trädens solum naturale. Jag frảgade Hr. Bartram, om han funnit, at trä och örter äro desto smärre, ju närmare til Norr, som Catesby menar? Han svarade: detta bör tagas med någon åtskilnad och uttydning. Det äro vissa trän och örter, som hälst trifvas, e. g. i Carolina; men ju närmare en kommer til norr, ju smärre blifva de.

p. 267 Foglar och annan hän|delse föra väl ibland deras frön och bär åt Norr; men de aftaga der altid i deras växt mer och mer, til dess de ändteligen komma så långt Norr, at de icke mer vela växa. Deremot äro andra örter och trän, som Skaparen gjordt för Norra orter, hvarest de växa til grufvelig högdi och storlek; men ju mera de flyttas til Söder, ju smärre blifva de, til dess de ändteligen blifva så smà, at de ej mera vela växa. Andra örter tycka om et visst land och en tract: flyttas de derifrån, antingen mera til Norr eller Söder, så vantrifvas de och blifva smärre och smärre. Således äro vissa trän, som trifvas bäst här i nya Sverige eller Pensylvania; men aftaga mer och mer, ju närmare de komma til Norr eller Söder. Jag fick sedan på mina resor se öfverflödiga prof af denna sanning: således fann jag, at Sassafras, som uti Pensylvanien vid en 40 grad. Lat. växa til tämmeligen höga och tjocka trän, voro både vid Osvego och Fort Nicholson, eller emellan den 43 och 44 graden, så små, at de sällan räckte öfver en eller par alnars lıögd, samt sällan sâ tjocka, 
som en halfvuxen människas lillfinger. Samma beskaffenhet var med Tulipan-trädet, som uti Pensylvanien växer til samma högd, som våra högsta Ekar och Furor, samt tjockleken derefter; men var vid Osvego näppeligen öfver en eller par famnars högd, samt tjockleken som en mans arm. Såcker-Lönnen är det almännaste trä uti skogarna i Canada, hvarest den ock växer til en alt | för stor högd; men längre til Söder, som uti Nya Jersey och Pensylvanien, finnes den endast på Norra sidan af Blåbärgen, samt på de branta elfsbackar, som vetta emot Norr, hvarest den dock nästan aldrig kommer til tredje eller fjärdedelen af den högd, som den har i Canada; at förtiga flera exempel.

\section{Den 1 October.}

Musquetoès kallades här myggor eller krankar, som voro mycket besvärliga om nattetid. De äro just en och samma med våra ordinaira myggor eller krankar uti Sverige, Culex cinereus; abdomine annullis fuscis octo. Linn. Faun. Svec. 1116, hvarest beskrifning och snart sagdt alt, som der säges om våra myggor, aldeles kommer öfverens med dessa, endast at de senare, eller Musquetoès, äro en liten grand mindre. De practicera sig om dagarna och aftnarna in $\mathrm{i}$ husen, och då en lagt sig, börja de sin obehageliga sång, komma då alt närmare til det stället en ligger, och då en somnar in, suga de sig fulla af blor, så at de näppeligen orka flyga. På den, som har finare skinn och hud, som Fruntimmer och dylika, upkommer som en blemma, eller liten böld, der de bitit. När det varit kallt väder några dagar, syntes ej så stort til dem; men då väderleken ändrade sig til mildare, och enkannerligen sedan det rägnat, samlades de ofta $\mathrm{i}$ hast til sådan myckenhet i husen, at det var hiskeligt. Ängelsmännernas korstenar utan spjäll, äro rätt| behändige, at släppa dem in i husen. De gjorde då om sådana aftnar boskapen följe hem från skogen til gårdarna eller Staden, och då boskapen drefs förbi husen, gömde desse sig hvar de kunde. Om sommartiden finnes på somliga ställen faseligen mycket deraf, 
så at skyn om aftnarna är likasom upfyld, hälst på sådana ställen, som ligga vid Morass och stilla stående vatten, e. g. vid Maurices River uti Nya Jersey. Invånarena göra då om aftnarna eld utan för sina hus-dörar, at hindra desse gäster ingången. De gamle Svenske sade, at här varit ännu mera mygg $\mathrm{i}$ forna tider: at de ännu finnas $\mathrm{i}$ ganska stor myckenhet ned mot sjökanten vid salta vatnet; at de, som denna höst funnos i Philadelphia, voro mera skadelige, än de vanlige; ty det blef fullt med små bulor efter der de beto. I Sverige har jag ej känt någon olägenhet af myggbett, mera, än at det kliat dả de sugit ut bloden; men här, dả de beto mig om nätterna, blef ansigtet så fullt af små röda knylar och bulor, at jag nästan skämdes gả ut i Staden.

Gärdesgård. Jag har förut p. 223. nämnt något om gärdesgårdarna. Nu får jag lägga til, at de mästa och snart sagt alla gärdestrådor, som brukades vid gärdesgårdarna omkring Philadelphia, voro af den röda Cedern, som sades vara et mycket varaktigt trä. I brist deraf togo de antingen den hvita eller svarta Eken. Til gärdesgårds störar hölts den röda Cedern för bäst. Dernäst p. 270 hvit Ek, och / sedan Castanie-trä, som H. Bartram berättade mig. Trä-slagen här kunna ej härda länge ut i jorden. Jag såg et Castanie-trä, som blifvit satt förledit år nytt $\mathrm{i}$ jorden til stafver; men var redan til en stor del bårtruttit af den delen, som stått ned i marken.

Sassafras-trädet växte här i landet til en tämmelig myckenhet. Det stod här och der i skogar, samt vid buskar och gärdesgårdar nog. På gamla åkrar, som nu voro lämnade at öfverväxas med skog, var detta et ibland de första trän, som började komma up, och det mäst til den myckenhet, som Björken hos oss på gamla Svedjeland. Jordmon, der desse växte, var en torr lös jord af blek tegelfärg, bestod mäst af sand, utblandad med något litet lera. Den syntes ock ej vara mycket fet, utan mera mager. En hop ställen på backar omkring Götheborg i Sverige skulle synas vara nog goda för detta träd; men jag fruktar, at jordmon vore der för fet. Jag såg detta 
växa här i skogen bland andra trän, äfvenledes ofta för sig sjelft allena vid gärdesgårdar; men var på bägge ställen lika frodigt. Aldrig blef jag varse, at det stod på våta och lågländta ställen. Folket här brukade samla des blommor och betjena sig af dem som Thée. Sjelfva trädet duger i hushållet til ingen ting; ty om det lägges på spisen, at brukas som ved, gör det ej annat än sprakar. Det propagerar sig ganska mycket med rötterna, slår up telningar här och der; derföre du|ger det ej, at taga p. 271 dessa små telningar; emedan de hafva så få andra fibrer, utom stamroten, at de ej vela taga rot; fördenskul den, som vil propagera det, bör skaffa sig dess bär, fast det är nog svårt få dem; emedan foglarna gemenligen äta up bären innan de blifva halfmogne. Korna äro ganska snåla efter dess unga telningar, dem de afbita och begärigt upäta. Med barken af detta trä gifva qvinfolken yllet en vacker orange-färg, som sitter ganska starkt uti och blekes ej bårt af Solen. Vid färgningen brukas ingen Alun, utan endast urin. Det kokas och då i en Malmgryta; emedan det på lảngt när ej blir så vackert, om en betjenar sig af en järngryta. Hr. Bartram berättade, at en Fru i Virginien förtält honom, huru som hon för några år tilbaka fått en värk uti den ena fotleden, så at hon näppeligen kunnat gå. Hon blef då rådd, at taga Sassafras-bär, steka dem i en panna, då en olja kom utur dem, med hvilken olja hon smörgde fotleden. Si snart hon det gjordt, fick hon en stark upkastning. Hon fortfor dock dermed 3 gånger; men med samma effect, näml. at hon gaf öfver hvarje gång. Dock hade hon derjämte den förmon, at värken och svedan aldeles försvann från hennes fot, och hon blef fullkomligen botad.

\section{Den 2 Oktober.}

Picus niger maximus, capite rubro. Catesbys Natural History of Carolina. Vol. 1. | p. 17. Tab. 17. finnes nog i skogarna i nya Sverige, och är här qvar äfven om vintern, som vi sjelfve sedan sågo. Denna hölts här ibland de 
foglar, som voro skadelige för Maysen; emedan han sätter sig på de mogna axen, och hugger dem sönder. Han kallades af de Svenska Tillkråka; men alla de andra Pici, undantagandes Picus alis aureis, kallades Hackspitar. Denne så väl, som de andre Hackspitar, hvilka jag i et annat värk skal nogare beskrifva, äro mäst alla skadeliga för Maysen, vid det den börjar blifva mogen; ty i det de hacka hål på baljan omkring axet, slipper rägn derigenom in, hvaraf axet och kornen deri rötas bårt.

\section{Den 3 October.}

Om morgonen reste jag ned til Wilmington, eller som det fordom kallades af de Svänska, Christina, hvilket är belägit 30 Ängelska mil från Philadelphia uti SW. Ungefär 3 Ängelska mil från Philadelphia for jag på färja öfver floden Skullkil. Utsigten hade sedan merendels en beständig omväxling af högder och dälder. Högderne voro långsluttige från alla sidor. Ned i dälderna rann merendels en större eller mindre bäck med Cristall-klart vatten. Mästa delen af landet var öfverväxt med skog, som bestod af allehanda slags löfträn. Jag såg näppeligen et enda barr-trä, utom några få röda Cedrar. Skogen var hög, och nedantil gles, at en kunde se långt der-

p. 273 igenom, | samt beqvämt rida der under. På många ställen kunde en hela fjärndels-vägen köra med kärra eller chaise, mäst hvart en ville under träden. Så glesa stodo de, och så jämn var marken derunder. Här och der voro små flacka fält, antingen ängar, ảkrar, beteshagar, eller til linda lämnade åkrar. På et eller annat ställe voro flera gårdar byggde tilsammans; men merendels voro de enstakade. En del af åkrarna voro redan besådde med hvete, och det på Ängelska sättet utan diken; men med nog täta vattufårar. Pả somliga ställen såddes Rågen nu som bäst. Mäst vid alla gảrdlar voro små plantationer af Mays. De som här bodde voro merendels antingen Ängelsmän eller Svänske.

Trän af àtskilliga slag blef jag hela denna dagen varse, såsom Valnötträn af flera slag, nu fulla med frukt. 
Castanie-trän likaledes helt fulla med sköna Castanier. Mulbärsträn, Sassafras, Liquidambar, Tulipan-trän, med många andra.

Vinrankor af flera slag växte här öfveralt villa. De klängde sig allestädes up i träden, öfvertäckte dem och hängde med sina refvor och löf ned på alla sidor. Jag såg huru de ibland hade klifvit up på Ekar til 5 à 6 famnars högd. Jordmon var här den vanliga, som förut ofta är omtalt, nämligen en lera, utblandad med en myckenhet sand och svartmylla. Enkannerligen syntes dessa villa | Vinrankor, hälst på något qvarlemnadt trä ut på åkrarna, eller i skogsbrynet mot åkrar, ängar och betesmarker. Likaledes vid gärdesgårdar, der de klängde sig på trän som der växte. När de reste sig högt up i träden, blefvo öfversta topparna så skakade af blåst och köld, at de sällan buro någon frukt högt uppe; men de, som suto lägre, voro helt fulla med drufvor, hvilka växte under löfven, och voro nu mäst mogna, samt hade en behagelig. syrlig smak. Desse drufvor samlades mycket af Landtfolket, som förde dem in til staden at säljas, hvarest de åtos rå sådana, som de voro. Ofta när en kom at hälsa på någon, blefvo desse inburne på et fat eller talrik, at ätas som andra confiturer eller söta saker.

Svartmyllan syntes icke vara härstädes mycket tjock. Den mylla, som låg öfverst och var svart, var näppeligen af par tums tjocklek. Jag hade tilfälle at se detta både der de gräfvit i jorden, som ock på sådana ställen, der vatnet vid starkt rägn skurit sig ned i jorden, hvilket här var nog allmänt. Den öfra jorden, eller så kallade Svartmyllan, var af en mörkare, och den nedre derunder af en blekare tegelfärg. Jag har öfveralt, hvar jag rest i America, funnit, at tjockleken af Svartmyllan på långt när ej svarar emot det, som mången skulle vela inbilla sig, när en besinnar, at den der på många ställen ej torde vara rörd eller rubbad sedan syndafloden; hvarom mera längre fram.

Datura pericarpiis spinosis erectis ovatis. Linn. Flor. Suec. 185, växte i otrolig myckenhet vid alla byar. Den 
var åtskillig til storleken, alt efter jordmon, som den växte uti. Var jordmon fet, så reste den ofta sig til 4 à 5 alnar's högd; men i skarp och mager jord gick hon ibland ej öfver et qvarters längd. Denna Datura tillika med Phytolacca Linn. hort. Ups. 117. upfylte här de ställen vid hus, gårdar, vägar \&c. som Nässlor och Chenopodia hos oss i Sverige och Europa, hvilka sistnämde Europæiska örter voro här i America ganska sällsynte; deremot voro Datura och Phytolacca de värsta ogräs, af hvilka de ej visste någon särdeles nytta.

Rofland syntes här och der vid vägen.

Orm. På vägen låg en af de så kallade Black Snakes ihjälslagen. Han var til färgen helt svart. Längden netto 9 qvarter. Bredden der han var tjockast $1 \frac{1}{2}$ tum. Var af huggorm slägtet.

Tecken til Väderlek. Om aftonen sent var en stor ring omkring månan. Folket sade, at det betydde antingen blåst, eller rägn eller bägge tilhopa: ju mindre denne ringen är, eller närmare til månan, ju snarare skal det samma komma. Men intetdera fölgde nu, utan ringen bebodade denna gången köld.

Chermes alni. Linnæi Faun. Suec. 698. fans i dag i p. 276 ganska stor myckenhet på Alqvi|starna, som deraf sågo hvitaktiga ut, och på långt håll sảsom öfverväxta med mögel.

\section{Den 4 October.}

Om morgonen fortsatte jag vidare min resa, och hade nu mäst samma utseende af land som i går, nämligen en omväxling af något höga långsluttiga backar, som voro kullriga åt alla sidor, med dälder deremellan. Jordmon bestod af den tegelfärgade svartmyllan, utblandad med lera, samt här och der små Klappurstenar. Stundom reste jag genom skogar och skogslunder af allehanda slags löfträn, ibland öfver eller förbi små fält, der skogen blifvit bårthuggen, och nu voro antingen åkrar, ängar eller betesmarker. Gårdarna lågo här och der, antingen vid vägen, eller et litet stycke från den samma, med små ảkrar eller 
ängar emellan dem och vägen. Husen voro somligstäds af sten, ofta par våningar höga, täkte med takspån af den så kallade hvita Cedern; men merendels voro de af trä, och i stället för måssa hade de strukit Jer i såtorna, Spjeld fans ingenstäds, ej eller visste de hvad det var. Bakugnarne voro gemenligen murade litet från husen, och stodo antingen under öppen himmel, eller hade de skjul öfver sig. Åkrarna voro besådde dels med Bohvete, hvilket ännu stod oskurit, dels med Mays, dels med nyss sådt Hvete, dels lågo de i träde. Uppå åtskilliga trän hade villa vinrankor klängt sig up ända til toppen, | och hängde så ned på sidorna. Äfven voro åtskilliga af dem öfverdragne med Hedera quinquefolia (Linn. spec. 202.), hvilken klöf lika argt, som den andra. Den hade haft en myckenhet af bär i detta år; men de voro nu alla bårta, antingen foglar ätit dem, eller de fallit ned. Smilax laurifolia (Linn. spec. 1030) blandade sig mäst altid här tilhopa med nyssnämde Hedera, och lindade sig om träden. De mästa bladen på denna Hedera voro nu röda, men på Vinrankorna voro de ännu helt gröna. - De trän, som voro öfverdragne med dessa växter, syntes på långt håll likasom der humla hos oss växer, at en lätteligen kunnat misstaga dem för vill-humla. Vallnötträn och Castanieträn syntes allestäds vid gärdesgårdar, i skogar, och på backar, samt voro nu fulla med frukt. Persimon-trän stod äfven allestäds vid vägarna och i skogar, samt voro likaledes fulla med frukt, som dock ej ännu var matdugsen, emedan den icke blifvit frostbiten. Litet från Willmington for jag öfver en bro, bygd öfver en liten elf, som sedan faller i Dellaware, hvarest betaltes 2 pence för häst och Karl i Bropenningar. Vid middags-tid kom jag fram til Willmington.

Willmington är en liten stad, belägen ungefär 30 Ängelska mil i S. W. från Philadelphia på et behagligt ställe och anlagd år 1733. En del af staden är bygd på den jord, som hörer Svenska Kyrkan til, hvarföre grund/penningar årligen betales til bemälte Kyrka, hvilka sedan användas dels til Prästens lön,' dels til Kyrkans 
behof. Husen i staden äro merendels af sten, tämmeligen vackra; men nog glest omkring strödda, at stora fläckar än stå toma. Quäkarene hafva här en meeting. Svenska Kyrkan ligger en half Ängelsk mil utan för staden åt Öster, hvarom mera framdeles. Svenska Prästens hus är i staden. Tätt förbi Staden stryker en liten elf, kallad Christinæ-kil, och löper sedan ned till floden Dellaware. Från Willmington til Dellaware, då en följer nyssnämde Christinæ-kil, är ungefär 3 Ängelska mil. Denna Christinækil sades vara djup nog för de största fartyg, at komma ända up til Willmington. Han är grundast vid mynningen, der han faller i Dellaware; men sades ock vara der, vid ebb, 2 à $2 \frac{1}{2}$ famn djup. Längre up från mynningen är han på de flästa ställen 3 famnar djup, annorstädes $3 \frac{1}{2}$, ja ända til 4 famnar. De största skepp sades tryggt kunna lastade gá til och från staden med flod eller högt vatten. Fran Willmington kan helt tydeligen ses en stor del af floden Dellaware, saint huru skeppen seglade derpå. På ömse sidor om Christinæ-kil, mäst ända från fästningsverket ned til Dellaware, ligga sanka ängar, på hvilka de årligen bärga en myckenhet hö. Staden drifver någorlunda handel, och skulle ännu hafva tagit sig mera, om ej Philadelphia låge den så nära på ena sidan, och NewCastle på den andra, bägge äldre än denna stad.

Skantsen, eller den art af Fästningsverk, som de i denna sommarn anlagt vid Christinæ-kil litet från staden, då de fingo förnimma, at Franska och Spanska Kapare ärnade gå up åt floden, at hälsa på dem, ligger efter Sal. Herr Pastor Tranbergs berättelse på samma ställe, som de Svenske fordom haft sin skants: och var märkvärdigt, at då de i denna sommar hölt på at gräfva $i$ jorden vid skantsens anläggning, hafva de funnit bland annat en aln ned en gammal Svensk Silfverpenning, ej fyllest så stor som et rundstycke, slagen i Drottning Christinæ tid, hvilken penning Past. Tranberg sedan förärte mig; på ena sidan står Wase vapen, med omskrift CHRISTINA: D: G: DE: RE: SVE: samt på ömse sidor om vapnet årtalet 1633. och på andra sidan orden MONETA NOVA REGNI 
SVEC. en myckenhet af gammalt järn redskap, såsom yxor, spadar, hackor \&c. funnos ock. Denna skants bestod nu af bräd-plank med jordvallar utanföre. Krutmagazinet var der bredevid, i en Källare, murad af tegel. Synnerligt var, at ehuru Quäkerne uti sina Religions-satser fördöma alt både offensivt och defensivt Krig, åtskillige af dem likväl, när denna skants nu bygdes, och de stundeligen lefde i fara för fiendteliga Kapares infall, arbetade lika starkt på skantsverket, som de af andra religioner, och många af dem, som icke ville sjelfve arbeta, understödde i det stället desto mera med pennin|gar och andra förnödenheter, hvilket Pastor Tranberg, som under hela arbetet var närvarande, sjelf berättade mig.

\section{Den 5 October.}

Min afsigt var väl, at resa öfver floden Dellaware til New-Jersey, at bese landet derstädes; men, som ingen färga nu var til hands, på hvilken hästen kunde öfverföras, så begaf jag mig på återresan tilbaka til Philadelphia, och fölgde ibland stora vägen, ibland reste jag hit och dit, at bese landet, och göra hvarjehanda anmärkningar i Historia Naturali.

Mays såg jag vara planterad på åtskilliga ställen. Somligstäds hade de afskurit Mays-stjelkarna litet ofvanför axen, låtit dem torkas, och satt dem i smala höga stackar, at om vintern gifva Kreaturen. Nedre delen af stjelken hade väl ock haft blan; men som desse gemenligen torka snart bårt af sig sjelfva, så brukas de ej gerna til foder; emecian all kraft och must gått från dem; men de öfre skäras medan de ännu äro gröna.

Bäckar runno merendels uti dälderna emellan backarna; men de voro icke särdeles stora. De flästa voro så små, at ingen bro behöfdes, utan en kunde utan fara både rida och köra deröfver; emedan vatnet sällan var öfver et quarters djup.

Löfven på mäst alla trän voro ännu helt gröna, såsom på Ekar, Castanie-trän, svarta | Vallnötträn, Hickery, p. 281 
Tulipan- och Sassafras-trän, som bägge funnos i myckenhet på sidorna af skogsbackar, på de i linda lämnade åkrar, samt bredevid gärdes-gårdar, och vid vägar. Persimon-trän hade til en del gröna löf, men på en del voro de ock affallne. Löfven på Americanska Björnbärs-buskar voro nu mäst helt röda, dock hade ock en del dem ännu gröna. Hund-trä (Cornus florida) hade ock antingen bruna eller bleka löf. Röda Lönnens löf voro äfven röda.

Jag fortsatte sedan min resa ned til Chichester, som är en liten by ned vid elfven Dellaware, der de ock med färga fara öfver den samma. Vid denna by byggas åtskilliga små fartyg, som försäljas til andra. Hit nedföres och inskeppas Jern-stänger från et Jernbruk, som ligger här ofvanföre.

Canoër kallas här en art af båtar eller ökstockar, dem de på floden Dellaware, och andra mindre vatten här i landet mycket bruka, och dem bönder och andre, som ej äro desto förmögnare, betjena sig af. De äro utholkade af et stort stycke trä; göras antingen af röd En eller Ceder (Juniperus virginiana Linn. spec. 1039.) eller hvit En, eller Ceder (Cupressus thyoides Linn. spec. 1003.) eller af Castanie-trä, eller af hvit Ek, eller af Tulipan-trä; de af röd eller hvit En eller Ceder räknas vara bäst, emedan p. 282 de flyta gan|ska lätt på vatnet, och vara $i$ hela 20 åren, i synnerhet räknas den af röd En aldrabäst och varaktigast: de af Castanie-trä vara ock tämmeligen länge: de af hvit Ek gemenligen icke öfver 4 à 6 år, och som den är tung, så sjunker den för diupt; Gyllenträ är väl et stort trä, men duger ej härtil, emedan det suger vatten til sig. Af Tulipan-trä vara de näppeligen så länge som af hvit Ek. Sådana Canoër äro större eller mindre, alt som en behöfver: kunna bära 6 och flera man, men en får ej vara mycket bångstyrig uti dem, utan sitta vackert stilla ned $i$ botten, om en annars är mon om, at de ej skola rulla öfver ända. De Svenske, som bo uti Pensylvanien och New-Jersey vid floderna, hafva sällan andra båtar at fara up til Philadelphia med, som gemenligen sker 2 gångor i veckan til marknaderna, fast de ibland bo flera mil der- 
ifrån, och ibland tämeligen starka stormar infalla. Dock höres sällan några olyckor ske dermed, som väl annars af så litet påliteliga fartyg skulle väntas; men så fordras mycken försigtighet at handtera dem, när det blåser något hårdt; emedan de äro smala, kullriga eller runda under och utan köl, så at de helt lätt kunna tumla omkull. Då vädret blef något starkt, vågade de sig ej, at vara länge på elfven Dellaware, utan sökte land.

Nasturtium hort. växte somligstäds vid vägarna i Chichester, och hade tvifvelsutan | kommit dit af frön från p. 283 de många trä-gårdar, som voro der omkring.

\section{Americanska Björnbärs-buskar (Rubus Occidentalis} Linn. spec. 493.) växte här i orten til stor myckenhet: af de Svenska kallades den Thorn, och af somliga RännThorn. När de lämnat någon åker i linda, var denne en bland de förste, som lät infinna sig derpå. Jag fick ock ofta se den på de åkrar, som årligen plögdes och brukades; ty detta var et ledsamt ogräs der det en gång kommit in. Det ränner ibland långs åt jorden til 2, 3 à 4 famnars längd från sin rot, och derefter slår den vid ändan rot ned $i$ jorden, så at då någon vil draga up en sådan, har det en rot vid hvardera ändan. På somliga gamla åkrar och lindar är så fullt deraf, som sålunda slagit rot vid bägge ändar, at det är mer än besvärligt och äfventyrligt, at gå på sådana ställen, emedan fötterna fastna under des stjelkar, och der en då har den olyckan at falla, och slår händarna eler ansigtet emot en sådan stjelk, kan en snart blifva märkt mera än en vill af des många, stora och ganska hvassa taggar. Af bären göres vin, hvarom förr är talt. Eljest ätas de ock, då de äro mogna, och smaka väl. Annan nytta vet man ej at den äger.

Den 6 October.

Chenopodium anthe/minticum (Linn. spec. 220.) växte här i myckenhet så vid vägen, | som på stranden vid p. 284 elfven, dock på torra ställen uti lös sandaktig mull. De Ängelske, som här bodde, kallade det Wormseed, det är 
Mask-frö, samt Jerusalems Oak, d. ä. Jerusalems Ek. Den luktar obehageligt. Des frön brukas öfver alt i Pensylvanien och New-Jersey at gifvas in åt barn mot maskar, hvartil de äro förträffelige. Denna växt finnes eljest allmänt bade i Pensylvanien och New-Jersey.

Trä-gårdar voro i myckenhet vid Chichester. De stodo fulla med Äppel-trän, hvilka nu likasom suckade under sin börda af de många äpplen, hvarmed de voro belastade. Mästa delen af dem var vinter-äpplen, hvilka voro tjenlige at förvaras öfver vintern, och altså vid denna tiden mreket sura. Mäst vid alla bond-gårdar och andra gårdar här i landet var en sådan äppelträgård, och den merendels tämeligen stor, hradan ägaren hade god hjelp både til mat och dryck i sit hushåld för en stor del af àret. Jag förundrade mig ofta öfver folkets kloka eftertanka här i landet. Så snart någon tilhandlat sig något nytt land, derest hvarken var hus eller upbrukad jord förut, var gemenligen des aldraförsta göromål, at köpa sig unga äppelträds-stammar och anlägga en äppelträgård. Sedan började han först, at se sig om efter hus, och uptaga mark til åker. De risste at träden fordrade tid, och at den försigtighet måste följas som är anförd i denna p. 285 A/mer. Resas T. 1 p. 4t1. Vid denna tiden såg jag allestädes vid gårdarna qvarnar, hjul, vältar och andra machiner, at krossa sönder äplen med, samt prässar, at sedan göra Cider deraf.

Resan skedde sedan derifrản til Philadelphia.

Ekar gjorde i skogarna af alla trän största antalet. De voro af atskilliga slag; men alla skilda frản de Europæiska. Jag ság nu allestäds stora skảckar af Srin gå uti Ek-skogar och Lunder, och föda sig af Ek-ollon, som nu i myckenhet började falla ned. Alla Svin hade på halsen et trä-ok passadt $i$ en triangel, hvarigenom de hindrades at tränga sig igenom de glesa, men mycket behändiga. snart upsatta och litet verke fordrande gärdesgårdar, som här öfveralt brukades, och som ganska mycket likna fållkedjor. I Ek-skogarna lupo ock nu en myckenhet af de grả Ickornar. hrilka ibland höllo sig på marken. 
ibland up i träden, och födde sig denna tiden förnämligast af Ek-ollon.

Bok fants någon enda då och då, sả at de voro nog sällsynte. Den var af samma slag med den vi hafve uti Europa. Detta trädet hölts bland det förnämsta til höfvelskaft, eller til trä, at sätta höfvel-jern uti.

Myror. Uti Pensylvanien mins jag mig ej blifvit varse några andra myror, än For|mica atra, Linn. Faun. 1023 eller svarta myror. Desse voro kålsvarte, och äro af 2:ne slag, et helt små, som de smärsta af våra, och et större, af den storlek, som våra ordinaire rödbruna myror. Jag hade ännu ej blifvit varse några stackar eller ställen, där desse sammanbo, utan endast råkat någon enda här och der. På andra orter i America har jag dock sett andra slags myror, hvarom på sit ställe.

Ligustrum vulg. (Linn. Flor. Suec.) brukades här på ganska många ställen til häckar eller stängsel omkring åkrar och kryddgårdar. Jag såg på hela denna resan ej något annat trä, som brukades til häckar än detta, fast Ängelsmännerne visste berätta, at Hagtorn vore långt tjenligare dertil. Häckar af Ligustrum växa väl täta; men som det har inga taggar, så kunna Svinen och andra kreatur lätteligen krypa in derigenom, och dả de en gång brutit hål, är svårt, at få det sedan igenväxt så snart. Átminstone kunna ej Liguster-häckar stå mot bångstyriga kreatur: men äro häckarne af taggiga trän, betaga de dem merendels all lust, at söka tränga sig in.

Chester är en liten fläck, den jag reste igenom vid middagstid, belägen vid floden Dellaware. En liten å, som kommer up från landet, flyter genom denna fläcken, och faller så i nyssnämde flod. Öfver denna å är en liten bro. Husen äro strödde här och der, de flästa bygde af sten, 2 à 3 våningar höge; som|lige äro dock af trä. Uti byen är en Kyrka och et ställe der de hålla marknad.

Hvete var nu mäst allestäds sått. Somligstäds var redan stora brådden uppe, och Hvetet der utsått för 4 veckor tilbaka. Åkrarne för Hvetet voro mäst lagde på det Ängelska sättet, nämligen inga diken, utan täta vattu- 
fåror på åkern, ungefär 2 alnar, à 10 eller 12 qvarter emellan hvardera. Mäst allestäds på åkrarna stodo stora stubbar ännu qvar, til et tecken, at landet ej varit länge upbrukadt.

Trädens rötter gingo här ej djupt ned i jorden, utan lupo mäst horizontelt. På åtskilliga ställen, der de gräfvit, hade jag tillfälle, at se detta tydeligen. Jag kunde sällan eller nästan aldrig få se, at något trä gick med sin rot öfver et qvarters djup ned $\mathrm{i}$ jorden, som dock alt bestod af en fin lös mylla.

Jernbruk. Ungefär par Ängelska mil från Chester, reste jag förbi et Jernbruk, som låg strax på högra handen om vägen. Tvenne Bröder sades vara ägare härtil. Malmen fants icke här, utan 30 à 40 Ängelska mil härifrån, hvarest den smältes i masugnen, och galtarne föras sedan derifrån hit til bruket. Här var en hammare och 2 härdar, samt par bälgar vid hvar härd. Bälgarne voro mäst af läder. Hammare, härdar och bälgar voro nog p. 288 små i anseende til våra. Alt. | drefs med vatten. Jernet smiddes här til stänger.

Äplen. Jag märkte i dag, och sedan ofta på mina resor här i landet, at hästar voro nog snåla efter äpplen, så at då han släptes i en Äppelträgård af beta, der äpplen lågo nedfallna, lämnade han ofta det gröna frodiga gräset, och började göra sitt mål af äpplen; men de höllo dock denna mat mindre nyttig för dem, utom det, at det var nästan för dyrt foder.

Rödblommige Lönnen (Acer rubrum, Linn. spec. 1055) växte i myckenhet här i trakten. Des naturliga ställe var i synnerhet kärr och våtländta platser, och hade gemenligen Alen til följeslagare. Af sjelfva trädet göres tallrickar, spånråckar, rullar, stol- och säng-stolpar, ja, den brukas til hvarjehanda Svarfvare-arbete. Med barken färgas både ylle och linne mörkblått, i det barken kokas i vatten, sedan lägges koppar-rök (sådan som 'Hatt- och Skomakare bruka) deri, innan dermed färgas. Af barken göres äfven et godt svart bläck. När en om våren bittida hugger detta trä, rinner derutur et sött vatten eller laka, på 
samma sätt som af vår Björk, hvilken laka här ej brukas til något, men uti Canada koka de deraf både Sirap och Sảcker. Af denna Lönnen finnes en art eller variation, som här kallas curled Maple, d. ä. masurerad Lönn; emedan trädet inuti är likasom marmoreradt eller masureradt, och brukas | densamma ganska mycket til Snickare-arbete. Bureaux, klädskåp, allehanda slags skrin och bord etc. gjorde af denna curled Maple, hade företrädet framför alla dylika af något annat trä som här växte, och betaltes altid dyrare, än det, som var gjordt antingen af svart Valnöteträd eller Vilska Kersbärs-trän (Prunus Virginiana Linn. spec. 473); men om någon vil hafva dessa saker af curled Black Walnut-tree, eller masurerat svart Valnöt-trä, så blifva de dyrast; emedan de äro så rare. Denna curled Maple, eller masurerade Lönn, är tämmeligen rar, och sker ofta, at ytan på trädet är masurerad, men inuti ej; derföre hugga de förut djupt inuti trädet, innan de fälla detsamma, at se, om den är masurerad altigenom.

Om aftonen kom jag til Philadelphia.

\section{Den 7 October.}

Om morgonen reste vi med båt öfver Floden Dellaware til New-Jersey sidan. I färje-penningar betaltes 4 pence för hvar person. Landet på andra sidan om floden, eller i New-Jersey, var af en hel annan beskaffenhet från det i Pensylvanien; ty här bestod jordmon mäst af bara sand, då den deremot uti Pensylvanien är mycket utblandad med lera, samt nog fet. Beskrifningar och anmärkningar öfver örter och insecter, som gjordes i dag, lämnas til et annat verk.

Mays, som var planterad på denna torra sanden, der man skolat tyckt ingen ting kunnat för den starka torkan och magra jordmon växa, stod ganska härlig. Vi sågo stora fält planterade dermed. Jordmon var den, som Tobak mäst tycker om, endast, at den på långt när icke var så fet. Längden eller högden af Mays-stjelkarna var allmänt 4 alnar, ibland litet mer, ibland litet mindre, samt 
hel fulla med blan. De voro, som ordinairt, planterade i fyrkant och rader, allmänt 11 qvarter emellan hvar kupa eller ställe där de stodo, så i längd som bredd; mullen var ej karad up til roten eller stjelken i kupor, utan de hade plögt med plog deremellan, och så fört mullen mot stjelkarna. 3 à 4 stånd stodo gemenligen tilhopa, likasom $\mathrm{i}$ en kupa. Här voro stånden ej ännu afskurna til boskapsfoder. Hvart stånd hade 1, 2, 3 à 4 kornfulla stora ax med en myckenhet af korn uti. Aldrig kunde en så sandig jord bättre användas. På andra ställen var jorden emellan Maysen upkörd, och Råg sådd deri, så at då Maysen blef afskuren, stod marken grön af Råg.

Sparis funno vi växa här och der vid gärdesgårdar i lös jord, samt på obrukade åkrar af sand. Den växte likaledes i tämmelig myckenhet emellan Maysen, och var nu full med bär. Om den kommit hit af frön från Kryddgårdar, kan jag ej säga. Jag har dock funnit den växa vildt på andra ställen i America.

p. 291 Chenopodium anthe/minticum eller Wormseed, växte äfven i myckenhet vid vägar i sandjord vid färgan midt emot Philadelphia. Förut är sagdt, at dess frön brukas åt barn emot maskar. De lägga dem i bränvin, taga dem efter några timar ut, låta torka dem, gifva barnen in deraf, antingen i Siraps-dricka, eller någon annan dryck. Omdömen om dess nytta voro åtskillige. Somlige sade, at den dödar maskarna: andra, at den mera förorsakar maskar. Jag har dock med egna ögon sett, at den gjort förträffelig nytta mot maskar hos barn, och det flera gånger.

Portulaca, den vi annars pläga så i kryddgårdar, växte här i ganska stor myckenhet vildt, uti bara lösa sanden, emellan Maysen. Den stod eller kröp der, med nog tjocka och saftfulla stielkar, der man dock tycktes hafva orsak at undra, hvadan den tog sin föda på et så tort ställe. Eljest finnes den nog allmänt vildt på sådana ställen här i landet.

Bidens Americana apii folio, Tournef. kallades här Spanish needle, d. ä. Spanska nålar. Den fans här och der vid gårdar, vägar, gärdesgårdar, på åkerrenar och 
dylika ställen, och blomstrade ännu til en del; men mäst var den utblomstrad. När dess frö voro fullmogne, var rätt ledsamt, at gå på sådana ställen, der den stod i någon myckenhet; emedan des frö fäste sig vid kläderna, at de blefvo helt svarta deraf, hvarefter var svårt / at få dem ut. Hvart frö har på öfra ändan 3 tänder, och hvar tand är full med små tilbaka bögde taggar, med hvilka de fästa sig så starkt vid kläderna.

Formica rubra Linn. Faun. 1022 eller små röda myror, vandrade här och der i skogar, och på åkerrenar vid skogskanten: antenna longitudine corporis.

Om aftonen reste vi tilbaka til Philadelphia.

\section{Den 8 October.}

Ostron. De få här i landet ganska sköna Ostron. Denna tiden började de föra dem hit til Philadelphia at försäljas, och kommo från de orter, som ligga vid mynningen af floden Dellaware. Desse höllos här så goda, som de vid New-York, hvarom längre fram. Dock tyckte jag, at de vid New-York voro både större, fetare och välsmakligare. Ostron sades vara goda at ätas uti alla månader, uti hvilkas Latinska namn bokstafven $\mathrm{R}$ finnes, och troddes vara märkvärdigt, at de börjat här få dem, när de hetsiga och invärtes brännande febrar begynte återvända. Karlar gingo nu med skåttkärror fulla deraf, långs efter gatorna, och utropade dem til salu. Här var eljest rart, at få höra någon utbjuda på gatan, hvad han hade at sälja; men deremot var ingen ting allmännare i London. Sättet, at här äta ostron, var gemenligen, at de stekte dem på glöd til dess de började litet öpna sig. De åto sedan köt|tet uti dem tillika med en smörgås af mjukt p. 293 hvetebröd. Uti vänstra handen hade de en näsduk, serviette eller trasa, med hvilken de fattade i ostran, emedan hon utanpå var sotig af elden. Skalet kastades nu bårt; men fordom brändes Kalk deraf, det de nu hafva återvändt här at göra, sedan de funnit dess olägenhet, och hafva bättre materialier at göra Kalk af. Mig vistes Sten- 
hus här i staden, vid hvilkets upmurning de betjent sig af kalk, bränd af ostron-skal. Murarne hade nu den egenskap, at 2 à 3 dagar förr än rägn kom, begynte de så svettas och vätskas, at vatnet nästan kunnat krystas derutur. De tjente således för en viss Hygrometer. Flera, som bodt $\mathrm{i}$ hus, upmurade af sten med Ostronskals kalk, visste at tala om denna olägenhet.

\section{Den 9 October.}

Ärter sås nu ej mycket i Pensylvanien; men i forna tider, som gamle Svenske mig berättade, hade mäst hvar bonde sit lilla ärtland. Samma beskaffenhet är med New Jersey, och nedra delen af New York, hvarest de fordom sått nog ärter, fast de nu äro der i mindre bruk; men uti norra delen af New Yorks Province, eller omkring Albany, samt öfver hela det af Fransoser bebodde Canada, sås ärter i myckenhet, och trifvas ganska väl. Orsaken, hvi de uti Pensylvanien, New Jersey och nedra eller södra delen af New Yorks Province öfvergifvit, at cul-

p. 294 tivera en så nyttig | sädes-art, är et litet förakteligit insect, det de i forna dagar i nyssnämde Provincier icke särdeles vetat af; men som i senare tider ganska mycket förökt och inrotat sig. Detta har sin leke- och pare-tid om sommaren, då ärterna som bäst blomma och sätta skidor, då det lägger et litet ägg mäst i hvar späd grön ärt. När ärterna tröskas, kan ej märkas utanpå dem något fel; men skäras de sönder, så finnes gemenligen inuti dem en helt liten mask. Om denna mask får vara orubbad uti ärten, ligger han der qvar hela vintern och et stycke in på följande sommaren, på hvilken tid han småningom förtärer det mästa af kärnan, eller den äteliga delen af ärten; så at om våren näppeligen stort mer, än yttra tunna hinnan är qvar, då den ändteligen förvandlar sig til et skaligt insect, kryper ut genom hålet den gjort på ärten, och flyger ut, at söka up nya ärtland, vid hvilka det kan hålla sin bröllops-fäst, och förse sit alster med tilräckelig föda. Detta skadeliga kräk har från Pensyl- 
vanien flyttat sig längre och längre norr-åt, så at på de ställen i New-Yorks Province, der de för 12 à 15 år tilbaka icke visste af detta, och hvarest de hel tryggt och med synnerlig fördel fått en myckenhet ärter årligen, har det sedermera låtit infinna sig, och det småningom i den myckenhet, at invånarena blifvit nödsakade, at lämna bårt all ärt-såning, hvilket jag på flera ställen hörde folket med klagande berätta. De som bodde omkring Albany, hvars ärtland ännu | njuta fullkomlig frid, lefva i dagelig p. 295 fruktan at snart få besök af dessa gäster; emedan de märkt, at de årligen maka sig närmare til dessa orter. Jag vet ej, huru de skulle vela trifvas i Europa. Åtminstone tyckas våra Svenska vintrar kunna känna efter maskarna, fast de ock lågo uti ärten förvarade; men så äro ock vintrarne uti New Yorks Province, deras nu varande hemvist, ibland icke särdeles mildare än våra, och dessa odjur tiltaga dock der årligen och flytta sig ständigt närmare åt norr. Jag hade så när sjelf ovetande kommit at föra denna olyckan med mig til Europa. Vid afresan från America tog jag äfven några Såckerärter med mig uti en liten strut. De sågo helt täcka och vackra ut. När jag i Stockholm någon tid efter hemkomsten, eller d. 1 Aug. 1751, öpnade samma strut, fann jag alla ärter iholiga. Et insect i hvar ärt, tittade ut genom hålet, och somliga kröpo ut, at försöka et nytt Climat. Jag var glad jag fick i ögnablecket täppa igen struten, och afstäcka dessa skadedjurs utkomst, och tilstår, at jag vid strutens öpning och dessa insecters första påseende, blef mera häpen, än om jag deruti funnit en huggorm; ty jag visste hvad skada kunnat ske mit k. Fädernesland, om endast 2 eller 3 af dem sluppit ut. Efterkommande i flere generationer och på flera orter, hade då fått orsak at läsa förbannelsen öfver mig, som åstadkommit så mycken olycka. Jag sände sedan några af dessa, ganska väl förvarade, til Hans Excel|lence Herr Grefve Tessin, och til Herr Archiater Linnæeus, med bifogad berättelse hvad slags skadeliga djur de voro. Herr Archiater Linnaus har ock lämnat beskrifning på dem uti en Disputation, som ut- 
kommit under hans Præsidio, under namn Noxa insectorum, hvarest han p. 15 kallar det Bruchus Americo Septentrionalis. Synnerligt var, at uti hela struten fans ingen ärt, som ej var iholig. När de uti Pensylvanien förskrifva sig ärter utifrån, och så dem, hålla de sig gemenligen goda och maskfria första året; men det andra året de sås, börja dessa skadedjuren äfven innästla sig deruti. Önskeligt vore, at ej något af de skepp, som årligen gå från Pensylvanien eller New-York til Ängland, Irland, Scotland, Portugal, Spanien, Frankrike och Holland, någon gång komme at transportera dessa med sig öfver til Europa. Sålunda kan en se, hvad et enda förakteligt yrfä kan göra, och at Vetenskapen om Insecternes Oeconomie och egenskaper icke är at räkna bland fåfänga tidsfördrif och minare nyttiga idrotter.

Rhus radicans (Linn. spec. 266) är en buske eller trä, som växer ganska mycket här i landet. Han har samma egenskap som Murgrön, eller Hedera arborea, i så måtto, at han ej kan komma up från marken af sig sjelf, om han icke får något at klänga sig på, antingen trä, gärdesgård, vägg, eller något annat. Jag har sett, huru han i p. 297 skogarna klifver up efter | stora trän mäst ända til deras topp, och utslår öfver alt från sin stjelk eller lilla stam fullt med rötter, med hvilka han så fäster sig vid träden, at han nästan inväxer uti dem. Då han hugges af, flyter en gulbrun saft, af nog vedervärdig lukt, allestäds utur barken, der den blifvit afhuggen. Om bokstäfver eller andra figurer skrifves med denna saft på Linne, fästa de sig så fast, at de sedan ej kunna uttagas, utan ju mera linnet tvättas, ju svartare blifva bokstäfverna. Gåssar bruka mycket, at rita med samma saft namn på sina skjortor, skrifves därmed på papper, gå bokstäfverna likaledes aldrig ut, utan blifva med tiden alt mörkare och mörkare. Denna har samma oart och elaka egenskap, som den Rhus, hvilken förut är omtalt under d. 20 September, eller pag. 211, nämligen, at den är på visst sätt förgiftig för somliga, för andra icke, så at alla de egenskaper, som äro upnämde vid den förra Rhus, tilkommer äfven denna; 
dock lärer den förra vara något mera förgiftig, fast jag sett folk så upsvullna och illa medfarna endast af dennas rök, som någonsin af den andre, och at den ena Systren kunnat utan någon olägenhet handtera denna, huru hon velat; men den andra blifvit förgiftad, äfven endast af dess ånga, eller när hon kommit den en aln när, och ibland ej så när, allenast vädret blåst från busken på henne. På mig har han ej haft den minsta skadeliga verkan, ehuru jag både med små och äfven de aldrastörsta gjort | väl öfver par hundrade försök på mig sjelf, p. 298 ja så, at ock saften af dem råkat komma in uti mitt öga. På en annans hand, der jag smörgde ymnigt af dess saft, blef huden på samma ställe några timar derefter hård, nästan som barkat läder, och skalade sig de följande dagar bårt, som små fjäll, hvilka föllo löst.

\section{Den 11 October.}

Om morgonen fölgde jag Handelsman P. Kock ut til dess gård, 9 Ängelska mil från Philadelphia åt Norra sidan.

Anmärkningar vid Ekar och Träverke. Ehuru uti skogarna i Pensylvanien finnes et öfverflöd af Ekar, och af långt flere särskildta slag, än längre til Norr der i landet; så bygges dock i denna Province ej så många skepp, som längre emot Norr, enkannerligen uti Nya Ängland. Orsaken är, at förfarenheten lärt, at et och samma slags trä, ju längre til Norr det tages, ju mera varaktigt är det, och ju längre härdar det ut emot röta; men alt tvärtom, ju längre til Söder. Träna här i landet, längre til Söder, göra årligen långt starkare växt och tjockare saf-ringar, än de emot Norr. Et och samma slags trä, som växt uti de Södra Ängelska Provincier i America, har långt större pores, än det, som vuxit i de Norra Provincier. Detta är orsaken, hvi ej så många skepp byggas i Pensylvanien, som i Nya Ängland, och hvi flere i Pensylvanien, än i Virginien och Ma|ryland, och ändteligen p. 299 alt för få uti Carolina; utan de i Carolina förskaffa sig 
häldre skepp från nya Ängland. Skepp, som äro bygda här i Pensylvanien af deras bästa Ek, vara sällan öfver $6,8,10$, högst 12 år, innan de blifva så genomrutna, at ingen mer vil våga sig til sjöss med dem. Årligen fara väl åtskilliga Sjö-Capitainer från gamla Ängland öfver til Norra America, at låta bygga skepp; men så sker dock, at nästan alla af dem utvälja Nya Ängland dertil, såsom mäst åt Norr belägit. Ja, fast de ibland gå öfver til America på Philadelphiæ-skepp, begifva de sig dock straxt vid ankomsten til Pensylvanien Norr åt til Nya Ängland. Spaniorerna uti Westindien bygga sina skepp af et slags Ceder som der växer, och skal vara mycket god at stå emot röta, hvilken Ceder ej finnes i de Ängelska Provincier på fasta landet. Men ehuru uti Norra America gifves öfver 9 särskildta slags Ekar, så gå de dock alla tilhopa på långt när ej uti varaktighet och godhet up emot vår enda Svenska Ek; derföre kostar ock et skepp, byggt af Europeisk Ek, flera resor mera, än et af Americansk.

Rön vid Kryddgårds-växters frön. Åtskilliga, som härstädes idkade Kryddgảrds skötsel, hade i flere år försökt, at de Rödbetor, som uppvuxit af de frön, de låtit förskrifva från New-York, hafva blifvit mycket söta och behageliga; men om de sedan sått af de frön de hemma p. 300 hos sig sjelfva samlat efter desse / Rödbetor, hafva de mist efter par år ganska mycket af sin behaglighet, så at de blifvit nödsakade, at årligen låta inkomma från New-York så mycket Rödbete-frö de til sit behof tarfvat. Eljest hafva de i gemen funnit, at Kryddgårds-örter och växter, som upkomma af de frön, hvilka blifvit sände directe från Ängland, äro altid långt bättre, behagligare och välsmakligare, än de, som upväxa af de frön, hvilka blifvit samlade här i landet.

En Rädisa (Raphanus minor oblongus C. B.) stod i Handelsman Kocks Kryddgård, hvilken uti den lösa mullen så i växt tiltagit, at diametern af henne var 7 tum. En och hvar närvarande sade, at det var mindre vanligt, at se dem här så stora. 
Bermudas Poteter kallades här den art Convonvulus, som annars har namn af Batatas, (se Linn. spec. p. 154). De planterades här nu mycket af Gentlemen och Landtmän. Deras plantering och ans skedde mäst på samma sätt, som med ordinaire Poteter. Somliga gjorde liksom kupor af jord, hvaruti de om våren planterades. Andra gjorde sängarna helt släta. Jordmon bör vara en sandmylla, ej för fet, och ej för mager. Vid planteringen skäres desse rötter liksom andra Poteter i små stycken sönder, dock at et eller par ögon lämnas på hvar bit, innan den nedsättes. Deras färg är gemenligen röd utanpå; men gul | inuti. Til storlek merendels större än ordinaire p. 301 Poteter. De hafva en söt och ganska behagelig smak, som i mit tycke vida öfverträffar andra ordinaira Poteter, Jord-Arctichoker, ja nästan alla mig bekanta rötter, så at de lika som smälta uti mun. Det äro ej många år sedan de begynte plantera dem härstädes. De brukade dem til mat på samma sätt, som de ordinaira Poteter, antingen kokade för sig sjelfva, eller hopblandade med andra Poteter. Gemenligen ligga de upradade omkring köttet på kött- eller stekfaten. Ibland läggas de ock på fat för sig sjelfva. De växa här ganska fort och trifvas mycket väl; men den största svårigheten med dem är, at kunna præservera dem väl öfver vintern, ty de tola då ingen köld, ingen stark värma, ingen fuktighet. Derföre böra de förvaras uti sandlådor $\mathrm{i}$ et rum, som eldas om vintern. Här i Pensylvanien, der de gemenligen ej bruka något spjäll, sättas de $\mathrm{i}$ en sandlåda at stå et litet stycke från spisen, så at de ej få blifva för kalla eller för varma. At lägga dem $i$ torr sand, och förvara om vintertid uti Källare som andra Poteter, går ej an; emedan fuktigheten, som är i Källaren, drager sig in i sanden, hvilket är deras död, och hvaraf de skämmas bårt. I våra varma rum här $\mathrm{i}$ Sverige skulle förmodeligen vara mycket lätt, at om vinteren förvara dem, allenast vi först finge dem hit. Jag försedde mig väl med en hop vid afresan från America, och | tog alla mått, at väl förvara dem; men som vi rå- p. 302 kade ut för ovanliga stormar, som mycket skadde vårt 
skepp, at fuktigheten allestäds så trängde sig in, at vi mäst kunnat krysta vatten både utur våra egna och sängsamt andra kläder, sả var ej underligt, om desse då rutnade bårt; men som de nu äfven cultiveras i Portugal och Spanien, ja uti Ängland; så lärer det ej vara så svårt, at få dem hit til Sverige. Här i Pensylvanien brukade de $e j$, at göra en sådan dryck af dem, som Spaniorerne tilreda i sina Americanska nybyggen, hvilken Herr Miller beskrifver i sit Gardeners Dictionary under Convolvulus 17. och 18.

Pappersqvarn. - Vid en liten bäck hade Herr Kock en Pappersqvarn, hvarest tilverkades åtskillige slags gröfre Papper. Den var nu ut-arrenderad för 50. Pund Pensylvaniæ-mynt om året.

Hvarjehanda anmärkningar gjordes vid Stenarter och växter.

\section{11 October.}

Äppelträ. - Jag har förut berättat, at hvar bonde har merendels et mindre eller större antal af Äppelträn planterade omkring sin gård. Af dem får han årligen en myckenhet Äpplen, hvilka han dels försäljer, dels gör han Cider deraf, dels brukar han dem til mat, som Äpplepastey, tortor, mos, och mera dylikt; men så äro ej alla

p. 303 år, som | han får lika ymnoghet deraf. Detta år sades de på långt när ej fått den välsignelse af Äpplen, som de förre. Orsaken var den stora och starka torkan, som inföll förut i Maji månad, hvilken skadađae och torkade bårt blomman på Äppelträden. Örterna och gräset på marken blefvo likasom bårtbrände deraf.

Björnmåssa (Polytrichum Linn. flor. Suec. 868.) växte ganska mycket på våta och lågländta skogsängar, at de mångenstäds voro helt öfverdragne dermed, som på våra måslupna ängar. Likaledes växte den mången städs ymnigt på backar.

Åkerbruket var här på många ställen nog usselt. När någon köpt sig et nytt oupbrukadt land, der jorden, 
tör hända, sedan skapelsen ej blifvit uptagen til åker; så rögde han bårt skogen, bröt upp stubbarna, plögde upp marken, och besảdde den med säd. Den gaf dả i början ganska ymnigt; men då han utan något underhjelpande med gödsel besått honom några år, blef den ändteligen utmagrad. Den lades då i linda, och uptogs på annat ställe ny oupbrukad jord. Således hölt han uti, til dess han användt en god del af sina ägor til åker, så at mästa jorden blifvit utmärglad, då började han der ägorna voro någorlunda stora, ả nyo upplöja de stycken, som aldraförst blifvit lagde til linda, och som i några år fått hvila sig. Hvilka åter brukades til åker så länge de voro nảgot gifvan|de; men dả de voro utmattade, lades de i linda, och andra dylika stycken uptoges. Som de merendels låto boskapen här ga ute om sommar och vinter, bảde natt och dag, at på fälten och i skogarna söka sin föda; så blir ej mycket gödsel samlad, hvarmed åkern skal förbättras. Af det åkrarna sålundá lämnas flera år at ligga i linda, så fả allehanda slags ogräs bästa tilfälle, at der inrota och så sig, så at sedan många år gå förbi, innan de kunna utrotas. Häraf sker, at otaliga ogräs finnes här bland den sådda säden. Den rika svartmyllan, som de först hitkomne Europeer fingo, och som nästan aldrig förut varit med plog eller spada rörd, har likasom inplantat en alt för stor vårdslöshet vid åkerbruket hos ganska många här i landet, hvilka ej besinna, at då jorden en gång blir här aldeles utmagrad, skal det fordras mer än lång tid och mycket besvär, särdeles i denna orten, der Solen och den starka torkan mäst hvar sommar så häftigt bränner och förtärer alt, innan den skal kunna rätt repa sig. Jordmon på de upplögda åkrar härstädes bestod öfverst af en tunn svartmylla, ganska mycket utblandad med en tegelfärgad sandjord och lera, hvari fans en ymnoghet af söndermalen skimmer, hvilken kommit af den lösa skimmersten, som fans här mäst allestäds ned i jorden, 1, 2 och flera qvarter under öfversta jordbrynet. Af dessa små skimmerbitar gläntsade jorden ganska mycket då Solen sken derpå. 
Stenhus. - Nästan alla husen àt denna kanten voro bygde antingen af gråsten eller tegel. De fläste voro af gråsten. Germantown, som är en stad mot par Ängelska mil lång, var mäst bygd af gråsten: så ock gårdarna och husen allestäds deromkring. Den stenart, som här mäst brukades, var åtskillig: ibland bestod den af en svart eller grå i vågor gående skimmer, utblandad här och der, samt mer eller mindre emellan flagorna med en grå, lös, ganska fin-grynig Kalkstens art, som lätteligen lät måra sig sönder. Här och der syntes i den samma något ljust eller grått quartz-liorn. Skimmern var dock den, som här var mäst rådande. Detta stenslag var tämmeligen blött, så at de med järnhackor och andra verktyg helt lätt kunde hugga och jämna honom i hvad skapnad de ville. Ibland bestod den sten, de murade hus af, utaf en svart smågrynig skimmer, en hvit små-grynig kalksten, samt några quartz-korn här och der, alt blandadt väl om hvart annat. Ibland voro stora ränder af den hvita kalksten hel rena, utan skimmer; men mäst voro de jämnt blandade, och gjorde stenen grå. På somliga ställen bestod denna sten af helt fina och små svarta skimmer-particlar, jämt utblandade med en grå, lös, hel fin-grynig kalksten, som lät likaledes utan möda arbeta sig til åtskillig skapnad; emedan han var mycket lös och mör. Desse stenarter funnos merendels blandvis om hvarandra. De funnos väl | p. 306 mäst öfver alt, då en gräfde litet ned i jorden; men sả var den icke allestäds i lika myckenhet och af lika godhet, ej eller lika lätt at upgräfva. Derföre dả någon ville bygga et hus, gick han och pröfvade på flera ställen, at se hvar det var bäst, at bryta sten. Den fans och gräfdes up på åkrar och utmarker til 1, 2 à 3. alnars djup, hvarest han låg så i större som mindre stycken. Somlige voro af 4 à 5. alnars längd, en alns bredd, och en half alns tjocklek. De voro ock ibland mycket större. Andre voro mindre. Den låg här stratum-vis eller hvarf på hvarf. Högden eller tjockleken af hvart hvarf ungefär en half aln, ibland mer eller mindre. Längden och bredden skiljaktig, dock mäst som ofvan omrördt är. Gemenligen måsté 
en gräfva til 6 à 8 qvarters djup genom jorden, innan en kom til första hvarfvet; dock rảkar man uti den lösa jorden, ofvanpå, fullt med små stycken af samma stenslag. Denna jorden, som ligger öfver stenen, är den här i landet öfver alt befinteliga tegelfärgade myllan, som består af sand och lera tilhopa blandade, dock at sanden är härskande. Deruti finnes fullt med små lösa skimmer-particlar, likasom de kommit af dessa stenar söndermalne. Det är altså af detta stenslag, som husen här upmuras. Hvar Landtman finner gemenligen på sina ägor nog häraf. Husen upmuras på vanligt sätt, och laga de gemenligen så, at den jämna eller släta sidan af stenen vändes utåt; | men som detta ej altid låter sig göra, emedan stenen ofta är på alla sidor ojämn; sả hugges de jämna och slätas med järnhackor, hvilket utan särdeles möda sker, emedan stenen är blöt och mycket lätt låter hugga sig. Aldenstund hvarfven af denna sten äro af olika tjocklek, så kunna de ej altid vid murningen, få alla hvarf, och lerbruket emellan dem, så noga efter vattupass och $i$ en rät linea, som det med tegel sker. Äfven händer ock här ibland, då stenen hugges jämn, at stycken spjelkas utur honom, hvilka då göra gropar på yttra sidan af muren. At bota alt detta, slå och bulta de med en järnhammare de mindre stenstycken, (som de icke så just kunna bruka vid murningen), til et fint pulver, blanda det väl tilsamman med något murbruk, och slå deraf i groparna emellan stenarna på yttra sidan af muren, samt göra det med murslefven slätt och jämt. När detta blifvit torrt, kan det et stycke bårt svårligen skiljas frản sjelfva stenen; emedan det mäst består af samma stenslag, som muren. De draga sedan med snöre băde horizontela och perpendiculaira ränder af hvit kalk på muren utantil, at ingen kan annat se, än muren vore upsatt af jämnhuggen quadresten, samt at det hvita är kalkbandet deremellan. Inra sidan på huset göres slät, kalkbeslås och hvitlimas. Det har ej märkts, at denna sten fuktar eller vätskar sig mot rägn eller nederbörd. Åtskillige hus i Philadelphia, samt mer än många på landet, rundt derom / kring äro upmurade deraf. Vid Ängelska p. 308 
husbyggnaden här på orten märkes ännu följande: 1) Gemenligen byggdes husen altid så, at det nedersta rumet var aldeles under jorden. Des grund-väggar nästan altid murade af förenämde stenslag, fast ock huset der ofvanpå var af tegel. Detta nedersta rummet eller vảningen brukades ibland til kök; men mäst antingen til källare, eller skafferie och visthus, eller vedbod, eller för Köpmän at förvara allehanda varor uti. 2) Öfverst på vảningen var ingen, egenteligen så kallad, skulle; utan byggningen var så gjord, at der voro rum, at bo och vistas uti, ända til sjelfva yttra taket, så at i det stället hos oss är öfverst en mäst obrukbar skulle, var här någon kammare, merendels med spis uti, fast fönstret ibland var utbygt, som en vindsglugg, âtminstone kunde legofolket om sommaren beqvämt vistas där, och dessutom kunde en altid hålla där kläder och andra husgerảd. 3) Der spisen uti salar eller förmak var bygd midt på nảgondera af gafvelväggarna, var på ömse sidor om den samma, hvarest hos oss är allenast en öppen vrả, at ställa ved eller stolar uti, här med bräder gående parallelt med gafvelväggen igenbygt och gjordt til skåp, at der förvara et och annat. 4) Fönsterna voro så gjorde, at uti en glugg eller öpning satt det ena ofvan- och det andra nedanföre. När en då ville öpna Fönstret, fördes det nedre upp, så at det kom at p. 309 sitta jämnt vid | och innanföre det öfra, hvilket skedde så, at det lopp i ramarna pả ömse sidor, och hielptes vid upskjutningen af et bly-lod, som lopp innan för fönsterkarmen uti väggen. Ofta voro fönsterne så gjorde, at det nedra kunde föras up, och det öfra dragas ned, alt som en åstundade antingen det öfra eller nedra fönstret öppet. De fördes mäst på samma sätt upp och ned, som hos oss fönsterna på vagnsdörar. Detta sätt, at öpna fönster, tyckes vara långt beqvämare, än det, som brukas hos oss med gångjärn och hakar. Man behöfver ej frukta, at en hastig oförmodad väderpust skal nedkasta eller sönderbryta det öpnade fönstret. Utsigten på sidorna hindras ej så här, som i våra, då en ibland, fast fönstret står öppet, likafullt måst se genom glaset, när en vil se til 
den sidan, der fönstret sitter på hakarna häftadt. 5) Mästa delen af husen i Philadelphia voro byggde af tegel, och begynte de äfven på landet bygga mycket tegel-hus; emedan här fans så skönt ler, at slå tegel af. At utanpå hvit-lima eller kalk-slå husen, var här ej brukeligt. Jag såg näppeligen $\mathrm{i}$ hela Philadelphia något enda hus, som utanpå var kalkslagit, utan de sågo ut, som en hop gamla stenhus och Kyrkor hos oss, nämligen af den färg tegelstenarne äro, med kalkbruk emellan. Det märktes ock ej, at muren tagit någon skada af luften och väderleken. På lika sätt syntes ock ingen korsten i Philadelphia utanpå hvitlimad eller kalk-slagen.

Gräfsvin. - En af Herr Kocks Negrar viste mig et p. 310 skinn af et gräfsvin, som han slagit ihjäl för några dagar tilbaka. Jag kunde ej af skinnet finna någon skilnad emellan detta och våra gräfsvin i Sverige. Det kallades här Ground Hog.

Om aftonen reste jag tilbaka til Philadelphia.

\section{12 October.}

Om morgonen spatserade vi ut àt Skullkils sidan, dels at samla frön, dels at inlägga örter, dels at göra andra observationer. Skullkil är en smal Elf, som faller ned i Dellaware flod, ungefär 4 Ängelska mil nedanföre och Söder om Philadelphia; men ehuru smal den är, tager den dock sin början på W. sidan om de höga så kallade Blå Bärgen, mot par hundrade Ängelska mil härifrån åt W. om ej än längre bårt. Det är en skada för landet, at der äro redan straxt litet från Philadelphia flera forssar och fall uti denna Elf, som göra den nu odugelig til segelfart. I dag gjordes Beskrifningar på örter och anmärkningar vid växter, som boskapen antingen åto, eller ständigt lämnade stå oätna.

Mullvad. Mullvadsgångar. Här och der såg jag på fälten helt små gångar, som lupo under jorden hit och dit i allehanda krokar och grenar. Hålet var så stort, som för en mullvad. Mullen ligger ofvanpå denna gån|gen p. 311 
uti en liten vall eller uphögning af 2 à 3 tvärfingers högd, och en god tvärhands bredd. Tjockleken af mullen ofvanpå gången 1 à 2 tvärfinger. Ofta såg jag stora fläckar på utmarkerna, som äro fulla med sådana gångar, hvilket kan skönjas af bankarna, som äro upkastade. När en stiger på en sådan, faller mullen ned, så at det är besvärligt, at gå på sådana ställen. De göras af en art Mullvadar, dem jag uti et annat verk skal beskrifva. Allehanda matdugsna rötter äro i synnerhet dess föda. Af en, jag haft fast, har jag märkt följande egenskaper: Han var styfvare $\mathrm{i}$ benen, och hade uti dem en starkare kraft, än många djur, i proportion til deras storlek, äga. När han ville krafsa sig fram, hölt han altid fötterna snedt, som áror. Jag lade min näsduk för honom, då han med nosen började likasom vela böka sig in i den samma. Jag tog strax bårt näsduken: at se hvad han gjort, och dả hade han, nästan inom en minuts tid, bårat en stor hop hảl på den samma. De voro borade i den skapnad, som hade man med en pril gjort en hop hảl pá näsduken. Pả asklåcket, hvari han lades, Inåste jag lägga flera böcker, annar's lyfte han det upp, som ingen ting. Han var mycket argsint, sả at dả något låg eller sattes honom i vägen, der han ville fram, bet han djupa gropar deruti. När jag satt mitt pennfoder af stål för honom; bet han i början p. 312 helt hvast och argt deri; men då han förnam, huru ! hårdt det var, kunde jag sedan ej förmả honom at bita, hvarken i det eller något annat. Desse mullvadar kasta ej up sảdana högar, som vàra Europæiske, utan göra endast dylika gångar, som nyss äro omtalte.

\section{Den 13 October.}

Talgbuske kallades här af de Svenska en art af Porss, af hvilkens bär man fâr et slags vax eller talg. Af de Ängelska kallas den dels Candleberry-tree, dels Bayberrybush, och af Herr Archiater Linswus uti dess Spec. plant. Myrica cerifera. Den växer på somliga ställen ymnigt på lågländt land i våt-däfvig sandjord, och tyckes den 
vara en älskare af hafsluft; emedan jag aldrig funnit den, långt upp i landet, från hafvet. Honbusken har gemenligen en myckenhet bär, hvilka se ut utanpå, som sute hvitt mjöl på dem. Desse samlas om sena hösten, dả de äro mogne, och kastas i en kettel eller gryta med kokhett vatten, då det feta smälter af bären, och flyter ofvanpå vatnet, hvadan det skummas, och lägges i et särskilt käril. Sedan fortfares at afskumma detta pả vatnet flytande fettet, til dess intet mer är qvar. När detta fett stelnar, liknar det talg eller vax, och har gemenligen en smutsig grön färg. Det upsmältes sedan alt tilhopa och skires, då det får en vacker och tämligen genomskinlig grön färg. Denna talg eller vax är dyrare än ordinair talg; men dock ej så dyr som vax. Uti Phi|ladelphia betaltes denna tiden en skilling i Pensylvaniæ mynt för sklp. af denna, men för et sklp. talg endast en half skilling. Deremot kostade vax mot par skillingar sklp. Af denna talg göres ljus på många ställen här i Landet. Gemenligen blandas vid ljusstöpningen ordinair talg och denna tilhopa. Ljus, sảlunda gjorde, böjas ej, ej eller smälta de sả snart om heta sommaren, som af ordinair talg: brinna nästan bättre och räcka längre än talg-ljus, samt osa ej som de, utan gifva tvärt om en behagelig lukt frản sig, dả de råka blảsas ut eller slåckna. En gammal Svensk af 91 års ålder berättade här mig, at de Svenske fordom ganska mycket brukat ljus, gjorde häraf; men nu betjena de sig ej så mycket deraf, när de kunna hafva tilgång på talg; emedan det fordras så mycket besvär vid bärens samlande; dock ser man sådana ljus nog hos fattigt Folk, som bo der desse i ymnoghet växa, och icke hafva råd til talgljus af egen boskap. Tvål göres ock nog häraf, som har en behagelig lukt, och är den bästa at bruka vid rakning. Af Medicis och Fältschärer brukas detta vax mycket, hvilka berömma det högeligen, som ganska skönt til Plåster för sårs helande. En Köpman här i staden sände en myckenhet ljus, gjorde häraf, til de Catholska länderna i America, och mente sig få dem väl betalte, emedan de bränna vaxljus i sina Kyrkor; men deras 
Präster ville icke köpa dem dertil. En utgammal Svensk p. 314 berättade / mig, at Villarne fordom brukat roten mot tandvärk, och då han en gång varit mycket plågat af samma sjukdom, har han tagit roten, klufvit den samma, och bundit om tanden, då värken saktat sig. En annan sade sig sluppit tandvärken dermed, at han skrapat barken af dennas rötter, och lagt på tanden som värkte. Utom det, at de uti Carolina göra ljus af denna talg, bruka de äfven at tilreda lack deraf til allehanda sakers försegling.

\section{14 October.}

Penny Royal kallades en ört af en ganska stark och synnerlig lukt, som til största myckenhet växte pả torra ställen här i landet. Af Botanicis heter han Melissa pulegioides (Linn. spec. 593.) Hon berömdes för vara ganska skön, at intaga eller bruka som Thée, när en pả nảgot sätt kylt sig, eller eljest, då en behöfde svettas; emedan hon befordrade svetten ganska mycket. När någon hade sveda eller värk i någon lem, sades hon ock vara härlig at böna det stället med.

Nya Änglands Producter til London äro enkannerligen följande: åtskillig slags fisk, som de fånga både vid New Foundland och annorstäds: âtskillig slags Tran, Valfiskben, Tjära, Beck, Master, nya skepp, af hvilka der årligen byggas en stor hop: något litet skinvaror: ibland något annat träverke. Til Ängelska öarna Jamaica, Barp. 315 bados \&c. utskep/pas från nya Ängland Fisk, Kött, smör, ost, talg, hästar, boskap, allehanda slags trävercke, såar, kar, ämbare, kimbar, m. m. De taga från dessa öar tilbaka Rum, Såcker, Sirap och andra samma öars producter, eller ock reda penningar, af hvilket alt det mästa, i synnerhet hvad penningarna angår, sändes öfver til London, at der betala hvad de af gamla Änglands fabricerade varor unfå, til hvilkas betalning detta alt ändock ej vil så aldeles förslå. 


\section{15 October.}

Al växte här i tämmelig myckenhet på våta och lågländta ställen, äfven ibland på nog höglända; men den hant dock aldrig til et så stort trä, som hos oss i Europa; utan stod merendels som en buske, sällan öfver en famns högd, och nästan aldrig högre än 2. famnar. Herr Bartram, och andre, som mycket rest omkring här i landet, visste berätta, at ju längre en reser åt Söder, ju kårtare och mindre blifver hon; men tvärtom, är hon af mycket större längd och tiocklek längre àt Norr. Jag fann ock sedan, at hon på somliga ställen i Canada var mäst så hög, som våra Svenska. Med dess bark färgades här rödt eller brunt. En af de Svenske förtälde mig, at då han en gång huggit sig uti benet ända in til benpipan, at sammanlupen blod samlat sig derinnanföre, har han på andras inrådan tagit Al-bark, kokat, och med decocten tvättat / såret som oftast, hvarigenom hans ben blifvit bättre, ehuru det $i$ början såg nog illa ut.

Phytolacca Linn. hort. Ups. 117 kallades af Angelsmännerne Poke. De Svenske hade intet särskilt namn derpå, utan brukade samma namn, soin de Ängelske, och nämde henne Påk. När saften kramas utur bären på papper eller något annat, gifva de en hög skön röd eller purpurfärg, at näppeligen täckare kan gifvas; men olyckan är, at man ännu ej funnit på något medel eller uptäckt något sätt, at väl fästa färgen deraf på ylle eller Linne; ty den har ännu den egenskap, at den helt snart blekes ut. Herr Bartram berättade, at han en gång kommit at stöta sit ben mot en sten, hvaraf han fått en olidelig värk. Han hade då bundit allenast et blad af denna ört derpå, hvarigenom värken och svedan efter en liten stund försvunnit, och hans ben blifvit bättre. Bären ätas denna tiden af åtskillige foglar. Ängelsmännerne och äfven en stor del af de Svenska taga bladen om Våren, då de nyss uprunnit och ännu äro mjuka eller späda, och bruka dem dels til grönkål, dels på sätt, som vi Spinat. Ofta betjena de sig ock deraf til grönkål, fast stjälken blifvit litet längre; i 
det de bryta af de öfversta gröna skåtten, som äro mjuka och ej ännu blifvit träaktiga, och koka dem. Men vid detta senare bör en vara mycket varsam; ty om örten p. 317 brukas til mat, sedan hon blifvit stor, | och bladen mera icke äro så mjuke eller späde, kan en snart äta sit sista mål; emedan hon hafver då den kraft, at ganska starkt purgera. Jag känner dem, som deraf, at de ätit grönkål af gamla och stora blan, fått en så stark purgation, at de sa nära satt lifvet til. Sålunda ätes hon utan någon olägenhet, så länge hon ännu är späd; men är mäst et förgift, när hon blir stor. Bären pläga dock af barn ätas ibland om hösterna utan nảgon särdeles fara.

Til gul färg på ylle och Linne togs barken af Hickery, och brukades på vanligt sätt, då färgen blef skön. Barken af den svarta Eken äfvenså (Quercus Linn. spec. 996. sp. 9.). Likaledes togo de af Impatiens Gron. flor. Virg. 108. băde blommor och blan, hvilka brukades på vanligt sätt, och gofvo ylle en vacker gul färg.

Collinsonia Linn. spec. 28. fans ymnogt uti skogslunder och buskar i god fet jord. Den älskade mäst skugg-rika ställen. Herr Bartram, som mycket rest här i landet, påstod, at Pensylvanien, och de orter af America, som ligga under samma Pol-högd dermed, vore dess rätta och naturliga hemvist; ty längre til Söder hade hvarken han, Herr Clayton eller Dr. Mittchel funnit henne, hvilka 2:ne sistnämde likväl tämmeligen noga genomfarit Virginien och en del af Maryland; och mycket längre til p. 318 Norr hade han sjelf ej blifvit den varse. | Det längsta til Norr jag sett henne, har varit ungefär 15. minuter Norr om den 43. grad. Latit. Bor. Årstiden i Pensylvanien är sådan, at hennes frön hinna der som knappast mogna, derföre tyckes hon ej kunna komma fort mycket långt til Norr. Herr Bartram var den förste, som uptäckt henne, och sändt henne til Europa. Hon är först af Herr Jussieu, då han var i London, och sedan af Hr. Archiater Linnæus kallad Collinsonia, efter den berömda Quakaren och Ängelska Handelsman Herr Peter Collinson i London, Ledamot af den Ängelska Vetenskaps Societeten, och Sv. 
Vetenskaps Academien, hvilken ganska väl har förtjent, at hafva en ört nämnd efter sit namn; emedan han har haft och hafver ganska få sina likar, som så högt främjat Natural Historien och alla nyttiga Vetenskaper, och som användt så mycket penningar til at upleta, cultivera och kringsprida allehanda örter, som han gjordt och gör. Denna ört har en alt för synnerlig lukt, som är behagelig, men tillika mycket stark. Hos mig hade han nästan altid den verkan, at då jag kom at resa, der denne i myckenhet växte, fick jag (i synnerhet då hon stod i blomma) en tämmelig stark hufvudvärk. Herr Bartram berättade, at hon vore makalös vid allehanda slags värk, at då böna stället och lemmen dermed; likaledes om någon kylt sig. Herr Conr. Weisser, Tolk för Villarna uti Pensylvanien, har berättat för Herr Bartram, at då han en gång | varit hos Villarna, och en af dem blifvit biten af en Skallerorm, hade de andre Villar gifvit honom förlorad; men han hade tagit denna Collinsonia, kokat och gifvit den sjuka decocten at dricka, hvaraf han kommit sig före. Längre til Norr och i New York kallas denna Horse-weed, eller häst-ört, emedan hästarne om våren äta henne, innan andra örter komma fram.

\section{16 October.}

Tillandningar. - Jag frågade Herr Benj. Franklin och åtskilliga andra, som länge vistats här i landet, om de hade några spår dertil, at vatnet fordom stått, der nu är torrt land? Mig gafs härpå följande svar: när en reser härifrån öfver landet til Söder, kommer en at färdas på et ställe, der landsvägen går vid en backe djupt ned i jorden, och på ömse sidor om den samma består backen ej af annat, än bara Ostron- och mussel-skal i oändelig myckenhet. Detta stället ligger dock ganska många mil från hafvet. Vid brunnars gräfning och husbyggnad här i staden har man funnit, at jorden ligger uti åtskilliga strata eller hvarf: at til 14 fots djup och mera ligga kullriga och runda stenar, hvilka utanpå äro så släta som 
de, hvilka pläga finnas på sjö- och hafsstränder, och der af vatnet så svarfvas och slätas: at sedan de på somliga ställen gräfvit sig igenom sanden, och kommit ned til 14, p. 32016,18 och flera fots djup, möter en sådan | gyttja, som plägar ligga vid sjöstränder, och på sjö- och Elfs-botnar, och är denna gyttja helt full af trän, stubbar, löf, qvistar, rör (arundo), kål af brändt trä, m. m. At nya hus börjat på somliga ställen efter någon tid sjunka på en sida, så at de nödgats rifva det ned, och då de derefter velat gräfva djupare, at få stadig grund til huset, har mött längre ned en myckenhet af förenämde sjö-gyttja, trän, stubbar \&c. af hvilket alt man tyckes hafva anledning at sluta, det de ställen här i Philadelphia, som nu ligga 14 . och flera fot under jordbrynet, i forna tider varit en sjöbotten, öfver hvilken sand och annat af hvarjehanda händelser kommit at föras; eller at floden Dellaware dá varit mycket bredare än nu, eller at den något ändrat sin gång, hvilket han ännu ofta gör, i det han äter bårt mullen vid sidorna på et ställe, och lägger den på et annat, hvarpå mig vistes flera ställen och prof, så af Svenska som Ängelsmän.

\section{18 October.}

Botaniska anmärkningar. Nu fann jag ej här mera, än 10. särskildta slags växter, som ännu stodo i blomma, nämligen en Gentiana, 2:ne Asteres, Solidago vulgatiss. et Hieracium Oxalis lut. Digitalis purp. Hamamelis, samt vår Achillea eller Millefol. vulg. och vår Leontodon eller Dens leonis vulg. Alla andra hade nu för detta året här p. 321 slutit sin blomstertid. Åtskillige trän, i synnerhet / de, som följande Våren skulle vara bland de första, at fira sina Bröllop, hade nu satt så stora blomknoppar för nästa år, at då de öpnades, funnos deri alla partes fructificationis ganska tydeliga, som calyx, corolla, stamina och pistillum, så at det redan var helt lätt, at determinera til hvad Genus et sådant trä skulle höra. Sådane voro: Acer rubrum, Laurus astivalis, och flera andra; så at naturen 
likasom gjorde sig färdig, at med första tilfälle följande år vara $\mathrm{i}$ stånd at frambringa blomster. Desse blomknoppar voro nu helt hårda, deras delar packade tätt tilhopa och på hvarandra, at kölden derigenom på alt sätt måtte från dem utestängas.

Svarta Valnötträn hade nu til en stor del fält sina löf, ja så, at många af dem stodo nu helt nakna. Valnotterne hade ock til en del fallit ned. Det gröna skalet, som var omkring nötterna, hade en synnerlig egenskap at svärta händerna, då de handterades, sả at denna svärtan ofta på 2 à 3 veckor icke gick frản fingerna, fast en tvättade sig aldrig så väl. Det var ej särdeles rådligt, at bära dessa nötter med det gröna skalet omkring dem uti något kläde, om en ej ville at det skulle skämmas bårt.

Hundträ, (Cornus florida Linn. Spec. 117.) så kalladt af de Svenska här på orten, och Dogwood af Ängelsmän, växte nog uti skogarna härstädes. Detta har ej liten prydnad, då det om Våren prålar med sina stora, mån/ga och snöhvita blommor. Sjelfva trädet är ganska hårdt, brukas til Väfspolar, hyflar, viggar och åtskilligt annat. När boskapen om Våren ragla af vanmägtighet, taga somlige en vidja deraf och binda om nacken på dem, dả de tro, at det skal hjelpa.

\section{19 October.}

Tulipan-trädet växte i skogarna öfveralt här i landet. Hos Örtekännare har det namn af Liriodendron (Linn. spec. 535) och Arbor Tulipifera; emedan dess blommor både i storlek, utvärtes skapnad, och äfven någorlunda til färg liknar Tulipaner. De Svenske kallade det Canöe-trä, eller med abbreviation Knu-trä; emedan sả Villarne som Europeerne härstädes bruka, at deraf uthollka sina Canöer, eller små båtar och ökståckar, om hvilka är talt tilförene pag. 281. Ängelsmännerne här i Pensylvanien kalla det gemenligen Poplar. Det räknas för vara det träd, som växer til största högd och tjocklek af alla trän i Norra America, och som altid täflar derutinnan med våra största 
trän i Europa; dock vela Hvita Eken och Hvita Furun här i landet icke mycket gifva det efter. Det kan derföre icke vara annat, än nöjsamt, at om Vårtiden, eller vid slutet af Maij månad, efter nya stylen, då denna står i blomma, se et af de största trän, som i verlden gifves, för par veckor vara fullt med blommor, som til skapnad, storlek och någorlunda färg likna Tulipaner. Löfven hafva p. 323 ock en | mycket synnerlig skapnad från andra träns, hvadan trädet ock på några ställen kallas af Ängelsmän Old womans smock, d. ä. en gammal kärings lintyg; emedan löfven hafva utseende något dit åt. Nyttan af detta trä är här åtskilligt. De göra häraf Canöer eller utholkade båtar, bräder, plankor, blåck åt skepp, skålar, fat, slefvar, dörträn, fönsterträn, och til mângfalligt Snickare-arbete. Jag. har sett en tämmelig stor Sädeslada, som hel och hållen, med tak och väggar, var gjord af et enda trä häraf, söndersảgadt til bräder. Snickare hålla detta för bättre än Ek; emedan Ek vil draga och vinda sig, men detta ej. Desutom är det lätt at arbeta. En del Snickare hålla detta trä ej så aldeles godt; emedan det af tort väder sâ drager sig tilhopa, at stora springor blifva emellan bräderna, och af vătt väder sväller det ut, at det nästan vil spricka; så at man näppeligen visste nảgot trä här pả orten, som i svällande och hopdragande går så långt som detta. Sảant oaktadt brukas det dock nog af dem, nämligen Snickare, hvilka häraf gjorde 2 slag, som dock icke är annat, än 2:ne variationer, nämligen, en som är gul inuti, dá den blir gammal, och den andra, som är hvit. Den gulare sades vara lösare än den hvita. Barken kunde delas i ganska tunna rimsor, den ena inom den andra, nästan likasom det sker med Marien-glas, var dessutom mäst så p. 324 seg som bast; men jag märkte ingenstädes, at de / betjente sig deraf til det samma, som bast. Mot hufvudvärk tagas löfven, krossas sönder, läggas omkring hufvudet. För hästar, som hafva maskar, krossas barken sönder, och gifves in torr. Månge tro, at barken af dess rötter skal vara så god mot frossan, som China-barken. Det växer 
mäst i allehanda slags jordmon, så på torra och högländta, som på lågländta ställen; dock trifs det ej i mycket våt jord.

\section{Den 20 October.}

Bäfverträdet fans på åtskilliga ställen uti Pensylvanien och New Jersey. Växte uti magra kärr och på våta ängar. På Latin kallas det Magnolia foliis ovatolanceolatis. Se Herr Archiat. Linnæi hort. Cliff. p. 222. De Svenske som här bodde, kallade det Bäfverträ, och Ängelsmännerne Beawer-Tree; emedan Bäfrar ganska gerna äta dess bark, hvarföre den ock brukas til agn eller bete uti Bäfverfällor. Somlige af de Svänska kallade det KärrSaltenbross. Af en del Angelska hette det Swamp-Sassafras, af andra åter White Laurel. De gamla trän fälla nog bittida om hösten sina löf; men somlige af de unga behålla dem hela vintern. Jag har ej funnit det mycket Norr om Pensylvanien. Detta trä börjar här at blomma mot slutet af Maij månad n. st. då blommorne gifva frản sig den behageligaste lukt i verlden. En kan mäst på en Svensk ảttondedels mils väg, om ej mera, i fall vädret ej hindrar, helt lätt veta om nå|got af dessa små trän är i nägden, af den mer än söta och ljufliga lukt, hvaraf hela luften är upfyld. Det kan knapt med orden utsäjas huru behagelig den tiden är, at här resa genom skogarna, i synnerhet mot aftnarna. De stå gemenligen 2 à 3 veckor sålunda i blomma, och ibland mera, alt efter rummet de växa på, och utsprida hela den tiden sin lifgifvande ånga. Bären se täcka ut, då de äro mogne och sitta på trädet; ty de äro af en vacker röd färg, och hänga som i klasar på smala trådar. Til bot för hosta och allehanda sjukdomar i bröstet, tages bären, lägges i Rum eller bränvin hvaraf en sup tages in om morgonen. Detta berömdes mäst af alla ganska högt, ja de sade, at det samma vore mycket godt mot Lungsot. Barken lagd i bränvin, eller kokad i någon annan liqueur, och drucken, sades ej allenast vara god för förenämde bröst-sjukdomar, utan ock ganska skön för allehanda invärtes värk, stick och bränne 
eller hetta. Barken kokad, och decocten deraf drucken, berättades vara god mot diarrhoée. Mot köld eller catharrhe berömdes det för ganska godt, at taga qvistarna, koka dem i vatten, och dricka deraf. En af de Svenska, benämd Lars Låck, berättade för mig, at en af hans anhöriga, en gammal man, hade haft såra ben, som varit fulla med hål, hvilka aldrig ville igenläkas. Han hade sökt bot hos ganska många och brukat åtskilligt; men alt fåfängt. Änteligen botade en Ville honom sålunda;

p. 326 han tog / detta trädet, brände det til kål, hvilka stöttes sönder til pulver, blandades tilsammans med färskt Svinister, hvarmed benen sedan några gånger smordes, då alla såren, som eljest nästan beständigt flöto, torkat bårt, och mannens ben blifvit helt goda ända til hans dödsdag. Af sjelfva trädet göres hyflar, eller skaft at sätta hyfveljärn uti.

\section{22 October.}

Villa djur och Foglar, som blifvit tama. Utaf de djur och foglar, som finnas villa uti skogarna här i Norra America, har det blifvit försökt, at följande slag kunnat göras tämmeligen tama, och mäst som hemdjur; Villa oxar och kor, som finnas uti Carolina, och Söder om Pensylvanien. Åtskillige Standspersoner uti Carolina hade förskaffat sig unga kalfvar, dem de låtit upföda bland den andra tama boskapen. Då desse kalfvar blifvit store, hafva de varit mycket tame; men tillika ganska bångstyrige, så at ingen hägnad kunnat stå emot dem, när de velat in på något ställe; ty som de hafva en ganska stor styrka i sin hals, så hafva de ock utan möda med deras horn kastat gärdesgårdarna öfver ända, och ej allenast sjelfve gått in uti de med hvarjehanda Sädesslag fulla åkrar, utan ock ledt den andra tama boskapen med sig. De hafva ock blandat sig med den tama boskapen hvaraf likasom en ny afvel framkommit. De Americanske Rådjur

p. 327 låta ock göra sig tama, | hvilket jag set på flera ställen. Uti New Jersey hade en Landtman et sådant, det han tagit, medan det var mycket ungt, och var nu blifvit sá 
tamt, at det om dagarna gick ut til skogen, at söka sig föda, och kom om aftnarna hem. Ofta, då det råkade andra villa Rådjur i skogen, narrade det dem hem med sig, hvarigenom dess husbonde fick tilfälle at skjuta dem. Åtskillige här i landet hafva sålunda gjort et eller flere af dessa Rådjur tama, då de varit mycket unge, och sedan drifvit Rådjurs jagt med dem, eller at, i synnerhet under brunstetiden, narra andra villa Rådjur genom dem hem. Bäfrar hade de ock haft så tama, at de gått ut at fiska, och fört fisk hem åt sin husbonde. Det samma sker ock här ofta med Uttrar. Jag har här sett dem, hvilka varit så tama som hundar, och fölgt husbonden efter hvart han gått. När husbonden rodt ut, har han fölgt med i båten, och då hoppat ut i vatnet, samt efter en liten stund kommit up med en fisk. Opossum kan ock göras så tam, at han följer folk efter, som en hund. Raccoon, eller som vi kalle den, Sjupp, kan göras så tam, at den går lös vid gården, som andre hemdjur; men som han ej kan hålla sig, at han ju skal göra illa, dels dermed at han i mörkret stjäl sig til hönsen, och ofta på en natt kan göra rent hus med dem alla, dels ock, at såcker och annat sött kan svârligen gömas undan för honom, så at om en ej hvar gång läser igen skåpet eller kistan, låter han obuden | infinna sig, äter up såckret och öser ur Siraps-kaggarna med sin tass eller fot, så at det är et dageligt klagomål af qvinfolken öfver honom; så nödgas mången derföre mista det nöjet och den ro, som annars kunde hafvas af detta til hvarjehanda uptog nog aplika djuret. De grå Ickornar, och de flygande Ickornar, göras af gåssar så tama, at de sitta på deras axlar och följa dem mäst hvart de gå. Uti skogarna finnes här mycket Villa Kalkoner. Desse skiljas nästan $\mathrm{i}$ intet annat från våra tama (utom det de äro villa), än at de merendels äro något större, samt köttet mörkare, dock mera välsmakligt. När någon uti skogen finner deras ägg, och lägger dem under tama kalkoner, at utkläckas, blifva de deraf framkomne ungar merendels mycket tame; ibland sker dock, at när de blifva store, flyga de bårt; derföre brukar man, hälst de första 
åren, gerna at stäcka deras vingar. Desse sả tamgjorde kalkoner äro gemenligen mycket argare, än de andre ordinaira tame. Villarne bruka äfven ibland, at göra dem tama, och hålla dem vid deras kojor. Villa gäss hafva ock här blifvit tamde. Det kan väl icke ske af ägg; emedan inga Villa gäss nu värpa och framkläcka uti Pensylvanien sina ungar; utan det har skedt derigenom, at då Villgässen först om Våren kommit hit, och legat här någon tid, har någon råkat skjuta dem så, at deras vingar endast blifvit qväste, men de $\mathrm{i}$ öfrigt oskadde. När någon p. 329 sedan genom roende / fått dem fast, har han hållit dem inne någon tid, hvarigenom de smảningom blifvit så tamde, at då de sedan blifvit utsläpte, hafva de hvar afton af sig sjelfva kommit hem. För säkerhet skull har man dock klipt af deras vingar. Jag har sett sådana tama, dem ägaren sagt sig haft öfver 12 år, och fast han hade 8 stycken sådana, kunde han dock, under all den tiden aldrig få dem at para sig och värpa ägg. De Villa Rapphöns, som finnas ymnogt här i landet, kunna äfven göras sả tama, at de följa med hönsen hela dagen, och då de af matmodern låckas, komma de löpandes i kapp med hönsen, at få mat. Likaledes har jag sett de Villa Dufvor, som somliga vintrar komma i en så oändelig myckenhet ned til Pensylvanien, så tamda gjorda, at de flugit ut, och kommit af sig sjelfva hem tilbaka.

\section{Den 24 October.}

Humming-bird. - Bland andra rara foglar, som Norra America har at skryta af, är väl den, som kallas af Ängelsmännerne Humming-bird, den raraste eller fram för andra synnerlig, hvilken för många orsaker skul, på få ställen lärer hafva sin like. Den kallas här af de Svenska Kungsfogel, och af en del Ängelsmän Kingsbird, dock är Humming-bird det namn han nu mäst får. Mr. Catesby har aftagit honom i naturelle storlek och med sina lifliga färgor, samt gifvit en beskrifning på honom uti sin NaturalHistory of Carolina Vol. I. p. 65. tab. 65. Storleken är 
näp|peligen mer, än som en stor Humla (Apis); altså den p. 330 minsta af alla foglar, åtminstone lära ganska få foglar i verlden vara mindre, än han. Färgorne af dess fjädrar utanpå äro förträffelige. Somlige och de fläste äro gröna, andre grå, andre med en gläntsande röd ring omkring halsen, stjärten spelande med gröna och kopparfärgade fjädrar. De komma hit om Våren, då det blifver rätt varmt, göra här sit bo om sommaren, och frambringa sina ungar, men fara åter igen om hösten härifrån til de södra orter i America. De föda sig endast af den honungs saft, som finnes $\mathrm{i}$ blomstren, deri de sticka sin långa smala näbb. Aldrahälst tycka de om sådana blomster, som äro djupa, och hafva en lång smal hals (tubus); sålunda har jag märkt, at de mycket uppehållit sig vid impatiens och Monarda floribus coccineis. Den som här bor på landet, och vil vara flitig, at plantera allehanda slags örter med täcka blommor i någon liten kryddgårds täppa fram för sit kammarfönster, skal vara säker, at hela sommaren igenom hafva dageligen en myckenhet af dessa mer än täcka och behageliga foglar uti den samma, och kan väl ej vara något nöjsammare at se, än dessa små qvicka kräken flyga som $\mathrm{Bi}$ vid blommorna, och suga saften ur deras djupa blomster med sina långa smala näbbar. Blommorne på förenämda Monarda floribus coccineis sitta i verticiller, eller här och der vid lederna cirkel-vis rundt omkring stjelken, eller | som på vår allmännaste villa Mynta, Plister, Cardiaca, Lamium \&c. Det är då roligt at se, huru de sticka näbben först $\mathrm{i}$ en blomma, så i den dernäst, och så rundt omkring hela cirkeln eller verticillen, och när de det gjort flyga de til en annan ört, och fortfara på samma sätt. Ingen kan tro, som ej det sett, huru snart de haft sit lilla hufvud i alla blomstren på en ört. Om blomman är stor, och med en djup hals, ser det ut, då fogeln sticker sit hufvud deri, som kröpe han halfparten in i blomman. Under det de så flyga och suga Honungen ur blomstren, sätta de sig aldrig på blomman eller örten, utan de äro $i$ et beständigt flygande, som en humla, hålla sina fötter bakåt krökte, och gå 
vingarna så fort, som en spinråcks rulle, at en näppeligen kan se dem. De göra vi flygandet et sådant brummande, som et svagt ljud af en liten spinråck, eller som $\mathrm{Bi}$ och humlor. När han sålunda sväfvat en stund omkring blomstren, utan at hvila, flyger han up i något närstående trä, eller sätter han sig på någon liten påle, och hvilar så en liten stund. Hvarefter han åter begynner sin förra brumning och blomsternas sugning. De äro ej särdeles rädde för folk. Jag har stått med andra ej fyllest en famn från, hvar de flugit och sugit blomstren. Vi hafve talt och rört oss; men de hafva ej brydt sig det ringaste derom. Dock om någon vil gå til dem, så fara de som en pil bårt. Ofta, då flere komma i en kryddgård, huggas |

p. 332 och slåss de häftigt sins emellan, då de råka hvarannan på blomstren; ty den ene vil drifva den andra derifrån. De flyga med sådan häftighet mot hvarandra i luften, at mången skulle mena, det de skulle hugga midt igenom hvarandra med sina långa smala hvassa näbbar. Under det de huggas, kunna de nästan stå stilla i fria luften, uppehålla sig genom det obeskrifveliga täta fläktande och flygande med vingarna. När fönsterne stå öpne, som vetta mot kryddgården, flyga de ofta efter hvarandra in i rummen och kamrarna, huggas och slåss der sins emellan, och fara sedan ut igen. Ibland, då de sticka näbben i nảgon blomma som börjat torkas, och finna ingen saft deri, rycka de som i illska blomman bårt, och låta den falla ned pá marken. Ej skal den samma mer narra dem en annan gång. Då månge äro på en gång i en kryddgård, rycka de sâ ned blomstren, at marken ligger öfvertäkt dermed, nästan likasom de skulle missunna hvarandra. Man hör i gemen intet annat ljud af dem, än deras surrande med vingarna; dock när de slåss och i luften flyga mot hvarandra, hafva de et läte nästan som en kykling, eller sparf. Jag har ibland spatserat tillika med andra af och til uti små kryddgårdar, hvarest desse likafullt flugit omkring oss på blomstren, utan at visa, det de voro mycket rädde. De äro ganska små, at då en ser dem flyga vid blomstren, skulle en snart mena det vore 
en stor humla eller fjäril, och liknar deras flygt $\mid$ mycket p. 333 en humlas. De flyga med en otrolig snällhet. Aldrig har det märkts, at de ätit insecter, eller utom honungssaften i blomstren någon annan frukt. När någon tagit dem fast, och velat, för deras täckhet skul, hålla dem i hus, hafva de i brist af föda inom kårt tid dödt; dock har Mr. Bartram i flere veckor hållit par stycken uti sin kammare, medelst det han födt dem med vatten deri Såcker varit upsmält. Den som der i, landet hade et Orangerie, torde ej hafva så svårt, at deri hålla dem öfver hela vintern. Denna fogel bygger sit bo altid midt uti en gren af et trä, och är det så litet, at det ned ifrån marken icke kan synas, innan en klifver up til grenen der det sitter; derföre räknas det här vara största raritet, at finna et sådant, hälst som träden desutom om sommartiden äro fulle med löf. Detta fogelbo lärer vara et af de minsta i naturen. Det jag hafver, är bygt hel rundt, består inuti af en brun och ganska mjuk materia, som synes vara den lanugo eller ludd och ull, som är på bladen af Verbascum mas latif. lut. C. B. och hvilken ludd esomoftast finnes af en sådan brun färg. Nysnämnde Verbascum växer i myckenhet här i landet. Utanpå är detta bo öfvertäkt af den gröngrå Lichen, som finnes på alla gamla gärdesgårdar och trän. Diametern af boet inuti är uppvid et knapt digit. Geom. Djupleken inuti $1 / 2$ digit. Geom. De sades desutom göra sina boen af Lin, blår, måssa, hår och sådant | mjukt, och skola värpa deri 2:ne ägg, stora som ärter.

\section{Den 25 October.}

Denna och den följande dagen var jag sysselsatt, at inlägga de denna höst samlade frön af allehanda slag, hvilka sändes öfver til Ängland med fartyg, som i dessa dagar härifrån afgingo. Från Ängland blefvo de sedan öfverstyrde til Sverige.

\section{Den 27 October.}

Om morgonen begaf jag mig i följe med H. Handelsmannen P. Kock, på resan til New York, dels at bese 
landet, dels at göra mig underrättad om säkraste vägen och bästa tilfället, at komma til Canada genom de ödemarker, som ligga emellan de Angelska Provincer och det samma.

Landet, der vi reste, var på ömse sidor om vägen tämmeligen bebodt af Ängelsmän, Tyskar och andra från Europa komne folkslag. Ibland var det jämt, ibland gick det antingen uti längre eller kortare uphögningar. Inga bärg eller stenar blef jag varse, utan då och då några få klappurstenar. Mäst vid hvar gård voro stora trägårdar planterade med Persike- och Äpleträn, hvilka til en del ännu voro fulle med frukt, til en del var ock frukten redan inbärgad.

Gärdesgårdarne voro på många ställen så låga, at boskapen utan möda kunnat hoppa deröfver. At förep. 335 komma sådant, hade / mäst alla Svin triangel-formiga trä-ok på halsen, hvilket jag sedan märkte mäst brukas öfver alt i de Ängelska! Colonier här i landet. Hästarne hade en klafve om halsen, hvarpå hängde et trä, som på nedre ändan] hade framtil en pinne eller krok, hvilken fastnade i gärdesgården och tog emot just då hästen skulle lyfta up framfötterna, at hoppa öfver gärdesgården. Jag vet ej om detta sätt altid kan vara så nyttigt och säkert för hästen. Annorstädes hade de et trä, hvilket med ena ändan var, til ex. bundit vid hästens högra framfot, och med den andra vid samma sidas bakfot, så at hästarne gingo tämmel. långsamt med dessa fjättrar. En häst kunde väl sålunda ogörligen hoppa öfver nảgon gärdesgård; men så tyckes, at han nog äfventyrades härmed.

Vid New Francfort redo vi öfver en liten stenbro, och något längre fram, ungefär 8 à 9 Ängelska mil från Philadelphia foro vi öfver en tämmelig stor bro upmurad af bara sten. Häri landet äro ännu ingenstäds några milstenar eller milstolpar upreste, utan Invånarena räkna som de ungefärligen tycka, så och så långt från det ena stället til det andra. Derefter färdades vi på en färga 
öfver en å, hvarest för häst och karl gafs 3 pences $\mathrm{i}$ färjepenningar.

Mocking bird. På et ställe, der vi bette hästarna, hade de i en bur en Mocking bird, hvilken hålles här på orten för den förnämsta | Sångfogel, fast den prålar så godt som ingen ting med färgor. Denna tid på året var han hel tyst och söng intet. Uti Mr. Catesbys NaturalHistory of Carolina Vol. I. p. 27. tab. 27. finnes denna fågel med lifliga färgor aftagen och beskrifven. Han sades göra sit bo uti buskar och trän, men vara dervid så tyckmyken, at om någon människa går dit, och ser på dess ägg, öfvergifver han då ofta boet, och kommer aldrig dit mera. Ungarne äro mycket kinkotta at upföda. När de tagas från moderns bo och sättas i bur, föder hon dem 3 à 4 dagar, men då hon ser intet hopp om deras lösgifvande, far hon sin väg: och som de ibland råka at dö strax derefter, tvifvelsutan, emedan de ej hinna vänja sig så snart, at äta hvad folk gifver dem, äro många af den tron, at modren sista gången fört til dem något förgift, at dermed snart göra slut på deras fängelse och jämmer. Desse foglar äro här hela sommaren; men fara om hösten til Söder, och äro hela vintern bårta. De kallas Mocking-bird, eller härmande fogel, derföre, emedan de äro i stånd at ganska likt härma mäst alla foglars läten och sång de höra. De sjunga förträffeligen, spela med tusendfalt särskilta läten, hvadan ganska månge i Norra America äro af den tanka, at ingen sångfogel $i$ hela verlden skal kunna gå up emot honom. Det måste en medgifva, at han lärer hafva få sina likar. Han är ock för den orsaken skul nog dyr. I De Svenske gifva honom p. 337 samma namn som de Ängelske.

Vid Middagstiden reste vi igenom New Bristol, eller nya Bristol, som är en liten fläck uti Pensylvanien på elfsbacken af Dellaware, 15. Ängelska mil från Philadelphia. De mästa husen äro af sten, fast mycket glest eller långt ifrån hvarandra bygde. Inbyggarne drifva någon liten handel, fast de måste hämta alla sina Köpmans varor från Philadelphia. Mäst midt emot på andra sidan om floden 
ligger staden Burlington, hvarest Gouverneuren öfver New Jersey har sit säte.

Vi hade derefter här och der gårdar på ömse sidor om vägen. Sedan redo vi efter et långt, tä, eller gata, der gärdesgårdar voro på ömse sidor om Landsvägen, innan för hvilka tämmelig stora åkrar lågo. Vidare genom en skog, der vi på 4. Ängelska mil ej sågo annat, än skog och mycket magert land, hvarest Lupinus perennis (Linn. spec. 721.) växte til ansenlig myckenhet och var ganska frodig. Jag fägnade mig mycket, at här finna en ört, som trefs så väl på sådana magra ställen, dả den kunde tjena, at göra en dylik jordmon nyttig; men jag måste sedan med harm ofta se, at hästar och kor åto upp mäst alla andra örter, samt lämnade nästan altid denna gröna, mjuka och frodiga orörd. Tör hända, at man dock kunde uptänka något sätt, at göra den hehagelig för kreaturen. Om aftonen kommo vi til Trenton, sedan vi näst förut hade låtit sätta oss med färga öfver floden Dellaware.

\section{Den 28 October.}

Trenton är en lång smal Fläck belägen litet från Floden Dellaware på en sandblandad jämn plan uti New Jersey, härifrån räknas 30 Ängelska mil til Philadelphia. Par små Kyrkor, en Ängelsk, och en Presbyterisk finnas här. Husen äro dels af sten, men mäst af trä eller bräder, gemenligen 2. våningar höga, med källare under byggningen, och kök ned i jorden brede vid källaren. Gårdarna ligga nog glest från hvarandra; gemenligen äro de så anlagde, at på ena sidan om byggningen går gatan, och på den andra är en kryddgård af större eller mindre storlek, brunnen är i kryddgården, derutur vatnet mäst med hink uptages. Orten sades vara ganska hälsosam. Vår värd berättade oss, at då han för 20 år tilbaka kom aldraförst til denna Fläck, var här icke stort mer än en enda gård; men sedan den tiden har den så tiltagit, at här nu äro mot 100:de sådana. Inuti voro husen afdelte i flera rum medelst tunna brädväggar. Inbyggarena uti 
denna Fläck drifva någon liten handel med de Varor de förskaffat sig från Philadelphia; men deras mästa inkomst är dels af den myckenhet resande, som beständigt färdas härigenom emellan Philadelphia och New York, hvilka gemenligen fara på denna lilla stadens jagter emellan Philadelphia och Trenton, och resa sedan på vagnar, som mäst dageligen afgå från denna staden til New Brunswig, och gå derifrån tilbaka hit: dels hafva de här sin näring af det myckna köpmans gods, som stundeligen antingen försändes från Philadelphia til New York, eller ock kommer från New York, och går til Philadelphia, då det föres på vagnar emellan | Trenton och New Brunswig, och på jagter emellan Trenton och Philadelphia, varandes det denna stadsens invånare, som härmed mäst sysselsättas. På jagten från Philadelphia til Trenton betales gemenligen $1 \frac{1}{2}$ Skill. Penns. penningar för hvar person, och särskilt för de saker, han förer med sig. Mat och drick håller hvar sig sjelf, eller betalar särskildt derföre. Från Trenton til New Brunswig betales för hvar person $2^{1 / 2}$ Skill. och för sakerna särskildt.

Om Morgonen fortsatte vi vidare vår resa. Landet, der vi nu foro fram, var dels och mäst tämmeligen jämnt, dels viste sig långsluttande högder. Somligstäds var det beväxt med skog, men merendels tämmeligen bart. Det var ock hela denna vägen så starkt bebodt, som något ställe jag sett i America, då jag undantager stäclerna; dock sade en gammal man, som bodde här, och fölgde oss et stycke på vägen, at han mindes, när icke mera, än 3 hus eller gårdar voro emellan Trenton och Brunswig, hvilket han sade vara för något mer än 50 år tilbaka. $\mathrm{Vi}$ hade nu, för största delen i dag, ganska stora åkrar på ömse sidor om vägen. Landet var gemenligen sluttande emot Söder. Stora Persike- och Äpple-trägårdar voro mäst vid hvar gård, och låg marken mångenstäds öfvertäckt af dessa träns frukt, som til en del blef der qvarliggande at rutna; emedan ingen hant bärga och äta dem alla. Hvar vi foro, kunde vi gå in i trä-gårdarna, och taga både hattkull och fickor fulla med skön frukt, 
utan at ägaren en gång vårdade sig at se dit åt. Kersbärsträn voro planterade vid och omkring vägen, der gårdar voro.

p. 340 Sädesladorna voro här bygde på et synnerligt sätt. Jag vil med få ord beskrifva dem. Ladan är mycket stor, nästan som en lagom Kyrka. Taket nog högt, spănlagt, stupande på bägge sidor från kroppåsen, dock nog lång sluttande. Väggarne ej stort öfver en mans högd. Ladan mycket bred. Midt efter ladan är logen, der de tröska. Ofvanpå, der skullen skal vara, hade de den otröskade säden, eller halm, eller annat, alt efter årstiderna. På ena långsidan af ladan stå hästarna, och på den andra korna. Voro några andra små kreatur, så hade de ock stängda rum för dem. På bägge gafveländarna voro stora dörar, at de kunde med hästar och vagn köra in genom den ena dören och gafveln, och ut genom den andra. De hade sålunda under et tak och uti et hus loga, lada, stall, fä- får- och svin-hus, agnhus, vagnslider, och än mera. Detta slags sädes-lador brukas i synnerhet af Tyskar och Holländare; ty det är at märka, at mäst allestäds emellan Trenton och New York bo ej många Ängelsmän, utan antingen Tyskt eller Holländskt folk, och i synnerhet de senare.

Innan jag går vidare, finner jag nödigt, at göra någon påminnelse, hvad Villarne eller de Ville Americaner angår. Min Läsare, som med många andra torde vara af den tankan, at Norra America vore mäst allestäds full med Villa Indianer eller Hedniska folkslag, lärer undra, huru jag i hela beskrifningen ända härtils kunnat undgå, at näppeligen nämna et ord om dem. Mången torde ock tänka, at då jag i denna Resebeskrifning sagt, at landet varit mångenstäds tämmeligen bebodt, husen antingen af p. 341 sten eller trä, | med åkrar och trägårdar omkring \&c., mentes alt de Villa Indianer; men härpå lämnas för denna gången följande svar och underrättelse: at landet på många ställen i de Ängelska Colonier, i synnerhet mot hafssidan, är af Europeiska folkslag ganska starkt bebodt, ja somligstäds så, at det ej kan vara tätare på de flästa ställen $i$ 
Europa: at Villarne såldt åt Europeerna sit land, och flyttat sig längre up från hafvet: at nästan på de flästa ställen äro 20,30. och flera Svenska mil från hafskanten til den första ort, der de Villa Indianer bo: at man kan få vistas uti Philadelphia och andra sjöstäder halfva året, innan man kan få se någon Ville eller Vilska. Framdeles, vil Gud, skal jag gifva omständelig beskrifning om dessa villa Indianer, deras Religion, lefnads-sätt och hushållning, m. m. men nu skyndar jag mig til min resa igen.

Röd jord och stenar. Vid pass 9 Ängelska mil från Trenton begynte jorden ändra sin färg: ty förut hade vi haft nog lera af en ljusgrå färg; men nu fick jorden en rödbrun, ibland på Violett stötande, och ibland en Brisiliefärg. Denna färgen förorsakades af en art röd kalksten, hvilken är i närmaste grad lik den röda kalksten, som finnes på Kinnekulle i Westergyllen, hvaraf Rödstensklefvan der består (Se min Vestgötha och Bohusländska Resa, p. 24. seqq.), och lärer denna Americanska endast vara en Varietet af den samma. Den låg här hvarftals, eller stratum super stratum, hvart stratum ordinairt af 2 à 3 tvär-fingers tjocklek; men det lät ännu dela sig i långt flera och tunnare skifvor, hvilkas superficies sällan var jämn och slät, utan mäst skroflig; eljest afskuros hvarfven ofta per lineam | rectam \& perpendiculariter. Så snart desse sten-arter kommo up i dagen, vittrade de sönder, först i små bitar, och sedan omsider til en mull. De som här bodde visste ej bruka den til någon ting. Ibland är jorden ofvanpå dessa stenar fet, ibland mager. Der de nyligen gräfvit brunnar, syntes, at mästa delen af det de ur brunnarna upkastat, bestod af denna sten-arten. Vi sågo denna jorden mäst ända til New Brunswig, omkring hvilken ort den fans i stor myckenhet, så at elfsbacken der på somliga ställen ej består af annat, än af hvarf eller strata af denna sten-art, dock ligga strata der ej horizontaliter, utan mycket stupande.

Kl. 10. för middagen ankommo vi til Princetown, som är en by på et tämmeligt flackt fält. Husen voro mäst af trä: gårdarne bygde nog glest från hvarandra, 
med trägårdar eller beteshagar emellan dem. Som landet här varit af Europeiska folkslag längre bebodt än Pensylvanien, så voro ock skogarna mera bårtrögde, landet upodladt och gjordt mycket lika med de gamla länder.

Vi tänkte vidare fortsätta vår resa, men som det nu började rägna så starkt, at det hälde nid och varade hela dagen, ja en del af följande natten; så nödgades vi töfva här så länge.

\section{Den 29 October.}

Om Morgonen begofvo vi oss åter på resan. Landet var nog bebodt, fast och mångenstäds stodo stora skogar. Hela skogen bestod af löfträn, och blefvo vi ej varse något barrträ förr än vi kommo til New Brunswig. Jordp. 343 mon var jämn, | och tycktes icke allestäds vara af det fetaste slaget. Somligstäds gick landet i mycket långsluttande uphögningar med en liten bäck, som rann ned uti dälderna. Stora Äppel-trägảrdar vid mäst hvar gård. Husen merendels af trä: bakugnarna voro nästan på de flästa ställen af bara ler, upsatte afsicles från husen för sig sjelfva. Här ock där lågo vackra stora åkrar.

Gråstenar af den storlek, at de mästa kunnat utaf 3 à 4 man vältras, lågo i tämmelig myckenhet på en skogsbacke, kallad Rockhill; men utom detta stället var landet tämmeligen fritt från stenar, ảtminstone för stora; ty mästa delen af dem vi sågo, voro ej större, än at en karl allena lätteligen orkade lyfta en sådan. På et och annat ställe låg en ymnoghet af små rundaktiga gråstenar. Inga bärg eller hällar blefvo vi varse.

Vid middagstid ankommo vi til New Brunswig, som ligger ungefär 30 Ängelska mil ifrån Trenton, och 60 från Philadelphia.

New Brunswig eller Nya Brunswig, är en liten vacker Stad belägen i New Jersey uti en dal på W. sidan om floden Rareton. För denna stadens låga belägenhet kan den ej synas, då en kommer från Philadelphia, förr än 
en är på backen hel när vid honom. Han sträcker sig från Söder til Norr långs efter sidan af Elfven. Är försedd med 2:ne Tyska kyrkor, den ena af sten, den andra af trä, en stor Ängelsk af trä, och en Presbyteriansk af sten, hvilken dock icke ännu var färdig; äfven har han et vackert Stads- eller Råd-hus. Husen äro några af tegel, men de mästa antingen af trä, eller af trä och tegel tilhopa. Trä-husen äro ej bygde af timber, utan af bara | bräder, med spjälor innantil. De, som jag sade bestå af tegel och trä tilhopa, äro bygde på det sätt, at den delen af huset, som vändes ut mot gatan, var upmurad af tegel, men de andra sidorna voro gjorde af bräder. Detta kunde lätt bedraga en främmande, som endast reste genom staden, at tro det största delen af husen vore bara tegel-hus. Et roligt sätt at skryta. Taken spånlagde. Vid ingången af husen emot gatan var gemenligen en bro med trappor gjord, som en liten Altan med bänkar å ömse sidor, der de om aftnarna satta sig, at taga frisk luft, och hafva det nöje at se de förbigående. Här är endast en lång gata, och en lång tvär-gata vid Norra ändan af staden. Elfven Rareton stryker tätt ute vid staden: är så djup, at tämmeligen stora jagter kunna segla dit up. Dess bredd vid staden är ungefär et Musket skott. Ebb och Flod går uti den, ännu några få Ängelska mil längre up, hvilket icke litet bidrager til seglationens lätthet och beqvämlighet. Jagterne ligga med sidan til bryggan. Elfven har höga och tämmeligen branta backar på ömse sidor, undantagandes der staden ligger, hvarest är en lågländ dal. Den ena af gatorna i staden bebos mäst af bara Holländare, komna från Albany, hvarföre den ock kallas Albany-gatan. Desse göra Visiter, den ena til den andra, men gå sällan til de andra stadsens invånare, utan hålla sig som skilde från dem. New Brunswig hörer til New Jersey; men drifver dess mästa, om ej enda handel på New York, som ligger ungefär 40. Ängelska mil därifrån. Dit föra de säd, mjöl i ganska stor myckenhet, bröd, åtskilliga andra matvaror, en ansenlig ymnoghet af Linfrö, | bräder, kimbar, träkäril och annat trävirke. Åtskilliga p. 345 
små jagter gå dageligen fram och tilbaka emellan dessa städer. Af en myckenhet resande, som stundeligen färdas denna stora allmänna stråtvägen, förtjena de ock vackert.

Den röda Kalkstenen, som omtaltes näst förut p. 341. var den, hvaraf de branta elfsbackar egenteligen bestodo. Här kunde helt tydeligen ses, huru strata lågo, nämligen ej horizontaliter, utan mycket sluttande, och det emot Söder. Vädret och luften hade ock här vittrat den mycket sönder. Jag frågade, om de ej kunde göra någon nytta deraf? De svarade, at den vore aldeles odugelig til husbyggnad; ty ehuru den ned i jorden är fast och stadig, och ser väl ut, så sker dock, at då han tages upp och lämnas någon tid i fria luften, vittras han sönder i stycken och smålas alt i små bitar, hvilka med tiden falla sönder til en mull. En af borgarena här i staden lät mura deraf et hus, men det började pả yttra sidan, som var mot fria luften, så smålas sönder, at han var nödsakad låta beslå det utanpå med bräder, at förekomma, at det ej skulle smälta ned. Men en nytta sades dock denna stenen hafva, hvilken bestod deruti, at den är en god gödsel på ảkrar, då den föres dit söndermårad, eller mäst til mull söndervittrad. Ogräs skal ej trifvas gerna der denna är lagd, och brukas den så på åkrar som i krydd-gårdar.

Mot aftonen begofvo vi oss härifrån, och låto med färga sätta oss och våra hästar öfver floden Rareton. Om sommaren då det är tort, och uti elfven är ebb, är vatnet ofta så grundt, at en utan fara kan rida deröfver. På andra sidan elfsbacken växte den röda Enen i tämmelig | p. 346 myckenhet. Landet, der vi sedan reste, var tämmeligen bebodt; men ock på de flästa ställen fullt med små klappursten.

Guinée-Höns fans på många ställen der vi reste. De gingo ibland långt från gårdarna ute på fälten.

Ungefår 8. Angelska mil från Brunswig blef vägen grenad. Vi togo til vänster: den til höger gick til Amboy, som är den förnämsta sjöstad i Nya Jersey. Utsigten af Landet blef sedan mycket behagelig; ty somt var högländt, annat lågländt, alt väl bebodt. Från hög- 
derna syntes en omväxling af hus, gårdar, trägårdar, åkrar, löfrika trän, sjöar, holmar, vägar, och ängar.

Jordens färg på de flästa ställen vi i dag reste, var rödaktig, tvifvelsutan deraf at under den samma lågo bärg af den förr omtalte röda kalkstenen. Jordmons färg var på somliga ställen tämmelig lik Cinnober-malm.

Woodbridge kallades en liten by, som låg på et jämt land, och bestod af några få hus, hvarest vi en liten stund hvilade hästarna.

Husen voro på de flästa ställen af trä; men ej af timmer, utan af bräder. Utanpå voro väggarna spånade: spånorna tvära på ändan, och alla, som voro i en rad, lika jämne. Somliga hus hade Italienska tak, andre och de fläste röst-tak, mäst alle täkte med spån. Brunnar fans på de flästa ställen, och brunshinckar, at draga upp vatnet med.

Elizabeth Town var en liten stad, vid pass 20 Ängelska mil från Brunswig, den vi straxt efter Solens nedergång reste igenom. Husen voro mäst omkring strödde, dock väl bygde. De fläste | af bräder, med spåntak, och väggarna spånslagne utanpå; här och der var dock något enda stenhus. En liten Å går genom staden, som flyter från W. til $\mathrm{O}$. hvilken vid ebb är mäst torr, men vid flod kunna små jagter komma dit up. Här i staden voro 2:ne sköna Kyrkor, hvardera nästan vackrare, än någon i Philadelphia. Den Ängelska var af tegel, med Torn, Klåckor, samt Altan eller skrankverck utan före der Klåckorna sitta, at en kunde gå der omkring. Den Presbyteriska är af trä, med 'Torn, hvari hänger en Klåcka. Utanpå är denna Kyrka öfver alt spånslagen likasom husen. Äfven är här en vacker Rảdstuga af trä, med et litet torn försedt samt en Klåcka. Åbackarna voro röda af den rödaktiga kalksten. Både uti och rundt omkring staden voro fullt med trägårdar, så at man nästan kan säja, at denna lilla fläck är anlagd uti en trägård. Landet här omkring är jämt, och väl upodladt.

Gässen hade på somliga ställen, der vi reste i dag och den följande, 23 a 4 stycken half alns långa smala 
språttar, satta nästan i korss om halsen, at de ej skulle kunna krypa in i åkrar, genom den glesa gärdesgården. De sågo helt rolige ut med denna halsbonaden.

Om aftonen togo vi vårt nattherbärge uti Elizabeth town point, en art af gästgifvare gård, ungefär 2 Ängelska mil från Elizabeth town, och den sista åt denna kanten af de hus, som höra til Nya Jersey. Den som nu arrenderat denna gård, tillika med färgan dervid, sade sig betala årligen åt ägaren 110 Pund i detta landets penningar.

Vi skyndade om morgonen vid Solens upgång vidare med vår resa, och foro först öfver en elf in vid verdshuset, der vi haft vårt nattqvarter, då både vi som hästarne fördes öfver i en usel och mäst genomruten färga. Denna floden gick et stycke up i landet, och kunde de med små fartyg gå up åt den samma, hvarigenom det omkring liggande landet hade en stor förmon, at försända sina varor til New York, eller ock skeppa dem bårt til Westindien. På ömse sidor om floden var landet lågländt och användt til ängsmark, som bestod endast af Kärr-hö. Och som i denna elf var ebb och flod; så stodo desse ängar stundom vid hög flod under vatten. Folket, som bodde här omkring, sades om sommartiden hafva den besvärligheten, at en oändelig myckenhet af Krankor och mygg, eller de här så kallade Musquetöes, oroa både dem och deras boskap ganska mycket, hvilket de tilskrefvo dessa lågländta och sumpiga ängar, hvaruti desse Insecter lägga sina ägg at framalstras.

Så snart vi kommit öfver floden, voro vi på Staten Island, som är en stor Ö, omfluten med salt vatten, och i öfrigt väl bebodd. Här börjas New-Yorks Province. Folket, som här satt sig ned, var mästendels Holländare, eller sådane, som ledde sin härkomst från den tiden, då Holländarne voro mästare af landet, fast de nu voro nog utblandade med Ängländare och andra, samt talade mäst Ängelska. Utsigten var här ganska behagelig. Här fans 
ej så mycken skog, utan | mera uprögdt och brukadt p. 349 land. Eljest gick landet på vanligt sätt uti uphögningar.

Gårdarne voro icke långt ifrån hvarandra, och husen gemenligen af trä, fast vi ock stundom fingo se något stenhus. Mäst vid alla gårdar var en större eller mindre trackt planterad med Äppelträn, hvaraf äpplena nu til största delen voro nedertagne, och förvarade. Jag såg så väl här, som på hela denna resan förut, mäst vid hvar Gård en Cider-präss, gjord antingen på et eller annat sätt, med hvilken de dels redan hade gjordt Cider, eller voro nu som bäst sysselsatte dermed. Ibland andra sätt de hade, at sönderkrossa sina äpplen, var äfven et hjul gjordt af tjocka ekplankor, hvilket drogs omkring en träaxel af häst, på lika vis, som det sker annars med Weide, och hvarpå en figur finnes i Herr Archiater Linnæi Västgötha Resa p. 128. endast at hjulet här går på trä-plankor. Kersbärsträna voro ock planterade långt vid gärdesgårdarna omkring åkrarna.

Åkrarna lågo härliga, och voro nu besådde antingen med hvete eller råg, eller ock afbärgade. De hade inga diken, utan allenast vattufårar på Ängelska sättet, närmare eller längre från hvarandra.

En Vattuqvarn var på et ställe bygd så, at då det var högt vatten och flod, släptes vatnet at rinna in $\mathrm{i}$ dammen; men då det föll ut eller blef ebb, öpnades dambolet, så at vatnet vid utrinningen dref qvarnen.

$\mathrm{Vi}$ kommo kl. 8. för middagen til färge-staden, der vi lämnade våra hästar, stego på jagten, och foro 9. Ängelska mil sjöledes til Staden | New-York, dit vi kommo p. 350 kl. 11. för middagen. På sjön sågo vi en ganska stor myckenhet af et slags Änder, som kallades Blew-bills, och tycktes aldeles vara samma som våra ahlor, men de voro mycket skygge. Vid stränderna af fasta landet syntes härliga sluttande åkrar nu gröna af sädesbrodden. Här och der på sjön fants en myckenhet båtar deri Fiskarena voro sysselsatte med Ostrons fänge på sjöbotten, hvartil de betjente sig af räfsor eller krattor med lảnga inåt 
krökta järnpinnar, antingen det då var en sådan enkel kratta, eller ock 2ne hvars tänger mot hvarannan vore hopsatte.

\section{Den 31 October.}

Ostrons insyltning och tilredning \&c. - Rundt omkring New-York finnes en ganska stor myckenhet af sköna och utvalda Ostron, hvilka i välsmaklighet lära på få orter i verlden hafva sin like, och äro dessutom mycket stora. De insyltas och försändas til Westindien och andra orter, och sker deras insyltning härstädes sålunda: Så snart de fått Ostronen, öpna de dem, tvätta det köttaktiga rent, slå litet vatten $i$ en gryta, lägga dem (nämligen köttet af Ostronen) deri, låta det sả koka en stund, lyfta sedan grytan af elden, taga Ostronen ut, lägga dem på et fat eller annat, til dess de blifva någorlunda torra. Sedan tages litet muskot, au Spice, eller krydd-Peppar, Peppar, samt Vin-ätticka sả mycket som en tycker, at få en syrlig smak derpå. Detta blandas med halfparten af spadet de förut kokat uti, som ater sättas på elden, at kokas, dả det tjocka skummet väl afskummas. Deruppå slàs det i p. 351 en glas- eller stenburk, då Ostronen jämväl | läggas deri. Denna bindes väl öfver, at ej luften må komma dertil. Sålunda kunna de förvaras och hållas goda öfver et helt ảrs tid, samt försändas til vidt aflägsna orter. Köpmännerna härstädes upköpa denna tiden om året en ymnoghet Ostron, dem de tillaga på förenämde sätt, och försända til Westindien, ofta med stor profit, at för den myckenhet af Ostron, som de här gifvit 5. Skillingar uti detta landets mynt, få de gemenligen der en pistol (det är ungefär 6 gångor så mycket, som de sjelfve först gifvit för Ostronen,) och ibland mera. Desse så insyltade Ostron sades vara mycket sköna at äta; dock kunna de icke stekas, sedan de en gång blifvit insyltade. Et annat sätt, at tillaga Ostron, är, at taga kötteț ur dem, steka det samma i en panna med smör, lägga dem så uti en glaseller stenburk, smälta smör derofvanpå, at det täcker väl öfver dem, så at intet väder eller luft må komma til dem. 
På detta sätt tilredde, äro de ock goda, och sändas äfven sålunda ibland til Westindien och andra orter. Det vanliga sättet, at här äta dem, var, antingen rå med Vinätticka, Peppar \&c. hvilket sätt dock ej mycket brukades, eller at stufva dem i smör uti en stekpanna, sedan skalen blifvit bårtkastade, eller at steka dem i deras egna skal på glöd och så öpna dem, til at äta köttet. En del kokade Ostrọnen i deras egit vatten, hvilket de i ymnoghet låta från sig, då de komma i värman, och sades de dâ smaka långt bättre, än om de kokades $i$ annat vatten. De höllo Ostron härstädes för en mycket hälsosam föda, och hvaraf de sade sig aldrig hafva nå|gon olägenhet, fast de ock åte dem til en tämmelig myckenhet. Här hölts äfven före, at Ostronen vore bäst i de månader om ảret, i hvilkas Latinska namn finnes bokstafven $R$, sảsom September, October \&c. men ej så goda i de andra. Dock finnes här fattigt folk, som mäst hela året igenom lefva af dem med litet bröd dertil. De fiskas här omkring New York i salta vatnet til myckenhet, och finnas der förnämligast på gyttjog botten, hvarest de ligga i gyttjan. $\mathrm{Pa}$ sandbotten fås ej så mycket. Klippor och stenbotten finnes här ej, der de tagas. Deras skal samlas i stora högar, och brännes til kalk, hvilken af många brukas til husbyggnad, fast den dock ej hålles före vara så god som kalk bränd och kalksten. På hitresan sảgo vi, vid de gårdar, som lågo när sjökanten, stora högar af Ostronskal. Här vid New-York funno vi många åkrar, som nu voro besådde med hvete, upfylta dermed, hvilka dock ännu voro til största delen hela och ej sönderkrossade. När Villarne fordom för Europeernas hitkomst bodde ned vid hafskanten, lefde de ganska mycket af Ostron och musslor, hvilket de ock ännu göra på sảdana ställen, hvarest de hafva sit tilhåld vid salta sjön, om desse der finnas. De sålde ock mycket deraf åt andra Villar, som bodde längre up i landet. Det ses ännu på de ställen, der de visst veta, at deras hus fordom stått, en myckenhet Ostron- och mussel-skal. Man finner häraf, at man ej strax får sluta, at på alla de platser i norra America, hvarest på hög- 
ländta ställen eller längre up i landet finnes Ostron- och mussel skal, de samma legat der sedan den tiden, som samma ställen varit en hafsbotten.

Hummer fås här i myckenhet, och sades insyltas på samma sätt merendels som Ostron, samt försändes sålunda til åtskilliga orter. Det är synnerligt hvad jag hörde både nu, och ofta sedan ganska många berätta, nämligen, at denna Staden New York varit länge bebodd af Européer, innan de visste af någon Hummer deromkring, eller at någon der fans; ty huru flitigt de fiskade, kunde de icke märka det ringaste tecken dertil; derföre fördes den tiden här altid stora sumpar fulla med Hummer från Nya Ängland, hvarest de ymnigt fångades. En af desse Hummer-sumpar kom en gâng at slảs sönder vid Hellgate, belägit mot 10 Ängelska mil från New York, då alla Humrarna sluppo ut; och efter den tiden sades de hafva så förökat sig omkring New York, at de nu finnas der i största myckenhet.

\section{Den 1 November.}

Bot emot Frossan. - En art af Frossa, som Ängelsmännerne härstädes kalla Feber and ague, är mycket gängse på åtskilliga ställen i de Ängelska Colonier: àter är let pả andra ställen i dessa länder, som folket nästan aldrig veta deraf. Jag skal framdeles omständeligare beskrifva denna sjukdom. Åtskillige Köpmän och Ståndspersoner här i staden berättade, at denne sjukan på långt när icke är så inycket gängse i denna Province, som i Pennsylvanien, sả at skillnaden derutinnan emellan bägge dessa Landskap skal mäst vara den, at då 100. människor i Pensylvanien äro plảgade af denna Frossa, skal här näppeligen finnas 10 personer sjuke deraf. De mente, at den p. 354 til en stor del förorsakades af de dunster, som up/stiga af friska vatnet, från morass, floder och dylika ställen; tvärt om troddes den $e j$ så kunna hafva sin fortkomst vid salta vatten och hafssidan. At de många frukter de här i landet äta rå om sommartiden, sorn Vatten-Meloner, 
meloner, Persiker \&c. ganska mycket bidraga dertil, var ej allenast en allmän tanka, utan den bestyrktes ock af mångfaldig förfarenhet; men jag lämnar dessa orsaker för denna gången. Chinchina-barken troddes stundom vara god; dock har man ock ofta funnit den mycket skadelig; antingen den då ej funnits oförfallskad, eller at något fel blifvit begått vid dess bruk. Handelsman Davis von Horne sade, at han mot denna frossan botat sig och många andra med följande: bladen tagas af Salvia hortens. eller Tysk Salvia (Linn. hort. ups. p. 10 sp. 1.) stötas sönder, och saften krystes derutur. Dermed fortfares til dess man fảr et skedblad fullt af saft. Sedan blandas saften af en Citron eller Limon deruti, och tages in just som frossen skal komma. När en 3 eller 4 gångor fortfarit härmed, viker gemenligen frossan bårt.

Hvita Ekens nytta. Barken af hvita Eken (Quercus alba. Linn. spec. 996.) sades af mer än många vara bland det aldrabästa, som nảgon här ännu vet mot Diarrhoée och dysenterie. Den stötes sönder til pulver och tages in. De sade sig flera resor funnit, at då nästan alt annat ej velat hjelpa, har detta skaffat en säker och skadeslös bot. Dessutom brukar folket här pả orten ganska mycket, at taga samma bark, och pả vanligt sätt färga ylle dermed, hvar af det far en brun eller Théebou-färg, som ej af Solsken kan blekas ut.

Musslor. Bland andra musslor, som finnas här på stränderna vid hafvet, är ock en, som Ängelsmännerne kalla Clam, och uti plurali Clams. Skapnaden af hvardera skalet på musslan är nàgelunda likt et människo-öra. Sjelfva skalet är tämmeligen tjockt, på de flästa ställen helt hvitt alt igenom, endast at den spitsigare kanten består både utanpå och inuti af en blå på violett eller på purpur stötande färg. Uti et annat verk skal gifvas bảde utförlig beskrifning och figur derpå. Nu märkes här allenast, at desse finnas i ganska stor myckenhet uti salta vatnet på stränderna omkring New York, på Long Island, samt annorstädes vid hafskanten. Inom skalet hafva desse en myckenhet kött, hvilket ätes så af Villar, som af Euro- 
peer, både Ängelsmän, Holländare och andra. Med de Villa Indianer, som bo upp i landet, drifves dermed en tämmelig handel. Fordom när Indianerne voro ägare af hela hafsstranden, fiskade de sjelfve dessa Clams, och födde sig çeraf, men nu för tiden fângas de i myckenhet af Holländare och Ängelsmän, som bo på Long Island, och annorstäds vid salta sjön, hvilka så snart de få dem, taga de ut köttet, träda det pả trådar, och då tråden blifvit in emot full deraf, hänges han upp i luft och Solsken at torkas; när detta mussle-köttet blifvit tort, lägges det ned i käril, och föres sjöledes up för Hudsons flod til Albany, hvarest det försäljes til Indianer, som hålla det för en af deras bästa rätter. Utom Europeer, komma äfven åtskillige Indianer ännu årligen ned til hafskanten, at fiska dessa Clams. De tilreda dem på nyss omrörde sätt. Europeerne reda köttet af dem til mat på åtskilligt p. 356 vis, eller pá | alla de sätt, som man plägar tillaga Ostron. Ibland stekas de med sit skal uti aska, och så ätas: ibland stufves köttet i smör: ibland kokas de, och läggas i köttsoppor: ibland läggas de kokade rundt omkring stek eller annat kiött pá fat \&c. På hvad sätt de tilredas, äro de merendels altid en skön mat. Jag har ofta ätit dem pả mina resor; dock tyckes de vara litet hảrda för magen. Deras skal kastas ej bårt, utan göres deraf Indianernas så kallade Vampum, som äro Villarnas både penningar och prydnad, hvarmed deras Qvinfolk utsmycka sig, då de vela vara mycket granna. Desse Vampum göras egenteligen af den violetta delen på skalet, och äro deras violetta eller mörkblå penningar af mycket mera värde, än de hvita. Med samma Vampum eller penningar kan en resande bland Indianerna vinna ganska mycket $\mathrm{i}$ handel; men tager han med sig penningar eller stycken af gull och silfver, kan han alt för mycket komma til kårta; emedan Indianerne up i landet sätta alsintet eller föga värde på sådana af oss så högt skattade Metaller, det jag här i landet under mina resor flera gånger försökt. I fordna dagar gjordes dessa Vampum med mycket besvär af Villarna sjelfva; nu förfärdigas de mäst af Europeer. 
Enkannerligen äro invånarena uti Albany sysselsatte med deras tilredning, hvarigenom de vinna ansenligt. Sättet huru de tilverkas skal längre fram utföras.

\section{Den 2 November.}

Judar. Utom andra Religions förvanter finnas i New York äfven nog Judar, hvilka hafva här i Staden stora privilegier. De hade / här en Synagoga: ägde sjelfve de hus, som de bodde uti: hade köpt sig stora Gods på Landet: höllo öpna Köpmans-bodar här i staden: hade åtskilliga skepp, som hörde dem allena til, och dem de på egen räkning och med egna varor och gods sände ut. De hade, kảrteligen sagt, här samma förmoner, som de andre eller Christne invånare $\mathrm{i}$ denna stad och Province. En af de aldrarikaste Judars dotter hade gift sig med en Christen, sedan hon förut afsagt sig den Judiska läran. Hennes Syster ville ej eller träda i äktenskap med någon Jude, utan reste öfver til London, at få en Christen til man. Under mit vistande härstädes både denna gången, och de bägge följande åren, var jag ofta i omgänge med Judar; de sade, at de aldrig koka åt sig någon mat om Lögerdagen, utan sker det altid dagen förut; dock sade de sig hafva hela vintern eld uti sina hus om Lögerdagerna. Judarne äta igemen intet Svinkött; dock hörde jag flera trovärdiga Ängelsmän berätta, at de på resor ofta sett Judar, i synnerhet de yngre, ej göra sig det minsta samvete vid at äta så Svinkött, som annat, hvad de kunna få, och det tilhopa med de Christna. I går om afton var jag första gången i deras Synagoga, och i dag lät jag äfven för middagen infinna mig derstädes. Et visst rum var i Synagogan, der de främmande eller Christne lämnades frihet at sitta. En ung Rabbi förrättade Gudstjensten, dels på Hebraiska, dels på Rabbinska. Judarne af bägge könen voro klädde på samma sätt, som de Ängelske. Manfolken hade hvar och en hatten på sig i Synagogan, utan at någonsin under Gudstjensten lyfta derpå: Qvinfolken voro på läck|tare. Under Gudstjensten kastade p. 358 
männerne på sig et hvitt kläde, som, tör hända, skulle hafva afbild af en säck, dock märkte jag, at detta kläde var mycket präktigare hos de rika, än hos de fattiga. Månge af Manfolken hade Hebraiska böcker, derutur de sunge och läste. Rabbi stod midt i Synagogan och läste, vände ansigtet mot Öster. All hans läsning och böner framfördes så fort och med den hastighet, som hade han fruktat, det fienden snart vore öfver honom, sả at det väl var nästan ogörligt, at någon kunde fästa en enda tanka på det han ramlade fram.

New York, hufvudstaden uti Provincen af samma namn, är belägen 40. grad. 40. min. Norr om æquator, samt 74. grad. 4. min. W. om Londons meridian, och ungefär 97. Ängelska mil från Philadelphia, på et för handelen ganska beqvämligt ställe, nämligen litet från Hafvet på en udd, som göres af 2ne vikar, hvaraf den ena emottager Hudsons flod, hvilken icke långt frản staden faller uti den samma. New York har sålunda sjön omkring sig på 3ne sidor. Grunden, hvarpả staden är bygd, är somligstäds jämn, annorstäds nảgot backog. Eljest räknas orten för vara ganska hälsosam.

Denna stad har först blifvit anlagd af Holländare, som säges vid år 1623. då de voro ägare af samma land, hvilka kallade den Nya Amsterdam, äfven som det omkring ligande landet då kallades Novum Belgium: men sedan Ängländarne vid slutet af år 1664. under Sir Cartes anförande, bemägtigade sig det samma, och fingo i den nästpåföljande friden behålla det, gofvo de både staden p. 359 och den derunder lydande Provincen | namn af New York. I storlek lärer den nu komma närmast til Boston och Philadelphia af städerna bland de Ängelska Colonier i Norra America; men uti sköna hus, rikedom och stark handel täflar han med dem om förträdet. Han lärer vara ungefär halfannan gång så stor som Götheborg i Sverige.

Gatorna äro väl icke så regulaira som i Philadelphia, utan gå ibland tämeligen krokut och i bugter; dock äro de på sit sätt nog vakre, Mäst alle äro stenlagde, undantagandes på högderna, der det ej behöfves. På de för- 
nämsta äro löfträn planterade vid sidorna, hvilka om sommaren gifva både et täckt utseende, och uti den starka hettan, den årstiden på dessa orter, en behagelig skugga, samt göra i öfrigt staden ganska angenäm, at det syntes mig som hade jag spatserat i en trägård, då jag gick här på gatan. De trä-slag som blifvit använde härtil, voro följande: Vatten-Bök (Platanus occidentalis Linn. spec. 999.) var i myckenhet här planterad. Hon gaf en skön skugga om sommartiden med sina stora och myckna löf. Locusttree (Robinia, Pseudo-accacia Linn. spec. 722.) Af denna fans här ock mycket: dess vakra löf, och den mer än angenäma lukt, som dess blommor gofvo, dá den stod i blomma, förtjente väl, at planteras både på gator, vid hus, och i trägårdar. Än stodo här ock Lindar och Almar, fast icke i den myckenhet, som de 2ne förra. Alla dessa trän voro skiftevis satte om hvarandra.

Utom hvarjehanda sjungande och qvittrande foglar, uppehöllo sig äfven i dessa trän om sommaren en myckenhet af et synnerligt slags Grodor, / hvilka om aftnarne och nätterne, hälst när det var varmt, eller liknade sig til rägn, upfylte luften med sit mångfalliga läte, och likasom täflade med foglarna. De höllo ofta sådant ljud, at den ene människan näppeligen kunde höra hvad den andre talte på gatan.

Husen äro til största delen af tegel: de fläste väl och mycket vackert bygda, samt flera våningar höga. På somlige ställen vända de, efter det gamla sättet, gafvelen mot gatan; men vid de i senare tider upbygda är detta ändradt. På många hus är öfverst på taket bygt som en altan, hvarest de om sommar-aftnarna sitta och roa sig, och hvarifrån de icke allenast kunna hafva en behagelig prospect öfver en god del af staden, utan äfven öfver en del af den dertil liggande sjön, samt det vid den samma belägna landet. Husen äro här gemenligen täckte antingen med taktegel, eller med takspån, hvilken spån är gjord af den hvita Tallen, som växer längre upp i landet (Pinus Strobus, Linn. spec. 1001.) och säges dessa spåntak i varaktighet mäst täfla med dem, som i Penn- 
sylvanien göras af den så kallade hvita Cedern (Cupressus thyoides, Linn. spec. 1003.) Inuti husen voro väggarna hvitlimade. Jag såg ingenstäds Tapeter, ty de visste ej stort af dem här i landet. De hıvitmålade väggar voro til en stor del öfvertäckte med små taflor af allehanda ritningar: å ömse sidor om spisen voro skåp; under fönsterna $i$ stenhusen brädslagit, och bänk dervid in i muren at sitta på: skåpen och alt det brädslagna var måladt gråblått.

Kyrkor äro i denna stad àtskillige, hvaraf märkes p. 361 följande. 1. Den Ängelska bygd år 1695. | i W. ändan på staden, af sten, med torn på, och klåcka deri. 2. Den Nya Holländska, som är nog stor, bygd af sten, med torn på och en klåcka deri, jämte timklåcka, hvilken lärer vara den enda, som finnes här i staden. Denna Kyrka står mäst uti SSW. och NNO. hvarvid märckes, at Kyrkorna i denna stad ej hålla något vist väderstreck i sin bygnad, utan den ene står från $O$. til W. på vanligt vis: den andre frân S. til N. och så vidare. Uti denna Kyrka var intet altare eller Sacrestia, ingen läktare, inga ljuskronor och ljusstakar, och inga figurer eller målningar. Omkring Kyrkogården äro åtskilliga trän planterade, hvilka göra, at Kyrkan står som uti en lund. 3. Den gamla Hollänska, är äfven af sten; men ej så stor som den förra. Inuti var den mâlad, fast utan bilder, och försedd med et litet orgverk, dit skänkt af Gouverneur Burnet. Mäst alla Manfolken sitta här på läktare, och Qvinfolken ned i Kyrkan. 4. Den Presbyteriska, var nyligen upbygd, tämlig stor, af sten, med torn och klåcka deri. 5. Den Tyska Lutherska. 6. Den Tyska Calvinska. 7. Den Franska för flyktingar af Reformerta Religion från Frankrike. 8. Quakarenas Meeting. Hit kan ock föras 9. Judarnas Synagoga, hvarom näst förut är talt.

Utemot sjön på yttersta udden är en tämmelig väl god Fästning anlagd, kallad Georgs Fort, som commenderar hamnen, och gör staden tämmelig säker för hastigt fiendteligt anfall från hafssidan. Dessutom är den mot norra eller landssidan med pallisader omstängd, hvilka 
dock nu, sedan de $\mathrm{i}$ långliga tider icke haft at särdeles frukta | för någon fiende, äro pả somliga ställen nog förp. 362 fallne.

Uti sjelfva staden finnes intet särdeles godt Vatten; men litet utan för den samma är en skön och tilräckelig källa, hvadan invånarena förse sig med alt det vatten de bruka til Thée, dricka och bättre matlagning; dock betjena de, som härutinnan äro mindre granlaga, sig af det vatten, som finnes i brunnarna, ehuru slätt det är. Af denna brist på godt vatten lida ock främmandes hästar här mycket, hvilka icke gerna vela smaka af det, som tages uti stadsens brunnar.

Hamnen är tämmelig god, de största skepp kunna ligga här på redden, och nästan tätt til bryggan. Vatnet deruti är, för dess belägenhet i sjelfva hafskanten, ganska salt; hvadan den ock mäst alla vintrar, om ej en ovanlig sträng köld sätter til, är öppen, til en icke ringa fördel för denna stad och dess handel, då skepp hela året igenom kunna här ut- och inkomma, när de vela, och vinden ej hindrar, hvilken förmon Philadelphia nödgas sakna, som förut är sagt. Den stora Ön Long Island, som ligger midt för staden mot hafssidan, gör hamnen för häftiga väder derifrån säker; och sades Sudväst-storm vara af alla väder värst för de skepp, som ligga i hamnen; emedan åt den kanten är från Hafvet en öpning. Ingången från Hafvet til New York är dock ej aldeles så god: den är väl tämmelig djup, dock kunna ej stora krigsskepp gå dit in; emedan det är för grundt. Stora Köpmansskepp hafva ibland i starkt svall stött litet på botten, när de sunckit ned emellan vågarna, dock utan skada. Månge skepp hafva likväl här förgåts; emedan Canalen | är smal, och om de icke segla rätt, komma de på bankar. Gamle män, som i alla sina dagar färdats här fram och tilbaka, försäkrade, at denna Canalen nu vore hvarken djupare eller grundare, än den fordom varit.

Ebb och Flod sades förhålla sig här vid New York sålunda, at vanliga skilnaden emellan högsta och lägsta vatten om dygnet är ungefär 6. Ängelska fot, och den 
tiden om månaden, som floden är högst, stiger skilnaden til 7. sådana fot.

Hvad Handelen angår, så är denna Staden den, som uti Ängelska Provincerne uti Norra America drifver den samma nästan större, än någon af de andre: åtminstone är der ingen, som öfvergâr honom derutinnan. Eljest lära så Philadelphia som Boston tämmeligen häruti täfla med honom. New York drifver handel på åtskilliga orter. Härifrån sades gå långt flera skepp til London, än från Philadelphia. De föra dit med sig allehanda slags skinvaror, dem de tilhandla sig af Villarna: äfven Såcker, Logwood och andra färg-trän, samt Rum, Mohogony och andra varor, dem de tagit frän Jamaica och andra Ängelska öar i Södra America, jämte alla de penningar, de annars med sin handel kunna få tilhopa. Äfven bygges här ârligen skepp, hvilka föras öfver til Ängland, och der försäljas. I dessa senare áren hafva de börjat skeppa öfver til Ängland en myckenhet Järn. Från London tages tilbaka icke allenast allehanda fabricerade varor och andra Änglands producter, utan ock alt sådant, som eljest uti lkrämare-bodar plägar försäljas, så at Ängland, och i synnerp 364 het London, hafver ge|nom sina Colonier uti America i sådant en otrolig vinst. Ja, ej allenast denna Stad, utan ock alle andre Ängelske Colonier på fasta landet i Norra America taga så mycket af allehanda Köpmans varor från London, at alla de penningar och begärligare varor de eljest på âtskilliga orter med deras handel kunna förtjena, gå alt til London och Ängland, at betala det samma, och ändock räcker det på långt när ej til, så at häraf ses, lıvad en väl inrättad Colonie kan bidraga til dess moderlands tilväxt och fromma.

Ganska många Fartyg gå härifrån New York til ofvannämde öar i Södra America, (hvilka af Ängelsmännerna med et ord kallas Westindien, som förut p. 244 är nämdt) dit de härifrån föra med sig mjöl, spannemål, skårpor, kimbar och laggkäril, bräder, kött, fläsk, smör och andra matvaror, samt af de få frukter här finnas. Ofta gå de til Boston i Nya Ängland, dit de föra Spanne- 
mål och mjöl, och taga derifrån kött, smör, allehanda slags träverke, hvarjehanda slags fiskvaror med mera, dem de sedan föra til Westindien, och der föryttra. Äfvenleds taga de från Boston Rum, som der i myckenhet distilleras, den de sedan här i landet med fördel försälja. Ibland löpa jagter härifrån til Philadelphia med Köpmans varor, och åter en annan gång komma jagter derifrån hit, nämligen alt som de af Gazetterna se, at en eller annan Vara är mera begärlig, eller betales dyrare i den ena orten än i den andra. Til Irland gå härifrån åtskillige Fartyg; lastade med hvarjehanda varor, som blifvit hämtade från Westindien; men i synnerhet med Linfrö samladt här i landet. Det försäkrades | mig, at somliga år gả mot 10. skepp härifrån til Irland, lastade nästan bara med Linfrö. Orsaken är, dels at Linet i Irland icke har godt och tilräckeligt frö; dels och förnämligast, at de uti Irland, til at få godt Lin, sägas updraga det, innan fröet hinner mogna, samt at de til samma ändamåls ernående, eller at bekomma utvaldt Lin, icke vela betjena sig af egit hemma samladt frö, utan af det, som kommit från längre aflägsne orter. Det är för samma orsak skul, at Linfrö är på denna ort en god Handels-vara. Denna tiden kostade en Buskel Linfrö här i staden 8. Skillingar New Yorks-penningar, eller just et Stück von achten. För de varor, som blifvit försålde på Americanska öarna, tages i betalning antingen reda penningar, eller Westindiska varor, som dels föras först hem, dels ock försändas strax antingen til London eller Amsterdam. Ville någon vid återkomsten från Ängland eller Holland ej taga varor, eller ock ingen vore, som fraktade skeppet, kunde en gå til New Castle i Ängland, taga stenkål til Barlast och fara så hit hem, hvarest de tämmeligen väl skulle blifva betalte. Häraf skedde ock, at de på många ställen här i staden betjente sig af Stenkảl, så i Kök, som i andra spisar, emedan de sades kunna således fås lättare, än ved, för hvilken sidstnämde nu betaltes 30. Skillingar New-Yorks-penningar famnen; (huru stor en sådan famn är, ses förut p. 225.) På Södra Carolina drefvo de ock härifrån handel. De förde dit Spanne- 
mål, Mjöl, Såcker, Rum, med mera och togo derifrản Risgryn, som är den Provincens snart sagt enda product.

Producterne af denna New Yorks Province | äro ej mångahanda, utan i synnerhet följande: Allehanda slags skinvaror, hvilka köpas af de villa Americaner, hälst och mäst vid Oswego. Bräder i ymnoghet, som mäst komma från Albany: allehanda slags kimbar och laggkäril, hvilka komma ifrån de omkring Hudsons Flod belägna orter: Hvete, Mjöl, Korn, Hafra \&c. som mäst kommer från New Jersey och andra ställen öfver alt i detta landet. Jag såg jagter från New Brunswig, lastade endast med Hvete, som låg löst $\mathrm{i}$ fartyget, samt Mjöl, som var inpackadt $\mathrm{i}$ tunnor, såsom ock en ymnoghet linfrö. Äfven utskeppas härifrản något fläsk och andra köttvaror, dock ej til särdeles myckenhet: ja ock något litet ärter, som komma från orterna omkring Albany. Ändteligen ock järn, som i myckenhet fås på flera ställen i denna Province, och det tämmeligen godt. De öfriga denna Provincens Producter äro ej af nagot särdeles värde.

Det mästa vin, som brukas, sả väl här, som uti de öfriga Ängelska Colonier i Norra America, tages från ön Madeira, och är nog starkt och hetsigt.

Inga särdeles Fabriquer voro här i landet ännu inrättade, utan mäst af kläde, linne, och andra fabricerade köpmans varor fördes hit fran Ängland, enkannerligen från London.

Hvad som i öfrigt ej ringa bidrager til handelens beqvämlighet för denna stad, är Hudsons Flod, hvilken är segelbar til 150 Ängelska mil up i landet, och faller ut $\mathrm{i}$ hafsviken litet $\mathrm{Väster} \mathrm{om} \mathrm{staden.} \mathrm{För} \mathrm{två} \mathrm{tredjedelar}$ af året är denna full med jagter, samt andra större och p. $36 \tau$ mindre bå|tar, hvilka färdas til och från New York, lastade med allehanda landets Producter och andra varor.

Huru många fartyg ungefär årligen inkomma til denna stad, och utgå därifrån kan jag icke säja; men uti en af Pennsylvaniæ Gazetter har jag funnit, at från den 1 Decemb. 1729. til d. 5 Decemb. 1730. äro til New York inkomma 211. fartyg, och innom samma tid 222. utgångne. 
Sedan den tiden har handelen här ansenligen til- och icke af-tagit.

Marknad hålles ock här i staden 2:ne gångor hvar vecka, mäst på samma sätt, som förut p. 189. vid Philadelphia är omordat; men $\mathrm{i}$ denna staden är dock den olägenheten, at här äro flera torg eller marknads-platser, hvarigenom sker, at en ej altid kan få det en vil på et ställe, utan nödgas ibland löpa från det ena torget til det andra, innan en får hvad som tarfvas.

Gouverneuren öfver New Yorks Province har här i staden sit säte, och residerar på sjelfva Fästningen. Bland andra detta Länets Höfdingar förtjenar at nämnas William Bunner, Son til den lärda och för sin theoria telluris namnkunniga Ängelska Biskopen Burner. Denne Gouverneuren var en mycket lärd Herre, och tillika på alt sätt så sorgfällig om detta Länets upkomst och vältrefnad, at Invånarena ännu $\mathrm{i}$ dag anse honom för den största och berömvärdaste Höfdinge, New Yorks Province någonsin haft, och den de tro sig ej kunna gifva nog låford. Hans hvarjehanda Astronomiska Observationer, gjorde här på orten, äro införde i åtskilliga Ängelska skrifter. År 1727. vid nu Regerande Ängelska Konungens GEORG II. anträde til Riksstyrslen blef han | flyttad från New-Yorks Höfdingdöme, til Gouverneur uti Boston i Nya Ängland, der han dog år 1729 d. 7. Sept. af alla ganska mycket saknad.

I denna stad kommer gemenligen en eller par gångor om året the Assembly af denna Province tilsamman, det är Deputerade från alla dess Härader, at här hålla sina små Parlament eller Riksdagar öfver det, som kan vara nyttigt til landets bästa. De kallas tilhopa af Gouverneuren, som ock hafver magt at skilja dem åt, när han behagar. Hvilket han ock gör, antingen när det ej mera är något angelägit at rådslå om, eller då han ej finner dem så eniga för Konungens och landets bästa, som sig bör, eller när Gouverneuren regeras af egna capriser och egit interesse, förgätande landets välfärd. Här har varit den Gouverneur, som, sedan han råkat i oenig- 
het med Invånarena uti landet, och desse sedermera på ofvannämde små Riksdagar af harm och arghet altid satt sig tvärt emot, hvad Gouverneuren proponerat, om det ock varit aldrig så nyttigt; så har han gripit til det rådet, at tätt och den ena gången strax efter den andra kalla dem tilsamman, och så snart han märkt deras envisa sinne, strax skildt dem åt, hvarigenom han så mycket uträttat, at de trötte af så många och täta utgifter, omsider voro glade at de fâtt förena sig med sin Gouverneur til landets bästa. Ja, det har ock de Gouverneurer här gifvits, som tätt sammankallat, och åter strax åtskildt Landets Deputerade, endast derföre desse ej i alt velat dansa efter deras pipa, och samtycka til alt hvad Gouverneuren proponerat, ehuru skadliga sảdana propositioner varit för Landet och det almänna. Konungen i ängland sätter här Gouverneurer til, alt efter egit behag; men de lönas af Undersåtarena i Provincerne, hvilka sammanskjuta til Gouverneurens underhåld; derföre alt som en Gouverneur mer eller mindre ställer sig in i förtroende med dem; så får han större eller mindre lön: det ges ock exempel på Gouverneurer både i denna och andra Ängelska Provincier p. 369 i Norra America, hvilka | derigenom, at de råkat i stridighet med Invånarena uti de sig anförtrodda Län, måst se sig gå i mistning af hela den vanliga årligen sammanskutna lönen, och Konungen sjelf har icke kunnat förmå dem, at utgifva den. En Gouverneur eller Lsandshöfdinge skulle således nödgas, antingen lägga ned sin syssla, eller hafva alt för usel utkomst, eller ock i alt rätta sig efter Invånarenas behag, om han derjämte icke hade andra utvägar, til at någorlunda få sin lön ut. Desse äro bland andra följande: 1. Får ingen i hela Länet, utan Gouverneurens saintycke, hâlla krögeri, utan bör en och hvar, som idkar krögeri, derföre betala något visst til Gouverneuren, alt efter omständigheterna. Sålunda hafva vissa Gouverneurer, då Invånarena undandragit sig, at sammanskjuta til deras underhåld, låtit mäst fördubbla antalet af Krogar i deras Province. 2. Brukar största delen af dem, som ärna gifta sig, (om de ej äro utfattige) at icke låta 
lysa för sig på Predikstolen, utan taga af Gouverneuren en så kallad Licence eller tilstånd, at få träda i äktenskap med den och den person; då på en sådan Sedels upvisande hvar Protestantisk Präst hafver lof, at sammanviga dem. För en sådan Licence betales til Gouverneuren ungefär 4 à 5 Plåtar, efter vårt mynt; detta indrager vackert öfver hela Provincen om året. 3. Kan ock Gouverneurens inkomst ökas genom Resepassers utgifvande, enkannerligen åt dem, som gå til sjös: at förtiga ännu àtskilliga andra utvägar.

Vid ofvannämde deras Assemblyes eller smá Riksdagar, öfverses och bättras de gamla Lagar, nya stiftas, anstalter göras, til nödiga penningars | eller mynts gảngbarhet, m. m.; ty det är at märka, at hvar Ängelsk Province i Norra America är aldeles independent af den andra, så at den hafver sina särskildta Lagar, sina särskildta penningar, och kunna i mycket anses, som särskildta Konungariken från hvarandra. Häraf sker, at vid krigstider går här ganska oordenteligen och senfärdigt til, så at då den ena Provincen vil fram, vil den andra tilbaka. När Gouverneuren vil hafva sả, vil Assemblén hafva tvärt emot. Det är då icke at undra öfver, at under det de här utdraga tiden med oenigheter sins emellan om bästa och minst kostsamma sättet at utföra kriget, intager fienden den ena orten efter den andra. Gemenligen har det skedt, at då Gräntse-Provincerne blifvit af fienden plundrade, hafva de längre ifrản belägne, suttit stilla i ro, likasom det ej bekommit dem något, och ofta hela 2 à 3 . ja flera år både dragit i betänkande, och äfven stått emot, at sända de förra och i nöden stadde någon hjelp. Ja, man har haft Exempel derpå, at då somlige Provincier hafva blifvit af fienden härjade och sköflade, har en annan Province, under hela den tiden ej allena sutit neutral, utan ock tillika drifvit stark handel med fienden. Genom sådant förhållandie hafva Fransoserne i Canada, hvilka äro endast at räkna som en hand full med folk, mot de Ängelska, likväl i ofreds tider så stora fördelar för de sistnämde; der dock mången, som vil döma efter mycken- 
heten och välmågan, skulle tycka, at Ängelsmännerne med största lätthet skulle snart kunna kufva de Franska; men med alt detta och ehuru oriktigt här tilgår i krigstider, kan dock ej nekas, det ju Ängelska Kronan hafver

p. 371 ganska stora | förmoner derigenom, at Fransosernas Canada gräntsar til deras Nybyggen i Norra America; och lärer finnas nog anledning at trifla, det Konungen i Ängland med fullt alfvare skulle vela taga Canada från Frankriket, om det ock stode $i$ hans förmàga. Orsaken är lätt at se: Ängelska Colonierne i Norra America äro i myckenhet af Invånare och välmåga redan så mägtige, at de börja föga gifva gamla Ängland efter. För gamla Änglands handels och välmagt skul, samt för andra orsaker, är des Nybyggen i America förment, at uprätta några Fabriquer och Manufacturer, som skulle lända moderlandet til skada och afsaknad. De få ej uptaga något af ädlare Metaller annorlunda, än at det straxt skal skickas til Ängland. De hafva ingen frihet, at handla på andra orter, än de Ängelska, undantagandes några fă ställen; ej eller hafva främmande Nationer tilstảnd, at drifva handel i de Ängelska Colonier i America. Utom atskilliga andra inskränkningar i deras handel och näring. Genom et sảdant tryckande sker, at Ängelska Invånarena uti Norra America äro mindre varme mot sit Moderland. Til en sadan kall tanka bidraga ock mycket de mảnga främmande Nationer af Tyskar, Holländare, Fransoser, Irländare, och andre, som flyttat hit öfver, och satt sig ned i de Ängelska Nybyggen, hvilka merendels ej äro så särdeles ömme om gamla Ängland. Dessutan äro en del människor så sinnade, at de aldrig kunna vara nögde med hvad de hafva, om det ock vore huru godt, utan längta altid efter mera, eller älska förändringar. At förtiga, det en alt för stor frihet, och för p. 372 mycket goda dagar, ofta kunna för/vandlas i et tygelfritt sjelfsvåld. Jag har flere resor hört Ängelsmän sjelfva, icke allenast dem, som varit födda i America, utan äfven i gamla Ängland, men sedan gått öfver til America, och der satt sig ned, uppenbarligen säga och spå, det de Ängelske Colonier i Norra America efter 30. 40 à 50 år 
torde utgöra et särskildt Konungarike, skildt aldeles från gamla Ängland; men som hela landet, hvilket sträcker sig långs efter hafsstranden, är åt den kanten öppit, och på lands- eller baksidan vid ofredstider oroas af Fransoserna; så kunna desse sista eller Fransoserne tilräckeligen åstadkomma, at kärleken emellan dessa Colonier och deras moderland ej så lätt kan alt för mycket kallna bårt eller utslåckna: utan bör Ängelska Kronan med all fog anse dem, som den bästa pådrifvare-staf, at hålla dessa deras Undersåtare i all tillbörlig och önskelig plikt och undergifvenhet. Men jag har nästan gått för långt från mit ögnamål, och vil derföre komma tilbaka til NewYork igen.

Magnetens Variation här i staden blef år 1686 af Öfver-Ingenieuren (Surveyor General) öfver New-Yorks Province Philipp Well observerad vara 8 grader $45 \mathrm{~min}$. Wästerlig; men år 1723 fant Gouverneuren Burnet den vara $7 \mathrm{grad} 20 \mathrm{~min}$. Wästerlig. Hvaraf det ses, at Magnetens Variation aftager här vid pass 1 grad 25 min. pá 38 års tid, eller litet mer än 2 minuter om året. Mr. Alexander, en Man väl förfaren både uti Mathematik och Astronomie i denna staden, berättade mig d. 18 Sept. 1750. at efter flera hans gjorda Observationer vore Magnetens $\mathrm{Va} \mid$ riation den tiden här ungefär 6 . grad 22 min. p. 373 Wästerlig.

Här sades vara par stycken Boktryckare, och gifves här från trycket ut hvar vecka Ängelska Avisor, deri hvarjehanda finnes infördt från alla verldenes delar.

Vintrarne äro här mycket kallare, än uti Pennsylvanien; ja, de kunna uti köldens stränghet täfla med åtskilliga orter här i Sverige; dock varar kölden på långt när ej i New-York så länge, som här hos oss. Våren kommer här (uti New-York) tidigt, hösten sent, och om sommaren är hettan här ganska stark; derföre kunna de ock hafva Vatten-Meloner, hvilka blifvit sảdde på öpna fältet, redan mogna vid början af Augusti månad: der vi dock hos oss under fönster uti drefbänkar svårligen kunna drifva dem til mognad. Huru sträng kölden här är om 
vinteren, kan jag ej så noga säga; emedan de Thermometriska Observationer jag här fått, voro alla märkte på oriktiga Thermometrar, hvilka dessutan sutit inne uti hus, och ej ute $\mathrm{i}$ fria luften. Snön ligger på marken några månader, och slädar brukas här på samma sätt som i Sverige, fast nog obäklige gjorde. Hudsons Flod, som ned vid dess mynning är ungefär mot en Svensk fjerdedels väg bred, och der skilnaden emellan högsta och lägsta vatten vid ebb och flod om dygnet är 6 à 7 fot, utan at nämna, det vatnet deruti är ganska salt, ligger dock til 3. 4. eller snart 5 månader hvar vinter belagd med Is, som ofta är af en half alns tjocklek, och mera.

Om sommartiden äro de ibland här nog plågade af p. 374 mygg, hvilka sägas inkomma med det hö, | som införes från de här i nägden belägna låga saltvattens ängar, samt om aftonen med boskapen. Jag har sjelf blifvit, och äfven sett andra vara om nätterna af dem så illa medfarne, at man ej kunnat gå ut i staden för de mánga knylor desse åstadkommit öfver hela ansigtet.

Vatten-Meloner fas i nägden omkring denna stad ganska stora och sköna; ja nästan bättre, än på andra orter i Norra America; fast de alla planteras ute på öpna fältet, och aldrig sättas förut i drefbänk. Hos Gouverneuren Clinton sảg jag i Septemb. 1750. en Vatten-Melon, som vägde 47. Ängelska skålpund, och hos en annan handlande der i staden en af 42. skålpunds tyngd; dock räknades desse bland de största, som här på orten fảs.

År 1710. sändes härifrån 5. Iroquoirnas Konungar eller Sachems öfver til Ängland, at förmå Drottning Avva til alliance med sig emot Fransoserna. Deras namn, klädedrägt, Audience i London, tal til Drottningen, utlåtelse om Ängland och Europeernas väsende, med mera, äro af andra skrifter förut bekante, så at det vore onödigt, at här uprepa det samma. En sådan Vilsk Konung eller Sachem har gemenligen ej mer at säja öfver sina underhafvande, än en Länsman hos oss i en Soknestämma, ja näppeligen så mycket. Under mina resor genom dessa Villars land, behöfde jag aldrig någon gång göra min 
upvaktning hos deras Sachems, utan desse Regenter infunno sig sjelfve obudne uti mitt qvarter, och det merendels för en eller par supar bränvin skul, hvilket är den dryck de älska öfver alt annat i verlden. Af ofvannämde 5 Vilska Sachems | sades en hafva blifvit död i Ängland; p. 375 men de andre 4 . hade kommit hem igen.

De första inbyggare i New York voro bara Holländare. När staden med det dertil hörande landet sedan blef af Ängelska Cronan intagit, och vid det påföljande fredsslutet bårtbytt til den samma mot Surinam, lämnades dess förra inbyggare frihet, at antingen blifva qvar, och njuta samma friheter och förmoner, som förr, eller ock flytta med all sin egendom bårt. De fläste utvalde hällre det förra; hvaraf kommit, at största delen af inbyggarena både i denna stad och den derunder lydande Province af samma namn, ännu i dag äro Holländare, och tala sins emellan mäst Holländska, enkannerligen de gamle; men så börja de dock småningom tämmeligen aflägga sit förra tycke, enkannerligen här i staden, och landet dernäst til, hvarest största delen af ungdomen nu talar gemenligen bara Ängelska, och äfven merendels går uti Ängelska Kyrkan, samt tycker illa, om nảgon kallar dem Holländare, och ej Ängelska. At Judar äfven här vistas, och njuta stora friheter, är förut omtalt.

Ehuru New Yorks Province varit mycket längre bebodd af Europeer än Pennsylvanien, är den dock på långt när icke så upfyld med folk, som den samma, fast jordmonen är äfven här tämmelig god. Orsaken sades förnämligast vara den: uti Drottning Axwas tid, ungefär ảr 1709, kommo hit en stor hop Tyskar, hvilka af Regeringen fingo land, och satte sig här ned: när de vistats här någon tid, och bygt sig hus och Kyrkor, samt uptagit åker och äng, begynte man inskränka deras privilegier, och under hvarje|handa förevändande taga en och p. 376 annan bit land ifrån dem. Häraf stöttes Tyskarna för hufvudet, som brukade våld mot våld, och slogo dem, som ville taga bårt landet. Detta togs så illa up af Regeringen, at Tyskarnas hufvudmän blefvo insatte och ganska illa 
medfarne och straffade. Et sådant förfarande förtröt dem så högt, at mäst en och hvar af dem lämnade sina hus och sin jord: gick derifrån och begaf sig til Pennsylvanien, derest de blefvo ganska väl emottagne och erhöllo land jämte stora friheter, dem de fingo orubbade sig til godo njuta. De låto ej benöja sig dermed, utan de skrefvo ock hem til deras anhöriga och vänner i Tyskland, samt inrådde dem, at, (i fal de hade lust at komma til America), skulle de ingalunda sätta sig ned uti New York, och afmålade den regeringen ganska illa. Detta hade det eftertryck, at 'Tyskar, som sedermera til många skepslaster foro öfver til America, frâgade aldrig efter New York, utan utvalde alla Pennsylvanien. Ja, det hände ibland, at de nödgades komma öfver med skepp, som gingo til New York; men näppeligen hinte de til lands, för än de skyndade sig derifrån til Pennsylvanien, midt för ögonen af New Yorks inbyggare. Härtil kan än föras en annan orsak: Vid det lenna Provinces första invånare eller Holländarne fingo vid frilsslutet meı Ängland frihet at blifve här qvar, och njuta alla sina förra förmoner och privilegier, utan någon afkortning, til godo, tilvällade sig dá en och hvar af dem ganska stora tracter land, så at mången ensam person af de förmögnare gjorde sig då p. 377 Herre och ägare af land, hvilket til vidd / och omkrets ofta kunde svara mot en af våra medelmåttiga, ja större Soknar. Som nu en stor del af dem voro mycket rike, så dref afunden mot de Ängelska dem, at ej sälja någon bit land, om de icke fingo den mångfalt betalt. Hvad de då gjorde, hafva deras efterkommande noga fölgt in til denna dag. Som nu bảde Ängelsmän och andre Nationer kunna fả land både för bättre pris och med mera säkerhet i de andra Provincier; så är ej at undra, at så många ställen i New Yorks Province ännu ligga obebodde, och se ut som ödemarker. Detta alt visar hvad et litet fel i Regeringen kan bidraga til et lands saknad på inbyggare. 


\section{Den 3 November.}

Vid middagstiden begofvo vi oss från New York tilbaka, och fortsatte så resan, at vi kommo til Philadelphia den 5. derpåföljande.

Cider. - Omkring Philadelphia hade de nästan för mer än en månad sedan gjort Cider; dertil nödsakade deraf, at äpplena voro så mogne, at de föllo af sig sjelfva ned frăn träden; men vid vår resa til New York märkte vi, at de åt den kanten då som bäst höllo på, at göra sin Cider. Hvaraf ses, at äpplena omkring Philadelphia falla förr af träden, än uti New York; antingen at jordmonen, eller en starkare hetta om sommaren i Philadelphia, eller något annat är orsaken dertil. Eljest hade de ingen förmon deraf, at de så bittida måste göra sin Cider, ty en långsam förfarenhet hade lärt dem, at ju tidigare de här kommo at göra den samma, ju sämre blef den; emedan den starka sommarhettan sades gö|ra, at p. 378 fermentation icke blef så god, som då det skedde senare.

Polcat kallades af Ängelsmännerna härstädes et fyrfotadt djur, hvilket finnes nog allmänt ej allenast i Pennsylvanien, utan ock längre både til Norr och Söder i Norra America. Uti New Yorks Province kallas det gemenligen Skunk. De Svenske här i landet kallade det Fiskatta, af den oliderliga stank, den ibland gifver från sig, hvarom strax nedanföre. Fransoserne i Canada kalla det för samma orsaks skul dels Bête puante, dels Enfant du diable. En del Fransoser kalla det ock Pekan. Det är beskrifvit och med lefvande färgor afritadt af Herr CATESBY uti dess Natural History of Carolina Vol. 11. p. 62. f. 62. under namn af Putorius Americanus Striatus. Han är i närmaste slägtskap med mårdar, och til storleken äfven mäst den samme. Färgen är gemenligen svart med en hvit rand midt långt efter ryggen, och par sådana hvita ränder långt efter hvardera sidan, hvilka gå parallelt med den första. Ibland, fast sällan, visa sig ock sådane, som äro mäst hel hvita. Litet för än vi nu återkommo til Philadelphia, sågo vi en ligga vid en gård, som var af 
hundar ihjälbiten. Sedan hade jag ock vidare en eller annan gång tilfälle under mit vistande här $\mathrm{i}$ landet, at se samma djur, och at göra mig underrättad om dess egenskaper. Denna Fiskatt har sina ungar antingen i iholiga trän, eller ned nti jorden. Des tilhåld är ock ej allenast ned på marken, utan han kan ock behändigt klifva up i trän. För Foglar är han en stor fiende, hvilkas ägg han slår sönder, och äter up deras ungar. När han kommer p. 379 ihop med höns, | håller han med dem et grufveligt gästabud. Men sả är han dock mäst bekant för en synnerlig egenskap: då han blifver jagad af hundar eller folk, äro väl hans fötter och klor gemenligen hans första tilflykt; ty med dem springer han undan, eller klifver up i träna; men om de hinna nog nära på honom, så at han ser sig ingen utväg at komma undan, har han ännu et hjelpemedel öfrigt, nämligen, han kastar sin urin emot den, som förföljer honom, antingen han, som somlige säga, väter sin svants dermed, och så med den samma stänker tilbaka, eller han eljest kan kasta det så långt. Det förra tyckes dock troligare; emedan trovärdige män berättat mig, at de fått synen full deraf då de varit mot 3 . famnar ifrån honom. Denna hans urin har en så vederstyggelig lukt, at värre ej kan gifvas. Ungefärligen är den sảdan, som hos Geranium robertianum primum C. B. (Linn. Flor. Suec. 578.) men i tusendfalt högre och starkare grad. När någon är nära in til Fiskattan, dả han gifver från sig denna stank, kan den samma på en stund svårligen hämta andan, utan den vil lika som qväfjas bårt eller storkna. Kommer något af dess vatten $\mathrm{i}$ synen pả någon, säges det vara fara vid at mista den samma och om något kommer på kläderna, kan denna grufveliga stank nästan aldrig så tagas bårt, at den ju ändock något litet skal kunna kännas. Hundarne löpa ofta tvärt af bårt från denna katten, så snart han fått bestänkt dem i synen och nosen; men de, som äro goda hundar, släppa honom ej gerna, innan de fått lifvet af honom; och at något förminska stanken de af dess urin fått, gräfva och stryka p. 380 de med nosen några gångor i jorden under | jagandet, 
och å nyo anfalla katten, til dess de göra ända med honom. Lukten af hans urin går sällan på en månad utur kläderna; ınen om kläderne gräfvas ned i jorden och få ligga der et dygn, så plägar mästa delen af den elaka lukten vara försvunnen. Äfvenledes bruka de ock flitigt gnida ansigte och händer med mull eller jord om någon blifvit dermed bestänkt; ja somlige hålla för samma orsak skul händerna hela långa stunden isänder $\mathrm{i}$ jorden; ty med vatten går han ej så snart bårt. En viss Ståndsperson, som oförtänkt blef af denna katt befuktad, stank deraf så illa, at då han ville gå in i nàgot hus, flydde antingen alla undan honom som för Pesten, eller budo de honom, vid det han öpnade dören, fara ända til _ _ och ej komma in $\mathrm{i}$ deras hus; så at mannen aldrig varit så illa utstält i alla sina dagar. Hundar, som varit i färd med denna katt, få ej på par dagar nalkas til husen. Jag såg en morgon på en marknad uti Philadelphia, hvad kastande det var af alla människor efter en hund, hvilken tvifvelsutan litet förut varit för nära til en Polcat, hvaraf han gräseligen luktade. Han toltes ej på långt håll komma när någon människa. Ofta, då en reser eller går i skogen, kännes lukten deraf på hela lảnga stycket. Ibland kommer man på de ställen i skogen, der det hela lảnga trakten luktar så stårkt, at man måste hålla sig för näsan, hvilket gifver tilkänna, at denna katt då är i nägden, eller hafver ej långt förut vistats på samma ställe: är vädret med, eller ock då det om aftnarna sent är helt lungt, kännes denna förgiftiga lukt på nog långt håll. En sådan katt kom en natt om vintern 1749, helt nära til gården, / der jag vistades, tvifvelsutan låckad efter et dödt lam, då den, vid det hundarna jagade efter honom, gaf från sig en så vedervärdig och genomträngande stank, at jag näppeligen annat visste, der jag låg i sängen, än at jag skulle qväfjas bårt: kona råmade helt högt deraf. När han var bårta, försvan ändteligen lukten småningom. Vid slutet af samma år hade et af dessa förtretliga djur practicerat sig in $\mathrm{i}$ vår källare; men utan at någon den ringaste lukt kunde kännas deraf, (ty de gifva ej från sig denna stygga lukten 
annars, än då de blifvit retade eller förfölgde). Pigan märkte några dagar i rad, at någon i källaren gjort skada på köttvarorna. Hon stänger alla gluggar igen, at hindra kattor komma in; men vaknar följande natt af det buller som gjordes i källaren af denna stinkande katten, som blifvit der instängd. Hon går dit ned, får i mörkret se et djur med 2. gläntsande ögon, brinnande som eld, det hon ändteligen slår ihjäl; men innan Polcatten satte lifvet til, parfumerade hon så källaren, at pigan icke allenast blef sjuk deraf i par dagars tid, utan bröd, kött och andra matvaror, vi der hade, blefvo sả bårtskämde och illa stinkande, at vi ej kunde nyttja det minsta deraf, utan nödgades kasta det alt bårt. At han ej altid måtte vara så mycket rädd för folk, eller ock at han om nätterna sofver mycket tungt, dömer jag der af, som hände en af mina bekanta uti New Jersey: vid det han om en sommarafton uti skymningen går hem från skogen, tycker han, at et visst slags gräs stod fram för honom. Vid det han dả lutar sig ned, at taga det samma, sprutas han alt öfver med Fiskattens urin, hvilken satt der på marken, och

p. 382 hölt svantsen i vädret, som mannen mente vara det gräs han ville taga. Han hade sedan mycken möda, at få denna stanken frản sig. Ehuru förtretlige de på ofvannämde sätt äro, bruka dock Ängelsmän, Svenske, Fransoser och Villar här på orten, at ibland göra dem tama, då de säjas blifva så spake, at de följa efter folket, som en hund, och pläga aldrig nyttja sin fula spruta, om de ej blifva dess mera retade eller slagne. När Villarne få skjuta eller slå ihjäl någon, äta de altid hans kött; dock vid det de flå honom. skära de strax bårt blåsan och dess hemliga saker, at köttet icke måtte taga någon osmak deraf. Jag har talt både med Ängelsmän och Fransoser, hvilka sagt sig ätit samma kött, samt at det smakat väl, och så godt som griskött. Skinnet, som är nog grof- och långhårigt, brukas ej af Europeer til något; men Villarne bereda det så, at håren lämnas qvar, dả de sedan bruka det til Tobakspung, den de bära framför sig, och vända det håriga ut. 


\section{Den 6 Novemb.}

Om aftonen reste jag ut til Mr. Bartran, hvarest jag råkade en man, som var hemma från Carolina, af hvilken jag fick underrättelse $\mathrm{i}$ et och annat, hvad den Provincen angàr. Jag vil nu allenast märka följande:

Tjära, Beck och Ris sades vara de förnämsta Producter uti Carolina. Jordmonen är der mycket sandig, på hvilken en myckenhet af Tall och Furu växer, hvaraf de bränna sin tjära. De Furor de härtil betjent sig af, äro gemenligen sådane, som af sig sjelfva kommit at torkas bårt. De visste ej allestädes, at tilreda Tallar til tjäru|bränning på sảdant sätt, som brukas i Österbotten genom Barkens afskalning pá en eller flera sidor. På somliga ställen i Carolina skal man ock betjena sig härtil af trädens qvistar. Han beskref sjelfva bränningen pả samma sätt, som det gemenligen sker hos oss i Finnland. Beck sades göras af tjära pá det sättet, at en grop gräfves i jorden, som smetas inuti starkt öfver med ler; tjäran slås deri, elden tändes pá, och lämnas frihet at brinna til dess tjäran blifver så tjock, som kan vara nog til Beck. Enkannerligen at tala, så brännes i de Ängelska Nybyggen i Norra America 2:ne slags Tjära. Den ena kallas allmän Tjära (Common Tar) och är den nyssnämnde, hvilken brännes af Furu-stubbar, afhuggna Furu-qvistar, och Fururötter, då trädet mästendels är tort när det tages. Detta är ock af det mäst allmänna sättet här i landet. Det andra sättet är, at Furun skalas eller barkas pả ena sidan och lämnas sedan at stå, och växa ännu vid pass et år, då kådan kommer ut i såren. Trädet hugges sedan ned, och brännes til Tjära, hvilken Tjära kallas grön Tjära (green Tar); färgen af bägge slagen är dock mäst den samme. Den kallas grön Tjära; emedan den brännes af gröna och färska trän, då den allmänna Tjäran (common Tar) brännes af dem, som äro torkade. Sättet at här bränna dessa Tjär-slagen, är i öfrigt aldeles det samma, som hos oss i Finnland. Af den här så kallade Svarta Tallen brännes tjäran; ty den hvita Tallen duger ej dertil, 
men är deremot förträffelig til Bräder, Master \&c. Den så kallade gröna Tjäran sades vara dyrare, än den allp. 384 männa. | Dock klagades redan mäst öfver alt, at Tallskogarne nu äro rätt mycket utödde.

Ris eller Risgryn planteras ganska mycket i Carolina. De ställen hvarpå det trifves bäst, äro moras och myror, hvilka kunna sättas under vatten, när det behagas. Det är pả sảdana ställen, som det ock blifver först mogit. De bruka ock, i brist af annat, at plantera det på torrare ställen; men det vil der icke gärna fort. De ställen sades aldrig gödas, derest Ris planteras. Tiden, dả de i Carolina plantera det, är i slutet af Martii, eller i början af April månader st. vet. dà det gemenligen blifver mogit i Septemb. De skola sätta det i rader, såsom ärter, och lämna gemenligen 15. tum emellan hvart korn. Något efter det kommit up, sättes åkern under vatten, hvilket ej allenast otroligen främjar dess växt, utan ock tillika utrotar alt ogräs, sâ at en ej behöfver ränsa deremellan. Halmen skal vara ganska skön för boskap, som äter den mycket gerna. Riset älskar et varmt Climat; häraf kommer, at det ej kan växa i Virginien; emedan somrarne äro der för kårta, och orten för kall. Än mindre kan det komma fort uti Pennsylvanien. De veta ej ännu uti Carolina konsten, at göra Arack häraf. Det är i Södra Carolina, som det mästa Ris planteras, och uti Norra Carolina brännes nästan den mästa Tjära.

\section{Den 7 Novemb.}

- Vatnets aftagande. Ofvannämde man från Carolina berättade, at han funnit Ostronskal uti botten på en brunn, som var 70. Ängelska mil från hafvet, samt 4. Ängelska p. 385 mil | från en dervid belägen flod. De lågo 14. Ängelska fot djupt från jordbrynet; vatnet i brunnen smakade saltaktigt; men i floden var alt vatnet friskt. Då samma man låtit grafva för sin sågqvarn, hvilken låg $1 \frac{1}{2}$ Ängelsk mil från en flod, råkade han först på sand, så blålera, deri han fant fullt med Ostronskal. Ibland dessa Ostron- 
skalen uptog han ảtskilliga af honom så kallade Sjöfogelnäbbar, hvilka nu hel och hållne voro petrificerade. Desse lära varit Glossopetre.

Räf. - Af Räfvar finnes uti de Ängelska Colonier enkannerligen 2:ne slag, nämligen de grå, och de röda; jag vil framdeles nämna om nảgra andra varieteter häraf, som ibland visa sig i Canada. De grå Räfvarne hafva varit här ifrån urminnes tider. Uti Pennsylvanien och Provincierne Söder ut derifrån, äro de mycket allmänna; men tvärtom nog sällsynte längre emot Norr, kallas ock af Fransoserna i Canada Virginiska Räfvar. Til storlek äro de något mindre än våra ordinaira Räfvar. De göra ingen skada på lamm; men med höns, ankor, gäss och kalkoner hålla de nog illa hus, när de kunna komma åt; dock räknas de ej här i landet bland de mera skadeliga djur; emedan för deras dödande är uti Lagarna intet præmium utsatt. Skinnet är begärligt af hattmakare, som göra sina hattar af dess hår; man fodrar ock kläder dermed. Fettet brukas mot värk. Desse Räfvar sades icke kunna löpa så fort som de röda. De hade dem ibland tama, dock at de ej fingo gå lösa, utan höllos $\mathrm{i}$ band. Denna arten är beskrefven och med lifliga färgor afritad af Herr | Cátesby uti dess Nat. Hist. of Carolina Vol. II. p. 78. tab. 78. under namn af Vulpis cinerea Americana. För et sådant skinn betaltes här i staden Philadelphia $2^{1} / 2$ Skill. Pennsylv. mynt. Af de röda Räfvar finnes här icke särdeles mycket. De äro aldeles af samma art med våra vanliga Räfvar $\mathrm{i}$ Europa. Herr Bartram och andre sade, at Villarne skola enhälligt berätta, at dessa slags Räfvar aldrig varit här i landet eller i Norra America för än Europeernas ankomst; men om sättet huru desse röda Räfvar först kommit hit, har jag fått 2:ne slags berättelser. Herr Bariram och åtskillige andre berättade, at Villarne icke allenast påstå, at desse Räfvar i senare tider kommit hit til America, utan at det ock skedt straxt efter Europeernas första hitkomst efter en ovanlig och mycket kall vinter, då hela Hafvet åt Norra kanterna varit belagdt med is, hvadan gissas, at de då först kommit öfver isen 
til America, antingen från Grönland, eller från Norra delarna af Europa eller Asien. Ingenieuren Herr L. Evans och àtskillige andre sade sig fätt af flera den berättelsen, at en Ängelsk Gentleman eller Ståndsperson, soin bodt i Nya Ängland, och haft mycken lust med jagt, och derföre låtit komma pa fartyg en hop Räfvar frản gamla Ängland, dem han sedan släpt lösa pả sina gods här i landet, at framdeles fả roa sig med deras jagande. Detta skal vara skedt vid första början af Nya Änglands besättjande med Europeiske invånare. Desse Räfvar menas sedan hafva sa förölkt sig, at alla de röda, som nn finnas här i landet, skola af dem leda sin härkomst. De räknas ibland de värre skadedjur här à orten; ty de lảta ej p. 387 benöja / sig allenast med samma heintamda foglars dödande, som näst förut är omtalt vid den grá Räfvens beskrifning; utan de göra ock tidiga anfall pá Lamm, dem de hålla til goda. Derföre betales efter Pennsylvaniens Lag 2. skillingar, som et præmium, åt den, som dräper en gammal Räf af detta slägtet, och en Skilling för en dess unge; uti de andra Provincier är ock utsatt lön för den, som rödjer et sadant skadedjur utur vägen. Skinnet upsökes af Handlande, som gifva derföre lika mycket, som för de gråas, nämligen $2^{1} / 2$ Skilling Penns. mynt.

Varg. - Af Vargar finnes i dessa länder 2:ne varieteter, som dock tyckas vara et och samma slag, nämligen en art, soin är gulaktig eller närmare ljusgrå, och den andra svart eller hel mörkbrun. Alle gamle Svenskar berättade, at i deras barndom, och än mer vid de Svenskas första ankomst hit i landet, fans här ganska mycket Vargar, så at man ofta dà hörde dem tjuta och ulfva hela nätterna. De gjorde ock ofta skada på får, svin och annan ung och små boskap. När Villarne något efter de Svenskas och Ängelskas hitkomst blefvo ansatte af kåppor, en sjukdom, den de då fingo af Europeerna, och den de aldrig förr vetat af här i landet, dödde många hundrade af dem deruti, så at de mäste Villar uti Nya Sverige derigenom blefvo utödde. Vargarne, som då blefvo låckade af liklukten, kommo til dem i så stor myckenhet, at de åto ej 
allenast up de döda asen, utan anföllo ock de andra, der de lågo sjuke i deras kåjor och kulor, så at de friske måste med störar och stafrar köra bårt dessa odjur. Men sedan den tiden hafva de så för|svunnit, at nu sällan här p. 388 på orten höres af nảgon, och än mindre, at de göra nảgon skada; orsaken sades vara, dels at landet blifvit mera bebodt, dels at de blifvit af folk utödde och bårtskrämde. Men längre up i landet, som ej är så bebodt, finnes ännu nog af dem. Fåren gå både uti Pennsylvanien och Nya Jersey ute natt och dag hela året igenom, utan at någon behöfver särdeles frukta för dessa odjur; dock at för framtiden pá alt sätt hindra deras tilväxt, är uti Pennsylv. Lagen utsatt 20. och uti Nya Jerseys 30. Skill. til præmium för hvar Varg, som någon dräper, skinnet den förbehållit, som dödat et sådant odjur, och för en Vargunge gifves i Pennsylvanien til præmium 10. Skillingar, Penns. mynt. Man har haft exempel på dessa Vargar, hvilka blifvit gjorde nästan så tama, som hundar.

Villa Oxar och Kor finnas i skogarna ofvanför Carolina, efter hvilka Inbyggarne anställa jagt. De slagta dem de då få och insalta köttet pá samma sätt, som det plägar ske med annat boskaps kött. Härmed födes til en del både tjenstefolket och andra. Skinnet af denna boskap sades ej duga mycket; emedan det är alt för spongieust, så at det ej tjenar til skor. Eljest bruka de mycket i Carolina, at breda dessa skin på gålfvet til säng för det fattigare folket.

Viscum filamentosum Sloan. sades finnas nog i Carolina. Det brukas af Invånarena i stället för halm uti sängar, samt til häst-prydnad. Creaturen skola äta det gerna. När de vilja lägga något i kistor eller lådor, som skal föras någon väg, / linda de omkring, och stoppa emellan dermed, at det ej af skakning eller stötande må taga någon skada.

Spartium scoparium Linn. Spec. 709. Flor. Suec. 589. växte uti Herr Bartrams trägård af de frön, som han fătt från Ängland. Han sade, at han haft åtskilliga stånd deraf; men de fläste hade dödt bårt, genom köld uti de 
här kalla vintrar. Den växer dock vildt på åtskilliga ställen i Sverige.

Tuckahoo. - Herr Bartram hade Tubera Terra (se Linn. Flor. Suec. 1116.) dem han tagit i sandig jord, i Nya Jersey, hvarest de växa ymnogt. Desse viste han åt mannen, som var från Carolina, och frågade honom, om de samma voro Indianernas eller Villarnas Tuckahoo? (se Grov. flor. virg. 205.) Han svarade: nej, och lade til, at desse Tubera terre finnas äfven der; men han hade aldrig sett dem brukas til annat, än at något deraf tages in i mjölk emot Diarhoee. Men hvad Tuckahoo angår, så växer den uti särskildta kärr och moraser, och det ofta ymnogt. Svina upsöka flitigt dessa rötter der de finnas i morass och kärr. Indianerne, som bo vid Carolina, samla dem, då de vandra i skogen, torka i solen, mala dem sönder, och baka bröd deraf. Då roten är färsk, och man äter deraf, är den mycket het och brännande; men den förlorar mäst all sin kraft, så snart hon är torkad. Efter hans beskrifning lärer hon vara Arum Virginicum Lins. spec. 966. Gron. flor. virg. 112. jämnförd med det, hvad längre fram skal nämnas vid Tahim och Tuckah. Efter middagen gick jag in til Philadelphia igen.

\section{Den 8 Novemb.}

Bi. - Åtskillige både af Svenskar, Ängelsmän och andra här i landet hade Bistockar, hvilka skattade hvart år vackert til deras ägare; ty Bien villa gemenligen här mycket fort. Vaxet såldes mäst bårt til de handlande; men honungen nyttjade de merendels sjelfve på åtskilligt sätt uti maten. Allas enhälliga berättelse här på orten var, at Bi aldrig varit i Norra America för än Europeerne kommo hit, och at de blifvit förde från gamla Ängland til det nya af de första Ängelsmän, som i sistnämde land satt sig ned. Villarne eller Indianerne skola ock alle tilstå, at deras förfäder aldrig blifvit varse några $\mathrm{Bi}$ hvarken $\mathrm{i}$ skogarna eller annorstädes, för än Europeerne hafva varit några år här i landet. Detta bestyrkes än ytterligare 
deraf, at Indianerne icke hafva i deras sprảk något särskilt namn på $\mathrm{Bi}$, utan lappa ihop, och kalla dem Ängelmans flugor, såsom kräk först hitbragte af Ängländare. $\mathrm{Nu}$ finnas de i myckenhet vildt svärmande uti skogarna i Norra America; dock är här i landet en allmän anmärkning eller rön, at Bin nästan altid vid deras svärmning flytta sig Söder- och ej Norr åt. De lära finna de Norra trakter af America ej så tjenliga för sig. Häraf härrörer ock, at inga Bin finnas uti Canada, utan de ditförde hafva frusit ihjäl om vintrarna. Bin uti America tyckas vara nästan liten grand smärre, än dem vi hafve uti Sverige. Ännu til senare tider hafver ingen märkt något $\mathrm{Bi}$ uti skogarna, som äro Norr- eller bakom de höga sả kallade Blå-Bärgen, hvilket bestyrker det kårta tide/hvarf de ännu haft uti denna verldenes del. Herr Bartram sade sig hört en Man berätta, det han funnit vid sina resor i skogarna här i Norra America et annat slags $\mathrm{Bi}$, hvilket i stället, at hafva sin honung och vax in cellulis, haft dem uti en stor påse, alt tilsammans; men denna berättelsen torde ännu tarfva mera ljus och visshet.

\section{Den 9 Novemb.}

Foglars förminskning \&c. - En och hvar så af Svenska, som Ängelsmän, hvilka voro födde här i landet, och komne til någon ålder, intygade lika som med en mun, at det denna tiden på långt när ej finnes här i landet så mycket Fogel, tjenlig til mat, som uti deras barndom, utan hafva de ögonskenligen märkt, huru starkt den aftagit. Samma klagovisa sade de sig äfven hört af sina föräldrar, som voro födde på denna orten. I deras barndom lågo vikar, floder, åar och bäckar så fulla med allehanda slags sjöfoglar af gäss, änder, \&c. at en knapt kunde se til vatnet för dem; men nu får en näppeligen se någon enda deraf. Man kunde för 60 à 70 år tilbaka skjuta på en förmiddag 80. änder, men nu svårligen en enda. En gammal Svensk öfver 90 år sade sig hafva uti sin ungdom en gång skutit 23 änder uti et skott: en sak, 
som icke så snart på dessa orter lärer kunna ske, då man nu kan få gå en hel dag, och ej få se 3 à 4 . af dessa foglar. Tranor kommo då hundradetals hit om Våren; men nu sällan några få. Af villa kalkoner, samt af de här, af de Svenska så kallade Hjerpar och Rapphöns svärmade då tjockt i skogarna; men nu hinner man nog p. 392 gå sig trött, innan man blifver nå|gon varse. Orsaken til alt detta är icke svàr at gissa: För Europeernas hitkomst var landet obebodt och fullt med stora skogar: de fả Villar eller Indianer, som här vistades, oroarle foglarna ej mycket. De brukade sins emellan ingen handel, visste ej hvad järn eller krut var, och lasssade sảlunda aldrig nagon byssa. Hundrade delen af de foglar, som här då upfylte landet, hade allena varit ymnig föda för dessa fả Indianer; men da härtil lägges, at de hade sina sma Maysland, at de idkade fiskeri, och anstäldte jagt efter Hjortar, Bäfrar, Björnar, Villa Oxar och Kor, hvilkas kött äfven var dem en läcker föda, sả ses lätteligen, huru sällan och litet foglarne af dem ofredades. Annorlunda har det gatt, sedan flere svärmar af Europeer kommit hit: landet har blifvit upfylt merl folk: skogarna bårthuggne: da folket förökts hafva de med jagande och skjutande utödt fogeln eller skrämt den bảrt: om Våren bårttages fritt bàde ägg. moder och ungar. Inga lagar äro ännu gjorde häremot, och dessutom vore man i detta fria landet mindre angelägen, at lyda en sadan lag. Men ehuru de Foglar, som brukas til mat, blifvit här i landet så otroligen utödde och minskade; så äro dock deremot andre, hvilka sedan Europeernas ditkomst mera til- än af-tagit. Sảdana äro i synnerhet de af Ängelsmännerna så kallade Black Birds, och af de Svenska Mays-tjufvar nämnde, hvilka äro en art kajor; samt af fyrfotade djuren àtskilliga slags Ickornar; bägge förenämde, både Mays-tjufvar och Ickornar lefva til en stor del af Mays, eller älska den framför alt annat. Ju mera nu som folket förökes här i landet, ju p. 393 mera Mays blifver ock planterad, | och följakteligen blifver mera ymnoghet til föda för dessa bägge Creaturen. Härtil kommer, at bägge desse skade-djuren sällan brukas til 
mat, så at de således hafva större frihet af föröka sig. Af andra Foglar, som ej tjena til mat, sades ock denna tiden vara ännu lika mycket, merendels som fordom. Denna klagan öfver len nyttiga fogelens ganska starka förminskning var ej allenast uti denna Province, utan öfver alt hvart jag kom eller reste uti Norra America.

Fiskars förminskning. Vid Fiskens aftagande och förminskning hade gamle män här på orten samma berättelse och klagan, som nyss förut om Foglen är anfördt. Uti deras barndom val en sảdan välsignelse af Fisk i vikar, floder, åar \&c. at dả man gick ut en morgonstund, och drog et varp, fick man så mycket fisk, at en häst näppeligen orkade draga det hem; men nu är det helt förändradt. Man kan flera gångor få vara nog trägen, at sätta ut sina fiske-bragder, men nödgas ändock ofta säja, at man arbetat hela natten fäfängt. Orsaken til denna Fiskens altför känbara förminskning, är dels mycket sådant, som straxt frammanföre vid foglarnas aftagande omordadt är, och at den nu på mảngfalt flera sätt utödes, än förr; dels de många qvarnar, som nu äro uprättade i floder och bäckar; ty de hafva här funnit, at Fisken om Vårtiden går up åt floderna til at lägga sin rảmm uti grundtvatten, och da han kommer til forssar, der nu äro qvarnar, och ej slipper längre, vänder han tilbaka nedåt, och kommer ej mera up. En Stånds-person frản Boston berättade mig, at i en Elf som var vid hans faders gård, fingo de altid om Vartiden, och mäst hela / sommaren öfver en myckenhet af et viss slags Sill; men sedan hans fader lät bygga en qvarn med damm uti Elfven, försvunno desse Fiskar. Samma klagan, som de öfver alt i dessa länder yttrade öfver Fiskens förminskning, hade äfven gammalt folk uti New York öfver Ostrornas aftagande derstädes: de intygade, at man uti deras barndom fått der vid staden mycket större ymnoghet af Ostron, än i denna tiden; ty ehuru de ännu fås der i ansenlig myckenhet, samt derhos de största och skönaste, som kunna finnas i verlden; så tilstå dock Ostron-fiskare, at de årligen ganska mycket minskas; orsaken sades vara, at man nu så flitigt 
öder ut dem med fiskande, och det nästan på alla tider om året. Månge gamle gjorde den skilnaden emellan myckenheten på Fisk i sin barndorn, mot det den finnes i denna tiden, så stor, som det är emellan dag och natt.

Anmärkning vid Fiskens förökelse. Herr Benj. FrankuIN lemnade mig följande berättelse: På den orten i Nya Ängland, der hans Fader bodt, voro 2:ne floder af den beskaffenhet, at det fångades en myckenhet af et slags fisk, de kallad Herring, i den ena, men i den andra fans alsingen. Mynningarne eller utloppen af dessa floder voro dock ej långt från hvarandra. När Herringen steg om Vảren up at lägga sin romm, gick han altid i den ena floden, der man fick Herring, men aldrig uti den andra. Herr Frankuns Fader som bodde emellan dessa floder, ville försöka, om det ej vore görligt, at Herring äfven kunde komma i den andra; derföre när Herringen just skulle gå up, at lägga rommen, lagade han, at han fick p. 395 några uti sina nät, utur dem han tog rommen, / förde den varsaint öfver land til den andra floden, och lade den deri, hvarest den kläcktes ut. Påfölgden var, at efter samma tid började det årligen mer och mer jämväl finnas Herring i denna flod, hvilket continuerat in til denna dag. Detta ger anledning at tro, at der fisken är utkläckt, och hvarifrån han först går til sjön, dit kommer han gerna sedan tilbaka, at lägga sin romm; emedan han är van, at vistas der. Således finne vi denna tid mycket Herring uti ofvannämde Elf, hvarest förut, och innan rommen på ofvansagde sätt blef ditförd, var alsingen. En annan synnerlig anmärkning var den, at ingen i forna dagar haft sig bekant, at någon Tårsk funnits här neder vid Caps; utan för mynningen af floden Dellaware; men nu fås han der i myckenhet, hvaraf kan slutas, at fisken äfven af sig sjelf ömsar de ställen, hvari den vistas.

Anmärkning vid Nordaste Delen af America. En Sjö-Capitain, som seglat til Grönland, påstod af egen förfarenhet, at då en kommer öfver den 70:de grad. af Lat. Boreal. blifver värman om sommaren derefter mycket starkare, än den är vid förberörde grad, hvaraf han slöt, 
at värman om sommaren vid sjelfva Norr-Polen skal ännu vara starkare, deraf at Solen der så länge utan nedergång, eller natt och dag, lyser. Samma berättelse och mening sade Herr Bens. Frankurn sig äfven fått af SjöCapitainer i Boston, som färdats åt de Nordaste Delar af Norra America. Nen mera synnerligit var det, som en Sjö-Capitain, vid namn Hexry Atrkixs, ännu boende i Boston, berättat för Herr Frankur, nämligen, at sedan han legat en tid pả fiskeri vid | stränderna utan för Boston, och ej fått der så mycket fisk han önskade, har han seglat längre Norr àt til Grönland, dả han omsider kommit så långt, at han råkat folk, som der bodt, hvilka aldrig förut sett nảgon Europée, och det, som ännu mera var, hade sig aldeles obekant nyttan af eld, den de aldrig. brukat. Om de ock hade haft sig kunnig, hade de ändock icke kunnat betjena sig deraf; emedan inga trän växa der i landet: de åto alla de Foglar och Fiskar de fingo råa. För Lappris saker bytte Capt. Arkiss til sig allehanda rara skinvaror. Sådan har varit Capt. Aтriss berättelse. hvilken pá det högsta bedyrat, at desse Folkslag aldrig haft sig bekant nyttan af eld. At långt til Norr finnes hvarken Trän, Buskar eller andra synnerliga växter, som kunna brukas til bränsle, är af flere Resebeskrifningar bekant; men mon icke desse, på sätt som månge andre af de Nordaste Folkslag, brukat Fisk-tran och annat fett til bränsle uti Lampor, både at koka mat, värma sina underjordiska rum om vintern, och lysa sig om nätterna och den mörkaste tiden med om âret? annars skulle de hafva en alt för lång natt, och bo uti närmaste granskap til det yttersta mörkret.

\section{Den 11 Novemb.}

Moose-deer. - Uti åtskilliga böcker läse vi om et mycket stort djur, som skal finnas i Nya Ängland och andra orter i norra America. De grufveligen stora och greniga horn, som ibland gräfvas up ur jorden i Irland, utan at någon hvarken der, eller annorstäds $\mathrm{i}$ verlden 
känner något djur, som har sådana horn, hafva gifvit p. 397 mången anledning at tro, at det i Norra America | utropade Moose-deer vore af samma slag, samt at ofvannämnde horn i Irland vore af Moose-deer, hvilka i forna tider varit der pả Oon, fast de sedermera blifvit aldeles utödde. Häraf hafva åtskillige trott, at Irland och Norra America torde $\mathrm{i}$ de första tider antingen hängt tilhopa, eller at åtminstone en myckenhet Oar då legat emellan dem bägge, hvilka nu mera icke finnas til. Detta gaf mig anledning, at noga spörja efter, om man någorstäds uti Norra America sett et sådant ofanteligt horn-djur, som man det utropat före. Herr Bartruy sade, at han noga frågat derefter, men ingen hade någonsin kunnat gifva honom något rätt besked derom, så at han aldeles var af den tankan, at et sadant djur aldrig finnes här i America. Her'r Frankin berättade väl, at han i sin ungdom sett par stycken af de djur, som här kallas Moosedeer; men så svarade de på långt när ej i storlek mot det, som fordrats af dem, hvilka burit de Irländska hornen. De 2:ne Moose-deer, han sett, voro förde til Boston, at derifrån sändas åt Ängland til Drotning Assa. En hvar, som der ville se dem, màste derföre betala 2. pence. En Köpman betalte då för alla Schol-Gåssarna, af hvilka Frankin var en, at de fingo se dem. Til högden af ryggen hade de varit lika med en stor häst; men hufvudet och hornen voro ännu högre. Herr Dudiey hafver gifvit en beskrifning om dessa i America befinteliga Moose-deer uti The Philos. Transact. N. 368. p. 165. seqq. Under mina resor i Canada frågade jag ofta Fransoserna, om de någonsin sett der i landet et sådant ofanteligt djur, som p. 398 somlige säga finnas i Norra America, och som / skal hafva lika stora horn med dem, man ibland grafver up i Irland? de svarade alle at de aldrig hört talas derom, mindre sett något sådant djur i Norra America, och trodde, at om någon skulle hafva sett et sådant, hade de bort vara de samme; emedan ingen så genomvandrat alla skogar i Norra America, som de, nämligen Fransoserne; men som här finnas Elgar, hvilka lära vara de samme med våra Svenska, 
eller en variation deraf, och man understundom råkar någon, som är tämmeligen stor, så torde sägnen om de ofanteligen stora djur i Norra America med faseligen stora horn fått $\sin$ upprinnelse deraf. Desse Elgar kallas af Fransoserna uti Canada Original, et namn lånt af Villarna, och lära desse djur vara samma med det af Duduex beskrifna Moose-deer.

Ollaris. - Herr FrankLin gaf mig et stycke af en sten, den de uti Nya Ängland bruka at mura masugnar. af, samt hafva vid smidjehärdar; emedan den stăr så starkt emot elden. Den var som en blanning af Ollaris och Asbestus; ty mästa delen var en grå Ollaris, vid kännandet mycket fet och hal, samt lät skära och arbeta sig; men här och der suto uti den som stjernor, eller en Asbestus fibris e centro radiantibus. Denna sten sades ej huggas i bärg, utan ligga strödd här och der på marken.

Såpsten kallades af en del Svenska här på orten en sten, hvilken är utanpâ så hal, som tvål, och den de. utom annan nytta, nog betjena sig af, at uttaga fläckar i kläder. Han kan kallas Saxum talcosum particulis spataceis | granatisque immixtis. Jag vil nogare beskrifva honom $\mathrm{i}$ et annat verk: dock nämnes nu allenast, at dess färg är ljusgrå, fast äfven mörkblå fläckar finnas här och der uti den samma; samt ibland fläckar som stöta på grönt. Han kännes mycket hal då han handteras, löper alt i flagor, låter dock någorlunda tälja och säga sig, fast han icke blifver särdeles slät, utan något gropig. Jag har sett stora hällar häraf, til en famns längd och mera, samt bredden proportionerad derefter, tjockleken gemenligen 1 a 2 qvarter; men jag kan icke döma något visst härom, emedan jag ej sett stenen der den gräfves up, utan endast. sedan han blifvit införd til Philadelphia, då han merendels är sågad. Myckenheten af Talkpartiklarna uti denna sten förhåller sig til dem af Spath och Granat ungefär, som 30. til 1. Den finnes på många ställen här i landet, som i Chester county, \&c. De Angelske kalla honom Soapstone, hvadan jag gissar de Svenske tagit sit namn på honom. Han nyttjas enkannerligen til följande: 
At uttaga fläckar utur kläder. Härtil dugde ej hela stenen; utan jag fant i den ljusare fläckar, som helt och hållne bestodo af en ollaris och kunde lätteligen skäras med knif eller annat järn. När någon fetma kommit på Silke eller annat kläde, skrapades något af denna lösa sten til et pulver, hvilket ströddes på flåttfläcken, dả fetman drog sig in i pulvret, som gnuggades ut, dả flåttfläcken försvan.

Som han är en eldfast sten, så brukas han pä landet, at muras in uti spisar vid eldstaden, der starkaste elden är, at stå emot eldens kraft och hetta.

p. 400 Trappor utan för hus äro gemenligen gjorde af denna sten, der han kan fås; men i brist deraf af Tegel.

Tegelstens murar omkring gårdar, Trä- Krydd- och Kyrkogårdar, Begrafningsplatser \&c. Tegelmurar för källarlukor ut emot gatan \&c. üro gemenligen täckte dermed; emedan han står emot Sol, luft, rägn, och oväder, och ändras icke deraf, då han hindrar dessas verkan pá Tegelstenen. Dörhakar voro gemenligen fäste i dessa stenar. Sidorna rundt omkring källargluggar voro äfven deraf och derutisuto gallrorna fäste.

Nedersta muren, samt hörnstenarna af somliga Publique hus, såsom Provinciens Assemblée-rum, bestodo äfven häraf.

Salt. Det Salt, som i Ängelska Colonierna mäst brukas, föres dit från Westindien, eller Americanska Öarna; men det är mera corrosivt, än det Europaiska. Indianerne här i landet hafva på et och annat ställe Saltkällor, af hvilkas vatten de koka salt. Jag får framdeles tilfälle, at beskrifva somliga. Herr Benj. Frankuin trodde, at man så mycket mera kunde tilverka Salt af hafsvatnet här utanföre Pennsylvanien, som de i Nya Ängland stundom förskaffat sig salt af det vatten som finnes i Hafvet derutan före, hvilket dock är så mycket längre til Norr belägit.

Blymalm är funnen i Pennsylvanien, fast icke i myckenhet, eller at någon gjort sig nytta deraf.

Magneter äro äfven här fundne tämmeligen gode, hvaraf jag fảtt vakra stycken. 
Järn fås både i denna och de andra Ängelska Pro- p. 401 vincier här i landet til en ganska stor myckenhet, at de dermed ej allenast tilräckeligen kunde förse gamla Ängland, utan ock nästan hela Europa; ja, tör hända, större delen af verlden. Malmen är här gemenligen mångfalt lättare at bryta lös i grufvorna, än den Svenska; ty man kan mångenstäds med en järnhacka, järnstör och träklubba nästan lika lätt bryta lös denna malm, som man hos oss gräfver en grop $\mathrm{i}$ hård jord. De veta der, i många grufvor, ej af bårning, sprängning och bränning; dessutom är malmen ganska lätt-smält. Detta Järn, som nu här i de Ängelska nybyggen i America arbetas, är icke allenast tilräckeligt til alla behof för den otaliga myckenhet af folk, hvaraf desse Colonier redan svärma, och til den myckenhet af skepp de årligen bygga, utan de förse ock Americanska Öarna härmed, utom hvad de nu börjat föra til Europa. Vid Skepsbyggeri hålles det före vara bättre, än Svenskt och alt annat järn i verlden; emedan det på långt när icke förtäres så af salta vatnet, som vårt. De trodde sig, oaktad frakten, knnna uti Ängland sälja sit järn til ringare pris, än andre Nationer, enkannerligen när landet blifver mera bebodt, och folket ej är så dyrlegt.

Bärg-lin, eller den Stenart, som Herr Biskop BrowalluUs uti sit År 1739 uti manuscr. utgifna Colleg. Mineral. kallar Amianthus fibris separabilibus molliusculis, finnes här i Pennsylvanien i tämmelig myckenhet. Somlige stycken äro mycket sköra: andre åter tämmeligen sega. Herr Benj. Frankuin berättade, at då han för några och tjugu år tilbaka var öfver til Ängland, | hade han med sig dit p. 402 en liten pung, som var spunnen och gjord af det Berglin, som finnes här i landet, det han förärte åt SIr Haxs SloANE. Likaledes hafva de ock här gjort papper af samma sten. Jag hafver fått af detta papper några små stycken, dem jag förvarat i min Naturalsamling. Herr Fraxkuis sade sig hafva hört berättas, at om detta Berg-lin lägges uti fria luften om vintertiden, och det får så ligga i köld och oväder, skal det blifva segare, och mera tjenligt at 
spinna af; men huru vida det hade sin grund, lämnade han derhän. Han förtälde tillika om detta Berg-lin en rolig Historia: han hade för några år tilbaka fått några stycken der af: lämnat dem åt en sin Boktryckare-gesäll, at låta i Pappersqvarnen göra et ark Papper deraf. När det var färdigt, tog Herr Franklin det samma, kastade det $\mathrm{i}$ elden och sade, at det ej skulle kunna brinna up. Gesällen påstod vederspelet; men han blef förskräkt, när han såg Franklin sagt sant. Herr Frankun uttydde då för honom hvad slags Papper det var, dock ej så tydeligen. När Herr Frankrıx gått bårt, kommo nàgre af hans vänner dit, som kände detta papperet. Gesällen mente nu göra et mirakel för dem, och at sätta dem i största förundran: han berättar för dem, det han hade et ark papper så konstigt tiliedt, at han kunde kasta det i elden, utan at det skulle brinna upp. De nekade för ro skul deremot; men han pastod, at han hade rätt, och kom det ändteligen til et vad: medan han lagade til elden, smörgde de andre oförmärkt flät på hans papper; hvarpå, sedan Gesällen kastat det i elden, började det brinna i ljusan p. 403 låga. Han blef då helt förvånad, hvilket gjorde, | at de andre ej kunde hålla sig för löje, och uptäkte ändteligen för honom hela saken.

Myror. Uti àtskilliga hus här i staden var en myckenhet af små myror, hvilka hade sit tilhảll så väl ned i jorden, som i hål uti muren. Längden af sjelfva deras kropp var just en lin. Geom. och til färgen voro de antingen svarta eller mörkröda. De hade här samma osed, som på andra orter i verlden, nämligen, at de drogo bårt Såcker, när de kunde komma öfver något. Herr Franklin sade sig hafva anledning at tro, det desse små kräk på något sätt måste kunna gifva hvarandra sina tankar eller åstundan tilkänna, och det för följande orsaker: när nảgon enda af dem hittar på något Såcker i skåpet, går hon strax bårt under golfvet, eller til deras hål, och efter en liten stund kommer en stor hop, som följas åt, och vandra rätt åt skåpet der Såkret är, det de börja släpa bårt. Om en enda af dem råkar en död fluga på golfvet, och 
rår ej med, at ensam bära henne bårt, löper hon på stunden til deras hål, och i en handvänning derefter komma flera af dem på en gång och taga kosan ända til den döda flugan, den de släpa bårt. Någon tid förut hade Herr Frarkin haft en liten burk med Sirap som stät i skåpet, i hvilken en hop af dessa myror smygt sig in, och ätit deraf. När han märkte det, skakade han bårt myrorna, och bandt burken med en smal trå fast vid en spik, som han slog up i taket, at burken hängde derifrản på tråden. Händelsen gjorde, at en enda myra kommit at lämnas qvar i burken. När hon ätit sig mätt, och skulle gå bårt, blef hon brydd, at slippa ned på golfvet derifrăn: hon lopp under botten på burken, | men derifrản var ingen gång ned. Ändteligen efter mycket arbete, fant hon på, at gå up efter tråden til taket, sedan långs efter det samma, och omsider utföre väggen ned pa golfvet. Det var näppeligen en half tima derefter, förr än stora skåcken af dem kom vandrandes långs efter taket och gerad til tråden, să ned efter den samma och i burken til Sirapen, den de började äta. De höllo på dermed så länge nảgot af Sirapen var qvar. Imedlertid gick den ena troppen up- och den andra nedföre trảden hela dagen igenom.

\section{Den 12 November.}

Spådom om väderleken i följande vinter. En hederlig Man, som en lång tid vistats här i landet berättade, at han nu i 20 års tid nästan beständigt utrönt, det ock andre märkt, nämligen, at väderleken om vintern härstädes gemenligen rättar sig efter den första November st. vet. så at, om dâ är uphålds väder, kommer litet snö och rägn den följande vintren; är det den första November för middagen vackert väder, men efter middagen obehageligt, skal början af vintern blifva vacker, men slutet och våren ful, o. s. v. Dylika väderleks spådomar har jag ock hört på andra orter; men Meteorologiska observationer, utom en sund eftertanka, hafva nogsamt vist dem oändeligen slå felt. 
Efter middagen fölgde jag Herr Handelsman Kock ut til dess gård på landet.

Källors nytta. Landet Nya Sverige eller Pennsylvanien är ganska rikt på källor. En skal gemenligen antingen på den ena eller andra sidan om en backe, ibland ock på flera sidor, finna någon källa, hvarifrån et klart

p. 405 flytande vatten | strömmar. Utom den nytta, som i allmänhet hämtas af et got käll-vatten, hade man ock den, som förut p. 223. är omnämd, nämligen, at de strax brede vid källan, då hon var nära til gården, bygt et litet stenhus, hvarigenom de ledt käll-bäcken. Alt som de sedan behagade, kunde de stoppa igen utgăngen för vatnet från huset, hvarmedelst det kom at stiga öfver hela golfvet. Uti detta vatten sattes ej allenast mjölk-kärilen om sommaren, utan äfven Bouteiller med vin eller andra drycker, hvarigenom de altid höllos kalla och friska, medelst det nya vatten som ständigt strömmade til från källan. Pả atskilliga ställen hade de ock på landet sa bygt köket eller något annat visthus, at de kunde leda käll-bäcken derigenom, och således ej hafva långt efter vatten.

Fiskdam. Ståndspersoner, och andre af något värde, hade gemenligen Fiskdammar vid sina gårdar pả landet, hvarvid de altid voro mona om, at friskt rinnande vatten kom at gá genom dammen, derigenom fisken sades trifvas väl; derföre anlades dammen gerna sả, at någon källa låg ofvan för den samma.

\section{Den 13 November.}

Ängars vatnande. På flera ställen här i landet såg jag et behändigt sätt, at göra ängar mera fruktbärande. Jag har nämt förut, at här finnes en stor myckenhet källor på sidorna af högder, och ibland i dälderna. Ängarna här på orten ligga mäst emellan högder uti dalar, hvarest, om det varit för sankt och vått, så hade de genom diken affört det mästa vatnet; men som somrarne äro här nog varma, och Solen ofta så bränner gräset, at det aldeles torkas bart, sả hafva omtänksamme hushållare p. 406 varit mone om, at på / ängarna bota detta. Til den ändan 
hafva de sökt up alla källor, som varit i nägden vid någon deras äng, och $\mathrm{i}$ stället at bäcken från dem runnit närmaste vägen ned til dälderna, hafva de ledt vatnet så högt som görligt varit, och de funnit nödigt, på de högre sidorna af ängarna, derest de från hufvudbäcken låtit som oftast gräfva smala rännilar ned ât ängen, at vatnet kommit at rinna mäst på alla sidor öfver den samma. Ibland, der någon däld var, leddes vatnet uti trä-rännor deröfver til andra sidan, och så deltes det omkring genom helt smala rännilar til alla ställen, som de ville. At få vatnet at gå desto högre, och på det de måtte kunna leda det til flera ställen, hade de upmurat höga dammar vid sjelfva källan, deri vatnet samlades, til dess det kom til den högd, at det måste gå den väg de ville hafva det. Ofta har omtanka och flit gått sả lảngt, at dả de funnit någon bäck i skogen, som lopp en hel annan väg, än åt ängen, och de dock genom vattupasset och den emellanliggande markens betraktande kunnat finna, at de voro i stånd, at leda vatnet dit, hade de gjort en dam, at hindra vatnet från dess förra gång, och fört det rundt omkring sidorna på många backar, ofta til en Ängelsk mils längd och mera, samt ibland uti trä-rännor öfver dälder, til dess de fått det til ängen, då de utdelt det på ofvannämde sätt. En som icke sjelf detta sett, kan näppeligen tro, hvad ymnighet af skönt gräs kom at växa på dessa ängar, enkannerligen närmast til rännilarna, då på andra, som ej så handterades, gräsväxten stod helt usel. Ängarne lågo här gemenligen $\mathrm{i}$ dalar, och en eller flere deras sidor voro sluttande, så at en helt lätt kunde få vatnet at / rinna utföre dem. Desse ängar, som här i landet så sköttes, slogos gemenligen hvar sommar 3. gångor: men det är ock at märka, at sommaren varar här 6 a 7 månader. Om någon källa eller flytande vatten var $\mathrm{i}$ nägden, eller ock ej för långt från någon äng, men kunde dock ledas til den samma; lämnades den ej gerna, med mindre de sökte göra nytta deraf.

Löfvet var nu fallit af alla trän, både Ekar och andra, som här på orten om vintern pläga mista dem, 
och låg i skogen til et qvarters högd på marken. Detta Löfvets årliga affallande tyckes ju ej annat kunna, än ansenligen öka svartmyllan; dock var den här i skogarna ej öfver en tvärhands tjocklek, hvarunder en tegel-färgad lera utblandad med en lika färgad sand tog emot. Underligt, at en jord, som tör hända ej varit rörd sedan synda-floden, skulle hafva så litet svartmylla på sig; men härom mera längre fram.

Machine at tilreda Sur-kål. Hos en Tysk fick jag se en synnerlig Machine, hvilken han vid denna tiden brukade, att skära sönder kål-hufvuden med, hvaraf Surkål skulle göras. Och som detta sättet, at fả sönder kålen, går mycket fortare, än med de vanliga Sur-kals-knifvar, som likna til skapnad et Latinskt $S$, det vi bruke; sa vil jag beskrifva sättet här kårteligen. Man hade gjort som en ränna utaf bräder med flat och jämn botten, af 6 . qvarters längd, bredden af botten 7 tum, högden af sidorna 2 tum; midt uppả denna rännas botten var et stort fyrkantigt hal inemot af samma bredd, som botten, samt p. 408 4 tums längd un|gefär. Öfver det samma suto 3:ne knifvar efter hvarandra. Bredden af hvardera knifven $\operatorname{var} 1 \frac{1}{2}$ tum. De voro satte med ägget sa sluttande, som järnet uti en höfvel, om icke mera, samt sả stälde, at baken af den föregáende ligger under det hvassa af den följande. Distancen eller vidden emellan det hvassa af den ena knifven och baken af den andra, var $2 / 3$ af en Geom. Linea; det var deremellan, som kålen skulle gá. Med ändarna voro knifvarna fäste uti sidorna af rännan. Uti rännan var satt en bottenlös fyrkantig låda af samma bredd som rännan. men et qvarter och 4 tum lång, samt et qvarter hög. Denna lådan sköts fram och tilbaka långs efter rännan, då en ville skära sönder kålen, och gick med nedre sidorna in uti sidorna af rännan, på sätt nästan, som et lảck skjutes igen $i$ en lảda. När de ville skära sönder kålen, lades rännan på en tunna eller annat tjenligt käril, så nämligen, at hålet, der knifvarna sitta, kom at stå midt öfver tunnan eller kärilet; derpå lades kål-hufvudet $\mathrm{i}$ den bottenlösa lådan, och trycktes ned med den 
ena handen; men med den andra sköts lådan fram och tilbaka efter rännan, likasom man stode och höflade, dả kål-hufvudet kom, at stöta mot äggen af de 3. knifvar, likasom mot 3 höfvel-järn, hvilka skuro det sönder uti helt tunna smala rimsor, likasom smala höfvel-spånor, som sedan föllo ned i tunnan under Machinen. På detta sätt kan en helt snart skära sönder en stor hop kål-hufvuden til Sur-kål. På bägge lång-ändarna af den bottenlösa lådan är ned vid hotten mot rännan så mycket afskurit, som behöfves, at ej lådan må taga mot knifvarna; och är Distancen emellan botten af rännan och nedra delen af lådan par Linier. | Af hosstående Figur lärer detta alt än p. 40 s bättre begripas. Denna Machine kan kallas Kål-höfvel, endast at höfvelen här ligger stilla.

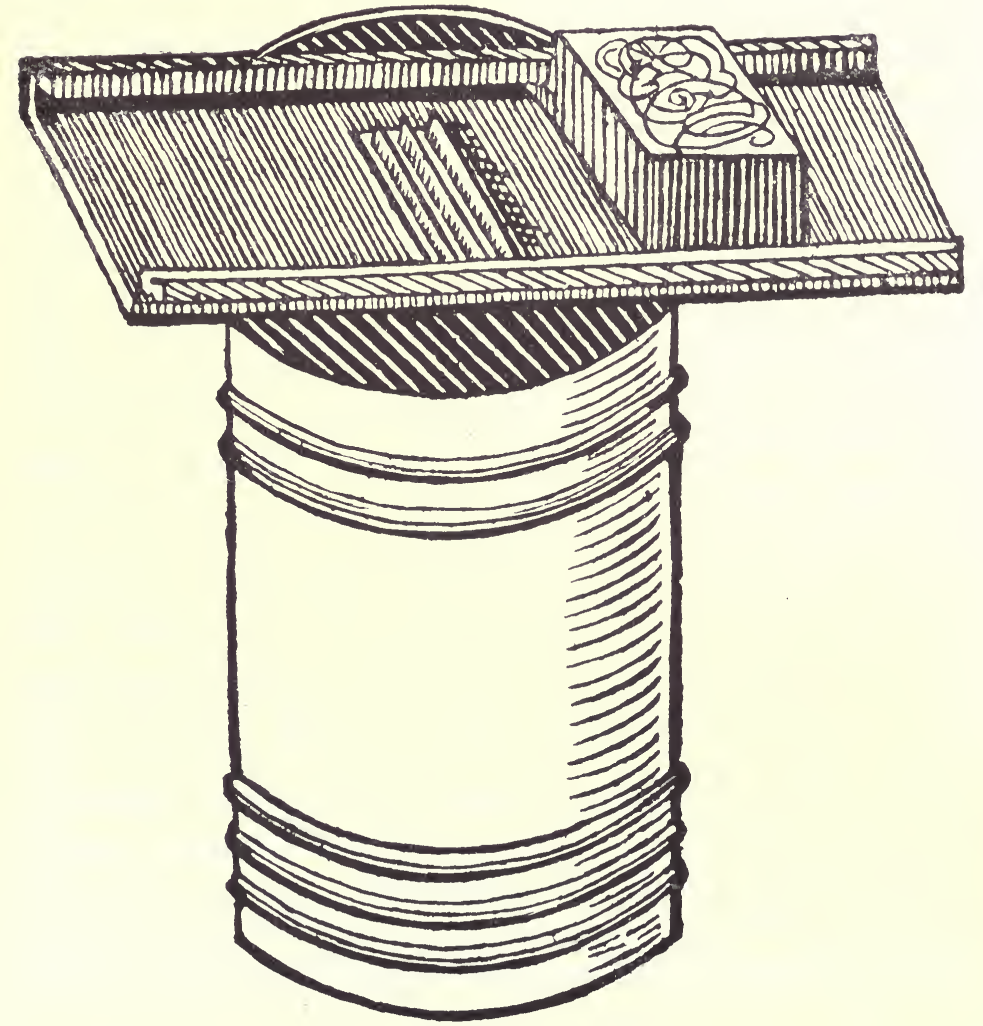




\section{Den 14 Novemb.}

Ickornar funnos här i skogarna af åtskilliga slag, och til stor myckenhet. Jag vil nämna de allmännaste.

Grå Ickornar. Et slags grå Ickornar finnes ganska mycket uti skogarna i Nya Sverige eller Pennsylvanien, och annorstäds i Norra America, hvilka til skapnad likna aldeles våra vanliga Ickornar i Sverige; men skiljas derutinnan frản dem, att desse Americanske behålla hela p. 410 året | både sommar och vinter sin grả färg, samt äro derjärnte merendels nágot större. Skogarne pà all denna trakten, enkannerligen uti Nya Sverige, bestå gemenligen af löf-trän, i hvilka de hälst vistas. Herr CATessy har beskrifvit och med lifliga fårgor afritat denna i dess Natural History of Carolina Vol. II. p. 74 tab. 74. under namn af Sciurus Iringianus cinereus major. Rai. Syn. Quadr. p. 215. De Svenske, soin här bo, kalla honom den grå Ickorn, och de Ängelska Gray Squirrel. De hafva merendels sina bon i iholiga trän, dit de draga måssa, båss och annat blött, som de kunna komma öfver. Deras förnämsta mat är allehanda slags nötter, som Hasselnötter, Chinquapins, Castanier, Valnötter, Hickery-Nötter, Ollon af allehanda de många slags här växande Ekar; men enkannerligen är Mays framför alt annat af dem begärlig. Marken är här om hösten nästan öfvertäkt med Ollon och allehanda slags nötter, hvilka nedfallit från den myckenhet af Ekar, Castanie- och Valnöt-trän, som här växa i skogarna. Desse Ollon och Nötter samla Ickornarna om hösten, bära dem tilhopa i högar, gräfva ned, och gömma en hög deraf här, den andra der, til sin vinterföda. De bära ock en hop deraf up uti sina bon. När vintern kommer, och snö eller köld faller in, ligga de ofta i flera dagar stilla i sina bon, hälst om det är fult och elakt väder med snögande och yrande, och äta då af det lilla förråd de dit samlat; men så snart väderleken blifver litet mildare, vandra de ut derifrån, och gå då at gräfva up någon af sina högar, den de til en del straxt äta up ned på marken, til en del föra de den ock up i träden 
til sina | bon. Vi märkte ofta, de följande vintrar, at då p. 411 det hade varit blidt väder, och sträng köld skulle infalla, så voro Ickornarne en dag, eller så vid pass, förut, mer än vanligt ute i skogen, dels at äta sig väl mätta, dels at förse sig med mat i sina gömmor och bon under den starka kölden, då de lågo stilla, och icke gingo ut. Man kunde då, af det man såg dem mer än vanligt vara allestäds ute på marken i skogarna, tämmeligen säkert spå och veta förut, när stark köld skulle infalla. Svinen, hvilka altid så länge marken är bar, gå här ute, och i skogen söka sin föda, göra ofta stor skada åt dessa Ickornar, i det de upsöka deras gömmor, och äta up deras vinterföda. Ängelsmän, Fransoser, Indianer, och andre Nationer, som bo här i landet, pläga flitigt spana up dessa deras förråds hus, antingen de då äro på marken, eller uti iholiga trän; emedan alla de Nötter, som finnas deruti, äro gemenligen af de utvaldaste, och sådane, som både äro fullmogne och derhos nästan aldrig af någon mask skadde. Sảdane äro ock de Ollon och Nötter, som Skogsmössen om hösten här samla tilhopa. De Svenske berättade, at när, under den långa vintern, som här var år 1741. föll sả mycket snö, at Ickornarne icke mera kunde söka up sina gömmor, svulto månge af dem ihjäl. Hvad skada desse som oftast göra på Maysen är förut omtaldt p. 227. de öda den samma så mycket mera, som de icke äta up hela kornen, utan endast den innersta och söta kärnan, men skräda bårt alt det andra. Om Våren midt uti April månad st. vet. då Ekarne blommade som bäst, såg jag en myckenhet Ickornar sitta uti dem, ibland 5, 6 och flere uti et en $/$ da trä, hvilka beto af stjelken litet nedanför blomman, och fälte den ned, antingen de då åto något deraf, eller de samlade det til något annat. Den tiden sågs marken helt full med Ekblomster, nedfälte med et stycke af stjelken vid. Härigenom sker, at Ekarne på långt när ej bära så mycket Ollon til föda för Svin och andra djur, som annars skulle ske, i fall deras blommor ej blefve så starkt af dessa Ickornar förstörde. Ibland de villa djur, som här i landet snarast kunna göras tama, 
räknas desse, enkannerligen då de tagas medan de ännu äro helt små. Jag har sett dem så tama, at de fölgt med gåssar i skogen, hvart de gått, samt sprungit och satt sig på gåssarna, när de ej mera velat gå: ofta, sedan de fölgt gåssarna et godt stycke in i skogen, hafva de vändt om och lupit tilbaka hem til gården, der de lagt sig i det bo, som blifvit gjordt för dem. När desse àto, suto de mäst raka, höllo maten emellan sina främre fötter, och svantsen i krok up i vädret: fingo de tame mera, än de orkade äta, buro de det uti sit hus, och gömde det der under ull-tappar eller annat, som de hade at ligga på; och då de blefvo hungrige, sökte de det fram igen. De syntes då ej! vara rädda för nảgon, och kunde en och hvar, äfven främmande, handtera dem emellan händerna, utan at de bödo til at bitas. Man sảg dessa tama äfven springa på främmande, och krypa emellan kläderna, at lägga sig och sofva. I gården der de höllos, lekte de både med kattor och hundar. Desse tama äta äfven bröd. När de grả Ickornarne suto i skogen på någon stubbe, höllo de svantsen up i vädret; och der de då blefvo varse

p. 413 någon Människa, var svantsen under den / tiden gemenligen uti beständig rörelse. Så snart de sảgo någon människa i skogen, började de på smattra och hålla mycket läte uti träden der de suto, sâ at det var svårt, at få dem at tiga. De som gå ut at skjuta foglar eller andra djur, äro för denna orsaken ofta rätt förtörnade på dem; emedan de härigenom blifva rögde, och andra djur varnade. Ehuru de tyckas ej vara särdeles skygge, så är det dock nog svårt, at kunna skjuta dem; ty så snart de blifva varse någon människa, löpa de up uti något trä, och utvälja dertil gemenligen det största, de finna i negden. De laga då straxt, at de komma bakom trädet, på det at den, som vil skjuta dem, icke skal få ögnasigte på dem; och ehuru skytten då går omkring trädet, är Ickorn lika snäll, om icke snällare, at ömsa sit ställe beständigt til den sidan af trädet, som vetter ifrån honorn, så at han har svårt, at en gång få ögnafäste pả honom. Om trädet är grenigt, lägger han sig midt $\mathrm{i}$ grenen, och klämmer 
sig så hårdt ned i den samma, at han näppeligen kan synas: skakas trädet, eller kastas med käppar och stenar til honom, eller skjutes dit med byssan; sà ligger han likafullt gemenligen helt stilla, utan at röra sig. Är trädet delt i 3 grenar, så lägger han sig midt emellan dem, klämmer sig så hårdt ned han kan, och då kan ingen komma åt honom. När han kommer uti trän, hvarest äro gamla Ickorn-bon eller stora fogel-bon, lägger han sig uti de samma, och kan nästan ej fås derutur, om man ock kastar, skjuter, eller gör hvad en vil åt honom. Sällan ses desse Ickornar hoppa ifrån det ena trädet til det andra, utan då måste merendels högsta nöden drifva dem dertil. De|ras vana är gemenligen, at löpa up i trädet, och så samma väg långs ned efter det, med hufvudet förut. På åtskilliga, som jag i skogen skutit, har jag funnit en myckenhet Loppor. At desse Ickornar äro bland de djur, hvilka nu finnas här i mycket större ymnoghet, än fordom, samt at Maysen, deras mäst begärliga mat, hvilken nu planteras här i långt större myckenhet, än tilförene, är förnämsta orsaken dertil, är tilförene i denna Tome omtalt. Dock är det synnerligt, at somliga år komma hit ned til Pennsylvanien och andra Ängelska Colonier en mångfalt större myckenhet af dessa Ickornar up ifrån landet, än eljest vanligt är. Det är då gemenligen om hösten, som de sålunda infinna sig, och äro de då alt för mycket sysselsatte, at samla ihop i skogarna allehanda slags Nötter och Ollon, dem de föra uti iholiga trän, eller andra gömmor, at förvara til vinterföda: de äro härutinnan så flitige, at ehuru ibland samma år varit en ymnoghet af dessa slags Nötter, har man dock haft nog svårighet, at få någon särdeles myckenhet deraf; emedan Ickornarne förut dragit dem bårt i sina hål. Folket hafver af långlig förfarenhet här $\mathrm{i}$ landet funnit, at när Ickornarne komma til någon ovanlig myckenhet up ifrån de öfra orter hit ned, plägar gemenligen en ganska sträng och kall vinter följa strax derpå; hvarföre de ock mäst altid taga sådant för et visst tecken til en sträng vinter; men så slår det dock ej altid in, hvilket jag sjelf förnam om hösten år 
1749. ty ehuru samma höst en myckenhet af Ickornar kommo ned til de Ängelska Colonier, var dock den näst påföljande vintren nog lindrig, och ej mera kall, än årp. 415 ligen här på orten är van/ligt. Orsaken til Ickornanas nedkomst i en sådan myckenhet den gången, var (hvilket äfven gamle män visste berätta, at ock ibland fordom händt) at längre upp i landet var samma år stor missväxt och brist på allehanda slags Ollon och Nötter, hvarigenom hungern och nöden tvang dem, at söka hit ned. De vandra gemenligen, til en stor del, följande året, up til landet igen, hvarifrån de först kommit. Deras kött ätes af somliga, hvilka hålla det som en läcker mat; men de måste akta det icke mycket. Skinnet duger ej stort. Somlige göra små remmar deraf, emedan det är någorlunda segt: andre bruka det i nödfall til foderverk: någre göra qvinfolks skors öfverläder til en del deraf. Ehuru qvicke desse Ickornar äro, blifva de dock ofta et rof för Skallerormen, hvilken ibland upsluker dem nästan lefvande. Denne oviga ormens sätt at fánga dessa snabba djur, säges ske genom förkjusning. Jag har väl aldrig sjelf haft tilfälle, at med egna ögon se huru här med tilgår; men jag har hört det af sả många trovärdiga personer, hvilka sagt, at de sjelfve helt noga åskådat det samma, at jag nästan nödgas sätta tro til deras enhälliga berättelse, ehuru orimlig han eljest förefaller mig. Förkjusningen säges altså ske på följande sätt: Ormen ligger ned på marken under något trä, deri Ickorn sitter. Så snart Ormen fäster sina ögon på honom, fast den ock sitter högst upp i trädet, är han ej mera i stånd, at hoppa bårt, utan börjar då få et särdeles ömkeligt läte, som gör, at eho, som går der förbi, kan af lätet märka, at ormen håller på at förkjusa honom. Ickorn hoppar då et stycke up åt trädet, så åter ned; åter up, derefter längre ned. p. 416 Hvar|vid märkes, at han hvar gång kommer närmare och närmare ned på trädet, och den senare gången han löper upföre trädet, hinner han ej så långt up, innan han vänder tilbaka, som den förra. Ormen ligger under alt detta vid trädets rot och håller ögonen orörligen fäste på djuret, 
utan at det minsta vända dem på något annat; ja han har ögonen då så starkt fäste på Ickorn, at en människa, som ser honom, kan tämmeligen bulra, utan at han gifver sig tid at höra derefter. I sådant löpande up och ned, som nu omtalt är, skrider Ickorn alt längre och längre ned, til dess han kommer til ormen, som då säjes ligga med vidöppen mun, hvarpå han med ängsligt läte rusar honom i gapet, och strax upslukes, om han icke är för stor; men om han är så stor, at ormen ej straxt kan svälja honom ned, slickar han honom några gångor med tungan, at göra honom hal, och så småningom upsluker honom. Hvad mera besynnerligt är vid denna förkjusning, har jag infört uti Kongl. Vettenskaps Acad. Handl. för år 1753. p. 59. och följande, det jag nu ej vil här uprepa. En dylik förkjusnings kraft tillägges äfven den i Norra America så kallade Svarta Ormen, hvilken på samma sätt säges fånga dessa Ickornar, och äta dem up. För den synnerliga skada, som desse Ickornar göra på Maysen, ej allenast då den står pả åkern, hvarom förut är talt, utan äfven hemma i sädesboden, der ifrån desse kunna på några nätter, om de fă hafva sin frihet, bära och draga bårt hela tunnan, och mera, til sina gömslor, har Regeringen mäst i alla Ängelska nybyggen i Norra America blifvit föranlåten, at gifva ut Lagar, som stadga något | visst, huru mycket af allmänna Cassan skulle betalas för hvart Ickorn-hufvud, som en kunde upvisa. Det tyckes nästan öfvergå all tro, hvad som betaltes uti Pennsylvanien allena för Ickorna-hufvuden af det grå och svarta slaget på et enda år, nämligen från den 1 Januarii år 1749, til samma dag år 1750. Ty när Deputerade från alla landsorter i Pennśylvanien vid början af Januarii månad 1750. kommo der tilhopa, at rådslå om Landets nödvändigheter, inkommo klagomål från alla orter, at deras Häradskistor voro uttömde endast för Ickornar skull; förut var stiftad en lag, at af allmänna Cassan skulle betalas 3. pence (är vid pass 12 a 14 öre Kopparmynt) för hvart Ickorn-hufvud; sả högt hade hämden gått emot dessa djuren, nämligen mot de grå och de svarta Ickornar. Man såg då af in- 
komne räkningar, at på det ena året til ofvannämde ändamål blifvit betalt 8000 . Pund i Pennsylvanie-penningar. Det är i våra penningar ungefär 40000 Plåtar. Jag har detta af den, som sjelf satt med öfver dessa Räkningar, hvilken ock lade orsaken til, hvarföre så mycket härtil åtgått, nämligen, at som man fick 3 pence för hvart Ickorne-hufvud, så lönte det mödan, at gå i skogen efter dessa kreatur; hvarföre mången, i synnerhet af ungdomen, öfvergofvo alt annat arbete, och lupo endast i skogen, at skjuta Ickornar. Regeringen blef derföre nu nödsakad, at ändra samma lag från 3 pence til hälften mindre för hufvudet.

Flygar-Ickorn, kallades af de Svenska här på orten en art, hvilken lärer vara aldeles den samma, med den vi hafve på somliga orter i Finland, och nämnes i Herr Archiat. Linnær Fauna Suec. § 22. Sciurus hypochondriis p. 418 prolixis voli|tans; åtminstone är den Americanska ej annat än en Varietet deraf. Ängelsmännerne kalla honom Flying Squirrel. Han är beskrefven och med lefvande färgor aftagen af Herr Catesir uti dess Natural History of Carolina Vol. II. p. 76. och 77. tab. 76. och 77. der han kallas Sciurus volans. De finnas här i skogarna, dock äro de tämmeligen sällsynte. Om dagen skal man nästan aldrig få se honom gå ute, (undantagandes då de blifvit af människor nödgade dertil, som râkat på deras tilhåld,) utan han ligger då och sofver; men så snart det blifver mörkt, kommer han fram, och är då ute mäst hela natten. De uppehålla sig om dagarna gemenligen uti iholiga trän, hvarest man ibland af en händelse, då man hugger sönder et sådant trä, kan råka 7 . stycken, och flere af dem ligga tilsammans på et ställe. Genom den tilökning af skinn, som Naturens HErre försett dem med, långs efter hvardera sidan, kunna de tämmeligen, såsom med flygande, hjelpa sig från det ena trädet til det andra. De utbreda under en sådan fart sina skinn-tilökningar, men draga dem tilhopa så snart de fått fäste på trädet dit de farit. Somlige påstodo, at deras flygt från det ena trädet til det andra sker $i$ en Horizontel Linea: andre sade, at de 
först släppa sig litet ned åt, och inemot trädet de vela til, åter litet upåt. Det längsta de kunna på en gång flyga, sades vara 4 à 5 famnar. Bland alla Ickornar här i landet äro desse de, som blifvit aldratamast. Gåssarne pläga bära dem med sig hela dagen, då de gå i Scholan, eller hvar de vistas, utan at de skola bjuda til at löpa bårt; men då gåssen släpper honom från | sig, springer han p. 419 straxt up til honom, och kryper antingen i barmen, eller ärmen, eller ock annorstäds, der han lägger sig at sofva. Deras föda är den samma, som de grå Ickornars.

Rösselvissla, som den här kallades af de Svenska, var åter et annat slag af helt små Ickornar, hvilket fans här i landet i skogarna til stor myckenhet. Af de Ängelska hette han Ground Squirrel, det är Jord-Ickornar. Denne är äfven beskrefven och med lifliga färgor aftagen af Herr Catessy uti dess Natural History of Carolina Vol. II. p. 75. tab. 75. der han kallas Sciurus striatus. Deras förnämsta tilhåll är ej up i träden, som andra Ickornars, utan de gräfva sig hål ned i jorden mäst på samma sätt, som Caniner, deri de vistas, och dit de taga sin undanflykt, då någon fara är på färde. Desse deras gångar gå djupt och långt under jorden, och dela sig gemenligen, längre in, uti åtskilliga grenar, hvarvid de varit så sluge, at laga, det åtskillige af dessa grenar sluta sig med et hål up i dagen. Däraf tilflyter dem den förmon, at om de äro uppe, at söka sig föda, och någon tiltäpper det hål de kommo igenom, blifva de deraf ej försagde, utan hafva strax et annat $\mathrm{i}$ beredskap, dit de försvinna. Om hösten vid löf-fallningen, eller ock strax derefter, är roligt at se, hvad bryderi desse ibland hafva, då man kasar efter dem; ty som af löfvets starka fall, eller blåsväder, som drifver löfven omkring, deras hål eller ingångar lätteligen öfvertäckas; så hafva de mycket at göra, innan de i sådan hast kunna finna dem igen. De löpa då, likasom de hade förvillat sig, af och | til, och tyckas vela känna p. 420 stället igen; men veta ej hvart deras ingång tagit vägen. Löper en då starkt efter dem, och klappar händerna tilhopa, är gemenligen för dem ingen annan undflykt, än 
at springa up i något träd; ty det är at märka, at desse altià hålla sig vid och under jorden, och gå ej oftare up i träd, än då de blifva skrämde, och icke i hastighet kunna få sina hål igen. Uti Pennsylvanien finnes af desse Rösselvisslor långt större myckenhet, än på de andra orter i America, der jag färdats. Deras längd är gemenligen netto et qvarter, utom den lilla svansen; men de äro derjemte nog smale. Färgen rödbrun med 5 svarta ränder, nämligen en långs midt efter ryggen, och 2ne pâ hvardera sidan. Deras mat är allehanda slags säd, som Råg, Korn, Hvete, Mays, Ek-Ollon, allehanda slags Nötter, med mera. De samla om hösten åt sig sit vinter-förråd på samma sätt, som de grả Ickornarne, och förvara det i sina hăl under jorden. Då de komma i en sädesstack, göra de samma skada som råttor och möss. Ofta har det händt, at då de ätit Råg, och sedan kommit dit, hvar hvete varit, hafva de spydt ut all rågen; emedan han ej varit dem så behagelig, som hvetet, och sedan åter fylt magen med hvete. När Maysen på åkern blifvit skalad, är denne ganska flitig, at skära af axen, taga mun full med Korn, så at käkarna stå som upblåste, samt föra det, han samlat, ned i sina hål under jorden. Vid det en af de Svenske sent om hösten gräfde $i$ en backe efter mull til en qvarndam, råkade han på et af dessas hål eller gångar under jorden, och när han med gräfning fölgt den samma en p. 421 stund, gick en gren af från gången til | en alns längd, uti ändan på hvilken låg en stor hop af ut-

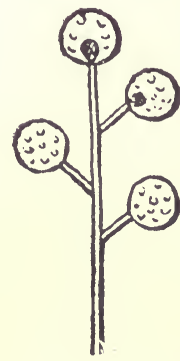
valda Ollon utaf den hvita Eken, som Rösselvisslan samlat til sin vinterföda. Litet derefter kom en dylik gren til en stor del upfyld med Mays. Sedan en annan straxt derefter full med Hickery-Nötter, och ändteligen alrainnerst låg en samling af sköna och utvalda Castanie Nötter til par hattkullars fyllnad, dem ofvannämde Svensk och hans Kamerater gjorde sig en god måltid af. Hos stående figur utvisar nyssnämde dess gömmor. Om vintern synes icke stort til dem, utan de uppehålla sig då i sina hål 
ned $\mathrm{i}$ jorden, och lefva af det de samlat medan vackert väder varit; dock när det är någon särdeles varm och vacker dag, komma de stundom fram. Ibland gräfva de sig genom jorden hål ned til källare, deri Landtmännerne förvara sina äpplen, dem desse Jord-Ickornar upäta och skämma samt göra sålunda stor skada. Uti Mays-bodar hålla de ock ibland illa hus; dock utödas de mycket af kattor, hvilka dels äta dem sjelfva, dels bära dem hem til sina ungar. Deras kött brukas eljest icke til mat af folk, ej eller nyttjas deras skinn til nảgot. Utaf alla Ickornar här i landet är ingen så svår, at göra tam, som denne; ty fast en ock förskaffar sig honom medan han ännu är helt liten, låter han ändock föga handtera sig med bara händer, innan han bitts hel argt. Gåssar, som använda mycken tid med dessa små djur, sade mäst alle, at det näppeligen var någon konst, at tämja JordIckorn: åtminstone blef han aldrig så tam, som de andre slagen. $\mathrm{Om} /$ de skola blifva någorlunda tama, böra de tagas medan de äro helt små. Somlige bruka hålla dem i burar, medan de äro små och se täcka ut.

De svarta och röd-bruna Ickornar, hvilka äfven finnas här i landet, skola framdeles omtalas.

\section{Den 15 November.}

Om morgonen reste jag til Philadelphia.

Tecken til Orcan, eller en grufvelig storm. Herr Kock berättade både i dag, och sedan ofta, at då han en gång seglat uti Westindien med en liten jagt, och haft bland andra om bord en gammal man, som uti en lång tid farit til sjöss i denna verldenes del, hade det händt sig, at då denne gamle mannen stått och kastat ut lodet, har han bedt Styrmannen säga àt Herr Kock, at de borde hasta ut med båtarna och folket $\mathrm{i}$ dem, at med roende hjelpa under den sakta vinden, på det de ju förr dess hällre måtte komma til den Ön, hvilken låg fram för dem, emedan de skulle inom 24. timar hafva en stark Orcan. Herr Kock har frågad honom, hvad anledning han haft, 
at tänka så? den gamle mannen hade svarat, at emedan han, då han kastade ut lodet, kunde se det samma i vatnet på långt flera famnars djup, än någonsin eljest var vanligt, och vatnet sålunda var i hast ganska klart blifvit, så var detta et tecken, at beredelsen nu skedde $\mathrm{i}$ hafsvatnet til en Orcan. Herr Kock såg ock med egna ögon, at vatnet var så klart; derföre hade han ut båtarna, at hjelpa under med roende, så at han innan aftonen kom i god hamn. Men förr än han hant fram, började vågorna gå alt större och större på hafvet, hvilket stod som en sjudande gryta, p. 423 fast intet väder märktes i luften. Följande natten | kom Orcan, hvilken var så häftig, at icke allenast månge skepp förgingos, och taken af husen togos bårt, utan Herr Kocks jagt och andre Fartyg, som lågo i en god hamn, blefvo ändock af vädret och vatnets häftiga upstigande drefne så långt up på landet, at några veckor gingo förbi, innan de fingo dem ut i vatnet igen.

Haj. En gammal Holländsk Skeppare sade, at han en gâng fătt en Haj uti fjerden utan för New-York. Dá den samma upskars, fans uti dess mage en ganska stor myckenhet ålar.

\section{Den 18 Novemb.}

Om morgonen gick jag ut til Herr BarTram, och kom in til staden tilbaka samma dag efter middagen.

Indianernas Ler-käril. Herr Bartram viste mig en stor kruka af ler, hvilken blifvit funnen ned i jorden här i landet, der Indianerne fordom bodt. Den som först funnit den, brukade at hålla fett deruti, at smörja läder med, och af honom såldes hon til Herr Bartram. Hon var ännu aldeles hel och oskadd. Jag kunde ej blifva varse någon glasering eller färg derpå; men eljest var hon utanpå mycket utkrusad och väl gjord. Utom denna viste han mig åtskilliga bitar af sönderslagne ler-käril, dem Indianerne $\mathrm{i}$ forna tider betjent sig af. Af alla dessa bitar syntes, at Indianerne ej gjordt dessa käril af bara ler, utan blandat andra Materialier deri, dem de kunde 
hafva på orten. Til Exempel: de som bodt när sjöstranden, hafva stött sönder Snäck- och Mussel-skal och blandadt deri; andre, som bodt längre up i landet, der Bärg-Cristaller finnas, hafva stött dem sön/der, och lagt dem bland bruket. Huru de i forna tider tilredt dem, vet ingen; men det var klart, at de ej lära brändt dem mycket; emedan de ännu äro så löse, at de med knif kunna täljas. Detta oacktadt måste det vara et varaktigt arbete; emedan hela krukor finnas ännu i denna dag i jorden, eller ock stycken samt bitar deraf, hvilka ännu äro oskadde, fast de legat mảnga hundrade år ned i jorden. Förr än Europeerne kommo hit i landet, hade Indianerne nästan inga andra käril, at betjena sig af til sin mats Kokning, än dessa, dem de sjelfve förfärdigat åt sig; men sedan Europeerne satt sig här ned, hafva Indianerne beständigt tilbytt sig af dem grytor, kettlar och andra nödiga käril, och icke mera sjelfve brydt sig om, at göra sådana, så at de ock denna tiden aldeles förlorat konsten, at tilverka dessa ler-käril. Sådane käril, då de äro hela, hållas nu för en ganska stor Raritet, äfven ibland Indianerna sjelfva, emedan det är mer än sällan, at någon kan komma öfver en sảdan; jag har ock sett sådana ler-krukor, och bitar af Indianernas grytor gjorda af Tälg-sten.

Tak-skifver. Herr Bartram viste mig små stycken af en svart Skifver-sten, hvilken skal finnas i ymnoghet somligstäds på sidorna of Floden Skullkil. Der skola vara stycken af 2. alnars längd och bredd, och äfven deröfver: til färg och skapnad aldeles lika med Bord-skifver, endast at den är nảgot tjockare. Folket, som bo deromkring, skola betjena sig deraf til at täcka husen med. Herr Bartram sade sig sett et hus, hvars tak var helt och hållit täckt med 4. sădana skifverstycken. Af Sol-sken, hetta, köld och rägn skola de ej taga någon skada.

Stalactites eller Dropp-sten. Likaledes berättade Herr Bar'Tram, at här finnes uti landet på flera ställen Caverner eller gråttor djupt in uti bärgen. Han sade sig varit inne uti åtskilliga sådana. Uti taket eller hvalfvet, på en stor 
del af dessa, hänger en myckenhet af Stalactites, som ispiggar, somlige större, andre mindre. Deras färg är åtskillig. Hvad han i synnerhet fant märkvärdigt, var, at han i somliga sett Stalactites, som hade haft yttra sidan gående i Spiral, eller som vriden upifrån ned åt. Han hade sändt några stycken deraf öfver til London, och ägde nu inga mera qvar.

\section{Den 19 Novemb.}

Apple Dumplins. Et sätt, huru en Äpplerätt af de Ängelska här plägar tilredas, var äfven detta: De taga et Äpple, skala det: göra så en deg af vatten, mjöl och smör, baka den tunt ut, och omgifva Applet dermed. Detta bindes sedan uti en ren Linklut, lägges i en gryta, och kokas. När det är fullkokadt, tages det af, och sättes på bordet. Medan det är varmt skäres skârpan af på ena sidan. Derpå hafva de smör och sảcker tilhopa blandade, hvilket lägges inuti, der Äpplet är, hvarefter Såckret, Smöret och Äpplet blandas väl tilhopa; då det är färdigt. De kalla detta Apple Dumplins: Somliga kalla det Apple Pudding. Det smakar rätt väl. Sả många Äpplen, så många särskildta Dumplins.

\section{Den 20 Novemb.}

Om morgonen reste jag i följe med en god vän p. 426 ned til Racoon uti New Jersey, hvarest / en myckenhet Svenskar bo och hafva sin särskildta Kyrka. Vi reste först 3. Ängelska mil ungefär, innan vi kommo til Färjestaden, hvarest vi foro öfver Floden Dellaware. Landet var här på somliga ställen nog lågt, eller sảdant, at det som låg vid sidorna af förenämde Flod, vid högt vatten, eller så kallad flod, stod under vatten; men vid ebb var det derifrån fritt, och tort. De som här bodde hade sökt göra nytta deraf, i det de på åtskilliga ställen mot elfven uppkastat vallar af jord, hvarigenom de utestängt vatnet, at det ej fick flöda öfver landet, som nu i det stället an- 
vändes til äng. På dessa låga ängar stodo mångenstäds å ömse sidor om vägen Vattu-bökar (Platanus occidentalis Lixx. spec. 999.) helt tätt in vid hvarandra, hvilka om sommaren med sina stora och täta löf gifva en vacker skugga, göra vägen behagelig, och at det ser ut, som vägen ginge genom en skön Allée. Dellaware Flod är här ungefär af samma bredd, som vid Philadelphia. På dess ömse sidor är här vid Färjestaden vackra hus bygde, hvarest de resande mot betalning kunna få hvarjehanda förfriskning. När vi reste från Pennsylvanien til New Jersey kommo vi at gâ öfver på den färgan, som hörde til den som bodde i Pennsylvanien; men tvärt om dả vi foro från New Jersey til Pennsylvanien. Sả snart vi kommit öfver Elfven, emottager et nytt och annat Gouvernement; ty Elfven Dellaware gör skillnad emellan bägge Gouvernementen Pennsylvanien och New Jersey, så at alt, som här ligger på W. sidan om Elfven Dellaware hörer til Pennsylvanien, men det på Ö. sidan om den samma til New Jersey. Bägge Höfdinge/dömerne hafva mäst uti alt helt särskildta lagar och penningar. Vi fortsatte nu vidare vår resa, och befunno, at landet på denna sidan hade uti mycket et helt annat utseende, än på den andra; ty uti Pennsylvanien är jordmonen mera utblandad med ler och svart-mylla, samt ganska fruktbärande; men uti New Jersey är det mera sandigt och nog magert, så at hästarna mångenstäds på resan måste vada djupt uti sanden. Näst vid Färje-staden, och et stycke bårtåt var tämmeligen mycket Tall-skog, dock voro Tallarna ej särdeles höga, utan mästadelen helt små, hvilka nu höllo på som bäst at ränna up; dock voro de nog utblandade med små Ek-skog. Men sedan vi rest ungefär 3 Ängelska mil, återvände Tallskogen, och sâgo vi ej några tallar mera, förr än vi kommo til Racoons Kyrka. På alla de ställen, jag rest uti Pennsylvanien, har jag funnit Tall-skogar ganska sällsynte; men deremot finnas de på åtskilliga ställen uti New Jersey, enkannerligen uti den nedra delen deraf. Vi hade sedan hela denna dagen bara Löf-skog, hvilken til största delen be- 
stod af allehanda slags Ekar, och de tämmeligen stora; fast de stodo allestäds nog glest, så at vi på de flästa ställen utan möda kunde åka med Chaise uti skogen emellan träden; och mäst allestädes beqvämligen rida; emedan under träden sällan voro några små buskar, hvilka hindrade det samma. Alla trän hade nu fällt löfven, hvilka öfvertäckte marken öfver en tvärhands högd, och tyckes böra mycket bidraga til svart-myllans förökande. Pá et eller annat ställe kom någon liten å eller bäck. Landet var mästendels jämnt, fast det somligstäds gick i långp. 428 sluttande uphögnin|gar. Inga bärg eller stenar syntes här, undantagandes på något enda ställe någon helt liten sten, af en knyt-näfvas storlek. Här och der viste sig enstakade gårdar, och på et ställe en liten by; dock var lanrlet ännu mera öfverväxt med skog, än upodladt, så at det var mästendels skog vi hade at fara igenom.

Ängar. Vi reste i dag, och de följande, öfver åtskilliga här så kallade kilar, eller åar, hvilka kommo up ifrån landet, och lupo ned til Elfven Dellaware. De lågo ej stupande, utan voro mycket jämne; så at vatnet rann nog sakta uti dem. När det var Flod i Dellaware Elf steg den ock et långt stycke up i samliga åar; och när det blef Ebb, at vatnet föll ut, blefvo desse nog smale. De lära varit vid flod eller högt vatten nog breda i forna tider; men nu voro ängar på ömse sidor om dem, hvilka tilkommit på det sätt, at de hade, då det varit ebb, kastat up fasta mull-bankar i det närmaste vid åbrädden, och dymedelst afstängt vatnet från öfverflödande öfver alt. Mäst vid alla kilar eller åar voro nu sådana bankar eller tjocka mull-vallar, hvilka afstängde vatnet från ängen. Då det var hög flod, stod vatnet i kilarna eller åarna inycket högre än på ängen. De hade dam-lukor på banken, dem de kunde öpna, antingen de ville släppa vatnet ut eller in. Pả somliga ställen voro desse dam-lukor så gjorde, at de voro satte på yttra sidan om banken, och öpnades utaf sig sjelfva af det vatten, som rann ifrån ängen ut; men klämdes åter igen af det vatten, som ville gå in från ån på ängen. 
Om aftonen reste vi til en af de Svenska, vid namn p. 429 Peter Rambo, der vi togo vårt nattherbärge.

Tall. Den Tall, som vi i dag sågo, och nyss omtalte, kallas Pinus foliis geminis, squamis conorum oblongorum aculeatis, uti Gron. flor. Virg. p. 190. och på Ängelska Jersey Pine eller Jersey Tall. Mästendels sitta 2:ne barr tilhopa uti en hölsa, som det sker på vår Svenska; men utur somliga hölsor utgingo ock 3. barr. Kåttarna hade långa taggar, så at de voro rätt besvärlige at handtera. Eljest se desse Tallar på långt håll aldeles ut, som våra Svenske, så at innan en ser på Kåttarna, skal en lätteligen taga dem för et och samma slags trä. Af denna Tall brännes en myckenhet Tjära, hvarom längre fram. Som mästa delen af desse äro Gảr-tallar, så duga de i öfrigt så godt som til ingen ting; ty om en sätter dem til stolpar i jorden, så rutna de på helt kårt tid. Masken är ock ganska snål derpå då den blifvit nedhuggen, sả at den då uti hast blifver genom-maskäten, och det ej många veckor efter det den blifvit nedfäld. De bruka den ock somligstäds i brist af annat, til bränsle; och på andra ställen bränna de Smidje-kol deraf, som framdeles skal omtalas. Eljest förtjenar vid detta trä nämnas, hvad åtskillige, och äfven jag här i landet rönt, nämligen, när det om sommaren är hett, älskar boskapen gerna stå i dess skugga: om der nu finnas på de ställen boskapen går både löf-rika Ekar, eller Hickery, Valnöt-trän, Vattubökar eller andra Löf-trän, och tillika Furu trän eller Tallar, så skal boskapen nästan altid hällre utvälja, at stå under et Furu-trä eller en Tall, fram|för at söka skygd under något löf-trä, fast löf-trädet kan vara mycket skuggrikare; ja om det ej finnes mer än en enda Tall på de ställen, så skola dock så många, som af boskapen få rum, skåcka sig omkring den samma. Häraf ville åtskillige sluta, at de kådige utdunstningar, som kommo från detta trädet, bekomma boskapen ganska väl, och derföre skola de utvälja dessa trän hällre än några andra.

Skedträ var et litet trä, som finnes nog allmänt uti Pennsylvanien, och det vi äfven i dag sågo på åtskilliga 
ställen. De Svenske, som här bodde, hafva gifvit det föregående namn, emedan Indianerne, hvilka i forna tider mycket vistades här i landet, brukade at göra sina skedar och slefvar deraf. Jag hafver uti min Natural-samling en sked gjord af detta trä, utaf en Indian, hvilken skutit många hjortar och andra djur på det ställe, der Philadelphia nu står; emedan samma plats i förberörde Indians tid var öfverväxt med hög skog. De Ängelske kalla det Laurel; emedan bladen eller löfven likna aldeles dem, som äro på Lauro Cerasus. Herr Archiatern och Riddaren LıNnæus har behagat, af dess synnerliga ynnest emot mig, kalla den Kalmia Foliis ovatis, corymbis terminalibus, eller ock kårteligen Kalmia Latifolia, uti dess Spec. plant. p. 391. De platser, som den hälst utväljer til sit hemvist, äro sidor af backar, hälst den Norra, der nảgon bäck flyter fram, så at om backen vid bäcken var brant, eller ock branta backar lảgo mot våta kärr, stodo de gemenligen fulla dermed, hvilken nog ofta hade Bök til följeslagare. Eljest finnes den ock uti skogarna i dälder. Ju p. 431 högre de stodo pá | Norra sidan af backen, ju kảrtare voro de. Jag har sett det växa ej allenast uti Pennsylvanien och Nya Jersey, utan ock i New Yorks höfdingadöme, dock börjar detta trä blifva i det sistnämda mera sällsynt, och Norr om den 42. grad. Lat. Bor. har jag ej kunnat blifva det varse, ehuru trägit jag sett derefter. Det har den egenskapen, at äfven om vintern behålla sina täcka gröna löf, så at dả nästan alla andra trän här i landet aflagt sina sommarkläder och stå helt nakna, pryder detta skogarna med sin behageliga gröna drägt mer, än något annat. Om Våren vid den 23. Maji, efter den nya stylen, börjar det på denna orten blomma, då det i prydnad täflar med de mästa trän, som uti Naturen finnes: blommorna sitta i stora klasar, och är trädet helt fullt med sådana. Innan blommorna spricka ut; hafva de en skön röd färg; men sedan de öpnat sig, bleker Solen småningom bårt dem, så at somlige på slutet blifva mäst helt hvita, på ganska många äro blommorna af en Rosenfärg. Dess skapnad är ock synnerlig; ty hon liknar mycket 
de gamlas skänkefat eller skålar. Lukten är dock ej särdeles. Om Jul- och Nyårsdagen pryddes Kyrkorna somligstäds med dess vakra löfrika qvistar. Men en synnerlig egenskap hafver detta trä, som består deruti, at dess löf äro som et förgift för somliga Creatur; för andra åter tjenar det til föda. Mångfallig förfarenhet har lärt, at om Får äta af dess löf, blifva de antingen döde, eller ock mycket sjuke, så at de med möda kunna frälsas. Unga Får få icke äta mycket deraf, innan de sätta lifvet til; men gamle tola något mera. Om ock de äta något mycket deraf, sätta de äfven | otvifvelaktigt lifvet til. Samma skadeliga verkan hafver det ock på kalfvar, hvilka deraf antingen dö, eller svårligen kunna komma sig före. Då om sommaren år 1748. några kalfvar hade ätit dess löf, blefvo de ganska sjuke, svälde up, fradgan stod dem ur munnen, och voro de nära at störta; men genom krut och annat, som blef dem ingifvit, kommo de sig ändteligen före. Det är om vinteren, som fåren här lupo mästa fara för cienna; ty när de hållits inne en tid, och de sedan släppas ut, när det ännu är snö på marken, äro de mycket snåle efter alt grönt, och således svårligen kunna hålla sig från at äta deraf. Det har ock skedt, at då hästar, oxar och kor kommit at äta af dess löf, hafva de äfven blifvit mycket sjuke, fast de dock icke dödt; dock trodde mäst alle, at om ock desse stora Creatur ätit nảgot mycket deraf, skulle de svårligen kunnat undvika en hastig död; ty det har märkts, at bara de ätit något litet af dess löf, hafva de begynt må illa. Men deremot äro dess löf en föda för Hjortar om vinteren, då snö ligger pả marken, och de icke kunna hafva något annat til uppehälle; derföre finnes ock, om de den tiden skjutas, at deras tarmar och inelfvor äro fulle med dessa löf. Härvid har åter märkts det som synnerligt, at när samma inelfvor blifvit kastade för hundar, och de ätit upp dem, hafva de deraf blifvit helt yra, eller som drukne, och ibland så sjuke, at det sett ut som de skulle sätta lifvet til; men folk, som ätit sådana Hjortars kött, som haft dessa löf uti sig, hafva ej kändt nảgon olägenhet deraf. Åt et slags Foglar, som 
de Svenske här kalla Hjerpar, och som blifva här qvar p. 433 hela vintern, tjena äfven / desse löf under samma tid til föda; ty då en skjuter dem, finnes deras kräfva full med sådana löf. Sjelfva trädet är mycket skarpt, derföre brukas det af somliga til axlar i trissor på blåck; men enkannerligen brukas det, fram för alt annat, til Väfspolar, och höllo Väfvarena intet trä härpả orten så godt dertil som detta; emedan det var hårdt, blef ganska slätt och halt, och sprack ej gerna. Af sjelfva trädet, men i synnerhet af roten, kan hvarjehanda Snickare- och Svarfvare-arbete göras, som af annat det finaste trä; ty färgen på dess rot är alt igenom gul, samt trädet ganska hảrdt och fint. Frản centrum af trädet gå ut som små radii, dock något glest. När dess löf läggas i elden, spraka de, som hade en kastat salt dit. I brist af annat betjena de sig om vinteren af dess löf och qvistar til at sopa korsstenar med. När orn sommaren 1750. et slags maskar åto up löfven på mäst alla trän i Pennsylvanien, vågade de sig ej här på, utan desse fingo vara aldeles i frid och orörde. Åtskillige berättade, at när elden om sommaren är lös i skogen, och kommer til detta trä, går han icke längre, utan stannar dervid.

\section{Den 21 November.}

Mays. Både de Svenske, och andre, som här bodde, planterade ganska mycket af Mays, den de brukade sả til föda för sig sjelfva, som för sin boskap. Den sades af alt vara den bästa föda, som svin kunna få; emedan de icke allenast blifva mycket feta deraf, utan de få ock deraf bättre och välsmakligare kött, än af någon annan föda. Uti Kongl. Vetenskaps Academiens Handl. för år p. 434 1751. p. 305. och följande; samt år 1752. p. | 24. och följande, hafver jag vidlyftigt talt om denna Sädesarten, hvarthän jag visar Läsaren.

Kärrhjulen, som här brukades, bestodo af desse träslag: löterna eller peripherien af Spansk Ek; men ekrarna eller radii af den hvita Eken. 
Sassafras-trädet fans här växa öfver alt. Jag har förut p. 270. nämnt et och annat derom; nu vil jag lägga något til. De Svenske kalla det Saltenbras eller Salssenfras, dock är det förra namnet mera i bruk. När något af detta träd lägges på elden, sprakar det som hade en kastat salt dit. Häraf lärer tvifvelsutan de Svenske formerat sit namn på trädet från Sassafras, det de vändt til Saltenbras eller Salssenfras. Trädet brukades til poster eller stolpar at sätta i jorden vid plank och gärdesgårdar; emedan det sades stå länge mot röta i jorden; men eljest troddes näppeligen något trä vara til, som i öpna luften och under bar himmel blifver så mycket maskätit som detta; ty inom en liten tid sades maskarne äta det mäst alt igenom. De Svenske berättade, at då Villarne fordom bodde här, brukade de göra sig skålar deraf. När en skär af trädet, eller dess unga telningar, och sätter dem åt näsan, gifva de en stark, dock behagelig lukt ifrån sig. En del taga barken af rötterna, koka den $i$ spisöl då de brygga, hvilket skal blifva deraf mycket hälsosamt. Samma bark lägges ock bland bränvinet då det distilleras, eller lägges den i gjordt bränvin, då det likaledes tros blifva ganska hälsosamt. En gammal Svensk berättade, at hans moder botat många, som haft Vattusot, med detta trä, i det hon tagit roten, kokat den i vatten, at decocten blifvit stark. | Detta hade hon lagt i flaskor, och låtit de sjuke dricka hvar morgon deraf. Hon brukade tillika, at koppa deras fötter. Denne mannen försäkrade, at han sett henne sålunda bota många, som fördes til henne uti lakan. När någon plats rödjes til åker, lämnas gemenligen desse trän at stå qvar; emedan de äro löfrike, och gifva om sommaren en behagelig skugga åt boskapen. Åtskillige af de Svenska brukade, at med decocten af barken eller rötterna tvätta och skura de käril, hvari de ville hafva Cyder, dricka eller bränvin; emedan de derigenom troddes blifva mycket hälsosammare. Til at fördrifva vägglöss sades somliga försökt, at låta göra Sängstolparna af Sassafras, hvilken med dess starka lukt kunde hindra, at inga vägglöss ville vistas deri. Detta har ock varit godt 
för 2 a 3 år, eller så länge Sassafrasen ännu behållit sin starka Aromatiska lukt qvar; men sedan den tiden har man ej befunnit det göra stort til saken. En Snickare viste mig en säng, han gjort sig, hvars stolpar voro af Sassafras. Denna säng, som då var 10 a 12 år gammal, var så full af vägglöss, at ingen kunde sofva i frid deri. Åtskillige af de Ängelska berättade mig, at för några år tilbaka var en tid nog uti bruk i London, at dricka Thée, gjordt af Sassafras-spånor eller blommor, såsom mycket hälsosamt; men sedan de påminte sig, at decocten deraf blef mycket brukad emot Luem Ven. eller kärlekssjukan, bårtlades denna arten af Thée; emedan de befarade, at deraf blifva beryktade för någon viss elak sjukdom. Uti Pennsylvanien brukade somlige, at taga spånor deraf, och lägga uti lådor och kistor, der de hade yllekläder, at derp. 436 med utehålla mal, som om sommaren / annars plägar komma deri. Roten af detta trä behåller dock tämmelig länge sin lukt; jag har sett den rot, som legat 5 a 6 år uti en bordlåda, men hade likafullt mäst ännu behållit sin starka lukt.

Röd färg. P. Rambo berättade, at Villarne fordom färgat hvarjehanda skinn röda med barken af Castanie-Ek.

Hård Vinter. Åtskillige gamle berättade, at ảr 1697 var här en så hård vinter, at isen pả Dellaware flod varit 2 fot tjock.

Litet för middagen reste vi härifrån, och foro til Kyrkovärden vid Svenska Kyrkan ERIck Ragnilssox, der vi förblefvo i par dagar.

\section{Den 22 November.}

Gräsets förminskning. А̊ке Нецм, en af de hederligaste Svenskar härpå orten, och nu öfver 70 år gammal, (hvars Fader kom in hit $\mathrm{i}$ landet med den Svenska Gouverneuren Priviz) berättade, at uti hans barndom var här så mycket gräs i skogarna, at det stod allestäds mot en alns högd; men nu är det så förminskadt, at det blifvit ganska litet, så at boskapen hafver svårt efter födan, och 
derföre mjölka nu 4 kor ej mera, än fordom en. Det är ej svårt, at finna igen orsakerna dertil: 1. uti Gubben HeLms barndom var detta landet ganska glest bebodt. Här fans då näppeligen en tionde del så mycket boskap, som nu; följakteligen hade en ko allena då sả mycken föda och bete, som $10 \mathrm{nu}$. 2:0 mästa delen af gräsarterna (Gramina) här på orten äro annuella, det är, de växa ej flera år i rad af samma rot, som de fläste af våra Svenska, utan de skola hvart år | så sig, dả altid det samma årets stånd om hösten dör ut; när nu desse genom den myckna boskapen hindras at säda sig, genom det de ätas up, innan de få blomma och bära frukt, så är ej underligt, at af gräsarter det ena strået står här, det andra der, på fält, backar och betesmarker här i landet. Detta är ock orsaken, hvi resande hafva nog svårt. at med egen häst komma fort båcle här i New Jersey, Pennsylvanien och Maryland, enkannerligen om vintern; emedan de få Gramina eller gräsarter, som der vuxit, småningom blifvit mer och mer utödde af boskapen, innan de fått fröda sig. Men längre mot Norr, som i Canada, finnes nog af de gräsarter, som kallas Gramina perennia. Således har här i landet den allvise Skaparen gifvit åt de Norra orter ymnigare gräsarter af de ständigt varande (Gramina perennia); emedan invånarena för de långa vintrar skull, behöfva mera hö til foder àt sin boskap; men deremot meddelt dem sparsamt uti de längre til Söder belägne Landskap; emedan Creaturen kunna der gå ute mäst hela vinteren. För samma orsak skul hafva ock mera eftertänksamme Hushảllare uti Pennsylvanien låtit förskrifva sig höfrö af Graminibus perennibus från Ängland och Europa, samt sått dem här på sina ängar, hvarest de synas nog vela trifvas.

Persimon (Diospyros Virginiana Lrns. spec. 1057.) eller af de Svenska så kallade Mispelträdet växte här nog allmänt. Jag har förut p. 200 och 255 talt om detta trädet; nu vil jag lägga något til. Somt af des frukt började nu blifva mogen och mat-dugsen. När den sent om hösten blifver väl mognad och frostbiten, ätes den | 
p. 438 af folket här, som annan frukt, och smakar då mycket söt och klibbig, dock at någon liten adstringerande smak äfven kännes deruti. Jag åt ofta nog deraf, utan at känna någon olägenhet. När någon äter deraf, suger han allenast til sig det blöta och klibbiga köttet, men spottar ut stenarna eller kärnarna. Af denna frukt brygga en stor del, så af de Svenska, som Ängelska och andra Nationer et skönt svag-dricka, hvilket sker på detta sätt: Om hösten sent, när frukten blifver frostbiten, och således söt och skön at äta, samlas deraf så mycket, som behagas, hvilket kan lätt och fort ske; emedan hvart trä bär en stor ymnoghet. Detta knảdas tilhopa med Hvete- eller annat kli, bakas kakor deraf, och sättes i ugnen, hvarest de stå til dess de äro väl genom-gräddade och torre. De tagas så ut, och då drickat skal bryggas, sättes en gryta på elden full med kallt vatten, deri förenämde kakor läggas, hvilka under det vatnet långsamt och smảningom blifver varmt, blötas up och smålas sönder. Grytan tages så af elden, och vatnet röres om, at de upblötta och söndersmålade kakor blanda sig jämnt med vatnet, hvilket alt sedan slås uti et kar. Sålunda fortfares, at upblöta så många, som behöfves til en brygd. Sedan mäskar man och brygger på vanligt sätt. Detta dricka hålles vara bättre än mycket annat. Brännvin brännes ock af denna frukt, som sker på det sätt, at sedan de om hösten samlat en stor hop deraf, lägges alltsammans i et käril, deri det står en vecka eller mera, at det blifver väl blött. Sedan slås vatten til, hvarmed det får stå och jäsa, hvilket sker af sig sjelft utan jäst, derefter brännes på vanligt sätt brän-

p. 439 vin deraf. Om en har / af de Vin-drufvor som här växa vildt, särdeles det sötare slaget, och blandar det ihop med frukten af Persimon, blifver Brännvinet rätt skönt. Somlige af dessa trän hafva sin frukt mogen mot slutet af September, men andra, och det de mästa, äro senare; ty somlige blifva icke mogne, förr än uti November och December, så at ock frosten fordras til deras mognad. Sjelfva trädet är mycket tjenligt til Snickare-verktyg, som til hyflar, skaft åt hugg-borar, och dylikt. Men om det 
får ligga ute under öppen himmel för sol och rägn, sedan det blifvit nedd-huggit, så är det nästan af alla trän det, som först rutnar; ty efter et år är det då mäst alt genomrutit. Om det kommer at växa på åkrar, blir det svårt at kunna utrota det, så trifvande är det. De sade, at om man skure en qvist, och lade den i jorden, skulle den taga rot. Uti mycket starka vintrar hafva somlige af dessa trän blifvit dödade af kölden, och sades, at detta och Persike-trädet var vid sådant tilfälle de mäst ömtolige.

\section{Den 23 November.}

Pumpor. Här i landet hafva de åtskilliga slags Pumpor och Meloner, dem de dels fått af Villarna, dels fört med sig hit från Europa. Crocknecks eller Krumhalsar kallades et slags Pumpor, som äro krokote på ändan, samt eljest nog aflånga. Dessa kunna förvaras och hållas goda mäst hela vintern. Än är et annat slag, som likaledes kan förvaras öfver vintern. En annan art Pumpor skäras i stycken eller skifvor, trädas på trå, och hängas up at torkas. Af dem kokas sedan eller stufves när en vil, och kunna de | brukas hela året. Eljest nyttjas alla dessa slags Pumpor på åtskilligt sätt til mat, som äfven hos oss vanligt är. En Landtman har här ofta et tämmeligen stort land planteradt dermed.

Squashes är en annan art Pumpor, dem Europeerne sägas först fått af Indianerna här i landet. Jag har något talt om dem förut p. 264. De ätas kokte, antingen allena, eller ock med kött, då de gemenligen läggas på fatet rundt omkring köttet. De äro här i landet icke det minsta kinkote; ty nästan i hvad jordmon, som de hälst sås, komma de up, och trifvas väl. Kastas dess frön om hösten ut på marken, komma desse Squashes deraf på samma ställe up, nästa vår, fast de legat ute under öppen himmel och i väta hela vintern.

Calabasser (Cucurbita Lrsv. hort. Ups. 291.) var en annan art af Pump-slägtet, hvilken ock nog planterades här af de Svenska och andra, dock ej til mat, hvartil den 
icke dugde, utan at tjena til hvarjehanda käril. Desse äro långt mera kinkote, än de föregående; ty de hinna ej mognas här alla år, om icke väderleken är desto varmare. När en vil göra dem til käril, låter en dem först väl torka, sedan gräfves ur dem frön tillika med köttet eller det svampaktiga, som frön sitta uti, som kastas bårt, hvarpå de skrapas väl rena inuti. De brukas sedan til skopor, trattar, skålar, fat; kårteligen til en stor hop käril, at hafva allehanda uti. Enkannerligen äro de sköna, at förvara hvarjehanda frön uti, när de skola skickas öfver Hafvet til andra orter; ty häruti behålla de nästan längre sin groende kraft än uti något annat. Ibland pläga de skrapa litet bårt det yttersta af dessa Calabasser, och så p. 441 torka dem, / innan de urgrafvas, då de sedan blifva så hårda som ben: sedan kunna de tvättas då och då, hvaraf de blifva utanpå helt hvita.

Bohvete brukas mäst af alla här i landet. Det sås här, efter gamla stylen, från början af Julii til den 10:de i samma månad, som gemenligen är den senaste tiden; ty om det sås senare, skadas det ofta af frost. Om det sås för Julii månad, står det väl och blomstrar hela sommaren; men blommorna torkas sedan bårt, at det blifver ingen frukt deri. Somliga plöja åkern 2 gångor, innan de så Bohvetet, andre endast en, och det ungefär 2 veckor innan de så det, hvarefter åkern harfvas jämn. Det sades trifvas här bättre uti våta år. De låta det stå ute, til dess frosten kommer. Om lyckan är god, få de af en bushel 20,30, ända til 40 bushels igen, som Kyrkovärden sjelf sade sig fått. Det brukas til Pankakor och Pudding. I synnerhet göres om mornarna kakor häraf, tilredde på samma sätt som Pankakor uti en Panna, eller gräddade på en sten, och när de komma ur Pannan eller från stenen, och äro heta, smörjas de alt öfver med smör, det de låta väl draga sig uti dem. Desse, då de ännu äro varme, ätas så tilredde om morgonen vid det en antingen dricker Thée eller Caffé; så at $\mathrm{i}$ stället de här annars, (som hos de Ängelska brukligt är) skulle äta smörgås, eller stekt bröd med Smör påstrukit, vid Thée; brukades desse, som 
smakade mycket väl. Detta skedde så här, som uti Philadelphia och annorstädes i de Ängelska Colonier, och var i synnerhet om vintern, som de hade dem. Uti Philadelphia voro visse, som | gräddade dem och om mornarna buro dem helt varma omkring at säljas. Til föda för hönsen spisade Bohvetet nästan bättre än annat, de åto det ganska gerna och värpte derefter bättre, än af annan mat. Svin göddes ock härmed. Bohvetshalmen sades ej vara dugelig til någon ting, hvarföre den ock lämnades at ligga qvar på de ställen af åkern, der det blifvit tröskat, eller kastades han ut at rutna til gödning pá Äppelträgårds landet. Boskapen ville ej äta den, icke eller andra Creatur, utan endast i högsta nöd när snön låg öfver marken, och de ej kunde få något annat, då kunde de tugga litet deraf. Ehuru Bohvetet såddes här nog allmänt i de Ängelska Provincier, så visste dock Fransoserne i Canada ej deraf, ej eller cultiverade de det någorstäds hos sig.

Lysmask. Om aftonen fants uti skogen en art af Lysmaskar: Corpus lineare constans undecim articulis, ante et post acutiusculum; Longitudo a capite ad caudam $5 \frac{1}{2}$ lin. Geom. Color fuscus articuli dispositi eodem modo ac Onisci. Antennæ breves, lineares. Pedes sex, siti ad anteriorem corporis partem. Då han gick, satte han stjertändan ned i marken, och sköt så på. Bak i ändan på stjerten satt en materia, som gaf sken från sig i mörkret, och var af en ljusgrön färg då den lyste. Denna lysande materia kunde masken draga in då han ville, at den icke syntes. Det hade nog rägnat denna dagen, men ändock funnos dessa Lysmaskar krypande fullt under buskarna på marken, at den syntes likasom beströdd med små stjernor. Framdeles får jag tala om et annat slag af Flugor eller Insecter, som | om nattetid under deras flykt i luften, lysa som eldgnistor. Mon denne lysmask ej är en variation allenast af de lysmaskar, som äro hos oss? se Linn. Faun. Suec. 584. 
Den 24 November.

Ilex Aquifolium Linn. Spec. 125. växte på våtländta ställen här och der i skogarna, fast det var bland de sällsyntare trän. Det behåller sina löf friska och gröna både sommar och vinter. De Svenske brukade at taga dess blan, torka dem, stöta sönder, koka i svagdricka, och taga in dem mot håll och stygn.

Rödt färgades här med Brasilie-trä; äfven med en Trämåssa. Blått färgas med Indigo.

Svart färgades sålunda: De togo af Bärg-syra (Rumex Acetosella Linn. flor. Suec. 296.) dess gröna blan, kokade dem med tyget, som sedan hängdes up at torkas. Sedan koktes tyget med Logwood eller Campechenhout och kopparaska, hvarigenom det sades få en beständig svart färg.

Folket spinna och väfva här en stor del sjelfva det de bruka til hvardags kläder. De färga dem ock hemma.

Lin såddes här af många, och blef nog skönt; men Hampa bruktes här icke.

Åkerskötsel. Med handskära skäres Råg, Hvete och Bohvete; men Hafra skars här med Lia. De handskäror, som här brukas, äro nog långa och smale, samt hela ägget på undra sidan fullt med små täta tvärskåror. Åkern ligger et år i träde, då boskapen under den tiden lämnas frihet at beta derpå.

Trägårdar. Hvar Landtman här på orten, ehuru usel han var, ja äfven de, som kunde säjas ej vara annat, än Torpare, hade vid sin gård eller koja en större eller mindre Trägård, upfyld med allehanda nyttiga fruktträn, hvaraf Persike-trän, äppel- och kersbärsträn gjorde det mästa. Se hvad härom är nämnt förut p. 207.

Litet för middagen foro vi härifrån, och fortsatte resan förbi den Svenska Kyrkan i Racoon til Peilsgroves. Landet var här på många ställen nog sandigt, och tämmeligen jämt. Här och der, fast nog glest, syntes enstaka gårdar. På de flästa ställen var det öfverväxt med löfskog, hvaraf åtskilliga slags Ekar gjorde det mästa, och 
dernäst Hickery. Ned vid marken var skogen så fri från buskar och stenar, at en ej allenast til häst kunde beqvämt rida derfram, mäst hvart en ville, utan ock på de flästa ställen utan hinder åka med Chaise eller kärra. Stora och lảnga trän, som antingen stormen eller deras ålder omkullkastat, gjorde dock somligstäds något litet besvär.

\section{Den 25 November.}

Tillandning. Under mit vistande här i Racoon, sökte jag så nu, som hela den följande vintern, göra mig underrättad af de gamla Svenska, om de spår, som kunde skönjas til tillandningar, eller vatnets aftagande här på orten. Jag vil fördenskul här införa de svar mig blifvit gifne på mina frågor, just som jag dem fảtt, och endast uti parenthesi lägga det til, som kan gifva någon mera uplysning: lämnar för öfrigt i Läsarnas egit behag, at häraf göra sina slutsatser.

En af de Svenska, vid namn KING, om nå|gra och p. 445 50 års ålder, berättade, at han säkert förnummit det denna tiden icke är så mycket vatten uti små träsk, bäckar, källor och åar, som uti hans barndom. Han visste många träsk och vattugölar, uti hvilka i hans ungdom varit så mycket vatten, at de kunnat ro deri med en båt, stor som en stor skötbåt, och ehuru torr sommar det då var, voro samma träsk dock aldrig torra; men nu äro de antingen aldeles uttorkade, eller åtminstone til största delen torra, och är ingen sommar, då desse sista ej äro aldeles vattenlösa. Han sade sig sett, huru fisken på slutet i dem, af brist på vatten, måst försmäkta och dö bårt: uti bäckar och åar är ock nu mindre vatten, än förr: han tyckte ock, at det nu icke rägnar så mycket om somrarna, som förr. En af hans slägtingar, som bodt ungefär 8 Ängelska mil från Dellaware flod, dock på backen vid en liten å, har der låtit gräfva en brunn vid sin gård, och då han kommit til ungefär 40 . fots djup, har han ned $i$ jorden funnit icke allenast en stor myckenhet af Ostronoch mussel-skal, utan äfven mycket Rör (Arundo), samt 
likaledes stycken af stockar. Jag frågade: hvad som mentes vara orsaken här til? mig svarades, at somlige säja, det de legat der sedan syndafloden; andre at jorden växer.

Peter Rambo, en Man närmare sina 60 år, sade, at han sjelf sett med sina ögon, at på många ställen här neder i Racoon, då någon gräfvit brunnar, eller annars gått djupt ned $\mathrm{i}$ jorden, har der funnits stora hopar af mussel- och andra Sjökräks skal. Vid brunnars gräfning har på 20 och flera fots djup funnits stycken af trä, ja ej allenast rutnade trän, utan ock sådane, som varit |

p. 446 brände. Ja, de hade ock på et sådant djup funnit en slef. (Men mon ej det brända trädet, som nu omtalas, varit öfverlupit af någon underjordisk mineral-ånga, som svärtat det?) Han sade, at folket deraf slutat, det America för syndafloden varit bebodd. Han berättade ock, at det funnits Tegelstenar djupt ned i jorden. (Men mon icke det endast varit en hopgyttring af den tegelfärgade jorden, hvaraf mästadelen af landet här består, hvilken är en blanning af sand och lera? Jag har här sett sådana hopgyttringar, dem en snart, hvilken ej såge nogare til, lätteligen kunnat taga för 'Tegelsten.) Eljest tyckte han, det vatnet i floder och ảar nu stode lika högt, som dả han började minnas; men små träsk, vattugölar och vattudammar, samt vatten i morass, hade ansenligen tagit af, så at många af dem nu aldeles torkats bårt.

MAns $K_{\text {eex }}$, en Man af några och 70 år berättade, det han sjelf sett vid en bruns gräfning, at på 40 fots djup ned $\mathrm{i}$ jorden ej allenast funnits en stor klats af Castanie-trä, utan äfven rötter och stjelkar af arundo, samt just en sådan lera, som plägar finnas vid stränder af de vikar, som löpa in i landet, och hafva salt vatten. Detta ler hade ock en likadan lukt, samt en saltaktig smak. Han, med flere andre, slöto deraf, det hela detta landet, der Racoon och Pennsneck nu ligga, hafva i forna tider varit sjöbotten. Han visste ock berätta, at man vid djup grafning ned i jorden funnit här en af Indianernas slefvar. 
Suex Lock och W. Совв, som hvardera voro öfver 50 år, berättade, at man här mångenstäds, som de med egna ögon sett, har vid / brunnars gräfning på 20,30 och p. 447 flera fots djup råkat en stor myckenhet af arundo, som dock mäst var bårtruten. Då Совв lät gräfva sin brunn, har under 20 fots djup en så tjock stock mött honom, at han ej kunde gräfva djupare, innan han måste på 2 ställen hugga af den samma, hvilken ännu var helt hård. En vanlig ting sades det vara här, at vid brunnars gräfning djupt ned i jorden, finnes ibland en stor myckenhet af åtskilliga slags löf, som ännu ej äro aldeles rutnade. Dả här för nảgra år tilbaka bygdes en qvarndam vid den ån, hvarvid Racoons Kyrka är bygd, och de dả grofvo igenom en bank eller ås, hafva de funnit, at samma ås bestảtt til största delen af Ostron-skal, då likväl från detta stället til den närmaste ort, hvarest nu lefvande Ostron finnas i salt vatten, äro öfver 120 Ängelska mil. Häraf slöto så desse män, som nästan alle andre här på orten utaf sig sjelfva, och utan någons erindran, at desse länder i forna tider varit en hafsbotten. De bekräftade enhälligt, at månge små träsk, som i deras barndom altid stått fulla med vatten, och det äfven, om de hetaste somrar, nu äro aldeles så uttorkade, at der fins näppeligen om sommaren någon vatten-år deruti, undantagandes vid starkt rägn; men eljest kunde de ej finna, at vatten i Elfvar, åar och bäckar nu var mindre, än förr.

Åke HeLM, en Man öfver 70 år, sade, at då han lät gräfva sin brunn, fant han först sand och smả stenar til 8 fot, sedan ljus lera, och derefter svart. Då han gräfvit 15 fot, råkade han et stycke hårdt trä, samt åtskilliga Svafvel-kesar. Han berättade sig veta et och annat ställe uti flo|den Dellaware, der han i sin barndom rodt med båt, hvarest nu äro små öar, af hvilka somlige äro mot en Ängelsk mil långa. När en sådan Ö blifver gjord, börjar först sanka sig en sandbank, sedan föres lera dit, hvarpå der begynner växa hvass, och så vidare.

På en sammankomst eller Soknestämma af de älsta Svenska i Racoon, fick jag följande til svar på mina frågor 
uti denna saken: En må här gräfva brunn hvar en vil, så skal det altid på 20 a 30 fots djup finnas en myckenhet af Ostron-skal och Clams. (Clams äro en art mycket stora musslor, hvilka finnas uti hafsvikar, och af hvilkas skal Indianerne göra sina penningar.) På ganska många ställen, så under stora backar, som annorstädes, har vid brunnars gräfning funnits en myckenhet af Hvass och Säf (Arundo \& Scirpus) de der ligga ännu mäst oskadde. Man har vid en bruns gräfning til 20 a 30 fot under jorden funnit en hel Lin kärfva, hvilken varit likasom den nys blifvit ditlagd; en och hvar har undrat, huru den kommit dit. (Men mon det ej kunnat ske, at de tagit några andra Americanska örter, som Linum virginianum, Antirrhinum canadense \&c. hvilka likna ganska mycket ordinairt Lin, för det samma) dock är det något synnerligt, at kärfvan sades varit ombunden. Vid Europeernas ankomst til America fans ej vårt vanliga Lin der i landet, hvarken af Indianerna cultiverat, eller vildt växande; hvadan har då denne Linkärfvan kommit? mon här för flera hundrade år tilbaka varit folk, som betjent sig af Lin? men jag är dock af den tankan, at menige man tagit

p. 449 någon af nyssnämda Americanska örter eller andra dylika, för ordinairt lin. Pả mer än många ställen hafva de funnit brända kol och kolbrandar. Kyrkovärden ERICH RagniLssox sade sig sett en stor hop kol, fundne i jorden, då en ny brunn gräfdes. De hafva som oftast funnit vid brunnars gräfning til 20,30, 40 a 50 fot djupt stora stockar och klabbar af trä. På par ställen hade de på 20. fots djup funnit Villarnas slefvar. Utaf föregående slöto de enhälligt af sig sjelfva, at hela denna trakten i forna tider varit en hafsbotten. Härvid är ännu at märka, det mäst alla brunnar, som hittils här blifvit uptagne, gräfvas på sådana ställen, der någon börjar uptaga en ny plantation, och hugga bårt skogen, hvilken stått på den platsen, der brunnen gräfves, tör hända uti många hundrade år. Utaf detta, som nu sagt är, som ock af det, som längre fram kommer at anföras, kan med tämmelig visshet sägas, at en ganska stor del af Provincien New Jersey eller Nya 
Jersey i de första tider varit en hafsbotten, men sedan småningom tilkommit af den gyttja, jord, råsk och annat, som floden Dellaware årligen förer ned med sig upp ifrån landet. Några tvifvelsmål härvid synes dock udden Cap May göra, hvarom på sit ställe.

\section{Den 27 November.}

Beständigt grönskande Trän. De Trän, som här behålla sina löf beständigt och äro gröna både vinter och sommar äro följande:

Ilex Aquifolium. Lins. Spec. 125.

Skedträ eller Kalmia latifolia. Lisv. Spec. 391.

Kalmia angustifolia. Lins. Spec. 391.

Bäfverträ, Magnolia glauca. Livs. Spec. 535. men endast någon enda af de yngsta; de andre fällde sina löf.

Misseltöe, Viscum album. Lixv. Spec. 1023. Denna växte mäst i Fiskarträ, gyllenträ, Ek och Lind, at ofta hela toppen af dessa trän om Vintern stod grön deraf.

Talgbuskar, Myrica cerifera. Lins. Spec. 1024. någon enda af de unga hade somliga gröna blan qvare; men de mästa hade fält dem.

\section{Granar.}

Tallar eller Furor.

Hvita Enen eller Cedern. Cupressus thyoides. Lins. Spec. 1003.

Röda Enen eller Cedern. Juniperus Virginiana. Lins. Spec. 1039.

Åtskilliga Ekar och andra trän fällde här om vintern alla sina löf, hvilka dock litet längre til Söder, eller uti Carolina stodo med dem gröna hela året igenom.

\section{Den 30 November.}

Tänders mistande. En synnerlig egenskap märktes uti Ängelska Provincierne hos de invånare, som härstammade från Europa, vare sig Svenska, Ängelska, Tyskar, 
Holländska eller andra, antingen de då voro födde i Europa, eller här i landet; hvilken egenskap bestod deruti, at de ganska bittida och $\mathrm{i}$ förtid misste en stor del af sina tänder; enkannerligen voro qvinfolken alt för mycket underkastade denna olägenheten, men manfolken ej så

p. 451 mycket. Det var just ej sällsynt, | at se tjugu-åra Flickor half tandlösa, eller som redan mist åtskilliga tänder, utan at hafva fått några igen. Jag har sökt utforska orsaken härtil; men jag vet ej om jag råkat den rätta. Många mente luften i landet vore vållande härtil; emedan den samma är ganska föränderlig, och det mycket hastigt, så at den ofta på en dag kan ombyta sig från stark värma til mycken köld, och så tilbaka. Men mot denna orsaken strider Landets gamla invånares, eller Indianernas exempel, hvilka, ehuru de lefva i samma luft, likväl behålla sina tänder förträffeligen sköna, oskadda, och hvita, ända in til sit lefnads slut, hvilket jag sjelf sett och andre äfven likasom med en munn mig berättat. Andre sköto skulden derpå, at man åt här så mångahanda frukter och söt mat; men så fans dock här ganska många, som hade alsingen lust för sådant, och dock voro mäst tandlöse. Jag har sedan börjat misstänka Théet härföre, som här drickes, enkannerligen af qvinfolken både bittida och sent, och är här nu i sảdant bruk, at näppeligen någon bonde-käring. är, eller nästan ingen fattig, hvilken ej om morgonen skal bruka Thée til frukost. I denna tanka styrktes jag ännu desto mer, när jag kom til at resa up til Indianerna eller Villarna, och nu varande General-Majoren Johssos berättade mig, at åtskillige af de Villar, som bo närmast til Europeerna lärt af dessa, at bruka Thée til sin morgonvard; men dock med den lärepenning, at de Vilskor, som varit flitiga med Thée-drickande, äfven på samma sätt som Europeerne börjat i förtid mista sina tänder, då de p. 452 likväl altid förut | haft dem aldeles goda och oskadda, och de af deras Camrater, som ej ännu låtit sig behaga en sådan mindre nödig dryck, veta ej af en sådan olägenhet, utan på samma sätt, som förr, behålla alla sina tänder orubbade och påliteliga in til sin höga ålder. Men jag 
nödgades sedan finna, at denna orsaken ej eller torde vara så tilräckelig. Åtskilligt nog ungt qvinfolk, som nu vistades här, men voro födde i Europa, beklagade sig, at de mist mästa delen af sina tänder, sedan de kommit i detta landet. Jag frågade: om de icke trodde, at de kunde tilskrifva Thée-drickningen en orsak dertil, hälst starkt Thée likasom biter sig in i tänderna; men mig svarades, at de mist sina tänder innan de någonsin börjat bruka Thée. När jag nogare undersökte detta, fick jag en tämmelig tilräckelig orsak härtil. Alla desse qvinfolk sade sig altid haft den vana, at äta alt ting nog hett. Således åto de stekta äplen, så snart de kommo af glöden, och på samma sätt med all mat, de betjente sig af, så at maten ej smakade dem väl, om de icke fingo äta honom så snart han kom af elden. Detta passar sig ganska väl på de andra qvinfolken här i landet; ty desse förlora snarare och mera sina tänder, än manfolken. De dricka ock mera och oftare Thée, både morgon och efter middagen, då manfolkens sysslor icke tillåta dem, at göra det samma, och dessutom äro få af Ängelska manfolken så särdeles för Thée: en skål med Punch smakar dem bättre. När Ängelska qvinfolken dricka Thée, slå de det ej ur Thée-kåppen på tallricken, eller fatet at något svalas, utan de dricka det ur sjelfva kåppen, så hett som det slås dit från Thée|kannan, så at mången skulle tro, det de borde blifva skållade invärtes deraf. De äro ganska få, som svala det något på Thée-tallriken förut. På samma sätt dricka ock de förr omnämde Villskor sit Thée; men hvad Villarna i gemen angår, som hafva så sköna tänder, så är det deras sed, at sällan äta någon mat het, utan mästendels helt kall, eller bara ljum. Jag frågade Svenska Kyrkovärden Bengtson i Philadelphia, och andra gamla Svenskar, om de Svenske i forna tider miste sina tänder här i landet så snart, som nu? mig svarades, at de gamle Svenske behöllo då sina tänder goda til deras höga ålder, och miste dem ej. Bengtson sade sig sett, at hans Fader, då han var 60 år gammal, har bitit sönder kärnorna så af Persiker, som svarta Valnötter, hvilka dock är ganska 
hårda, och det ingen af den åldern nu ville våga sig til. Detta bestyrker, hvad ofvan sagt är; ty den tiden visste man ej här i landet hvad Thée-drickning var.

Frossa. Den nästan mäst gängse sjukdom här i landet, är den, som Ängelmännerna kalla Feber and ague, eller som de uttala det, Feber neger. Det är, hvad vi på Svenska kalle Frossa eller Skälfva, och på Latin Febris Quotidiana, Tertiana och Quartana; emedan somlige hafva honom hvar dag, andre hvar annan, och någre hvar tredje. Ofta, då nảgon har haft tredje dags Febern, och sluppit honom för en eller par veckor, får han hvar dags Febern, hvilken sedan åter går bårt, och efter liten tid vändes om til tredjedags Febern. De få honom gemenligen vid slutet af Augusti månad, eller ock uti September, och håller p. 454 han då merendels uti hela hösten och / vintern ända emot Våren, då de mäst pläga slippa honom. Han begynnes merendels med hufvud-värk, sedan rysningar, och ändteligen Frossa, hvilket slutes med en stark hetta. Ofta är sjelfva Frysningen eller skälfvan så stark, at alt hvad som lägges på Patienten, skakas häftigt tillika med hela sängen, at det näppeligen kan ligga qvar. Under Febern, och äfven emellan den samma, har den sjuke stark ryggvärk: likaledes har han ock stundom under Febern, antingen stick eller ock qväljande under hjärtat. Främlingar, som komma hit i landet, få honom gemenligen första eller andra året, och ansätter han dem hårdare, än de, som äro födde $i$ landet, så at de ock ibland sätta lifvet til; men merendels hafva de den förmon, at de sedan et annat år och mäst altid slippa honom, om de första gången gå väl igenom. Man säger här allmänt, at främlingar få den til at vänjas vid Climatet. En del af de här i landet födda hafva honom på somliga ställen hvart år. Somlige dragas längre tid dermed. Andre kårtare. Mången har honom halfva året, och leker han ibland så länge med somliga, til dess han får dem omsider til Kyrkogården. Indianerne få dragas med denna sjukan äfven, fast ej så mycket som Europeerne. Det är ock ingen ålder fri derföre. På de orter, der han årligen har 
sit tilhåld, ses ej allenast utlefvade gubbar och käringar brytas och plågas deraf, utan ock helt små barn, som ännu ligga i vaggan, ja, som ej voro öfver 2 à 3 veckor gamle, måste äfven nödgas så bittida vänja sig dervid. Det var ymka at se, huru desse små stackarena pinades, då frossan kom på dem, och at höra huru de då stankade | och våndades. Somlige af dessa späda hade honom, likap. 455 som de äldre, hvar dag: andre hvarannan, eller hvar tredje. Denna höst grasserade ock frossan här mera, än eljest sades vara vanligt. Han gör folket, som hafver honom, ganska bleka, at de se ut som lik, samt utmattar dem mycket. Hos de mästa var han dock ej svårare, än at de någorlunda kunde göra sit arbete emellan de tider, han häftigt ansatte dem. Det var synnerligt, at på somliga ställen hade de honom hvart år, annorstädes visste de ej Exempel, at någon haft honom. Synnerligt var ock det, at på somliga ställen, der de i manna-minne varit aldeles frie derföre, började han småningom infinna sig: man tycktes dock ej kunna se någon särdeles skillnad i den ena orten från den andra. Alla gamla, så af Svenska, Ängelska och Tyska, som andre, påstodo enhälligt, at han aldrig var så svår och pinsam, och varade ej hälften så lång tid, i deras barndom, som nu. De mäste af gammalt folk sade ock, at Frossan i deras barndom, eller vid år 1680. på långt när icke var så gängse och allmän som $i$ denna tiden; men andre lika gamla påstodo åter deremot, at han väl den tiden var i Proportion så allmän, som nu; men det kunde då ej märkas, at så många lågo sjuka deruti; emedan här var ganska litet inbyggare; och landet då var mycket glest bebodt. Tör hända det mäst varit lika, men at det nu förekommer de gamla all ting mycket svårt, för deras kropps beskaffenhet, hvilket det ej gjorde, när de voro unge, och kroppen i et annat tilstånd. Eljest är Frossan ännu årligen hos den ena mycket skiljaktig från det han är hos en annan. Äfven sker, at en, som haft honom / et år, och får honom sedan et annat, finner p. 456 honom den ena gången mycket skild från det han var den andra. 
Orsakerna til denna sjukdom lärer vara svårt, at väl utreda: de torde finnas åtskillige, och ej altid enahanda. Ibland och merendels lära flere stöta tilhopa. Utaf Medicis och andra här i landet sökte jag nog utspana dem: jag vil derföre anföra hvad de trott vara vållande dertil.

Somlige mente den bestå i en synnerlig luftens egenskap i detta landet.

De fläste höllo före, at stillastående och illaluktande vatten vore bland de förnämsta orsaker. Detta tyckes med mångfallig förfarenhet besannas; ty de hade här märkt, at folk, som bo vid morass, eller på sådana orter, hvarest finnes stillastående eller illa-stinkande vatten, äro sällan något år frie för Frossan, samt mera fallne, at få honom, än andre, enkannerligen den tiden på året, som samma vatten af den starka Solens hetta här i landet begynner häftigt lukta och osa från sig. Likaledes äro de ganska mycket underkastade denna sjukdom, som bo på sådana ställen, der landet är mycket lågländt, och der salta hafsvatnet kommer at blanda sig vid flod eller högt vatten, (som här sker par gångor hvart dygn) med det stilla-stående eller sakta flytande friska vatnet, som på dylika ställen finnes. När en ovan, om sommaren, kommer at resa på sådana låga ställen, der friskt och salt vatten blandas tilhopa, måste han ofta hålla för näsan för den elaka stanken, som upstiger derifrån. Derföre äro de p. 457 fläste Invånarena uti Pennsneck och | Salem här i New Jersey, hvarest landet har nyssnämde beskaffenhet, hvart år plågade med Frossa, och det långt mera, än på andra högländtare ställen. Der någon up ifrån landet, der de ej veta af Frossan, flytter hit ned at bo, kan han nästan vara helt säker, at på den vanliga tiden få den samma, sedan får han dragas dermed årligen, så länge han sig der uppehåller. Sådane kommo dit friske och rödbrusige; men då de varit der någon tid, miste de sin lifliga färg, blefvo bleke och sågo ut som lik. Men denna orsak lärer ock ej allena kunna göra til saken til Frossan; ty jag har på åtskilliga ställen här i landet sett lågländta platser 
med stillastående vatten, der dock folket sade sig sällan vara bekajade med denna sjukdom; men det var 2 à 3 Grader längre til Norr.

Andre trodde, at Diæten, eller ens mat och dryck ej mindre skulle bidraga härtil: enkannerligen var deras mening, at de många frukters obetänksamma och för giruga ätande ej torde hafva minsta skulden häruti, i synnerhet då någre från de gamla länderna kommo hit, och icke voro vane vid detta landets Climat och de frukter det frambringar. Det kan vara en annan sak med dem, som här äro födde, fast det kan ock hafva verkan på dem. Jag har hört många Ängelsmän, Tyskar och andra här i landet beropa sig härutinnan på egen förfarenhet, och säga, at de ofta försökt, och vore visse derpå, at då de ätit på nyckter maga en eller par gångor en Vatten-Melon, hade de inom par dygn Feber and ague, eller Frossan. Det är synnerligt, hvad Fransoserne i Canada flera resor berättat för mig; nämligen, at Frossan är uti Canada en mindre gängse sjukdom, och ehuru de / hvar sommare plantera der en myckenhet Vatten-Meloner, dem de äta, hade de dock nästan aldrig märkt, at någon der fått Frossan deraf; men när de om somrarna kommit til Illinois (en art Indianer, som bo mäst i samma Latitude, som Nya Sverige eller Pennsylvanien och New Jersey) och ätit endast några gångor af de Vatten-Meloner, som der planteras, kunde de vara försäkrade derom, at få Frossan, hvarföre samma Villar altid afråda Fransoserna, at äta af denna frukt. Skulle icke någon tro, at den starkare hettan uti Nya Sverige och hos Illinois, som bägge ligga ungefär 5 à 6 Grader längre til Söder än Canada, på något sätt är behjelpelig här til? Vatten-Meloner planteras både i Pennsylvanien, New Jersey, och de andra Angelska Nybyggen här i landet til myckenhet af hvar Landtman, som både vid hö- och sädes-anden på nyckter maga, och eljest äter dem i ymnoghet til förfriskning och kylning mot den häftiga hettan, som den tiden här varar; och uti hvilken denna frukt tyckes gifva en alt för behagelig läskning. På samma sätt äter så Landtmän, som 
andre, om sommaren här en myckenhet af andra frukter, som Meloner, Gurkor, Pumpor, Squashes, Mulbär, Applen, Persiker, Kersbär, med mångfalliga flera, hvilka lära hvar på sit sätt något bidraga härtil. At Diæten lärer göra ganska mycket i denna saken, tyckes vara anledning at sluta af de utgamlas enhälliga berättelse, nämligen, at folket här i landet i deras barndom på långt när icke voro underkastade så många sjukdomar som nu, och at det var tämmeligen sällsynt, at då se någon sjuk. Lika-

p. 459 ledes kommo alla gamle Svenske enhälligt derutin|nan öfverens, at de förste Svenske, som kommo hit i landet, hunno mäst gemensamt til en hög ålder. Deras barn lefde ock tämmeligen länge; men dessas barn, eller tredje Generation med deras afkomlingar, nå aldeles icke i ålder up emot de första Svenska, och hafva dessutom ej den starka och beständiga helsa, som de. De förste Svenske lefde mycket sparsamt. De voro fattige, och hade intet råd at köpa sig Rum, brännvin eller starka drycker. Sällan brändes hos dem brännvin; emedan ganska få hade fört någon brännvins-panna med sig. Godt Öl hade de dock ibland. De kunde ej göra Cider, som nu sả mycket brukas. Thée, Caffé och Chocolad, som nu, äfven hos Landtmän, är mäst en hvardags frukost, visste de ej af. De mästa hade aldrig smakat Sảcker eller Punch. Det Thée, som nu allmänt brukas, är antingen mycket förlegadt och odugligt, eller är det så utblandadt med allehanda främmande blan, at det näppeligen bör hafva namn af något Thée. Det tyckes derföre ej kunna åstadkomma alt godt hos dem, som flitigt hålla uti dermed, utom det, at af den ständiga drickningen både förr och efter middagarna, och det kokhett, ej annat kan ske, än at inelfverna skola blifva nog slappa. Villarne, landets urgamla invånare, bestyrka äfven til en del, hvad nu är anfördt. Vid Europeernas första hitkomst hunno de til en alt för hög ålder. Det säges ej då varit sällsynt, at finna dem, som varit hundrade år gamla, och deröfver. De lefde då sparsamt, och visste af ingen annan dryck utom vatten. Brännevin, Rum, vin, eller andra starcka våtvaror, voro 
dem så obekante, som våra Hälsinge Runor; | men sedan p. 460 de Christne infört til dem Brännevin och Rum, och Villarne nästan för ofta velat försöka huru det smakat, kommo de, som så trägit medicinera dermed, näppeligen mera til halfva den ålder, som deras förfäder.

Än mente någre, at den myckenhet af välluktande örter, som funnos här i skogarna vid Europeernas första hitkomst, men nu af boskapen äro utödde, vore orsaken, at fråssan nu är mera gängse. Desse välluktande örter gjorde, at hvar morgon och afton kändes då en så behagelig lukt i skogen, som hade en gått i den bästa örtegård, och tyckas de hafva mildrat de annars elaka våta dunster, och gjort dem mera helsosamma för inbyggarena.

Til Bot mot denna sjukdom hade de här brukat åtskilligt. I början fans at China-Barken var et säkert läkemedel häremot; men nu vil det ej altid så taga lag, fast denna barken ofta utgifves, at vara god och utvald. En stor del beskylte honom, at han lämnade något skadeligt qvar i kroppen efter sig. Det fans dock här gemenligen, at om Barken var god, och någon tog honom in, så snart en först fått frossan, och ännu hade starka krafter, så halp han ofta helt säkert, utan at Frossan vidare kom igen, och utan at lämna någon värk eller stelhet i lederna; men lämnades denna sjukdom för djupt insteg, at krafterna blefvo mycket utmattade, eller at någon af naturen var svag, och tog då in barken, så slapp en väl merendels Frossan, men den infant sig ofta efter 7 eller 14 dagar igen, så at han ả nyo nödgades intaga barken, til dess han ändteligen slapp sjukdomen; men påfölgden var stundom den, at | de hade länge derefter en värk och styfhet $i$ alla sina leder, och ibland uti inelfvorne, at de ofta ej kunde gå för stelhet. Denna olägenhet varade ibland i flera år, och förblef hos somliga ända til deras graf. Skulden til alt detta gafs dels på barken, som här sällan kunde fås oförfalskad, dels på Patienten, som vårdslöst brukade den samma. En af mina bekanta var mästare, at med China curera Frossan på följande sätt: om görligt var, skulle Patienten bruka barken i början af Frossan, 
och innan den väl fått likasom inrota sig. Han hölt ganska rådligt, at Patienten vid Curen borde svettas braf; nu som Frossan här på orten ofta var af den beskaffenhet, at han vid sjelfva hettan ej förorsakade svett, hvilket dock var en nödvändig sak, upväktes derföre svetten med konst. Til den ändan intogs intet botmedel den dagen Frossan infant sig. Om aftonen efter samma dag, som Frossan påstått, åt Patienten ingen ting. Den följande morgonen hölt han sig uti en varm säng, och der drack en myckenhet af varmt Thée, lät så täcka öfver sig väl med kläder, at han måtte starkt svettas. I denna värmen låg han til dess ingen svett vidare ville visa sig, då han steg up uti et varmt rum, tvättade hela kroppen med ljumt vatten, at den orenlighet, som med svetten kommit fram, måtte afsköljas, på det den ej skulle stoppa igen svetthålen. Sedan torkades kroppen väl. Derpå togs Chinabarken in några gångor samma dag; detta skedde 2 a 3 gångor efter de dagar, en haft Frossan, då den nästan altid säkert gick bårt, utan at komma igen. De flästa blefvo härigenom så botade, at de icke fingo någon blek hy eller färg efter Frossan.

Andre sluppo med det de brukade barken af rötterna på Tulipan-trä (Liriodendron Lins. Spec. 535.) på samma sätt som China-barken.

Andre då de på lika sätt brukade barken af rötterna på Hundträdet (Cornus florida Lins. Spec. 117.) Ja månge, som brukat China-barken, och ej sluppit, blefvo fullkomligen hulpne af nyssnämde. Jag såg at somliga sluppo sin Frossa, dermed at de stötte Svafvel helt fint som mjöl, blandade det med Såcker, togo in deraf om aftonen, då de gingo til sängs, samt om morgonen, innan de stodo up. De gjorde detta 3 eller 4 gångor, under den tid eller de dagar de voro frie från Frossan, och drucko hvar gång något varmt derpå, at skölja det ned med. Men hos andra åter, som försökte detta, hade det ingen särdeles verkan.

Några togo den gula barken af Persike-trä, hälst den, som fans vid roten, kokade den i vatten til dess 
halfparten ungefär var inkokad. Häraf drack den sjuke vid pass et vinglas fullt hvar morgon på nykter maga. Det smakar ganska illa, och drager ihop mun och tunga nästan som Alun. Genom detta blefvo ganska många här i Racoon botade, hvilka förut fåfängt brukat åtskilligt annat.

En del togo bladen antingen af Potentilla reptans Linn. flor. Suec. 456. eller Potentilla Canadensis Linn. Spec. 498 , kokade dem i vatten, och drucko samma decoct just då Frossan skulle komma, hvarigenom de blefvo til helsan återstälde.

Många redo från sig Frossan.

Somlige brukade intet, utan lät honom vara, til dess han gick bårt af sig sjelf.

Et Fruentimmer, som $\mathrm{i}$ en lång tid dragits med p. ${ }^{463}$ Frossan, och mot den förgäfves brukat åtskilligt, lade efter en Kärings inrådande et stycke Spinnelväf uti en bit stekt äpple, det hon åt och svälgde ned. Detta gjorde hon tvenne resor, de 2 första gångorna hade det ingen verkan; men då hon tredje gången intagit det, blef hon otroligt sjuk, så at hvar man mente, at hon skulle dö. Hon föll uti sådan vanmägtighet, at det näppeligen kunde ses, om hon lefde. Ändteligen efter 2 eller 3 timars förlopp kom hon sig åter före, slapp Frossan och fick sin helsa igen; men det var ock en bảde svår och äfventyrlig cur.

Invånarena vid Mohaks flod i New Yorks Province, så Indianer, som de af Europaiskt ursprung, togo roten af Geum rivale Lısns. flor. Suec. 461. och stötte eller refvo den sönder mäst til pulver. Somlige koka detsamma uti vatten til dess Decocten blir tämmeligen tjock. Andre blandade det uti kallt vatten och lät det stå et dygn; några lade det uti Brännevin; af denna lag togs in et Vinglas fullt om morgonen på nykter maga, den dagen en ej haft Frossan. Detta läkemedel sades der vara et ibland de aldratilförliteligaste mot Frossan, och säkrare, än China-barken.

De, som bodde vid Järngrufvor, sade sig aldrig eller 
ganska sällan få Frossan; och der de då få honom, är deras läkemedel, at dricka sådant vatten, som kommer ur källor, hvilka upvälla ur sjelfva Järnmalmen, och smakar starkt af samma Metall, då de försäkrade, at de visst blefvo från denna sjukan befriade. Derföre brukade ock andre, som bodde ej långt från sådana källor, då de

p. 464 fingo Frossan, at resa dit, och några gångor eller dagar dricka af samma vatten, då de merendels sluppo denna plågan.

Huru Salvia tillika med Citron-saft är befunnit mycket godt til Frossans häfvande, är förut vid New York omtalt under den 1 Novemb.

Eljest märktes öfver alt vid denna sjukdom, at det, som ofta var et visst läkemedel för den ena, gjorde så godt som ingen verkan hos en annan.

Pleuresie är likaledes en af de sjukdomar, som i synnerhet äro ganska mycket gängse här på orten. De Svenske, som här bodde, kalla honom Stick och bränna, så at när de säja, at någon af dem har Stick och bränna, eller blifvit' död af Stick och bränna, så förstå de altid denna sjukdom. Åtskillige af de äldsta Svenska här på orten berättade mig, at de i sin barndom icke vetat mycket deraf, och än mindre i deras föräldrars barndom; men nu i denna tiden är han här mycket gängse, så at åtskillige årligen dö deraf; dock har man märkt det, at somliga år är den mera skonsam, så at då ej så många deraf angripas eller dö: åter i andra år bårtryckas hopetals folk deraf. Dessutom äro somlige orter mera underkastade denna sjukan, än andre. År 1728. om Hösten grasserade han grufveligen ned uti Pennsneck (som är en liten Svensk församling nedan för Racoon närmare mot floden Dellaware), så at mäst alle utaf de gamla Svenska, hvilka dock voro ganska många, blefvo utödde och dogo bårt derigenom, hvaraf händt, at deras barn, som då voro unge, men sedan upväxte bland de Ängelska, så förglömt deras

p. 465 Förfäders språk Svenskan, at ganska få af / demı nu kunna förstå något deraf. Sedan den tiden har väl mäst hvart år någon der neder i Pennsneck dödt af Stick och bränna, 
men dock ej så mycket, utan sjukdomen har lika som hvilat intil denna Höst, eller år 1748. dả han återigen begynt faseligen gripa omkring sig, så at hvar vecka öfver 6 eller 10 Personer af de gamla deraf blifvit döde. Sjukdomen var då så häftig, at sällan någon kom at lefva öfver 2 eller 3 dagar, som deraf blef angripen; och voro de ganska få, som kommo up igen til hälsan, som råkat häfta för den samma. När han kom in i et hus, ödde han $\mathrm{i}$ hast ut mästa delen af de älsta. Det var väl en rätt Pleuresie; men han hade ock något enskildt med sig; ty han börjades gemenligen med en stor svullst under halsen, i nacken, eller igenom svảrighet at svälja. Somlige sade, at han var smittosam. Andre ville aldeles försäkra, at om han kom in i någon Familie, dödde ej allenast de, som bodde tilhopa, utan äfven deras slägtingar, som bodde långt derifrån ned i Pennsneck; fast de icke varit hos sina sjuka anhöriga, fingo de den dock, och måste följa med, hvilket jag lämnar derhän. Uti November månad var han som häftigast; dock dödde följande vintern då och dả någon gammal häraf. Barn blefvo nog fria derföre. När kölden började sätta til, stannade sjukdomen. Läkarena kunde icke finna sig i den samma eller skaffa bot derföre. Hvad orsaken är til denna sjukdom, är svårt at säja. En gammal Ängelsk Chirurgus, som bodde här, föregaf, at folket, här på orten, om Sommaren, då det är ganska hett, taga mycket til lifs Punch och andra starka drycker, hvilka hopdraga ådrorna uti Diaphragma | och göra blodet tjockt. När sedan i slutet af October och början af November det sker hastiga förändringar i väderleken från hetta til köld, och tvärt om, och det flere resor på en dag, och folket då äro ute, få de denna sjukdom gemenligen. Luftens synnerliga beskaffenhet det ena ảret mer än det andra, förorsakad af Solens hetta \&c. hjelper ock til. Det var märkvärdigt, at så väl år 1728. som detta året, då bägge gångorna så många af Stick och bränna dödde i Pennsneck, ganska få deraf blefvo angrepne eller döde uti Racoon, som dock ligger der tätt bredevid, och der jordmon och landets situation, samt folkets mat och lef- 
nadsart i mycket tyckes vara mäst enahanda; dock är denna skilnad emellan dem, at hela Pennsneck är nog lågländt, deremot är i Racoon et tämmeligen högländt land. Dessutom är Pennsneck fullt med kärr och morass, der vatnet står qvar och syrar eller rutnar. Mästadelen af dessa kärr äro beväxte med skog, som än mera håller fuktigheten qvar. Vid och omkring sådana morass bor folket. Dertil med tros vatnet, som de dricka, ej pả långt när vara så godt, som det i Racoon, utan hafver någon osmak. En del af det vatten, som der är i små åar, får en saltaktig smak, då Elfven Dellaware vid flod stiger högt, och tvingar vatnet gå up i dessa åar. En stor del af folket bor vid berörcle åar, och brukar samma vatten.

\section{Den 3 December.}

Om morgonen reste jag up til Philadelphia, dit jag kom fram om aftonen.

Villa Vinrankor. Af villa Vinrankor fans uti skop. 467 garna, til en tämmelig ymnoghet, och / af flera slag. Et slag, som är stort, växer uti kärr, och ätes gerna af Espar, eller de så kallade Sjuppar. De samma kallas kärrdrufvor; men på Ängelska Fox grapes. Folket äter dem ej gerna; ty de hafva icke så särdeles god smak. De villa vindrufvor, som begärligen ätas, äro små, och växa på torra ställen. Om Hösten sent, när de äro mogne, pläga de plåcka af dem och äta dem så rå, som de äro, då de smaka tämmeligen väl, och hafva en sötsur smak. Somlige bruka samla de små drufvor af det lilla söta slaget, torka dem, och bruka dem i tortor och bakelser, hvilka deraf smaka mycket väl. Eljest bruka de ock, at lägga dem torkade på tallrikar, och gifva fram til Fruentimmer och andra främmande, som annan confiture eller söt-saker. En och annan af de Svenska hafva i forna tider gjort vin deraf, som varit tämmeligen godt; men nu bruka de det ej mera. Somliga utaf de Ängelska bruka dock ännu årligen, at af dessa villa drufvor göra et tämmeligen skönt vin, det de påstå skola $i$ godhet ej gifva efter Franskt 
vin, och äfven hålla sig godt i flera års tid. Sättet at tilverka det, finnes ock infördt uti en detta landets Almanach för år 1743. och är följande: de börja at samla drufvorna från den 21 September til ungefär den 11 November st. n. nämligen alt efter som de mogna. Detta bör ske i torrt väder, och sedan daggen gått bårt. Sedan göras de rena från Spinnelväf, torra löf, och annat fnas. Dernäst beredes et stort oxhufvud, hvaruti antingen varit Sirap eller brännevin, hvilket väl tvättas, då den ena botten stötes ut, och den andra ställes på klabbar eller annat uti källaren, eller | något annat varmt rum, ungefär en aln från gålfvet. Detta fylles med drufvor, och som de sedan sjunka, lägges mera in deri uti 3 eller 4 dagar. Derpå stiger en barfotad in i oxhufvudet, trampar drufvorna väl, til dess saften börjar stiga up omkring benen, hvilket gemenligen sker inom en half timas tid. Då Han stiger ut, vänder han up de drufvor, som legat närmast botten, de der sedan trampas på lika sätt ungefär en fjerndels tima. Detta är tilräckeligt, at få ut den goda saften; ty mera prässning ville äfven kramma sönder den omogna frukten, och derigenom gifva alt en elak smak. Derefter öfvertäckes oxhufvudet med en tjock vepa, och om ingen källare finnes, eller väderleken är kall, lägges tvänne vepor derpå. På sådant sätt lämnas det at hafva sin första jäsning; ty för de första 4 eller 5 dagarna arbetar det häftigt. När Gäsningen börjar stanna, boras et tapphål 6 tum från botten, genom hvilket något deraf släppes ut, par gångor om dagen. Omsider, när det blir klart, tappas det af uti et rent ankare, som har tilräckelig storlek; ty af 20 buskels vindrufvor fås 20 gallons saft. I detta ankare lemnas det at stå någon tid, at deruti undergå en ny gäsning. Ankaret bör vara helt fullt. Det grummel, som sätter sig up vid sprundet bör afskummas, och fyllas igen med ny saft, som enkom dertil förvaras. Härmed fortfares til Jul, då det kan igensprundas. Uti Februarii månad är det färdigt, at tappas i bouteiller. Eljest brukade de mäst öfver alt, at om Hösten, då de blifva mogna, samla något deraf, lägga i käril, och låta 
det stå, at hlifva ättika, hvilken häraf blifver nog skön. Åtskilliga bränna brännevin af dessa drufvor, hvilket p. 469 blifver mycket skönt, och ännu mera välsmak|ligt blifver det, om det brännes af dessa drufvor sammanblandade med frukten af Persimon. Sjelfva trädet tjente dem til ingen nytta. Det är så skört, at det icke kan duga til vidjor. När en hugger i stammen, rinner efter några timar en hvit smaklös kåda derutur. På många ställen planteras det med flit uti örte- och trägårdar, at öfvertäcka lusthus, gjorde af spjälverk, hvartil det är förträffeligt; emedan det om sommaren med sina stora och många löf ganska noga täcker dem, som sitta derunder i bästa skugga, frie för Solens hetta, och när det uti Maji och Junii månader här blomstras, gifva dess blommor en stark, men tillika den allrabehageligaste och hjertstyrkande lukt ifrån sig; at den ock kan kännas på långt håll. Reser någon den tiden uti skogarna, kan den behageliga lukten gifva tilkänna, innan en ser trädet, at det är i nägden. Af vintrarna, ehuru stränga de äro, taga desse trän här aldrig någon skada. Frukten eller Russinen af alla dessa drufvor, äro ej större, än som ärter; men längre til Söder skola de vara stora som ordinaira Russin, samt mera behaglige; längre up i landet äro desse drufvor för en tid af Hösten Björnarnas förnämsta föda, hvilka då klänga sig up i träden efter dem. Dessutom tjena de til uppehälle för en myckenhet foglar. Man menar, at om desse med flit cultiverades, skulle drufvorne deraf blifva både större, skönare och välsmakligare.

Bot mot hosta och bröstverk. En Svensk Fru berättade, at bland de bästa ting mot hosta, kikhosta och värk i bröstet, var: at taga et stycke stål, lägga det i elden, at det blifver glödande, kasta det sả i en skål med p. 470 söt mjölck uti, | och när mjölken blifver så ljum, at den kan tolas, drickes den samma. Detta göres flere gångor. Hennes barn hade haft en farlig kikhosta, at de varit långa stunden som döde; ty blef hon inrådd af en sin bekant, at bruka föregående, med försäkran, at hennes barn skulle blifva bättre inom 2 eller 3 dagar. Hon sade 
sig gjort så, och funnit, at det var sant. Sedan har hon hulpit ganska många genom samma medel.

\section{Den 5 December.}

Tecken til väderlek. Åtskillige spådde, at vintern i detta år ej skulle blifva mycket sträng; ty uti början af October st. v. flögo villgässen och andra flyttfoglar norr ifrån til de Södra orter; men för par dagar sedan kommo de i ganska stora hopar tilbaka och flugo norr ut. Den följande vintern befans sedan vara af de medelmåttiga.

Äfven försäkrade någre, at vi innan följande dagens afton skulle hafva rägn; emedan de denna morgon vid solgången kunde från sina fönster se all ting så tydeligen på andra sidan om Elfven midt emot, hvilket nu syntes vara mycket närmare, än vanligt, som de befunnit mäst altid hafva varit et visst tecken til nederbörd. Träffade tämmeligen noga in.

Indianer. Ehuru Indianerne, vid Europeernas första hitkomst, voro alldeles okunnige om Järn, och fast Järnmalm fans här i största myckenhet; så var dock kopparens nytta dem ej aldeles obekant. Åtskillige Holländare, som bodde här i landet, visste berätta, at då deras förfäder först kommit til New York, hade de der råkat åtskilliga India|ner, hvilka hade Tobakspipor gjorde af koppar, den de sade sig hafva tagit der i nägden. Den sköna Koppargrufvan vid Second River emellan Elizabets town och New York, fants omsider igen, uti hvilken de vid gräfningen ej allenast råkat på hål, utarbetade i bärget, hvarutur malm eller Koppar var tagen, utan äfven åtskilliga Instrumenter, hvaraf Indianerne förmodeligen betjent sig vid kopparens brytning til sina pipor. Sådana hål utarbetade i bärg har man ock funnit på några ställen i Pennsylvanien, och äfven nedanför New Castle mot sjökanten, och har på samma ställen altid funnits spår til Kopparmalm. Somlige hafva ment, at sedan Spaniorerne uptäkt Mexico, hafva de seglat långs vid Americanska stranden Norr åt, samt här och der landstigit, at under- 
söka, om några ädlare metaller funnos der på landet, och at de då, tör hända, brutit dessa hål i bärgen; men om de ock gjort en sådan resa långs efter stranden, så hafva de just ej straxt kunnat råka på dessa kopparhaltiga bärg, ej eller hade de gifvit sig tid, at spränga efter koppar, när de voro angelägnare, at leta efter guld. Det lärer tvifvelsutan varit Indianernas göromål. Eller mon någon skal töras gissa, at våre gamle Norrske gjort detta långt för Columbi tid, då de anstälte sina resor til Vinland det goda, som våra gamla Sagor omtala, och hvilket ofelbart var Norra America, hvarom mera längre fram? Synnerligt är, at på alla ställen, der man i senare tider funnit dessa hål i bärgen, som ock ögonskenligen varit med Människohänder gjorde; hafva de altid varit med mycken mull p. 472 öf|vertäckte, likasom man med flit sökt gömma dem undan för andra.

\section{Den 6 December.}

At känna förgiftiga Fiskar. Under långa sjöresor sker ibland, at sådane fiskar kunna fångas dem ingen af skepsfolket känner. Som de då äro mycket mone om, at få färsk mat; så äter gemenligen skepsfolket den; men det är, at våga något mycket, och har förfarenheten vist, at mången genom sådan dristighet lagt sina ögon i en evig blund; emedan han ofta råkat äta förgiftiga fiskar. At undvika detta, hörde jag af många gamla Sjö-Capitainer, och annat gammalt sjöfolk, flera resor berättas vara brukligt, at vid sådana okända fiskars kokning lägga en silfverknapp eller något annat af Silfver uti grytan; om fisken är giftig, försäkrades, at Silfret efter kokningen blefve helt svart; men är fisken god, skal det ej ändra sig. Åtskillige af dessa Sjömän beropade sig härutinnan på flera resors egen förfarenhet.

At få skönt Smör. Madame Robeson, en af de Svenska qvinfolken här i Staden, hade altid smör, som til godhet och välsmaklighet tycktes öfvergå mycket annat smör, som fants här på orten. Det, som kärnades om vintern, 
var äfven så behageligt, som et sommar-smör, och ehuru det ibland var flera veckor gammalt smakade det dock, som det hade varit nyss kärnadt. Det sades ock hålla sig mycket längre, än annat smör. En Quakares hustru, som bodde på landet, hade lärt henne konsten, at få det så godt. Utom det, at kona fordras väl med godt hö, och smöret kärnas af god grädda, som icke blifvit gammal, vid | samlandet; så skal det förnämligast göra til saken, at mjölken aldrig tvättas ur smöret, efter kärningen, med vatten, utan genom arbetning och knådning. Detta fordrar väl något mera tid och besvär, än det andra; men Smörets godhet betalar rikeligen omaket. At smöret härigenom blifver mycket bättre, skal den finna, som vil försökat.

Glas-ögon väl betalte. Herr Benj. Frankuin, och åtskillige andre, berättade för mig flera gångor, at en Ville eller Indian, som ägde ön Rhode-Island, hvilken är stor som et litet höfdingedöme, och gör nu et särskilt Gouvernement, sålde den samma hel och hållen til de Ängelska för et par Glasögon. Denne Indian visste, at sätta det rätta värde på Glasögon, hvilka, om ej deraf vore en så stor myckenhet, utan endast någre få stode at finna, skulle täfla $\mathrm{i}$ värde och price med de dyrbaraste ädla stenar för den nytta, som deraf kan hämtas.

Barna-uppfostringen var hos de Ängelska här i landet på flera sätt väl inrättad. För små Gåssar hade de särskilta Scholor, och särskilta för Flickor. När en Gåsse eller Flicka var något öfver 3 år gammal, sändes den hvar dag både för och efter middagarna i Scholan. De hade väl ej den afsigten, at et så litet barn skulle kunna då lära läsa der något; men det'skedde derföre, at föräldrarne skulle slippa dess buller hemma, och at det i Scholan skulle blifva hindrat från all odygd och sjelfsvåld, samt mer och mer få smak, at vara der med de andra barnen. Angelsmännerne brukade aldrig mera, än et slags bokstäfver, at skrifva med, som voro de Latinske; derföre kunde | ungdomen lättare lära dem, än det sker hos oss, p. 474 som nödgas betjena oss af både Latinska och Svenska, 
för de mångahanda främmande ord, som inlöpa i vårt språk från utlänningar, hvilka ord vi äro vane, at skrifva med Latinska bokstäfver. Det torde vara så godt, at vi började äfven skrifva alt med Latinska bokstäfver; ty gemenligen äro samma bokstäfver jämnare, och se bättre ut. De äro ock läsligare, samt stadigare och tjockare, til ganska stor lindring för svaga och gamla ögon. I gemen skrifva de Ängelska en mycket ren och läslig styl; ja, en stor del af deras Fruentimmer skrifva likaledes ganska väl, åtminstone måla de ej sådana kråkfötter, som några af våra, hvarifrån äfven åtskillige af våra manfolk ej aldeles kunna sig befria. En torde mäst kunna med lika besvär lära sig skrifva väl som slurfvigt. Det, som bland annat hjelper de Ängelska til en sådan färdighet, är, at de hafva böcker af rent papper, uti hvilka på hvart blad äro bokstäfver utstukne i koppar ganska rent och tydeligt, nämligen somliga böcker in Quarto, med bokstäfverne A, B, C \&c. både de större och mindre; sedan andra sådana böcker, der orden finnas hoplagde; ändteligen andra, der öfverst på bladet fins en hel rad. Med et ord: alt på samma sätt, som en eljest brukar skrifva med penna för barn. Men detta var i koppar utstuckit makalöst. väl, och var dervid den förmon, at alla, äfven uti flera Scholor, lärde skrifva likasom efter en hand, samt så väl, som hade det varit stuckit i koppar. Man fick ock för et tämmeligen lindrigt pris köpa dessa skrifböcker. Det vore önskeligt, at detta sätt äfven komme något mera $\mathrm{i}$ bruk hos oss.

Tjenste-folk. Det Tjenste-folk, som brukas här i de Ängelska Colonierna, äro antingen Frie, eller Slafvar. De Frie äro åter af 2:ne slag.

1. Aldeles Frie, som årligen legas, och kunna gå sin väg ej allenast vid årets slut, utan nästan när de vela, om de icke kunna förlikas med sin Husbonde och Matmoder; men löpa dock då fara, at gå miste om den årslön de kommit öfverens om. Deras lön är tämmelig stor: en god dräng får här i årslön från 16 til 20 Pund uti Pennsylvaniæ mynt, som efter nu varande Växelcurs, då et Pund Pennsylvaniæ mynt räknas til ungefär 30 Dal. 
Kopp:mynt, blifver från 480 til 600 Dal. samma mynt. Ute på landet få de dock ej så mycket. En Piga fảr här i årslön från 8 til 10 Pund, och utom årslönen fả Dräng och Piga mat \&c. men kläder skola de hålla sig sjelfva; och är det husbondens eller matmoderns egen godhet, om de vela skänka dem några kläder.

2. Det andra slags fria tjenstefolk äro de, som årligen hitföras från Tyskland, Ängland, Irrland \&c. at sätta sig ned, och bo här i landet. Med dem är så beskaffadt, at mäst hvart år kommer en myckenhet af folk, gamla och unga, män och qvinnor, hvilka ledsna vid det slafveri och tvång, de der varit under, samt ofta för deras Religions frihet, lämna samma land, och komma hit öfver. Största delen af dem äro fattige, och hafva icke råd, at betala frakten för resan, som för en person bestiger sig från 6 til 8 Pund Sterl. derföre komma de öfverens med Capitain af skeppet, at låta vid öfverkomsten sälja sig för nå|gra år, då den, som köper dem, betalar Capitain frakten för de samma. Som ofta gammalt folk äfven sålunda kommer öfver, och ingen vil gerna betala frakten för dem, så sälja de sina barn at tjena $i$ flera år, så för sig sjelfva, som för föräldrarna. En del af dem, som komma öfver, betalar àt Capitain en del af frakten, och då komma de endast at säljas för en kảrt tid. Af föregående kan ses, at priset på dem, som komma öfver, blifver olika; och derföre komma somliga at tjena längre, än andre. När tiden är ute, som det varit öfverenskommit $\mathrm{om}$, at de skola tjena, få de en ny klädning, och något annat smått, af sit husbondefolk, och utom dess skal husbonden hela deras tjenstetid hålla dem mat och kläder. Månge af de Tyska, som komma öfver, kunna väl hafva tilräckeliga penningar, at betala sin frakt; men låta ändock sälja sig, hvilket de göra för den orsaken skul, at de under tjenste-tiden måtte få lära språket i landet, samt känna landets tilstånd, med mera, och under samma tid få veta, hvad de skola taga sig före, när de blifvit frie. Detta tjenstefolket utväljes fram för de andra, emedan de ej äro så dyre; ty at köpa en svart Slaf, eller så kallad 
Neger, fordras för mycket penningar på en gång: och at hålla dräng och piga, som skal hafva årslön, kostar ock för mycket; så at man kan få sådana nykomne för halfparten mindre och än lättare. När 14 Pund Penns. penningar betales för en sådan, skal han gemenligen tjena uti 4 år, och så i proportion, så at lönen blifver ej stort mera, än 3 sådana Pund om året. Detta tjenstefolk kallas efter Ängelskan Servingar. Om jag köpt en sådan, at p. 477 den skal tjena mig så och så / många år, och jag sedan vil sälja honom; så står det i min frihet; dock är jag skyldig, sedan hans tjenstetid är ute, at lảta honom fả en ny klädning, så framt jag icke förbehållit mig, at den, som köpt honom af mig, skal låta honom få det. Ängelsmän och Irländare säljas gemenligen för 4 år at tjena; men ofta är med Tyskarna den beskaffenhet, at innan de komma hit öfver, accordera de med Capitain, at de vela betala honom så mycket för så många personer: när de komma hit, gå de omkring at höra efter, hvem som vil betala deras frakt; så skal derföre, alt efter omständigheterna, et eller flere af deras barn tjena tilbaka så och så många år. Med den, som då bjuder det mästa, sluta de accord.

Negrar eller Morianer äro det tredje slags tjenstefolk, som brukas här i landet. Desse äro Slafvar på visst sätt, nämligen, at sedan jag köpt en sådan, är han min lifegen för hela sin lifstid (så framt jag ej säljer honom til någon annan, eller låter honom lös, at gå hvart han vil); men så står det ej uti husbondens frihet, at dräpa en sådan, om han gjort illa, utan det bör ske efter lag genom Ofverheten. I forna tider fördes Negrar hit från Africa, och köptes då mäst af alla, utom Quakare, hvilka den tiden gjorde sig et samvetsmål, at hafva en slaf; men nu äro de ej så samvetsgranne derom, utan finnes nästan så många Negrar hos dem, som hos andra; likväl är en och annan Quakare, som ännu är så helig, at han håller för ochristeligt, at hålla en Slaf. Här i staden finnas ock åtskillige frija Negrar, som varit så lycklige, at hafva fått någon stark Quakare til husbonde, hvilken, då Negron 
gått | honom någon tid väl tilhanda, har skänkt honom p. 478 sin frihet. $\mathrm{Nu}$ för tiden föres sällan några Negrar hit, utan de förra hafva fortplantat sig ansenligen här i landet. Vid deras giftermål är den sed, at om en husbonde har både Negrar och Negrinnor, låter han dem gifta sig med hvarandra, och då äro alla barnen hans lifegne. Har någon bara en Neger, och den vil gifta sig med en Negrinna, som hörer en annan til, låta de det gemenligen ske, at ej göra emot Negern i en så öm sak. Men han har sjelf ingen. nytta deraf; ty alle barnen, som födas uti detta ägtenskap, höra den husbonden til, som äger Negrinnan; så at det sålunda är en förmon, at hafva Negrinnor. Om en husbonde skulle slå ihjäl en sin Neger, så är det lifsstraff derpå; fast man ej hafver här exempel, at någon hvit man mist lifvet derföre. För några år tilbaka hände sig, at en husbonde slog ihjäl sin Neger. Han blef då strax $i$ hemlighet rådd så af sina vänner, som af de lagstiftande, at gifva sig på flykten; emedan han annars ej kunde undvika, at blifva kastad i fängelse, hvadan han sedan genom lagen skulle blifva bragt til döden, utan at någon skulle kunna frälsa honom. Denna ynnest vederfors honom, at ej lämna Negrarna den fägnad, at se en hvit man gå til döden för deras skul; aldenstund det samma kunde inplanta hos dem några skadeliga tankar mot husbönder och matmödrar, samt för stora inbillningar om sig sjelfva. Som sades, så fördes fordom Negrar hit gerad från Africa; men nu sker det sällan, utan de köpas denna tiden gemenligen från Westindien (se tilförene p. 244), dit de blifvit förde från Africa, emedan man fun|nit, at om man förer dem gerad til dessa Norra orter ifrån Africa, trifvas de icke så väl, som då de ömsas småningom hit, nämligen först til Wästindiska öarna, och sedan hit til Norra America. De hafva här mer än ofta rönt, at Negrarne icke kunna uthärda kölden så starkt som de hvita, så at då en hvit människa tager ingen skada af köld, kan Negern vid det samma frysa tår och finger af sig. Hvad åter Negrarne i synnerhet angår, så har man vid dem funnit, at de Negrar, som först komma hit til 
landet directe från Africa, kunna på långt när ej härda så ut kölden, som de, hvilka antingen varit födde här i landet, eller åtminstone vistas här en lång tid; så at när på de nysskomne tår eller finger frysa bårt, eller de eljest få en häftig värk i kroppen eller några dess delar, af kölden, hafve de andre, som länge varit här, så godt som ingen känning deraf. Man har ofta haft exempel, at då Negrarne blifvit directe förde från Africa, och kommit hit om vintertiden, har et ej särdeles bistert väder på fartyget kylt bårt deras lemmar, då båtsmän och andre vid samma tid näppeligen behöft hafva något på händerna. Det försäkrades, at de här sett Negrar, som fått af kölden först en grufvelig värk i benen, och sedan hafva benen af sig sjelfva brustit af midt på, och fallit med kött och alt aldeles från kroppen. Således händer med människor här, hvad i örtriket ofta rönes vid Södra länders växter, innan de hinna vänjas vid et kallare Climat. Priset på Negrar är här åtskilligt, alt efter deras ålder, hälsa och de slögder de kunna. Man gifver för en fullvuxen Neger från 40 til 100 Pund Pennsylvaniæ mynt; p. $480 \mathrm{ja}$ / exempel finnas, at man gifvit här i staden 100. Pund Sterl. för en Neger, och den, som då köpte honom så dyrt, hade ej velat sälja honom sedan för samma Summa. En Neger-Flicka eller Gåsse af 2 eller 3 års ålder, kan näppeligen köpas under 8, 10 til 14 Pund Penns. penningar. De som nu denna tiden gifva Negrar sin frihet, äro icke allenast Quakare, utan äfven rätt så månge af andra; hvilket sker på det sätt, at om en husbonde eller matmoder haft en trogen Neger, som gått dem väl tilhanda, och samma husbondfolk skiljas genom döden härifrån, gifva de stundom åt en sădan trogen Neger sin frihet; men det är dock någon omkostnad dermed; ty de måste då lägga af några penningar til den sammas underhåld, då den blifver gammal, at ej nöden skal tvinga honom, at göra illa, eller, at han skal ligga andra til besvär; ty gemenligen blifva sådana frigifna Negrar tämmeligen late. De barn, som äro födde af en sådan Neger, innan den blifvit frigjord, måste vara likafullt Slafvar, fast 
Fadern eller modern blifvit fri; men de, som blifva födde efter den tiden Föräldrarna blifvit frigjorde, äro frie. Negrarne hafva här i landet mycket större friheter, och blifva bättre handterade och födde, än uti Westindien; de njuta samma underhåld, som annat tjenstefolk, och hafva i alt mäst samma förmoner, endast at de måste tjena för hela sin lifstid, och få ingen lön, mer än det deras husbönder af egen godhet gifva dem; men eljest hålla de dem här med kläder. Uti Westindien, i synnerhet hos de Spanska, handteras Negrarna mycket obarmhertigt. Hvadan sker, at näppeligen kan någon skrämma de mästa af de här | på orten varande Negrar med mera, än at säja, det en har tanka, at sälja en sådan til Westindien. Det har man margfalliga rön på, at om man är för flat med detta folket, blifva de snart så treskna och sjelfgoda, at mången ej skal fả dem längre, än de sjelfve behaga; derföre är en Faderlig aga dem så nödig, som halfva födan, om husbonden annars vil hafva nöjaktig nytta af dem.

År 1620 förde et Holländsk skepp från Africa Negrar til Norra America, hvaraf 20 blefvo sålde i Virginien, hvilka säjes varit de första Negrar, som kommit til dessa orter. När Villarne eller Indianerne, som då i myckenhet voro här i landet, fingo först se dessa Negrar, trodde de fulleligen, at de voro sjelfva Hin ondes afvel, och at man fört dit en skepslast med djeflar: de kallade dem sedan en långan tid Manitto, et ord, som på Villarnas språk beteknar både Vår HErre och hin onde. Någon liten tid förut, när Villarne fingo se det första Europeiska skepp segla up för deras Floder, mente de, at det var Gud sjelf, som då kom, och var derpå, som jag sjelf hört dem berätta, om sina förfäder. Så växlades alt om hos Indianerna. $\mathrm{Nu}$ mera hafva de mildare tankar om Negrarna; ty denna tiden bo åtskillige af förrymde Negrar ibland dem, och äfven äro gifte med dem, det jag sjelf sett. Som man då redan haft här Negrar uti 130 år, och vintrarne här, i synnerhet i New Ängland och New York, ofta äro så stränga, som någonsin hos oss i Sverige; så frågade jag 
p. 482 flitigt och noga efter, om icke de då här märkt, at köl|den gjort någon verkan och ändring på Negrarnas färg, så at de, som nu äro i tredje eller fjerde generation af de först inkomne Negrar, ej äro aldeles så svarte, som de samme? men mig svarades öfver alt, at de icke kunnat märka. den ringaste skillnad derpå, utan är en Neger, som nu födes der af Föräldrar, som bägge varit i landet födde Negrar, och hvars förfäder både på mans- och qvinnosidan, ända til tredje eller fjerde led upåt, varit äfven i landet födde Negrar, aldeles så svarte, som de Negrar, hvilka än i dag ditföras från Africa; så at många deraf slöto, at den svarta färgen en Neger har, kan aldrig ändras hvarken hos honom eller dess afföda, ehuru länge de skulle vara och vistas i et kallt Climat. Annat vore, om en hvit man hade at beställa med en Negrinna, eller en Neger med et hvitt qvinfolk. At förekomma, det ej någon mindre behagelig blanning måtte ske emellan hvita och svarta, samt at hindra, det Negrarne ej måtte fatta för stora tankar om sig sjelfva til deras husbönders skada, sades den Lagen vara stadgad, at nästan lifsstraff vore satt på den hvita, som gifter sig med någon Neger, af hvad kön det ock vore, och den Präst, som vågade sig binda tilhopa et så orimligt par, lupe fara, at icke allenast mista ämbetet, utan ock mera. Men at eljest de hvita och svarta stundom nalkas hvarandra för nära, vitnar den deraf härflytande blanning, som då och då yppar sig. Vid dessa Negrar är det än at beklaga, at deras husbondefolk mäst öfveralt $\mathrm{i}$ dessa orter nästan aldrig bry sig om deras andeliga välfärd, utan låta dem vara och p. 483 blifva i de/ras Hedniska mörker. Jag vil ej säja, at det torde ganska många husbönder finnas, som skulle tycka illa, och tör hända på alt sätt hindra, at deras Negrar skulle vela söka undervisning $i$ den Christna läran, af den falska inbillning, at det vore dem en skam, at hafva en sådan Christendoms broder eller Syster; eller, at de då ej torde kunna handtera dem så hårdt, som eljest, eller at Negrarne då torde blifva för högdragne, när de funno, at de $\mathrm{i}$ det andeliga vore så gode, som husbonden. 
Negrarnas Förgift. Det är af åtskilliga skrifter bekant, at Negrarne uti Södra America hafva et slags Förgift, hvarmed de kunna taga lifvet af hvarandra, och det ej på ögnablecket, utan på en lång tid efter det den tagit förgifftet in, som de velat afhända lifvet. Samma konst kunna ock de Negrar, som finnas här i landet. Derpå gifvas många Exempel. Alla Negrar hafva dock sig ej detta förgiftet bekant, utan endast några få, och är märkvärdigt, som säges, at de, som gifva förgiftet, veta ock bot deremot; men ej, eller sällan, andre. Deraf händer, at om en Neger märker sig vara förgiftad, och vet af hvem det skedt, går han tilbaka til honom, och med penningar eller goda ord förmår honom, at gifva sig bot emot det onda han förut gifvit honom; men om den Negern är arg, nekar han, både at han gifvit honom något samt at han vet bot för den andras sjuka. Detta Förgift dödar ej straxt, utan löpa ibland flera år förbi, innan den sjuke dör; men från den stund han tagit Förgiftet, börjar han tråna småningom bårt, och kan efter den dagen ej | hafva någon beständig helsa. Den, som p. 484 blifver förgiftad, kan ofta märka mäst sjelfva ögnablecket, då han fått Förgiftet. Gemenligen förgifta Negrarne sådana, til hvilka de bära hat. I synnerhet, om det är någon Neger, som förer sig ganska väl up, som älskas af sin Husbonde mycket, som likasom vil skilja sig från de andra Negrarna, och ej gerna omgås med dem. Ofta ock af andra orsaker. Sällan gifves något Exempel, at de vågat med detta Förgift skada sit Husbondefolk; tör hända, antingen derföre, at de handteras här gemenligen ömt, eller at de frukta det Husbonden sedan snart skulle märka det, och då vore intet straff så hårdt, det en sådan Neger ju måste undergå. De lảta ej veta, hvaruti detta Förgiftet består, utan hålla det otroligen hemligt; men det är troligt, at det måste vara någon ting, som är mycket allmänt, och som finnes på alla orter i verlden; emedan de kunna så lätt få det hvar de hälst vistas. Det kan för denna orsaken skul ej allena vara den ört, som somlige Lärde ment; emedan den på de fläste orter 
ej står til fångs. Jag har här hört flera Historier om Negrar, som blifvit förgiftade, af hvilka jag endast vil anföra en, som fullbordades under mit vistande på desse orter. En man hade här en Neger, som var honom ganska trogen, och som förde sig så up, at han ej velat byta honom bårt emot 20 andra Negrar. Husbonden var ock på sin sida nog öm om honom. Negern liknade i upförande en den trognaste och bästa Europeer. Han omp. 485 gicks så litet han kunde med andra Negrar. | Häraf kastade desse et oändeligt hat på honom; men af det, at han nästan aldrig omgicks med dem, fingo de ingen lägenhet, at gifva honom Förgiftet, ehuru de ofta sökte tilfälle dertil. En gång vid en marknad, då han kom til staden (ty han bodde mäst ute på landet), budo någre andre Negrar honom in, at dricka med dem. Han ville ej; men slapp icke, innan han måste göra dem sällskap. När han kom in, togo de fram en kanna, som stod på muren, drucko honom til, och budo honom äfven göra besked för sig. Han drack, och vid det han tog kannan från munnen, sade han: hvad dricka är detta, det är ju fullt med - - - (jag utsätter ej med flit, hvad han sade det var; emedan det tyckes nästan ofelbart varit det förgiftet, hvarmed de göra så stor skada, och som finnes mäst på alla orter i verlden, ty någon elak människa kunde alt för mycket missbruka sådan til sin Nästas skada; det är bättre, at det är okunnigt) då började de andre Negrarne och Negrinnorne at le, sprungo up på golfvet, söngo och dansade, likasom de hade uträttat en god gerning och ändteligen vunnit det, som de så länge traktat efter. Denne oskyldige Negern gick strax bårt, och vid hemkomsten sade, at de andre Negrarne säkert gifvit honom förgift. Han trånade sedan bårt, och ingen ting kunde hjelpa honom, utan han dog någon tid derefter.

Den 7 December.

Om morgonen reste jag ned til Racoon uti Nya Jersey. 
Folkets Förökelse här i landet. At Folket.| förökar p. 486 sig här fortare, än $\mathrm{i}$ de gamla länder, tyckes ej vara svårt at finna orsaken til. Här i landet kan en utan fruktan eller mycket betänkande gifta sig, så snart en hunnit til sådan ålder; emedan här är en myckenhet af ouptagit och skönt land, så at en gift snart och straxt kan få et ställe, der han väl och tilräckeligen skal kunna föda sig med sin hustru och barn. Utlagorne äro så godt som inga, så at han ej behöfver oroas derföre, och friheten är sådan, at haan på sin jordlapp nästan kan anse sig som Kong. $\mathrm{Nu}$ vil jag med några klara Exempel bevisa, hvad detta alt uträttar.

En af de Svenska uti Racoon, vid namn Mass Keen, var nu mot 70 år gammal. Han hade många barn, barnabarn och barnabarns-barn, så at, då han räknade dem alla tilhopa, som af hans afföda ännu lefde, steg antalet sig til 45 stycken. Utom àessa hade en stor hop af hans barn och barna-barn dödt, dels då de varit helt små, dels då de redan varit inemot fullväxte. Detta är väl vackert, men det spisar dock ej mot följande Exempel, dem jag utur Pennsylvaniæ Gazetter utdragit:

År 1732 d. 24 Januarii afled uti Ipswich i Nya Ängland, Enkan SARA Tưril, 86 år gammal. Hon har födt 13 barn, och utaf sju allena af de samma har hon haft 177 barna-barn och barna-barnsbarn.

År 1739 d. 30 Maji voro tilhopa hemma hos RIChard Butringron i Chester-Härad uti Pennsylvanien, hans barn, barna-barn och barnabarns-barn, tilsammans til antalet 115 stycken. Denna Gubben född i Ängland, gick då på sit 85 ålders | år, och var ännu mycket frisk, rörlig och ägde et godt minne. Hans älsta son, som då redan hunnit til 60 år, var den första Ängländare född i Pennsylvanien. $\begin{array}{lll}\text { Ar } & 1742 & \text { d. } 8 \text { Januarii afsomnade uti Trenton i Nya }\end{array}$ Jersey, Enkan Sara Furman, 97 år gammal. Hon var född i Nya Ängland, och lämnade nu efter sig 5 barn, 61 barnabarn, 182 barnabarns-barn, och 12 barnabarns-barnabarn, tilsammans 260 personer, alla då lefvande.

År 1739 d. 28 Januarii skildes från detta jordiska 
uti South Kingston i Nya Ängland, Enkan Maria Haszard på sit 100:de ålders år: hon var född pả Rhode-Island, och Farmoder til då nyss afledne Vice-Gouverneuren Georg Haszard dersammastädes, och har hon haft 500 barn, barna-barn, barnabarns-barn och barnabarns-barnabarn, hvaraf 205 vid hennes död än lefde; en hennes Dotter-dotter hade då redan varit Mormoder uti 15 år.

Sảlunda har den vanliga önskan eller välsignelsen, som står uti Brude-mässan: at de (gifte) måge se sina barna-barn til tredje och fjerde slägte, tämmeligen noga blifvit upfyld på somliga af nyssnämde.

\section{Den 9 December.}

Skadeliga Insecter. Uti hvart land finnes gemenligen en myckenhet Insecter eller yrfä, hvaraf somlige hafva den egenskapen, at ehuru små och föraktelige de synas, kunna de dock tilfoga Invånarena stor skada. Sådana får ock Norra America kännas vid, hvaraf somlige p. 488 höra lika|som detta landet enskildt til, somlige åter har det gemensamt med de gamla Länder. Jag har förut p. 268 talt om Musquetoes eller detta landets förtretliga myggor, och p. 293 och följande, om de yrfän, som aldeles utöda ärt-åkrarna i dessa länder; nu vil jag öka några til:

Gräshoppor. Utaf dem är en art, som infinner sig här ungefär hvart 17:de år uti obeskrifvelig myckenhet. De komma dả midt i Maji månad up utur jorden från sina hål, och göra vid pass i 6 veckors tid med sit skri et sådant ljud i träden och skogarna, at den ene människan svårligen kan höra et ord hvad den andra på sådana ställen bredevid henne talar, så framt en icke ropar hårdt. De sticka då med darten uti deras stjert hål på den mjuka barken af små grenar på träna, hvaraf ofta desse grenar torkas bårt; men eljest tilfoga de ej träden eller andra växter någon skada. Emellan förenämde år, då de uti sådan ovanlig myckenhet komma, ser och hörer man allenast någon enda här och der 
i skogarna. Af de Ängelsmän här bodde, kallas de Locusts.

Maskar på Trän. En annan ohyra här på orten är et slags maskar, som äter up löfven på träna. Desse infinna sig ock vissa år i oändelig myckenhet; men deremellan visa sig gemenligen endast några fả af dem. De år, desse komma i så obeskrifvelig mängd, upäta de så aldeles löfven på träden, at träden och skogarna midt om sommaren stå så nakna och löflösa som om vintern. De angripa då mäst alla slags trän, så at det endast äro några få arter, som de ej våga sig på, och som få stå för dem orörde. Som det / gemenligen är den tiden på året, en ganska stark hetta här på orten; så har detta maskarnas frätande den skadeliga påfölgd med sig, at de nakna och löflösa trän ej kunna stå mot den häftiga värman, utan torkas bårt, hvarmedelst ibland stora trakter af skog sålunda fått stryka åt. De Svenske, som bodde här, viste mig här och der i skogarna hela fälten, der ung skog nu uprunnit uti den gamlas ställe, som några år förut genom dessa skadeliga maskar gått ut. Af Ängelsmännerna heter denna ohyra Caterpillers. De förvandla sig sedan i Phalæena af smutsig gulbrun färg, som framdeles på sit ställe skal beskrifvas.

Gräs-masken plägar åter andra år göra här stor skada både på ängar, och sädes-brodden, der den kan komma åt. Han infinner sig, på samma sätt som de föregående, vissa år uti grufvelig myckenhet; dock är vid alla dessa den förmon, at de sades aldrig infinna sig alla til öfverflöd på et och samma år, utan det år, som här är en ovanlig myckenhet gräshoppor, veta de ej stort hvarken af löf- eller gräs-masken, och så likaledes med dessa, så at bara et slag på en gång i stor myckenhet vist sig. Dessutom löpa ibland flera år förbi, då af intetdera slaget någon synnerlig myckenhet märkes. Vid denna gräsmasken fans, at den enkannerligen hade sit tilhåld på fett och rikt land. När de blefvo honom varse på något ställe, grofvo de smala diken med mäst perpendiculaire sidor rundt omkring den plats han intagit, i hvilka diken han 
föll, och kunde ej hjelpa sig derifrån. Här sades af många, at förenämde 3:ne ohyror fölgde tämmeligen tätt på hvarp. 490 andra, nämligen då | första året gräshopporna låtit infinna sig, kom det andra året löfmasken, och det tredje fölgde gräsmasken derpå. At detta ibland til en del träffar in, har jag sjelf rönt.

Mal, som skära sönder kläder, finnes äfven här i landet. Jag har sett kläde, ullvantar, och annat af ylle, som om sommaren hängt i Contoir eller skåp, och ej så noga blifvit eftersett, vara om hösten af denna ohyran så sönderskuren, at ofta hela stycken föllo ut af sig sjelfva. Stundom voro kläderna af dem så illa medfarne, at de näppeligen stodo at lagas. Pälsverk och andre skinnkläder, som hängt up i vindar, voro ofta af malen så skadade, at hela stora hårtapparne lossnade, och föllo bårt af sig sjelfva. Om denna ohyra från urminnes tider varit här i landet, eller om den först fölgd hit med Europeerne, kan jag ej säja.

Loppor (Pulex Lisv. Faun. 1171.) saknades ock intet i denna verldenes del. Somlige af dem har väl, tvifvelsutan, gjordt följe hit från de gamla länder; men så lärer ock en myckenhet varit här från urminnes tider. Jag har funnit dessa luftspringare på detta landets Harar, och gråa Ickornar, skutne i villa ödemarker, der ingen människa bodt. När jag sedan reste längre up i landet, och kom at ligga uti Indianernas kojor och sängar, fans af denna ohyran der en sådan välsignelse, at jag mente jag legat i sjelfva brinnande elden; så at jag var glad jag fick stiga up, och lägga mig på bräderna, som voro lagde under taket $\mathrm{i}$ dessa deras hyblen. Men det är ock intet at undra öfver; ty den stora mängd af hundar de hafva,

p. 491 kan väl vara tilräckelig, at | samla dessa gäster tilsammans från alla kanter. Här ligga i kojorna hundar och Indianer alt om hvarandra, och näppeligen har en främmande hunnit här lägga sig, och låtit ögonen rinna tilhopa, innan han vet $e j$ annat, än han skal blifva antingen ihjälkrossad eller förqvafd af 8 eller 12. och flere hundar, som lagt sig både rundt omkring, och öfver honom på alla ställen, 
at sålunda taga sin nattehvila hos den främmande, den de förmodeligen tro ej skola töra så bulta och vräka sig bårt, som deras husbönder och matmödrar det göra.

Sirssor af det oroliga slaget, som vi ibland här i Sverige hafve $\mathrm{i}$ våra hus, blef jag ej varse på något ställe, der jag rest, hvarken i Pennsylvanien eller Nya Jersey; ej eller visste någre andre, som jag derom tilsporde, berätta mig, at de här sett nảgra dylika. Nog var det om sommaren ute på marken et slags svarta Sirssor, hvilka leto aldeles och just så, som de, hvilka hos oss hafva sit tilhåld uti murarna och spisarna; men desse uppehöllo sig nästan altid endast ute på marken; och då vintern, eller kallare väderlek kom, tilstoppades deras mun. Dock skal ibland ske, at nyssnämde svarta Sirssor mot hösten taga sin tilflykt til husen, och der skrika altid, då väderleken är varm, eller det är nog varmt i stugan; men åter, då kölden infaller, stana de aldeles med sin Musique. Deremot på et och annat ställe i Nya Yorks höfdingedöme, och nästan uti hvar och en bondstuga hos Fransoserna i Canada, samt äfven i de flästa hus i städerna dersammastädes, var så tjockt förråd af våra vanliga Spis- och ugns-Sirssor, at näppeli|gen i någon bondstuga hos oss kan vara värre. De höllo der sin Musique ständigt vid magt vinter och sommar, och hade äfven der ej aflagt sin vanliga oart, nämligen, at ibland skära sönder kläder och dylikt.

Vägglöss hafva ock ej varit nödbudne, at inställa sig i denna del af verlden. Jag har mot min vilja måst hafva besök af dem på alt för många ställen, så hos Ängelsmän, som de Franska; men hos Villarna mins jag mig aldrig märkt dem. Vid mit vistande på Fort S:t Frederic, berättade der då varande Commendanten, Monsr. Louisignan, at hos de Indianer, som kallas Illinois, och hos de andra, som bo ännu längre bårt åt väster, vet ingen hvad denna ohyran är, hvilket han sade sig noga sjelf förfarit, som uti långan tid uppehållit sig på samma orter. Om dessa skadedjur först blifvit hitbragte med Europeerne, eller om de varit här långt förut, kan jag ej 
säja. Månge mente, at de voro af detta landets uråldriga invånare, och togo skäl deraf, at de ofta funnit Vägglöss under vingarna på detta landets Flädermöss, der de sugit sig djupt in. De trodde derföre, at desse fått dem uti iholiga trän, eller annorstädes, och sedan fortplantat dem på hus, emedan Flädermössen fästa sig på husväggar, eller krypa in i några trånga hål på husen. Men som jag ej sett dem på Flädermöss, kan jag ingen ting säja derom. Tör hända, det varit någon art af Löss, eller Acarus, som setat på Flädermusen, den de ment varit Vägglös. Lät vara, at det varit en rätt Vägglus, så har det ju lätt kunnat ske, at hon fäst sig på Flädermusen vid det denne p. 493 trängt sig in i skrymslor uti / hus, der Vägglöss varit. Som desse ledsamme gäster icke voro här mere välkomne, än hos oss, så brukades här åtskilligt, at fördrifva dem med. At sängar gjorda enkom af Sassafras-trä ej voro tilräckelige, at beständigt hålla dem ute, är förut p. 434 . omtalt. Någre påstodo, at de af egen och mångfallig förfarenhet funnit bästa och säkraste medlet til denna ohyrans utrotande, at taga kokhett vatten, och spruta det in uti såten och hålen, der de utvaldt sit tilhåld, samt tvätta sängen öfver alt dermed. Om härmed fortfares 2 eller 3 gångor, sades de kunna utrota dem alla. Men om någen bor i nägden til andra, der äfven detta skamlösa packet innäslat sig, och der ofta omgås, så kan han ej göra sig länge fri; emedan han från granskapet kan snart få nya recrüter. Uti Pennsylvaniæ Gazette N. LXXVIII. eller för den 14 Maji 1730, blef infördt et sätt at fördrifva Vägglöss, hvilket var tagit utur Londons Daily Journal of Jan. 26 för samma år, och som blifvit så berömdt, at det i London inom par dagar tryktes 2:ne gångor om. Jag har sett detta redan til en del bekant hos oss här i Sverige, dock vil jag införa innehållet der af. Det försäkras förut, at en Medicus flere resor och på flere ställen härmed aldeles utrotat denna ohyran, samt at flere andre, efter samma hans föreskrift med lika lycka försökt det samma. Sättet är sådant: tag af det starkaste distilleradt brännevin (nämligen sådant, som är så starkt, at då eld tändes derpả, 
brinner det alt up, utan at nảgon vätska lemnas qvar) ungefär litet mer än et halft qvarter, Terpentins Spiritus lika mycket, som blandas bägge väl tilhopa. Bryt deri sönder i små bitar et halft | unts Camphert, hvilket deri uplöses på få minuter. Detta skakas väl tilhopa, då man hafver antingen en svamp eller en borste, som doppas deri, hvarmed sängen noga vätes eller de husgerådssaker, deri denna ohyran har sit tilhåld. Härigenom dödas och utrotas både den och dess ägg ofelbart, om det ock krälade huru mycket deruti. Men sängen och husgerảdssakerne böra väl genomvätas härmed (sedan dambet förut blifvit afstrukit) hvarmedelst de hvarken fläcka, orena eller på det minsta skada hvarken det finaste silke eller Damask, som sängen är af. Ofvannämde sats är tilräckelig til en säng, om deri ock vore ehuru mycket ohyra. Om allenast en droppa af denna vätska fälles på en vägglus, skal hon strax sätta lifvet til. Skulle någon vägglus märkas, sedan man en gång brukat föregående, så är det et tecken, at en ej vätt väl på alla ställen, der ohyran haft sit tilhåld; derföre bör man nogare än en gảng väta härmed, och der något litet hål är, dit en ej med borsten kan komma, bör man droppa eller spruta denna mixturen dit in, då den otvifvelaktigt skal aldeles utrota dem. Somlige sängar, som bestå af flere delar, kunna svårligen frigöras, förr än man först tagit dem sönder; men vid andra, som kunna dragas ut, och man väl kan komma til alla ställen, behöfves ej det omaket. Den lukten, som denna mixture förorsakar, försvinner inom '2 eller 3 dagar, hvilken lukt dock är ganska hälsosam, och äfven för åtskilliga mycket angenäm. Det bör ej förgätas, at mixturen sqvalpas väl om vid hvar gång han brukas, hvilket bör ske om dagen, och ingalunda vid eldsljus, på det $e j$ de fina dun/ster af denna mixture måga draga p. 495 elden til sig, då en betjenar sig deraf och åstadkomma skada. Jag lämnar förenämde medel, at utrota Vägglöss, i sit goda värde, emedan jag ej försökt dern; men det hafver jag af flera resors egen förfarenhet inhämtat, at (då man beqvämligen kan) svafvel visligen och rätt bru- 
kadt, dödar och utöder totaliter denna ohyra och alla dess ägg både i sängar och väggar, om den ock krällde der tio resor tjockare, än myror i en myrstack.

Toraker eller Brödätare hafva trott, at de icke böra mer än de förre vara från den nya verlden uteslutne. De hafva derföre på många ställen i den samma tagit sit hemvist. Den lärde Doct. Colden i Nya York var väl af den tanka, at Brödätarenas förnämsta fädernesland vore Westindien eller de Americanska öarna, och at de af detta slägtet, som nu finnas i Norra America blifvit förde dit på skepp frân förenämde ort; emedan man ännu dageligen ser, at då fartyg komma från Westindien med Varor til Norra America, är det fullt af desse Brödätare uti skeppen; men af de rön jag samlat här i landet, hvilka strax skola anföras, har jag mycken anledning at sluta, det Brödätarena varit här på fasta landet i Norra America från långliga tider tilbaka. Jag nekar dock ej, at ju en myckenhet af dem ock kunnat följa med skepp från Americanska öarna. De finnas i Staden Nya York mäst i alla hus, hvilka ofelbart til största delen kommit dit från skeppen; men så kan det ej säjas om alla, som finnas ute på landet i skogarna, ja, dem man blifver varse i de p. 496 största ödemarker. Ängels/männerne kalla dem Cockroches, och af de Holländska heta de Kackerlack: de Svenske, som här bodde, kalla dem Brödätare, för den skada de göra på bröd, som bekant är, och rättnu skal omnämnas. Uti Herr Archiater Linner Fauna Suec. 617. föres den til Blatta. Átskillige af de här i landet varande Svenske kallade dem ock Kackerlack. Desse finnas ej allenast ofta $\mathrm{i}$ husen, utan äfven om sommaren kräka både på och under stubbar i skogen. När de i denna vinter midt uti Februarii månad förde hem från skogen gamla rutna stubbar til bränsle, blef jag varse åtskilliga Brödätare, som hade tagit sit vinterqvarter deri. De voro i början som döde; men då de legat en liten stund inne $\mathrm{i}$ stugan, qvicknade de vid och blefvo helt lefvande och snällfotade. Jag märkte sedan ganska många gångor om vintern, då gamla rutna trän fördes hem til ved, och 
klyfdes sönder, at en myckenhet af Brödätare krupit dit in, och der lågo $i$ dvala. När en karl samma vinter högg ned et högt torrt trä, och det sedan klyfdes sönder til ved, fann jag uti en dess sprynga, som dock varit några famnar up i luften, åtskilliga af dessa Brödätare tillika med de vanliga myror. De hade således vandrat nog högt up uti vädret, at ligga uti vinterqvarter. När jag midt uti October månad 1749. reste igenom ödemarkerna, som ligga emellan de Ängelska och Franska Colonier, och vi om aftonen gjordt eld vid en stor garnmal ruten stock på stranden af sjön Champlein, kom en stor myckenhet af Brödätare krypande ur stocken, dem elden och röken upväkt och drifvit utur deras vinterqvarter. Fransoserne, som då fölgde med mig, kände dem ej, ej eller viste de något | namn på dem. Uti Canada hade de sig ock ej bekant, at desse nảgonsin uppehålla sig in i husen. Uti Pennsylvanien skola desse ibland finnas i myckenhet vid skördetiden under sädesstackarna. De uppehålla sig mångenstäds uti de Ängelska Nybyggen i husen, och hafva der sit mästa tilhåld i springor, i synnerhet i dem, som äro i sparrarna i taket midt för eldstaden, hvarest är nog varmt af hettan. De äro deruti förtretlige, at de äta up det mjuka bröd, de kunna komma öfver. Slippa de in i en limpa, äro de i stånd, at på kårt tid göra slut på alt det mjuka deri finnes, så at då en vil skära up limpan, är endast den yttra hårda skårpan qvar. De sades ock förtära andra matvaror. Ibland bita de folk i näsan och fötterna om natten, då de sofva. En gammal man af de Svenska, vid namn Sven Láck (Soneson til Lackenius, en af de första Svenska Präster, som kommit til Nya Sverige) berättade, at han en gång $\mathrm{i}$ sina yngre år varit ganska illa utsatt för en af dessa Brödätare; ty vid det han en natt sof, vaknade han deraf, at en af dem krupit in i hans öra; han sprang då strax up, och märkte, at hon arbetade, tvifvels utan af räddhoga, at tränga sig längre in. Detta hennes arbetande förorsakade honom en sådan sveda, at han mente hufvudet skulle spricka sönder på stunden i många stycken, och blef han nästan ifrån sig. 
Han ilade til brunnen, fick up et ämbare vatten, hvaraf han hällde i sit öra. Så snart Kackerlacken kände vatnet, som ville qväfja henne, hade hon intet vidare tid, at blifva qvar i örat, utan började strax sparka sig baklänges ut, då han sålunda fick henne bårt från örat.

Skogslöss är et annat fult pack, som på sit sätt nästan är värre, än alla de föregående. Jag har tilförene omständeligen beskrifvit dem i Kongl. Svenska Vetenskaps Acad. Handlingar för år 1754 p. 19 och följande. Dit jag visar Läsaren.

\section{Den 11 December.}

Litet före middagen reste jag til Pennsneck, och så vidare öfver Elfven Dellaware til Willmington. Landet uti Pennsneck hade samma beskaffenhet, som på andra ställen här neder uti Nya Jersey, nämligen, jordmon består mäst af sand, hvarpå ligger en tunn svartmylla. Dessutom är landet ej mycket backigt, utan mäst jämt, och på de flästa ställen öfverväxt med gles löfskog, hvaraf Ekar af åtskilliga slag göra det mästa. Här och der var någon enstaka gård med en liten åker rundt omkring: då och då syntes något litet moras, samt ibland någon liten $\AA$ med sakta flytande vatten.

Skogarna härstädes bestodo af åtskilliga löfträn, dock mästendels af flera slags Ekar och Hickery; ehuru en stor del af dessa skogar ännu voro sådane, at de aldrig af folk lära blifvit utödde, utan fått stå och växa som de sjelfve velat. Häraf skulle kunna slutas, at uti dem skulle finnas trän af en ganska hög ålder; men det var dock ej så; utan fast mera svårt, at här få något trä, som hunnit til eller litet öfver 300 år. De mästa trädens ålder sträkte sig näppeligen til 200 år. Jag fant altså, at träden hade samma egenskap, som invånarne uti p. 499 djur-riket, nämligen, at dả de | hunnit til någon viss ålder, dö de bårt af sig sjelfva. Således stodo här stora skogar; men då träden uti dem nalkats 150 eller 180 år, blefvo de antingen rutne invärtes ned uti, eller bårtrutne i öfra 
delen af trädet, eller blef det mycket skört, eller kunde rötterna ej mera draga tilräckelig föda àt det, eller började det gå ut af någon annan orsak. Häraf skedde, at då de starka stormarna kommo, hvilka ibland pläga här infalla, brötos desse trän af, dels strax ofvanför roten, dels midt på, eller ock up vid skatan, eller rycktes det up med rot och alt; hvarföre man får räkna stormarna ibland en af trädens dödar här pả orten. Skogarne äro således fulla af stora kullfallna trän, hvilka kastats omkull genom någon af förenämde orsaker. Härtil kan ännu skogselden läggas, som ibland här slipper lös, då träden ned vid roten til halfparten, och mera, afbrännas, hvarigenom de sedan så lätt af vädret omkullbrytas. Då jag reste genom dessa skogar, gaf jag med flit akt uppå, om jag ej af trädens läge kunde märka, hvilka väder här varit de häftigaste; men jag kunde icke sluta något visst deraf; ty de lågo omkull från alla väderkanter. Hvaraf jag kunde se, at det väder, som kom från den sidan, der trädets rötter äro kårtast och svagast, eller eljest der det hafver den minsta styrkan at stå emot, stjelper det samma omkull, eller brytes det af. Således dö beständigt de gamla träna bårt, och lämna de unga rum, at uprinna i deras ställe. De nedfallne trän ligga och rutna bårt på marken, antingen fortare, eller långsammare, och föröka sålunda svartmyllan. De löf, som här om hösten i myckenhet nedfalla, föras af vädret omkring, men fast|na gemenligen altid på ömse sidor af dessa nedfallna trän, der de merendels blifva qvarliggande, och hjelpa til, at på det stället föröka svartmyllan. Et nedfallit trä ligger i flere år, innan det blir bårtrutnat aldeles til mull. När et trä blåser omkull, så at roten tillika rifves up, följer gemenligen en hop mull med roten, som en tid sitter dervid. Då det faller ned, gör det en liten hög, som sedan blifver ökad af de löf, hvilka stanna vid roten. Häraf upkommo en myckenhet små ojämnheter af helt små gropar och högder i skogarna. Häraf tiltager ock svartmyllan mera på somliga ställen, än på andra. Hvad trädens rutnande vidgår, så voro somliga slag mera benägna dertil än andra. 
Fiskareträ (Nyssa), Tulipan-trä, och Gylleneträ (Liquidambar) rutnade mycket snart; med Hickery gick ock tämmeligen fort; Svart Ek rutnade snarare, än hvit Ek. Men det kom ock mycket an på vissa omständigheter; om barken lämnades qvar på trädet, blef det inom 6,8 eller 10 år merendels genomrutit, och inuti af maskar genomboradt, at det var mäst helt och hållit som et rödbrunt mjöl eller mull; men togs barken af, så lågo somliga trän ända til 20 år, innan de blefvo nedrutne. Trädens hastiga växt, mycket stora porer, starka hetta och fuktighet skiftevis om somrarna, jämte det, at hvarjehanda slags Insecter bårade de nedfallna trän fulla med hål, och gjorde sålunda en myckenhet öpningar för väta och luft, bidraga ej litet til hastigt rutnande. De mästa trän i desse skogar äro löfträn. En myckenhet af dem rutna inuti, då de blifva något store, medan de ännu stå p. 501 och växa; uti dessa / iholiga trän hafva en stor del af djuren här i landet sina bon, tilflykt och tilhåll.

Elfven Dellawares bredd midt mot Willmington, sades vara $2^{1} / 2$ Ängelsk mil; dock tyktes ögonmåttet ej vela tillåta så mycket. Djupet sades här vara midtpå från 4 til 6 famnar.

\section{Den 12 December.}

Trän til Snickare-arbete. De förnämsta trän här i landet til Snickare-arbete sades af Snickare vara svart Valnötträ, Vilskt Kersbärsträ och masurerad Lönn. Af det svarta Valnötträdet (Juglans nigra Linn. spec. 997) är här ännu et ymnigt förråd, fast de nog arbeta på, at utöda det, så at Bönderne på somliga ställen bruka det til ved. Vilskt Kersbersträ (Prunus virginiana Spec. 473.) är ganska skönt och ser förträffeligen väl ut. Trädet är gult til färgen, och ju äldre de ting varda, som deraf blifvit gjorde, ju skönare börja de se ut. Men detta är nu ej så lätt at få; emedan det väl öfver alt hugges ut, men ingenstäds återplanteras. Masurerad Lönn, som är en varietet af den rödblommiga Lönnen (Acer rubrum. Spec. 
1055.) är likaledes makalöst skön, men ock ganska svår at erhålla. En får hugga i många Lönnar, innan en kan råka på den rätta. Gyllenträ (Liquidambar) brukas väl ock til allehanda Snickare-arbete, som bord och andra husgerådssaker; men sades ej få stå vid elden, emedan det då drager sig. Furu och den så kallade hvita Cedern (Cupressus thyoides) betjena Snickare sig ock utaf til åtskilligt.

Virke til qvarnhjul och trällar. Mölnaren vid qvarnen härstädes berättade, at qvarn-hjulstảckarne här på orten göras af den hvita Eken, samt at en sảdan ståck kan härda ut 4 eller 6 år, innan den rutnar. Furu sades ej vara så varaktig som hvit Ek. Kuggarna och trällan äro af hvitt Valnöt, emedan det skal vara et af de hårdaste trän af alla, som här finnas.

Mulbärsträdet sades icke hafva sin like til dymblingar uti skepp och båtar.

Om aftonen reste jag ifrån Willmington öfver floden Dellaware til färgstaden på Nya Jersey sidan.

\section{Den 13 December.}

Om morgonen fortsatte jag resan up til Racoon.

Knylar på trän. På en stor hop af träden här i skogarna, voro antingen på sidan af trädet, eller midt på och rundt omkring någon af grenarna, större eller mindre knylar eller växter, som satt sig derpå. Ibland kunde det endast finnas en enda på et trä, på någondera sidan och af olika storlek; ty ibland var det som et människohufvud, ja ock större, och stundom mindre. Den satt som en bålda på trädet. Ibland var på et enda trä en stor hop deraf, ej allenast på en sida, utan de gjorde ibland likasom en Cirkel rundt omkring trädets gren, ja ibland hade ock en sådan Cirkel satt sig rundt omkring tjockaste stammen på trädet. Det var ej allenast stora trän, som hade sådana | växter och knylar, utan äfven p. 503 små trän af näppeligen en famns längd. Gemenligen voro desse knylar af samma Solida materia, som sjelfva trädet, 
och sågo merendels inuti ut som masur. Ibland voro de ock til en del iholige. När en sådan på de små trän skars sönder, så fants den gemenligen full med små maskar, ibland voro ock maskar i de store. Således ses hvaraf de härröra, nämligen, at då trädet blifvit stuckit af Insecter, som inom barken lägga sina ägg, hvaraf utkläckas maskar, löper saften ut, och blir som et svallande, då desse knylar småningom tilskapas. Det äro endast löfträn, hvarpå desse finnas, och af löfträn äro förnämligast Ekar, som hafva dem, enkannerligen den svarta och Spanska Eken; dock finnas de ock nog på Ask (Fraxinus excelsior) och på den rödblommiga Lönnen (Acer rubrum). I fordna tider hade de Svenske, men i synnerhet Finnarne, som här bodt, svarfvat fat, skålar och skopor af desse knylar, som finnas på Asken, hvilka sedt ut nog vakra och varit som masurerad. De på Ek hafva ej dugt dertil; emedan de gemenligen inuti äro rutna och fulla med maskar. $\mathrm{Nu}$ bruka de Svenske ej mera sådana fat och skålar, utan betjena sig af stenkäril i stället, eller ock svarfvade skålar af annat trä. Somlige af förenämde knylar äro oändeligen stora, och göra, at trädet ser nog vanskapeligt ut. Sådana trän äro ock nog allmänna uti skogarna här i landet.

Vägarna här i landet rätta sig efter jordmon. Der det är sandgrund, äro de torra och goda; men elaka, hvarest är lera. Folket är här ock ganska vårdslöst vid p. 504 vägarnas omlagande. | Om bäcken ej är desto större, bry de sig icke om, at lägga nảgon bro deröfver, utan må den resande hjelpa sig öfver, som han bäst gitter; derföre löper ock mången fara vid starkt rägn på sådana ställen. Om et trä råkar falla öfver vägen, hugges det sällan af, at få vägen ren, utan de göra då en krok omkring trädet, hvilket är lätt at verkställa; emedan marken merendels är jämn och ej stenig, samt träden mycket glesa, och icke underväxta af små skog. Häraf kommer, at vägarna gå här i så många små krokar. Aldrig möter här någon grind eller åker, då man färdas på en allmän väg, utan åkrarna ligga ofta på ömse sidor om vägen, men gärdesgårdar löpa på bägge sidor, och en reser då liksom genom 
et tå. Vil en til någon gård, så kan en väl ibland komma, at fara genom någon åker tätt vid gården och husen; men då brukas icke grindar, utan endast led. Hemmanen och gårdarne äro alt enstakade, och finnes ej gerna 2, mindre flere gårdar tilhopa, undantagandes i städer, eller sådana platser, som mäst skola passera för städer; altså ses här ej många byar. Hvar gård har sin åker, mark, skog, bete och äng för sig sjelf särskildt. Mon detta hulpit til, at vargar nu äro här så mycket utödde, eller lupit bårt; emedan de funno mäst allestädes hus, samt folk, som sköto efter dem. Utmarker eller skogar kunna ibland vara allmänne för 2 eller 3 gårdar, men mycket sällan för flere; dock äro de mäst enskildte eller afdelte.

\section{Den 18 December.}

Giftermål. Til följe af den Ängelska lagen får ingen Präst viga något brudfolk, innan det $/$ antingen blifvit p. 505 lyst för dem 3 gångor på Predikstolen, pả samma sätt, som det sker i Sverige, eller at de förskaffat sig tillstånd dertil af Gouverneuren i landet, samt upvisa det åt Prästen, hvilken då behåller det samma för sin säkerhet skul. Om Prästen icke i akt tager detta, utan af egit bevåg viger ihop några Personer, som det begära af honom, så kan han lätteligen få böta ansenligt nog, om det upkommer klagomål emot honom. Gemenligen är här i landet bara fattigt folk, som låta lysa för sig; alla de som äro något förmögnare, när de skola blifva gifte, taga de af Gouverneuren et tilstånd dertil, eller så kalladt Licence, hvilket innehåller, at Gouverneuren undersökt denna saken, och funnit intet hinder til samma giftermål, hvarföre han tillåter det. Detta Papper är gemenligen tryckt, endast at et rum är lämnadt, der Contrahenternas namn med penna blifva införde. Likaledes har ock Gouverneuren merendels med egen hand satt sit namn derunder. Men innan denna Licence gifves, måste Brudgumen hafva med sig en eller par ärliga och kända män, som gå $\mathrm{i}$ borgen för honom, at intet lagligt hinder är til hans ägtenskap med den 
person han ärnar taga til hustru. Desse Löftesmän måste underskrifva en trykt skrift, hvars innehåll är, at de påtaga sig, at stå all skada och löpa alt äfventyr, om något klagomål af endera Contrahenternas anhörige, Förmyndare, husbönder, förut trolofvade eller eljest kärande, skulle yppas, ty det är ogörligt för Gouverneuren, at kunna hafva sig alt sådant bekant. Desse Cautionister intyga ock uti samma deras skrift, at icke det ringaste hinder p. 506 är eller kan vara emot det deri | omnämde ägtenskapet. I Philadelphia betalas för en sådan Licence 25. Shillingar Pennsylvaniæ-penningar, hvaraf et Pund eller 20 Skillingar kommer Gouverneuren til; men det öfriga eller 5 Skillingar får Gouverneurens Secretaire. Denna Licence är stäld bara til de Protestantiska Präster; ty de Påfviska Präster hafva här ej frihet at fästa något ägta par tilhopa, och Quakarena hafva et särskildt tilstånd til de band de binda. Efter Ängelska lagen är det här så, at så snart en Karl fylt 21 år, och en Flicka 18, äro de myndige, så at de sedan kunna gifta sig, om tillfälle tilbjudes, när de sjelfve vela, utan at fråga sina föräldrar til råds; men för den tiden, och innan de räkt sina myndiga år, hafva de icke lof at gifta sig utom Föräldrarnas eller förmyndares samtycke. Som det vore besvärligt, för dem i synnerhet, som bo långt från den orten, der Gouverneuren hafver sit Residence, at enkom resa dit at uttaga Licence, och hafva sina Löftesmän med sig, när de vela träda i ägta stånd; så är här brukeligt, at Prästerna på landet taga ut af Gouverneuren så många Licences de tro sig behöfva, jämte Charta för Cautionisterne; och när den, som vil gifta sig, kommer til dem med sina Löftesmän, erhåller han Licence så snart Löftesmännerne underskrifvit den förr omtalte skriften. Prästen emottager då af dem de 25. Skillingar, som äro för Gouverneuren och hans Secretaire, samt sit egit arfvode för det besvär han sjelf haft. Och då han kommer til staden, lefvererar han penningarne, som influtit för Licences, til Gouverneurens Secreterare, jämte alla skrifterne, som Cautionisterna med p. 507 sin hand och namn|teknat, och får då, om han så be- 
höfver, flera Licences, at gifva til dem, som vela gifta sig. Häraf ses, at en Gouverneur härstädes, utom sin ordinaira lön, kan hafva vakra Accidentier om året. Som i desse nybyggen är en stor blanning af hvarjehanda slags folk, så af dem, som nyss flyttat hit från de gamla länder, som andra, hvilka i början ofta vistas endast en kårt tid i hvar Province, så har ibland skedt, at då Prästen vigt et sådant Brudfolk, har Brudgummen ursäktat sig ej då hafva penningar, at betala Prästens omak; dock lofvat göra det med det första; men strax derpå rest sin kos derifrån med sin nya hustru, utan at Prästen något erhållit. Detta har gifvit anledning til det bruk, som är i Maryland, nämligen, at när en Präst kommer at viga något Brudfolk, hvilka just ej kunna räknas bland hederliga ståndspersoner eller eljest bemedlade, läser han up för dem halfparten af Brudvigningen, och innan han går vidare, frågar han efter betalning för sit besvär, säjande: Where is my Fee? d. ä. Hvar är det, som mig tilkommer? đå Brudgummen måste fram med penningarna, och när Prästen dem fått, fortfar han med vigningen; men om Brudgummen då ej råkar hafva några Penningar, stannar Prästen med Brudmässan, och upskjuter dermed til en annan gång, til dess Brudgummen hinner förse sig bättre med en så gällande Vara, hvilken således ej får blifva gift, innan han gifvit den skatt, som skatt tilkommer. Men åt så kallade Gentlemen eller Ståndspersoner, dem Prästen är försäkrad om, at kunna betala, blifver aldrig under Vigningen denna förtretliga fråga förestäld. Men at komma | til Gouverneurernes tilstånd, så oaktat, at en Präst har fått sådana Licences at gifta Brudfolk, kan han ändock löpa i stor fara, om han icke ser sig visligen före; ty på många ställen här i landet är en lag gjord, som så lyder: at ehuru en Präst har Gouverneurens tilstånd at sammangifta folk, får han 1) ej viga dem, som ännu äro under sina myndiga år, om han ej har Specielt Föräldrarnas samtycke dertil. 2) Får han ej viga dem, som hafva förbundit sig, at för sin frakt hit från Europa tjena några år hos någon här i landet, så framt Prästen icke har 
deras husbönders särskildta tilstånd dertil; gör han emot någondera af dessa stycken, måste han (til ex.) i Pennsylvanien böta 50 Pund i samma lands penningar, fast han ock hade Cautionister, och fast han ägde Gouverneurens Licence; ty Föräldrarna eller husbönderna söka Prästen, och bry sig ej om Löftesmännerna, utan lämna honom frihet, at sjelf taga ut sin skada af dem. Men har han Föräldrarnas eller husböndernas bifall, så må han göra det fritt utan fara. Än är ingen Präst tillåtit, at i ägta-band tilhopa knyta en Neger eller Morian med någon hvit eller af Europæiskt ursprung; den, som deremot bryter, är, efter Pennsylvanska Lagen, fallen til 100 Punds böter.

En rolig sed är här vid somliga giftermål dessutom brukelig, nämligen, om en Enka lämnas efter sin man uti stor fattigdom och skuld, eller at hon väl har något qvart, men at det på långt när ej spisar mot det hon är skyldig efter sin man; och en annan sedan friar til henne, består ofta vid och under sjelfva vigseln hela hennes präktiga p. 509 Brud|klädnad på hennes hedersdag endast deri, at hon träder fram för Prästen til Brudstolen och vigseln i blotta och bara särken, och lämnar sin förra mans Creditorer frihet, at taga både hennes kläder, och alt annat, hvad i samma hennes förra mans bo finnes; och derefter är hon icke förbunden, at betala något mera för sin förra mans skuld, emedan hon lämnat dem alt, ända til sina gångkläder, och ej behållit utaf altsammans mera, än bara blotta Lintyget, at skyla sin blygd med, det både lag och anständighet ej kan neka henne, at taga så mycket med sig. När vigselı är förrättad, och hon nu icke mera hörer til dess förra man, kläder hon på sig de kläder, som hennes nya man henne förärt. Våra Svenska Präster hafva åtskilliga gångor här på orten ej fått låta sig underligt förekomma, at se Enke-brudar framträda för sig uti en så sparsam och mindre vidlyftig brudeskrud, som Kyrkoböckerne utvisa, och deras egna berättelser. Uti Ängelska Gazetterna här i landet, har jag ock ofta sett denna roliga plägsed omtalas, och bland andra påminner 
jag mig en, at då Bruden kom i bara blotta särken, i följe med sina närmaste anhörige, från dess förra mans hemvist til sin nya Brudgummes hus, at blifva vigd, mötte hennes fästman henne på halfva vägen med nya sköna Brudkläder, dem han uti fleras närvaro sade sig låna sin Brud, och klädde dem sjelf på henne. Han lärer tvifvelsutan endast derföre sagt sig vela låna henne dessa kläder, emedan om han gifvit tilkänna, at han förärt dem, hade hennes förra mans Creditorer kunnat komma, och tilägna sig dem, i det de ansedt henne ännu dả, | til dess vigseln p. 510 gått för sig, som hennes förra mans Enka.

\section{Den 21 December.}

At Europeer varit $\mathrm{i}$ detta land långt för än de Svenske kommo hit, tyckes vara tämmeligen sannolikt af följande (utom hvad längre fram kommer at omtalas.) En sjuttio åra man af de Svenska, vid namn Mass Keen, berättade åtskilliga gångor för mig, at då de Svenske i förra hundrade talet aldraförst kommo hit, och satte sig ned at bo på et ställe vid namn Elsenborg, belägit vid floden Dellaware, litet nedanföre der nu Salem är, hafva de der funnit gamla murade brunnar til 20 fot djup af tegelstenar, hvilka icke kunnat vara Indianernas verk; emedan de för Europeernas hitkomst vid slutet af 15:de Seculo ej visste hvad tegel var, mindre at de skolat bruka det. Desse brunnar voro då vid landet, dock på et sådant ställe vid elfven, som ibland stod under vatten, och ibland var tort; men sedan har vatnet skölgt bårt mullen, at de nu ligga et stycke ut $\mathrm{i}$ floden, så at denna tiden sällan är så tort, at de nu mera kunna synas. När de Svenske samma tid litet derifrån höllo på at gräfva sig brunnar, hafva de neder uti jorden funnit icke allenast sönderslagne lerkäril, utan äfven nästan hela oskadda tegelstenar; ja vid plöjandet hafva de äfven här och der funnit tegelstenar. Af detta tyckes följa, det Europeer eller andra, den gamla verldens invånare, $i$ gamla tider antingen af storm eller annan händelse kommit hit, satt sig ned 
vid Elfsmynningen at bo, slagit tegel, med mera; men sedan antingen blandat sig med Indianerna, och gift sig p. 511 med dem eller blifvit | af dem ihjälslagne. De torde småningom iklädt sig af orngänget med Villarna deras natur, likasom de Svenske vid Ängelsmännernes hitkomst vid år 1682 beskylles varit som halfva Villar, och man än dageligen ser, at de Europeer, Franske, Ängelsmän, Tyska, Holländska \&c. hvilka i flera år vistats allena afsides bland Villarna, så blifvit dem i art och sinnelag lika, at de näppeligen mera, än i färgen kunna skiljas från dem. At Europeer vid och efter Conumb tid ej gjordt förenämde brunnar, och slagit det tegel, visar både Historien och Villarnas berättelse, som säga, at desse brunnar hafva varit til der långt för samma tid. Samma berättelse, om desse brunnar af tegel, jämte tegelstenar fundne på flera ställen i jorden här ned vid Elfsmynningen, hörde jag sedan af àtskilliga andra gamla Svenskar.

\section{Den 22 December.}

Tecken til väderleken. En gammal Bonde spådde, at vi snart hade at förvänta annat väder; emedan det nu vid middagstid var så varmt i luften, der det dock var om morgonen hel kalt; dessutom slöt han det äfven deraf, at Solen begynte draga moln omkring sig. At han råkade rätt, visa Meteorologiske observationerne, som finnas vid slutet.

\section{Den 31 December.}

Läkemedel mot Tandvärk finnas gemenligen flera, än dagar i året. Näppeligen gifves någon käring, som icke skal vara i stånd at rada up hela tjoget af sådana, hvilka heligt försäkras vara så vissa at skaffa en hastig p. 512 och otvifvelak|tig bot deremot, som en månads fasta på bara vatten och hröd mot en tjock isterbuk; dock detta oaktadt, händer mer än ofta, at denne smärtefulla värken gäckar alla dessa dråpeliga hjelpemedel. Icke desto mindre; at ej minska antalet af de förra, kan jag ej 
underlåta, at lämna vid handen, hvilka medel man här på orten funnit ibland vara mot denna våndan hjelpande.

När Tandvärk förorsakats af iholiga tänder, så sades följande ibland gjordt god verkan: tag en bomullslapp, lägg honom i botten på en gammal tobakspipa, stoppa tobak derofvanpå, tänd eld deri, och rök til dess tobaken mäst är upbränd. Under det en så röker, samlar Tobaksoljan sig uti bomullslappen, hvilken bomullslapp sedan lägges uti den iholiga tanden så hett en nảgonsin kan.

Iroquoirnas förnämsta bot mot dylik tandvärk af iholiga tänder, sades vara detta, som Capitainskan Lindsey uti Oswego mig förtälde, och uti hvilket mot sina tänder hon altid funnit en pålitelig cure. Man tager af Anemone virginiana Lrss. Spec. 540. fröknopparna, dả fröna äro mogne, rifver dem sönder, då de äro luddiga, som en Bomull. Denna ullen doppas i starkt brännevin, och stoppas i den iholiga tanden, då värken gemenligen strax stillas. Bränvinet är bittert; frön af Anemone, som de flästa af Polyandria Polygynia Lrsv. äro ock ampra; och således hjelpa bägge, at döfva värken. Detta medel är nära slägt med det föregående. Dessutom, kunde vi nog hos oss hafva Succedanea i stället för den Americanska Anemone \&c.

Mot Tandvärk, som hade svullnad med sig, berömdes följande: En gröt kokas af Mays-mjöl och mjölk. Deri lägges, medan gröten än står på spisen, ister eller annat fett, som sedan röres väl om, at fettet blandar sig jämnt uti gröten. Denna gröt bredes på et kläde, och lägges så hett en kan tola på det svullnade kinbenet eller stället, der det får ligga til dess det blir kalt. Detta har jag äfven af egen förfarenhet funnit vara nästan en ofelbar hjelp mot svullnader, som lindrar värken, nederlägger och mognar svullnaden, samt gör, at om det är en art af bålda, den går sönder, och det elaka flyter bårt. Detta brukas mycket här på orten.

Ibland förorsakas tandvärk af mycket iholiga och bårtfrätta tänder; i sådan händelse sades vara bäst, at låta draga dem ut; men då borde man bruka försigtighet 
dervid; ty värken flytter sig då gerna til nästa tand; derföre bör den sjuke, innan tanden ryckes ut, taga om morgonen förut något at svettas på. Mot Tandvärk, förorsakad af köld, försäkrades äfven svettningen vara et bland de bästa läkemedel.

Iroquoiska Villarne såg jag koka inre barken af Sambucus Canadensis Lins. Spec. 269 och lägga den på det stället af kindbenet, derunder tandvärken var starkast; sades ofta hjelpa.

p. 514 Hos de Iroquois, som bo vid Mohaks flod, såg jag en ung Villska, hvilken genom flitigt och mycket hett Thée-drickande hade förskaffat sig en häftig Tandvärk; til dess bot kokade hon bladen af Myrica asplenifolia Lins. Spec. 1024. och bandt dem, så varma hon kunde tola, öfver hela kindbenet, hvarigenom värken förut ofta sades varit häfven.

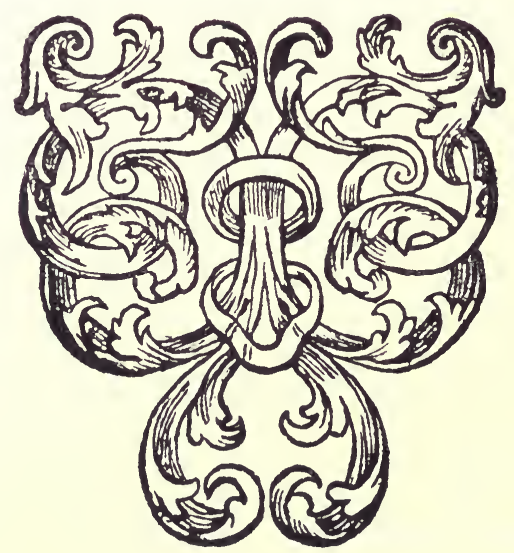




\section{Meteorologiske Observationer.}

1748. Augustus. nov. st.

\begin{tabular}{|c|c|c|c|c|c|}
\hline Dag. & $K l$. & Therm. & Vind. & & Väderlek. \\
\hline 1. & $\begin{array}{c}\text { 5. f. } \\
2^{1} / 2 \text { e. }\end{array}$ & $\begin{array}{l}20.0 . \\
24.5 \text {. }\end{array}$ & $\begin{array}{ll}\text { OSO. } & 2 \\
\text { O. } & 2\end{array}$ & $\begin{array}{l}2 . \\
2 .\end{array}$ & $\begin{array}{l}\text { Klart. } \\
\text { Klart. }\end{array}$ \\
\hline 2. & $\begin{array}{l}5^{1} / 2 \\
2^{1} / 2 \\
\text { e. }\end{array}$ & $\begin{array}{l}22.0 . \\
24.5 .\end{array}$ & O. & $\begin{array}{l}2 . \\
2 .\end{array}$ & $\begin{array}{l}\text { Klart } \\
\text { Klart. }\end{array}$ \\
\hline 3. & $\begin{array}{l}5^{1} / 2 \mathrm{f} \\
2 . \mathrm{e}\end{array}$ & $\begin{array}{l}22.0 . \\
25.5 .\end{array}$ & $\begin{array}{ll}\text { O. } & 1 \\
\text { SSW. } & 1\end{array}$ & $\begin{array}{l}1 . \\
1 .\end{array}$ & $\begin{array}{l}\text { Klart. } \\
\text { Mulit; stänkte rägn ibland e. m. }\end{array}$ \\
\hline 4. & $\begin{array}{ll}5^{1} / 2 & \text { f. } \\
11 / 2 & \text { e. }\end{array}$ & $\begin{array}{l}22.0 \\
21.0\end{array}$ & $\begin{array}{l}\text { S. } \\
\text { S. }\end{array}$ & $\begin{array}{l}\text { 1. } \\
1 .\end{array}$ & $\begin{array}{l}\text { Mulit, klart och rägnskurar skifte- } \\
\text { vis h. d. }\end{array}$ \\
\hline 5. & $51 / 2 \mathrm{f}$. & 17.0. & SSW. 2 & 2. & Rägn merendels h. d. \\
\hline 6. & $\begin{array}{ll}6^{3} / 4 & \mathrm{f} \\
2^{1} / 2 & \text { e. }\end{array}$ & $\begin{array}{l}17.0 . \\
19.0 .\end{array}$ & $\begin{array}{l}\text { S. } \\
\text { S. }\end{array}$ & $\begin{array}{l}2 . \\
2 .\end{array}$ & $\begin{array}{l}\text { Mulit. } \\
\text { Småmulit, dock mäst klart e. m. }\end{array}$ \\
\hline 7. & $5^{1} / 2 \mathrm{f}$. & 15.5 . & SSW. 1 & 1. & Klart och mulit skiftevis h. d. \\
\hline 8. & $\begin{array}{l}\text { 5. f. } \\
\text { 3. e. }\end{array}$ & $\begin{array}{l}18.0 . \\
19.0 .\end{array}$ & $\begin{array}{ll}\text { SSW. } & 0 \\
\text { SSW. } & 0\end{array}$ & $\begin{array}{l}0 . \\
0 .\end{array}$ & Klart h. d. \\
\hline 9. & $\begin{array}{l}6^{1} / \mathrm{f} \\
4 . \mathrm{e}\end{array}$ & $\begin{array}{l}17.5 . \\
21.0 .\end{array}$ & $\begin{array}{l}\text { WNW. } 0 \\
\text { WSW. } 1\end{array}$ & $\begin{array}{l}0 . \\
1 .\end{array}$ & Klart h. d. \\
\hline 10. & $\mid \begin{array}{ll}5^{3} / 4 & \text { f. } \\
2^{3} / 4 & \text { e. }\end{array}$ & $\begin{array}{l}18.5 . \\
20.5 .\end{array}$ & O. & $\begin{array}{l}1 . \\
1 .\end{array}$ & Klart. \\
\hline 11. & 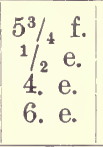 & $\begin{array}{l}17.0 \\
18.5 \\
22.0 \\
-\end{array}$ & $\begin{array}{l}\text { ONO. } \\
\text { SW. } \\
\text { W. } 3\end{array}$ & $\begin{array}{l}1 . \\
1 . \\
3 .\end{array}$ & $\begin{array}{l}\text { Småmulit eller glesmulit. } \\
\text { Klart. }\end{array}$ \\
\hline 12. & $\begin{array}{c}\text { 6. f. } \\
4^{1} / 4 \\
\text { e. }\end{array}$ & $\begin{array}{l}16.0 . \\
19.0 .\end{array}$ & $\begin{array}{ll}\text { NW. } & 1 \\
1\end{array}$ & $\begin{array}{l}1 . \\
1 .\end{array}$ & $\begin{array}{l}\text { Mulit; fint rägn ibland. Kl. } 10 \mathrm{f} \text {. } \\
\text { klart, mulit och fint rägn skifte- } \\
\text { vis h d. sedan. }\end{array}$ \\
\hline 13. & $\begin{array}{l}\text { 6. f. } \\
\text { 2. e. }\end{array}$ & $\begin{array}{l}17.0 . \\
18.5 .\end{array}$ & WNW. 2 & $\begin{array}{l}2 . \\
0 .\end{array}$ & $\begin{array}{l}\text { Mulit; dimbelikt rägn ibland. } \\
\text { Klart. }\end{array}$ \\
\hline 14. & $\begin{array}{l}5^{1} / 2 \text { f. } \\
4 . \text { e. }\end{array}$ & $\begin{array}{l}18.5 . \\
20.0 .\end{array}$ & WSW. & $\begin{array}{l}0 . \\
0 .\end{array}$ & $\begin{array}{l}\text { Småmulit; klart från kl.11.f.til3.e.m. } \\
\text { Mulit. }\end{array}$ \\
\hline 15. & $\left|\begin{array}{ll}5^{1} / 2 & \mathrm{f} \\
2^{1} / 2 & \mathrm{e}\end{array}\right|$ & $\begin{array}{l}18.0 . \\
19.0 .\end{array}$ & $\begin{array}{l}\text { WSW. } \\
\text { NO. }\end{array}$ & $\begin{array}{l}0 . \\
2 .\end{array}$ & $\begin{array}{l}\text { Mulit; ibland klart; kl. } 10 \mathrm{f} . \mathrm{m} . \text { kom } \\
\text { en tunn dimba, som föll ned. }\end{array}$ \\
\hline
\end{tabular}


Augustus.

\begin{tabular}{|c|c|c|c|c|}
\hline Dag. & $K l$. & Therm. & Vind. & Väderlek. \\
\hline 16. & $\begin{array}{l}5^{3} / 4 \mathrm{f} \\
2^{1} / 4\end{array}$ & $\begin{array}{l}18.3 . \\
19.5\end{array}$ & NNO. $\begin{array}{l}2 \\
2\end{array}$ & $\begin{array}{l}\text { Småmulit; klart ibland. } \\
\text { Mulit; följande natten rägn. }\end{array}$ \\
\hline 17. & $\begin{array}{l}\text { 6. f. } \\
\text { 2. e. }\end{array}$ & $\begin{array}{l}18.5 . \\
19.5 .\end{array}$ & ONO. $\begin{array}{r}2 \\
2\end{array}$ & $\begin{array}{l}\text { Mulit; duggrägn. } \\
\text { Duggrägn h. e. m. }\end{array}$ \\
\hline 18. & $\begin{array}{l}6^{1} / 2 \text { f. } \\
2^{1} / 2 \text { e. }\end{array}$ & $\begin{array}{l}19.0 . \\
20.5\end{array}$ & O. & Duggrägn h. d. \\
\hline 19. & $\begin{array}{l}61 / 2 \text { f. } \\
2 . \mathrm{e}\end{array}$ & $\begin{array}{l}19.5 \text {. } \\
20.0\end{array}$ & $\mathrm{O}$ & $\begin{array}{l}\text { Mulit. } \\
\text { Strömoln. }\end{array}$ \\
\hline 20. & $\begin{array}{l}\text { 6. f. } \\
\text { 2. e. }\end{array}$ & $\begin{array}{l}19.5 \\
21.5\end{array}$ & $\begin{array}{l}2 \\
2\end{array}$ & $\begin{array}{l}\text { Klart. (Strömoln, ibland någon rägn- } \\
\text { skur.) }\end{array}$ \\
\hline 21. & $\begin{array}{l}5^{3} / 4 \text { f. } \\
13 \% \text { e. }\end{array}$ & $\begin{array}{l}20 . \overline{8} \\
21.3 .\end{array}$ & O. & $\begin{array}{l}\text { Småmulit; kl. 9. f. klart. } \\
\text { Glesa moln. }\end{array}$ \\
\hline 22. & $\begin{array}{c}\text { 5. f. } \\
11_{2} \mathrm{e}\end{array}$ & $\begin{array}{l}21.0 . \\
23.5\end{array}$ & $\begin{array}{ll}\text { O. } & 1 \\
\text { Oso. } & 1\end{array}$ & $\begin{array}{l}\text { Klart; kl. 12. f. m. börj. mulna. } \\
\text { Mulit. }\end{array}$ \\
\hline 23. & $\begin{array}{c}\text { 5. f. } \\
2 \% \text { e. }\end{array}$ & $\begin{array}{l}22.2 . \\
24.2\end{array}$ & $\begin{array}{l}\text { OSO. } 1 \\
\text { 7.f.StO. } 2\end{array}$ & $\begin{array}{l}\text { Strömoln; kl. } 7 . \text { f. StO. } 2 \text {. } \\
\text { Strömoln; mot afton mulit. }\end{array}$ \\
\hline 24. & 5. f. & 23.5. & WSIV. 2 & $\begin{array}{l}\text { Häftigt rägn; kl. 7. f. m. blef klart. } \\
\text { Kl. 6. f. W. 2. kl. 7. f. WNW. } 1 . \\
\text { kl. 9. f. NW. 1. } \\
\text { Strömoln. }\end{array}$ \\
\hline 25. & $\begin{array}{l}61 / 4 \mathrm{f} . \\
2 . \mathrm{e}\end{array}$ & $\begin{array}{l}24.5 \\
23.5\end{array}$ & $\begin{array}{l}\text { W. } 3 \\
\text { WNW.3 }\end{array}$ & Strömoln; kl. 10 f. m. WNW. 3. \\
\hline 26. & $\begin{array}{l}\text { 6. f. } \\
\text { 2. e. }\end{array}$ & $\begin{array}{l}24.0 . \\
24.5\end{array}$ & $\begin{array}{l}\text { WV. } \\
\text { SW. }\end{array}$ & $\begin{array}{l}\text { Klart; kl. 11. f. m. stor ring kring Solen. } \\
\text { Mul. om afton stark aftonrodna. }\end{array}$ \\
\hline 27. & $\begin{array}{l}\text { 6. f. } \\
\text { 11. f. } \\
\text { 1. e. } \\
\text { 4. e. }\end{array}$ & $\frac{24 .}{-}$ & $\begin{array}{ll}\text { WSW. } & 1 \\
\text { SO. } & 2 \\
\text { (). } & 3 \\
\text { NO. } & 4\end{array}$ & $\begin{array}{l}\text { Mulit; kl. 10. f. börj rägna, som } \\
\text { contin. h. d. } \\
\text { Rägn. }\end{array}$ \\
\hline 28. & $\begin{array}{l}\text { 7. f. } \\
\text { 2. e. }\end{array}$ & $\begin{array}{l}23.0 . \\
23.5\end{array}$ & N. & Strömoln h. d. \\
\hline 29. & $\begin{array}{l}\text { 6. f. } \\
\text { 2. e. }\end{array}$ & $\begin{array}{l}23.5 . \\
25.5\end{array}$ & SW. & $\begin{array}{l}\text { Strömoln, om afton duggrägn med } \\
\text { blixtande. }\end{array}$ \\
\hline 30. & $\begin{array}{l}\text { 6. f. } \\
\text { 2. e. }\end{array}$ & $\begin{array}{l}23.5 \\
21.5\end{array}$ & NW. & Strömoln. Luften mycket kulen. \\
\hline 31. & $\begin{array}{l}\text { 6. f. } \\
\text { 2. e. }\end{array}$ & $\begin{array}{l}22.2 . \\
24.0\end{array}$ & SW. & $\begin{array}{l}\text { Klart. Middags tid börj. mulna; om } \\
\text { afton blixt och häftigt rägnande, }\end{array}$ \\
\hline
\end{tabular}


1748. September. nov. st.

\begin{tabular}{|c|c|c|c|c|c|}
\hline Dag. & $K l$. & Therm. & \multicolumn{2}{|c|}{ Vind. } & Väderlek. \\
\hline 1. & $\begin{array}{l}\text { 7. f. } \\
\text { 2. e. }\end{array}$ & $\begin{array}{l}20.0 . \\
21.5 .\end{array}$ & NW. & $\begin{array}{l}2 . \\
2 .\end{array}$ & $\begin{array}{l}\text { Strömoln. } \\
\text { Molnilar med rägnskurar och starkt } \\
\text { blåsande h. e. m. }\end{array}$ \\
\hline 2. & $\begin{array}{l}6^{1} / 2 \text { f. } \\
2^{1} / 2 \text { e. }\end{array}$ & $\begin{array}{l}19.0 \\
20.5 .\end{array}$ & NW. & $\begin{array}{l}1 . \\
0 .\end{array}$ & $\begin{array}{l}\text { Strömoln h. d. om afton stor ring } \\
\text { kring manan. }\end{array}$ \\
\hline 3. & $\begin{array}{l}\text { 6. f. } \\
\text { 2. e. }\end{array}$ & $\begin{array}{l}21.5 . \\
23.0 .\end{array}$ & $\begin{array}{l}\text { WSW. } \\
\text { S. }\end{array}$ & $\begin{array}{l}0 . \\
1 .\end{array}$ & $\begin{array}{l}\text { Strömoln. } \\
\text { Mulnade mer och mer. Om afton } \\
\text { stor ring kring Solen. }\end{array}$ \\
\hline 4. & $\begin{array}{l}\text { 6. f. } \\
\text { 12. f. } \\
\text { 2. e. }\end{array}$ & $\begin{array}{l}23.3 . \\
27.5 . \\
24.0 .\end{array}$ & O. & $\begin{array}{l}1 . \\
1 . \\
1 .\end{array}$ & Strömoln h. d. \\
\hline 5. & $\begin{array}{l}\text { 6. f. } \\
\text { 12. f. }\end{array}$ & $\begin{array}{l}24.5 . \\
26.5 .\end{array}$ & so. & $\begin{array}{l}3 . \\
3 .\end{array}$ & Strömoln h. d. \\
\hline 6. & $\begin{array}{l}\text { 6. f. } \\
\text { 1. e. }\end{array}$ & $\begin{array}{l}27.0 . \\
28.5 .\end{array}$ & SO. & $\begin{array}{l}2 . \\
2 .\end{array}$ & $\begin{array}{l}\text { Strömoln h. d. om afton stor ring } \\
\text { omkring månan, aftonrodnad. }\end{array}$ \\
\hline 7. & $\begin{array}{l}\text { 6. f. } \\
\text { 12. f. }\end{array}$ & $\begin{array}{l}27.5 . \\
28.5 .\end{array}$ & $\begin{array}{l}\text { O. } \\
\text { No. }\end{array}$ & $\begin{array}{l}3 . \\
2 .\end{array}$ & $\begin{array}{l}\text { Mulit; dock syntes Solen ibland emel- } \\
\text { lan molnen. } \\
\text { Strömoln. }\end{array}$ \\
\hline 8. & $\begin{array}{l}\text { 6. f. } \\
\text { 1. e. }\end{array}$ & $\begin{array}{l}26.0 . \\
26.5 .\end{array}$ & NNO. & $\begin{array}{l}2 . \\
2 .\end{array}$ & Strömoln h. d. \\
\hline 9. & $\begin{array}{l}\text { 6. f. } \\
\text { 1. e. }\end{array}$ & $\begin{array}{l}24.5 . \\
24.5 .\end{array}$ & N. & $\begin{array}{l}1 . \\
1 .\end{array}$ & Strömoln h. d. \\
\hline 10. & $\begin{array}{l}\text { 5. f. } \\
\text { 1. e. }\end{array}$ & $\begin{array}{l}24.0 . \\
24.5 .\end{array}$ & NNW. & 1. & Klart. \\
\hline
\end{tabular}

11. 6. f. 23.2. WNW.1. Klart. Om afton en stor ring om-

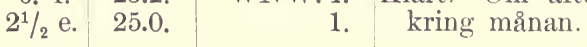

12. $5^{3} / 4$ f. 24.0 . $\quad$ ingen vind. Klart, och ganska hett. $1 / 2$ e. 26.0 .

\begin{tabular}{l|l|l|ll|l}
\hline 13. & 5. f. & 25.5. & SO. & 1. & Klart.
\end{tabular}

1. e. 26.5 .

\begin{tabular}{l|l|l|ll|l} 
14. & 6. f. & 25.5. & SO. & 1. Klart. Blåste dock hel kulit och
\end{tabular} 1. e. 26.5. svalt h. f. m.

\begin{tabular}{l|l|l|ll|l}
\hline 15. & 5. f. & 23.0. & SO. & 1. Strömoln.
\end{tabular}

1. e. 27.5. 1. Mulnade mer och mer; om afton och följ. natten ganska häftigt rägn och blåst. 
September.

\begin{tabular}{|c|c|c|c|c|}
\hline Dag. & $K l$. & Therm. & Vind. & Väderlek. \\
\hline 16. & $\begin{array}{l}\text { 5. f. } \\
\text { 2. e. }\end{array}$ & $\begin{array}{l}21.5 \\
21.5\end{array}$ & $\begin{array}{ll}\text { NNO. } & 1 . \\
1 .\end{array}$ & Ganska starkt rägn h. d. \\
\hline 17. & $\begin{array}{l}5^{1} / 4 \mathrm{f} \\
1 . \mathrm{e} .\end{array}$ & $\begin{array}{l}25.5 . \\
21.0 .\end{array}$ & $\begin{array}{ll}\text { NW. } & 1 . \\
& 1 .\end{array}$ & $\begin{array}{l}\text { Mulit. } \\
\text { Strömoln. }\end{array}$ \\
\hline 18. & 6. f. & 13.0 & ingen vind. & Klart. \\
\hline 19. & $11 / 2$ e. & 24.5 . & NNO. 1. & Klart h. d. \\
\hline 20. & 6. f. & 14.0 & NO. 1. & Strömoln. \\
\hline 21. & $\begin{array}{l}\text { 6. f. } \\
\text { 1. e. }\end{array}$ & $\begin{array}{l}11.0 . \\
23.0\end{array}$ & $\begin{array}{ll}\text { NO. } & 0 . \\
& 0 .\end{array}$ & Strömoln. \\
\hline 22. & $\begin{array}{l}\text { 7. f. } \\
\text { 1. e. }\end{array}$ & $\begin{array}{l}10.5 \text {. } \\
25.0\end{array}$ & NO. $\quad 1$. & Klart. \\
\hline 23. & $\begin{array}{l}61 / 2 \mathrm{f} . \\
2 . \mathrm{e} .\end{array}$ & $\begin{array}{l}11.0 . \\
28.0\end{array}$ & N NO. 1 & Klart. \\
\hline 24. & $\begin{array}{l}\text { 6. f. } \\
\text { 2. e. }\end{array}$ & $\begin{array}{l}14.0 \\
28.0\end{array}$ & $\begin{array}{ll}\text { NO. } & 1 . \\
& 1 .\end{array}$ & $\begin{array}{l}\text { Klart. } \\
\text { Mulnade mer och mer; om afton rägn, } \\
\text { varade in på natten. }\end{array}$ \\
\hline 25. & $\begin{array}{c}\text { 6. f. } \\
2^{2} / 2 \text { e. }\end{array}$ & $\begin{array}{l}18.0 \\
28.0\end{array}$ & $\begin{array}{ll}\text { NIV. } & 1 . \\
\text { NO. } & 1 .\end{array}$ & $\begin{array}{l}\text { Mulit; kl. 8. f. Strömoln. } \\
\text { Strömoln. }\end{array}$ \\
\hline 26. & $\begin{array}{l}\text { 6. f. } \\
\text { 2. e. }\end{array}$ & $\begin{array}{l}15.5 . \\
27.5\end{array}$ & NNO. 1. & Klart. \\
\hline 27. & $\begin{array}{l}\text { 6. f. } \\
\text { 2. e. }\end{array}$ & $\begin{array}{l}17.0 . \\
17.0 .\end{array}$ & NO. 1. & $\begin{array}{l}\text { Mulit; kl. 8. klart sedan h. f. m. } \\
\text { Mulit. }\end{array}$ \\
\hline 28. & $\begin{array}{l}\text { 6. f. } \\
\text { 2. e. }\end{array}$ & $\begin{array}{l}14.0 \text {. } \\
20.0\end{array}$ & NO. $\quad 1$. & Klart och mulit skifteris. \\
\hline 29. & $\begin{array}{l}\text { 7. } \mathrm{f} . \\
\text { 1. e. }\end{array}$ & $\begin{array}{l}155 . \\
20.5\end{array}$ & $\begin{array}{ll}\text { NO. } & 1 . \\
& 1 .\end{array}$ & $\begin{array}{l}\text { Mulit. } \\
\text { Fint duggrägn. }\end{array}$ \\
\hline 30. & 7. f. & 16.0 & NO. $\quad 0$. & Klart och mulit skiftevis. \\
\hline
\end{tabular}


1748. October. nov. st.

\begin{tabular}{|c|c|c|c|c|c|}
\hline Dag. & $K l$ & Therm. & Vind. & & Väderlek. \\
\hline 1. & $\begin{array}{l}51 / 2 \mathrm{f} . \\
2 . \mathrm{e} .\end{array}$ & $\begin{array}{l}19.0 . \\
28.5\end{array}$ & S. & $\begin{array}{l}1 . \\
1 .\end{array}$ & $\begin{array}{l}\text { Mulit; kl. 8. Strömoln. } \\
\text { Strömoln, mot afton mulit. }\end{array}$ \\
\hline 2. & $5^{1} / 2 \mathrm{f}$. & 18.5 & SIV. & 0. & Mulit. \\
\hline 3. & $\begin{array}{l}\text { 6. f. } \\
\text { 1. e. }\end{array}$ & $\begin{array}{l}15.0 . \\
18.0\end{array}$ & NW. 1 & 1. & $\begin{array}{l}\text { Mulit. } \\
\text { Strömoln, om afton sent en stor ring } \\
\text { kring månan. }\end{array}$ \\
\hline 4. & $\begin{array}{l}\text { 7. } \mathrm{f} . \\
\text { 1. } \mathrm{e}\end{array}$ & $\begin{array}{r}6.0 \\
16.0\end{array}$ & $\mathrm{NW}$ & $\begin{array}{l}1 . \\
1 .\end{array}$ & Klart. \\
\hline 5. & 7. f. & 2.0 & N. & 1. & Klart. \\
\hline 6. & $\begin{array}{l}\text { 7. f. } \\
\text { 1. e. }\end{array}$ & $\begin{array}{r}2.0 \\
18.0\end{array}$ & NO. & 1. & $\begin{array}{l}\text { Klart, om afton en stor ring kring } \\
\text { mảnan. }\end{array}$ \\
\hline 7. & 6. f. & 7.0. & ONO. 1 & 1. & Mulit; kl. 9. f. klart, varade h. d. \\
\hline 8. & 6. f. & 14.0 & ONO. 1 & 1. & Mulit; sedan kl. 8. strömoln. \\
\hline 9. & $\begin{array}{l}\text { 6. f. } \\
\text { 3. e. }\end{array}$ & $\begin{array}{l}18.0 \\
23.0\end{array}$ & SSO. 1 & 1. & $\begin{array}{l}\text { Rägn h. f. m. } \\
\text { IIulit. }\end{array}$ \\
\hline 10. & $\begin{array}{l}\text { 6. f. } \\
\text { 2. e. }\end{array}$ & $\begin{array}{l}20.0 \\
23.0\end{array}$ & SIV. & $\begin{array}{l}0 . \\
0 .\end{array}$ & $\begin{array}{l}\text { Tökn och duggrägn. } \\
\text { Klart. }\end{array}$ \\
\hline 11. & $\begin{array}{l}\text { 7. f. } \\
\text { 2. e. }\end{array}$ & $\begin{array}{l}20.0 \text {. } \\
26.0\end{array}$ & $\begin{array}{ll}\text { SW. } & 1 \\
& 1\end{array}$ & $\begin{array}{l}1 . \\
1 .\end{array}$ & $\begin{array}{l}\text { Dimba, som föll ned; kl. 8. klart. } \\
\text { Klart. }\end{array}$ \\
\hline 12. & $\begin{array}{l}\text { 6. f. } \\
\text { 8. f. } \\
\text { 2. e. }\end{array}$ & $\frac{8.0}{20.0}$ & $\begin{array}{l}\text { WXW.1 } \\
\text { W. } 1 \\
\text { WSW. } 1\end{array}$ & $\begin{array}{l}1 . \\
1 . \\
1 .\end{array}$ & Klart h. d. \\
\hline 13. & $\begin{array}{l}\text { 6. f. } \\
\text { 2. e. }\end{array}$ & $\begin{aligned} 2.0 & \\
17.0 & \end{aligned}$ & $\begin{array}{l}\text { WNIV. } \\
\text { WSIV. }\end{array}$ & $\begin{array}{l}0 . \\
5 .\end{array}$ & $\begin{array}{l}\text { Rimfrost om morgon på bladen af } \\
\text { örter; klart h. d. }\end{array}$ \\
\hline 14. & $\begin{array}{l}\text { 6. f. } \\
\text { 2. e. }\end{array}$ & $\begin{aligned} 5.0 & \\
21.0 & \end{aligned}$ & SSIV. & $\begin{array}{l}0 . \\
0 .\end{array}$ & Klart. \\
\hline 15. & $\begin{array}{l}\text { 6. f. } \\
\text { 2. e. }\end{array}$ & $\begin{array}{l}4.5 . \\
24.0\end{array}$ & SSO. & $\begin{array}{l}0 . \\
0 .\end{array}$ & Klart. \\
\hline
\end{tabular}


October.

\begin{tabular}{|c|c|c|c|c|c|}
\hline Dag. & $K l$. & Therm. & Find. & & Täderlek. \\
\hline 16. & 6. $\mathrm{f}$. & 11.0 & ONO. & & Mulit. \\
\hline 17. & $\begin{array}{l}\text { 6. f. } \\
\text { 2. e. }\end{array}$ & $\begin{array}{r}8.0 \\
18.0\end{array}$ & NO. & $\begin{array}{l}1 . \\
1 .\end{array}$ & $\begin{array}{l}\text { Klart. } \\
\text { Mulit; mot afton börj. rägna och } \\
\text { det ganska häftigt följ. natt. }\end{array}$ \\
\hline 18. & $\begin{array}{l}\text { 6. f. } \\
5 . \text { e. }\end{array}$ & $\begin{array}{r}12.0 . \\
4.0 .\end{array}$ & $\begin{array}{l}\text { NW. } \\
\text { S'W. }\end{array}$ & $\begin{array}{l}0 . \\
0 .\end{array}$ & Mulit. \\
\hline 19. & $\begin{array}{l}6^{1 / 2} \mathrm{f} . \\
2 . \mathrm{e} .\end{array}$ & $\begin{array}{r}00.0 . \\
9.0 .\end{array}$ & IVSW. & $\begin{array}{l}2 . \\
1 .\end{array}$ & Strömoln. \\
\hline 20. & $\begin{array}{l}\text { 5. f. } \\
\text { 1. e. }\end{array}$ & $\begin{array}{r}01.0 . \\
9.0 .\end{array}$ & WNW. & $\begin{array}{l}1 . \\
1 .\end{array}$ & Klart. \\
\hline 21. & $\begin{array}{l}\text { 7. f. } \\
\text { 1. e. }\end{array}$ & $\begin{array}{l}00.0 . \\
15.0 .\end{array}$ & W. & $\begin{array}{l}0 . \\
0 .\end{array}$ & $\begin{array}{l}\text { Om morgonen is påstillaståendevatn, } \\
\text { och marken hel hvit af rimfrost, } \\
\text { klart h. d. }\end{array}$ \\
\hline 22. & 6. f. & 00.0 . & W. & 0. & Klart. \\
\hline 23. & $\begin{array}{l}\text { 6. f. } \\
\text { 1. e. }\end{array}$ & $\begin{array}{r}4.5 . \\
16.0\end{array}$ & NNO. & $\begin{array}{l}1 . \\
1 .\end{array}$ & Klart. \\
\hline 24. & $\begin{array}{l}\text { 6. f. } \\
\text { 2. e. }\end{array}$ & $\begin{array}{r}4.5 . \\
18.0 .\end{array}$ & $\mathrm{N}$. & $\begin{array}{l}0 . \\
0 .\end{array}$ & Klart. \\
\hline 25. & $61 / 2 \mathrm{f}$ & 4.5 . & SIV. & 1. & Klart, e. m. mycket tjockt i luften. \\
\hline 26. & $\begin{array}{l}61 / 2 \mathrm{f} . \\
3 . \mathrm{e} .\end{array}$ & $\begin{array}{r}4.0 \\
19.0\end{array}$ & SW. & $\begin{array}{l}0 . \\
0 .\end{array}$ & Klart. \\
\hline 27. & $\begin{array}{c}6^{1} / 4 \mathrm{f} \\
3 . \mathrm{e}\end{array}$ & $\begin{array}{r}1.0 . \\
17.0 .\end{array}$ & SIV. & $\begin{array}{l}0 . \\
0 .\end{array}$ & Klart. \\
\hline 28. & $6{ }^{1} / 2 \mathrm{f}$ & 9.0 & O. & 2. & Häftigt rägn h. d. \\
\hline 29. & $\begin{array}{l}\text { 6. f. } \\
\text { 1. e. }\end{array}$ & $\begin{array}{l}14.0 \text {. } \\
20.0 \text {. }\end{array}$ & W. & $\begin{array}{l}1 . \\
1 .\end{array}$ & $\begin{array}{l}\text { Klart, om afton kl. 8. flög et stjern- } \\
\text { skått mycket långt från NW. til SO. }\end{array}$ \\
\hline 30. & 6. $\mathrm{f}$. & 3.0. & NW. & 1. & Klart. \\
\hline 31. & $\begin{array}{l}\text { 7. f. } \\
\text { 1. e. }\end{array}$ & $\begin{aligned} 4.0 . & \\
18.0 . & -\end{aligned}$ & W. & $\begin{array}{l}1 . \\
1 .\end{array}$ & Klart. \\
\hline
\end{tabular}


1748. November. nov. st.

\begin{tabular}{|c|c|c|c|c|c|}
\hline Dag. & $K l$. & Therm. & Vind. & & Väderlek. \\
\hline 1. & 7. f. & 3.0 . & $\mathrm{S}$. & 1. & Klart. \\
\hline 2. & $\begin{array}{l}5^{3} /{ }_{4} \mathrm{f} . \\
3 . \mathrm{e}\end{array}$ & $\begin{aligned} 4.0 . \\
18.0 .\end{aligned}$ & N. & $\begin{array}{l}0 . \\
0 .\end{array}$ & Klart. \\
\hline 3. & $1 \% \mathrm{f}$. & $\begin{aligned} 7.0 & \\
14.0 & \end{aligned}$ & $\begin{array}{l}\text { NW. } \\
\text { SO. }\end{array}$ & $\begin{array}{l}1 . \\
0 .\end{array}$ & Klart. \\
\hline 4. & $7 i \mathrm{f}$ e. & $\begin{aligned} 1.0 . & \\
19.0 & \end{aligned}$ & SW. & $\begin{array}{l}0 . \\
0 .\end{array}$ & $\begin{array}{l}\text { Klart, om morgon rimfrost på mar- } \\
\text { ken. }\end{array}$ \\
\hline 5. & $\begin{array}{l}6^{1} / 2 \mathrm{f} . \\
1 . \mathrm{e} .\end{array}$ & $\begin{aligned} 4.0 & \\
17.0 . & \end{aligned}$ & SW. & $\begin{array}{l}1 . \\
1 .\end{array}$ & Klart. \\
\hline 6. & $\begin{array}{l}\text { 7. f. } \\
\text { 1. e. }\end{array}$ & $\begin{aligned} 4.5 . & \\
12.0 . & 0 .\end{aligned}$ & NO. & $\begin{array}{l}1 . \\
1 .\end{array}$ & $\begin{array}{l}\text { Klart. } \\
\text { Mot afton mulnade litet. }\end{array}$ \\
\hline 7. & $\begin{array}{l}\text { 7. f. } \\
\text { 4. e. }\end{array}$ & $\begin{aligned} 7.0 . & \\
11.5 . & \end{aligned}$ & ONO. & $\begin{array}{l}1 . \\
1 .\end{array}$ & Mulit. \\
\hline 8. & $\begin{array}{l}\text { 7. f. } \\
1 / 2 \mathrm{e}\end{array}$ & $\begin{array}{l}11.5 . \\
18.0 .\end{array}$ & $\begin{array}{l}\text { ONO. } \\
\text { OSO. }\end{array}$ & $\begin{array}{l}2 . \\
3 .\end{array}$ & $\begin{array}{l}\text { Duggrägn. } \\
\text { Häftigt rägn. }\end{array}$ \\
\hline 9. & $\begin{array}{l}\text { 7. f. } \\
\text { 9. f. } \\
\text { 1. e. }\end{array}$ & $\begin{array}{l}17.0 . \\
15.0 \\
17.0\end{array}$ & $\begin{array}{l}\text { s. } \\
\text { sitw. }\end{array}$ & $\begin{array}{l}0 . \\
1 . \\
1 .\end{array}$ & $\begin{array}{l}\text { Duggrägn kl. 8. f. m. klart. } \\
\text { Strömoln. }\end{array}$ \\
\hline 10. & $\begin{array}{l}\text { 7. f. } \\
1 / 2 \mathrm{e} \text {. }\end{array}$ & $\begin{array}{r}6.0 . \\
13.0 .\end{array}$ & $\begin{array}{l}\text { SSW. } \\
\text { WNW. }\end{array}$ & $\begin{array}{l}1 . \\
2 .\end{array}$ & Klart. \\
\hline 11. & $\begin{array}{l}\text { 7. f. } \\
1 / 2 \mathrm{e} \text {. }\end{array}$ & $\begin{aligned} 4.0 . & \\
12.0 . & \end{aligned}$ & WSW. & $\begin{array}{l}1 . \\
1 .\end{array}$ & $\begin{array}{l}\text { Mulit. } \\
\text { Strömoln. }\end{array}$ \\
\hline 12. & $\begin{array}{l}51 / 2 \mathrm{f} . \\
2 . \mathrm{e} \\
\text { 4. e. }\end{array}$ & $\begin{array}{l}03 . \\
11.5 . \\
5.0 .\end{array}$ & $\begin{array}{l}\text { SW. } \\
\text { NW. }\end{array}$ & $\begin{array}{l}1 . \\
2 . \\
2 .\end{array}$ & $\begin{array}{l}\text { Klart. } \\
\text { Mulit. }\end{array}$ \\
\hline 13. & $\begin{array}{l}\text { 7. } \mathrm{f} \text {. } \\
\text { 2. e. }\end{array}$ & $\begin{aligned} & 00.0 . \\
& 5.5 .\end{aligned}$ & NNO. & $\begin{array}{l}1 . \\
1 .\end{array}$ & Klart, om morgonen is på vatnet. \\
\hline 14. & $\begin{array}{l}\text { 7. f. } \\
\text { 1. e. }\end{array}$ & $\begin{array}{l}0.5 . \\
8.0 .\end{array}$ & N. & $\begin{array}{l}3 . \\
2 .\end{array}$ & Klart. \\
\hline 15. & $\begin{array}{l}\text { 7. f. } \\
\text { 1. e. }\end{array}$ & $\begin{array}{l}3.0 . \\
8.0 .\end{array}$ & $\Sigma$ & $\begin{array}{l}2 . \\
2 .\end{array}$ & $\begin{array}{l}\text { Stark morgonronna; mulit, duggregn } \\
\text { h. d. }\end{array}$ \\
\hline
\end{tabular}




\section{November.}

\begin{tabular}{|c|c|c|c|c|c|}
\hline Dag. & $K l$. & Therm. & \multicolumn{2}{|l|}{ Vind. } & Väderlek. \\
\hline 16. & 7. f. & 4.5 . & SW. & 1. & Klart. \\
\hline 17. & $\begin{array}{l}\text { 7. } \mathrm{f} . \\
\text { 1. e. }\end{array}$ & $\begin{array}{l}01.0 . \\
8.0 .\end{array}$ & W. & $\begin{array}{l}1 . \\
1 .\end{array}$ & Klart och mulit ömsevis. \\
\hline 18. & $\begin{array}{l}\text { 7. } \mathrm{f} . \\
\text { 3. e. }\end{array}$ & $\begin{array}{l}4.0 . \\
6.5 .\end{array}$ & $\begin{array}{l}\text { S. } \\
\text { NiW. }\end{array}$ & $\begin{array}{l}1 . \\
2 .\end{array}$ & Duggrägn ibland. \\
\hline 19. & $\begin{array}{l}\text { 7. } \mathrm{f} . \\
\text { 2. e. }\end{array}$ & $\begin{array}{l}03.0 . \\
11.5 .\end{array}$ & W. & $\begin{array}{l}0 . \\
0 .\end{array}$ & Klart. \\
\hline 20. & $\begin{array}{l}\text { 7. f. } \\
\text { 2. e. }\end{array}$ & 01.0 & $\begin{array}{l}\text { NNO } \\
\text { S. }\end{array}$ & $\begin{array}{l}1 . \\
1 .\end{array}$ & Klart. \\
\hline 21. & $\begin{array}{l}\text { 7. f. } \\
\text { 1. e. }\end{array}$ & $\begin{array}{l}15.0 . \\
19.0 .\end{array}$ & SIV. & $\begin{array}{l}2 . \\
2 .\end{array}$ & Klart. \\
\hline 22. & $\begin{array}{l}\text { 7. f. } \\
\text { 2. e. }\end{array}$ & $\begin{array}{l}10.0 \\
10.0 .\end{array}$ & $\mathrm{O}$. & $\begin{array}{l}1 . \\
1 .\end{array}$ & Rägn h. d. \\
\hline 23. & $\begin{array}{l}\text { 8. } \mathrm{f} . \\
\text { 8. e }\end{array}$ & 16.0 & $\begin{array}{l}\text { S. } \\
\text { sw. }\end{array}$ & $\begin{array}{l}1 . \\
4 .\end{array}$ & Mulit, tökn, rägn ibland. \\
\hline 24. & 7. f. & 00.0 & WNW. & 3. & Klart. \\
\hline 25. & 7. $\mathrm{f}$. & - & NW. & 0. & Klart, mycket kalt natten förut. \\
\hline 26. & h. d. & - & NW. & 0. & $\begin{array}{l}\text { Klart och småmulit skiftevis; tämlig } \\
\text { kalt. }\end{array}$ \\
\hline 27. & h. d. & - & - & & $\begin{array}{l}\text { Klart och strömoln; tämmelig varmt } \\
\text { i luften. }\end{array}$ \\
\hline 28. & h. d. & - & - & & Mulit, töknigt, lungt. \\
\hline 29. & h. d. & - & - & & Småmulit. \\
\hline 30. & h. d. & - & N. & 1. & Klart, något kalt. \\
\hline
\end{tabular}


1748. December. nov. st.

\begin{tabular}{|c|c|c|c|c|}
\hline Dag. & $K l$. & Therm. & Vind. & Väderlek. \\
\hline 1. & h. d. & - & 1. & Klart. \\
\hline 2. & h. d. & - & WSW. 1. & $\begin{array}{l}\text { Klart kalt, om afton stor ring kring } \\
\text { månan. }\end{array}$ \\
\hline 3. & h. d. & 一 & WSW. 1. & $\begin{array}{l}\text { Klart; dock om morg. täml morgon- } \\
\text { ronnad. }\end{array}$ \\
\hline 4. & $\begin{array}{l}\text { 7. f. } \\
\text { 3. e. }\end{array}$ & $\begin{array}{r}6.0 . \\
18.0 .\end{array}$ & $\begin{array}{ll}\text { SSIV. } & 0 . \\
0 .\end{array}$ & Klart \\
\hline 5. & $\begin{array}{l}\text { 7. f. } \\
\text { 4. e. }\end{array}$ & $\begin{array}{l}5.5 . \\
9.5 .\end{array}$ & NNO. 1. & Klart \\
\hline 6. & $\begin{array}{l}\text { 7. f. } \\
\text { 2. e. }\end{array}$ & $\begin{array}{r}6.5 \\
14.0\end{array}$ & SSW. 1. & $\begin{array}{l}\text { Mulit. } \\
\text { Småmulit, följ. natt starkt rägn. }\end{array}$ \\
\hline 7. & $\begin{array}{l}\text { 7. f. } \\
\text { 2. e. }\end{array}$ & $\begin{array}{l}13.5 . \\
19.0 .\end{array}$ & SW. 1. & $\begin{array}{l}\text { Mulit. } \\
\text { Klart. }\end{array}$ \\
\hline 8. & $\begin{array}{l}\text { 7. f. } \\
\text { 2. e. }\end{array}$ & $\begin{array}{r}5.0 . \\
13.5 .\end{array}$ & $\begin{array}{l}1 . \\
1 .\end{array}$ & $\begin{array}{l}\text { Mulit. } \\
\text { Följande natt blåst och rägn. }\end{array}$ \\
\hline 9. & $\begin{array}{l}\text { 7. f. } \\
\text { 2. e. }\end{array}$ & $\begin{array}{l}12.0 . \\
10.0 .\end{array}$ & $\begin{array}{l}\text { SW. } \\
\text { WNW. } \\
2 .\end{array}$ & Tiocka strömoln. \\
\hline 10. & h. d. & - & WNIV. 2. & Strömoln. \\
\hline$i 1$. & $\begin{array}{l}\text { 7. f. } \\
\text { 2. e. }\end{array}$ & $\begin{array}{l}2.0 . \\
12.5\end{array}$ & SSW. 1. & Klart. \\
\hline 12. & $\begin{array}{l}7^{1} / 2 \text { f. } \\
2 . \text { e. }\end{array}$ & $\begin{array}{r}0.5 . \\
10.5 .\end{array}$ & $\begin{array}{ll}\text { NO. } & 1 . \\
& 1 .\end{array}$ & $\begin{array}{l}\text { Mulit, kl. 9. f. börj. rägna, contin. } \\
\text { h. d. med tökn tillika. }\end{array}$ \\
\hline 13. & $\begin{array}{l}\text { 8. f. } \\
\text { 2. e. }\end{array}$ & $\begin{array}{r}7.5 . \\
10.0\end{array}$ & $\begin{array}{ll}\text { SW. } & 0 . \\
& 0 .\end{array}$ & Töknigt och mulit, följ. natt NW. 3 . \\
\hline 14. & $\begin{array}{l}7^{1} / 2 \text { f. } \\
2 . \mathrm{e}\end{array}$ & $\begin{array}{l}1.0 . \\
2.0\end{array}$ & $\begin{array}{ll} & \text { NW. } \\
& 2 . \\
2 .\end{array}$ & Strömoln. \\
\hline 15. & $\begin{array}{l}7^{1} / 2 \mathrm{f} . \\
2 . \mathrm{e} .\end{array}$ & $\begin{array}{l}07.0 . \\
01.0\end{array}$ & $\begin{array}{r}\text { WN W. } 1 . \\
1 .\end{array}$ & Klart och mulit skiftevis. \\
\hline
\end{tabular}


December.

\begin{tabular}{|c|c|c|c|c|c|}
\hline Dag. & $K l$. & Therm. & Vind. & & Väderlek. \\
\hline 16. & $\begin{array}{l}71 / 2 \text { f. } \\
2 . \text { e. }\end{array}$ & $\begin{array}{r}01.0 . \\
1.5\end{array}$ & W. & $\begin{array}{l}1 . \\
1 .\end{array}$ & Klart. \\
\hline 17. & $\begin{array}{l}7^{1} / \mathrm{f}_{2} \mathrm{f} \\
2 . \mathrm{e}\end{array}$ & $\begin{array}{l}02.5 \\
00.0\end{array}$ & NW. & $\begin{array}{l}1 . \\
1 .\end{array}$ & $\begin{array}{l}\text { Mulit; snögade ibland något, som } \\
\text { var första gången denna vinter. }\end{array}$ \\
\hline 18. & $\begin{array}{l}71 / 2 \mathrm{f} . \\
2 . \mathrm{e}\end{array}$ & $\begin{array}{r}03.0 \\
4.0\end{array}$ & $\mathrm{~W}$. & $\begin{array}{l}1 . \\
1 .\end{array}$ & Klart \\
\hline 19 & $\begin{array}{l}71 / 2 \mathrm{f} \\
2 . \mathrm{e}\end{array}$ & $\begin{array}{l}1.0 . \\
8.0 .\end{array}$ & W. & $\begin{array}{l}1 . \\
1 .\end{array}$ & $\begin{array}{l}\text { Mulit. } \\
\text { Klart. }\end{array}$ \\
\hline 20. & $\begin{array}{l}71 / 2 \text { f. } \\
2 . \text { e. }\end{array}$ & $\begin{array}{r}01.5 . \\
7.5\end{array}$ & WSW. & $\begin{array}{l}2 . \\
1 .\end{array}$ & $\begin{array}{l}\text { Strömoln, om afton kl. 6. voro hel } \\
\text { röda streck på himmelen uti Norr. }\end{array}$ \\
\hline 21. & $\begin{array}{l}71 / 2 \mathrm{f} \\
2 . \mathrm{e}\end{array}$ & $\begin{array}{r}07.0 . \\
2.0\end{array}$ & $\mathrm{~N}$ & $\begin{array}{l}0 . \\
0 .\end{array}$ & Klart. \\
\hline 22. & $\begin{array}{l}71 / 2 \mathrm{f} \\
2 . \mathrm{e}\end{array}$ & $\begin{array}{l}04.5 . \\
13.0\end{array}$ & S. & $\begin{array}{l}0 . \\
0 .\end{array}$ & Klart, e. m. börj. mulna något. \\
\hline 23. & $\begin{array}{l}71 / 2 \text { f. } \\
2 . \mathrm{e} .\end{array}$ & $\begin{array}{l}13.0 . \\
18.0\end{array}$ & SSW. & $\begin{array}{l}0 . \\
0 .\end{array}$ & $\begin{array}{l}\text { Starkt rägn. } \\
\text { Mulit och töknigt. }\end{array}$ \\
\hline 24. & $\begin{array}{l}7^{1} \mathrm{f} \\
2 . \mathrm{e}\end{array}$ & $\begin{array}{l}13.0 . \\
17.0\end{array}$ & $\begin{array}{l}\text { WSW. } \\
\text { SW. }\end{array}$ & $\begin{array}{l}0 . \\
1 .\end{array}$ & $\begin{array}{l}\text { Stark tökn. } \\
\text { Klart, om afton sent tämmeligt rägn. }\end{array}$ \\
\hline 25. & $\begin{array}{l}71 / 2 \text { f. } \\
2 . \mathrm{e}\end{array}$ & $\begin{array}{l}18.0 . \\
18.5\end{array}$ & $\begin{array}{l}\text { S. } \\
\text { SSO. }\end{array}$ & $\begin{array}{l}3 . \\
2 .\end{array}$ & $\begin{array}{l}\text { Natten förut storm, starkt rägn med } \\
\text { åskedunder och ljungande; starkt } \\
\text { rägn hela denna dag. }\end{array}$ \\
\hline 26. & $\begin{array}{l}71 / 2 \mathrm{f} . \\
2 . \text { e. }\end{array}$ & 3.0. & $\begin{array}{l}\text { W. } \\
\text { WNW. }\end{array}$ & 3. & $\begin{array}{l}\text { Natten förut häftig S. och W. storm } \\
\text { med starkt rägn; denna förmiddag } \\
\text { mulit, med snö ibland. } \\
\text { Klart. }\end{array}$ \\
\hline 27. & $7^{1} / 2 \mathrm{f}$. & 04.0 & WNW. & 1. & Klart. \\
\hline 28. & $\begin{array}{l}7^{1} / 2 \mathrm{f} \\
2 . \mathrm{e}\end{array}$ & $\begin{array}{r}07.0 . \\
8.0\end{array}$ & W. & $\begin{array}{l}0 . \\
0 .\end{array}$ & Klart. \\
\hline 29. & $\begin{array}{l}71 / 2 \mathrm{f} . \\
2 . \mathrm{e}\end{array}$ & $\begin{array}{r}3.0 \\
13.0\end{array}$ & NNO. & $\begin{array}{l}1 . \\
0 .\end{array}$ & Halfmulit; rägn stänkte ibland \\
\hline 30. & $\begin{array}{c}71 / 2 \text { f. } \\
2 . \text { e. }\end{array}$ & $\begin{array}{r}8.0 \\
10.0\end{array}$ & NNO. & $\begin{array}{l}1 . \\
0 .\end{array}$ & Mulit och töknogt h. d. \\
\hline 31. & $\begin{array}{l}71 / 2 \mathrm{f} . \\
2 . \mathrm{e} .\end{array}$ & $\begin{array}{l}6.0 . \\
4.0 .\end{array}$ & $\begin{array}{l}\text { W. } \\
\text { NW. }\end{array}$ & $\begin{array}{l}3 . \\
2 .\end{array}$ & Klart, om afton ring kring månan. \\
\hline
\end{tabular}


Anmärkning. Vid dessa Meteorologiska observationer märkes, at i första columnen står Dagtalet af månaden; i den andra tiden eller klåckan på dagen, då observation skedt; i den tredje Thermometern; i den fierde vinden; och i den femte eller sista väderleken i gemen, om det varit klart, mulit, rägn \&e. Vid Thermometern är at i akt taga, at jag betjent mig af den så kallade Svenska eller Celsianska, hvarom mera förut är nämnt i förtalet til första Tomen af denna Americanske resa. At skilja de grader, som stå ofvanför frysnings puncten, ifrản dem, som äro under den, har jag märkt sjelfva frysning puncten med 00 , och vid alla grader, som äro under den samma, står framför de andra Numrerne et 0 ; men der intet 0 står främst, betecknar graden öfver samma punct. til ex. den 17. Decemb. står at Therm. var klåckan half otta för middagen 02.5. det är, 2 grader, och $5 / 10$ eller $1 / 2$ grad under frysnings puncten: men kl. 2. e. m. samma dag var Therm. 00.0. det är just vid frysnings puncten. 00.3. betyder, at Therm. stått $3 / 10$ grad under frysnings puncten; men 0.3 . betecknar, at Therm. varit $3 / 10$ grad öfver samma punct. Således den 18. Decemb. var Therm. kl. half 8. f. m. 03.0. eller just 3. grader under frysnings puncten; men kl. 2. e. var den 4.0. det är, just 4 grader öfver samma punct. Vid Vinden märkes, at 0 . betyder hel lugn, 1 . betyder sakta blåsande, 2. något mera blåsande, 3. en stark blåst, och 4. en stickande storm. När antingen uti Columnen för vind eller väderlek, står upfört bara en gång vind eller väderlek, bemärkes, at så varit hela dagen; til ex. den 21 December, står N. 0. klart; som gifver tilkänna, at hela dagen har flaggan stått för $\mathrm{N}$. men dock varit hel lungt; likaledes har då varit klart hela dagen. 
From Christmas 1722. to Christmas . . . . . . 1723

\begin{tabular}{r|rr|r|r|r|r|r|r|r|}
\hline 1723 & 5199 & 13 & 5 & 10793 & 5 & 1 & 15992 & 19 & 4 \\
1724 & 9373 & 15 & 8 & 20951 & - & 5 & 30324 & 16 & 1 \\
1725 & 10301 & 12 & 6 & 31908 & 1 & 8 & 42209 & 14 & 2 \\
1726 & 9371 & 11 & 6 & 28263 & 6 & 2 & 37634 & 17 & 8 \\
1727 & 10243 & - & 7 & 21736 & 10 & - & 31979 & 10 & 7 \\
1728 & 14075 & 13 & 9 & 23405 & 6 & 2 & 37478 & 19 & 11 \\
1729 & 12948 & 8 & 5 & 16851 & 2 & 5 & 29799 & 10 & 10 \\
1730 & 15660 & 10 & 11 & 32931 & 16 & 6 & 48592 & 7 & 5 \\
1731 & 11838 & 17 & 4 & 32421 & 18 & 9 & 44260 & 16 & 1 \\
1732 & 15240 & 14 & 4 & 26457 & 19 & 3 & 41698 & 13 & 7 \\
1733 & 13187 & - & 8 & 27378 & 7 & 5 & 40565 & 8 & 1 \\
1734 & 19648 & 15 & 9 & 34743 & 12 & 1 & 54392 & 7 & 10 \\
1735 & 18078 & 4 & 3 & 30726 & 7 & 1 & 48804 & 11 & 4 \\
1736 & 23456 & 15 & 11 & 38057 & 2 & 5 & 61513 & 18 & 4 \\
1737 & 14517 & 4 & 3 & 42173 & 2 & 4 & 56690 & 6 & 7 \\
1738 & 20320 & 19 & 3 & 41129 & 5 & - & 61450 & 4 & 3 \\
1739 & 9041 & 4 & 5 & 45411 & 7 & 6 & 54452 & 11 & 11 \\
1740 & 10280 & 2 & - & 46471 & 12 & 9 & 56751 & 14 & 9 \\
1741 & 12977 & 18 & 10 & 78032 & 13 & 1 & 91010 & 11 & 11 \\
1742 & 14458 & 6 & 3 & 60836 & 17 & 1 & 75295 & 3 & 4 \\
1743 & 19220 & 1 & 6 & 60120 & 4 & 10 & 79340 & 6 & 4 \\
1744 & 14681 & 8 & 4 & 47595 & 18 & 2 & 62214 & 6 & 6 \\
1745 & 13043 & 8 & 8 & 41237 & 2 & 3 & 54280 & 10 & 11 \\
1746 & 18103 & 12 & 7 & 55595 & 19 & 7 & 73699 & 12 & 2 \\
1747 & 8585 & 14 & 11 & 73819 & 2 & 8 & 82404 & 17 & 7 \\
\hline Totals & 343789 & 16 & - & 969049 & 1 & 6 & 1312838 & 17 & 6
\end{tabular}




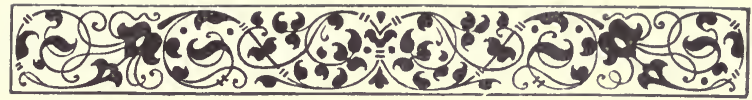

\section{Register.}

A merica, anmärkningar vid nor- Bly 4.5. 6.

A daste delen deraf 395 .

America, Folk der, se Folk.

Americaner, se Indianer.

Americanske örter, hvi de blomstra så sent 236.

Amianthus 401.

handskar, papper, pungar gjorde deraf 401. 402.

Ankor 122.

Apple dumplins 425.

Aranea 53.

Azoriska öarna 126. 127.

Bakugn 276. 343.

Barna-upfostring hos de Ängelska 473.

Barnsvånda, hjelp deruti 145 .

Bartram (Joh.) 242.

Beck 383.

Begrafning 107.

Ben, såra, bot derföre 325 .

Bärgarter 216.

Bärg-Cristall 216. 423.

Bärg-Lin 401. 402.

Bermudas Poteter 300.

Bernicles 137.

Beteshagar 13.

Bi 390.

Bibliotheque 181.

Biscayska viken 116.

Björn 246. 469.

Blew mountains 249.

Blubber 156.
Blymalm 400.

Blåck på skepp 132.

Bohvete 29. 221. 265. 441.

Bonitos 155 .

Boskap 233.

stă i hetta hälst under tallar 429.

Botaniska anmärkningar 320 .

se ock Trän, Örter.

Bottle nose 112. 121. 159.

Bruchus 296.

Brudevigning 507. 508.

Brunn 48.

Brynstenar 217.

Brännvin 226.

Brödätare 495 .

Bröstsjukdomar, bot derföre 325. 469.

Burnet (Wilj.) 367.

Båt 281.

Bäfver 324. 327.

Bönor 16. 23. 30. 45. 56. 59. 122.

Calabaster 440.

Cancer 142.

Caniner 77.

Canoër 281.

Cape Henlopen 162. 163.

Catarrhe 325.

Chalk-eggs 76.

Champignioner, huru de insyltas 100.

Chatham 48.

Chermes 275.

Chester 166. 286.

Chichester 281. 
Christina 272.

Cider 349. 377.

Clams 355. 448.

Clover 29. 57. 91.

Collinson (Peter) 318.

Concha 244.

Coryphana 134.

Crystaller 75. 216.

Culex 268. se Mygg.

Curculio 54.

Current 120. 137.

Dagg 206.

Deal 103.

Dellaware Flod 184. 237. 501.

Diarrhoée, bot derföre 325. 354. 389.

Diken i ställe för gärdesgård 2. 13.

Dolphin 134. 135. 139. 141. 157. 159.

Dover 106.

Droppsten 425.

Dufvor 114.

villa 329 .

Drlander 176.

Dysenterie, se Rödsot.

Ebb och Flod 185. 363.

EIg 398.

Elizabet town 346.

Europeer varit i America för Columbi tid 510.

Norra Europas örter i America 262.

Feber and agule 353. 453. och följ. Fiskar, förgiftige at igenkänna 472 . Fiskars förminskning 393.

Fiskars förökning 394.

Fiskar, flygande, se flygande Fisk. Fiskdam 405.

Fiskmåse 112. 141.

Fiskatta 378.

Flinta 3. 46. 62. och följ. 101. 103. Fluga 162.

Flygande Fisk 129. 133. 135. 142. 147. 148. 149. 150.

Foglar, förkiuses af ormar 197.
Foglars förminskning 391.

Foglar, Landtfoglar långt ut i hafvet 122 . 139. 146. 154. 155. 158 .

Foglar, tama gjorde 326 .

Folket i America, anmärkning dervid 233.

Folkets förökelse i America 485.

Formica, se Myror.

Franklin (Benj.) 168. 181.

Frossa 453. och följ.

bot derföre 353. 460. och följ.

Får 56. 92. 193. 388. 431.

Fönster 308.

Förkylning, bot derföre 314 .

Germantown 221.

Giftermål 369. 504. och följ.

Glasbruk 47.

Glasögon 473.

Glossopetra 385.

Golfweed 130. se andra Registret.

Gouverneurer i Ängelska Provincerne i Norra America 368. 505. 506. 507.

Gravesend 101.

Grodor 205. 359 .

Ground Squirrel, se Ickorn.

Gråsten, hvaraf hus 173. 305.

Gräfsvin 310.

Gräsarter i Norra America mäst annuella 436.

Gräsets förminskning 436 .

Gräshoppor 205. 488.

Gräsmask 489.

Guinée-höns 346.

Gumrik 12. 23.

Gärdar 24.

Gärdesgård 14. 42. 223. 269. 334.

Gäss 6. 347. villa 328.

Gödning 2. 14. 25. 26. 27. 56. 60. Gödselstackar 27.

Hackspik 158.

Hackspit 270.

Hafre 24. 265. 
Hafsdjur 109.

Hafsvatten, ej godt at tvätta kläder med 119. anmärkning dervid 151. 153.

Hafvets lysande 112. 123.

Haj 147. 423.

Hampa 443.

Handskära 4. 443.

Hare 236.

Harf 45.

Hesselius (Gust.) 169.

Holländare 340. 344. 348. 358. 361. 375.

Horn, lyktor deraf 128.

Horsebreak 56.

Hosta, bot derföre 325. 469 .

Hudsons flod 366. 373.

Hufvudvärk, bot derföre 324 .

Huggsår 315.

Humla 59.

Hummelgård 59.

Hummer 353.

Humming bird 329 .

Hund 379. 380. 490.

Hus 2. 8. 24. 222. 276. 305. och följ. 344. 346. 360 .

Hvalfisk 147.

Hvete 3. 55. 56. 59. 265. 273. 287.

Hvetemjöl 152.

Hall och styng, bot derföre 443 .

Häckar 42.

Hägnad 42.

Häst 57. 59. 288. 335.

maskar hos hästar at fördrifva 324.

Hö-bärgning 32.

Hö-stack 4. 32 .

Ickorn 227. 392. 409.

(flygande) 328. 417.

(grå) 227. 285. 328. 409. och följ.

förkjuses af ormar 415 .

(ground squirrel eller Rösselvissla) 227. 419.

Jern 401. 470.

Jernbruk 287.
Jerngafflar vid hö-bärgning 37.

Indianer 229. 232. 233. 234. 240. 247. 263. 340. 355. 356. 374. 382. 387. 392. 451. 459. 470. 481.

Indianernas grafvar 263.

Konungar 374.

Lerkäril 423.

Penningar 356.

Sädesarter 264.

Insecter, skadelige 31. 294. 487. och följ.

Jord, röd 341. 346.

Jordbäfning 191.

Irland menes fordom hafva hängt tilhopa med America 397.

Iroquoirnas Konungar 374.

Isor, se Marsvin.

Judar 356.

Jättar 231.

Jättgrytor 250. 262.

Kalk, bränd af krita 78 och följ.

Kalk af Ostronskal 218. 229. 293. 352.

Kalksten 217. 341. 344.

Kalkoner, villa 328.

Kersbär, Kersbärsträ 9. 40. 59. 208. 218. 226. 238. 339. 349.

Kikhosta, bot derföre 469 .

Kött, huru färskt förvaras 118 .

Knylor på trän 502.

Kor 57. 58. 266.

Koppar, bekant hos Indianerna för Europeernas ditkomst 470.

Koppargrufva 471.

Koppor 387.

Korn 55. 265.

Krabbtaska 146.

Krita 2. 7. 8. 21. 22. 25. 29. 30. 39. 41. 46. 48. 49. 56. 57. 59. 60-90. 95. 96. 102. 103. 106. 107.

Krukor, som Indianerne fordom brukat 423.

Kryddgårdsväxter, rön vid dem 299.

Kråka 250.

Kungsfogel 329. 
Kyrka 3. 46. 76. se äfven Phila- Mjölk 5. 223.

delphia, New-York.

Kål 122.

Kålhöfvel 407. 409.

Källor, sällsynta 93.

Källor, huru de göras nyttiga på flera sätt 223. 404. 406.

Kärna 6.

Kärrhjul 434.

Lada 24. 25.

Land, lăgländt, huru nyttigt gjordt 1. 2 .

Latinska bokstäfvers nytta 474 .

Lepas 137.

Lia 5 .

Lin 443. 448.

Linfrö 364 .

Loga 24.

Loppor 414. 490.

Lucerne 58.

Lumbricus marinus 104.

Lycktor 128.

Lysmask 442.

Löf 280. 407.

Lön för dräng eller piga 475 .

Mal 490.

Machine at vinda up båtar med 105. at tilreda Surkål 407.

Madera-vin 125. 366.

Magnetens variation 191. 373.

Marchasita 216.

Marien-glas 128. 217.

Marknad 189. 367.

Marmor 217.

Marsvin 107. 111. 119. 121.

Maskar 31.

\section{i sår, at fördrifva 256.}

hos barn, at fördrifva 284. 291. på trän 488 .

Mays 221. 227. 263. 264. 272. 280. 290. 392. 410. 411. 416. 433. 513. Mays-tjufvar 392.

Medusa 109. 113. 117. 146. 156.

Meteorologiska observationer 515. följ. Penningar (Indianernas) 356.
Mocking bird 335.

Mohravianer 180.

Moose-deer 396.

Morianer, se Negrar.

Mullvad 310.

Musselskal 75. 249. 261. 355.

Musslor 244. 355 .

Musquetoes 218. 348.

Mygg 268. 348. 373.

Myror 285. 292. 403.

Måssa 52.

Negrar 477 och följ.

Negrarnas förgift 483 .

New Brunswig 343.

New Castle 165.

New-York 358. och följ.

Northfleet 62.

Nya Bristol 377.

Nya Brunswig 343.

Nya Änglands Producter 312.

Nya York 358 och följ.

Nötter af Ickornar och Skogsmöss samlade, ganska utvalde 410.411.

Ollarts 398 och följ. 424.

Oniscus 52.

Opossum 327.

Orcan, tecken dertil 422.

Orm 229.

huru de förkjusa foglar 197.228. it. Ickornar 415.

Orm, Skallerorm 197. 228. 246. 415. Svartorm 197. 275. 416.

Ormbett, bot derföre 319 .

Ost 59. 138. 199.

Ostron 292. 350 och följ. 394 .

Ostronskal 218. 229. 249. 259. 293. 319. 352. 384. 445. 447. 448.

Oxar 56. 92.

villa 326.388 .

Pappersquarn 302.

Penn (Wilj.) 170. 171. 
Persiketrän, se andra Registret.

Petrell, se Stormväders fogel.

Petrificationer 259. 261. 385.

Petrificerat trä 241.

Phalcena 53.

Philadelphia 170 och följ.

Picus 271.

Pleuresie 464.

Plog 45. 56.

Plåster för sår 313.

Plägsed 196. 508.

Polcat 378.

Portlands sten 3. 4. 47.

Poseter (Bermudas) 300.

Presbyteriska 177.

Prince town 342.

Printsen af Libanon 191.

Procellaria, se Stormväders fogel.

Prognost. tempestat. se Väderlek.

Pumpor 238. 439.

Purpoises 122. 123. 124. 125. 126. 154. 155. 156. 158. 161.

Putorius 378.

Pyrites 216.

Päronträ 40. 208. 246. 254.

Quakare, se Quäkare.

Qvarn, se vatten- och väderqvarn.

Qvarnhjul, virke dertil 502.

Quäkare 169. 170. 180. 183. 190.231. 279. 477.

Raccoon 228. 327.

Rapphöns 329.

Rareton flod 344.

Recommendations bref 168 .

Regeringen i Ängelska Provincierne i Norra America 368.

Rhode Island 473.

Rida 31.

Risgryn 384.

Rochester 48.

Rofvor 56. 92. 275.

Russin, vin deraf 18. 19.

Rådjur 326.

Råg 3. 26. 59. 265.
Rädisa 300.

Räf 385 .

Räka 142. 143. 146.

Rödbetor 299.

Rödsot, bot derföre 199. 354 .

Rösselvissla 419.

Sachem 374.

Saint foin 4. 29. 57. 91. 97.

Salt 400 .

Sea hen 154.

Shearwater 113. 119. 124. 148. 153. 155.

Se Tärna.

Silkesmaskar 252.

Sirssor 491.

Siupp 327.

Sjögräs, se andra Registret.

Skepp bygda i America 163. 186. 235. 298. 299.

Skepps deckets tvättande 131.

Skogar 498.

Skogslöss 498.

Skogsmöss 411.

Skrifvande, huru det läres hos de Ängelska 474.

Skullkil 310.

Skära 4. 443.

Sköldpadda 132. 142.

Skördetid 236.

Smör 5. 6. 8. 59. 156. 472.

Snickare, hvilka Amer. träslag de tycka om 284. 285. 501.

Snäckskal 249.

Spanish man of war 146. 150. 154. 156. 159. 161.

Sparis 101. 290.

Squashes 264. 440.

Stalactites 425.

Staten Island 348.

Stenar, röda 341. 344.

Stenhus 305 och följ.

Stenkol 83. 125. 218.

Stick och bränna 464 .

Stormväders fogel 114. 118. 126. 136. 138. 139. 140.147.154.155.157.159. 
Strata terræ 20. 41. 50. 51. 65. och Träd planterade på gator 359. följ. 248.

Strålflinta 75.

Surkål, machine at tilreda den med 407.

Svala 146. 155 .

Svartmyllans tjocklek 17. 274.

Svart orm, se Orm.

Svenske 171. 175. 195. 205.266. 279. 453. 459.464.

Svett, at befordra 314 .

Svin 22. 29. 55. 59. 138. 219. 285. 335. 411.

Såningstid 265.

Såpsten 398.

Sädeslador 349 .

Tak 3. 222. 360.

Takskifver 424 .

Tamgjorda djur 326. 382. 388. 412. 418.

Tandvärk, bot derföre 314. 511 och följ.

Tares 58.

Taskkräfta 131. 142. 143. 146.

Tegelbränneri 47.

Thée 451. 459.

Thermometriska observationer 237. 238. 240. 515. följ.

Tjenstefolk 475 .

Tillandning 319. 444. följ.

Tillkråka 272.

Tjära 382. 383.

Tobak 131.

Toraker 495 .

Trappor 26.

Trenton 338.

Tropicbird eller Tropic-fogeln 146. 147. 149. 151.

Träd i Norra America, anmärkningar dervid 235. 266. 287. 315.

- - deras ålder 498. 499.

- - hvilka störst i Norra America 322.

- - deras Solum naturale 266. 315.

- - mäst ömtoliga för köld 439.

- - beständigt grönskande 449 .

- - som snart rutna 500.

- til Snickare arbete 501.

- - hvaraf skogarna i Norra America bestå 201. 498.

Trägårdar 40. 205. 207. 221.284. 334 . 339. 444.

Tufvor, orsak dertil 14.

Tyskar 375.

Tänders mistande 450 .

Tärna 128. 133. 134. 136. 137. 138. 140. 147. 148. 150. 151. 153. 155. Tättingar 77.

Ursus 228.

Utsäde, hvad făs derefter 55.

Utter 327.

Vallar vid floder 61.

Valnötträ, se andra Registret.

Vampum 356.

Varg 387. 504.

Vatten, hafs-, ej godt at tvätta kläder med 119.

- - stillastaende, menas förorsaka Frossa 456.

- - ur kritjord 48. 49.

- - at hafva välsmakeligt på hafvet 115 .

- - dess aftagande, eller tvärt om 249. 259 följ. 319. 352. 363. 384. 444 följ. Se ock Tillandning.

Vattuho 4.

Vattuqvarn 349. 393.

Vattusot, bot derföre 434 .

Ved 224.

Westindien 186. 244.

Whitefield 177.

Wight 110.

Vin af Russin 18. 19.

Madera-vin 125. 366.

af Americanska frukter 218.226. 283. 466 . 
Vinrankor 9. 25.

Americanska villa, se andra Registret.

Vinland det goda 471.

Willmington 277.

Vinter i Nya Sverige 237. 436.

uti Nya York 373.

Vinter mycket hård 436.

Woodbridge 346.

Väderlek, tecken til hurudan 115 . 123. 128. 130. 137. 151. 161. 275. 293. 404. 411. 414. 422. 470. 511. Väderqvarn 46.

Vägar 15. 46. 503.

Vägglöss 492.

at fördrifva 431. 493.

Vält 45 .

Värk, bot derföre 254. 258. 271. 314 . 316. 318.

Västanvind mycket i Ängland 46 .

blåser mycket emellan Europa och America 126. 127. 133.

Zinzendorff 192.

Zinzendorffiska eller Herrenhuther 180.

$\AA$ A ker 12. 23. 30. 42. 55. 232. 276. 349.

Åkerbruk 55. 56. 93. 443.

vårdslöst 15. 43. 44. 303.

Ång 12. 256. 428.

Ängars vatnande 405 .

Ängskötsel 56. 405. 428.

Se ock Clover, Lucerne, Saint Foin, Tares.

Äpplen, Äppleträ 40. 207. 226. 254. 284. 288. 302. 339. 349. 377. 425. Ärter 30. 44. 56. 59. 293.

Ökståck 281.

Örter eller Växter tjenliga til

- - Bröd 389. 441.

- - Välling 209. 439.

- - Grönkål 209. 316.
Örter eller Växter tjenliga til

- Annan mat 200. 204. 208. 253. 300. 302. 425. 437. 439. 440. 441.

- Mos 302.

- - Angenäm frukt 256.

- - Syltsakeri och confiturer 97. 100. 255. 274. 302. 467.

- - Såcker 288.

- - Dricka 302. 438.

- - Vin 18. 19. 218. 226. 253. 255. 283. 467.

- - Brännevin 226. 438. 468.

- - Ätticka 468.

- - At lägga i Brännevin 325.434.

- - At lägga i dricka 434.

- Krydder i mat 209.

- - I stället för Thée 270. 435.

- - Foder för hästar 57. 58. 59. 91. 92. 288. 319.

- - Foder för kor 56. 58.92.271.

- Foder för Får 56. 92. 122.

- - Foder för Svin 56. 59. 285. 389. 433. 442.

- - Foder för hjortar 432.

- Föda för Bäfrar 324.

- - Föda för höns 122. 442.

- - föda för anckor 122.

- - på ängar 4. 13. 29.

- - nyttiga i Medicine 145. 256. 258. 271. 284. 291. 314. 315. 316. 354. 389. 434. 460. följ. 512. 513. 514 .

- - mot boskaps sjukdomar 256 . 322.

at fördrifva ohyror 435 .

- - Färg, blå 288. 443. brun 315.354 . gul 12. 227. 271. 317. röd 210. 315. 436. 443. svart 443.

- - til bläck 210. 288.

- - husbyggnad 174.

- - Snickare-arbete 284.285.501.

- - der hårdt trä fordras 132. 322. 433. 
Örter tjenliga til husgeråds saker Örter at öfverkläda väggar och murar 198. 245. 285. 288. 322. 323. 9. 25. 266. 296. 469 . 430. 433. 434. 439. 503.

- - käril 440. 503.

- - qvarnhjul och trällor 502.

- - skepp eller båtar 163. 186. 235. 245. 281. 323.

- - til ved eller bränsle 28. 224. 225.

- Lampor, ljus 312.

- - som gifva vax 312.

- - til lack 314. tvål 313.

- - at tvätta käril med 435.

- - i stället för halm eller måssa 388.

- - i stället för Lin 258 .

- - til gärdesgårdar 224. 269.

- - til häckar 28. 219. 245. 286.

- - til alleer 198. 199.

- - til skjul i trägårdar 198.

- - hvilkas blommor se täcka ut 257. 258. 321. 322. 431.

- - som lukta ganska väl 324 . 359. 469 .

- - tidigt blomstrande 321.

- - sentblomstrande236.239.320.

- - som trifvas i utmager jord 337.

- - som förorsaka tufvor 14 .

- - ogräs bland säd 12.15. 30. 43. 210.

- - af särdeles egenskap 200.212. 250. 297. 431.

- - förgiftiga 212. 297. 431.

- - Americanske, hvarföre en del blomstra så sent 236 .

- Americanske enahanda med Norra Europas 262.

Östanväder, anmärkning dervid 126. 127. 133.

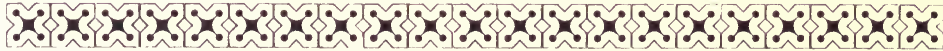

\section{Register}

På de Växter, som antingen för deras nytta eller annan egenskap äro nämnde i detta verk.

Acer rubrum 288. 501. 503.

Accr saccharinum 267.

Afvenbok 28.

Agrifolium, se aquifolium.

Al 275. 315.

Alm 22. 28. 103. 132. 359.

Alopecurus pratensis 13.

Anemone virginiana 512.

Aquifolium 132. 443. 449.

Apocynum cannabinum 258.

Arum virginicum 253.

Arundo 2. 13.

Ask 28. 503.

Bärgsyra 443.

Bermudas Poteter 300.
Betula alba 262.

Betula nana 263.

Bidens bipinnata 291.

Björk 40.

Björnbärsbuskar 28.

Americanske 218. 226. 283.

Björnmåssa 303.

Bohvete, se förra Registret.

Bok 28. 285.

Buttonwood 198.

Bäfverträ 324. 450 .

Bönor, se förra Registret.

Calabasser 440 .

Canoe-trä, se Tulipan-trä.

Capsicum annuum 209. 
Cassia chamacrista 250.

Castanie-trä 209. 224. 270. 281.

Ceder, hvit, se Cupressus. röd, se Juniperus Virginiana.

Centaurea Jacea 239.

Champignioner 100.

Chenopodium anthelminticum 283. 291.

Clover 29. 57. 91.

Collinsonia 317.

Comarum palustre 263.

Convolvulus Batatas 300.

Cornus florida 321. 462.

Cratcegus korfstick hagtorn 244.

Cupressus thyoides 174. 222. 276. 281. 360. 450. 501.

Daphné Mezereum 239.

Datura Stramonium 275.

Diospyros Virginiana 200.255. 437.

En, hvita, se Cupressus.

Enbuskar 40.

Ek 28.

- - Americansk, anmärkning dervid 186. 235. 245. 285. 298. 411. 450 .

Grodblad 247.

Gyllenträ 282. 500. 501.

Hagtorn 28. 42.

Americansk 244.

Hallon 218.

Hedera Helix 9. 266.

Hedera quinquefolia 277.

Hepatica 239.

Hickery (en art Valnöttrï) 224. 225. 242. 317. 500 .

Holcus lanates 13.

Hundträ 321. 462.

Ilex aquifolium 443. 449.

Impatiens noli tangere 317. 330.

Ironwood 132.

Juneus acutus 14.

Juniperus Virginiana 224. 245. 269. 281. 450 .

Kalmia latifolia 430. 449.

Kalmia angustifolia 450.

Kersbärsträ, se förra Registret.

Kersbürsträ, vilskt 289. j01.

Krumhalsar 439.

Larix 254

- - Hvit, 224. 225. 269. 281. 322. 354. 500. 502.

Life everlasting 257.

Lignum vite 132.

- - svart 224. 225. 245. 269. 317. 434. 500. 503.

- Spansk 434. 503.

Ligustrum 28. 219. 223. 286.

Lind 359.

Linncea 263.

Locusttree 359.

Lucerne 58.

Lupinus perennis 337.

Lönn, rödblommig, se Acer rubrum

Furu, se Tall.

Förgiftiga trä 211.

Genista Spinosa 27.

Gentiana amarella 239.

Gentiana lutea 263.

Geranium robertianum 379.

Geum rivale 463.

Gnaphalium Margaritaceum 257.

Magnolia 334. 450.

Melisa pulegioides 314.

Meloner 238.

Mispel 200. 255. 437.

Misselton 450 .

Mohogony-trä 186.

Monarda coccinea 330.

Mulbärsträ 209. 252. 502.

Golfweed 130. 133. 139. 140. 142. 144. 146. 148. 149. 150. 151. 153. 154. 155 . 
Myrica cerifera 312. 450.

Myrica asplenifolia 514.

Nasturtium hort. 282.

Okra 209.

Ormbunkar 30.

Penny royal 314.

Peppar 209.

Persimon 200. 255. 437.

Persiketrä 207. 226. 339. 439. 462.

Phytolacea americana 227. 257.275. 316.

Plantago major 247.

Platanus occidentalis 198. 359. 426. Portulaca 291.

Potentilla canadensis 462.

- - fruticosa 263.

- - reptans 462.

Poysontree 211.

Pteris aquilina 30.

Pumpor 238. 439.

Påk 316.

Päronträ, se förra Registret.

Qrickrot 12. 43.

Renfana 248.

Rhus glabra 210.

- - radicans 214. 296.

- - rernix 212.

Robinia Pscudo-acacia 359.

Rubus occid. se Björnbärsbuskar Amer.

Rumex acetosella 443.

Rännthorn 283.

Salicornia herbacea 97.

Saltenbrass 434.

Salvia hort 354.

Sambucus canadensis 513.

Sargazo 130.

Sarothra 253.

Sassafras 267. 270. 434.

Scabiosa arvensis 53.

Scirpus maritimus 13.
Saint Foin, se förra Reg.

Serratula arvensis 15.

Sjögräs 121. 123. 124. 129. 139. 157. Se Golfweed.

Skedträ 430. 449.

Slån 28.

Smilax laurifolia 277.

Smultron 218.

Solidago Virgaurea 239.

Sparis 101. 290.

Spartium Scoparium 389.

Squashes 264. 440.

Sumach 210. 211.

Svinmålla 248.

Såcker-Lönn 267.

Talgbuska 312. 450 .

Tall, hvit 322. 360. 383. svart 383 .

Jersey 429.

Tares 58.

Trientalis europera 263.

Triglochin maritimum 263.

Tubera terro 389.

Tuckahoo 389.

Tulipan-trä 267. 281. 322. 462. 500.

Verbascum thapsus 206. 256.

Verbena officinalis 248.

Vicia sativa 58. 92.

Viola canina 239.

Viscum album 450.

Viscum filamentosum 388.

Valnötträ, Europæiskt 40.

- - Svart 209. 289. 321. 501.

- - Hvit 502.

Vattenbok 198. 359. 426.

Vatten-meloner 238. 373. 374. 458.

Vinbär, röda 218. hvita 218.

Vinrankor 9. 25.

Americanska villa 200. 218. 253. 266. 273. 276. 439. 466.

Vilsk Tobak 256.

Äppleträ, se förra Registret. 


\title{
SVENSKA LITTERATURSÄLLSKAPETS
}

\author{
hittills utgivna skrifter:
}

I. H. G. Porthans bref till M. Calonius. 1, utg. af W. Lagus. $341+68$ sid., tr. 1886

Fms:

8: Lagus och Schybergson.) $-62+112$ sid., tr. 1887

III. Finlands territoriala församlingars ålder, utbildning och utgrening intill 1885 års utgång, af K. G. Leinberg. - 159 sid., tr. 1887 .

IV. Borgareståndets Protokoll vid Borgå landtdag 1809, utg. af Elis Lagerblad. - 411 sid., tr. 1887

V. H. G. Porthans bref till M. Calonius. 2, utg. af W. Lagus. $263+106$ sid., tr. 1887

VI. *Förhandlingar och Uppsatser 2. (Längre uppsatser af Estlander, Frosterus, Lagus m. fl.) $-44+268$ sid., tr. 1888 .

VII. Ordbok öfver estländsk-svenska dialekterna, af A. O. Freudenthal och H. A. Vendell. - 328 sid., tr. 1888

VIII. *Historiskt-politiska anteckningar af H. F. Adlercreutz. 17431796, utg. af Elis Lagerblad. - 185 sid., tr. 1888 .

IX. *Förhandlingar och Uppsatser 3. (Längre uppsatser af Th. Westrin, Freudenthal, Schybergson m. fl.) $-40+318$ sid., tr. 1889

X. Reseanteckningar af P. J. Bladh och C. F. Hornstedt, utg. af J. O. I. Rancken och Elis Lagerblad. 176 sid., tr. 1889 .

XI. 1-7. Åbo akademis studentmatrikel, af W. Lagus. - 1,439 sid., tr. 1890 .

Vöråmålet, ljud- och formlära, ordlista med register, sprâkprof, af A. O. Freudenthal. - 200 sid., tr. 1890

*Förhandlingar och uppsatser 4. (Längre uppsatser af Schybergson, Hultin, Vendell m. fl.) $-34+136$ sid., tr. $1890 \ldots$

KIV. De finska klostrens historia, af K. G. Leinberg. 509 sid., tr. 1890 .

$\mathrm{XV}$. *Helsingfors stads historia från 1640 till stora ofreden, af Erik Ehrström. -- 171 sid., tr. 1890

Åbo universitets lärdomshistoria. 1. Medicinen, af L. W. Fagerlund och Robert Tigerstedt. - 216 sid., tr. 1890

lund och Robert Tigerstedt. - 216 side, tr. 1890 . strand. - 94 sid., tr. $1890 \ldots \ldots$. . . . . . . . . . . . .

Förhandlingar och Uppsatser 5. (Längre uppsatser af Frosterus, Schybergson, Leinberg, Nordmann m. fl.) $-45+218$ sid., tr. 1891 *Åo universitets lärdomshistoria. 3. Historien, af M. G. Schybergson. - 168 sid., tr. 1891

XX. *Förhandlingar och Uppsatser 6. (Längre uppsatser af Gustafsson, W. Lagus, Elfving m. fl.) - $108+121$ sid., tr. 1892.

3: -

8:-

8:-

3: 75

6:

3:

4:-

$3:$

XXI. Katalog öfver den svenska litteraturen i Finland samt därstädes utkomna arbeten på främmande språk 1886-1890. Uppgjord af H. Bergroth. - 175 sid., tr. 1892 .

3: -

XII. Finska prästerskapets besvär och Kongl. majestäts därpå gifna resolutioner. Från slutet af 1620 -talet intill stora ofredens slut. Samlade af K. G. Leinberg. - 474 sid., tr. 1892 .......... XIII. *Åbo universitets lärdomshistoria 4. Teologin, förra delen, af Herman Råhberg. - 187 sid., tr. 1893 . 
XXIV. *Förhandlingar och Uppsatser 7. (Längre uppsatser af J. E. Strömborg, R. Hausen, P. Nordmann m. fl.) $-72+137$ sid., tr. 1893

XXV. Bondeståndets Protokoll vid Borgå landtdag 1809, utgifna af Elis Lagerblad. - 282 sid., tr. 1894

XXVI. *Åbo universitets lärdomshistoria. 5. Filologin, af I. A. Heikel. - 334 sid., tr. 1894

XXVII. Johan Henrik Kellgrens Bref till Abraham Niclas Clewberg, utgifna af Henrik Schück. $-39+136+19$ sid., tr. $1894 \ldots$

XXVIII. *Förhandlingar och Uppsatser 8. (Längre uppsatser af E. Lagerblad, E. W. Bergman, C. G. Estlander, R. Hausen och M. G. Schybergson.) $-47+288$ sid., tr. 1895 .

XXIX. Östgötalagen med förklaringar, af A. O. Freudenthal. - IV +280 sid., tr. 1895 .

XXX. Förhandlingar och Uppsatser 9. (Längre uppsatser af E. Lagus, V. Söderhjelm, G. Cygnæus, A. Hultin och P. Nordmann.) -- $50+336$ sid., tr. 1895

XXXI. Jöns Buddes bok. En handskrift från Nådendals kloster, utgifven genom O. F. Hultman. - XXII + 256 sid., tr. 1895

XXXII. *Åbo universitets lärdomshistoria. 6. Naturalhistorien, af Otto E. A. Hjelt. - IV + 446 sid., tr. 1897

XXXIII. *Raseborgs slotts historia, af Torsten Hartman. - 155 sid., tr. 1897

XXXIV. *Förhandlingar och Uppsatser 10. (Längre uppsatser af G. Cygnæus, K. G. Leinberg, C. G. Estlander och E. Lagus.) $82+194$ sid., tr. 1897

XXXV. Katalog öfver den svenska litteraturen i Finland samt arbeten af inhemska författare på främmande språk 18911895. Uppgjord af Yrjö Hirn. - 266 sid., tr. 1897

XXXVI. Förhandlingar och Uppsatser 11. (Längre uppsatser af I. A. Heikel, G. Frosterus och Yrjö Hirn.) - $69+216+33$ sid., tr. 1898

XXXVII. *Åbo universitets lärdomshistoria. 7. Matematiken och fysiken, af K. F. Slotte. 293 sid., tr. 1898

XXXVIII. Bref frản Henrik Gabriel Porthan till samtida, utgifna af Ernst Lagus. - 360 sid., tr. 1898

XXXIX. *Förhandlingar och Uppsatser 12. (Längre uppsatser af Carl v. Bonsdorff och Hj. Appelqvist.) $-71+192+11$ sid., tr. 1899

XL. Prästestandets protokoll vid Borgå landtdag år 1809 jämte Handlingar rörande landtdagen, utgifna af Elis Lagerblad. - 586 sid., tr. 1899

XLI. Finlands svenska vitterhet. 1. Jakob Tengströms vittra skrifter i urval med en lefnadsteckning, af $M$. G. Schybergson. - CLIX + 280 sid., tr. 1899

XLII. *Åbo universitets lärdomshistoria. 8. Kemien, af Robert Tigerstedt. - 210 sid., tr. 1899

XLIII. En samling öfversättningar och bearbetningar från romerske och franske författare. Utgifningen ombesörjd af T. S. Dillner. -. XX +145 sid., tr. 1899

XLIV. "Dagbok, förd under kriget i Finland 1788-1790 af auditören C. C. Ekman, utgifven af Reinh. Hausen. - XI + 266 sid., tr. 1900

XLV. Förhandlingar och Uppsatser 13. (Längre uppsatser af V. T. Rosenqvist, W. Söderhjelm och C. v. Bonsdorff.) $-45+254$ sid., tr. 1900

XLVI. Karl August Tavaststjerna. En lefnadsteckning af Werner Söderhjelm. - 324 sid., tr. 1900

XLVII. "Förhandlingar och Uppsatser 14. (Längre uppsatser af R. F. von Willebrand, C. v. Bonsdorff och G. Castrén.) -- LXXXI +244 sid., tr. 1901 
VIII. *Finlands svenska vitterhet. 2. Mikael Choræi valda dikter med en lefnadsteckning, af Ernst Lagus. - CXC + 226 sid., tr. 1901 ..................

LIX. *En idéernas man. Biografi öfver August Fredrik Soldan, af Juhani Aho. - 421 sid., tr. $1901 \ldots . . . . . .$.

L. * Åbo universitets lärdomshistoria. 9. Teologin, senare delen, af Herman Råbergh. - 229 sid., tr. 1902

LI. *Förhandlingar och Uppsatser 15. (Längre uppsatser af $P$. Nordmann, A. O. Freudenthal, J. Ahrenberg, Z. Schalin och O. Grotenfelt.) - LXIX + 243 sid., tr. 1902 .

3:

LII. *Finlands svenska vitterhet. 3. Valda skrifter af Jakob Frese med en teckning af hans lefnad och skaldskap, af Arvid Hultin. --. CXIX + 218 sid., tr. 1902

Katalog öfver Den svenska litteraturen i Finland samt arbeten på främmande språk af finländske författare eller utgifna i Finland 1896-1900. Utarbetad af H. Bergroth. 302 sid., tr. 1902

LIV. *Torsten Rudeen. Ett bidrag till karolinska tidens litteraturoch lärdomshistoria, af Arvid Hultin. - IV + 276 sid., tr. 1902

LV. M. Calonii bref till H. G. Porthan, utgifna af W. Lagus. $\mathrm{XI}+449+91$ sid., tr. $1902 \ldots \ldots$. $\ldots$ - 1902. (Längre uppsat-

LVI. * Förhandlingar och uppsatser 16. -1902 . (Längre uppsat-
ser af H. Pipping, R. Nordenstreng, O. Grotenfeldt, A. Hultin,
K. G. Leinberg.) - LXVII + 236 sid., tr. 1903 ... . . . -
.VII. *Bref, tal och andra skrifter af Mikael Choræus, utgifna af

LVI. *örhandlingar och uppsatser 16. -1902 . (Längre uppsat-
ser af H. Pipping, R. Nordenstreng, O. Grotenfeldt, A. Hultin,
K. G. Leinberg.) - LXVII + 236 sid., tr. 1903 . . . . . . -
.VII. *Bref, tal och andra skrifter af Mikael Choræus, utgifna af Ernst Lagus. VIII +400 sid., tr. 1903

VIII. *Skildring af krigshändelserna i Öster- och Västerbotten 1808-1809, af C. J. Ljunggren. - III + 153 sid., tr. 1903 .

Bidrag till Eddametriken, af Hugo Pipping. - 118 sid., tr. 1903

LX. *Per Brahe. Illustrerad lefnadsteckning, författad af P. Nordmann. - 520 sid., tr. 1903

Joh. Ludv. Runeberg, hans lif och hans diktning I, af Werner Söderhjelm. - 468 sid., tr. 1904 . . . . e tskrift 5 febr. 1904. - 441 sid., tr. 1904.

*Förhandlingar och Uppsatser 17. - 1903. (Längre uppsatser af M. G. Schybergson, Gunnar Castrén, Z. Schalin, F. Gustafsson, R. F. von Willebrand, K. G. Leinberg och G. A. Nordmann.) - LXIII + 408 sid., tr. $1904 \ldots \ldots \ldots \ldots$

Ordbok över de östsvenska dialekterna, av Herman Vendell. Första häftet. - XLII + 280 sid., tr. 1904

4: -

7:-

XV. *Finlands svenska vitterhet. 4. "Den svenska vitterheten i Finland under stormaktstiden 1640-1720, af Arvid Hultin. - CCLXXXVIII + 230 sid., tr. 1904 .

XVI. Pehr Kalms Resa till Norra Amerika, ånyo utgifven af Fredr. Elfving och Georg Schauman. Första delen. Med en inledning af Georg Schauman. - LI + 400 sid., tr. 1904

IVII. Ridderskapets och Adelns Protokoll vid Borgà landtdag 1809, utgifna af Elis Lagerblad. - 454 sid., tr. 1905 . . . .

VIII. *Förhandlingar och Uppsatser 18. - 1904. (Längre uppsatser af W. Söderhjelm, A. Hultin, M. G. Schybergson och O. Andersson.) - XCVIII + 204 sid., tr. $1905 \ldots$. . . . .

Bidrag till Helsingfors stads historia, samlade och utgifna af P. Nordmann. I. Bref från 1550-1650. - Stadens domböcker 1623-1639. - 252 sid., tr. 1905.

XX. *Bref och dagboksanteckningar af Georg August Wailln, utgifna jämte en lefnadsteckning af Knut Tallqvist. - CXXXIV +366 sid., tr. $1905 \ldots$. . . . . . . . . . . . . . . Andra häftet. - 588 sid., tr. 1905 . 
LXXII. Bidrag till Helsingfors stads historia, samlade och utgifna a P. Nordmann. II. Prosten Henrik Forsii biografi och skrifter. - 129 sid., tr. 1906

LXXIII. *Förhandlingar och Uppsatser 19. - 1905. (Längre uppsatser af R. Tigerstedt, $M$. G. Schybergson, P. Nordmann, A. Hultin, K. G. Leinberg och Yrjö Hirn.) - LXIV + 322 sid., tr. 1906

LXXIV. 1. Minnespenningar öfver enskilda personer, födda eller verksamma i Finland, beskrifna af Mauritz Hallberg. 154 sid., tr. 1906

LXXV. Ordbok över de östsvenska dialekterna, av Herman Vendell. Tredje häftet. - pp. $589-900$, tr. 1906

LXXVI. Bidrag till Helsingfors stads historia, samlade och utgifna af P. Nordmann. III. Bref från 1651-1697. Stadens domböcker 1639-1643. - 210 sid., tr. 1906

LXXVII. Joh. Ludv. Runeberg, hans lif och hans diktning II, af $\mathrm{W}$. Söderhjelm. - 558 sid., tr. 1906.

LXXVIII. Förhandlingar och Uppsatser 20. - 1906. -- (Längre uppsatser af W. Ruin, R. Lagerborg, G. Heinricius, K. G. Leinberg och G. Castrén.) - LXV + 397 sid., tr. 1907.

LXXIX. Ordbok över de östsvenska dialekterna, av Herman Vendell. Fjärde häftet. pp. $901-1215+6$ sid., tr. $1907 \ldots$. . . .

LXXX. *Åbo universitets lärdomshistoria. 10. Filosofin, af Th. Rein. 326 sid., tr. 1908

LXXXI. *Förhandlingar och Uppsatser 21. - 1907. (Längre uppsatser af E. Wrangel, Th. Westrin, G. Heinricius, J. G. Nikander, L. F. la Cour, K. G. Leinberg, Ossian Grotenfelt, W. Söderhjelm.) - LXXIV + 397 sid., tr. 1908.

LXXXII. Bidrag till Helsingfors stads historia, samlade och utgifna af P. Nordmann. IV. Bref från 1714-1796. 228 sid., tr. 1908

LXXXIII. *Henrik Gabriel Porthan. Lefnadsteckning, af M. G. Schybergson. Förra delen. - XIII + 281 sid., tr. 1908 .

LXXXIV. Biografiska undersökningar om Anders Chydenius, af Georg Schauman. - XI + 645 sid., tr. 1908

LXXXV. *Sjukvård och läkare under kriget 1808-1809, af K. E. Lindén. - IX + 229 sid., tr. 1908

LXXXVI. Bidrag till Helsingfors stads historia, samlade och utgifna af P. Nordmann. V. Gamla Helsingfors 1550-1640, 184 sid., tr. 1908

LXXXVII. *Elias Lönnrots Svenska skrifter, utgifna af Jenny af Forselles. I. Afhandlingar och öfversättningar. -355 sid., tr. 1908 .

LXXXVIII. *Förhandlingar och Uppsatser 22. - 1908. (Längre uppsatser af G. Heinricius, A. Hultin, B. Sjöros.) - XCVIII + 210 sid., tr. 1909

LXXXIX. *Josef Julius Wecksell. En studie av Arvid Mörne. 290 sid., tr. 1909

XC. Svenska Litteratursällskapet i Finland 1885-1910. Minnesskrift den 5 februari 1910. $194+138$ sid., tr. 1910. . .

XCI. Förhandlingar och Uppsatser 23. - 1909." (Längre uppsatser af E. Westermarck, G. Heinricius och P. Nordmann.) - XCIII + 233 sid., tr. 1910

XCII. Studier i Nordisk filologi. Utgivna genom Hugo Pipping. Första bandet. Uppsatser av E. Lidén, H. Pipping och R. Saxén. $-52+24+183$ sid., tr. 1910 .

XCIII. Pehr Kalms Resa till Norra Amerika, ånyo utgifven af Fredr. Elfving och Georg Schauman. Andra delen. Med ett förord af Georg Schauman. - XI + 390 sid., tr. $1910 \ldots \ldots$. . . .

OBS. De med * utmärkta tomerna hava utdelats åt alla medlemm de övriga endast åt stiftare. 


\section{Tillkännagivande.}

Personer, som önska inträda $i$ Svenska litteratursällskapet, unna anmäla sig hos Sällskapets skattmästare, direktör Sigfr. ullhem, å Brandförsäkringsaktiebolaget Fennia, Unionsgatan 25. ällskapets medlemmar fördelas $i$ tre kategorier: "stiftande medmmar", vilka inbetala 200 mark eller därutöver, "ständiga edlemmar", vilka en gång för alla erlägga 100 mark, samt årsmedlemmar", vilka betala 10 mark årligen $i$ tolv års tid, arefter de överföras till ständiga medlemmar. Ständiga medmmar och årsmedlemmar kunna övergå till stiftare genom att enlighet med en därför uppgjord tariff inbetala differensen melin stiftareavgiften 200 mark och det som de tidigare erlagt till ällskapet. Stiftande medlemmar äga rätt att erhålla samtliga thommande tomer af Sällskapets skrifter. Ständiga medlemmar ch årsmedlemmar få alla "Förhandlingar och Uppsatser" och på ïrkild anhållan även skriftserien "Studier i nordisk filologi“, men $v$ de övriga skrifterna blott de mera populära; dock kunna de ir halva priset tillösa sig även de andra skrifterna. Nyinträande stiftande medlemmar erhålla ännu gratis några få förut tkomna tomer, av vilka ett större antal exemplar finnes $i$ arkiet. Rekvisitioner adresseras till Sällskapets arkivarie, lektor lis Lagerblad, Helsingfors, Västra Hamngatan 2.

Med Svenska litteratursällskapet $i$ Uppsala har överensommelse ingåtts, att $i$ detsamma mot erläggande af endast halv vgift eller kr. 2: 75, postportot inberäknat, kunna inträda medmmar av Svenska litteratursällskapet $i$ Finland, vilka därienom bliva delaktiga av det $i$ Sverge verkande Sällskapets krifter. Också äga medlemmarna af bägge Litteratursällskapen ätt att för halva priset tillösa sig de båda Sällskapens äldre krifter, ifall det aterstående lagret sådant medgiver. Ständiga zedlemmar av Uppsalasällskapet kunna Litteratursällskapets $i$ inland medlemmar bliva, om de så önska, mot en avgift en ång för alla av 50 kronor. Inträdessökande äga anmäla sig os lektor Lagerblad. 
to 






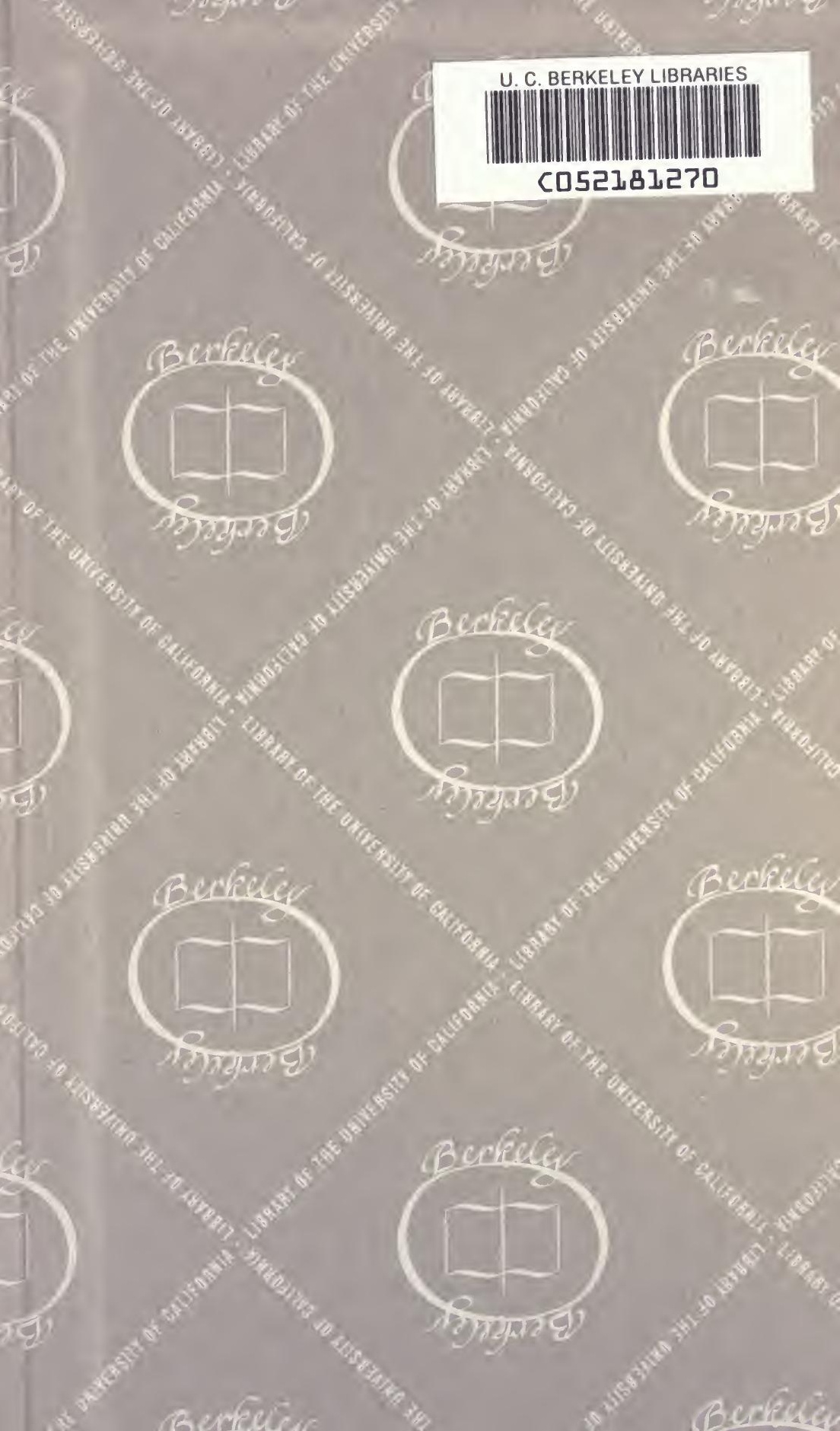


